\title{
INTERAÇÃO DE PAREDES EM ALVENARIA ESTRUTURAL CERÂMICA SOB AÇÕES VERTICAIS
}

Tese apresentada à Escola de Engenharia de São Carlos, da Universidade de São Paulo, como parte dos requisitos para a obtenção do título de Doutor em Engenharia de Estruturas.

ORIENTADOR: Prof. Assoc. Márcio Roberto Silva Corrêa

São Carlos

2005 


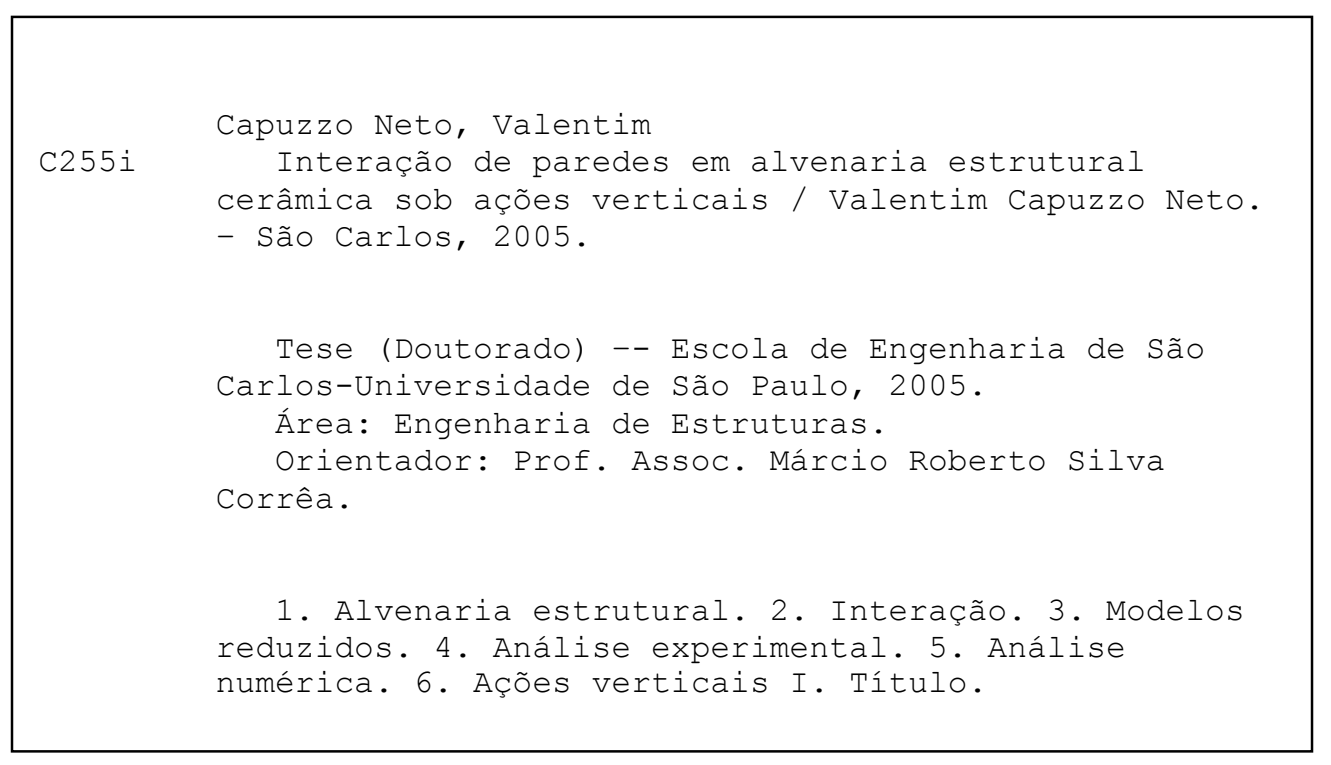


FOLHA DE JULGAMENTO

Candidato: Engenheiro VALENTIM CAPUZZO NETO

Tese defendida e julgada em 08-07-2005 perante a Comissão Julgadora:

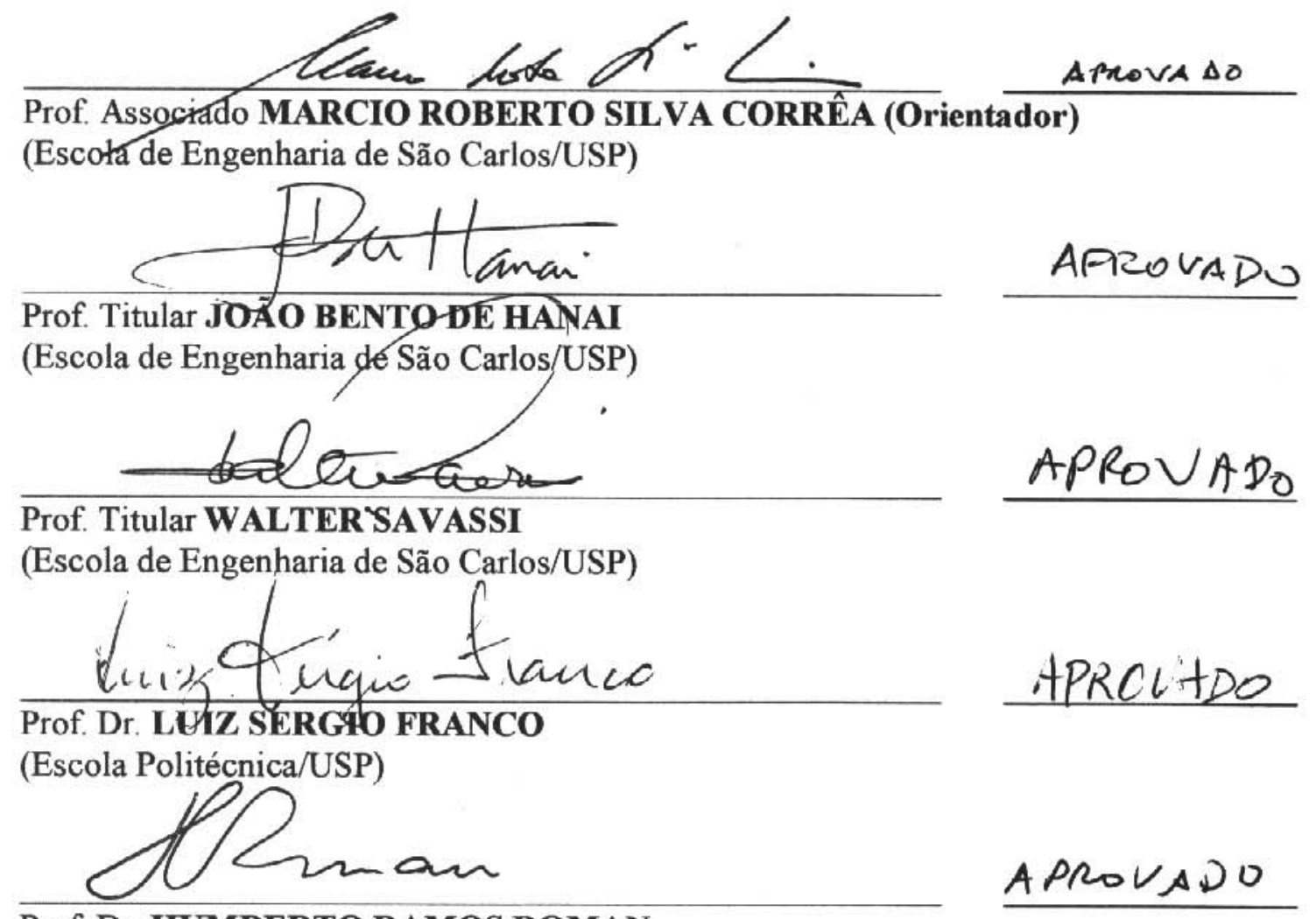

Prof. Dr. HUMBERTO RAMOS ROMAN

(Universidade Federal de Santa Catarina/UFSC)

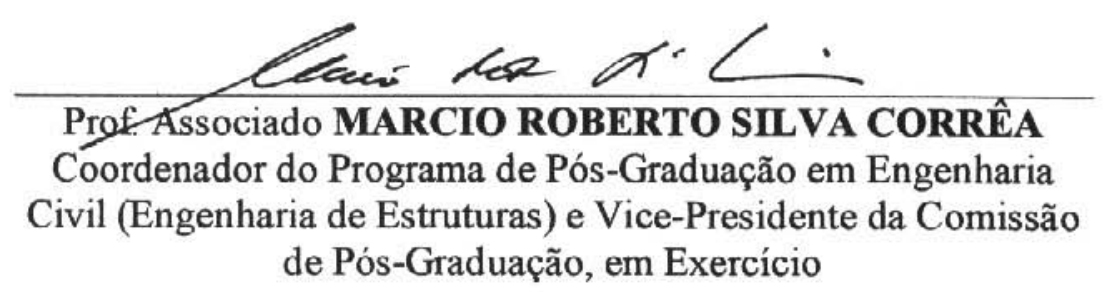


Dedico à minha mãe, Yara Cupertino de Barros Capuzzo, um exemplo de vida e dedicação. 


\section{Agradecimentos}

A Deus, por iluminar meu caminho ao longo da vida.

Aos meus irmãos Doralice, Luciano e Denise, e aos meus sobrinhos Mateus, Danilo e Luiza que sempre me deram forças nos momentos que necessitei.

À minha noiva Valdirene, pelo companheirismo, incentivo e amor que tanto me auxiliaram nos momentos difíceis.

Ao Professor Márcio Roberto Silva Corrêa pela orientação, sugestões e dedicação ao longo dos sete anos de pesquisa em conjunto.

À empresa JCE Tecnologia em Boquilhas, pelo desenvolvimento e doação das boquilhas utilizadas na produção dos blocos em escala reduzida.

Agradecimentos especiais à Cerâmica Maristela, na pessoa da Enga . Paula Marchi, não só pela doação dos blocos em escala natural e reduzida, mas também por permitir e auxiliar o desenvolvimento do processo de produção dos blocos em escala reduzida.

À Fundação de Amparo a Pesquisa do Estado de São Paulo - FAPESP pelo financiamento da pesquisa, através da bolsa de doutorado e a reserva técnica.

A todos os funcionários do Laboratório de Estruturas da EESC - USP, que auxiliaram no programa experimental .

Aos professores, colegas e funcionários do Departamento de Engenharia de Estruturas da Escola de Engenharia de São Carlos - USP, pela colaboração.

Aos amigos Joel e Osvaldo, que compartilharam o entusiasmo e o conhecimento pela pesquisa em alvenaria estrutural.

Aos amigos: Andrea, Gerson, Luciano, Luis Cláudio, Marcelo, Patrícia Lizi, Rejane, Ricardo, Robson, Rodrigo, Suzana, Valério e Yuri, porque, em nossas conversas descontraídas, encontrávamos soluções para grandes problemas da engenharia e da vida. 
Resumo

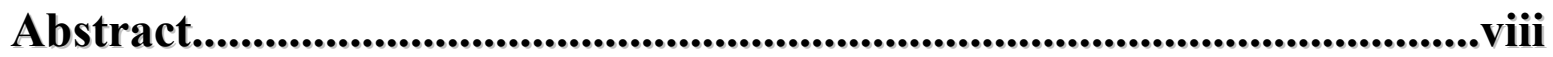

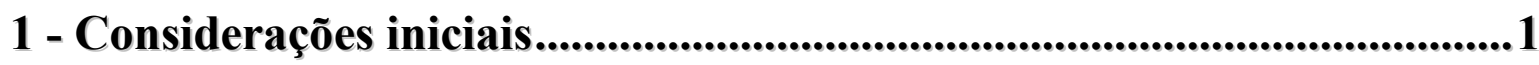

1.1 - Introdução.............................................................................................................................. 1

1.2 - Objetivos ..................................................................................................................... 4

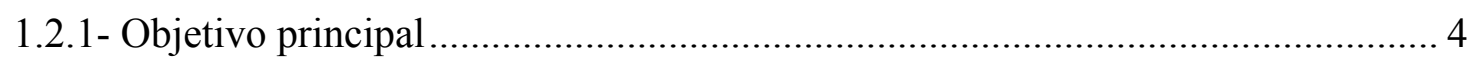

1.2.2- Objetivos secundários................................................................................. 5

1.3 - Metodologia ....................................................................................................................... 5

1.4 - Organização do trabalho ..................................................................................................... 7

2 - Interação de paredes em alvenaria estrutural não-armada .....................9

2.1 - Generalidades ......................................................................................................... 9

2.2 - Influência da interação de paredes no procedimento de distribuição das ações verticais............................................................................................................ 10

2.2.1 - Procedimento de paredes isoladas .................................................................... 10

2.2.2 - Procedimentos de grupos de paredes................................................................. 11

2.3- Pesquisas sobre a interação de paredes..................................................................... 23

2.3.1 - Medições em um edifício realizadas por Stockbridge....................................... 23

2.3.2 - Ensaios realizados por Sinha e Hendry ............................................................ 24

2.3.3 - Ensaios de torres realizados por Camacho …………………………………....... 27

2.3.4 - Ensaios de painéis realizados por Capuzzo Neto …………………………........ 30

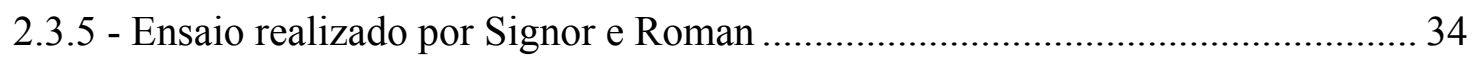

2.4 - Pesquisas sobre a eficiência das ligações de paredes............................................... 35

2.4.1 - Trabalho realizado por Lissel, Shrive e Page .................................................... 35

2.4.2 - Ensaios sobre a eficiência de ligações realizados no Brasil ................................ 37

2.5 - Pesquisas numéricas sobre a interação de paredes.................................................. 43 
2.5.1 - Análise numérica realizada por Capuzzo Neto ............................................ 43

2.5.2 - Análise numérica realizada por Ali, Sinha e Usmani ...................................... 46

2.5.3 - Modelagem numérica da interação de paredes realizada por Peleteiro............. 49

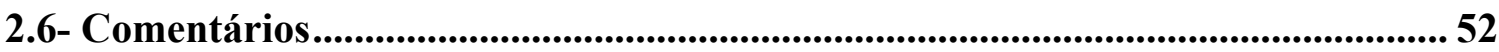

3 - Modelos físicos reduzidos.....................................................................56

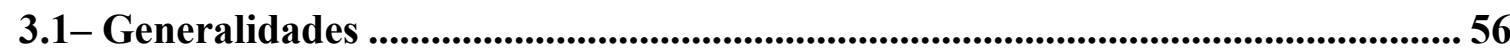

3.2 - Teoria de modelos físicos reduzidos.............................................................. 57

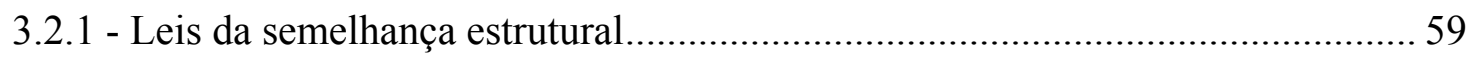

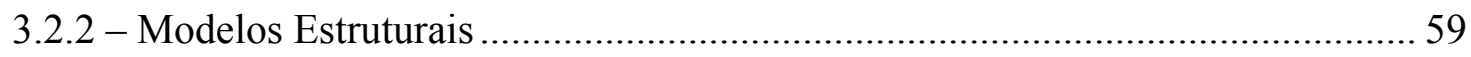

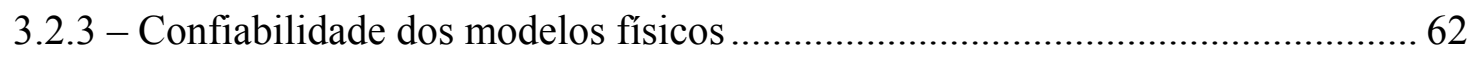

3.3- Ensaios de modelos em alvenaria …..........................................................................6 63

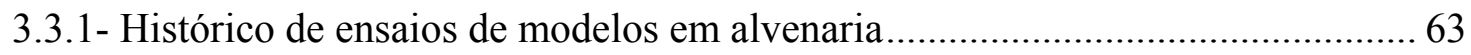

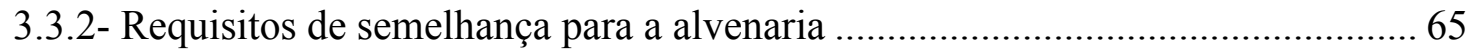

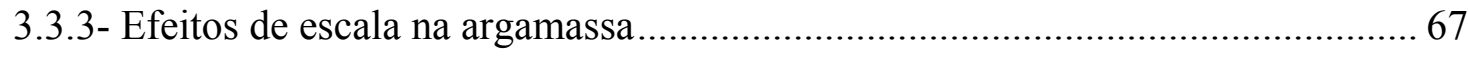

3.4- O uso de modelos físicos reduzidos em alvenaria no Brasil .............................. 68

3.4.1 - Histórico do uso de modelos em alvenaria no Brasil....................................... 68

3.4.2 - Ensaios de modelos reduzidos em alvenaria no Brasil ....................................6 69

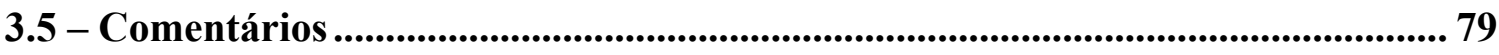

4 - Modelagem numérica da alvenaria estrutural...........................................81

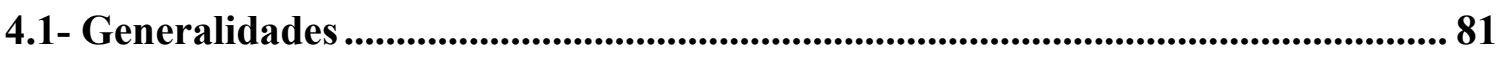

4.2- Tipos de modelagens .................................................................................. 81

4.3- Características mecânicas da alvenaria estrutural ............................................... 84

4.3.1 - Propriedades mecânicas da unidade e da argamassa ...................................... 84

4.3.2 - Propriedades mecânicas da interface unidade-argamassa ............................... 86

4.3.3 - Propriedades mecânicas do material composto ................................................... 87

4.4- Tipo da análise: bidimensional ou tridimensional ................................................. 89

4.5- Natureza da análise: linear ou não-linear .............................................................. 91

4.5.1 - Modelo para a não-linearidade do material ..................................................... 94 
5.2.1 - Procedimentos e equipamentos utilizados na caracterização dos blocos 100

5.2.2- Resultados da análise dimensional .....

5.2.3- Resultados dos ensaios de absorção de água, de massa específica e de área líquida

5.2.4- Resultados dos ensaios de resistência à compressão ....................................... 113

5.2.5- Resultados dos ensaios de tração indireta ........................................................ 115

5.2.6- Resultados dos ensaios de taxa de absorção inicial (IRA) .............................. 116

5.2.7- Resultados dos ensaios de resistência à compressão do bloco na direção paralela à junta de assentamento

5.2.8- Resultados dos ensaios de módulo de deformação do bloco............................. 119

5.2.9- Análise geral dos resultados dos blocos ......................................................... 122

5.3- Caracterização da alvenaria em escala natural e reduzida ............................. 123

5.3.1 - Procedimentos e equipamentos utilizados na caracterização da alvenaria...... 124

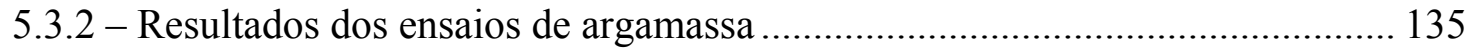

5.3.3 - Resultados dos ensaios de compressão de prismas de três blocos.................. 137

5.3.4 - Resultados dos ensaios de prismas de dois blocos submetidos à compressão

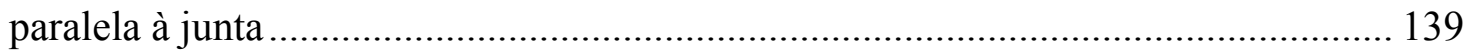

5.3.5 - Resultados dos ensaios de prismas de quatro blocos à flexão ........................ 141

5.3.6 - Resultados dos ensaios de "paredinhas” à compressão ................................. 143

5.3.7 - Ensaios de "paredinhas" à compressão na direção paralela à junta de

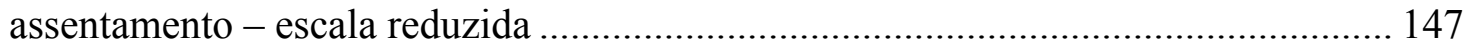

5.3.8 - Análise final dos ensaios da alvenaria ...................................................... 152

6- Análises numéricas iniciais ...........................................................157

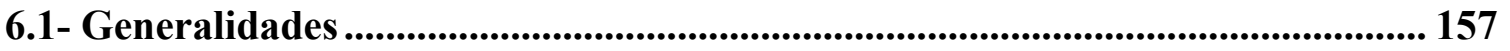


6.2- Estudo de um corpo-de-prova para determinação da resistência ao cisalhamento vertical da alvenaria. 159

6.3- Estudo de painéis de alvenaria com diferentes seções em planta 174

6.4- Modelos dos ensaios de caracterização da alvenaria 187

6.4.1 - Modelos dos ensaios na direção normal à junta de assentamento 189

6.4.2 - Modelos dos ensaios na direção paralela à junta de assentamento. 198

6.4.3 - Análise final da modelagem numérica dos ensaios de caracterização. 205

7- Ensaios dos corpos-de-prova de cisalhamento 207

7.1- Generalidades 207

7.2- Modo de execução dos corpos-de-prova de cisalhamento 208

7.3- Procedimentos e equipamentos utilizados nos ensaios 212

7.4- Resultados dos corpos-de-prova de cisalhamento sem cinta de amarração em escala reduzida $(1: 3)$ e natural $(1: 1)$ 215

7.5- Resultados dos corpos-de-prova de cisalhamento com cinta de amarração no topo do exemplar em escala reduzida $(1: 3)$

7.6- Resultados dos corpos-de-prova de cisalhamento com cinta de amarração na fiada intermediária do exemplar em escala reduzida (1:3) 225

7.7- Comparação dos resultados dos diferentes corpos-de-prova em escala reduzida 228

7.8- Análise numérica dos corpos-de-prova de cisalhamento em escala reduzida. 230 7.9- Comentários. 236

8.2- Ensaios dos painéis em escala reduzida tipo H1.............................................. 238

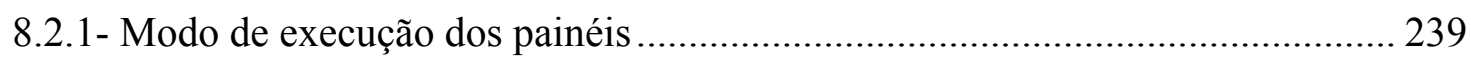

8.2.2- Procedimentos e equipamentos utilizados nos ensaios dos painéis H1 ............ 241

8.2.3- Resultados do painel H1 sem laje de topo (Painel H1-1) ................................. 243

8.2.4- Resultados do painel H1 com laje de topo (Painel H1-1a) 
8.2.5- Comparação dos resultados dos painéis H1 com e sem laje de topo 250

8.2.6- Comparação dos resultados do painel H1-1 em escala reduzida (1:3) com os ensaios de painéis em escala natural de Capuzzo Neto (2000).. 252

8.3- Ensaios dos painéis em escala reduzida tipo H2 H............................................. 255

8.3.1 - Modo de execução dos painéis ...................................................................... 256

8.3.2- Procedimentos e equipamentos utilizados nos ensaios .................................... 259

8.3.3- Resultados do painel $\mathrm{H} 2$ com cinta de respaldo e sem laje de topo (Painel $\mathrm{H} 2-1)$ 260

8.3.4- Resultados do painel H2 com cinta de respaldo e com laje de topo (Painel H2-1a) 263

8.3.5- Resultados do painel H2 com cintas intermediária e de respaldo e sem laje de topo (Painel H2-2) 266

8.3.6- Resultados do painel H2 com cintas intermediária e de respaldo e com laje de topo (Painel H2-2a). 269

8.3.7- Comparações entre os resultados dos painéis $\mathrm{H} 2$........................................ 272

8.4- Ensaio do painel em escala reduzida tipo $\mathrm{H} 2$ com dois pavimentos.................. 276

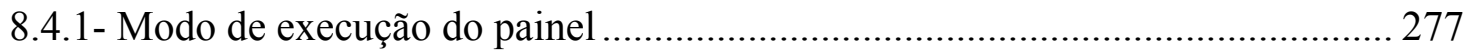

8.4.2- Procedimentos e equipamentos utilizados no ensaio ..................................... 278

8.4.3- Resultados do painel H2 com dois pavimentos.............................................. 280

8.4.4- Comparação entre os resultados do painel $\mathrm{H} 2$ com dois pavimentos e dos

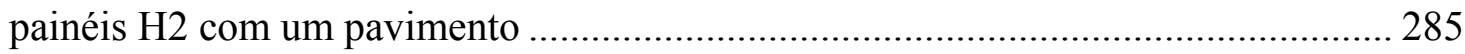

8.5- Análise numérica dos painéis de alvenaria ..................................................... 290

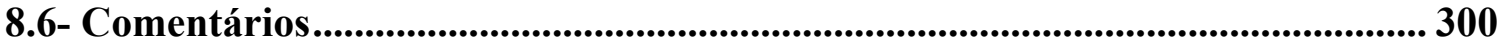

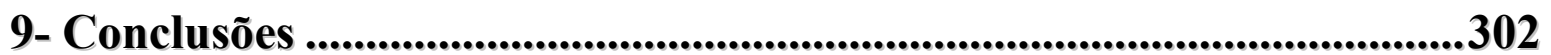

Referências bibliográficas ............................................................................311

Bibliografia complementar.......................................................................318 
CAPUZZO NETO, V. (2005). Interação de paredes em alvenaria estrutural cerâmica sob ações verticais. Tese (Doutorado) - Escola de Engenharia de São Carlos, Universidade de São Paulo, São Carlos, 2005.

O objetivo do presente trabalho é esclarecer, sob o ponto de vista estrutural, a interação de paredes em alvenaria estrutural cerâmica com amarração direta submetidas a ações verticais, por meio de análises experimentais e numéricas. Para permitir a execução de ensaios complexos, empregam-se as técnicas de modelos físicos reduzidos. São realizados estudos sobre os temas relacionados: interação de paredes de alvenaria estrutural não-armada, modelos físicos reduzidos e modelagem numérica da alvenaria. Realiza-se a caracterização dos materiais na escala reduzida e natural para determinar suas propriedades mecânicas e correlação entre as escalas. É desenvolvido numericamente e testado experimentalmente um corpo-de-prova para a determinação da resistência ao cisalhamento da alvenaria no plano vertical. Estuda-se, numérica e experimentalmente, a influência das características geométricas dos painéis de alvenaria, da presença de lajes e de cintas de amarração e do número de pavimentos. Verifica-se uma boa correlação entre os modelos reduzidos e em escala natural, quanto às principais propriedades da alvenaria, demonstrando a viabilidade de sua utilização, desde que se considere uma correta análise de semelhança. A modelagem numérica representa de forma adequada o comportamento global dos painéis de alvenaria. A cinta de amarração na fiada intermediária produz um prolongamento do comportamento linear dos painéis de alvenaria. Conclui-se, também, que a presença das lajes de concreto e a aplicação do carregamento dividido em diferentes pavimentos produzem efeitos benéficos no aspecto de resistência da alvenaria.

Palavras-chave: alvenaria estrutural; interação; modelos reduzidos; análise experimental; análise numérica; ações verticais. 


\section{ABSTRACT}

CAPUZZO NETO, V. (2005). The interaction of ceramic structural masonry walls under vertical loads. Ph.D Thesis - Escola de Engenharia de São Carlos, Universidade de São Paulo, São Carlos, 2005.

The main goal of the present work is to clarify, under the structural point of view, the interaction of walls with running bond under vertical loads, by means of experimental and numerical analyses. To allow the execution of complex tests, small-scale models techniques are used. The studies are accomplished on the related themes: interaction of structural masonry walls without reinforcement, small-scale models and masonry numerical modeling. The materials characterization is carried out in small and full scale to determine their mechanical properties and correlation between the scales. A specimen to evaluate the masonry shear strength in the vertical plane is numerically developed and experimentally tested. The influence of the geometric characteristics of the masonry panels, the slabs and bond-beams and the number of floors are also numerically and experimentally studied. A good correlation is verified between small and full scale models for the main masonry properties, demonstrating the viability of its use, since a correct similarity analysis is taken into account. The numerical modeling represents adequately the global behavior of masonry panels. The bond-beam in the intermediate course extends the linear behavior of the masonry panels. It is also concluded that the existence of the concrete slab and the load application in different levels enlarge the masonry load bearing capacity.

Keywords: structural masonry, interaction; small-scale models; experimental analysis; numerical analysis; vertical loads. 


\section{Capítulo}

\section{CONSIDERaÇões INICIAIS}

\section{1 - Introdução}

A crescente demanda por projetos de edifícios em alvenaria estrutural, com a progressiva elevação do número de pavimentos, impõe a necessidade do aprimoramento dos modelos de cálculo. Assim, busca-se uma melhor representação das possíveis trajetórias de tensões ao longo da estrutura do edifício. Sem esse melhoramento, podese incorrer em dois erros extremos: o desenvolvimento de um projeto que seja economicamente inviável ou que apresente problemas relativos às condições de segurança.

Uma questão ainda pouco entendida é o comportamento da interação de paredes sob forças verticais. De acordo com a NBR 10.837/1989 a interseção de paredes pode ocorrer por amarração direta ou indireta. A amarração direta é realizada com $50 \%$ dos blocos penetrando alternadamente na parede interceptada (Figura 1.1a). Na amarração indireta, indicada para o caso de juntas a prumo, utilizam-se barras metálicas convenientemente dispostas ou em forma de treliças (ou telas) soldadas, ou mesmo peças em forma de chapa metálica de resistência comprovada (Figura 1.1b).
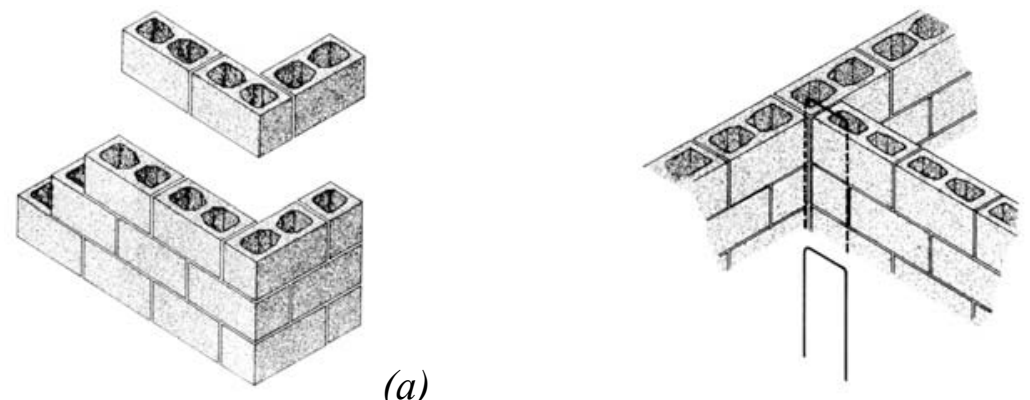

(a)

Figura 1.1 - Tipos de amarração de paredes. ABCI (1990) 
A interação de paredes adjacentes somente ocorrerá se na ligação entre esses elementos puderem se desenvolver as forças de interação. No caso dos cantos e bordas, a principal característica a ser analisada para se verificar a existência das forças de interação é a amarração dos blocos componentes. Nesse caso, é praticamente impossível a ocorrência de deslocamentos relativos entre as paredes, a menos que se verifique uma ruptura no local. Portanto, havendo essa amarração, forças de interação de valores significativos estarão garantidas, ver Figura 1.2.

Figura 1.2 - Interação de paredes em um canto. Corrêa e Ramalho (1998b)

Já a inexistência de amarração entre as paredes praticamente elimina a possibilidade da ocorrência das forças de interação e, conseqüentemente, o espalhamento e a uniformização das forças que atuem em um ou outro elemento. Para o caso de amarração indireta não há um consenso sobre o grau de interação das paredes. Em relação a esse tema, vêm sendo realizados estudos sobre a avaliação da eficiência das ligações entre paredes de alvenaria estrutural de blocos cerâmicos em escala reduzida e natural sujeitas às ações verticais [CAMACHO et al. (2001) e $\operatorname{SILVA}(2003)]$.

Existem poucos e divergentes estudos internacionais sobre a interação de paredes de alvenaria estrutural. Sinha e Hendry (1979) consideram que paredes ortogonais, mesmo com amarração direta, trabalham isoladamente, Curtin et al (1984) admitem a interação de paredes adjacentes, por meio da transferência de força de uma parede para outra. Sutherland apud Hendry (1981) aceita a interação de um modo indireto, considerando que paredes adjacentes trabalham em conjunto. Lissel et al. (2000) verificam a influência do tipo de amarração das interseções de paredes no comportamento da alvenaria após perceberem significativas diferenças nos ensaios de paredes diafragmas com diferentes tipos de ligação.

•SUTHERLAND, R.J.M. (1969). Design Engineer's Approach to Masonry Construction. In: Designing, Engineering and Constructing with Masonry Products . Houston, ed. F.B. Johnson, p.375-385. 
Nas interseções das paredes, além das amarrações citadas anteriormente, é usual a presença de cintas, que são fiadas compostas por blocos canaleta preenchidos com graute e armadura (Figura 1.3). A NBR 10.837/1989 define a cinta da seguinte maneira: “elemento construtivo estrutural apoiado continuamente na parede, ligado ou não às lajes ou às vergas das aberturas, e que transmite cargas para as paredes resistentes, tendo função de amarração". Neste caso, também não se sabe com certeza o quanto e como essas cintas auxiliam na transferência de forças entre paredes. Não é encontrado nenhum estudo internacional que aborde esse objeto.

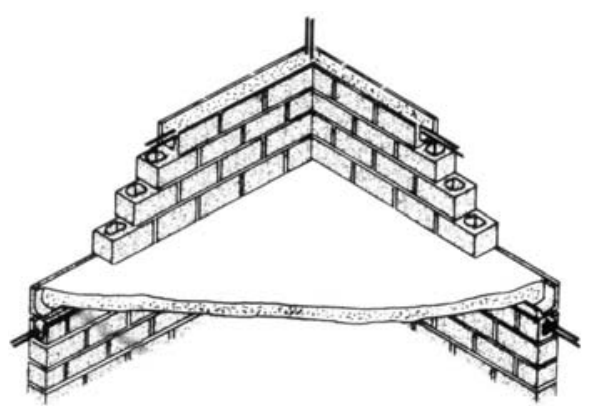

Figura 1.3 - Cinta de amarração. ABCI (1990)

A laje de concreto é outro elemento que também pode contribuir na interação das paredes de alvenaria estrutural. Semelhantemente às cintas de amarração, não há indicações de como as lajes influenciam a transferência das forças verticais entre as paredes que se interceptam.

A reduzida investigação internacional no assunto relaciona-se, provavelmente, à prática usual de se construírem edifícios de poucos pavimentos em alvenaria e também devido às questões de conforto ambiental que exigem uma maior espessura das paredes. Nesses casos a consideração de funcionamento isolado das paredes não leva a problemas econômicos, mesmo com o desprezo da interação, já que as resistências mínimas exigidas por normas e/ou a espessura necessária para garantir o conforto ambiental são mais do que suficientes para a absorção dos esforços provenientes da consideração das paredes isoladas. Entretanto, esse assunto ganha interesse e necessidade de investigação, devido à importância de mensurar a interação de paredes e verificar a sua influência tanto para situações de ruptura, estado limite último (ELU), quanto para situações em serviço, estado limite de serviço (ELS).

No Brasil pode-se admitir que a primeira pesquisa que avalia o comportamento da interseção de paredes sob ações verticais, mesmo não sendo o objetivo principal, é a realizada por Camacho (1995), que ensaia torres de alvenaria de blocos cerâmicos em 
modelo físico reduzido com paredes submetidas a diferentes carregamentos. Já em 1.999 Capuzzo Neto (2000) realiza ensaios de painéis em formato " $\mathrm{H}$ " de blocos cerâmicos em escala natural, com o objetivo específico de verificar a interação de paredes adjacentes. Camacho et al. (2001) e Silva (2003) realizam ensaios em painéis de alvenaria de blocos cerâmicos em modelo reduzido e natural, respectivamente, visando obter e comparar a eficiência de diferentes tipos de ligações na interseção de paredes. Corrêa e Page (2001) apresentam um modelo simples para a análise da interação de paredes submetidas às ações verticais. Signor e Roman (2002) iniciam na Universidade de Santa Catarina estudos sobre a transferência de cargas verticais entre paredes ortogonais, também utilizando blocos cerâmicos em escala reduzida.

Verifica-se que apesar dos estudos citados, persiste a necessidade de uma maior investigação tanto numérica como experimental para que se possam compreender os níveis de interação na alvenaria estrutural. Para isso, é fundamental determinar a capacidade máxima de transmissão de forças nas regiões de interseções de paredes. Também é importante estudar as influências das dimensões em planta do painel de alvenaria, do número de pavimentos e da presença de lajes de concreto e cintas na distribuição das ações verticais. Dentro deste contexto é recomendável a utilização de modelos físicos reduzidos para o estudo em questão, graças à diminuição de custos e dificuldades operacionais. Tal redução é relativa a dois fatores: diminuição dos equipamentos de aplicação de força e seus respectivos pórticos de reação, e redução nos custos de fabricação, preparação e remoção da estrutura.

Vale ressaltar que no caso do dimensionamento da alvenaria sob ações horizontais é prática usual e estabelecida em normas (nacionais e internacionais) a inclusão da contribuição dos flanges, isto é, a hipótese do trabalho conjunto das paredes ortogonais. A única restrição é que a tensão de cisalhamento vertical não exceda os limites recomendados.

\section{2 - Objetivos}

\subsection{1- Objetivo principal}

O objetivo do presente trabalho é esclarecer, sob o ponto de vista estrutural, a interação de paredes em alvenaria estrutural cerâmica com amarração direta submetidas a ações verticais, por meio de análises experimentais e numéricas. Tal fenômeno está diretamente ligado à distribuição dessas ações ao longo da altura de um edifício de 
múltiplos andares em alvenaria. Portanto, é necessária uma melhor compreensão da interação de paredes para sua utilização em projetos estruturais. Ressalta-se que é estudado apenas o caso de amarração direta de paredes em alvenaria estrutural cerâmica não-armada.

\subsection{2- Objetivos secundários}

Para se alcançar o objetivo principal da pesquisa, é fundamental a realização de diversos estudos do comportamento da alvenaria estrutural e da interação de paredes. Esses estudos são aqui definidos como objetivos secundários da pesquisa, e estão listados a seguir:

$>$ Verificação de semelhanças e de diferenças entre as escalas por meio da caracterização da alvenaria em escala reduzida (1:3) e em escala natural (1:1);

$>$ Definição de modelos numéricos para a representação do comportamento da alvenaria;

> Proposição de um ensaio simples para a verificação da resistência ao cisalhamento vertical da ligação de paredes em planos ortogonais;

> Estudo teórico e experimental das influências das dimensões em planta do painel de alvenaria em formato " $H$ ", do número de pavimentos e da presença de lajes de concreto e cintas na distribuição das ações verticais.

\section{3 - Metodologia}

A metodologia empregada na pesquisa é apresentada esquematicamente na Figura 1.4.

No trabalho emprega-se tanto a modelagem física reduzida quanto a modelagem numérica. Como se verifica que as hipóteses de semelhanças são aferidas, os modelos físicos reduzidos representam o comportamento mecânico da alvenaria em escala natural. Desse modo, como a modelagem numérica é capaz de representar o comportamento mecânico da alvenaria em escala reduzida, através da calibração do modelo teórico, ela também o será para a escala natural, pois o fenômeno mecânico é semelhante para as duas escalas. Por este motivo, todas as análises numéricas da pesquisa são realizadas apenas para os ensaios em modelos físicos reduzidos, que são em maior quantidade e complexidade. Apresenta-se na Figura 1.5 um esquema das relações entre as modelagens e a alvenaria em escala natural. 


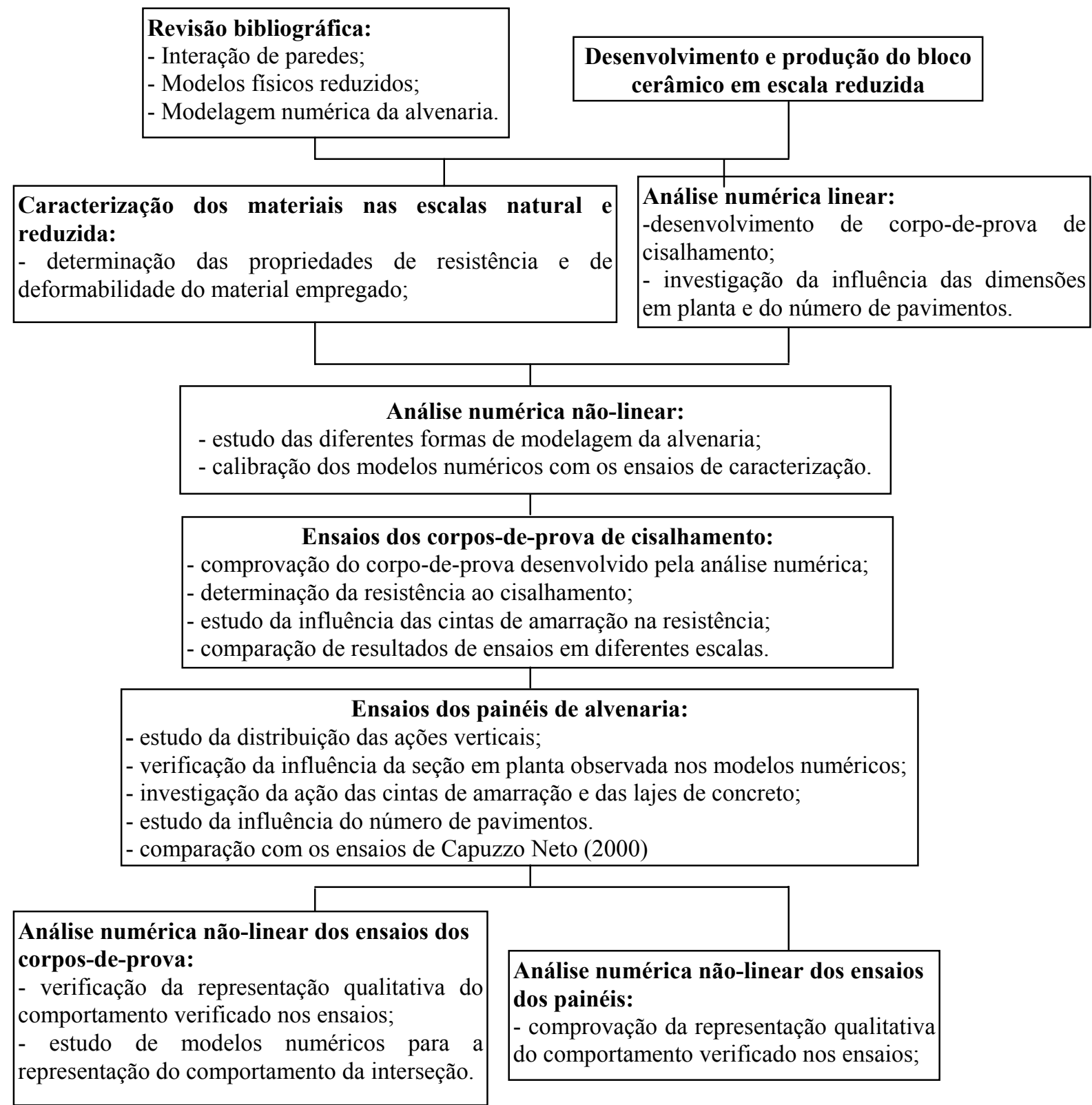

Figura 1.4 - Esquema da metodologia empregada na pesquisa.

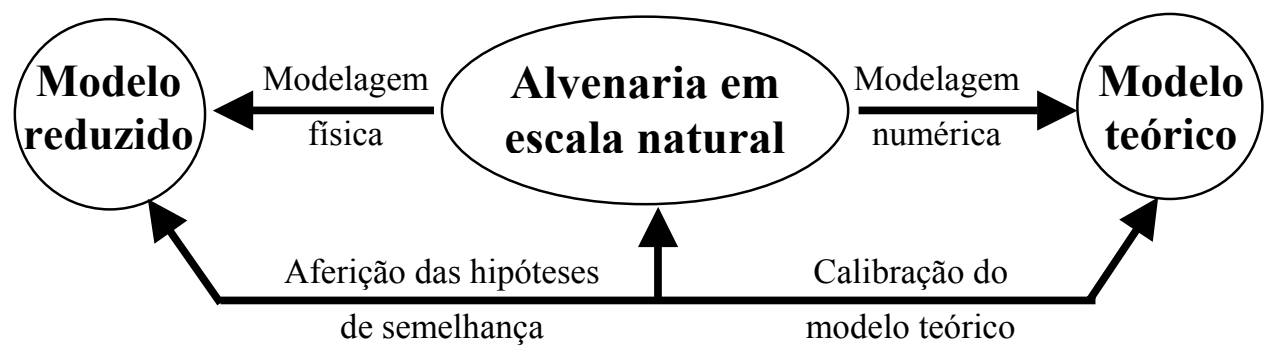

Figura 1.5 - Relações entre as modelagens e a alvenaria em escala natural 


\section{4 - Organização do trabalho}

No capitulo 2 realiza-se uma revisão bibliográfica sobre a interação de paredes em alvenaria estrutural não-armada. Apresenta-se o estudo da influência da interação no procedimento de distribuição das ações verticais, além de serem descritas as pesquisas experimentais e numéricas sobre o tema.

O estudo dos modelos físicos reduzidos é feito no capítulo 3. Esse capítulo aborda a teoria de modelos e apresenta resultados experimentais que comprovam a viabilidade de sua utilização em alvenaria, inclusive com ensaios de modelos já realizados no Brasil por outros pesquisadores.

Já no capítulo 4 apresenta-se a modelagem numérica da alvenaria estrutural. São discutidos os tipos de modelagens utilizados, as características mecânicas envolvidas, os tipos de análise (bidimensional e tridimensional) e as naturezas da análise (linear ou não-linear).

Os ensaios de caracterização dos blocos, prismas e paredinhas em escala reduzida, bem como em escala natural, visando obter propriedades de resistência e deformabilidade do material empregado estão no capítulo 5. O objetivo dessa caracterização é verificar semelhanças e diferenças do comportamento entre a alvenaria na escala reduzida e natural, visando validar a extrapolação dos resultados obtidos nos modelos reduzidos para o caso natural. Essas características da alvenaria também são importantes para a realização de uma coerente análise numérica (linear e/ou não-linear).

No capítulo 6 são realizadas as análises numéricas iniciais. Procura-se desenvolver, por meio de modelos numéricos, um corpo-de-prova para a determinação da resistência ao cisalhamento vertical da região de interseção de paredes com amarração direta. Também se investiga a influência de parâmetros geométricos (dimensões em planta e altura do painel) na distribuição das ações verticais, auxiliando, dessa forma, na escolha de dimensões representativas para painéis de alvenaria em formato "H" a serem ensaiados. Por fim, são modelados numericamente os ensaios de caracterização da alvenaria, considerando-se o comportamento não-linear dos materiais. É uma etapa importante para definição dos parâmetros da modelagem numérica, a serem empregados nas etapas seguintes.

Os ensaios dos corpos-de-prova de cisalhamento estão apresentados no capítulo 7. Comprova-se a eficácia do corpo-de-prova desenvolvido pela análise numérica, determinando a resistência ao cisalhamento vertical da alvenaria. São comparados os 
resultados de corpos-de-prova na escala natural e reduzida, para demonstrar a viabilidade dos modelos físicos reduzidos. Investiga-se, também, a influência das cintas de amarração na resistência ao cisalhamento. Ao final do capítulo, realiza-se uma análise numérica não-linear dos ensaios dos corpos-de-prova comprovando-se que qualitativamente os modelos numéricos representam o comportamento verificado nos ensaios. Estuda-se, também, diferentes formas para a representação do comportamento da interseção de paredes por meio de modelos numéricos.

O estudo da distribuição das ações verticais é feito por meio de ensaios dos painéis de alvenaria estrutural em escala reduzida apresentados no capitulo 8 . Investigase experimentalmente a influência das dimensões em planta dos painéis, além da ação das cintas de amarração e das lajes de concreto na transferência de forças verticais entre as paredes que se interceptam. Realiza-se, também, a comparação do comportamento de painéis em escala reduzida com os painéis em escala natural ensaiados por Capuzzo Neto (2000), demonstrando a representatividade dos modelos físicos reduzidos. Ainda é realizado um ensaio com mais de um pavimento para se estudar como se dá a distribuição das ações verticais quando o carregamento é aplicado em níveis diferentes. Por fim, faz-se uma análise numérica não-linear de todos os ensaios de painéis de alvenaria para demonstrar que os modelos numéricos são capazes de representar qualitativamente o comportamento observado nos ensaios.

No capítulo 9 são expostas as conclusões do trabalho, bem como sugestões para futuras pesquisas nesta área. 


\section{Capítulo \\ 2 INTERAÇÃO DE PAREDES EM ALVENARIA ESTRUTURAL NÃO-ARMADA}

\section{1 - Generalidades}

Este capítulo faz um apanhado geral das pesquisas relacionadas com a interação de paredes em alvenaria estrutural não-armada. Investiga-se a sua influência no procedimento de distribuição das ações verticais, apresentando-se diversos processos de determinação das ações atuantes nas paredes, que variam de acordo com a forma de considerar ou não a transferência de esforços entre paredes interligadas.

São apresentados resultados de diferentes trabalhos experimentais que envolvem o estudo da distribuição das ações verticais em painéis de alvenaria, confirmando ou dando indícios da existência da interação de paredes. São, também, analisados trabalhos que estudam a capacidade de transmissão de forças de diferentes tipos de ligação de paredes, fator fundamental para a análise da interação. É com base na eficiência da ligação que se pode admitir ou desconsiderar a interação das paredes.

Apresentam-se, ainda, trabalhos envolvendo análises numéricas sobre a interação de paredes. Neste caso, o objetivo é demonstrar a viabilidade do uso de modelos numéricos para representar o fenômeno da transferência de forças, além de apontar as dificuldades encontradas nesse tipo de modelagem. Ressalta-se que no capítulo 4 será apresentada uma revisão mais aprofundada sobre a modelagem numérica da alvenaria estrutural não-armada.

Ao final do capítulo, são feitos comentários sobre o desenvolvimento das pesquisas sobre o tema, apresentando-se os pontos já estabelecidos e os que ainda necessitam uma maior investigação. 


\section{2 - Influência da interação de paredes no procedimento de distribuição das ações verticais}

A maior influência da consideração da interação no dimensionamento estrutural está no procedimento de distribuição das ações verticais, pois a trajetória das tensões ao longo da altura de um edifício de alvenaria estrutural é dependente das interseções de paredes. Hendry (1981) comenta que, de acordo com o procedimento adotado, a distribuição das ações verticais atuantes no pavimento para um complexo arranjo de paredes pode levar a consideráveis diferenças na estimativa de ações para as paredes.

$\mathrm{Na}$ literatura técnica encontram-se dois tipos gerais de procedimentos de distribuição das ações verticais: um primeiro que não considera a possibilidade de interação, sendo as paredes tratadas isoladamente, e um segundo em que as paredes são consideradas como grupos, existindo variações na forma de se levar em conta a interação. Ressalta-se que para a consideração da interação, a amarração deve ser a direta, enquanto não estejam disponíveis informações sobre a eficiência da amarração indireta.

\subsection{1 - Procedimento de paredes isoladas}

Segundo Hendry (1981) um procedimento usual é a subdivisão das lajes em áreas de contribuição, formadas por triângulos e trapézios, que distribuirão as ações para as correspondentes paredes, de maneira análoga à determinação de ações em vigas de concreto armado (Figura 2.1). Para lajes retangulares isto é provavelmente razoável, porém deve-se notar que a distribuição das ações não é uniforme ao longo do comprimento da parede, sendo, na verdade, mais intensa na região central. No entanto, é admissível que esta não uniformidade diminua gradualmente ao longo da altura da parede, não existindo nos pavimentos inferiores dos edifícios. Este procedimento é conhecido como o das paredes isoladas, por tratar cada parede como um elemento independente, não considerando a interação com as demais. 


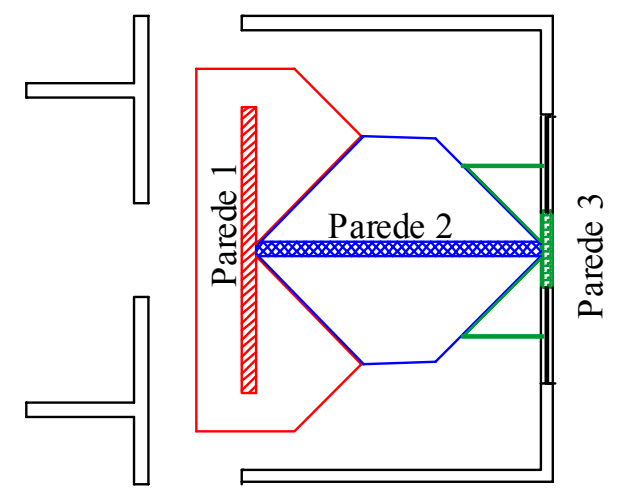

Figura 2.1 - Procedimento das paredes isoladas. Adaptado de Hendry (1981).

\subsection{2 - Procedimentos de grupos de paredes}

Alguns procedimentos de distribuição das ações verticais consideram que as paredes interligadas comportam-se como um grupo de paredes. Este funcionamento como um conjunto pode ser explicado através da interação entre as paredes. Segundo Curtin et al. (1984) a maioria das paredes são construídas com a amarração direta dos blocos, deste modo o travamento das unidades permite a distribuição das ações verticais e laterais ao longo do comprimento e altura dos painéis de alvenaria. A Figura 2.2a mostra o espalhamento de uma força parcialmente distribuída, sendo geralmente tomado a $45^{\circ}$ com a vertical. Quando a ligação entre paredes adjacentes é contínua, devido ao inter-travamento dos blocos, pode-se também admitir que parte da força parcialmente distribuída transfere-se de uma parede a outra (Figura 2.2b). Neste caso, Curtin et al. (1984) comentam que o espalhamento deve depender da rigidez da parede adjacente, já que a força transferida será excêntrica. Desta forma, acredita-se que a seção geométrica em planta dos painéis de alvenaria deva influenciar o fenômeno da interação.

Sobre o espalhamento de forças verticais a NBR 10.837/1989 no item 4.3.3.1.1 diz: "nas paredes estruturais, uma carga concentrada ou parcialmente distribuída na situação da Figura 2.3 pode ser suposta repartida uniformemente em seções horizontais limitadas por dois planos inclinados a $45^{\circ}$ sobre a vertical e passando pelo ponto de aplicação de carga ou pelas extremidades da faixa de aplicação". A norma britânica BS 5628 (1992), a norma australiana AS 3700 (1998) e o código americano ACI 530-92 (1995) também indicam este espalhamento a $45^{\circ}$, observando que nos dois primeiros casos o espalhamento é limitado até uma certa fração da altura da parede, 0,4 e 0,5 respectivamente. Já o código europeu EUROCODE 6 (1997), mais conservador, propõe um espalhamento a $30^{\circ}$, limitando-o à metade da altura da parede. 


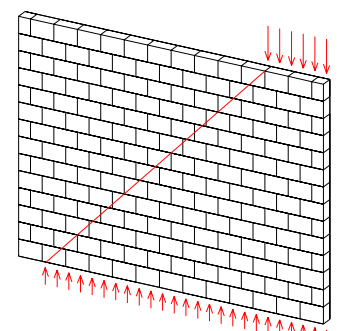

(a)

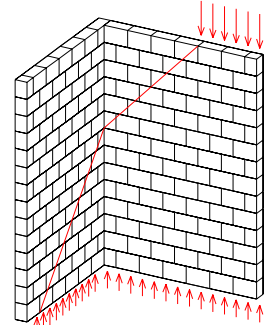

(b)

Figura 2.2 - Espalhamento de uma força parcialmente distribuída. Adaptado de Curtin et al (1984).

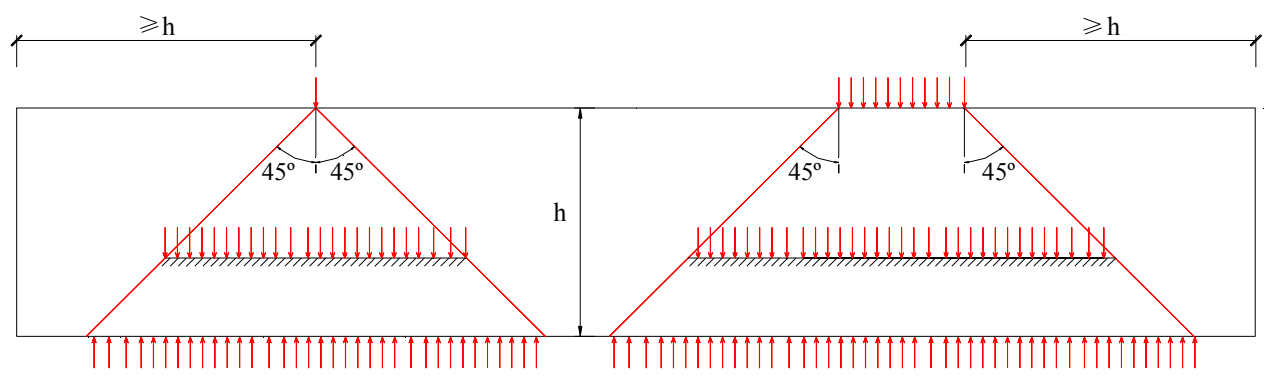

Figura 2.3- Espalhamento segundo NBR 10.837/1989

Este espalhamento de forças, permitido por diferentes normas internacionais, juntamente com a adoção da transmissão de força entre paredes em planos distintos são as idéias iniciais para o desenvolvimento de alguns procedimentos de distribuição das ações verticais. Nem todos os procedimentos consideram diretamente a interação das paredes, mas analisando-os cuidadosamente percebe-se que a interação é implicitamente considerada.

\subsubsection{1 - Grupos de paredes - Sutherland}

Um procedimento desenvolvido por Sutherland apud Hendry (1981) é a divisão do pavimento em áreas de contribuição em torno de grupos de paredes interligadas. Cada grupo de paredes é tratado, em planta, como uma seção transversal única submetida à ação correspondente a uma referida área do pavimento. Admite-se a distribuição linear das tensões normais, computando-se a excentricidade da resultante das ações do pavimento em relação ao centróide do grupo de paredes (Figura 2.4). Portanto, ao permitir a distribuição linear de tensão normal ao longo do grupo, está-se reconhecendo que a ligação entre as paredes é perfeita, podendo-se concluir que a interação das paredes neste procedimento é considerada indiretamente. Hendry (1981)

- SUTHERLAND, R.J.M. (1969). Design Engineer's Approach to Masonry Construction. In: Designing, Engineering and Constructing with Masonry Products . Houston, ed. F.B. Johnson, p.375-385. 
comenta que este procedimento é provavelmente o mais correto, embora exija um maior trabalho de cálculo quando comparado ao procedimento de paredes isoladas.

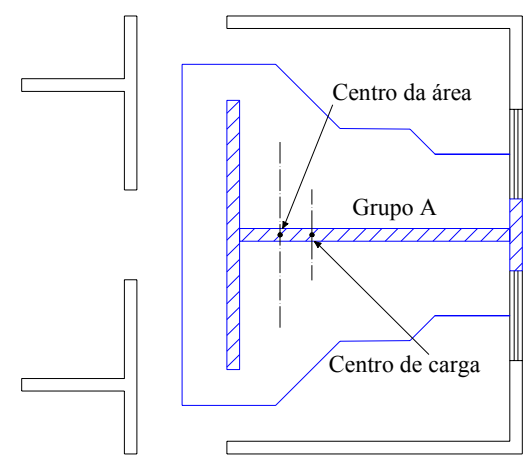

Figura 2.4-Grupo de paredes isoladas. Adaptado de Hendry (1981).

Ressalta-se que Sutherland não considera a contribuição das restrições horizontais originadas pela presença da laje, o que levaria a uma redução da excentricidade das ações.

\subsubsection{2 - Grupos isolados de parede}

Andrade (s.d) propõe um método prático para a distribuição e uniformização das ações ao longo da altura de um edifício de alvenaria estrutural. Inicialmente deve-se fazer a divisão da estrutura de alvenaria em subestruturas, também denominadas de grupos de parede por Corrêa e Ramalho (1998b). Os grupos podem ser conceituados como sendo partes da estrutura onde as ações de uma parede influenciam as de outra, devido ao fenômeno da interação. Parte da ação de uma parede mais solicitada é transmitida para uma menos solicitada, evidenciando uma tendência de uniformização das ações atuantes nas paredes que compõem o grupo. A definição de grupo é puramente prática, não existindo critério fixo para a sua delimitação. Para um edifício de quatro pavimentos, um procedimento aceitável seria a interrupção dos grupos nas regiões com aberturas e em grandes lances de parede sem aberturas, por se acreditar que nesses casos não seja possível a uniformização total devido a altura restrita para a distribuição das ações (Figura 2.5). A seguir, procede-se a homogeneização das ações verticais nas paredes de um pavimento e, dessa forma, qualquer carregamento que esteja atuando sobre uma parede de um grupo é distribuído sobre as demais, resultando sempre num único valor de tensão normal média para cada grupo. 


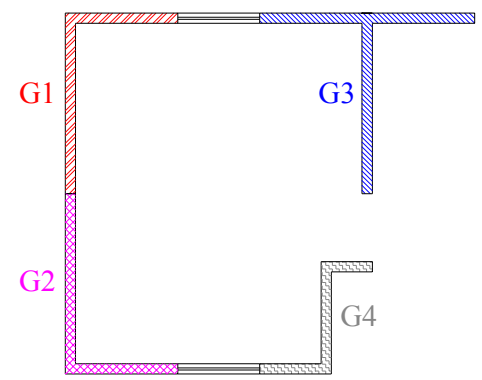

Figura 2.5 - Planta exemplo de grupos.

O procedimento de homogeneização das ações verticais consiste em somar as ações distribuídas e concentradas que estão atuando em um grupo e, então, redistribuílas uniformemente para as paredes que compõem esse grupo. Vale ressaltar que as ações atuantes nos trechos sobre aberturas são transformadas em forças concentradas aplicadas nos grupos adjacentes. O algoritmo do processo é dado abaixo:

$$
\mathrm{q}=\Sigma\left(\mathrm{q}_{\mathrm{oi}} \ell_{\iota}+\mathrm{P}_{\mathrm{i}}\right) / \Sigma \ell_{\iota}
$$

Sendo:

$\mathrm{q}$ = ações homogeneizadas uniformemente distribuídas no nível considerado;

$\mathrm{q}_{\mathrm{oi}}=$ ações uniformemente distribuídas nas paredes do grupo no nível considerado;

$\mathrm{P}_{\mathrm{i}}=$ ações concentradas nas paredes do grupo no nível considerado;

$\boldsymbol{\ell}=$ comprimento da parede i que constitui o grupo.

\subsubsection{3 - Grupos de parede com interação}

Corrêa e Ramalho (1998c), após simulações de modelos em elementos finitos, propõem um procedimento que, além da homogeneização proposta no item anterior, permite que diferentes grupos interajam segundo uma determinada taxa, formando um macrogrupo. É fundamental que se avalie corretamente a possibilidade real de ocorrência das forças de interação, tanto em cantos e bordas como em regiões de abertura (Figura 2.6). Também é necessário especificar que grupos de paredes estão interagindo, e com que taxa. Essa taxa pode ser estimada mediante modelo teórico, como por exemplo, o espalhamento a $45^{\circ}$, ou por procedimento experimental disponível. 

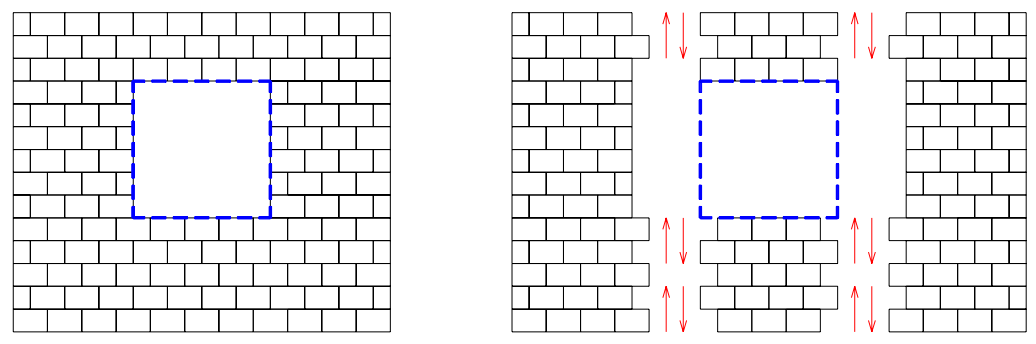

Figura 2.6 - Funcionamento do lintel. Corrêa e Ramalho (1998c)

A taxa de interação representa o quanto da diferença de cargas, entre grupos que interagem, deve ser uniformizado entre dois pavimentos sucessivos. Considerar que esta taxa seja igual a 100\% significa que há a homogeneização total das ações, funcionando o macrogrupo como se fosse um único grupo. Caso a taxa seja igual a zero, não haverá nenhuma transferência de ações, comportando-se os grupos como isolados. Para valores intermediários, por exemplo, uma taxa de $20 \%$, indica que $80 \%$ da diferença é mantida. Assim, grupos com uma ação maior que a média do macrogrupo transmitem parte dessa diferença para grupos com ações menores que essa média. Na Figura 2.7 é apresentado um exemplo de macrogrupo, onde os grupos são interligados tanto pelo trecho sobre uma abertura de janela como sobre uma abertura de porta.

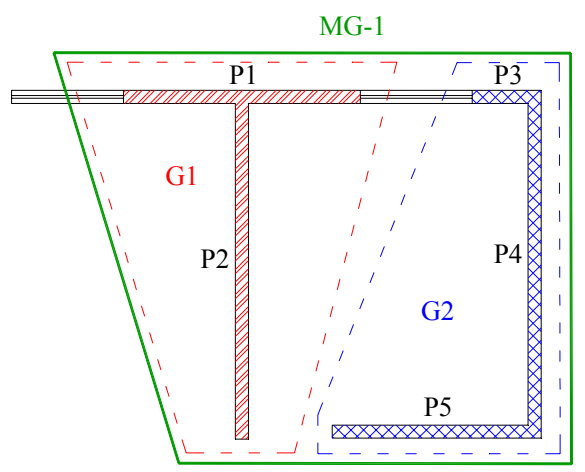

Figura 2.7- Exemplo de macrogrupo

Neste procedimento também há a liberdade para utilizar a taxa de interação do macrogrupo de acordo com o tipo de ligação existente. Grupos ligados pelos trechos de alvenaria acima e abaixo das janelas podem proporcionar uma taxa de interação maior que grupos ligados somente pelo trecho acima das portas. Uma alternativa possível é a consideração de cada parede como um grupo, permitindo estabelecer uma taxa de interação entre elas, sem a necessidade de adotar a uniformização total.

A implementação desse procedimento de macrogrupos pode ser resumida pelas seguintes expressões: 


$$
\begin{aligned}
& \mathrm{q}_{\mathrm{m}}=\left(\mathrm{q}_{1} \cdot h_{1}+\mathrm{q}_{2} \cdot l_{2}+\ldots+\mathrm{q}_{\mathrm{n}} \cdot / \mathrm{n}\right) /\left(h_{1}+/ 2+\ldots+/ n\right) \\
& \mathrm{d}_{\mathrm{i}}=\left(\mathrm{q}_{\mathrm{i}}-\mathrm{q}_{\mathrm{m}}\right) *(1-\mathrm{t}) \\
& \mathrm{q}_{\mathrm{i}}{ }^{*}=\mathrm{q}_{\mathrm{m}}+\mathrm{d}_{\mathrm{i}}
\end{aligned}
$$

sendo: $\mathrm{n}$ = número de grupos componentes;

$\mathrm{q}_{\mathrm{i}}$ = ações uniformemente distribuídas do grupo i no nível considerado;

$\ell_{i}=$ comprimento do grupo $\mathrm{i}$;

$\mathrm{q}_{\mathrm{m}}=$ ação média uniformemente distribuída do macrogrupo no nível considerado;

$\mathrm{d}_{\mathrm{i}}=$ diferença de ações do grupo i no nível considerado;

$\mathrm{t}$ = taxa de interação;

$\mathrm{q}_{\mathrm{i}}{ }^{*}=$ ações uniformemente distribuídas do grupo i levando em conta a interação no nível considerado.

\subsubsection{4 - Método proposto por Parsekian \& Franco}

O método de distribuição dos esforços verticais proposto por Parsekian e Franco (2002) tem como base as características geométricas das paredes envolvidas: comprimento, altura do pavimento, presença de aberturas e o número de pavimentos. A distribuição das ações é fundamentada na idéia do espalhamento de forças verticais a $45^{\circ}$. Por considerar a transferência de forças em regiões com aberturas, o processo permite o espalhamento de uma ação atuante em uma parede para diversas outras. A distribuição pode até mesmo abranger todas as paredes do edifício, dependendo apenas de que o número de pavimentos seja suficiente para isso.

A Figura 2.8 mostra o caso da interação de três paredes com carregamentos distintos apresentado por Parsekian e Franco (2002). O espalhamento da ação atuante na Parede 01 é exibido na Figura 2.9. Já a Figura 2.10 apresenta a distribuição da ação atuante na Parede 02 para as Paredes 01 e 03. A distribuição da ação atuante na Parede 03 não é exibida, mas seu comportamento é bem similar ao caso da Parede 01.

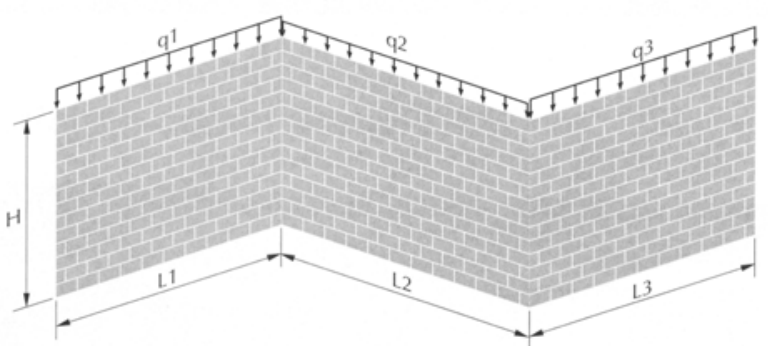

Figura 2.8 - Interação de três paredes. Parsekian e Franco (2002) 


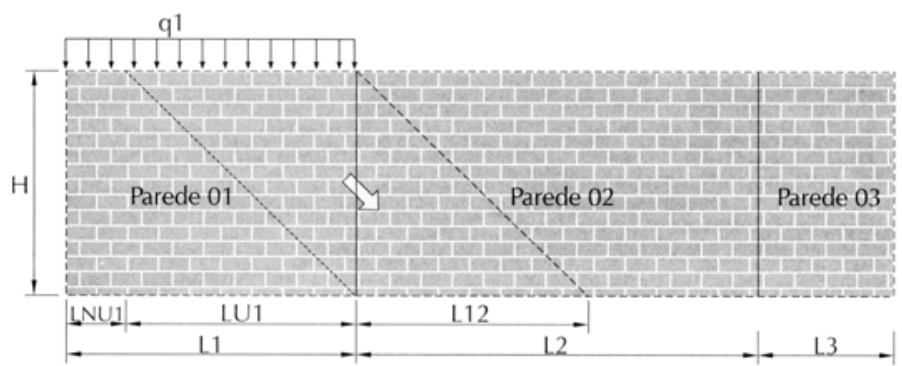

Figura 2.9 - Distribuição da ação atuante na Parede 01. Parsekian e Franco (2002)

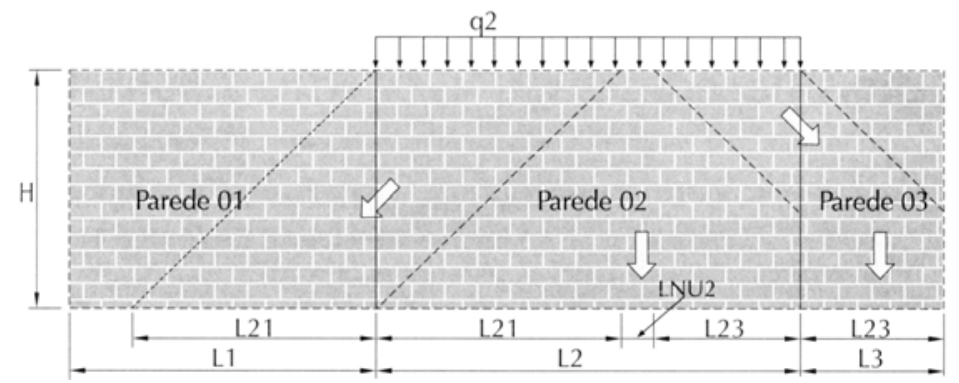

Figura 2.10 - Distribuição da ação atuante na Parede 02. Parsekian e Franco (2002)

Os autores do método também apresentam hipóteses para a consideração da distribuição da ação vertical em paredes com aberturas (ver Figura 2.11). Primeiramente adotam que a ação aplicada de um lado da abertura tem um espalhamento a $45^{\circ}$, semelhante ao caso anterior. O comprimento de distribuição $(\mathrm{C} 1)$ é a distância entre aberturas $(\mathrm{H}-\mathrm{Ha})$ menos o comprimento da abertura (La). Para considerar que metade das ações atuantes sobre a verga da abertura seja transferida para a parede, emprega-se um segundo comprimento de distribuição (C2), que é igual a metade da largura da abertura $(\mathrm{La} / 2)$. Portanto, a região de influência total é dada por: $\mathrm{C} 1-\mathrm{C} 2=\mathrm{H}-\mathrm{Ha}-$ $\mathrm{La} / 2$. Como no caso sem abertura, a força transferida para a parede é uniformemente distribuída ao longo do comprimento da parede.

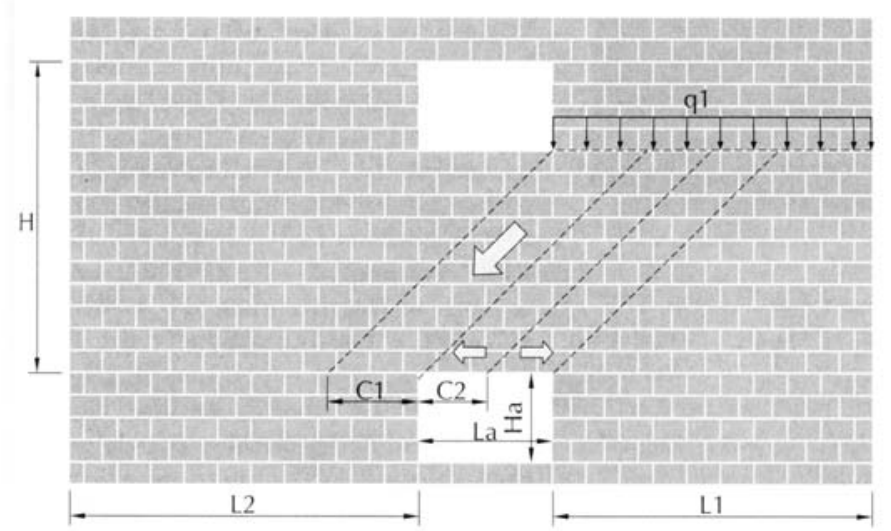

Figura 2.11 - Distribuição em regiões com aberturas. Parsekian e Franco (2002) 
Parsekian e Franco (2002) apresentam o algoritmo para aplicação do método proposto em um caso geral:

1- Seja um pavimento com $\boldsymbol{n}$ paredes, cada qual com um respectivo carregamento distribuído $\boldsymbol{q} \boldsymbol{n}$ e de comprimento $\boldsymbol{L n}$.

2- Determina-se o comprimento de influência das paredes laterais para cada parede da seguinte forma:

- $\mathrm{x}=1 . . \mathrm{n}$ ( $\mathrm{x}$ variando de 1 até $\mathrm{n})$

- y=1..n (y variando de 1 até $n)$

$-\operatorname{Lxy} \leq\left\{\begin{array}{c}\mathrm{Lx} \\ \mathrm{Ly} \\ \mathrm{H}-\mathrm{Ha}-\mathrm{La} / 2\end{array}\right.$

- Ha e La $=0$, quando não há aberturas entre paredes

- Lxy=0, quando PARx e PARy não se interceptam

- $\operatorname{Lxx}=0$

3- Calculam-se as ações distribuídas para as paredes laterais e as não transferidas de acordo com os subseqüentes passos:

- $\mathrm{x}=1 . . \mathrm{n}$ ( $\mathrm{x}$ variando de 1 até $\mathrm{n})$

- comprimento de uniformização: $L U x \leq\left\{\begin{array}{c}\sum_{\mathrm{y}=1 . . .} \mathrm{Lxy} \\ \mathrm{Lx}\end{array}\right.$

- comprimento da ação não uniformizada: LNUx $=$ Lx - LUx

- carga distribuída uniformizada: $q x u=\frac{q x \cdot L U x}{L U x+\sum_{y=1 . . n} L x y}$

- força transmitida para as paredes laterais:

$\mathrm{y}=1 . . \mathrm{n}(\mathrm{y}$ variando de 1 até $\mathrm{n})$

$\mathrm{pxy}=\mathrm{qxu} . \mathrm{Lxy}$

- força não distribuída: pxx=qx . LNUx + qxu . LUx

4- Finalmente, determina-se a carga distribuída uniformizada final para cada parede:

- $\mathrm{x}=1 . . \mathrm{n}$ ( $\mathrm{x}$ variando de 1 até $\mathrm{n})$

$-\mathrm{qx}^{\prime}=\frac{\sum_{\mathrm{y}=1 . . \mathrm{n}} \mathrm{pyx}}{\mathrm{Lx}}$ 


\subsubsection{5 - Método proposto por Corrêa e Page}

Corrêa e Page (2001) apresentam um modelo simples para a análise da interação de paredes submetidas às ações verticais. O modelo se baseia na uniformização das tensões normais verticais e a distribuição das tensões de cisalhamento na interface do encontro de paredes. São investigados, por meio de uma análise numérica simplificada, exemplos de painéis variando-se o tipo de carregamento, o número de pavimentos e as dimensões em planta. Os autores propõem um procedimento de dimensionamento em que além da distribuição das forças verticais, também é considerada a capacidade de transmissão de forças da interseção das paredes.

Os autores do trabalho consideram o Princípio de Saint Venant para o espalhamento das forças aplicadas centradas em relação à seção transversal da parede (ver Figura 2.12a). Explicam que o critério de espalhamento de forças a $45^{\circ}$ graus, adotado por diversas normas internacionais, tem como argumento esse Princípio, que resumidamente estabelece que "se um sistema de forças atuante em uma região de um corpo for substituído por outro que lhe seja equivalente, atuando na mesma região, as tensões, deformações e os movimentos (excetuando-se os de corpo rígido), em pontos do corpo suficientemente afastados da região carregada, são aproximadamente iguais".

Para carregamentos excêntricos (Figura 2.12b) o espalhamento da força não é uniforme, a menos que ocorram outras forças que reconstituam uma condição de carregamento centrado ou de pequena excentricidade. Num edifício de múltiplos andares, essas forças adicionais são as reações horizontais das lajes dos pavimentos (Figura 2.12c).

Para a análise da interação de paredes e verificação da aplicação do Princípio de Saint Venant os autores adotam um modelo simples em elementos finitos, com as seguintes características: comportamento elástico linear, macro-modelagem e elementos de membranas bidimensionais. O software de elementos finitos utilizado é o STRAND7. Por simplicidade os autores admitem características isotrópicas para as propriedades elásticas do material alvenaria. Por meio desta análise simplificada são variados alguns parâmetros: número de pavimentos, dimensões das paredes e a excentricidade da força no plano da parede. 


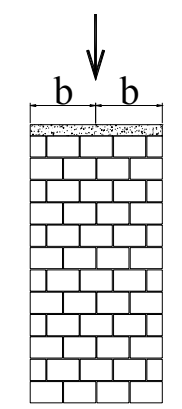

(a) carregamento centrado
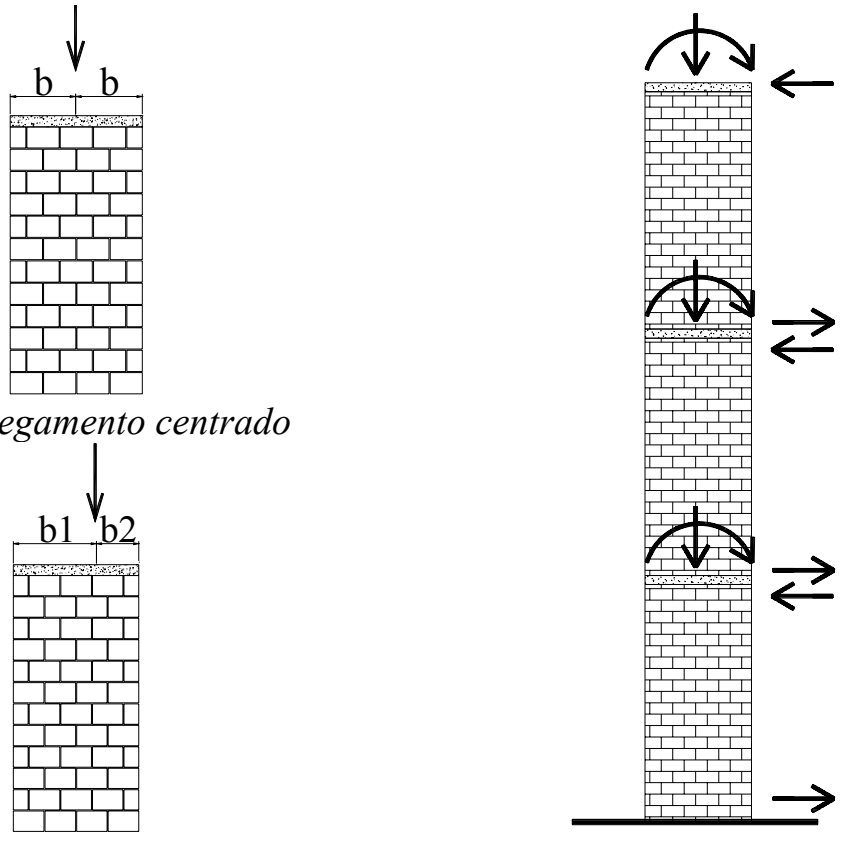

(b) carregamento excêntrico

(c) compensação da excentricidade em edificios de andares múltiplos

Figura 2.12 - Tipos de carregamentos. Adaptado de Corrêa e Page (2001)

Com base em uma série de resultados das análises numéricas realizadas, Corrêa e Page (2001) concluem que o Princípio de Saint Venant governa o processo de uniformização das tensões. Dessa forma propõem que a distância vertical necessária para a igualdade das tensões deve ser maior que o diâmetro do círculo que circunscreve a seção do painel em planta. A Figura 2.13 apresenta um exemplo onde existem três grupos de paredes com interseções cujos diâmetros são $d_{1}, d_{2}$ e $d_{3}$, respectivamente. Cada diâmetro deve ser comparado com a altura do pavimento (h) e, então, determinado o número mínimo de andares necessários à uniformização das tensões normais verticais para o grupo de paredes em questão. Também verificam que no caso de carregamentos excêntricos são necessários no mínimo dois andares para a uniformização, visto que essa também depende das restrições horizontais proporcionadas pelas lajes.

Os autores assumem que em cada parede a força a ser transferida através da interseção é a diferença entre as reações verticais considerando a uniformização das tensões normais verticais e as reações verticais desprezando-se esse processo, isso para dois andares adjacentes. A distribuição das tensões cisalhantes ao longo da altura da interseção é aproximada usando uma forma parabólica quadrática, com os valores máximos junto aos pavimentos. O valor máximo entre dois pavimentos é estimado de uma forma simples e segura como sendo três vezes a tensão média de cisalhamento. 
Esse valor médio é calculado dividindo-se a força transferida entre paredes pela área da interface.

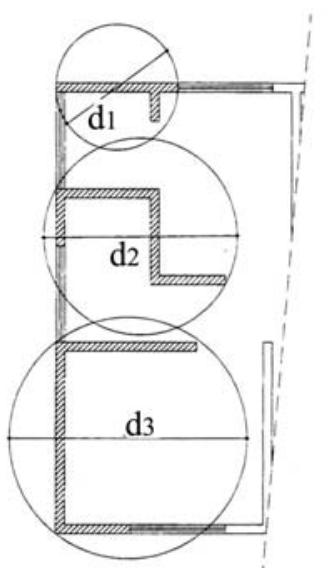

Vista em planta do pavimento

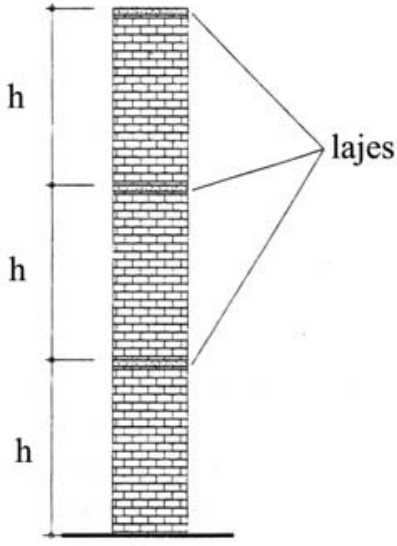

Vista frontal

Figura 2.13 - Distâncias importantes para uniformização. Corrêa e Page (2001)

Os autores também comentam que altura (h) típica de edifícios residenciais é de $3 \mathrm{~m}$, sendo que a maioria dos grupos de paredes possui o diâmetro (d) menor que $6 \mathrm{~m}$. Assim, usualmente são necessários dois pavimentos para que ocorra a uniformização das tensões normais verticais, que é o número mínimo requerido para os casos com carregamentos excêntricos. Lembram, ainda, que o processo de uniformização só é aplicado em casos onde as paredes que compõem o grupo estejam submetidas a carregamentos diferentes e em que a interseção tenha capacidade suficiente para a transmissão de forças. Também não se deve esquecer que, para a obtenção dos valores de forças e tensões finais de projeto, devem ser superpostos os esforços devido às ações horizontais.

Corrêa e Page (2001) propõem um procedimento de cálculo para a alvenaria estrutural sob ações verticais. Os passos desse processo proposto são apresentados resumidamente:

- avaliar a ação atuante em cada parede para cada pavimento de acordo com as respectivas áreas de influência;

- determinar o número de pavimentos necessários para que ocorra a uniformização das tensões normais verticais em cada grupo de paredes pela comparação das dimensões em planta do grupo com a altura dos andares;

- calcular as tensões verticais na base das paredes para cada nível onde a uniformização das tensões é completada; 
- caso sejam necessários mais que dois pavimentos para que ocorra a uniformização, deve-se seguir os seguintes passos:

- para cada parede componente do grupo, calcular as reações verticais no nível em que a uniformização já é completa;

- avaliar a diferença entre essas reações e as obtidas considerando-se o carregamento original;

- para estimar as reações verticais nos pavimentos intermediários relacionados ao carregamento, distribuir igualmente a diferença dentre os andares localizados entre o carregamento e o nível onde ocorre a uniformização;

- determina-se a tensão final em cada pavimento pela soma do carregamento aplicado no nível em questão e o carregamento devido à uniformização total ou parcial das ações dos andares superiores;

- em cada pavimento, avalia-se a força transmitida através da interface pela diferença entre os carregamentos verticais de uma mesma parede entre andares adjacentes e determina-se a tensão de cisalhamento correspondente;

- testa-se a capacidade da interseção em transmitir essas tensões:

○ em caso afirmativo, o procedimento é válido;

- caso contrário, ou as paredes são dimensionadas como isoladas, ignorando a interação, ou limitam-se os níveis de carregamentos para as paredes em que o cisalhamento é crítico.

Os autores ressaltam que, para a efetiva aplicação do método, existe a necessidade de se desenvolver um ensaio para determinação da resistência ao cisalhamento vertical das interseções de paredes de alvenaria estrutura. Sugerem que tal ensaio deva envolver corpos-de-prova de pequenas dimensões, para simplificar sua determinação em laboratório e evitar efeitos de shear-lag presentes em painéis com grandes dimensões. Enquanto não ocorre o desenvolvimento de tal ensaio, Corrêa e Page (2001) indicam que se adotem como limites os valores propostos pela BS 5628 (1992) e a AS 3700 (1998) para o cisalhamento vertical.

Corrêa e Page (2001) também apresentam suas preocupações em relação ao dimensionamento das fundações dos edifícios de alvenaria estrutural. Verificam que a determinação das ações atuantes nas fundações é dependente de se considerar ou não a interação das paredes. Caso as fundações sejam dimensionadas adotando-se que as 
paredes tenham o comportamento isolado, fica implícito que todas as interseções de paredes devem romper antes que a capacidade de cada elemento da fundação seja alcançada. No entanto, se as fundações são dimensionadas para o caso em que ocorra a distribuição de tensões pelas interfaces, fica subentendido que é necessário que seja garantida a transmissão de força entre paredes até que se atinja a capacidade de carga dos elementos de fundações. Portanto, adotado um procedimento para o cálculo das ações nas fundações é importante verificar se as hipóteses adotadas estão corretas. Caso contrário o projeto pode se tornar potencialmente inseguro. Observa-se que o procedimento proposto pelos autores evita essa possibilidade, visto que considera a resistência da interseção. A interação de paredes só é considerada para os casos em que a interface tenha capacidade suficiente para a transmissão de forças. Portanto, a determinação das ações nas fundações pelo método aqui apresentado é mais realista.

\section{3- Pesquisas sobre a interação de paredes}

\subsection{1 - Medições em um edifício realizadas por Stockbridge}

Considera-se que a primeira pesquisa que fornece informações sobre a interação de paredes é a realizada por Stockbridge em 1967. Stockbridge apud Hendry (1981) encontra evidências, através da medição de deformações tomadas em um edifício de cinco andares, que levam a acreditar que em edifícios, preferencialmente altos, haja uma tendência das tensões se uniformizarem nos pavimentos inferiores, tanto em paredes isoladas como em grupos de paredes interligadas. A Figura 2.14a mostra as leituras de deformações em uma parede desse edifício durante a construção dos pavimentos superiores. Com base na Figura 2.14b, é de se esperar que a leitura da deformação no ponto 1 seja consideravelmente menor que a do ponto 2, pois na região central deveria haver uma concentração das ações da laje. Entretanto, elas são praticamente iguais. As tensões na parede no ponto 3 são influenciadas pela presença de um lintel, XY, vide Figura 2.14c. O efeito deste lintel é, em princípio, o de atrair as forças desta área; mas, após a construção alcançar o primeiro pavimento, o incremento da deformação diminui consideravelmente até a construção do quinto pavimento. Verifica-se que as tensões ao longo do comprimento da parede tornam-se mais uniformes que nos estágios iniciais.

•StOCKBrige, J.G. (1967). A Study of High-Rise Load Bearing Brickwork in Britain. Thesis, University of Edinburgh. 


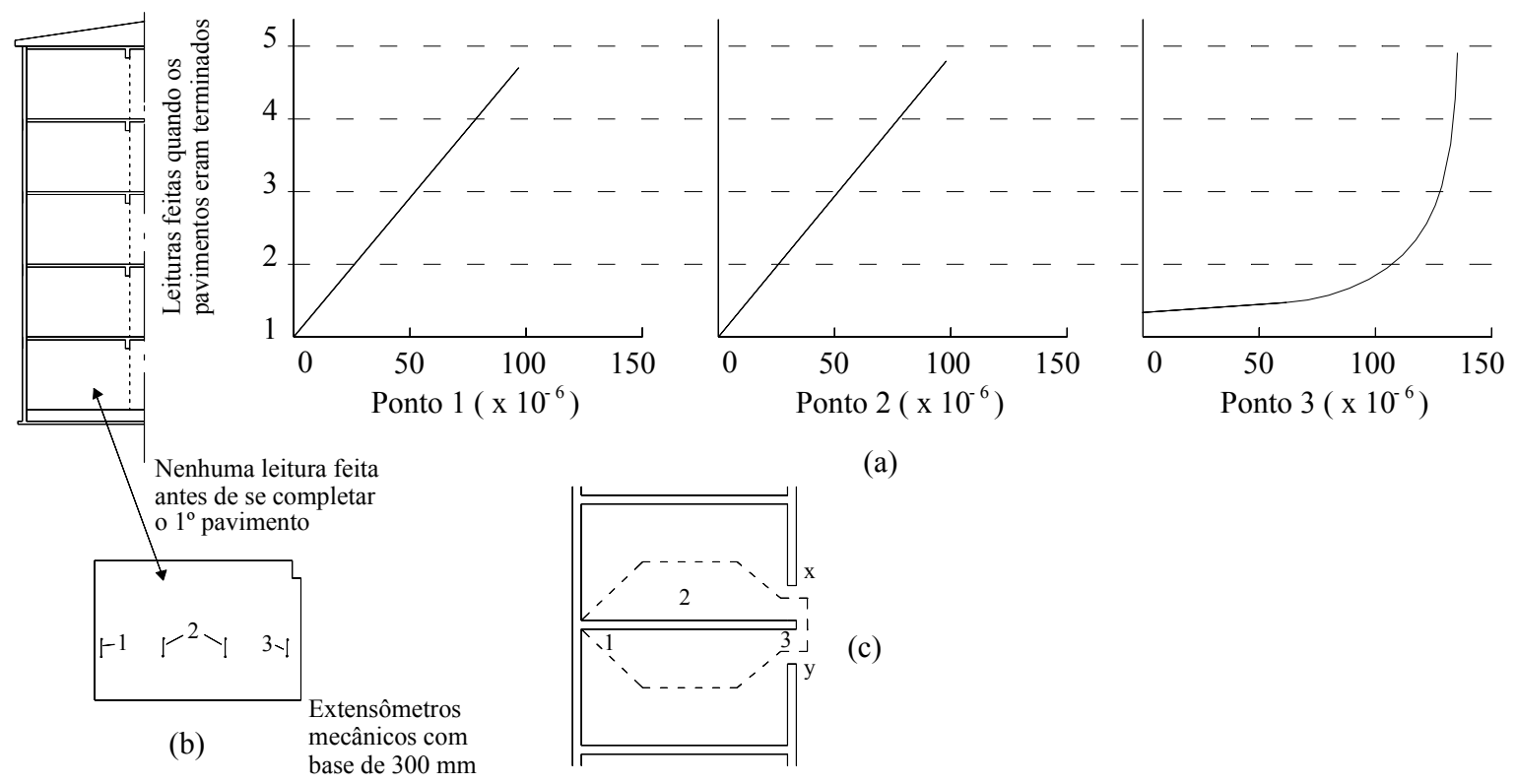

Figura 2.14 - Deformações medidas numa parede de um edificio. (a) Medidas feitas na parede do $1^{o}$ pavimento; (b) Localização dos extensômetros mecânicos (mesma disposição na face oposta); (c) área de contribuição estimada. Hendry (1981).

\subsection{2 - Ensaios realizados por Sinha e Hendry}

Sinha e Hendry (1979) realizam um programa experimental com o objetivo de comparar a capacidade de carga entre paredes isoladas e paredes enrijecidas, avaliando os coeficientes de enrijecimento indicados pela BS 5628 (1992). São conduzidos ensaios com diferentes valores de esbeltez (altura efetiva / espessura efetiva), proporções entre altura e comprimento e dois tipos de carregamento (Figura 2.15). São utilizados tijolos cerâmicos em diferentes escalas [natural (1:1), (1:2) e (1:3)].

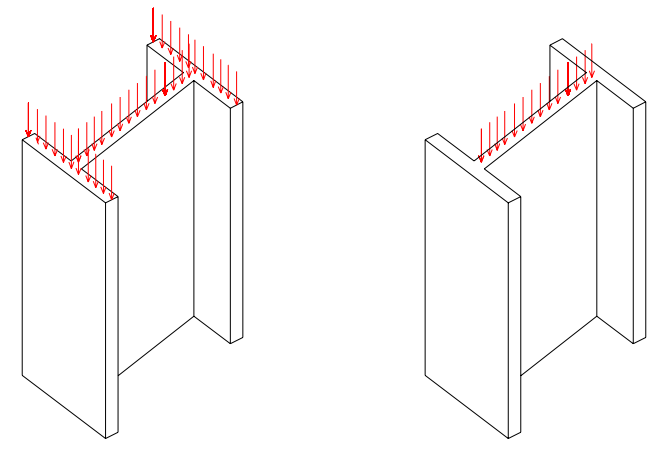

Figura 2.15 - Esquemas de carregamento. Sinha e Hendry (1979)

Para os ensaios em escala natural (1:1) e (1:3) é utilizado um pórtico especialmente projetado, sendo que o carregamento distribuído é aplicado por vários macacos hidráulicos ligados a uma única bomba. As paredes em escala (1:2) são ensaiadas em uma máquina universal de ensaios tipo "Avery", tomando-se o cuidado de 
se aplicar a força o mais centralizada possível. Em algumas paredes em escala natural os flanges das paredes em formato " $\mathrm{H}$ " estão apoiados em um determinado número de células de carga para se verificar a transferência de força da parede central para os flanges.

Os resultados dos ensaios indicam que em ambos os casos de carregamentos, as paredes com flanges não mostram aumento da resistência quando comparadas com paredes não enrijecidas. Entretanto, percebe-se que estas paredes com flanges comportam-se como placas enrijecidas até o aparecimento de fissuras verticais entre a parede principal e os flanges. A partir desse ponto as fissuras neutralizam o efeito do enrijecimento e, como resultado, a resistência última da parede é similar a uma não enrijecida. No caso onde apenas se aplica força na parede central, as fissuras aparecem na interseção entre o flange e a parede central (Figura 2.16a). Para as paredes onde se aplica igualmente a força, as fissuras aparecem em ambos os flanges e nos dois lados, dividindo o flange em duas partes (Figura 2.16b).
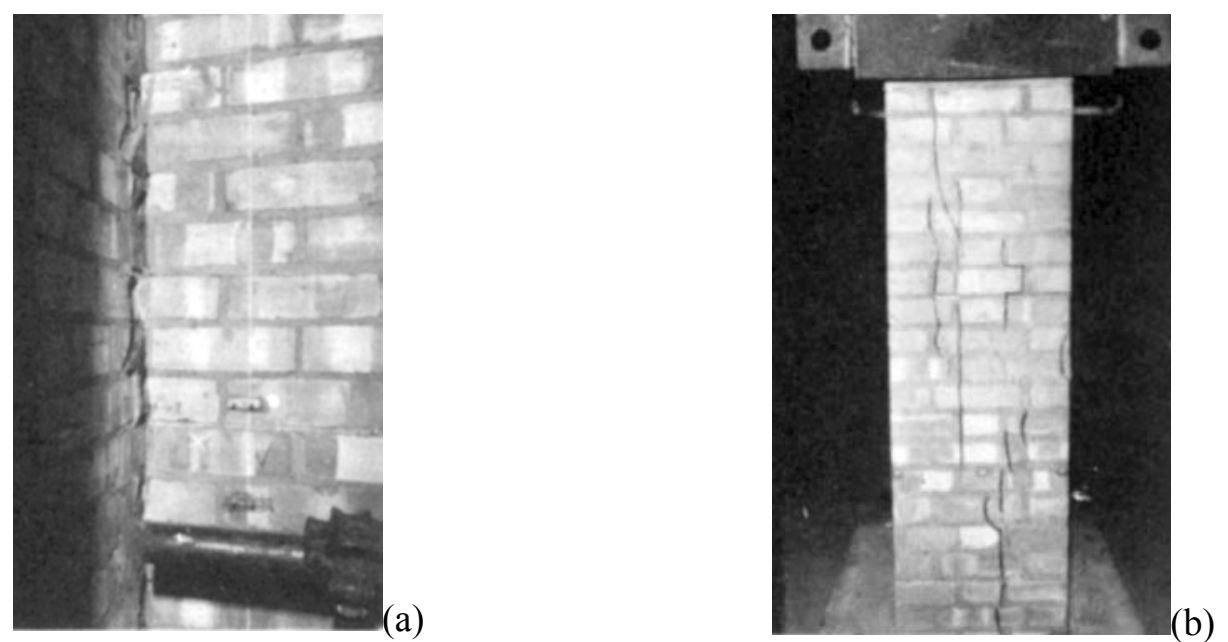

Figura 2.16 - Fissuração típica. Sinha e Hendry (1979)

Verifica-se, também, que o deslocamento ortogonal ao plano da parede enrijecida, anterior à fissuração dos flanges, é muito menor que o caso correspondente às paredes não enrijecidas. Isto mostra que o efeito do enrijecimento é evidente antes das fissuras separarem os flanges da parede principal. Observa-se que este efeito de enrijecimento diminui com o aumento da relação entre comprimento e altura. Esta diminuição é esperada já que mantendo a altura constante e aumentando o comprimento, a distância entre os enrijecedores é maior e, portanto, menor é sua influência. Considerando, agora, que o comprimento é constante e diminuindo a altura, 
a influência da esbeltez diminui e, conseqüentemente, o efeito dos enrijecedores é menor.

As deformações na parede com flanges são menores que os casos correspondentes às paredes não enrijecidas, confirmando a evidência inicial do efeito de enrijecimento antes da fissuração. Novamente, o efeito diminui com o aumento da razão entre comprimento e altura. A curva tensão x deformação obtida foi linear até $90 \%$ da força de ruptura (Figura 2.17).

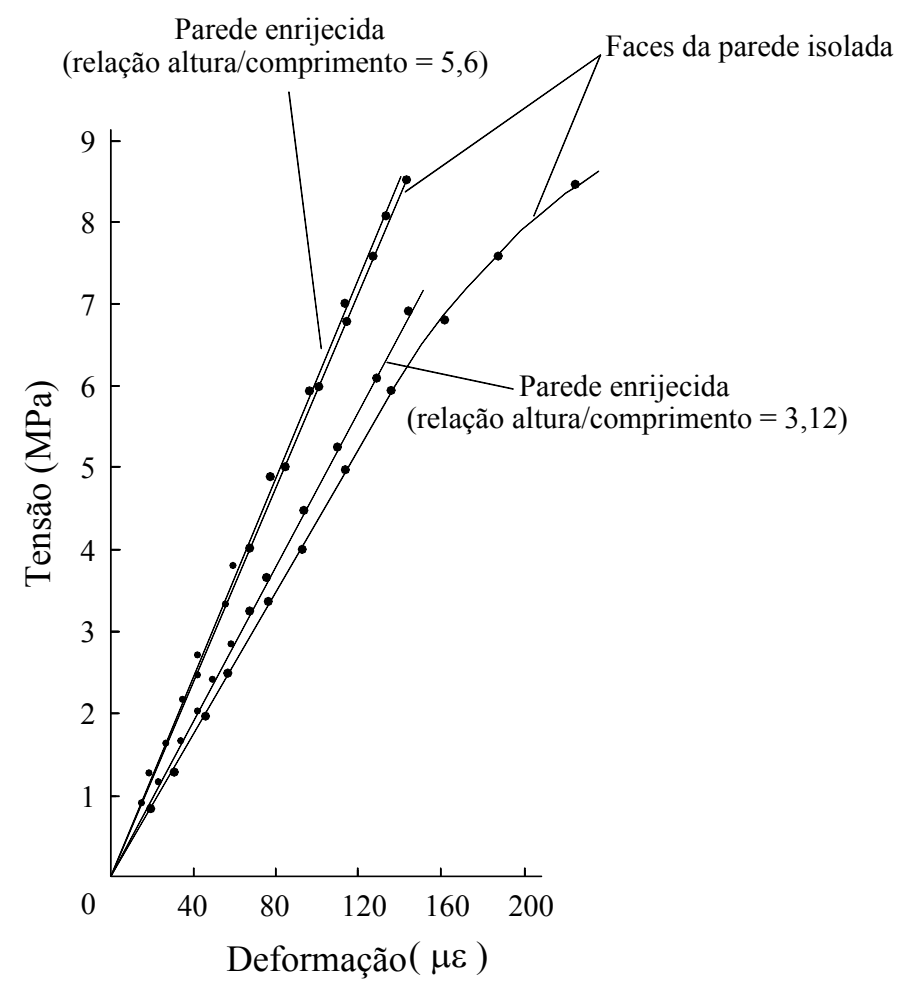

Figura 2.17 - Relações tensão $x$ deformação de diferentes paredes. Sinha e Hendry (1979)

Analisando-se os dados apresentados, acredita-se que para haver a linearidade da curva tensão x deformação obtida nos ensaios, as paredes que constituem o painel devem trabalhar em conjunto (até $90 \%$ da força de ruptura). Pois, caso contrário, deveria existir uma descontinuidade no diagrama tensão $\mathrm{x}$ deformação no momento da separação entre a parede central e os flanges.

No caso de parede com flanges, onde apenas a alma estava carregada, parte do carregamento é transferido para os flanges. Segundo os autores, cerca de 5,8 até 6,7\% do carregamento total é suportado em cada flange antes da separação da parede principal, entretanto no artigo não se comenta se esta separação é próxima ou não da ruptura. A média da tensão cisalhante vertical última que destrói completamente a ligação está entre $0,35 \mathrm{MPa}$ e $0,68 \mathrm{MPa}$ (calculada com a área igual ao produto da altura 
pela espessura da parede central). Ressalta-se, também, que nestes ensaios, como em alguns casos os flanges são apoiados sobre células de carga para a determinação da parcela de força transferida, pode-se ter distorcido os resultados, visto que o apoio da parede principal é mais rígido.

Nota-se, também, que o tipo de amarração pode ter influenciado os resultados, pois apesar de ser do tipo direta, o bloco de amarração no flange se apóia em apenas um terço ou menos do comprimento dos blocos da fiada abaixo (Figura 2.16b e Figura 2.18). Esse fato pode ter prejudicado a eficiência da ligação entre as paredes, pois caso o bloco de amarração tivesse um apoio maior, haveria uma menor concentração de tensões e conseqüentemente as fissuras poderiam aparecer em um estágio posterior.

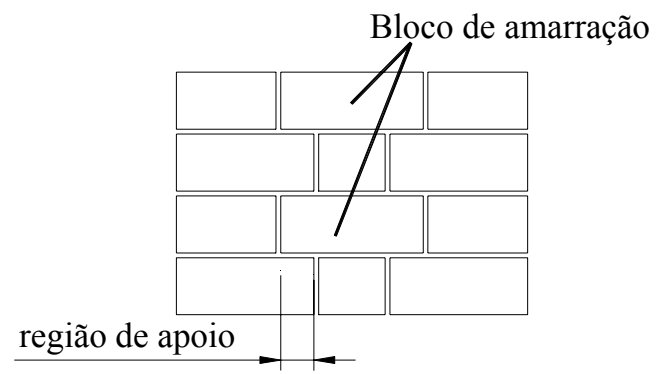

Figura 2.18 - Detalhe da amarração do flange

Sinha e Hendry (1979) chegam à conclusão que o enrijecimento não promove o aumento da resistência do painel, inclusive nos ensaios onde os flanges também estão carregados. Entretanto, deve-se ressaltar que as condições dos ensaios não representam bem a situação de um painel em um edifício de múltiplos andares, pois nos ensaios o carregamento total é aplicado em um único nível, existindo uma grande concentração de tensão no topo, o que pode levar a uma ruptura localizada do painel.

\subsection{3 - Ensaios de torres realizados por Camacho}

Camacho (1995) realiza ensaio de torres de alvenaria estrutural em modelo físico reduzido, nas escalas (1:3) e (1:5), cujas formas e dimensões estão apresentadas na Figura 2.19a. O objetivo do ensaio é verificar se o comportamento das torres é influenciado pelo fator de escala. Para tanto, são realizadas medidas de deformações em vários pontos ao longo da seção e da altura das torres (Figura 2.19b), permitindo, também, avaliar a distribuição da ação vertical. O carregamento aplicado é uma ação distribuída apenas sobre as duas menores paredes.

$\mathrm{O}$ autor verifica que o comportamento das torres em relação às deformações é praticamente o mesmo independente da escala utilizada. Apresentam-se aqui apenas os 
resultados referentes à escala (1:3). Na Figura 2.20, nota-se que próximo ao topo existe uma concentração de tensão nas regiões de aplicação de forças, enquanto que nas paredes não carregadas as deformações são praticamente nulas. Isso acontece porque não há comprimento suficiente para que se mobilizem forças de interação de grande magnitude. À meia altura da torre observa-se que já não existe uma concentração de tensão tão acentuada quanto no topo, devido à transferência de forças das paredes menores para as paredes maiores que não são diretamente carregadas. Na região próxima à base, a tendência é de deformações iguais ou ligeiramente maiores que no centro.

\begin{tabular}{|c|c|c|c|}
\hline \multirow{2}{*}{ Esc. } & \multicolumn{3}{|c|}{ Dimensões (cm) } \\
\cline { 2 - 4 } & $\mathrm{a}$ & $\mathrm{b}$ & $\mathrm{h}$ \\
\hline $1: 3$ & 90 & 50 & 190 \\
\hline $1: 5$ & 55 & 30 & 115 \\
\hline
\end{tabular}

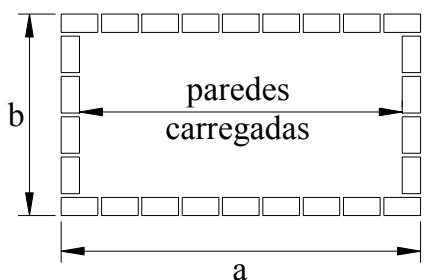

Planta

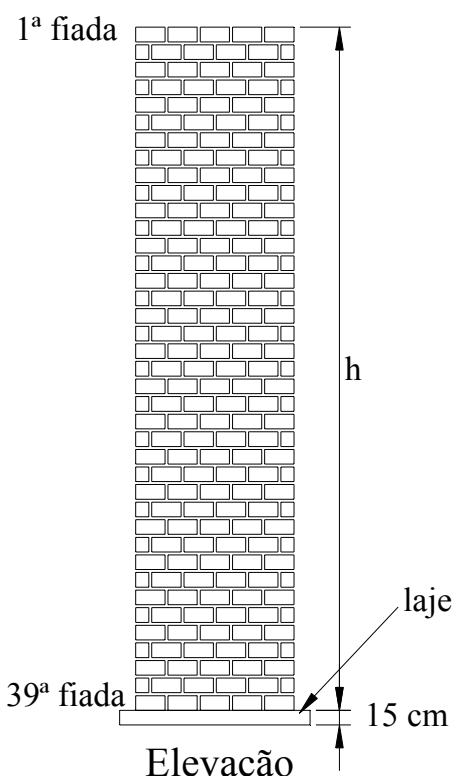

(a)

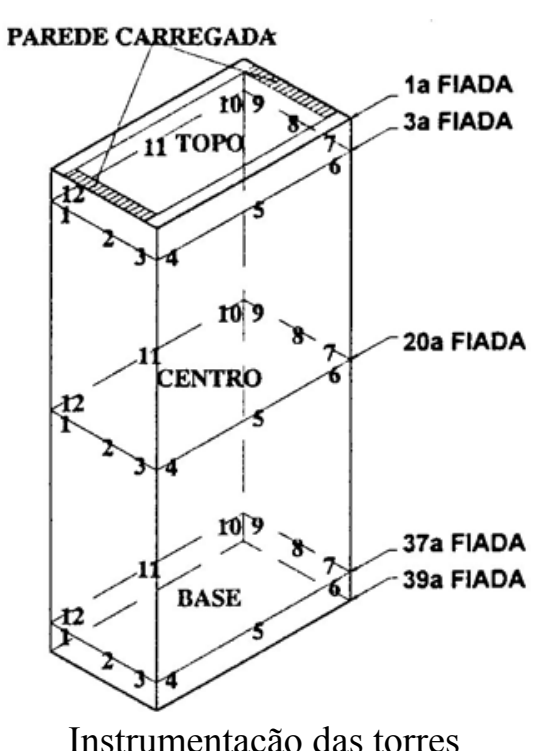

(b)

Figura 2.19 - Torres ensaiadas por Camacho (1995)

Os processos de fissuração e ruptura para as torres nas duas escalas são exatamente iguais. $\mathrm{O}$ estado de fissuração tem início nas paredes menores, na primeira fiada, nos cantos. Com o aumento do carregamento, as fissuras se prolongam para baixo. Novas fissuras surgem nas paredes maiores, também se iniciando nos cantos e caminhado em forma de escada para o centro da torre, com a indicação clara de transferência de força. A forma de ruptura para as duas escalas é caracterizada pela quebra da parede menor, na região superior da torre, onde é realizada a aplicação do carregamento. Indicando uma ruptura localizada devido à concentração de tensão, que também é observada pelas leituras de deformação. A Figura 2.21 apresenta fotos da ruptura das duas torres. 

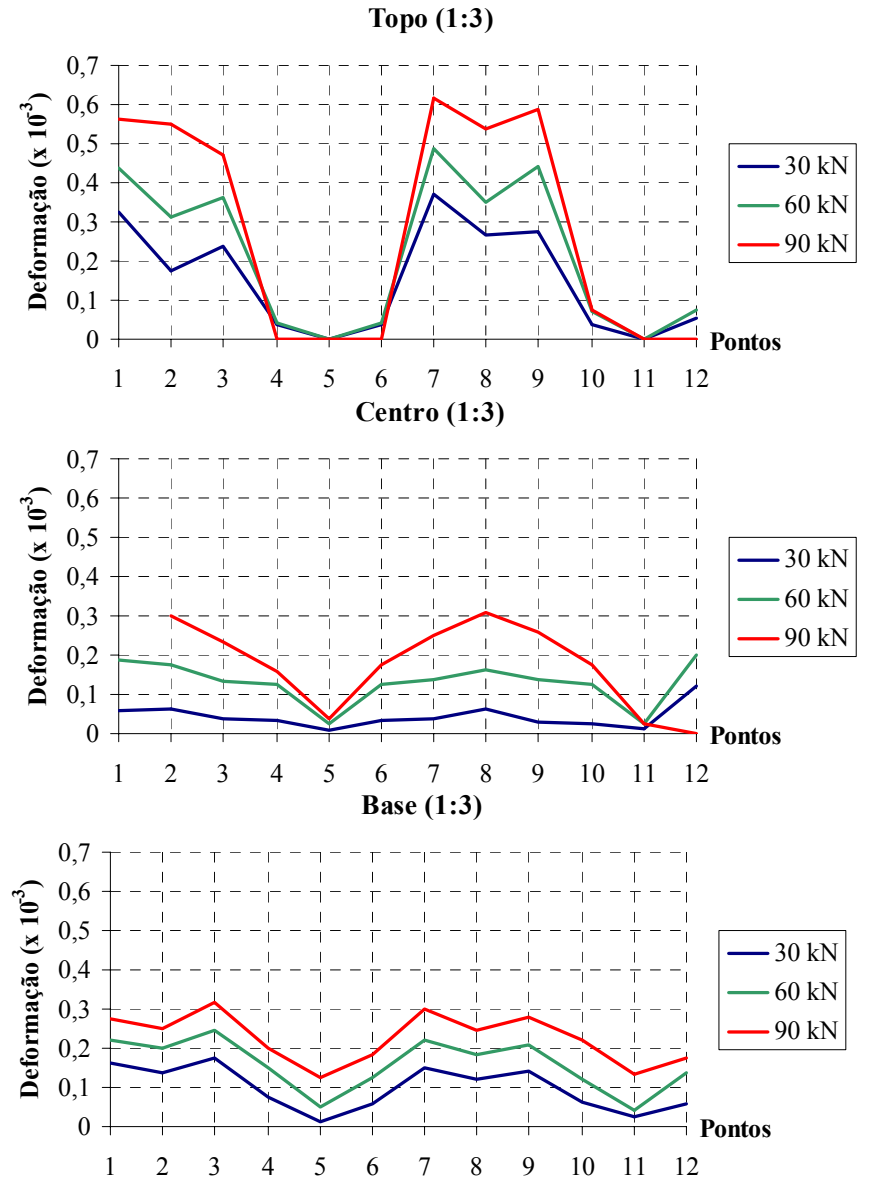

Figura 2.20 - Deformações para torre na escala 1:3. CAMACHO (1995)
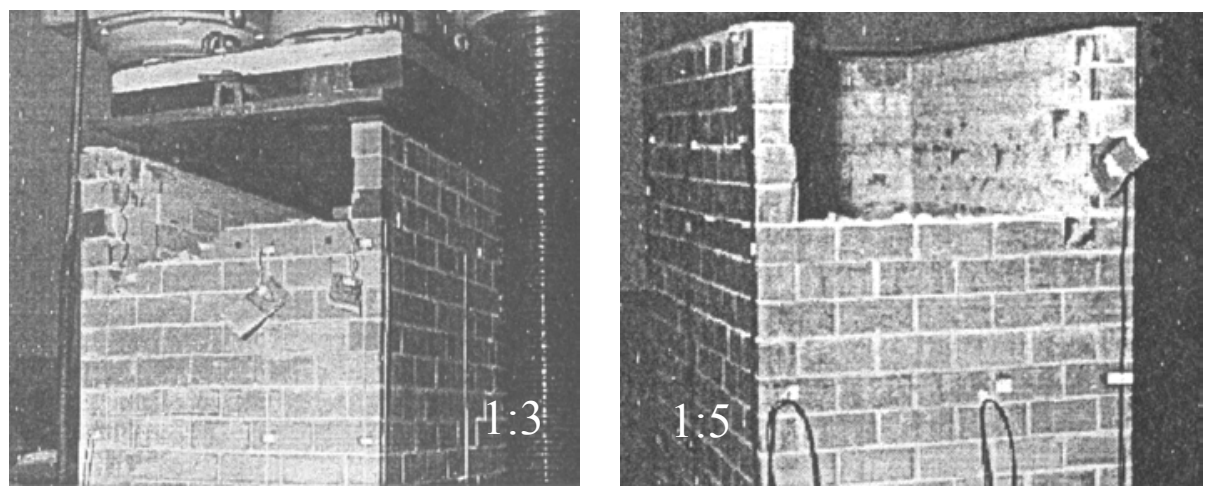

Figura 2.21 - Forma de ruptura das torres. Camacho (1995).

Camacho (1995) conclui que seria de se esperar uma maior homogeneização das deformações, tanto na região central quanto na base das torres. Afirma a necessidade da realização de mais ensaios, de diferentes tipos e dimensões, com a presença de lajes intermediárias para se poder concluir com maior segurança sobre o assunto. 


\subsection{4 - Ensaios de painéis realizados por Capuzzo Neto}

Capuzzo Neto (2000) realiza duas séries de ensaios de painéis de alvenaria em escala natural com o objetivo de se estudar a interação de paredes, buscando também a influência da cinta de amarração à meia altura. A série 1 é constituída de três painéis em formato "H" com cinta de amarração na última fiada (Figura 2.22a). A série 2 também é formada por três painéis " $\mathrm{H}$ ", tendo como diferença a presença de mais uma cinta na fiada intermediária (Figura 2.22b). As duas séries são construídas com amarração direta, utilizando-se juntas verticais e horizontais, totalmente preenchidas. O formato " $\mathrm{H}$ " é adotado visando diminuir os efeitos de excentricidades em relação ao plano de simetria.

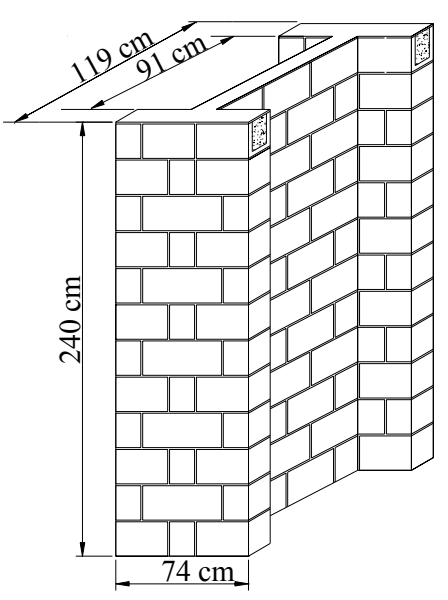

(a) Sem cinta intermediária - Série 1

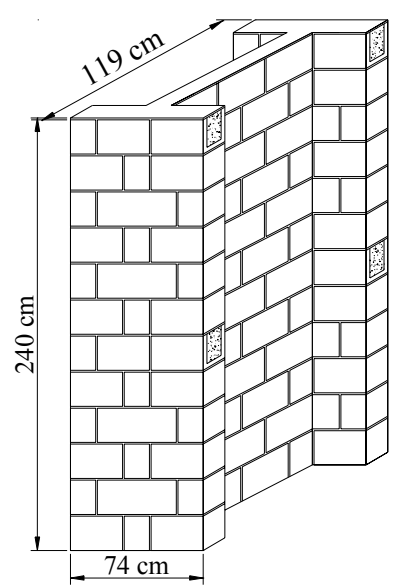

(b) Com cinta intermediária - Série 2

Figura 2.22 - Painéis de alvenaria construídos - Capuzzo Neto (2000)

$\mathrm{Na}$ construção dos painéis são empregados blocos cerâmicos com dimensão modular de $15 \mathrm{~cm}$ x $20 \mathrm{~cm}$ x $30 \mathrm{~cm}$, utilizando-se inclusive o bloco de amarração (15 $\mathrm{cm}$ x $20 \mathrm{~cm} \times 45 \mathrm{~cm})$ e o bloco canaleta. Os valores médios das características mecânicas dos materiais e dos corpos-de-prova estão apresentados na Tabela 2.1; ressalta-se que para os prismas e o graute os módulos de deformação longitudinal não são determinados experimentalmente.

Tabela 2.1 - Características mecânicas dos materiais empregados

\begin{tabular}{|c|c|}
\hline Tensão de Ruptura (MPa) & - área bruta \\
\hline Bloco $\left(\mathbf{f}_{\mathbf{b}}\right)=$ & 11,0 \\
\hline Argamassa $\left(\mathbf{f}_{\mathbf{a}}\right)=$ & 12,3 \\
\hline Graute $\left(\mathbf{f}_{\mathbf{g}}\right)=$ & 28,4 \\
\hline Prisma 2 blocos $=$ & 5,4 \\
\hline Prisma 3 blocos $=$ & 5,1 \\
\hline
\end{tabular}

\begin{tabular}{|c|c|}
\hline Módulo de deformação (MPa) - área bruta \\
\hline Bloco $\left(\mathbf{E}_{\mathbf{b}}\right)=$ & 4.013 \\
\hline Argamassa $\left(\mathbf{E}_{\mathbf{a}}\right)=$ & 10.900 \\
\hline Graute $\left(\mathbf{E}_{\mathbf{g}}\right)=$ & $30.000^{*}$ \\
valor estimado \\
valiquida $/ \mathrm{A}_{\text {bruta }} \approx 0,50$ \\
$\mathrm{~A}_{\text {liqu }}^{*}$
\end{tabular}


No ensaio aplica-se uma força distribuída apenas na parede central, visto que o objetivo é observar a transferência de parte deste carregamento para os flanges. Nota-se que a base dos painéis de alvenaria é toda apoiada. A Figura 2.23 apresenta o esquema do carregamento e uma visão geral do ensaio. Os painéis são instrumentados de modo a verificar a variação das deformações do painel ao longo da altura, sendo uma forma de se observar a transferência de carregamento. A Figura 2.24 mostra a localização dos instrumentos de medida.
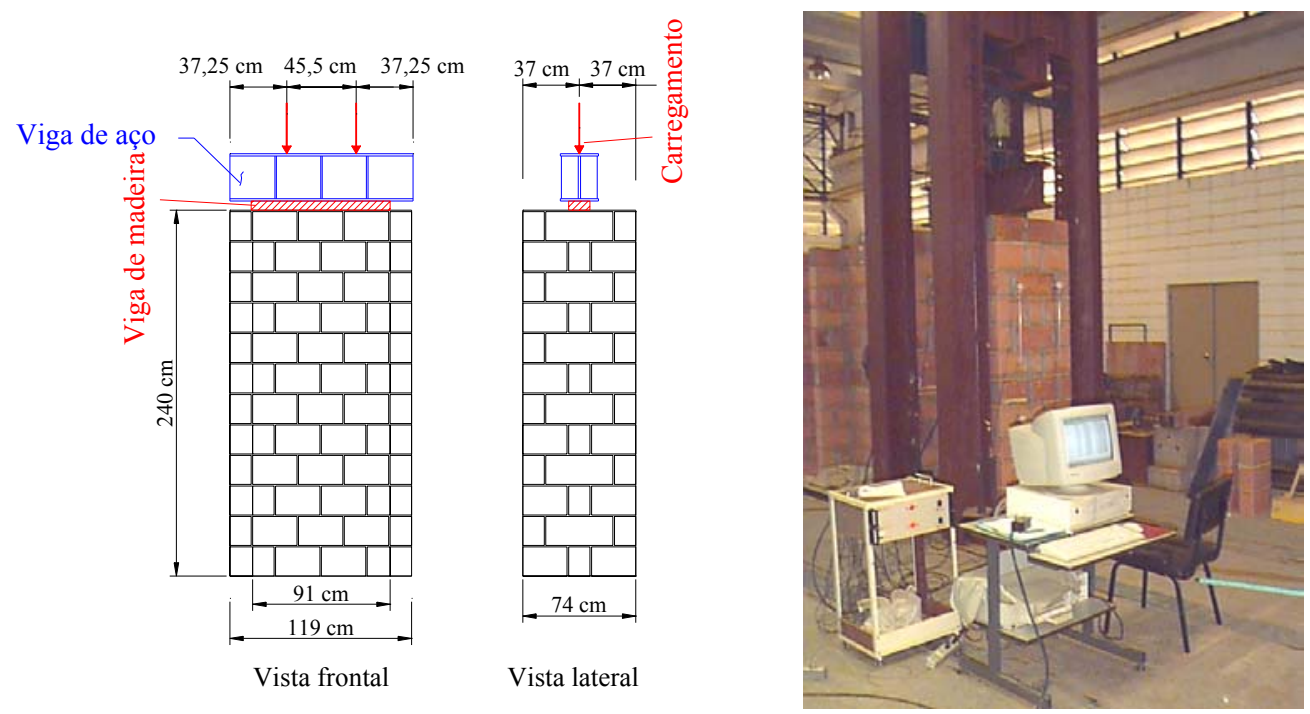

Figura 2.23 - Esquema de carregamento e visão geral do ensaio - Capuzzo Neto (2000)

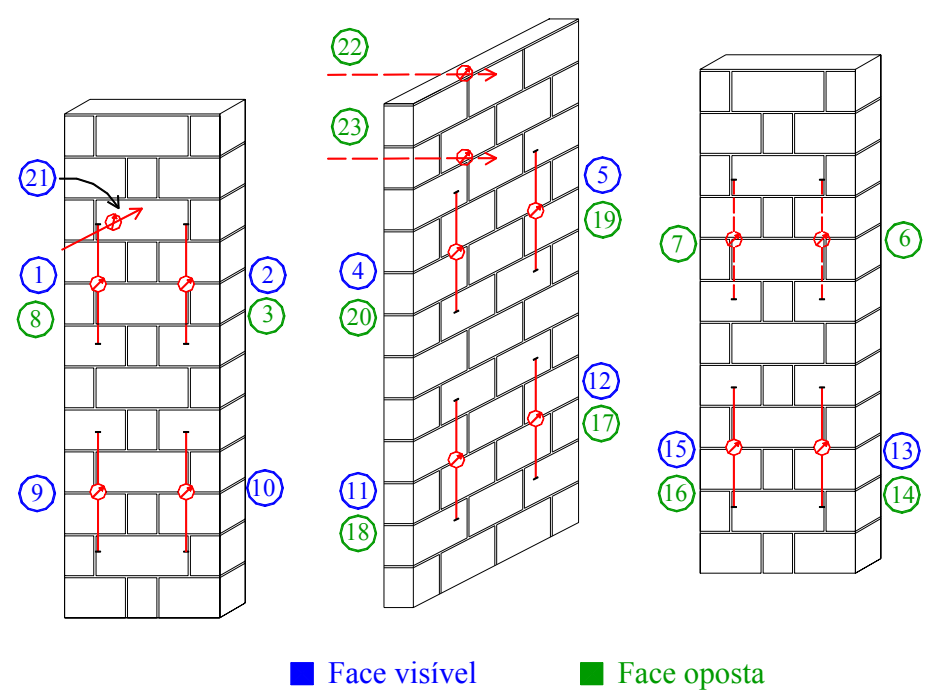

Figura 2.24 - Instrumentação dos painéis - Capuzzo Neto (2000)

$\mathrm{Na}$ análise dos resultados experimentais, os diagramas de força versus deformação para as duas séries ensaiadas são divididos em trechos superior e inferior, visando uma melhor visualização e comparação do comportamento do painel (Figura 
2.25). Em todos os gráficos consideram-se somente as leituras antes da perda acentuada da linearidade. Verifica-se, facilmente, a diferença entre os trechos superior (maiores deformações na parede central por causa da pequena transferência para os flanges) e inferior (tendência de uniformização graças a uma maior transferência). Esse comportamento global pode ser melhor visualizado considerando-se apenas as deformações médias da parede central e dos dois flanges, tanto para o trecho superior como para o inferior (Figura 2.26).
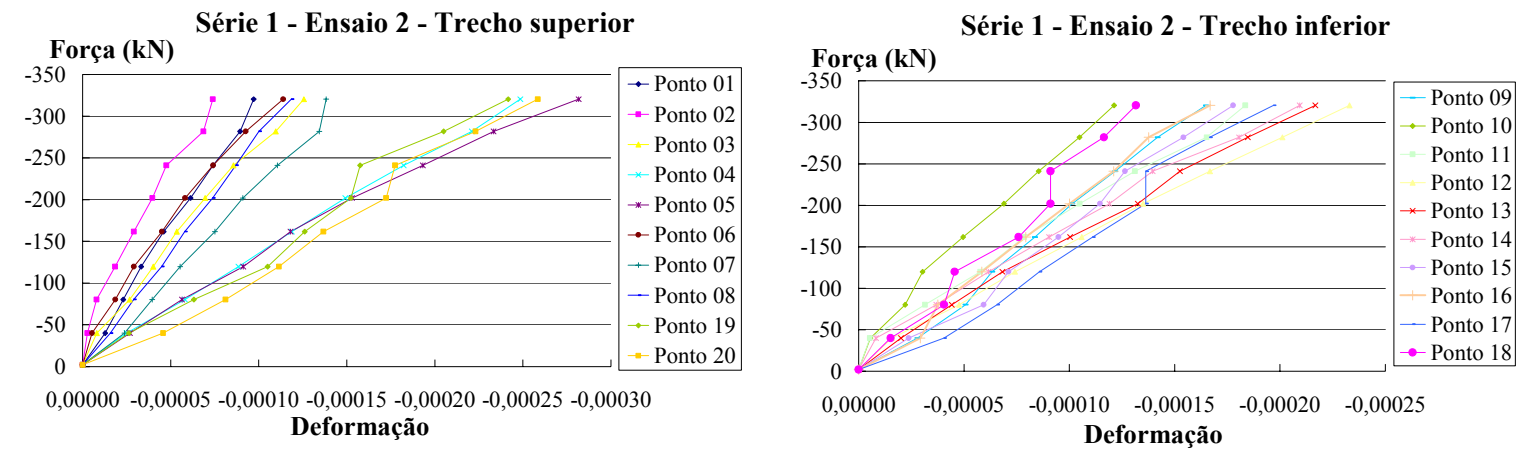

Figura 2.25 - Resultado típico da série 1

1

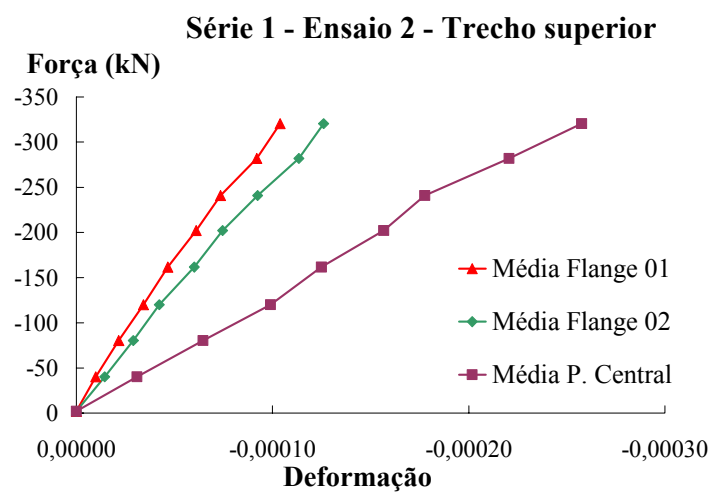

Série 1 - Ensaio 2 - Trecho inferior

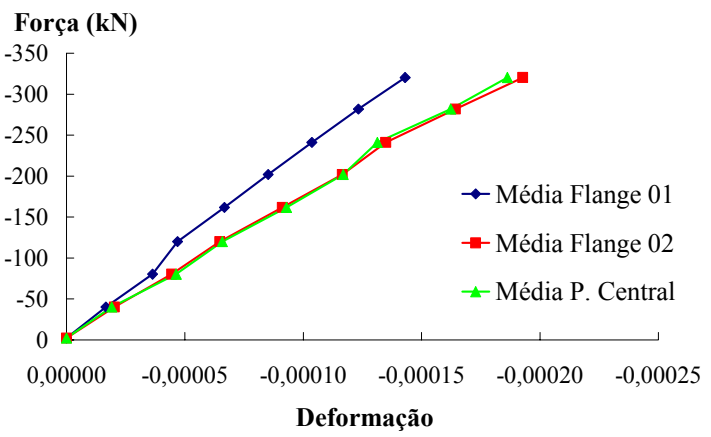

Figura 2.26 - Diagrama típico das deformações médias da série 1

Capuzzo Neto (2000) verifica que o comportamento, antes da perda de linearidade, dos painéis com e sem cinta de amarração ã meia altura é praticamente o mesmo. Uma análise numérica preliminar realizada pelo autor leva a essa mesma conclusão. Desta forma, os painéis são analisados como um único conjunto, visto que também não se observa uma diferença significativa de resistência nos ensaios.

A força de ruptura média dos painéis, considerando-se as duas séries, é igual a 467 kN. Este valor corresponde a resistência à compressão da parede central, onde há uma concentração de tensões no topo causada pelo carregamento aplicado. A tensão de ruptura calculada em relação à área bruta da parede central é de 3,66 $\mathrm{MPa}$, o que equivale a eficiência de 0,33 em relação à resistência do bloco. Essa eficiência é a 
mesma obtida por Machado Jr. et al. (1999) e Garcia (2000), para diversos ensaios de paredes à compressão simples de blocos cerâmicos do mesmo fabricante.

Ainda nos ensaios observa-se para a série 1 um comportamento linear em média até $68 \%$ do valor da tensão máxima de compressão, com a perda de linearidade dos diagramas força x deformação alguns estágios de carregamento antes da ruptura. Para a série 2 a perda de linearidade ocorre em uma etapa mais próxima da força de ruptura, em média a $82 \%$ desta. Considerando-se as duas séries obtém-se um valor médio de $75 \%$, que corresponde ao valor indicado por Hendry et al. (1981). Já durante os ensaios, as primeiras fissuras visíveis são observadas para uma força correspondente a $81 \%$ da força de ruptura, contudo, ressalta-se que a marcação de fissuras era realizada apenas nos intervalos dos estágios de carregamento, sendo um valor aproximado.

Em relação à forma de ruptura dos painéis, observa-se que a ruptura ocorre por compressão na região superior da parede central, geralmente nos blocos da cinta de amarração ou logo abaixo dela. As fissuras iniciam na parede central, em região próxima à interseção e abaixo da cinta de amarração do topo. Com o aumento do carregamento, as fissuras se propagam, fazendo com que os flanges se separem da parede central, indicando uma ruptura por cisalhamento da interface.

Na série 1 as fissuras ocorrem ao longo de toda a altura do painel (Figura 2.27), enquanto que na série 2 a cinta de amarração à meia altura impede a propagação dessas fissuras para a metade inferior (Figura 2.28).

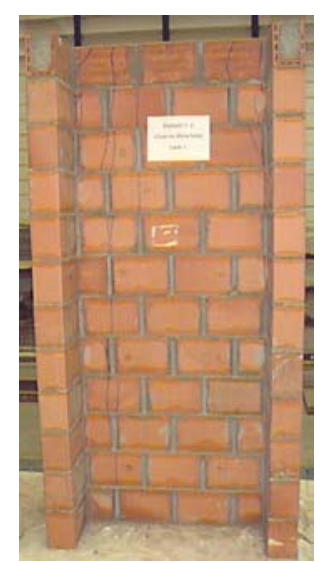

Figura 2.27 - Forma de ruptura da série 1
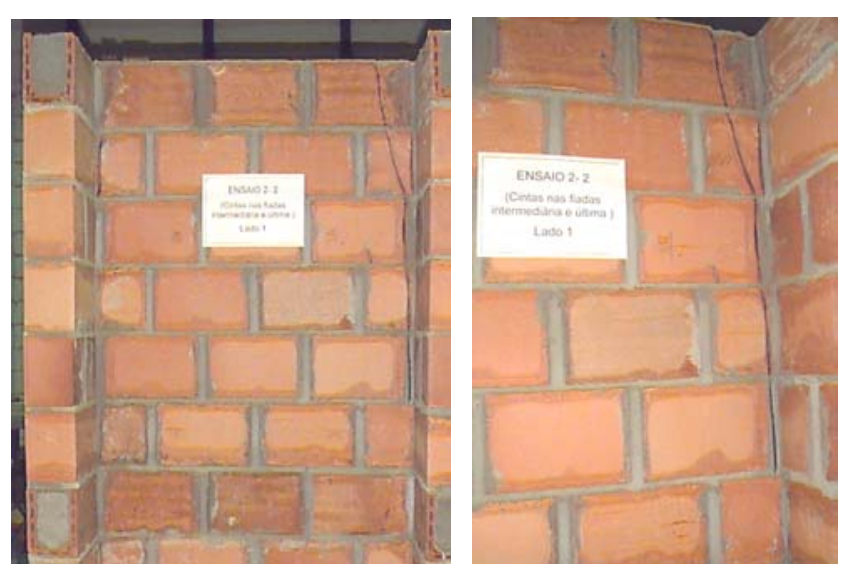

Figura 2.28 - Forma de ruptura da série 2 


\subsection{5 - Ensaio realizado por Signor e Roman}

Signor e Roman (2002) realizam um ensaio em caráter exploratório de um painel "H" de alvenaria de blocos cerâmicos em escala reduzida, com o objetivo de verificar a transferência de ações verticais entre paredes ortogonais. O painel " $\mathrm{H}$ " é construído utilizando-se blocos cerâmicos em escala $(1: 3,33)$ com amarração direta. Entretanto, por não possuírem o bloco de amarração, os autores utilizam o artifício de serrar dois blocos com septo transversal duplo, de forma a obter a dimensão desejada. A falta de experiência em modelos reduzidos leva a alguns problemas na execução, gerando uma qualidade inferior nas alvenarias normalmente executadas. Mesmo assim, os autores consideram a parede satisfatória, visto a natureza investigatória do ensaio.

O carregamento é aplicado de forma distribuída apenas na parede central por um dispositivo da prensa, que mantêm o topo da parede articulado. A Figura 2.29 apresenta o esquema do ensaio, bem como uma visão geral da parede construída. Ressalta-se que toda a base do painel está apoiada, inclusive a parede central.
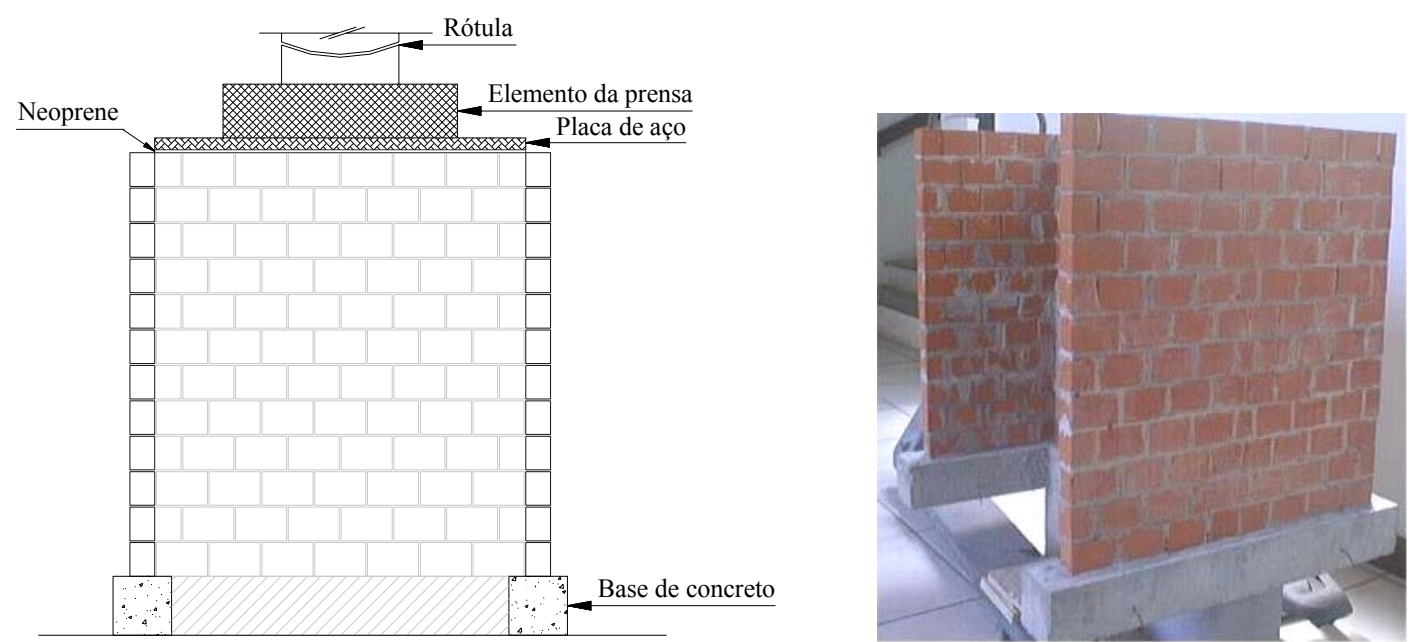

Figura 2.29 - Esquema do ensaio e visão geral da parede. Signor e Roman(2002)

Desde o início do ensaio, Signor e Roman (2002), por meio de medições de deformações, verificam a transferência de forças para os flanges. Também observam uma certa excentricidade do carregamento, o que gera tensões de tração em um dos flanges e conseqüentemente uma maior compressão no outro flange. O acréscimo de deformações na base da parede central é relativamente linear desde o começo até a ruptura, indicando a interação das paredes.

A ruptura do painel ocorre para uma tensão de compressão na parede central igual a 4,6 MPa. O colapso da estrutura é devido a uma ruptura localizada da parede 
central (Figura 2.30a). Na mesma figura nota-se o cisalhamento da parede central, no lado onde houve transferência de esforços de compressão, além de fissuras próximas à base de um dos flanges, devido a tensões de tração. Na Figura 2.30b e Figura 2.30c verifica-se, pela forma de fissuração no flange comprimido, um espalhamento da força a cerca de $45^{\circ}$.

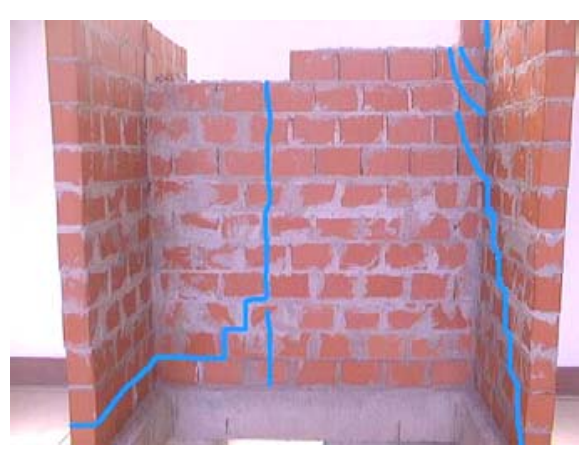

(a)

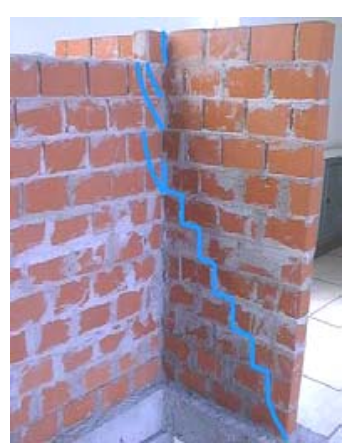

(b)

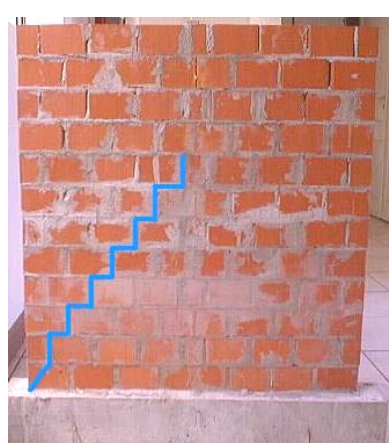

(c)

Figura 2.30 - Forma de ruptura e fissuração do painel. Signor e Roman(2002)

Signor e Roman (2002) concluem que a adoção de processos que levam em conta a interação de paredes é bastante razoável. Isso considerando que nas estruturas reais a qualidade de execução é boa, que existe a utilização do bloco de amarração e da cinta de respaldo, esta última auxiliando na distribuição do carregamento. Observa-se que essas condições são mais favoráveis que as existentes no ensaio realizado.

\section{4 - Pesquisas sobre a eficiência das ligações de paredes}

\subsection{1 - Trabalho realizado por Lissel, Shrive e Page}

Lissel et al. (2000) ao realizarem um trabalho experimental com o objetivo de estudar paredes diafragma protendidas com cabos não-aderentes percebem a influência do tipo de amarração no comportamento e resistência das mesmas. Observam que a ligação alma-flange realizada por amarração direta aumenta a resistência ao cisalhamento desta interseção quando comparada à amarração indireta.

Desta maneira, Lissel et al. (2000) decidem realizar ensaios em corpos-de-prova com seção transversal em formato "H" com o objetivo de estudar a influência da amarração na resistência da ligação alma-flange. Os corpos-de-prova foram construídos utilizando tijolos em acordo com a norma australiana e argamassa comum. Dois tipos de fibras de vidro poliméricas (GFRP 60 e GFRP 120) são utilizados como material alternativo para os conectores para a amarração indireta. São realizados ensaios com 5 
tipos de combinação entre amarração e tipo de conector, sendo dois corpos-de-prova por combinação. Em todos os ensaios aplica-se nos flanges uma força de compressão nominal, com a finalidade de estabilizar o corpo de prova antes e durante o ensaio. Esta força é aproximadamente equivalente à força normal de um pavimento. A Figura 2.31 apresenta o esquema de ensaios desses corpos-de-prova; observa-se que a alma não é apoiada, podendo se deslocar.

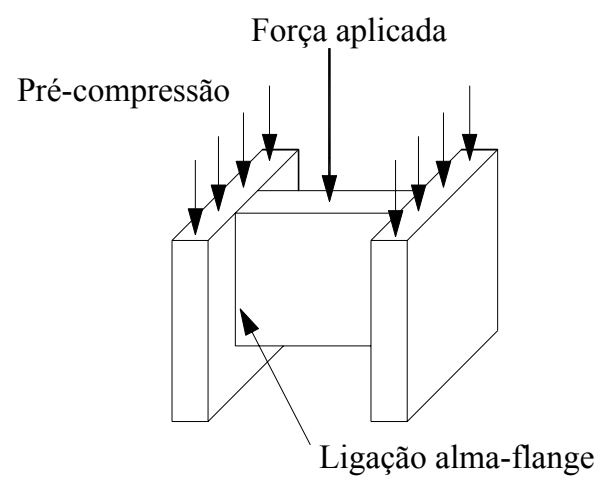

Figura 2.31 - Esquema do ensaio. Lissel et al. (2000)

As rupturas típicas para a amarração indireta e para a direta estão apresentadas na Figura 2.32. Nota-se que, para o caso da amarração indireta (Figura 2.32a), fica clara a ruptura das juntas de argamassa e dos conectores, enquanto que para a amarração direta (Figura 2.32b) ocorre a ruptura dos tijolos e a instabilidade dos flanges, causadas pelas forças de inter-travamento proporcionadas pela amarração dos tijolos.
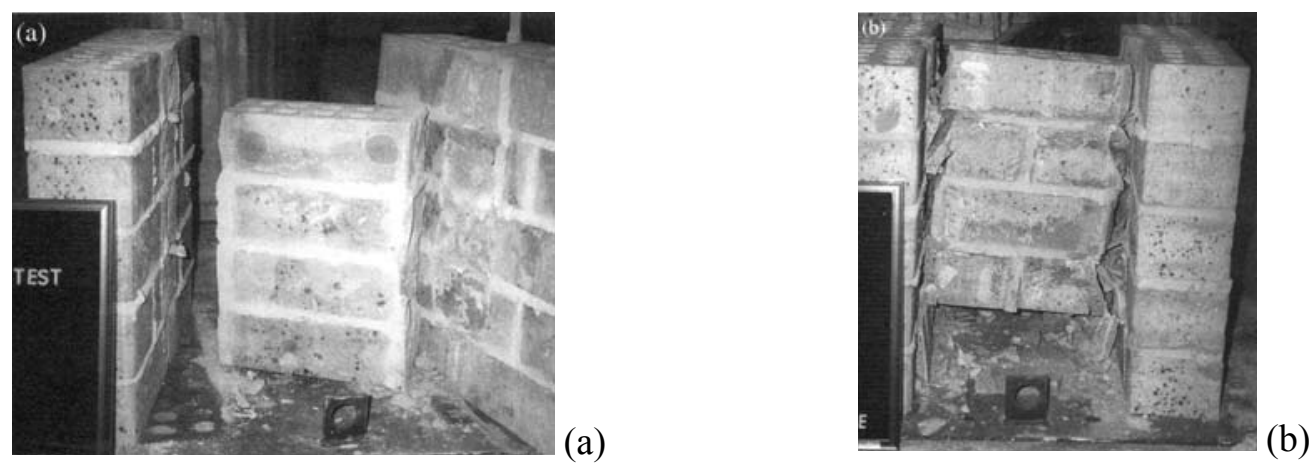

Figura 2.32 - Formas de ruptura. Lissel et al. (2000)

Segundo Lissel et al. (2000), os resultados desta pequena série de ensaios indicam que o inter-travamento mecânico gerado pela amarração direta da ligação almaflange proporciona uma significativa vantagem estrutural em relação à amarração indireta. As forças aplicadas nos corpos-de-prova com amarração direta são, em média, três vezes maiores do que os com amarração indireta. A tensão de cisalhamento média 
obtida para o caso da amarração direta sem conector é de 1,82 $\mathrm{MPa}$, considerando que a seção resistente ao cisalhamento é igual à área da interface.

\subsection{2 - Ensaios sobre a eficiência de ligações realizados no Brasil}

Camacho et al. (2001) e Silva (2003) desenvolvem pesquisa experimental englobando ensaios de painéis em formato " $\mathrm{H}$ ", de prismas tipo "cavalete" e de cisalhamento em blocos. Os primeiros ensaios têm a finalidade de estudar a transferência das ações verticais entre paredes com diferentes amarrações, em especial a indireta. Já os ensaios de cisalhamento de prismas tipo "cavalete" são realizados para se levantar uma possível correlação entre a resistência desses elementos e a resistência da ligação por amarração indireta. Também há a tentativa de se correlacionar a resistência ao cisalhamento do bloco e a resistência da ligação por amarração direta. Em todos os ensaios realizados por Camacho et al. (2001) são utilizados blocos cerâmicos na escala (1:3), enquanto Silva (2003) emprega blocos cerâmicos na escala natural (1:1) com dimensões homólogas.

Os painéis em formato " $H$ " são construídos sobre bases de concreto, com uma abertura na região central de tal forma que a parede interna não seja apoiada, sendo ligada apenas aos flanges. Os painéis em modelos físicos reduzidos de Camacho et al. (2001) são construídos com três tipos de amarração nas ligações: amarração direta sem graute no encontro (PHCV), amarração direta com graute no encontro (PHCG) e amarração indireta através de grampos e graute (PHTG). Os painéis em escala natural de Silva (2003) são construídos do tipo PHCV e PHTG. Na Figura 2.33 são apresentadas as elevações das paredes, bem como as dimensões dos painéis nas escalas natural e reduzida
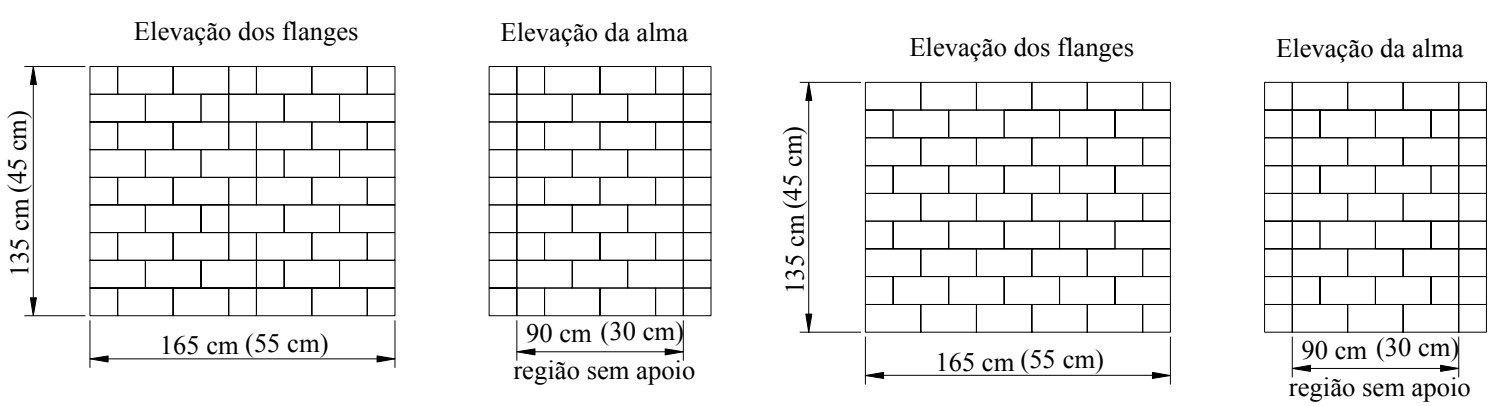

As medidas entre parênteses são referentes aos painéis na escala (1:3)

(a) Painel PHCV e PHCG

(b) Painel PHTG

Figura 2.33 - Paredes tipo H: Formas e dimensões 
Nos ensaios, Figura 2.34, o carregamento vertical é introduzido apenas na parede central, uniformemente distribuído, de forma que toda força deva ser transferida aos flanges através da ligação.

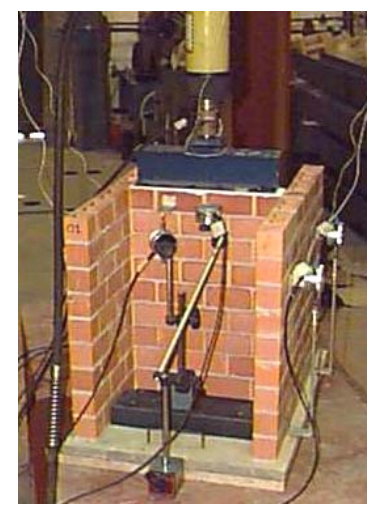

(a) Escala (1:3)

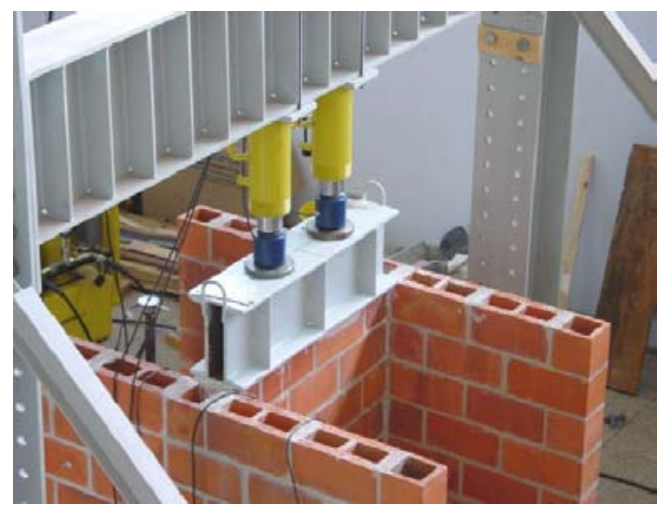

(b) Escala (1:1)

Figura 2.34- Aplicação do carregamento vertical dos painéis nas escalas (1:3) e (1:1). Camacho et al (2001) e Silva (2003).

A Figura 2.35 apresenta um gráfico com a relação entre a força aplicada nos painéis em escala (1:3) e o deslocamento absoluto vertical no topo da parede central. Percebe-se que os painéis PHTG, amarração indireta, rompem com uma carga superior aos outros painéis e de maneira dúctil. Já os painéis com amarração direta, PHCV e PHCG, possuem rupturas frágeis. Nota-se, ainda, que apesar de alguns painéis com diferentes amarrações terem praticamente a mesma rigidez (PHCV03 e PHTG05), observa-se uma certa variação nas inclinações da curva força/deslocamento para painéis com mesma amarração (PHCV01 e PHCV02).

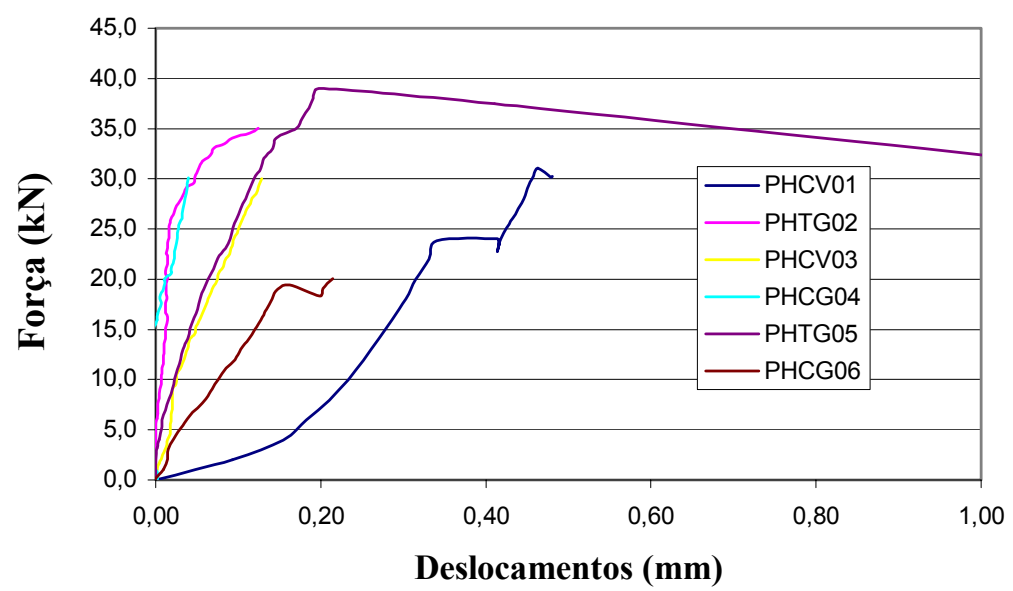

Figura 2.35 - Relação força-deslocamento da parede central - painéis na escala (1:3). Camacho et al. (2001)

O gráfico da relação entre a força aplicada e o deslocamento da parede central para os painéis na escala natural (1:1) está ilustrado na Figura 2.36. Neste caso, a 
instrumentação nos painéis PHCV é retirada em alguns estágios antes da ruptura para se evitar danos aos aparelhos. Nos ensaios dos painéis PHTG nota-se uma grande ductilidade dos painéis, mesmo comportamento verificado nos painéis semelhantes em escala reduzida. Também se observa que mesmo painéis com amarrações diferentes apresentam praticamente a mesma rigidez (PHCV 02 e PHTG 01), enquanto que nos painéis da amarração direta (PHCV) obtêm-se inclinações ligeiramente diferentes.

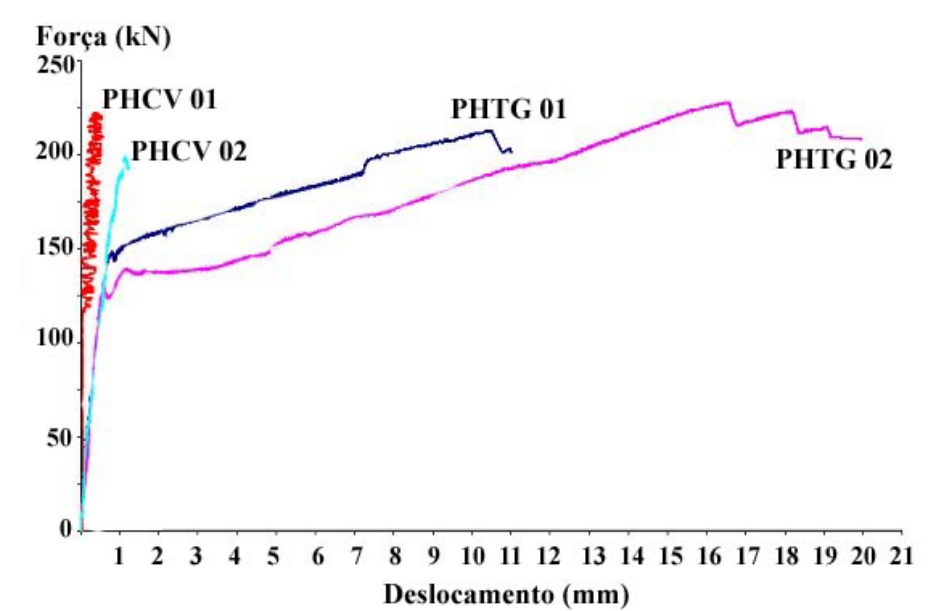

Figura 2.36 - Relação força-deslocamento da parede central - painéis na escala natural (1:1). Silva (2003)

O aparecimento de fissuras inclinadas no encontro da parede central com os flanges é uma característica usual do ensaio tanto na escala reduzida quanto na natural. Para os painéis PHCV e PHCG, com amarração direta, a ruptura é sempre frágil, caracterizando-se pelo desprendimento total de um flange, com ou sem desmonte. Para os painéis PHTG, amarração indireta, a ruptura é do tipo dúctil, conduzindo a parede central a grandes deslocamentos verticais. Há, até mesmo, o aparecimento de fissuras horizontais no topo dos flanges, algumas vezes com o desprendimento dos blocos. A Figura 2.37 apresenta as formas típicas de ruptura dos painéis.

Os resultados médios da força de ruptura e da tensão de cisalhamento obtidos para os diferentes painéis estão apresentados na Tabela 2.2. Neste caso, a tensão de cisalhamento é calculada dividindo-se a força de ruptura pela área da interseção das paredes. Observa-se que os painéis na escala (1:3) com amarração indireta (PHTG) apresentam valores 6\% superiores aos obtidos para a amarração direta (PHCV). Contudo, na escala (1:1) não se obtêm esses mesmos resultados. Pelo contrário, os painéis com amarração indireta (PHTG) apresentam valores 35\% inferiores aos com amarração direta $(\mathrm{PHCV})$. Os painéis com amarração direta e graute no encontro (PHCG), realizado apenas na escala (1:3), apresentam valores inferiores aos demais da 
sua escala, mas isso se deve ao fato de ter ocorrido uma ruptura prematura em um dos ensaios, o que levou a um valor médio reduzido.

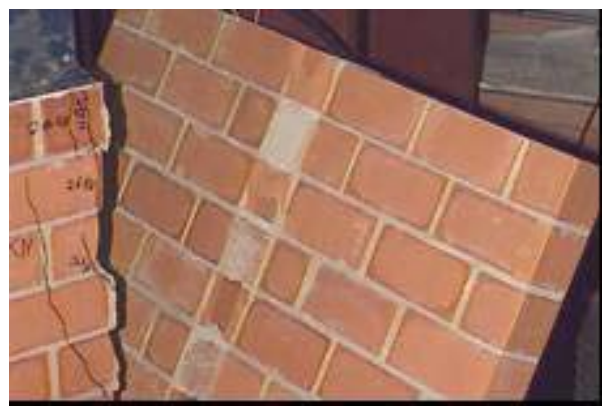

(a) Painel PHCV (1:3)

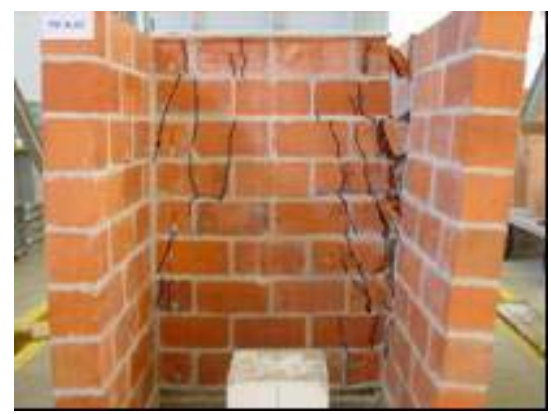

(b) Painel PHCV (1:1)

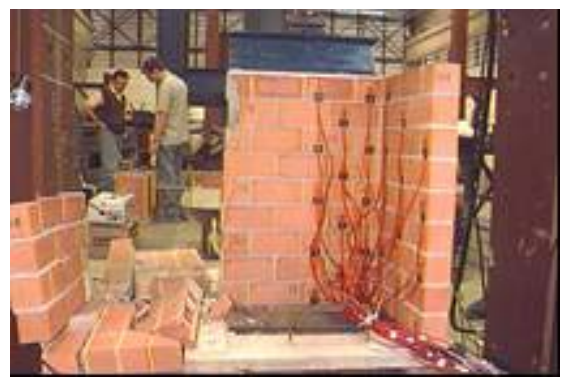

(c) Painel PHCG (1:3)

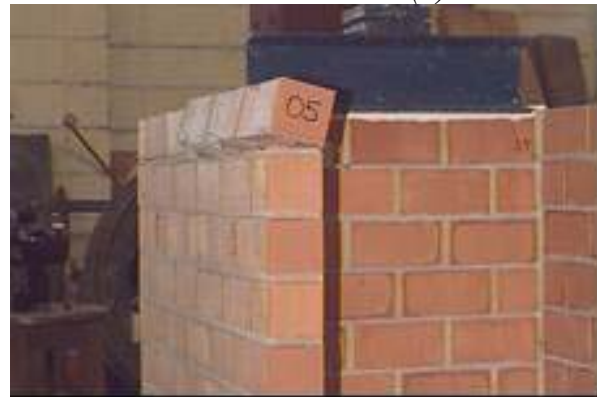

(d) Painel PHTG (1:3)

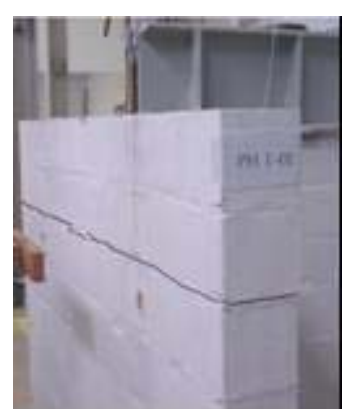

(e) Painel PHTG (1:1)

Figura 2.37 - Formas de ruptura. Camacho et al. (2001) e Silva (2003)

Tabela 2.2 - Resultados médios obtidos para os painéis ensaiados. Camacho et al. (2001) e Silva (2003)

\begin{tabular}{|c|c|c|c|}
\hline Escala & Tipo de Painel & Força de ruptura (kN) & Tensão de cisalhamento (MPa) \\
\hline $\mathbf{( 1 : 3 )}$ & PHCV & 39,58 & 0,96 \\
\hline$(\mathbf{1 : 3 )}$ & PHCG & 33,60 & 0,80 \\
\hline$(\mathbf{1 : 3 )}$ & PHTG & 41,92 & 1,01 \\
\hline$(\mathbf{1 : 1 )}$ & PHCV & 342,35 & 0,90 \\
\hline$(\mathbf{1 : 1 )}$ & PHTG & 224,10 & 0,60 \\
\hline
\end{tabular}

São também ensaiados, nas escalas (1:3) e (1:1), prismas tipo "cavalete" para a avaliação do cisalhamento na junta da ligação indireta (Figura 2.38). O cavalete é totalmente grauteado, com a colocação de um grampo metálico na junta intermediária, em ambos os lados (Figura 2.38). A força vertical é aplicada apenas sobre sua parede central. A força de ruptura média obtida é de $8,03 \mathrm{kN}$ para a escala $(1: 3)$ e de $51,22 \mathrm{kN}$ 
para a escala (1:1). O comportamento da ruptura em ambas as escalas é sempre dúctil, caracterizado pelo esmagamento da argamassa na junta vertical, verificando-se, em alguns casos, a presença de pequenas fisssuras nessa região. Os blocos onde se aplicam as forças têm a tendência de deslocamento vertical como um corpo rígido, levando os grampos que efetuam a ligação ao escoamento (Figura 2.39).

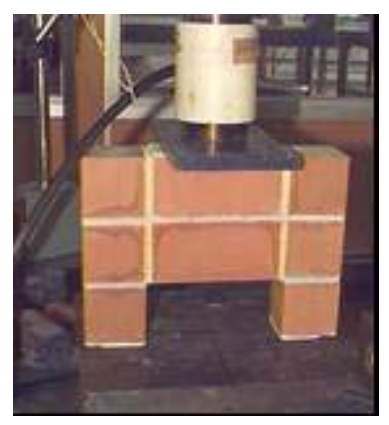

(a) escala (1:3)

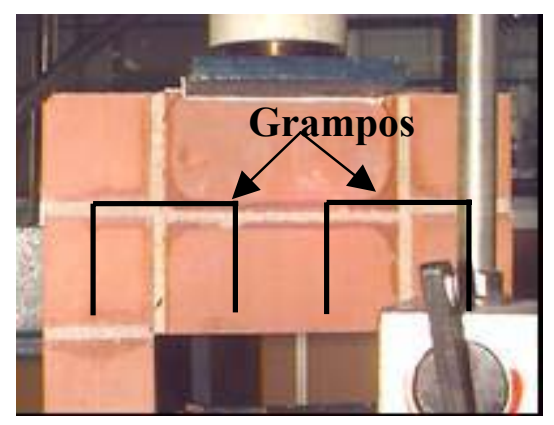

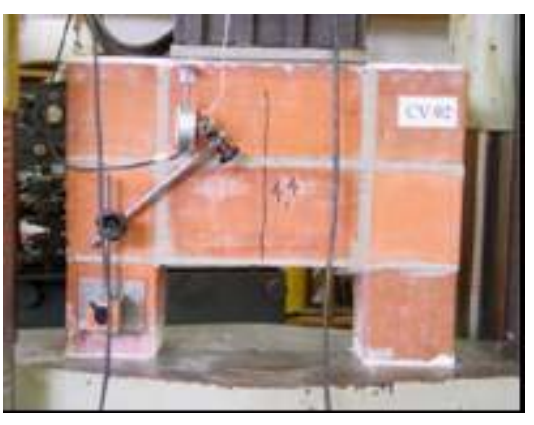

(b) escala (1:1)

Figura 2.38 - Ensaio de cisalhamento nos "cavaletes". Camacho et al. (2001) e Silva (2003)

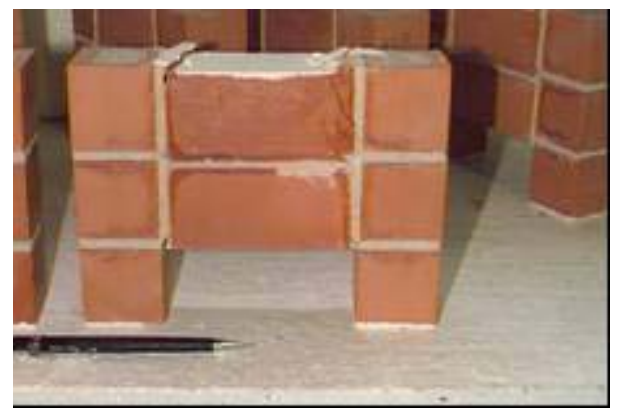

(a) escala (1:3)

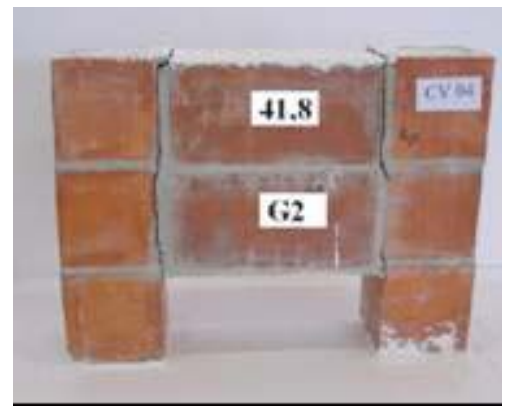

(c) escala (1:1)

Figura 2.39 - Forma de rupturas dos "cavaletes". Camacho et al. (2001) e Silva (2003)

$\mathrm{Na}$ tentativa de se avaliar o cisalhamento na amarração direta desenvolveu-se um aparelho no laboratório do Departamento de Engenharia Civil da FEIS/UNESP para o ensaio de cisalhamento do bloco. A introdução do carregamento é próximo da região de engaste, minimizando a introdução de esforços de flexão, Figura 2.40. A força de ruptura média encontrada foi de $3,77 \mathrm{kN}$ para a escala $(1: 3)$ e de $55,54 \mathrm{kN}$ para a escala natural (1:1). Considerando que existem 10 unidades inter-travadas na interseção das paredes que compõe o painel PHCV, uma estimativa para a força de ruptura para a escala (1:3) seria $37,7 \mathrm{kN}$, um valor cerca de $5 \%$ inferior ao obtido no ensaio. Porém, ao utilizar o mesmo raciocínio para a escala (1:1) obtém-se uma força de ruptura de 555,4 $\mathrm{kN}$, que é $62 \%$ superior ao valor obtido no ensaio dos painéis. 


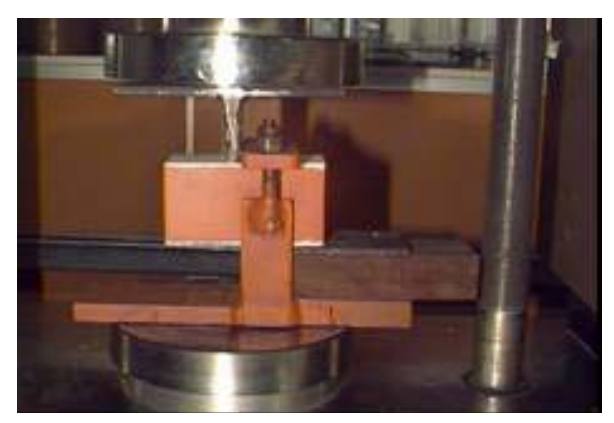

(a) escala (1:3)

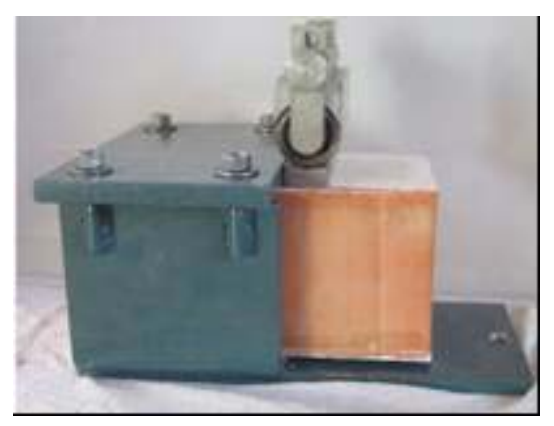

(c) escala (1:1)

Figura 2.40 - Ensaio de cisalhamento dos blocos. Camacho et al. (2001) e Silva (2003)

Camacho et al. (2001) concluem, para a escala reduzida (1:3), que a amarração indireta com a utilização de grampos apresenta vantagens em relação à amarração direta. A força de ruptura é ligeiramente superior; a ruptura ocorre de modo dúctil, sem a separação das paredes; a fissuração do painel é menor; e mesmo após a ruptura, caracterizada pelo deslocamento excessivo, a força aplicada apresenta uma pequena queda e permanece praticamente constante. Contudo, Silva (2003) verifica que na escala natural (1:1) a amarração direta leva a uma força de ruptura $50 \%$ superior à obtida com a amarração indireta. A vantagem da amarração indireta que permanece na escala (1:1) é a ruptura dúctil sem a separação das paredes. Observa-se que a tensão de cisalhamento obtida para a amarração direta pelas duas pesquisas é bem próxima, 0,96 MPa para a escala (1:3) e 0,90 MPa para a escala natural.

Em relação aos prismas tipo "cavalete", os pesquisadores observam que apesar do comportamento ter sido similar ao do painel com amarração indireta, é necessária uma investigação experimental mais ampla, que leve a relações seguras. Até porque, no caso dos painéis, pode ter ocorrido uma maior influência da flexão no seu comportamento.

Para os ensaios de cisalhamento de blocos, por meio de uma relação simplista, obteve-se uma boa representação do resultado do painel com amarração direta para a escala reduzida. Todavia, essa mesma relação não foi encontrada para a escala (1:1). Porém, como no caso do prisma tipo "cavalete", é importante realizar uma investigação complementar para a confirmação ou não deste resultado.

De uma maneira geral, percebe-se que os modelos físicos reduzidos reproduziram satisfatoriamente o comportamento da escala natural. Entretanto, não atingiu-se uma correlação numérica entre os modelos de diferente escala. 


\section{5 - Pesquisas numéricas sobre a interação de paredes}

\subsection{1 - Análise numérica realizada por Capuzzo Neto}

Além da parte experimental apresentada anteriormente, Capuzzo Neto (2000) também realiza uma modelagem em elementos finitos discretizando as paredes, com a simulação de blocos, juntas de argamassa e cintas de amarração. Por simplificação, não se considera os vazados dos blocos, empregando-se uma espessura efetiva para os mesmos. São utilizados os módulos de deformação do bloco e da argamassa obtidos experimentalmente (Tabela 2.1). Ressalta-se que em relação ao bloco, devido ao uso da espessura efetiva, utiliza-se o módulo de deformação em relação à área líquida (cerca de $50 \%$ da área bruta). O programa de elementos finitos utilizado é o ANSYS 5.5, onde se realiza apenas a análise linear do problema. Na modelagem numérica o carregamento adotado equivale a uma força de $280 \mathrm{kN}$ aplicada uniformemente apenas na parede central, o que representa um dos estágios do ensaio, servindo para posterior comparação com os resultados experimentais.

Nessa modelagem numérica verifica-se que os resultados correspondentes aos modelos com e sem cinta de amarração à meia altura são praticamente idênticos. Observa-se na análise uma concentração das tensões normais verticais na região de aplicação do carregamento (Figura 2.41a), o que no ensaio leva à ruptura do painel. Nessa mesma figura nota-se a tendência de uniformização dessa tensão na região inferior do painel, fato observado na parte experimental. O gráfico da variação da tensão normal vertical ao longo da altura do painel (Figura 2.41b) permite uma melhor visualização deste comportamento, onde se percebe que a partir da meia altura as tensões ficam uniformes, exibindo os mesmos valores para todas as paredes. Ressalta-se que no gráfico os valores da análise numérica correspondem ao mesmo alinhamento da instrumentação utilizada. 
Tensão normal vertical $(F=280 \mathrm{kN})$

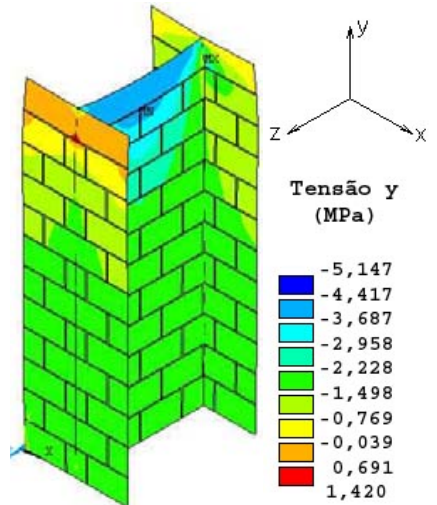

(a)

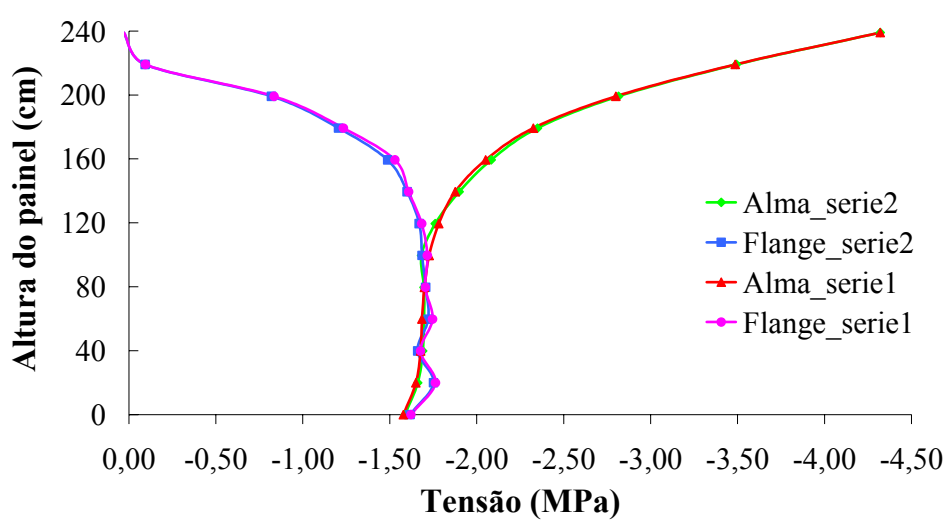

(b)

Figura 2.41 -Tensão normal vertical ao longo da altura $(F=280 \mathrm{kN})$. Capuzzo Neto (2000)

Verifica-se na simulação numérica que na região da interseção das paredes, próximo ao topo, ocorrem as maiores tensões de cisalhamento (Figura 2.42), mostrando novamente coerência entre o resultado experimental e o teórico. Observa-se ainda que a cinta intermediária está localizada abaixo da região de transferência de força entre a parede central e os flanges, portanto, neste caso sua influência na interação das paredes é pequena. Esse fato é comprovado durante os ensaios, onde não se percebe diferenças significativas nas forças de ruptura do painel das duas séries. Apenas verifica-se que os painéis da série 2 (com cinta intermediária) apresentam um comportamento linear mais pronunciado que os painéis da série 1 .
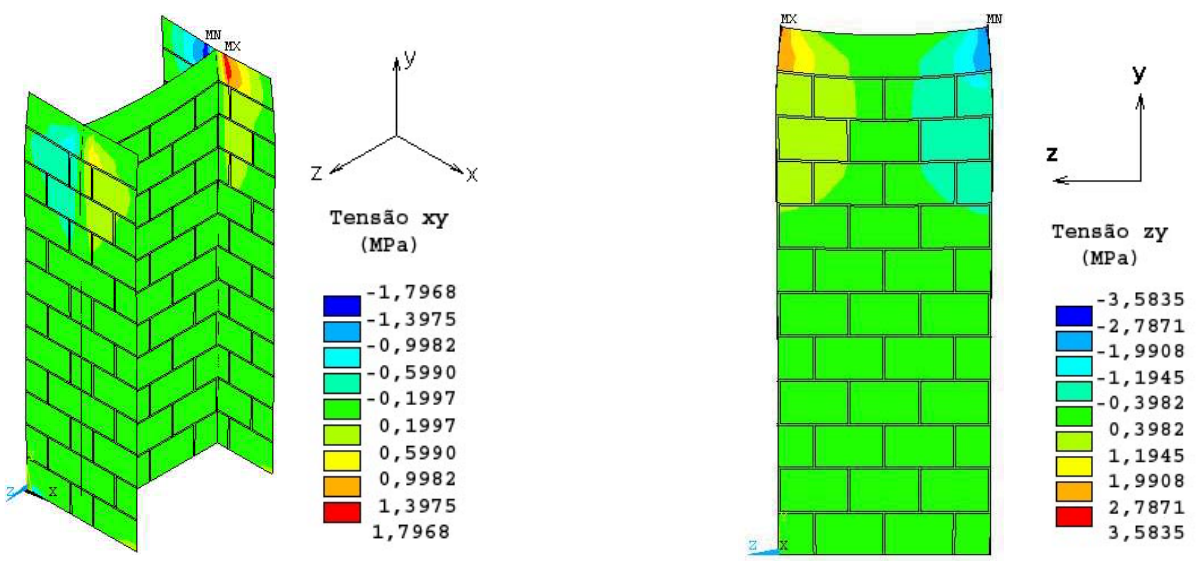

Figura 2.42 - Tensões de cisalhamento $(F=280 \mathrm{kN})$. Capuzzo Neto (2000)

Visto a boa representação da análise numérica em relação ao comportamento dos painéis ensaiados, Capuzzo Neto (2000) realiza algumas extrapolações numéricas, variando-se o número de pavimentos. Essas extrapolações permitem analisar situações que são muitas vezes inviáveis de se realizar em laboratório ou in loco. Para a 
modelagem em elementos finitos utilizam-se os mesmos princípios e características dos materiais adotados para a análise numérica do painel ensaiado com um pavimento.

É analisada a influência da presença de mais de um pavimento na simulação numérica, entretanto sem considerar a existência de lajes. Nessa extrapolação, ao invés de aplicar o carregamento total no topo de um painel, o carregamento é dividido igualmente pelo número de pavimentos simulados e aplicado no topo de cada trecho. Assim, existe uma melhor representação do que ocorre em um edifício. O carregamento é constituído por forças por unidade de comprimento, aplicadas apenas na parede central, totalizando-se $280 \mathrm{kN}$ para todas as variações de número de pavimento. Novamente verifica-se que o comportamento linear do painel com a cinta intermediária (série 2) é praticamente igual ao do painel sem cinta intermediária (série 1). Deste modo, são analisados apenas os resultados correspondentes aos painéis da série 1 .

Na Figura 2.43 fica evidente a redução na máxima tensão de compressão ao dividir o carregamento pelo número de pavimentos. Isso acontece devido à transferência do carregamento aplicado nos níveis superiores para os flanges; deste modo a parede central no $1^{\circ}$ pavimento tem um menor carregamento e conseqüentemente uma tensão menor. A redução mais drástica ocorre ao comparar o painel de 1 pavimento com o de 2 pavimentos, cerca de $50 \%$.

Percebe-se, na Figura 2.44, que as concentrações de tensões de cisalhamento ocorrem nas regiões onde há aplicação de forças (regiões superiores dos pavimentos) e onde ocorrem os desvios de trajetória das tensões normais verticais (regiões inferiores dos pavimentos). As maiores tensões de cisalhamento ocorrem nos últimos pavimentos de cada modelo, pois nestas regiões existem as maiores diferenças entre as forças atuantes nos flanges e na parede central, já que não há nenhum carregamento nos flanges. Observa-se, também, a progressiva redução das tensões máximas de cisalhamento. No exemplo de 2 pavimentos existe uma redução de cerca de $50 \% \mathrm{em}$ relação a 1 pavimento, no exemplo de 3 pavimentos a redução foi de cerca de $30 \%$ em relação ao de 2 pavimentos e no exemplo de 4 pavimentos chegou a uma redução de $25 \%$ em relação ao de 3 pavimentos. Essas reduções são superiores às observadas para a tensão normal vertical, isto porque o cisalhamento máximo, neste exemplo, é diretamente proporcional ao número de pavimentos, enquanto que a máxima tensão normal tende a um valor limite, a tensão uniformizada. 
Capuzzo Neto (2000) também realiza extrapolações numéricas variando as dimensões em planta, na tentativa de verificar a sua influência na distribuição do carregamento. Entretanto, mesmo percebendo que o principal parâmetro na análise da interação é a relação entre a altura e o comprimento em planta do painel, não foi possível obter resultados conclusivos.

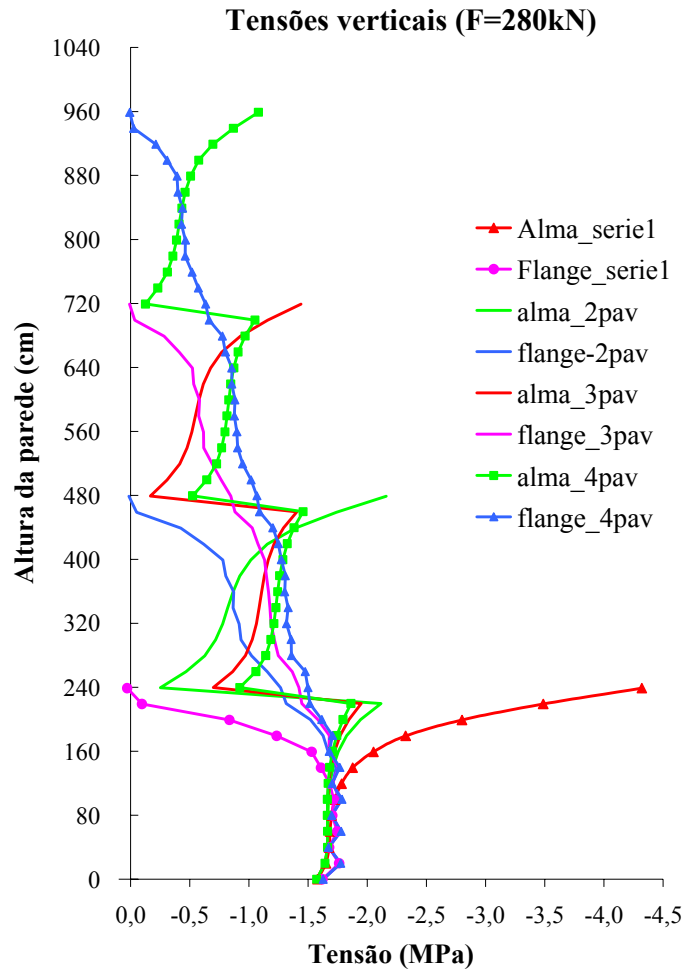

Figura 2.43 - Distribuição da tensão normal vertical. Capuzzo Neto (2000)

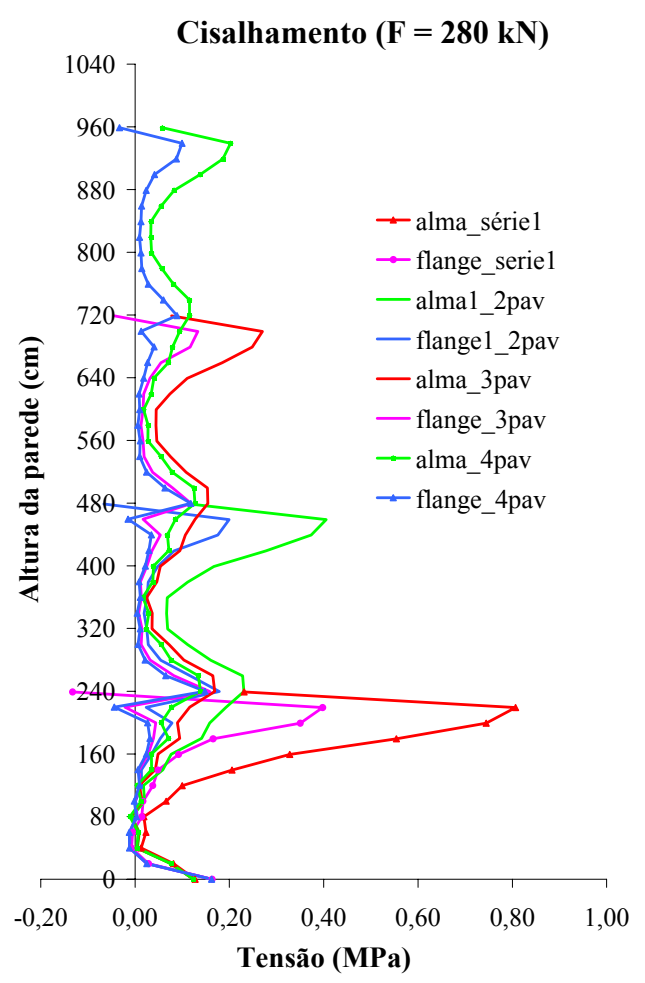

Figura 2.44 - Distribuição da tensão de cisalhamento. Capuzzo Neto (2000)

\subsection{2 - Análise numérica realizada por Ali, Sinha e Usmani}

Ali et al. (2000) realizam uma análise numérica de paredes de tijolos enrijecidas por paredes ortogonais considerando as não-linearidades da alvenaria. O objetivo dos autores não é especificamente a interação das paredes, mas sim verificar os coeficientes de enrijecimento indicados por diversas normas (BS 5628, AS 3700, EUROCODE 6, entre outras). Estes coeficientes de enrijecimento permitem considerar que uma parede enrijecida possua uma resistência maior que uma parede sem enrijecimentos (parede isolada). Também comparam os resultados obtidos na análise numérica com os ensaios de Sinha e Hendry (1979) e Sinha (1982).

Os autores indicam que para a modelagem numérica da parede enrijecida é necessária uma análise tridimensional. Contudo, para reduzir o esforço computacional, a alvenaria é considerada como homogênea (macro-modelagem) ao invés de modelá-la 
com tijolos e juntas de argamassas separados (micro-modelagem). Para essa análise numérica os autores utilizam o programa de elementos finitos ABAQUS. No artigo apresenta-se brevemente o modelo de material utilizado, que é desenvolvido especificamente para análises de estruturas de concreto. Utilizam-se elementos tridimensionais (3D), sendo que as dimensões dos elementos são escolhidas de tal forma que possam acomodar tijolos e juntas vertical e horizontal de argamassa, visto que se está utilizando a macro-modelagem. São ainda consideradas as não-linearidades geométrica e do material. As características mecânicas da alvenaria são obtidas de ensaios uniaxiais realizados por Sinha e Hendry (1979) e Sinha (1982).

No total são analisadas numericamente 42 paredes enrijecidas (formato " $\mathrm{H}$ " em planta) e 18 paredes isoladas. Ali et al. (2000) investigam a influência da altura, da localização do carregamento e do comprimento da parede. Em todos os casos são aplicadas forças distribuídas nas áreas correspondentes aos carregamentos. Na base das paredes, as translações horizontais e verticais são restringidas. Na região de aplicação do carregamento, os deslocamentos horizontais também são impedidos para simular as características dos ensaios de Sinha e Hendry (1979) e Sinha (1982). Na Figura 2.45 apresenta-se uma típica malha de elementos finitos utilizada nas análises.
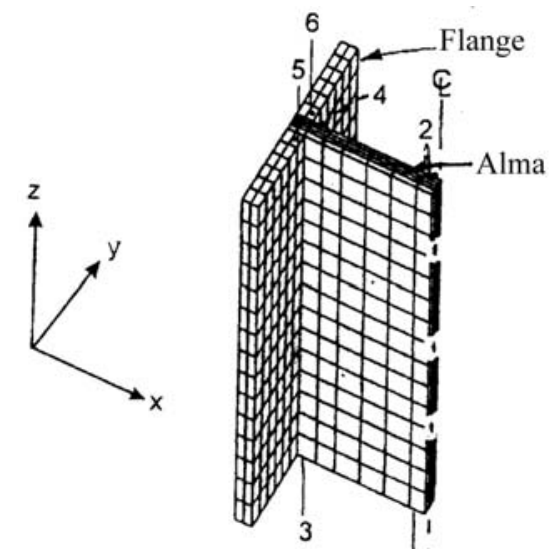

Figura 2.45 - Malha típica de elementos finitos. Ali et al. (2000)

Na Tabela 2.3 são descritos apenas os resultados de análises numéricas que apresentam valores experimentais para comparação. Variam-se a altura dos painéis, o comprimento da parede central (alma), a excentricidade do carregamento (axial ou não) e, no caso das paredes enrijecidas, a região de aplicação da tensão (somente na alma ou na seção total). Como já adiantado antes, os resultados experimentais são do trabalho de Sinha e Hendry (1979) e Sinha (1982). Por estes resultados percebe-se uma boa relação entre valores numéricos e experimentais. 
Tabela 2.3 - Comparação de resultados numéricos e experimentais. Ali et al. (2000)

\begin{tabular}{|c|c|c|c|c|}
\hline & Altura (cm) & $(h / t)$ & Parede enrijecida (MPa) & Parede isolada (MPa) ${ }^{*}$ \\
\hline \multirow{3}{*}{$\begin{array}{c}\mathbf{L}=52,0 \mathrm{~cm} \\
e=0-\text { Carr. }=\text { total }\end{array}$} & 42 & 8 & $10,98(10,8)$ & $10,62(11,2)$ \\
\hline & 84 & 16 & $10,56(10,35)$ & $10,56(11,15)$ \\
\hline & 166,4 & 32 & $10,92(8,60)$ & $10,44(9,35)$ \\
\hline \multirow{2}{*}{$\begin{array}{c}\mathrm{L}=92,6 \mathrm{~cm} \\
\mathrm{e}=0-\text { Carr. }=\text { alma }\end{array}$} & 127,2 & 24 & $6,92(8,13)$ & 10,53 \\
\hline & 166,4 & 32 & $6,7(6,84)$ & 10,44 \\
\hline \multirow{3}{*}{$\begin{array}{c}\mathrm{L}=92,6 \mathrm{~cm} \\
\mathrm{e}=\mathrm{t} / 6-\text { Carr. }=\text { alma }\end{array}$} & 84 & 16 & $6,13(7,45)$ & 8,11 \\
\hline & 127,2 & 24 & $5,95(7,1)$ & 5,86 \\
\hline & 166,4 & 32 & $5,8(6,1)$ & 4,88 \\
\hline
\end{tabular}

* Os valores entre parênteses correspondem a resultados experimentais

No caso do carregamento axial $(\mathrm{e}=0)$ apenas na parede central (alma), os autores verificam que a ruptura ocorre pela formação e propagação de fissuras verticais predominantemente na ligação alma-flange. As fissuras iniciam na ligação alma-flange, próximo ao topo, onde as tensões de cisalhamento são muito altas, e propagam praticamente na vertical com o aumento do carregamento (Figura 2.46). Estes resultados são compatíveis com os observados nos ensaios de Sinha e Hendry (1979), Sinha (1982) e Capuzzo Neto (2000).
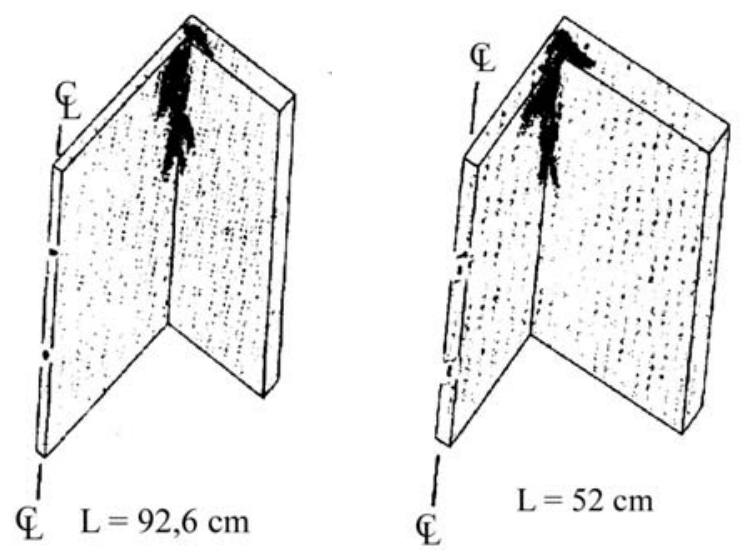

Figura 2.46-Esquema de ruptura das paredes com $e=0$ e $\mathrm{H} / \mathrm{T}=32$. Ali et al. (2000)

Ali et al. (2000) ressaltam que nas análises numéricas a parede enrijecida com o carregamento apenas na alma tem uma resistência significativamente menor que as paredes isoladas e as com o carregamento aplicado em toda a área. Essa menor resistência pode ser explicada pela concentração de tensões normais e de cisalhamento na região de aplicação do carregamento, que levam à perda de convergência do problema. Observam, também, que o efeito da esbeltez na resistência da parede enrijecida com o carregamento aplicado em toda a área é insignificante. Entretanto, 
percebem que para o caso do carregamento aplicado apenas na parede central o aumento da esbeltez leva a uma certa redução da resistência.

Os autores também verificam, como é de se esperar, que os valores de resistência obtidos para as paredes com excentricidades são sempre inferiores aos obtidos para as paredes com carregamento axial. Quanto maior a excentricidade, menor é a resistência da parede, tanto para as paredes enrijecidas como para as isoladas. Notase também que quanto maior a esbeltez menor será a resistência da parede. Contudo, para as paredes enrijecidas com grande esbeltez (acima de 24), o aumento da altura não traz uma queda significativa da resistência.

\subsection{3 - Modelagem numérica da interação de paredes realizada por Peleteiro}

Peleteiro (2002) realiza uma modelagem numérica de painéis de alvenaria nãoarmada, cujo objetivo é verificar a transferência de forças entre paredes. A análise numérica é realizada empregando-se o software ABAQUS, considerando-se o comportamento linear e não-linear dos materiais. O ensaio modelado é o realizado por Capuzzo Neto (2000), painéis em formato " $\mathrm{H}$ " com cinta de amarração na última fiada (Figura 2.22a), apresentado anteriormente no item 5.2.4.

A autora utiliza para a análise não-linear um modelo de material elastoplástico, cujos detalhes são apresentados no item 4.6. Os blocos e as juntas de argamassa são discretizados separadamente, empregando-se um elemento de casca. Igualmente a Capuzzo Neto (2000), não se consideram os vazados dos blocos, utilizando-se uma espessura efetiva para eles $(7 \mathrm{~cm})$. $O$ carregamento, uma força uniformemente distribuída, é aplicado apenas no topo da parede central. As propriedades dos materiais são as mesmas apresentadas na Tabela 2.1. Ressalta-se que na análise numérica, devido ao uso da espessura efetiva, é necessário converter os valores referentes ao bloco na área bruta para a área líquida.

Peleteiro (2002) adota a resistência à tração do bloco e da argamassa como sendo $10 \%$ da resistência à compressão. Para o modelo numérico do painel, a cinta de amarração na última fiada é considerada como constituída apenas pelo graute e apresentando um comportamento elástico linear. Essa simplificação é feita porque tal elemento tem função apenas de amarrar o topo das paredes e distribuir de maneira mais uniforme o carregamento aplicado.

A principal diferença entre a modelagem numérica feita por Peleteiro (2002) e por Capuzzo Neto (2000), é que a primeira leva em consideração tanto o 
comportamento linear dos materiais como o não-linear. A adoção da não-linearidade dos materiais torna possível a obtenção das forças de início de fissuração e de ruptura para o painel. A autora ressalta que a força admitida como de ruptura na análise numérica é o valor máximo para qual é possível atingir a convergência com o uso do programa.

Na Tabela 2.4 apresentam-se os valores experimentais da força média em que se visualiza a primeira fissura e a força média de ruptura dos painéis da série 1, comparando-se esses valores médios com os obtidos na análise numérica de Peleteiro (2002). Observa-se que os resultados numéricos são aproximadamente $80 \%$ dos valores médios experimentais, indicando uma boa consistência com os ensaios. Ainda mais se for considerado que a obtenção das propriedades dos materiais (bloco e argamassa) em laboratório não é exata. Cabe também lembrar as simplificações feitas tanto na realização dos ensaios quanto na modelagem numérica.

Tabela 2.4- Comparação de valores numéricos e experimentais Força de fissuração e ruptura. Peleteiro (2002)

\begin{tabular}{|c|c|c|c|}
\cline { 2 - 4 } \multicolumn{1}{c|}{} & Força 1 $^{\text {a }}$ fissura $(\mathbf{k N})$ & Força de ruptura $(\mathbf{k N})$ & $\mathbf{F}_{\text {fissuracão }} / \mathbf{F}_{\text {ruptura }}$ \\
\hline Média experimental & 387 & $\mathbf{5 1 0}$ & $\mathbf{7 5 , 9 \%}$ \\
\hline ABAQUS não-linear & $\mathbf{3 1 0}$ & $\mathbf{4 2 5}$ & $\mathbf{7 2 , 9 \%}$ \\
\hline ABAQUS/ média & $\mathbf{8 0 , 1 \%}$ & $\mathbf{8 3 , 3 \%}$ & $\mathbf{9 6 , 0} \%$ \\
\hline
\end{tabular}

Um outro parâmetro que também pode ser comparado é o deslocamento relativo vertical, que é a principal medição realizada no ensaio. Por esse motivo, a autora realiza comparações para diferentes níveis de carregamento, inclusive valores teoricamente acima do limite linear (adotado como $75 \%$ da força de ruptura), empregando-se modelos lineares e não-lineares.

Na comparação para uma força de $280 \mathrm{kN}$, inferior a $75 \%$ da força de ruptura numérica e experimental, os valores obtidos pela análise linear e não-linear são idênticos (Tabela 2.5). Confirmando, dessa forma, que para esse nível de carregamento o comportamento do material é realmente linear. Nessa fase, a modelagem numérica apresenta uma boa representação dos deslocamentos obtidos experimentalmente, tanto na região inferior, quanto na superior do painel.

Numa segunda comparação, para uma força de $400 \mathrm{kN}$, portanto, superior ao limite do regime linear, os valores dos deslocamentos das análises linear e não-linear são novamente iguais (Tabela 2.6). Isso indica que a alvenaria, mesmo fissurada, não apresenta um comportamento não-linear tão evidente em termos de deslocamentos 
relativos. Na região inferior do painel ainda há uma boa correlação entre valores numéricos e experimentais. Entretanto, na região superior já não existe uma boa correspondência; os valores numéricos para os flanges são superiores aos experimentais, enquanto que para a parede central ocorre o inverso.

Tabela 2.5 - Deslocamentos relativos verticais numéricos e experimentais $(F=280 \mathrm{kN})$ - [PELETEIRO (2002)]

\begin{tabular}{|c|c|c|c|c|c|c|}
\cline { 2 - 7 } \multicolumn{1}{c|}{} & \multicolumn{3}{c|}{ Trecho inferior } & \multicolumn{3}{c|}{ Trecho superior } \\
\cline { 2 - 8 } & $\begin{array}{c}\text { Flange } \\
(\mathbf{m m})\end{array}$ & $\begin{array}{c}\text { Alma } \\
(\mathbf{m m})\end{array}$ & $\begin{array}{c}\text { Flange/ } \\
\text { Alma }\end{array}$ & $\begin{array}{c}\text { Flange } \\
(\mathbf{m m})\end{array}$ & $\begin{array}{c}\text { Alma } \\
(\mathbf{m m})\end{array}$ & $\begin{array}{c}\text { Flange/ } \\
\text { Alma }\end{array}$ \\
\hline Média experimental & $-0,089$ & $-0,090$ & 0,99 & $-0,064$ & $-0,134$ & 0,48 \\
\hline Abaqus Linear & $-0,108$ & $-0,113$ & 0,96 & $-0,089$ & $-0,142$ & 0,63 \\
\hline Abaqus Não-Linear & $-0,108$ & $-0,113$ & 0,96 & $-0,089$ & $-0,142$ & 0,63 \\
\hline Média/Abaqus & $82,4 \%$ & $79,6 \%$ & -- & $71,9 \%$ & $94,4 \%$ & -- \\
\hline Média/Abaqus Não-Linear & $82,4 \%$ & $79,6 \%$ & -- & $71,9 \%$ & $94,4 \%$ & -- \\
\hline
\end{tabular}

Tabela 2.6 - Deslocamentos relativos verticais numéricos e experimentais $(F=400 \mathrm{kN})$ - [PELETEIRO (2002)]

\begin{tabular}{|c|c|c|c|c|c|c|}
\cline { 2 - 7 } \multicolumn{1}{c|}{} & \multicolumn{3}{c|}{ Trecho inferior } & \multicolumn{3}{c|}{ Trecho superior } \\
\cline { 2 - 7 } & $\begin{array}{c}\text { Flange } \\
(\mathbf{m m})\end{array}$ & $\begin{array}{c}\text { Alma } \\
\mathbf{( m m}\end{array}$ & $\begin{array}{c}\text { Flange/ } \\
\text { Alma }\end{array}$ & $\begin{array}{c}\text { Flange } \\
\mathbf{( m m}\end{array}$ & $\begin{array}{c}\text { Alma } \\
\mathbf{( m m}\end{array}$ & $\begin{array}{c}\text { Flange/ } \\
\text { Alma }\end{array}$ \\
\hline Média experimental & $-0,126$ & $-0,148$ & 0,85 & $-0,062$ & $-0,232$ & 0,27 \\
\hline Abaqus Linear & $-0,155$ & $-0,162$ & 0,96 & $-0,128$ & $-0,204$ & 0,63 \\
\hline Abaqus Não-Linear & $-0,155$ & $-0,162$ & 0,96 & $-0,128$ & $-0,204$ & 0,63 \\
\hline Média/Abaqus & $81,3 \%$ & $91,4 \%$ & -- & $48,4 \%$ & $113,7 \%$ & -- \\
\hline Média/Abaqus Não-Linear & $81,3 \%$ & $91,4 \%$ & -- & $48,4 \%$ & $113,7 \%$ & -- \\
\hline
\end{tabular}

Na Tabela 2.7, uma última comparação é feita para uma força de $425 \mathrm{kN}$, valor correspondente à ruptura no modelo numérico e $83 \%$ da força de ruptura experimental. Para esse nível de carregamento verifica-se uma diferença mínima entre os deslocamentos obtidos na análise linear e não-linear. Nota-se, novamente, que no trecho superior não há correlação entre resultados numéricos e experimentais, tendo o mesmo comportamento ocorrido para o nível anterior de carregamento. No trecho inferior, os valores numéricos nos flanges também são superiores aos experimentais, só que a diferença entre eles não é tão grande. Acredita-se que essa diferença entre o comportamento do modelo numérico e o experimental seja devida à separação dos flanges e da parede central, fato verificado no ensaio. Na análise numérica realizada não é possível observar a separação das paredes, visto que a ligação entre as elas é 
considerada perfeita, não sendo permitido o deslocamento relativo dos nós na interseção. Por esse motivo, os valores experimentais relacionados aos flanges, no estágio após a fissuração, são inferiores aos valores numéricos. Nesse mesmo estágio, os valores experimentais obtidos para a parede central são superiores aos observados no modelo numérico.

Tabela 2.7 - Deslocamentos relativos verticais numéricos e experimentais (F=425 kN)- [PELETEIRO (2002)]

\begin{tabular}{|c|c|c|c|c|c|c|}
\cline { 2 - 7 } \multicolumn{1}{c|}{} & \multicolumn{3}{c|}{ Trecho inferior } & \multicolumn{3}{c|}{ Trecho superior } \\
\cline { 2 - 7 } & $\begin{array}{c}\text { Flange } \\
\mathbf{( m m})\end{array}$ & $\begin{array}{c}\text { Alma } \\
\mathbf{( m m})\end{array}$ & $\begin{array}{c}\text { Flange/ } \\
\text { Alma }\end{array}$ & $\begin{array}{c}\text { Flange } \\
\mathbf{( m m})\end{array}$ & $\begin{array}{c}\text { Alma } \\
\mathbf{( m m}\end{array}$ & $\begin{array}{c}\text { Flange/ } \\
\text { Alma }\end{array}$ \\
\hline Média experimental & $-0,120$ & $-0,170$ & 0,71 & $-0,062$ & $-0,256$ & 0,24 \\
\hline Abaqus Linear & $-0,164$ & $-0,172$ & 0,97 & $-0,135$ & $-0,216$ & 0,63 \\
\hline Abaqus Não-Linear & $-0,163$ & $-0,172$ & 0,95 & $-0,135$ & $-0,216$ & 0,63 \\
\hline Média/Abaqus & $73,2 \%$ & $98,9 \%$ & -- & $45,9 \%$ & $118,5 \%$ & -- \\
\hline Média/Abaqus Não-Linear & $73,6 \%$ & $98,9 \%$ & -- & $45,9 \%$ & $118,5 \%$ & -- \\
\hline
\end{tabular}

A princípio pode-se achar incoerente que o modelo numérico apresente valores consistentes em termos de forças (aparecimento da primeira fissura e ruptura), mas não represente corretamente os deslocamentos verticais relativos para os estágios após fissuração. No entanto, isto acontece porque independentemente da consideração da separação ou não das paredes no regime não-linear, a resistência última do painel é limitada pela resistência da parede central. Havendo ou não transferência de força para os flanges, não é possível aplicar um carregamento além da capacidade resistente da parede central considerada como isolada.

Conclui-se que o modelo numérico considerando o comportamento não-linear dos materiais apresenta resultados consistentes com os observados nos ensaios, mostrando a viabilidade do uso do software ABAQUS. Contudo, percebe-se que para uma melhor representação é necessário avaliar a separação das paredes por meio de uma modelagem numérica ainda mais complexa. A separação das paredes deve ocorrer em função do nível de cisalhamento atuante na interface, de modo que acima de um limite pré-determinado não ocorra mais a transmissão de forças entre paredes.

\section{6- Comentários}

Analisando-se os itens anteriores percebe-se que o fenômeno da distribuição das tensões normais verticais é influenciado pelas características geométricas dos grupos de 
paredes que compõem o edifício. Na maioria dos procedimentos é considerada a interação das paredes, permitindo-se ou não o espalhamento das forças através de paredes com aberturas. No entanto, quase a totalidade dos procedimentos não contempla a capacidade de transmissão de forças das intersecções. Apenas Corrêa e Page (2001) apresentam um método simplificado para a verificação da tensão máxima de cisalhamento que ocorre na intersecção e propõem um procedimento para o dimensionamento de paredes de alvenaria estrutural sob ações verticais em que se avalia a capacidade de transmissão de forças através das intersecções. Observam, também, a atuação benéfica das restrições horizontais provenientes das lajes nos casos de carregamentos excêntricos. Ainda notam a importância de se avaliar corretamente as ações atuantes para o projeto das fundações do edifício.

Com relação aos trabalhos sobre a interação de paredes de alvenaria estrutural percebe-se que não há nenhum estudo conclusivo sobre o assunto. Isto talvez se deva ao modo indireto que as pesquisas abordaram o tema. Por exemplo, Sinha e Hendry (1979) e Ali et al. (2000) tinham o objetivo de estudar os coeficientes de enrijecimento e não se preocuparam com a transferência de forças entre paredes. Camacho (1995) em seus ensaios de torres em escala reduzida concentrou-se apenas na uniformização do carregamento e não no fenômeno da interação das paredes. Em Capuzzo Neto (2000) o objetivo principal era o estudo da interação, no entanto, apesar de verificar a transferência de forças entre paredes, a influência do número de pavimentos e das dimensões em planta dos painéis, não se chegou a resultados mais abrangentes. Lissel et al. (2000), Camacho et al. (2001) e Silva (2003) estudaram a eficiência de diferentes tipos de amarrações e conectores. Signor e Roman (2002) realizaram apenas um ensaio exploratório sobre a transferência de forças entre paredes, onde chegaram a resultados que também comprovam a interação.

$\mathrm{Na}$ maioria dos estudos percebeu-se uma concentração de tensões de cisalhamento na ligação flange-alma, devido à transferência de forças de paredes carregadas para paredes não carregadas. Esta concentração de tensões gera um quadro de fissuração típica, onde as fissuras iniciam no topo dos painéis próximas à ligação alma-flange e se propagam ao longo da interface. Este tipo de fissuração foi observado em Sinha e Hendry (1979), Camacho (1995), Capuzzo Neto (2000), Lissel et al. (2000), Signor e Roman (2002), Camacho et al. (2001) e Silva (2003). As análises numéricas 
realizadas por Capuzzo Neto (2000) e Ali et al. (2000) também mostraram estas altas tensões de cisalhamento.

Em alguns ensaios notou-se que ocorreu a ruptura localizada dos painéis, sendo que a região de aplicação do carregamento limitava a resistência. Isto ocorreu nos ensaios de Sinha e Hendry (1979), Camacho (1995), Capuzzo Neto (2000) e Signor e Roman (2002). Capuzzo Neto (2000) também verificou em suas análises numéricas uma grande concentração de tensões normais na região de aplicação do carregamento. Estes resultados revelam um problema na realização de ensaios de estruturas de alvenaria: a ruptura localizada. Nos ensaios de estruturas de concreto, as rupturas localizadas são evitadas com a utilização de cintamentos ou armaduras de fretamento, o que não é normalmente utilizado na alvenaria.

Em relação à eficiência da ligação de acordo com a amarração utilizada, os estudos ainda são incipientes. Lissel et al. (2000) verificaram que a amarração direta dos blocos era muito mais eficiente que a amarração indireta através de conectores de fibra de vidro (GFRP). Camacho et al. (2001) obtiveram em seus ensaios com modelos reduzidos que a amarração indireta através de grampos metálicos era mais eficiente que a amarração direta. Já Silva (2003), em ensaios com modelos em escala natural, verifica que a amarração direta dos blocos é mais resistente que a indireta. Percebe-se que o tipo de conector pode ter uma grande influência na eficiência das amarrações indiretas.

Fica evidente a necessidade do desenvolvimento de um ensaio para a determinação da resistência ao cisalhamento vertical da intersecção. Somente com esse valor estipulado é que se pode realizar a distribuição das ações verticais de um modo seguro e mais próximo do que acontece no edifício de múltiplos andares de alvenaria. Enquanto não há um ensaio normalizado para tal resistência sugere-se a utilização das recomendações da norma britânica BS 5628 (1992) e da norma australiana AS 3700 (1998).

Verificou-se na análise numérica de mais de um pavimento realizada por Capuzzo Neto (2000) uma grande diminuição das tensões máximas de compressão e cisalhamento, indicando que o ensaio de painéis com um pavimento é uma situação extrema. Portanto, a realização de ensaios ou medições em campo, semelhantes à de Stockbridge, podem fornecer dados para uma melhor compreensão da trajetória das tensões ao longo da altura do edifício. 
Também se verifica a necessidade de um aprimoramento do modelo numérico para o estudo da interação de paredes. Apesar dos modelos numéricos considerando a não-linearidade dos materiais apresentarem resultados razoáveis para as forças de ruptura e de fissuração, quando se comparam os deslocamentos relativos pós-fissuração não é possível observar nos resultados numéricos a separação entre parede central e flanges que ocorre no ensaio. Portanto, é interessante a tentativa de se introduzir uma nova forma de modelagem numérica de modo a permitir que se simule a separação entre flanges e parede central. 


\section{CAPÍtulo}

\section{MODELOS FÍSICOS REDUZIDOS}

\section{1 - Generalidades}

Neste capítulo é realizada uma breve apresentação da teoria de modelos físicos reduzidos, enfocando os tipos de modelos estruturais usuais e a confiabilidade da técnica. Todo modelo estrutural tem como base as leis de semelhança, porém alguns de seus critérios podem ser abrandados quando o rigor da análise não é de todo necessário. Portanto, para um correto emprego dos modelos reduzidos é fundamental definir qual tipo de modelo estrutural e as suas respectivas considerações.

Investiga-se a utilização de modelos reduzidos em alvenaria, realizando-se um histórico do desenvolvimento das pesquisas com o objetivo de demonstrar a sua viabilidade e as diferentes finalidades de seu emprego. Apresentam-se os modelos estruturais usuais para alvenaria e seus respectivos requisitos de semelhança, que são de grande importância para a análise de resultados. Comenta-se, também, o efeito de escala para a argamassa.

Apresentam-se, ainda, alguns dos trabalhos sobre alvenaria estrutural realizados em modelos reduzidos no Brasil. Os ensaios envolvendo a caracterização das propriedades da alvenaria de blocos cerâmicos em escala reduzida são o enfoque principal, sendo uma forma de analisar quais são os ensaios mais representativos e de se obter valores para futuras comparações.

Para o fechamento do capítulo são feitos comentários sobre os diferentes modelos estruturais, as dificuldades que podem ser encontradas no emprego de modelos físicos reduzidos em alvenaria e indicações de ensaios para a caracterização das propriedades físicas. 


\section{2 - Teoria de modelos físicos reduzidos}

De acordo com o ACI C-444 (1987), modelo estrutural é uma representação física da estrutura ou de parte dela. De fato, não existe uma linha divisória bem definida entre ensaios de modelos e de outras estruturas. Mesmo o ensaio de uma viga em tamanho natural com um simples carregamento pode ser considerado como um ensaio de modelo, já que os seus resultados são utilizados para o cálculo de uma viga que faz parte de uma estrutura mais complexa, com dimensões diferentes e com materiais de resistências distintas. Entretanto, a idéia de modelo está geralmente associada a estruturas construídas em escalas reduzidas.

O uso de modelos reduzidos em pesquisa e cálculo de estrutura data de muitos anos. O emprego com sucesso dos modelos em problemas não-lineares de concreto armado e protendido, com carregamentos estáticos e dinâmicos, demonstra que a técnica de modelagem é uma alternativa viável aos ensaios em escala natural [ROCHA (1952), PREECE et al. (1964), LITLE e PAPARONI (1966), ROLL (1968), SABNIS e ROLL (1971), HOOSDORF (1972), CHOWDHURY e WHITE (1977), SABNIS et al. (1983), ACI C-444 (1987), HARRIS e SABNIS (1999), entre outros].

Entre 1959 e 1986 os modelos físicos reduzidos foram utilizados no Laboratório de Estruturas da EESC/USP, desde estudos do comportamento elástico-linear até outros relacionados à ruína. A grande maioria destes ensaios foi comandada ou orientada pelos professores Dante Martinelli, Ilio Montanari, Walter Savassi, Régis Lima entre outros. Dentre os trabalhos realizados podem-se citar: cascas piramidais invertidas do CEPEC (Centro de Pesquisas do Cacau), pilar típico do vertedouro da barragem de Ilha Solteira (Figura 3.1), modelo para estudo da barragem de abóbadas múltiplas para São Felix (rio Tocantins), pilar típico do vertedouro da barragem de Jaguara, lajes em regime de ruptura, pórticos elastoplásticos, modelos de grelhas de pontes (com e sem lajes), punção em lajes cogumelo etc.

O avanço dos métodos numéricos no final do século passado, aliado ao alto desempenho computacional, levou a uma diminuição da utilização de modelos físicos reduzidos. Principalmente para os estudos do comportamento elástico-linear das estruturas, onde os modelos físicos foram substituídos por modelos numéricos. Contudo, ainda não é possível considerar todos os detalhes e particularidades da estrutura na análise numérica. Por isso, a principal vantagem do uso de modelos físicos reduzidos sobre os modelos analíticos é a capacidade de representar o comportamento 
sob carregamento de uma estrutura completa até o estágio da ruptura, Harris e Sabnis (1999).
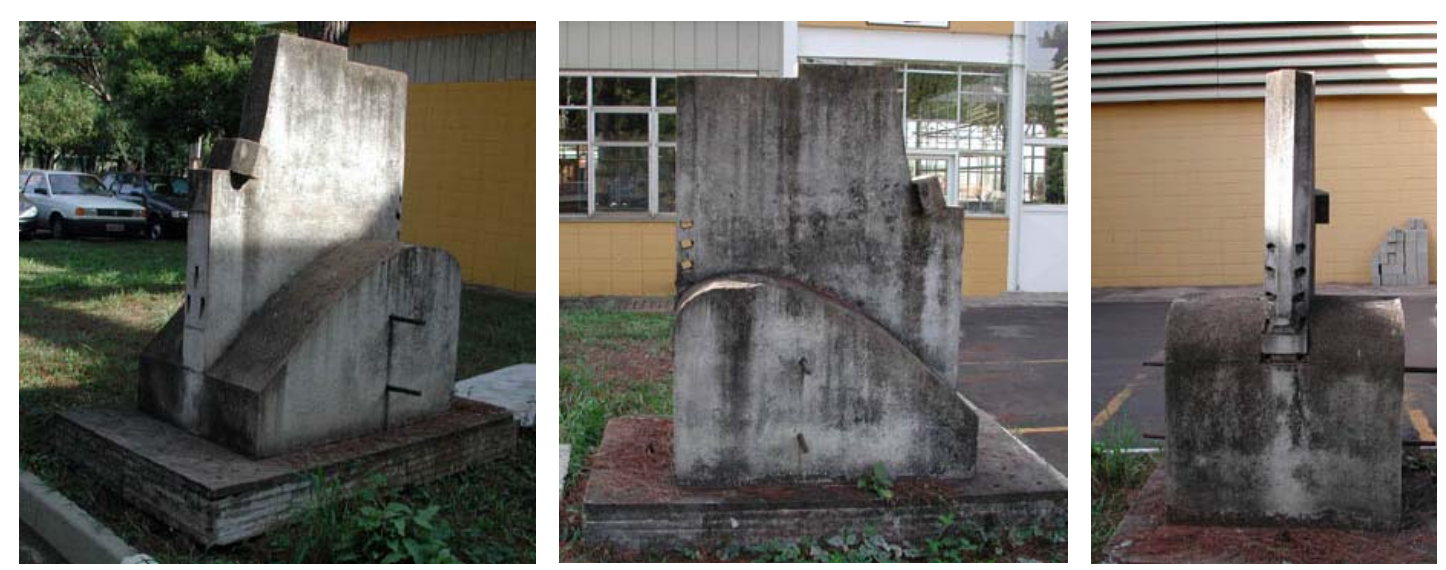

Figura 3.1 - Modelo do pilar típico do vertedouro de Ilha Solteira - escala 1:20

Harris e Sabnis (1999) também indicam que a principal motivação para a realização de experimentos em escala reduzida é a redução de custos. Tal redução é relativa a dois fatores: diminuição dos equipamentos de aplicação de força e seus respectivos pórticos de reação, e a redução nos custos de fabricação, de preparação e de remoção da estrutura. Mesmo assim, os ensaios de modelos físicos reduzidos encontram uma certa resistência no meio técnico. Hossdorf (1972) comenta que as críticas se fundamentam na incerteza dos próprios métodos do ensaio. As desaprovações dirigemse essencialmente à precisão dos resultados das medições, ao tempo de construção e montagem dos ensaios, e aos custos para a sua realização, quando comparados aos modelos teóricos (analíticos e numéricos). Porém, com o desenvolvimento da instrumentação e do uso de dispositivos mais precisos de aplicação de forças parte das críticas já não têm mais fundamento.

Apesar dessa resistência de parte do meio técnico, o ACI C-444 (1987) indica o uso de modelos físicos reduzidos para os projetos de complexas estruturas não-usuais, para o caso da ruptura da estrutura levar a conseqüências catastróficas ou para quando o projetista utilizar técnicas analíticas não comprovadas experimentalmente. Nestes casos, o ensaio de modelos reduzidos é utilizado para modificar, suplementar ou comprovar a análise realizada. Outra importante aplicação é na área de pesquisas, onde os modelos servem como base para especificações de normas e comprovação de modelos analíticos propostos. 


\subsection{1 - Leis da semelhança estrutural}

No momento que se define pela utilização de ensaios de modelos para representação de uma estrutura é essencial garantir que os materiais a serem empregados e o carregamento estejam de acordo com o tipo de modelo utilizado. Também é necessário converter os resultados obtidos no ensaio do modelo para prever o comportamento da estrutura em escala natural, isto é, devem-se conhecer os fatores de escala que transformam os resultados do ensaio nos correspondentes do protótipo. Para isso existe toda uma teoria sobre as leis de semelhança que pode ser encontrada em Rocha (1952), Preece e Davies (1964), Hossdorf (1972), Harris e Sabnis (1999) entre outros. Não se pretende aprofundar sobre o assunto, visto não ser o objetivo do trabalho.

Harris e Sabnis (1999) também enfatizam que a aplicação estritamente formal da teoria de modelos para um problema estrutural, sem pelo menos algum entendimento do comportamento estrutural esperado, pode levar a um programa experimental inadequado ou até mesmo incorreto. Assim, a teoria de modelos deve ser vista apenas como um dos aspectos do programa experimental.

\subsection{2 - Modelos Estruturais}

Harris e Sabnis (1999) conceituam três tipos de modelos estruturais de acordo com o grau de obediência às leis de semelhança:

\section{- Modelo com completa semelhança}

No modelo com completa semelhança todos os requisitos das leis de semelhança são obedecidos. Assim, as deformações específicas e as distorções angulares do modelo e do protótipo devem ser iguais. Os materiais do modelo e do protótipo podem ser diferentes, desde que a forma do diagrama tensão-deformação seja semelhante, levando em consideração o fator de escala de tensões $\left(s_{\sigma}\right)$. Estas condições são automaticamente satisfeitas quando o modelo e o protótipo são feitos do mesmo material. Na Figura 3.2 apresenta-se o comportamento tensão - deformação que o material do modelo deve ter em relação ao protótipo, para o caso de um estado de tensão uniaxial.

Entretanto, existem diversos fatores que muitas vezes impedem que a completa semelhança seja obtida. Algumas vezes pode ocorrer a omissão acidental na análise dimensional de alguma variável que influencie o problema. Muitas vezes não se respeita a igualdade do coeficiente de Poisson, por não ser um valor crítico na análise. Certas vezes é necessário substituir uma força uniformemente distribuída por um sistema 
equivalente discreto de forças. Existe, também, a dificuldade de manter condições de semelhança em relação à aderência, além do material do modelo poder apresentar um critério de ruptura diferente do material do protótipo.

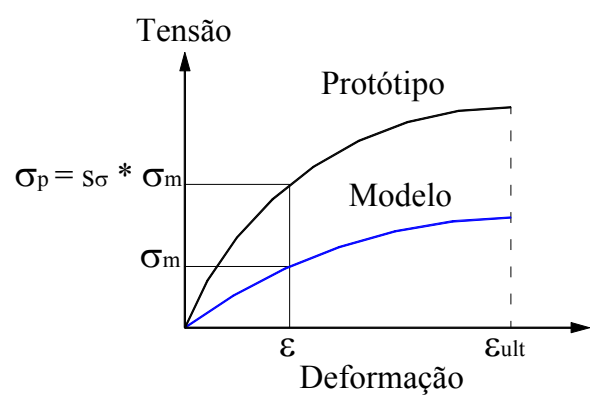

Figura 3.2 - Modelo de material para completa semelhança. Adaptado de Harris e Sabnis (1999)

Esta perda de semelhança, devido a um fator conhecido ou desprezado, muitas vezes gera diferenças entre os resultados do modelo e do protótipo chamadas de "efeitos de escala".

\section{- Modelo com semelhança de primeira ordem}

O modelo com semelhança de primeira ordem é aquele onde se desconsidera ou se relaxa algum dos critérios de semelhança, de tal modo que o erro introduzido seja considerado desprezível. Este é o caso da substituição de uma força uniformemente distribuída por um sistema discreto de forças, onde a diferença de comportamento da estrutura pode ser negligenciada, com base no princípio de Saint Venant.

Existem certos tipos de problemas estruturais que podem ser considerados como situações especiais. A natureza destes problemas pode ser melhor compreendida ao considerar o tipo de resposta da estrutura como um todo. Então, do ponto de vista analítico, qualquer resposta estrutural pode ser categorizada pela deformação: axial, cisalhante, por flexão e por torção ou qualquer combinação desses quatro tipos. Estas categorias são idealizadas na tentativa de superar certas dificuldades associadas com a análise teórica de tensões. Desta forma, em certas análises, o conhecimento teórico do tipo de resposta pode ser utilizado nos modelos, de forma a relaxar alguns critérios de semelhança, sem que o resultado seja comprometido.

Por exemplo, na análise de um problema de pórtico plano com ligações rígidas é fato notório que as forças axiais e de cisalhamento são de segunda importância quando comparadas aos momentos fletores. Deste modo, as condições de semelhança para os momentos de inércia dos elementos são fundamentais, enquanto que para a seção 
transversal estes requisitos podem ser relaxados, pois não terão grande influência no resultado final e facilitarão a construção do modelo. Entretanto, certos cuidados devem ser tomados quando se assumem tais liberdades. Por exemplo, o fato dos momentos fletores serem semelhantes não garante que as tensões também o serão.

\section{- Modelo distorcido}

Nos modelos distorcidos, qualquer tipo de desvio em relação às leis de semelhança pode ser permitido, desde que seja possível determinar a influência gerada por isto. No caso dos modelos de semelhança de primeira ordem são permitidos alguns desvios de leis de semelhança relacionados a parâmetros de pequena influência, pois o erro cometido é pequeno. Já quando não se obedecem as leis de semelhança para parâmetros considerados como de grande importância, o erro é geralmente desconhecido.

A distorção pode ser devida à não similaridade das condições iniciais e de contorno, da geometria e das propriedades dos materiais. Em problemas estruturais, uma distorção das condições iniciais e de contorno ou da geometria é raramente necessária ou vantajosa. Entretanto, em modelos hidráulicos a distorção da geometria pode ser proveitosa. Por exemplo, a partir do momento em que se distorce a altura da coluna d'água, construindo um modelo com uma altura maior que a necessária para os critérios de semelhança, o efeito da tensão superficial pode ser negligenciado como numa situação real. Entretanto, neste caso existem meios de se considerar esta distorção.

Para os modelos estruturais, a maior utilidade das distorções é a possibilidade de reproduzir, com certos desvios, as características de tensão-deformação dos materiais do protótipo. Por exemplo, caso não seja disponível um material para o modelo que satisfaça todas as condições de semelhança (Figura 3.2), ele poderá ser substituído por um dos materiais que seguem as relações tensão-deformação apresentadas na Figura 3.3. Entretanto, no caso de se utilizar um material para o modelo como o apresentado na Figura 3.3a, as deformações dos modelos serão inferiores às do protótipo. Para o material apresentado na Figura 3.3b as deformações do modelos serão maiores que as obtidas no protótipo. Deste modo, os deslocamentos do modelo, que são função das deformações, não serão semelhantes aos deslocamentos do protótipo. Para estruturas em que o comportamento é dependente dos deslocamentos (não-linearidade geométrica), tal distorção não pode ser permitida, pois a posição efetiva das forças aplicadas é alterada. 
Além do que, a maneira como o protótipo e o modelo suportam o carregamento pode ser diferente devido à não semelhança da configuração deformada. Entretanto, se os deslocamentos forem suficientemente pequenos de modo a não perturbar as condições de equilíbrio, a distorção da deformação pode ser admitida. Os valores de deformação e deslocamentos obtidos no modelo podem não ser semelhantes ao do protótipo, mas o erro devido à distorção pode ser conhecido através do fator de escala da deformação $\left(\mathrm{s}_{\varepsilon}\right)$, que, neste caso, é diferente de 1. É óbvio que quanto maior for a diferença de $\mathrm{s}_{\varepsilon}$ e a unidade, maiores serão as diferenças entre o comportamento do modelo e do protótipo e maior será a possibilidade de se obterem falsos resultados com os modelos.

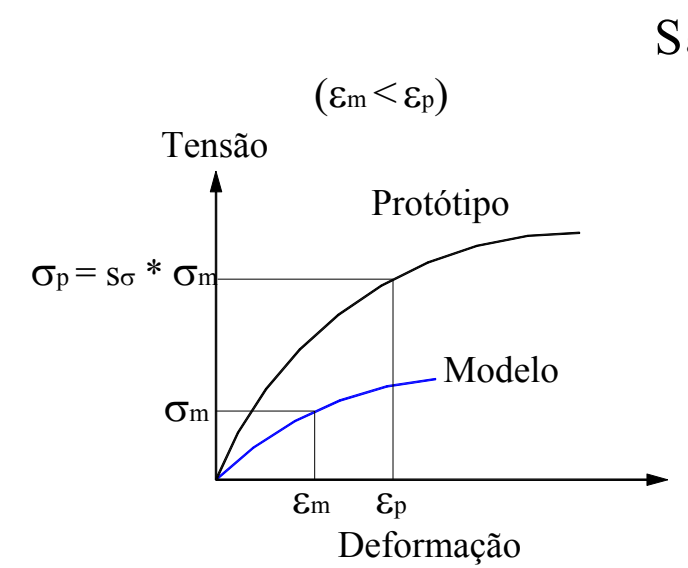

(a)
$\mathrm{S}_{\varepsilon} \neq 1$

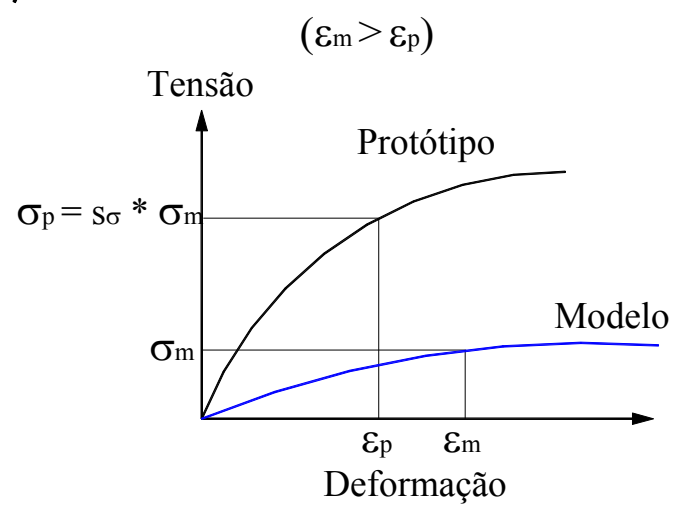

(b)

Figura 3.3 - Modelo de material com distorção. Adaptado de Harris e Sabnis (1999)

Segundo Preece e Davies.(1964) e Rocha (1952), a partir do momento que o fator de escala da deformação $\left(\mathrm{s}_{\varepsilon}\right)$ é diferente de 1 , as expressões que relacionam $\mathrm{o}$ modelo ao protótipo devem ser modificadas. Considerando-se pequenos deslocamentos, as relações que se modificam estão apresentadas a seguir:

- deformação: $\varepsilon_{\mathrm{p}}=\mathrm{s}_{\varepsilon} * \varepsilon_{\mathrm{m}}$;

- deslocamento: $\mathrm{u}_{\mathrm{p}}=\mathrm{u}_{\mathrm{m}} * \mathrm{~s}_{\varepsilon} * \mathrm{~s}_{\mathrm{L}}$;

- rotação: $\phi_{\mathrm{p}}=\mathrm{s}_{\varepsilon} * \phi_{\mathrm{m}}$;

- módulo de deformação: $\mathrm{E}_{\mathrm{p}}=\mathrm{E}_{\mathrm{m}} * \mathrm{~s}_{\sigma} / \mathrm{s}_{\varepsilon}$.

\subsection{3 - Confiabilidade dos modelos físicos}

Segundo o ACI C-444 (1987), a confiabilidade dos resultados originados de um estudo de modelos físicos reduzidos é talvez o fator mais importante para a análise do engenheiro projetista e do pesquisador. O estabelecimento do nível aceitável de precisão dos resultados $( \pm 10 \%, \pm 25 \%$, etc) é normalmente função do engenheiro responsável pelo ensaio do modelo. Podendo, optar por diferentes níveis de acordo com o objetivo do trabalho. 
Contudo, o comitê do ACI responsável pelo estudo de modelos [ACI C-444 (1987)] arbitrou a seguinte terminologia: os termos "excelente confiabilidade" e "excelente ajuste" implicam que os resultados do modelo variem entre $\pm 10 \%$ do comportamento do protótipo, o termo "boa confiabilidade" significa uma diferença máxima de $\pm 20 \%$ entre modelo e protótipo. Também existe o termo "adequada confiabilidade", que significa um ajuste mais pobre $( \pm 30 \%)$, mas que continua sendo um afastamento aceitável, dependendo dos propósitos definidos.

Os fatores que afetam a precisão dos modelos são: as propriedades dos materiais dos modelos, a exatidão na fabricação, as técnicas utilizadas na aplicação de força, as técnicas e os equipamentos de leituras e a interpretação dos resultados. Portanto, para se obter uma excelente ou boa confiabilidade é necessário tomar o máximo cuidado no projeto, na construção, no carregamento do modelo e na análise dos resultados.

\section{3- Ensaios de modelos em alvenaria}

\subsection{1- Histórico de ensaios de modelos em alvenaria}

Segundo Abboud et al. (1990), o conceito da utilização de modelos físicos reduzidos em alvenaria estrutural é posterior ao emprego em estruturas de concreto. A primeira tentativa de modelar estruturas de alvenaria na literatura internacional é feita por Vogt ${ }^{\bullet}$ apud Abboud et al. (1990) em meados da década de 50. Ele inicialmente modela alvenaria de tijolos na escala (1:4) e depois na escala (1:10). Contudo, estes estudos têm uma natureza exploratória, não fornecendo resultados consistentes. No início da década de 60, inicia-se na Universidade de Melbourne, Austrália, uma série de trabalhos com modelos em alvenaria. No entanto, alcança-se um sucesso limitado, devido às dificuldades encontradas na fabricação das miniaturas dos tijolos e na execução das paredes. Entretanto, melhores resultados são alcançados por Mohr ${ }^{*}$ apud Abboud et al. (1990) utilizando modelos de tijolos na escala (1:6) com uma produção mais próxima do tijolo em escala natural e uma melhoria na execução.

\footnotetext{
- VOGT, H (1956). Consideration and investigations on the basic principles of model tests in brickwork and masonry structures. Library Comumunication $n^{\circ}$ 932, Building Research Station, Garston, Watford, 30p.

* MORH, G.A. (1970). Slender load bearing brickwork walls with returns. MSc thesis, Civil Engineering Departament, University of Melbourne
} 
O primeiro trabalho sobre modelos em alvenaria nos Estados Unidos é o realizado por Benjamin e Williams (1958), que executam ensaios de painéis de alvenaria com e sem pórticos no contorno, em diferentes escalas. O objetivo dos ensaios é obter a influência da parede no enrijecimento dos pórticos. Com os resultados, é verificada a viabilidade da utilização de modelos, pois as variações devidas à redução da escala são da mesma grandeza das variações devidas à mão-de-obra.

No entanto, os estudos de modelos de alvenaria que servem como um marco histórico iniciam-se nos meados da década de 60 na Universidade de Edinburgh, Escócia. Hendry e Murthy (1965) realizam um estudo sobre a viabilidade da utilização de modelos físicos reduzidos, nas escalas (1:3) e (1:6), para representar o comportamento de pilares e paredes de tijolos cerâmicos maciços em tamanho natural. Nesse estudo, concluem que, para as resistências de tijolos e de argamassas utilizadas, a resistência da alvenaria em escala natural pode ser representada com razoável precisão através dos modelos.

Posteriormente, Sinha et al. apud Abboud et al. (1990) conduzem ensaios em tamanho natural e em escala (1:6) de um edifício de cinco pavimentos. Eles concluem que apesar de haver algumas diferenças na rigidez entre o modelo e o protótipo, de uma forma geral, o modelo em escala reduzida comporta-se de maneira similar.

Em relação aos blocos de concreto, segundo Sabnis et al (1983), uma das primeiras tentativas de sua utilização em modelos de alvenaria é realizada pelo National Bureau of Standards (NBS), no final da década de 60. São utilizados blocos na escala (1:4), cuidadosamente fabricados, para a execução dos modelos. No entanto, este estudo não é conclusivo. Nos meados da década de 70, Harris e Becica retomam esses estudos, na Universidade de Drexel, EUA, desenvolvendo metodologias e técnicas na modelação de estruturas de alvenaria em blocos de concreto na escala (1:4). Verificam, então, que esta técnica é viável. Estudos seguintes, realizados por Hamid e Abboud também concluem a viabilidade do uso de modelos, bem como a capacidade desta em prever o comportamento global dos protótipos [HAMID e ABBOUD(1986), ABBOUD et al. (1990), HAMID e CHANDRAKEERTHY (1992), entre outros].

A partir da década de 80 iniciam-se os estudos dinâmicos em modelos de alvenaria estrutural. Na Europa, a finalidade dos ensaios é estudar o comportamento de

- SINHA,B.P.; MAURENBRECHER, A.H.P., HENDRY, A.W. (1970). Model and full scale tests on a five-story cross-wall structure under lateral loading. In: IBMaC, 2, Stoke-on-Trent, apr. 1970, p. 201-208 
estruturas históricas em situações de sismos, buscando também desenvolver técnicas de reabilitação [por exemplo: TOMAZEVIC e VELECHOVSKY (1992) e BENEDETTI et al. (1998)]. Nos Estados Unidos e Japão, o maior interesse dos modelos dinâmicos é analisar a segurança de edifícios em alvenaria estrutural armada sob a ação de sismos [por exemplo: CHEN e SHAH (1988) e ABRAMS (1988)]. Já Ergemann et al (1991) iniciam estudos em modelos reduzidos, buscando obter técnicas confiáveis para representar o comportamento de estruturas antigas de alvenaria em relação à estabilidade, à formação de fissuras e à tolerância a recalques.

$\mathrm{Na}$ atualidade existe uma preocupação no Reino Unido de verificar a segurança das pontes de alvenaria em forma de arco em relação à sua capacidade, isto porque a capacidade dos veículos vem aumentando a cada dia [ROYLES e HENDRY (1991)]. No caso desse tipo de estrutura o seu peso próprio não pode ser desprezado, fazendo com que ou se altere a densidade do material utilizado no modelo ou se realizem os ensaios em centrífugas para que se faça a correção do peso próprio com o aumento das forças gravitacionais [HUGHES e KITCHING (2000)]. Os ensaios de modelos passam a ter, também, a finalidade de validar modelos numéricos, além do objetivo de reproduzir o comportamento da estrutura em tamanho natural [HUGHES e KITCHING (2000), HOGG e CHOO (2000) e GUINEA et al. (2000)].

\subsection{2- Requisitos de semelhança para a alvenaria}

Segundo Harris e Sabnis (1999), as técnicas de modelos mais gerais e úteis usadas no projeto e na análise de alvenaria estrutural sujeita a ações estáticas e dinâmicas são aquelas capazes de prever tanto o comportamento elástico como o inelástico, tendo, também, a capacidade de estudar com segurança o modo de ruptura da estrutura. Contudo, estas técnicas são muito restritivas em relação à escolha dos materiais do modelo e os métodos de fabricação.

O carregamento estático na estrutura consiste de cargas permanentes e sobrecargas, mas que também podem consistir de carregamentos estáticos equivalentes a efeitos dinâmicos (ação de vento e sismos) e ações excepcionais (explosões e impacto). Neste caso, pode-se supor que os efeitos dependentes do tempo não influenciam o comportamento da estrutura, considerando apenas as grandezas estáticas na análise. Para que haja uma completa semelhança do comportamento estrutural, incluindo os efeitos não-lineares da fissuração, do encruamento e do amolecimento, o modelo estrutural deve ser um modelo com semelhança completa (modelo real). 
Para o caso onde as tensões originadas do peso próprio da estrutura não são significantes, que ocorre na maioria dos edifícios de alvenaria estrutural, pode-se utilizar um modelo de semelhança dito "praticamente real". Para este procedimento, as curvas tensão deformação do modelo e do protótipo devem ser iguais, o que é um grande desafio para os pesquisadores. A razão da dificuldade é que a alvenaria é um material composto. Desta maneira, devem ser respeitados os mesmos requisitos de semelhança para o bloco/tijolo, argamassa, graute e armadura para o caso de alvenaria armada. Além disso, existem dificuldades para a fabricação de unidades com as dimensões reduzidas. Esse modelo estrutural pode ser classificado como de semelhança de primeira ordem, pois o erro introduzido por não se cumprir o critério de semelhança em relação à tensão devida ao peso próprio é considerado pequeno. A impossibilidade de se respeitar esse critério é devido a força total correspondente ao peso próprio ser reduzida proporcionalmente ao volume $\left(s_{L}^{3}\right)$ e não à área $\left(s_{L}^{2}\right)$ como todas as outras forças.

No caso de uma análise estática, ainda podem ser utilizados os modelos distorcidos, em que material dos modelos apresenta distorções em relação à deformação. Segundo o ACI C-444 (1987), no caso de modelos em concreto armado, mesmo com a distorção da deformação, eles são capazes de representar o protótipo quanto à sua resistência última, além da correta manutenção da posição da linha neutra até a ruptura. Por analogia, admite-se que para a alvenaria isso também seja válido.

Os requisitos de semelhança podem ser classificados em quatro categorias diferentes: carregamento, geometria, propriedades dos materiais e projeto. A Tabela 3.1 apresenta algumas das grandezas envolvidas numa análise estática, os parâmetros de semelhança para o modelo real, para o "praticamente real" e para o distorcido. 
Tabela 3.1 - Requisitos de semelhança para a alvenaria. Harris e Sabnis (1999)

\begin{tabular}{|c|c|c|c|c|c|}
\hline Grupo & Grandeza & Dimensão & $\begin{array}{c}\text { Modelo } \\
\text { Real }\end{array}$ & $\begin{array}{c}\text { Modelo } \\
\text { Praticamente } \\
\text { Real }\end{array}$ & $\begin{array}{c}\text { Modelo } \\
\text { Distorcido }\end{array}$ \\
\hline \multirow{4}{*}{ Carregamento } & Força concentrada & $\mathrm{F}$ & $S_{\sigma} S_{L}^{2}$ & $s_{L}^{2}$ & $s_{\sigma} s_{L}^{2}$ \\
\hline & Força linear & $\mathrm{FL}^{-1}$ & $s_{\sigma} S_{L}$ & $s_{L}$ & $s_{\sigma} s_{L}$ \\
\hline & Pressão & $\mathrm{FL}^{-2}$ & $s_{\sigma}$ & 1 & $s_{\sigma}$ \\
\hline & Momento & FL & $s_{\sigma} s_{L}^{3}$ & $s_{L}^{3}$ & $s_{\sigma} s_{L}^{3}$ \\
\hline \multirow{4}{*}{ Geometria } & Dimensão linear & $\mathrm{L}$ & $s_{L}$ & $s_{L}$ & $s_{L}$ \\
\hline & Deslocamento & $\mathrm{L}$ & $s_{L}$ & $s_{L}$ & $s_{\varepsilon} s_{L}$ \\
\hline & Rotação & -- & 1 & 1 & $s_{\varepsilon}$ \\
\hline & Área & $\mathrm{L}^{2}$ & $\overline{s_{L}{ }^{2}}$ & $\overline{s_{L}^{2}}$ & $s_{L}^{2}$ \\
\hline \multirow{9}{*}{$\begin{array}{l}\text { Propriedades } \\
\text { dos materiais }\end{array}$} & Tensão - bloco & $\mathrm{FL}^{-2}$ & $s_{\sigma}$ & 1 & $s_{\sigma}$ \\
\hline & $\begin{array}{c}\text { Deformação - } \\
\text { bloco }\end{array}$ & -- & 1 & 1 & $s_{\varepsilon}$ \\
\hline & $\begin{array}{l}\text { Mod. de elast. - } \\
\text { bloco }\end{array}$ & $\mathrm{FL}^{-2}$ & $s_{\sigma}$ & 1 & $s_{\sigma} / s_{\varepsilon}$ \\
\hline & $\begin{array}{l}\text { Coef. Poisson - } \\
\text { bloco }\end{array}$ & -- & 1 & 1 & 1 \\
\hline & Peso específico & $\mathrm{FL}^{-3}$ & $s_{\sigma} / s_{L}$ & $1 / s_{L}$ & $s_{\sigma} / s_{L}$ \\
\hline & $\begin{array}{c}\text { Tensão - } \\
\text { argamassa }\end{array}$ & $\mathrm{FL}^{-2}$ & $s_{\sigma}$ & 1 & $s_{\sigma}$ \\
\hline & $\begin{array}{l}\text { Deformação - } \\
\text { argamassa }\end{array}$ & -- & 1 & 1 & $s_{\varepsilon}$ \\
\hline & $\begin{array}{l}\text { Mod.de elast.- } \\
\text { argamassa }\end{array}$ & $\mathrm{FL}^{-2}$ & $s_{\sigma}$ & 1 & $s_{\sigma} / s_{\varepsilon}$ \\
\hline & $\begin{array}{c}\text { Coef. Poisson - } \\
\text { argamassa }\end{array}$ & -- & $s_{\sigma}$ & 1 & 1 \\
\hline \multirow{3}{*}{ Projeto } & $\begin{array}{l}\text { Resistência a } \\
\text { compressão da } \\
\text { alvenaria }\left(f_{k}\right)\end{array}$ & $\mathrm{FL}^{-2}$ & $s_{\sigma}$ & 1 & $s_{\sigma}$ \\
\hline & $\begin{array}{l}\text { Deformação da } \\
\text { alvenaria }\end{array}$ & -- & 1 & 1 & $s_{\varepsilon}$ \\
\hline & $\begin{array}{l}\text { Mód. de elast. - } \\
\text { alvenaria }\end{array}$ & $\mathrm{FL}^{-2}$ & $s_{\sigma}$ & 1 & $s_{\sigma} / s_{\varepsilon}$ \\
\hline
\end{tabular}

( $s_{\sigma}-$ fator de escala de tensão ; $s_{L}$ - fator de escala de comprimento; $s_{\varepsilon}$ - fator de escala de deformação)

\subsection{3- Efeitos de escala na argamassa}

De acordo com Harris e Sabnis (1999), em estudos na Universidade de Drexel observa-se que mesmo com a redução dos volumes dos corpos-de-prova, cilíndricos e cúbicos (Figura 3.4), não há representatividade da resistência da junta de assentamento. O mesmo ocorre para os ensaios de protótipos, onde os corpos-de-prova normalizados para argamassas não são representativos da resistência da junta. Entretanto, o intuito de se utilizar espécimes reduzidos é correlacionar os resultados do modelo com do protótipo. Isto porque, é fato comprovado que com a redução do volume do corpo-de- 
prova ocorre o aumento da resistência da argamassa. Desta maneira, é de se esperar que uma junta de assentamento, feita com uma mesma argamassa, tenha uma maior resistência quanto menor for seu volume. Portanto, a junta de assentamento do modelo deve ter uma maior resistência à compressão que a do protótipo, e uma maneira de obter uma indicação deste ganho de resistência é através da redução do espécime. Todavia, não é aconselhável a utilização de corpos-de-prova muito reduzidos por causa das dificuldades na moldagem e os possíveis problemas de confinamento.

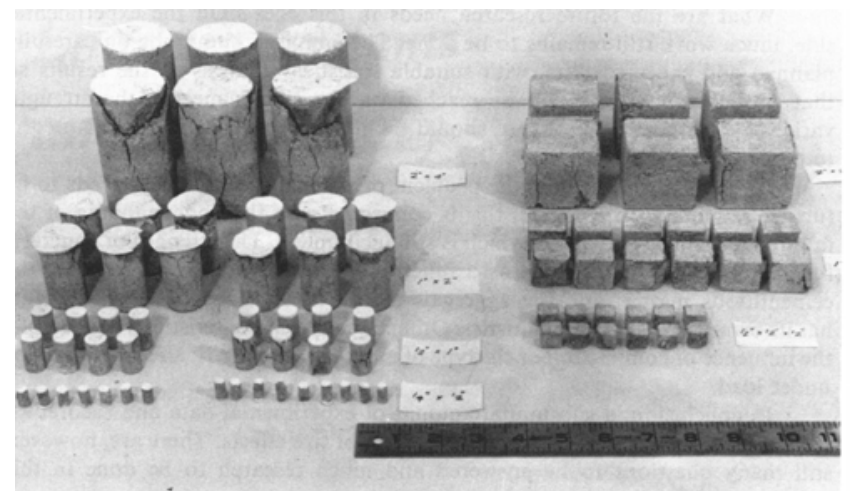

Figura 3.4 - Variação de dimensão dos corpos-de-prova. Harris e Sabnis (1999)

\section{4- O uso de modelos físicos reduzidos em alvenaria no Brasil}

\subsection{1 - Histórico do uso de modelos em alvenaria no Brasil}

As pesquisas nacionais em alvenaria estrutural em escala natural (1:1) iniciamse somente no final da década de 70, sendo os primeiros estudos publicados no início da década de 80. A Escola Politécnica da Universidade de São Paulo (EPUSP), o Instituto de Pesquisas Tecnológicas de São Paulo (IPT) e a Universidade Federal do Rio Grande do Sul (UFRGS) são os centros de pesquisa pioneiros. Atualmente a Escola de Engenharia de São Carlos da Universidade de São Paulo (EESC-USP), a Universidade Federal de Santa Catarina (UFSC), a Universidade Estadual Paulista (UNESP), a Universidade Federal de Santa Maria (UFSM) entre outros centros, também realizam pesquisas na área de alvenaria estrutural.

Em relação aos modelos físicos reduzidos em alvenaria os estudos são ainda mais recentes, iniciando-se apenas na década de 90 na EPUSP e UNESP de Ilha Solteira, resultando na tese de doutoramento de Camacho (1995). Após este primeiro passo, principiam-se estudos em outros centros de pesquisa, tais como UFSC, UFSM e EESC-USP. 
O primeiro trabalho que se preocupa em realizar comparações diretas do comportamento e da resistência da alvenaria em diferentes escalas é o realizado por Camacho (1995). Atualmente na UFSM e UNESP de Ilha Solteira vêm-se desenvolvendo trabalhos que procuram relacionar o comportamento entre modelos e protótipos. Outros trabalhos, tais como Santos (2001), Holanda Jr. (2002), Signor e Roman (2002) e Nascimento Neto (2003) não se preocupam com a correlação direta com resultados de protótipos, utilizando os modelos apenas como previsão do comportamento ou como meio de verificar a viabilidade do uso de procedimentos numéricos.

Ressalta-se que a maioria dos estudos até aqui realizados utilizam os blocos cerâmicos em escala reduzida. Sendo que a utilização de blocos de concreto em modelos reduzidos foi somente iniciada recentemente na UNESP de Ilha Solteira, onde desenvolveram-se as técnicas necessárias para a fabricação de blocos vazados de concreto em escala (1:4) [ANDOLFATO (2002)].

Alguns dos trabalhos em modelos físicos reduzidos já estão apresentados no capítulo anterior, pois o enfoque não é o uso de blocos em escala reduzida [CAMACHO et al. (2001) e SIGNOR e ROMAN (2002)] e sim a interação de paredes. Dessa forma, são apresentados a seguir apenas os trabalhos em que se realizam a caracterização das propriedades físicas dos materiais. Em Camacho (1995) é feito um estudo tanto da alvenaria em escala natural como reduzida, enquanto que Santos (2001), Holanda Jr. (2002) e Nascimento Neto (2003) abordam apenas os modelos reduzidos.

\subsection{2 - Ensaios de modelos reduzidos em alvenaria no Brasil}

\subsubsection{1- Ensaios realizados por Camacho}

O trabalho de Camacho (1995) tem o objetivo de estudar a viabilidade do uso de modelos físicos reduzidos de alvenaria de blocos cerâmicos na representação do comportamento da alvenaria em escala natural, tanto em serviço quanto na ruptura. Para avaliar como o fator escala pode alterar o comportamento da alvenaria, são utilizadas duas escalas diferentes, (1:3) e (1:5), além da escala natural. Estuda-se neste trabalho as correlações de resistência à compressão entre unidades, prismas e paredinhas • Ressalta-se que todas as resistências e módulos de deformação são considerados em relação à área bruta.

\footnotetext{
- Termo empregado para designar corpos de prova de parede.
} 
As unidades utilizadas nos ensaios são blocos cerâmicos com duas cavidades e dimensões de $(290 \times 140) \mathrm{mm},(97 \times 47) \mathrm{mm}$ e $(58 \times 28) \mathrm{mm}$, nas escalas (1:1), (1:3) e (1:5), respectivamente (Figura 3.5). A altura do bloco na escala natural é de $140 \mathrm{~mm}$, sendo reduzida proporcionalmente para as demais escalas.

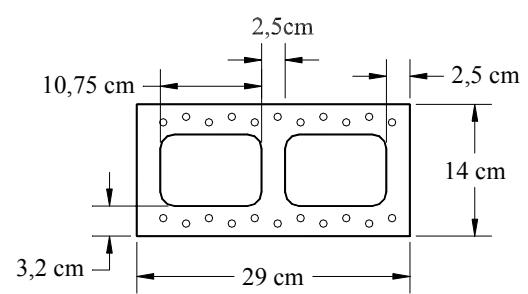

Escala 1:1

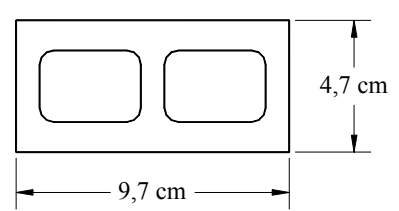

Escala 1:3

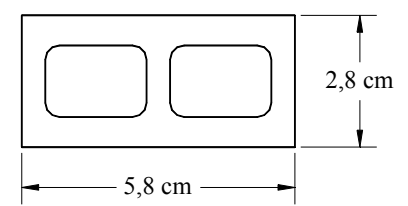

Escala 1:5

Figura 3.5 - Blocos utilizados em diferentes escalas. Camacho (1995)

A argamassa empregada é do tipo mista, com traço em peso de (1:1:6) (cimento:cal:areia). Para a escala natural, utiliza-se uma areia composta por duas partes iguais: retidas nas peneiras \#50 e \#100. Nas escalas (1:3) e (1:5) trabalha-se com areia retida e passante na peneira $\# 100$, em partes iguais. A argamassa aplicada nos prismas e paredinhas em escala natural tem uma resistência à compressão de 5,45 $\mathrm{MPa}$ aos 28 dias; já a utilizada nas escalas (1:3) e (1:5) tem resistência de 4,13 $\mathrm{MPa}$.

Camacho (1995) trabalha com prismas de 2, 3 e 4 blocos justapostos, buscando obter relações de resistência entre prisma e bloco, verificando se esse comportamento reproduzir-se-ia de forma semelhante para as três escalas. Também se empregam paredinhas, nas três escalas, para comparações de resistências e eficiência. A Figura 3.6 ilustra os corpos-de-prova empregados.
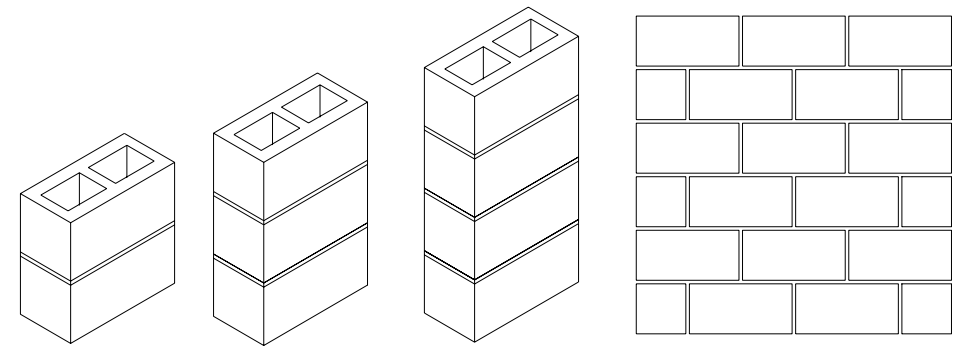

Figura 3.6 - Corpos-de-prova utilizados nos ensaios. Camacho (1995)

Os valores obtidos por Camacho (1995) para as resistências nos ensaios de compressão uniaxial dos corpos-de-prova, nas três escalas, são apresentados na Tabela 3.2. Cada valor apresentado corresponde à média de pelo menos 6 corpos-de-prova ensaiados, com exceção das paredinhas, que são ensaiadas três para cada escala. A eficiência corresponde ao valor da resistência respectiva do corpo-de-prova, dividida pela resistência do bloco. 
Tabela 3.2- Resistências e eficiências dos corpos-de-prova de Camacho (1995)

\begin{tabular}{|c|c|c|c|c|c|c|}
\hline \multirow{2}{*}{ Corpo-de-prova } & \multicolumn{3}{|c|}{ Resistência à compressão (MPa) } & \multicolumn{4}{|c|}{ Eficiência em relação ao bloco } \\
\cline { 2 - 7 } & $\mathbf{( 1 : 1 )}$ & $\mathbf{( 1 : 3 )}$ & $\mathbf{( 1 : 5 )}$ & $\mathbf{( 1 : 1 )}$ & $\mathbf{( 1 : 3 )}$ & $\mathbf{( 1 : 5 )}$ \\
\hline Bloco & 15,49 & 18,21 & 15,03 & $100 \%$ & $100 \%$ & $100 \%$ \\
\hline Prisma 2 blocos & 6,59 & 10,46 & 9,39 & $42,5 \%$ & $57,4 \%$ & $62,5 \%$ \\
\hline Prisma 3 blocos & 5,95 & 9,36 & 8,49 & $38,4 \%$ & $51,4 \%$ & $56,5 \%$ \\
\hline Prisma 4 blocos & 5,09 & 6,88 & 7,31 & $32,9 \%$ & $37,8 \%$ & $48,6 \%$ \\
\hline Paredinha & 4,45 & 5,22 & 6,10 & $28,7 \%$ & $28,7 \%$ & $40,5 \%$ \\
\hline
\end{tabular}

De acordo com Camacho (1995) a forma de ruptura dos prismas e paredinhas é similar para as três escala, sendo caracterizada pelo aparecimento de fissuras verticais, seguidas de estilhaçamento e quebra das paredes dos blocos. Percebe-se também que o comportamento da resistência dos blocos, prismas e paredinhas para as três escalas é semelhante, entretanto os modelos nas escala (1:3) e (1:5) apresentam eficiências mais elevadas que a escala natural. Em relação à deformação de ruptura, verifica-se uma grande diferença das escalas (1:3) e (1:5) para a escala natural. Os corpos-de-prova na escala reduzida apresentam deformações superiores às observadas na escala natural. $\mathrm{O}$ autor acredita que essa divergência ocorre somente pelas diferenças no processo de fabricação.

Para os prismas de 2, 3, 4 blocos e para as paredinhas, a relação entre o módulo de deformação e a resistência à compressão, $\left(E_{p} / f_{p}\right)$, é ilustrada na Figura 3.7. Esse comportamento reproduz, aproximadamente, o verificado por Ergemann et al. (1991), onde essa relação diminui com a redução da escala. Vale ressaltar que o módulo de deformação é determinado simplificadamente como a resistência dividida pela deformação de ruptura, visto o comportamento altamente linear dos corpos-de-prova.

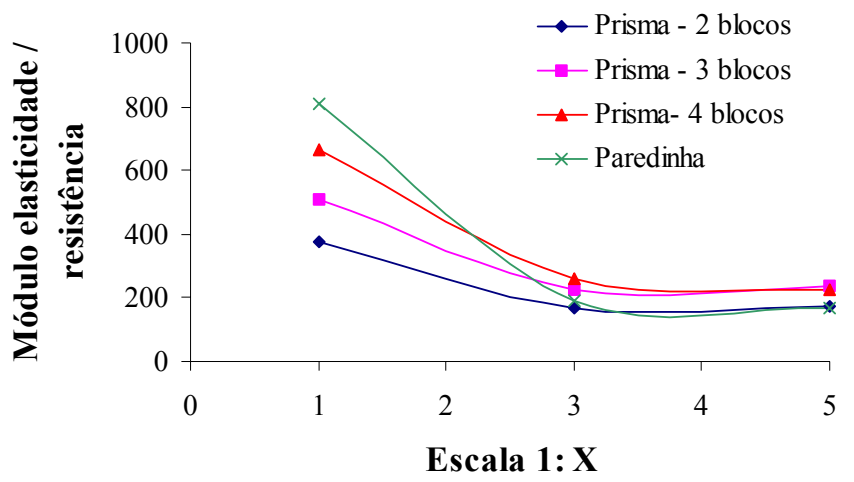

Figura 3.7 - Influência do fator de escala na variação da razão módulo/resistência.

Camacho (1995) conclui que de forma geral, as resistências à compressão uniaxial dos modelos são semelhantes entre si. Porém, para os prismas e paredinhas, os modelos apresentam valores superiores aos observados no protótipo. As deformações de 
ruptura medidas nos modelos são consideravelmente superiores aos valores medidos no protótipo, fato já observado em outras pesquisas [HENDRY e MURTHY (1965) e ERGEMANN et al. (1991)]. Apesar da diferença dos valores numéricos, o comportamento e os modos de ruptura apresentados pelo protótipo e modelos são semelhantes. Salienta-se a necessidade de estudos complementares no sentido de investigar a diferença, entre protótipo e modelo, em relação aos valores do parâmetro deformação.

\subsubsection{2 - Ensaios realizados por Santos}

Santos (2001) realiza um trabalho teórico e experimental do efeito do nãopreenchimento de juntas verticais no desempenho da alvenaria estrutural. Contudo, neste trabalho, será abordada apenas a parte de caracterização física e mecânica dos materiais utilizados nos modelos físicos reduzidos. Maiores detalhes e informações sobre a parte teórica e os ensaios principais podem ser obtidos diretamente na tese.

Os blocos cerâmicos empregados são produzidos em escala reduzida (1:3), correspondendo à família de blocos em escala natural de $(14 \mathrm{~cm}$ x $29 \mathrm{~cm}$ x $19 \mathrm{~cm})$. São utilizados três tipos de blocos: o meio-bloco, o inteiro e o de amarração. A Figura 3.8 apresenta as dimensões médias dos três tipos, enquanto a Tabela 3.3 indica a resistência à compressão dos diferentes blocos, bem como a relação entre área líquida e bruta.

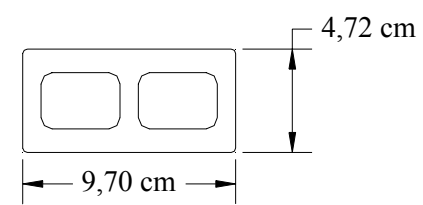

Bloco inteiro $(\mathrm{h}=6,40 \mathrm{~cm})$

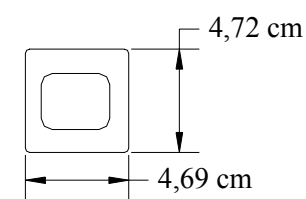

Meio bloco $(\mathrm{h}=6,36 \mathrm{~cm})$

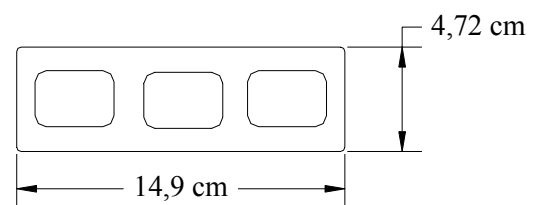

Bloco de amarração $(\mathrm{h}=6,39 \mathrm{~cm})$

Figura 3.8 - Dimensões médias dos blocos utilizados por Santos (2001)

Tabela 3.3- Resistência e relação entre área dos diferentes blocos. Santos (2001)

\begin{tabular}{|c|c|c|c|}
\hline \multirow{2}{*}{ Tipo de bloco } & \multicolumn{2}{|c|}{ Resistência à compressão (área bruta) } & \multirow{2}{*}{$\begin{array}{c}\text { Relação } \\
\mathbf{A}_{\text {líquida }} / \mathbf{A}_{\text {bruta }}\end{array}$} \\
\hline & Média (MPa) & Coef. Var. (\%) & \\
\hline Meio-bloco & 24,17 & 12,3 & 0,60 \\
\hline Inteiro & 15,78 & 25,3 & 0,54 \\
\hline Amarração & 13,19 & 18,3 & 0,53 \\
\hline
\end{tabular}

Utiliza-se para todos os ensaios uma argamassa com traço em volume de 1:1:6 (cimento:cal:areia), sendo que a relação água/cimento depende da trabalhabilidade desejada pelo pedreiro. São empregados corpos-de-prova de argamassa cúbicos com 
aresta de $10 \mathrm{~cm}$. Para se evitar problemas com a junta de assentamento, é utilizada uma areia muito fina, próxima ao limite inferior especificado pelas normas britânicas.

Para a determinação do módulo de deformação e resistência perpendicular à junta de assentamento, Santos (2001) opta por utilizar prismas com 5 fiadas e 2 blocos de largura, com juntas verticais preenchidas ou não, empregando-se extensômetros mecânicos com base de medição de $150 \mathrm{~mm}$. A Figura 3.9a apresenta o corpo-de-prova utilizado e os pontos de medição de deformação.

Como a alvenaria é um material ortotrópico, isto é, possui propriedades mecânicas diferentes dependendo da direção considerada, Santos (2001) também determina o módulo de deformação paralelo através de ensaio de compressão uniaxial. Os corpos-de-prova utilizados nestes ensaios estão representados na Figura 3.9b, juntamente com os pontos de medição de deformação (extensômetros mecânicos com base de $150 \mathrm{~mm})$.
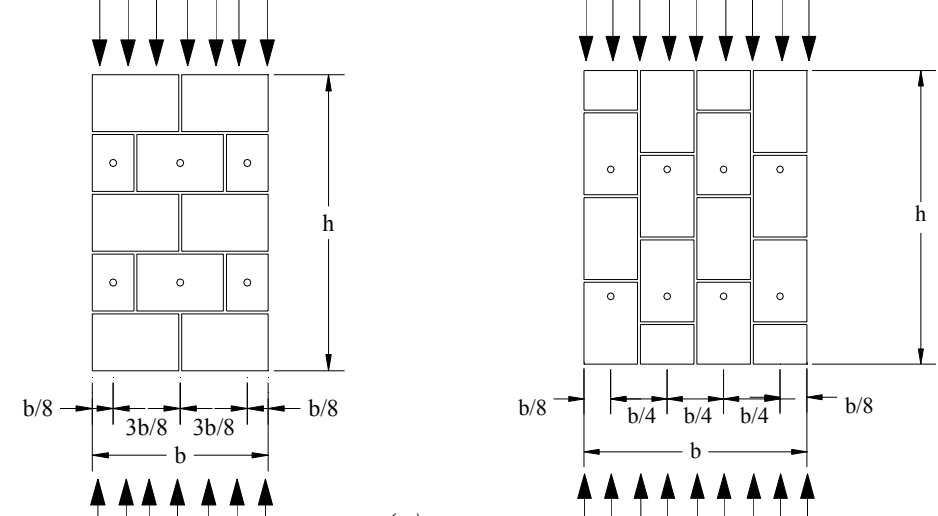

(a)

(b)

Figura 3.9 - Corpo-de-prova e pontos de medição utilizados por Santos (2001)

Segundo o autor, para o caso perpendicular às juntas, as relações tensãodeformação são estabelecidas até um limite de aproximadamente $90 \%$ da força de ruptura, com a perda da linearidade do comportamento próxima à ruptura $(75 \%)$. Para a determinação do módulo de deformação utiliza-se o método tangente inicial (inclinação inicial da curva tensão-deformação). Os valores de resistência e de módulos de deformação tangentes médios, juntamente com a resistência da argamassa empregada, são apresentados na Tabela 3.4.

Tabela 3.4- Resultados dos ensaios perpendiculares às juntas. Santos (2001)

\begin{tabular}{|c|c|c|c|}
\hline $\begin{array}{c}\text { Tipo de corpo-de- } \\
\text { prova }\end{array}$ & $\begin{array}{c}\text { Resistência à } \\
\text { compressão (MPa) }\end{array}$ & $\begin{array}{c}\text { Módulo de deformação } \\
\text { tangente (MPa) }\end{array}$ & $\begin{array}{c}\text { Resistência da } \\
\text { argamassa (MPa) }\end{array}$ \\
\hline Juntas preenchidas & 5,03 & 5888 & 5,19 \\
\hline J. não-preenchidas & 3,99 & 3675 & 5,30 \\
\hline \multicolumn{2}{|r}{} & * Valores em relação à área bruta \\
\hline
\end{tabular}


Já para o ensaio paralelo às juntas, Santos (2001) aplica apenas um carregamento de cerca de $30 \%$ da força de ruptura esperada, determinada anteriormente. Por isso o comportamento é bem próximo ao linear. O módulo de deformação tangente neste caso é imediato. A Tabela 3.5 apresenta os valores obtidos para os módulos de deformação, bem como a resistência da argamassa utilizada.

Tabela 3.5- Resultados dos ensaios paralelos às juntas. Santos (2001)

\begin{tabular}{|c|c|c|}
\hline Tipo de corpo-de-prova & $\begin{array}{c}\text { Módulo de deformação } \\
\text { tangente (MPa) }\end{array}$ & $\begin{array}{c}\text { Resistência da } \\
\text { argamassa (MPa) }\end{array}$ \\
\hline Juntas preenchidas & 3508 & 5,19 \\
\hline Juntas não-preenchidas & 1995 & 5,19 \\
\hline \multicolumn{2}{|c|}{ Valores em relação à área bruta } \\
\end{tabular}

Para uma caracterização mais completa Santos (2001) determina os coeficientes de Poisson nas direções ortogonais $\left(v_{\mathrm{x}}\right.$ e $\left.v_{\mathrm{y}}\right)$ através dos corpos-de-prova apresentados na Figura 3.10. Devido ao nível do carregamento aplicado, as deformações nas direções ortogonais são muito pequenas, optando o pesquisador pela utilização de extensômetros elétricos. São utilizados três corpos-de-prova para cada direção. Os valores médios obtidos para os coeficientes de Poisson, juntamente com a resistência da argamassa utilizada, são apresentados na Tabela 3.6.
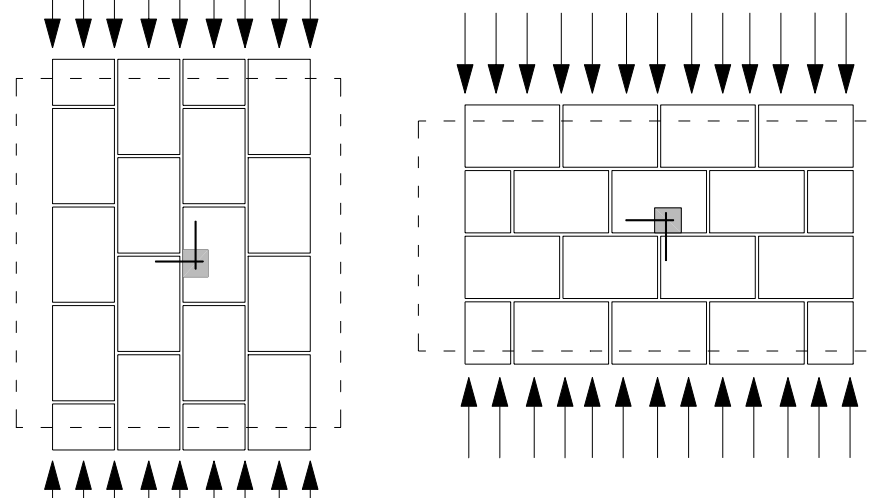

Figura 3.10 - Esquema de carregamento e instrumentação para obtenção dos coeficientes de Poisson em direções ortogonais. Santos (2001)

Tabela 3.6- Coeficientes de Poisson. Santos (2001).

\begin{tabular}{|c|c|c|c|}
\hline Tipo de corpo-de-prova & $\begin{array}{c}v_{\mathbf{x}} \text { (perpendicular à } \\
\text { junta horizontal) }\end{array}$ & $\begin{array}{c}\mathrm{v}_{\mathbf{y}} \text { (paralelo à } \\
\text { junta horizontal) }\end{array}$ & $\begin{array}{c}\text { Resistência da } \\
\text { argamassa (MPa) }\end{array}$ \\
\hline Juntas preenchidas & 0,16 & 0,13 & 5,19 \\
\hline Juntas não-preenchidas & 0,17 & 0,23 & 5,19 \\
\hline
\end{tabular}


Apesar de Santos (2001) obter valores coerentes de coeficiente de Poisson, acredita-se que a forma de instrumentação utilizada não é a mais indicada. Ao utilizar os extensômetros elétricos, a base de medidas fica muito reduzida quando comparada às dimensões do corpo-de-prova. Os extensômetros ficam localizados geralmente somente em um bloco, ou, no máximo, cruzando uma única junta de argamassa. Entende-se que a instrumentação não é a mais representativa, sendo que uma melhor solução é a utilização de bases de medições maiores, cobrindo blocos e juntas.

\subsubsection{3 - Ensaios realizados por Holanda Jr. e Nascimento Neto}

Holanda Jr (2002), em conjunto com Nascimento Neto (2003), realizam ensaios de caracterização da alvenaria de blocos cerâmicos em escala reduzida. São empregados blocos e meio-blocos cerâmicos em escala reduzida (1:3), Figura 3.11, sendo referentes à família de blocos de $14 \mathrm{~cm}$ x $29 \mathrm{~cm}$ x $19 \mathrm{~cm}$ (largura x comprimento x altura). Os resultados médios, com coeficientes de variação de no máximo $1 \%$, são apresentados na Tabela 3.7.

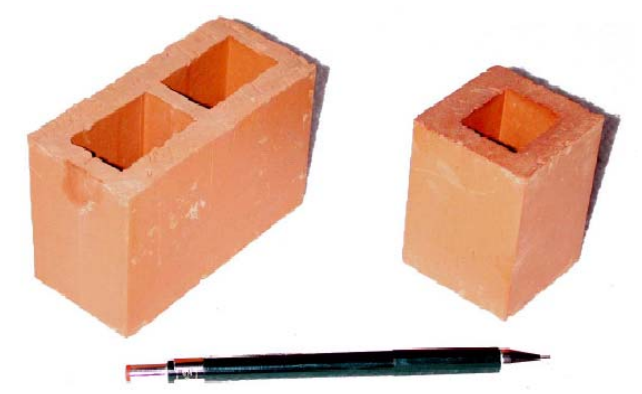

Figura 3.11 - Blocos em escala reduzida utilizados por Holanda Jr. (2002)

Tabela 3.7- Dimensões médias dos blocos. Holanda Jr. (2002)

\begin{tabular}{|c|c|c|c|c|c|}
\hline \multicolumn{3}{|c|}{ Bloco $^{*}$} & \multicolumn{3}{c|}{ Meio-Bloco* $^{*}$} \\
\hline Largura (cm) & Comp. (cm) & Altura (cm) & Largura (cm) & Comp. (cm) & Altura (cm) \\
\hline $4,65(4,67)$ & $9,76(9,67)$ & $6,41(6,33)$ & $4,68(4,67)$ & $4,65(4,67)$ & $6,37(6,33)$ \\
\hline \multicolumn{3}{|c}{ As medidas entre parênteses são as ideais } \\
\hline
\end{tabular}

Para a determinação da resistência dos blocos, seguem-se as prescrições da NBR 6461/1983. Já em relação ao módulo de deformação do bloco utiliza-se a recomendação do ACI 530-92 (1995), onde se determina o módulo secante no intervalo de 5 a 33\% da força de ruptura. Empregam-se extensômetros elétricos para a medição das deformações. Os resultados estão apresentados na

Tabela 3.8. Os blocos possuem uma absorção de água igual a 13,2\% e uma relação entre área líquida e área bruta de 55\%. 
Tabela 3.8- Resistência e módulo de deformação do bloco. Holanda Jr. (2002)

\begin{tabular}{|c|c|c|c|}
\hline $\begin{array}{c}\text { Força de Ruptura } \\
\mathbf{F}_{\text {rup }}(\mathbf{k N})\end{array}$ & $\begin{array}{c}\text { Tensão de Ruptura } \\
\mathbf{f}_{\mathbf{b}}(\mathbf{M P a})\end{array}$ & $\begin{array}{c}\text { Módulo de Deformação } \\
\left.\mathbf{E}_{\mathbf{b}} \mathbf{( M P a}\right)\end{array}$ & $\begin{array}{c}\text { Relação } \\
\mathbf{E}_{\mathbf{b}} / \mathbf{f}_{\mathbf{b}}\end{array}$ \\
\hline 133 & 29,31 & 10554 & 360 \\
\hline \multicolumn{3}{|c}{ Valores referidos à área bruta } \\
\hline
\end{tabular}

A argamassa utilizada nos ensaios tem o traço em volume de 1:0,5:4,5 de cimento, cal e areia respectivamente. Como a junta de argamassa dos painéis de alvenaria na escala (1:3) possui apenas $3 \mathrm{~mm}$, tem-se a preocupação de se escolher uma areia com granulometria tal que não tenha grãos maiores que $1 / 3$ da junta, isto é, $1 \mathrm{~mm}$. O cimento escolhido é do tipo ARI (alta resistência inicial), pois os ensaios são realizados 14 dias após a moldagem. Nesse período a resistência média dos corpos-deprova de argamassa $(5 \times 10 \mathrm{~cm})$ obtida é de $10 \mathrm{MPa}$, tendo um coeficiente de variação de $17 \%$.

São também ensaiados prismas de três blocos, obtendo-se apenas sua resistência à compressão. Esses ensaios são realizados com diferentes idades a fim de se avaliar a evolução da resistência da alvenaria. Entretanto, Holanda Jr. (2002) percebe nesses ensaios que a idade do prisma praticamente não tem influência na sua resistência. Dessa forma, levando-se em conta todos os prismas ensaiados, não considerando as diferentes idades, obtém-se uma resistência média de prisma $\left(\mathrm{f}_{\mathrm{p}}\right)$ igual a 19,2 $\mathrm{MPa}$ (em relação à área bruta).

Para o ensaio à compressão uniaxial, empregam-se 3 paredinhas com $40 \mathrm{~cm}$ de altura por $40 \mathrm{~cm}$ de comprimento, o que equivale em escala natural a um painel de 120 x $120 \mathrm{~cm}$. As paredinhas são ensaiadas à compressão uniaxial, com o objetivo de se determinar a resistência, o módulo de deformação da alvenaria perpendicular às juntas de assentamento e o coeficiente de Poisson da alvenaria paralelo às juntas. Na Figura 3.12 pode-se visualizar a instrumentação utilizada (transdutores de deslocamento), como também a forma de ruptura da paredinha. Os valores obtidos estão apresentados na Tabela 3.9, sendo que a tensão de ruptura e o módulo de deformação da alvenaria são calculados em relação à área bruta. O módulo de deformação é determinado segundo as recomendações do ACI 530-92 (1995). 

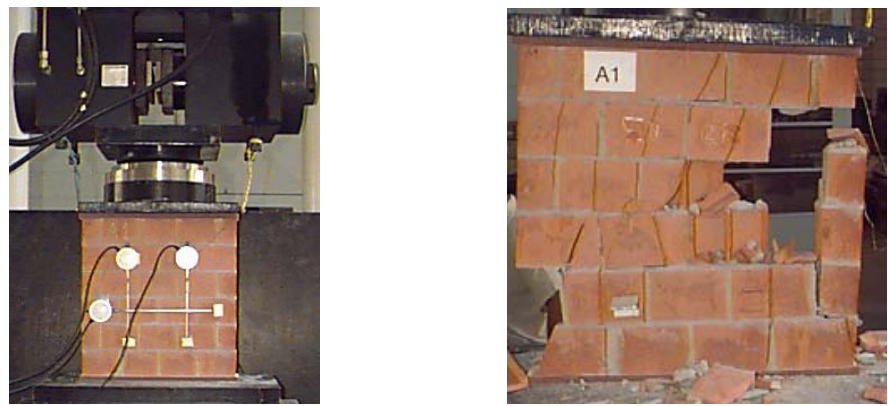

Figura 3.12 - Instrumentação e forma de ruptura do painel. Holanda Jr. (2002)

Tabela 3.9- Resultados dos ensaios de painéis com carregamento perpendicular às juntas de assentamento. Holanda Jr. (2002)

\begin{tabular}{|c|c|c|c|c|}
\cline { 2 - 5 } \multicolumn{1}{c|}{} & $\begin{array}{c}\text { Força de ruptura } \\
\mathbf{F}_{\text {rup }} \mathbf{( k N )}\end{array}$ & $\begin{array}{c}\text { Tensão de } \\
\text { ruptura (MPa) }\end{array}$ & $\begin{array}{c}\text { Módulo de } \\
\text { deformação (MPa) }\end{array}$ & $\begin{array}{c}\text { Coeficiente } \\
\text { de Poisson }\end{array}$ \\
\hline Média & 222,3 & 11,95 & 6479 & 0,10 \\
\hline Coef. Var. & $18 \%$ & $19 \%$ & $5 \%$ & $11 \%$ \\
\hline \multicolumn{4}{r}{${ }^{*}$ Valores referidos à área bruta } \\
\hline
\end{tabular}

Holanda Jr. (2002) e Nascimento Neto (2003) também ensaiam três paredinhas à compressão diagonal com as mesmas dimensões utilizadas. O objetivo do ensaio é determinar a tensão de cisalhamento convencional $\left(\tau_{\text {alv }}\right)$ e o módulo de deformação transversal $\left(\mathrm{G}_{\text {alv }}\right)$ utilizando-se os preceitos da NBR 14.321/1999. A Figura 3.13 apresenta a instrumentação utilizada e a forma de ruptura do painel. Os valores obtidos estão apresentados na Tabela 3.10.
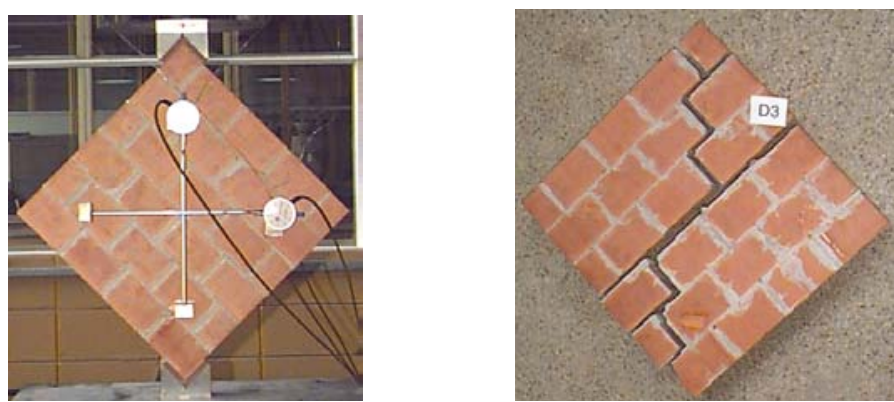

Figura 3.13 - Instrumentação e forma de ruptura do painel à compressão diagonal. Holanda Jr (2002)

Tabela 3.10- Resultados dos ensaios de compressão diagonal. Holanda Jr.(2002)

\begin{tabular}{|c|c|c|c|}
\cline { 2 - 4 } \multicolumn{1}{c|}{} & $\begin{array}{c}\text { Força de ruptura } \\
\mathbf{F}_{\text {rup }}(\mathbf{k N})\end{array}$ & $\begin{array}{c}\text { Módulo de deformação } \\
\text { Transversal }-\mathbf{G}_{\text {alv }}(\mathbf{M P a})\end{array}$ & $\begin{array}{c}\text { Tensão de cisalhamento } \\
\text { convencional }-\boldsymbol{\tau}_{\text {alv }}(\mathbf{M P a})\end{array}$ \\
\hline Média & 15,6 & 1883 & 0,58 \\
\hline Coef. Var. & $8 \%$ & $5 \%$ & $8 \%$ \\
\hline
\end{tabular}




\subsubsection{4 - Análise dos resultados}

Apesar das pesquisas apresentadas anteriormente nem sempre utilizarem os mesmos tipos de corpos-de-prova, procura-se realizar um resumo dos resultados dos ensaios com blocos cerâmicos na escala (1:3) para confrontação. São considerados apenas os ensaios em que as juntas verticais são preenchidas. Ressalta-se que rigorosamente os valores não são comparativos, visto que cada pesquisa utiliza metodologias de ensaio, corpos-de-prova e normas diferentes. Contudo, é possível estabelecer a ordem de grandeza para algumas relações, que servirão de parâmetros para o decorrer deste trabalho.

A Tabela 3.11 apresenta o resumo dos valores de resistência dos blocos, dos prismas de três blocos e da alvenaria na direção perpendicular à junta de assentamento, bem como das suas relações. Todos os valores são referentes à área bruta. Para Camacho (1995) e Holanda Jr. (2002) a resistência da alvenaria é dada pelo ensaio das paredinhas, enquanto que para Santos (2001) o valor é referente aos prismas com cinco fiadas de altura e dois blocos de largura. Observa-se que apesar de todas as diferenças existentes nos ensaios, os valores das relações entre as resistências demonstram uma coerência dos resultados.

Tabela 3.11 - Valores de resistência para diferentes corpos-de-prova e suas relações.

\begin{tabular}{|c|c|c|c|c|c|c|}
\hline Pesquisa & $\begin{array}{c}\text { Resistência } \\
\text { do bloco }- \\
\mathbf{f}_{\mathbf{b}} \mathbf{( M P a )}\end{array}$ & $\begin{array}{c}\text { Resistência } \\
\mathbf{d o} \text { prisma } \\
\mathbf{f}_{\mathbf{p}} \mathbf{( M P a )}\end{array}$ & $\begin{array}{c}\text { Resistência da } \\
\text { alvenaria- } \\
\mathbf{f}_{\text {alv }} \mathbf{( M P a )}\end{array}$ & $\frac{\mathrm{f}_{\text {alv }}}{\mathrm{f}_{\mathrm{p}}}$ & $\frac{\mathrm{f}_{\text {alv }}}{\mathrm{f}_{\mathrm{b}}}$ & $\frac{\mathrm{f}_{\mathrm{p}}}{\mathrm{f}_{\mathrm{b}}}$ \\
\hline Camacho & 18,21 & 9,36 & 5,22 & 0,558 & 0,287 & 0,514 \\
\hline Santos & 15,78 & -- & 5,03 & -- & 0,319 & -- \\
\hline Holanda Jr. & 29,31 & 19,2 & 11,95 & 0,622 & 0,408 & 0,655 \\
\hline
\end{tabular}

Os valores encontrados nas pesquisas citadas referentes aos módulos de deformação do bloco e da alvenaria na direção perpendicular à junta de assentamento e algumas relações entre deformabilidade e resistência estão descritos na Tabela 3.12. Percebe-se que apesar dos valores do módulo de deformação da alvenaria serem da mesma ordem de grandeza para Santos (2001) e Holanda Jr. (2002), as sua relações com as resistências são díspares. Não se acredita que o procedimento de determinação dos valores dos módulos tenha tamanha influência nos resultados. Isso indica que a deformabilidade possue uma maior complexidade que a resistência, estando ligada diretamente as propriedades do material cerâmico que compõe o bloco. Assim, ao contrário do concreto, é difícil determinar uma correlação geral entre o módulo de 
deformação e a resistência do material cerâmico, visto a variabilidade intrínseca da matéria prima entre blocos de diferentes fábricas. Portanto, as relações entre módulo de deformação e resistência da alvenaria de blocos cerâmicos devem ser analisadas com uma certa restrição.

Tabela 3.12 - Valores de módulo de deformação da alvenaria e do bloco e algumas relaçães

\begin{tabular}{|c|c|c|c|c|c|c|}
\hline Pesquisa & $\begin{array}{c}\text { Módulo de } \\
\text { deformação da } \\
\text { alvenaria }-\mathbf{E}_{\text {alv }}(\mathbf{M P a})\end{array}$ & $\begin{array}{c}\text { Módulo de } \\
\text { deformação do } \\
\text { bloco- }-\mathbf{E}_{\mathbf{b}} \mathbf{( M P a )}\end{array}$ & $\frac{\mathrm{E}_{\mathrm{alv}}}{\mathrm{f}_{\mathrm{alv}}}$ & $\frac{\mathrm{E}_{\text {alv }}}{\mathrm{f}_{\mathrm{p}}}$ & $\frac{\mathrm{E}_{\text {alv }}}{\mathrm{f}_{\mathrm{b}}}$ & $\frac{\mathrm{E}_{\text {alv }}}{\mathrm{E}_{\mathrm{b}}}$ \\
\hline Santos & 5888 & -- & 1170 & -- & 373 & -- \\
\hline Holanda Jr. & 6479 & 10554 & 542 & 337 & 221 & 0,614 \\
\hline
\end{tabular}

Pode-se, também, tentar estabelecer relações entre os parâmetros referentes ao ensaio de compressão diagonal e os parâmetros referentes aos ensaios de compressão na direção perpendicular à junta de assentamento. Neste caso os valores são apenas de Holanda Jr. (2002). A Tabela 3.13 apresenta algumas dessas relações.

Tabela 3.13- Relações entre resistências à compressão uniaxial e diagonal. Holanda Jr.(2002)

\begin{tabular}{|c|c|c|c|c|c|c|c|}
\hline $\begin{array}{c}\text { Módulo de deformação } \\
\text { transversal - } \mathbf{G}_{\text {alv }} \text { (MPa) }\end{array}$ & $\begin{array}{c}\text { Tensão de } \\
\text { cisalhamento- } \tau_{\text {alv }} \\
(\mathbf{M P a})\end{array}$ & $\frac{\mathrm{G}_{\mathrm{alv}}}{\mathrm{f}_{\mathrm{alv}}}$ & $\frac{\mathrm{G}_{\text {alv }}}{\mathrm{f}_{\mathrm{p}}}$ & $\frac{\mathrm{G}_{\mathrm{alv}}}{\mathrm{f}_{\mathrm{b}}}$ & $\frac{\tau_{\mathrm{alv}}}{\mathrm{f}_{\mathrm{alv}}}$ & $\frac{\tau_{\mathrm{alv}}}{\mathrm{f}_{\mathrm{p}}}$ & $\frac{\tau_{\text {alv }}}{\mathrm{f}_{\mathrm{b}}}$ \\
\hline 1883 & 0,58 & 157,6 & 98,0 & 64,2 & 0,049 & 0,030 & 0,020 \\
\hline
\end{tabular}

Outra relação que pode ser estabelecida a partir dos resultados de Santos (2001) é a razão entre o módulo de deformação da alvenaria nas direções perpendicular e paralela a junta de assentamento (Tabela 3.14), explicitando a ortotropia da alvenaria.

Tabela 3.14- Relações entre o módulo de deformação da alvenaria nas direções perpendicular e paralela a junta de assentamento. Santos (2001)

\begin{tabular}{|c|c|c|}
\hline $\begin{array}{c}\text { Módulo de deformação } \\
\text { perpendicular à junta (MPa) }\end{array}$ & $\begin{array}{c}\text { Módulo de deformação } \\
\text { paralelo à junta (MPa) }\end{array}$ & $\frac{\mathrm{E}_{\text {paralelo }}}{\mathrm{E}_{\text {perpendicular }}}$ \\
\hline 5888 & 3508 & 0,596 \\
\hline \multicolumn{2}{|c|}{ "Valores referidos à área bruta } \\
\hline
\end{tabular}

\section{5 - Comentários}

O modelo físico reduzido ideal seria aquele que possui completa semelhança com o protótipo, no entanto isso levaria a grandes dificuldades, ou mesmo a impossibilidade, para a obtenção de um material para o modelo reduzido que obedecesse a todos os requisitos da análise dimensional para representar o 
comportamento do material do protótipo. Dessa forma, a utilização dos modelos de semelhança de primeira ordem e os distorcidos fornecem uma opção para a utilização de modelos em escala reduzida, pois permitem um abrandamento em relação às leis de semelhança e conseqüentemente ampliam a possibilidade de serem utilizados diferentes materiais. Todavia, esses modelos devem ser empregados com cautela, visto que a negligência de algum parâmetro importante para a análise do fenômeno pode gerar grandes distorções dos resultados entre os modelos reduzidos e os reais.

Verificou-se a viabilidade dos ensaios de modelos em alvenaria, apesar de todas as dificuldades por ser a alvenaria ser um material composto. Apresentaram-se, também, os requisitos de semelhança para a alvenaria de acordo com os modelos e graus de semelhança escolhidos. Pode-se concluir que para o sucesso do uso da escala reduzida em alvenaria deve-se ter atenção desde a escolha dos materiais até o processo de fabricação das unidades. Além dos cuidados que necessitam serem tomados em relação à argamassa, ao graute e à armadura.

Investigaram-se, ainda, alguns estudos em modelos físicos reduzidos em alvenaria já efetuados no Brasil, principalmente em relação ao estudo da viabilidade do uso e a caracterização dos materiais utilizados. Percebe-se que atualmente existe um crescente interesse no uso de modelos reduzidos, visto a possibilidade da realização de ensaios de estruturas mais complexas, bem como a redução de custos. Observa-se que para a caracterização das propriedades físicas dos materiais são empregados basicamente ensaios de compressão na direção normal às juntas de assentamento, havendo também a possibilidade de ensaios de cisalhamento e de compressão na direção paralela. 


\section{Capítulo MODELAGEM NUMÉRICA DA ALVENARIA ESTRUTURAL}

\section{1- Generalidades}

A alvenaria não-armada é constituída por unidades (blocos, tijolos ou mesmo pedras) unidas por um material de ligação (argamassas). Portanto, diversos fatores influenciam as suas propriedades tais como: dimensões e geometria das seções transversais das unidades, espessuras das juntas, propriedades das unidades e das argamassas, propriedades da interface unidade-argamassa, tipo de amarração utilizada, qualidade da mão de obra, etc. Essa complexidade intrínseca da alvenaria reflete em um grande esforço computacional necessário para uma análise numérica detalhada, fazendo com que se adotem diferentes graus de simplificações de acordo com o objetivo desejado.

Neste trabalho apresentam-se apenas aspectos relacionados à modelagem numérica via Método dos Elementos Finitos (MEF). Opta-se por esse método devido à sua versatilidade e à viabilidade nos tempos atuais, além da disponibilidade de programas comerciais para a realização da pesquisa no ambiente do SET-EESC-USP (ANSYS e ABAQUS). A aplicação do MEF na modelagem numérica da alvenaria tem se ampliado de forma rápida nos últimos tempos. Em Peleteiro (2002) se encontra um estado da arte sobre o assunto, com uma extensa bibliografia.

\section{2- Tipos de modelagens}

Os procedimentos de análises numéricas podem ser focados na micromodelagem das unidades individuais (blocos, tijolos) e da argamassa, ou na macromodelagem da alvenaria como um material composto. Lourenço (1996) indica as seguintes estratégias, dependendo do nível de precisão e simplicidade desejado: 
- micro-modelagem detalhada (Figura 4.1b): as unidades e a argamassa são representadas por elementos contínuos, sendo a interface representada por elementos descontínuos;

- micro-modelagem simplificada (Figura 4.1d): unidades com suas dimensões expandidas são representadas por elementos contínuos, sendo que o comportamento das juntas de argamassa e da interface são acumulados em elementos descontínuos;

- macro-modelagem (Figura 4.1e): unidades, argamassa e interface unidadeargamassa são consideradas em conjunto como um meio contínuo.

Pode-se ainda acrescentar um segundo tipo de micro-modelagem simplificada (Figura 4.1c), onde as unidades e a argamassa são representadas por elementos contínuos e a ligação entre bloco-unidade é considerada perfeita (desprezo da interface).

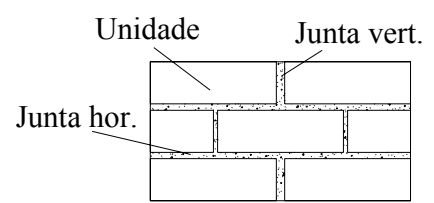

(a)

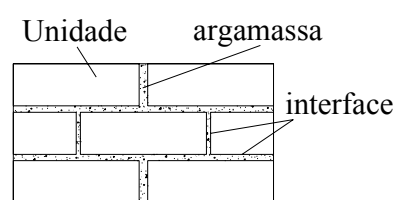

(b)

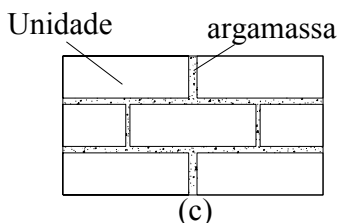

(c)

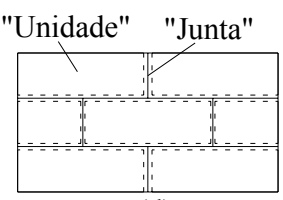

(d)

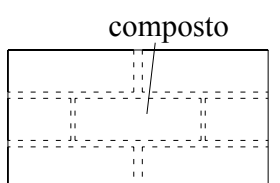

(e)

Figura 4.1 - Estratégias de modelagem para alvenaria estrutural: (a) amostra da alvenaria; (b) micro-modelagem detalhada(c) micro-modelagem simplificada tipo I (d) micromodelagem simplificada tipo II (e) macro-modelagem . Adaptada de Lourenço (1996).

$\mathrm{Na}$ micro-modelagem detalhada são consideradas as propriedades elásticas (módulo de deformação longitudinal, transversal e coeficiente de Poisson) e opcionalmente as inelásticas tanto das unidades como das argamassas. A interface unidade-argamassa é representada por elementos descontínuos, sendo um plano potencial de fissuração/deslizamento com uma falsa rigidez inicial para se evitar a interpenetração do meio contínuo. Portanto, essa modelagem permite estudar de forma minuciosa a ação combinada da unidade, da argamassa e da interface. No entanto, a representação detalhada leva a modelos complexos e que demandam grande esforço computacional, além de uma grande quantidade de parâmetros dos materiais. Dessa forma, esse tipo de modelagem é indicado para análise onde o maior interesse é o 
comportamento localizado, sendo geralmente estruturas de pequeno porte quando comparadas à edificação como um todo.

$\mathrm{Na}$ primeira consideração para a micro-modelagem simplificada, as unidades são simuladas por modelos contínuos em que podem ser consideradas suas propriedades lineares e opcionalmente as não-lineares. Já a argamassa é substituída por uma interface média representada por elementos descontínuos, que permitem representar por leis constitutivas os planos potenciais de fissuração e deslizamento. O custo computacional ainda é elevado, apesar de ser inferior ao da micro-modelagem detalhada. Outra dificuldade, não mencionada no caso anterior, é a dificuldade na geração dos elementos descontínuos em arranjos complexos, tais como modelos tridimensionais.

$\mathrm{Na}$ segunda consideração para a micro-modelagem simplificada, tanto as unidades quanto a argamassa são representadas por elementos contínuos em que são consideradas suas propriedades elásticas e/ou inelásticas. Entretanto, não são utilizados elementos descontínuos para a representação da interface; a ligação entre as unidades e a argamassa é assumida como perfeita. Portanto, não é um tipo de modelagem recomendada para situações onde o deslizamento ou a abertura das juntas seja um fator determinante para o comportamento da estrutura analisada. O esforço computacional ainda pode ser considerado como razoável.

Na macro-modelagem não se faz distinção entre unidade, argamassa e interface. Adota-se um único material homogêneo, contínuo e anisotrópico (ou isotrópico por simplificação), capaz de representar um comportamento médio da alvenaria. A grande vantagem desse processo é que não é necessário representar cada unidade e cada junta de argamassa da alvenaria. O esforço computacional pode ser bastante reduzido, viabilizando análises de grandes estruturas. Apesar de não representar modos localizados (concentrações de tensões, deslizamentos, etc), permite simular o comportamento global da estrutura.

Segundo Lourenço (1996), não é possível afirmar qual das formas de modelagem é a mais vantajosa em relação às outras, pois existem diferentes campos de aplicação para cada tipo descrito. A escolha deve ser feita de acordo com o objetivo desejado, sabendo-se das limitações de cada uma. 


\section{3- Características mecânicas da alvenaria estrutural}

Para a realização de uma acurada micro ou macro-modelagem da alvenaria estrutural é necessária uma completa descrição dos materiais. No caso da micromodelagem é importante definir as propriedades da unidade, da argamassa e da interface unidade-argamassa. Já para a macro-modelagem os aspectos mais importantes são as propriedades relacionadas ao material composto. A seguir são apresentadas as principais propriedades para cada caso.

\subsection{1 - Propriedades mecânicas da unidade e da argamassa}

Uma das principais propriedades mecânicas da unidade, senão a mais importante para o dimensionamento de estruturas, é a sua resistência à compressão. Os ensaios de compressão de unidades são de fácil realização, por suas pequenas dimensões, e fornecem um parâmetro importante para o controle do material empregado. Existem normas, tais como a BS 5628 (1992) e o EUROCODE 6 (1997), que utilizam as resistências dos componentes para determinar a resistência da alvenaria, apesar da obtenção de uma correlação entre elas não ser fácil, pois depende de uma grande quantidade de ensaios normalizados para componentes.

Ressalta-se, no entanto, que os resultados dos ensaios normalizados para a resistência à compressão das unidades (blocos ou tijolos) são influenciados pelos efeitos de confinamento, devido à restrição das placas das prensas e o tipo de capeamento utilizado [PAGE e KLEEMAN (1991)]. Isto gera uma resistência artificial para a unidade, fazendo com que algumas normas, EUROCODE 6 (1997) e AS 3700 (1998), indiquem fatores de correção que dependem da forma e das dimensões da unidade, obtendo-se uma resistência normalizada para um corpo-de-prova fictício.

Outra propriedade importante para a modelagem numérica é o módulo de deformação da unidade. Porém, pela pesquisa realizada até o momento, não existe uma norma específica para sua determinação, apenas seguem-se as mesmas recomendações utilizadas em outros materiais. O principal problema para a determinação desse módulo é a obtenção da deformação específica, pois a utilização de extensômetros elétricos colados nas unidades pode levar a valores errôneos, principalmente em unidades com perfurações e/ou de concreto onde ocorrem grandes perturbações. Acredita-se que a maneira mais correta seja determinar a deformação da unidade através de deslocamentos relativos de pontos suficientemente afastados. A determinação do coeficiente de Poisson também não é imediata, visto que as leituras das deformações 
transversais são muito pequenas e influenciadas por perturbações devidas à seção transversal da unidade.

Não existe uma correlação entre a resistência à tração da unidade e sua resistência à compressão, visto que essa relação depende de diversos fatores: dimensões da unidade, material, processo de produção, forma da seção transversal, etc. $\mathrm{Na}$ literatura internacional encontram-se valores dessa relação para blocos cerâmicos, concreto e sílico-calcário que variam entre 3 a 10\%. Para a determinação da resistência à tração da unidade a ASTM C-1006 (1996) indica um ensaio de tração indireta, semelhante ao ensaio de compressão diametral realizado em corpos de prova de concreto.

Segundo Lourenço (1996), existe, também, uma lacuna em relação a ensaios para determinação do comportamento biaxial dos blocos e tijolos. Esse aspecto tem certa relevância devido a usual ortotropia causada pelas perfurações existentes nas unidades. Como conseqüência, o comportamento biaxial da unidade, com uma dada forma, geralmente é desconhecido, mesmo que o comportamento do material da unidade seja conhecido, por exemplo concreto ou cerâmica.

Em relação às argamassas, a resistência à compressão pode ser determinada através de ensaios normalizados, tais como corpos de provas cilíndricos, cúbicos ou prismáticos. Contudo, esses corpos-de-prova são geralmente moldados em formas metálicas, fazendo com que o efeito de absorção da água pela unidade não seja considerado, não representando bem as condições da argamassa na estrutura. A ASTM C-1019 (1984) chega a propor, no caso específico do graute, que os corpos de prova sejam moldados utilizando-se as unidades como forma, procurando diminuir essa diferença. Existe, ainda, a opção de se extrair discos de argamassas das juntas de assentamento para serem ensaiadas, caracterizando-se o seu comportamento. Para a resistência à tração da argamassa são utilizados procedimentos análogos ao do concreto, ou seja, ensaios à tração direta, compressão diametral e flexão.

A determinação do módulo de elasticidade da argamassa também não é um consenso, pois o valor pode ser obtido por diferentes maneiras. A forma mais simples é a utilização de ensaios semelhantes aos normalizados para corpos de prova de concreto. Uma segunda maneira é a determinação do módulo de elasticidade com o corpo-deprova submetido a um estado triaxial de tensões, visando representar o estado de tensões a que a argamassa é submetida na alvenaria. No entanto, o nível de 
confinamento da argamassa é dependente da forma de assentamento e da geometria da seção transversal da unidade. Uma forma de resolver esse problema é a determinação do módulo de elasticidade da argamassa diretamente no ensaio de prisma ou de parede. Dificuldades semelhantes ocorrem para a determinação do coeficiente de Poisson.

Lourenço (1996) conclui que existe uma completa falta de conhecimento sobre o comportamento da argamassa, tanto na compressão quanto na tração, quando esta trabalha no conjunto alvenaria (unidades e juntas).

\subsection{2 - Propriedades mecânicas da interface unidade-argamassa}

A ligação entre a unidade e a argamassa é geralmente o ponto fraco da alvenaria como um todo. Segundo Lourenço (1996), a resposta não-linear das juntas, que é controlada pela interface unidade-argamassa, é uma característica importante do comportamento da alvenaria, principalmente na presença de ações horizontais. Existe a possibilidade da ocorrência de dois tipos de rupturas na interface unidade-argamassa: um associado à ruptura por tração e um outro associado à ruptura por cisalhamento.

a) Ruptura por tração da interface

A resistência à ruptura por tração da interface unidade-argamassa é a aderência. Existem alguns métodos normalizados para sua determinação, geralmente desenvolvidos para obtenção da resistência à tração na flexão. Um primeiro método [ASTM E-518 (1993)] utiliza o ensaio de flexão de prismas, com forças aplicadas nos terços dos vãos ou uma força uniformemente distribuída (ver Figura 4.2a). É um ensaio simples, porém apresenta grande dispersão de resultados, visto que a ruptura ocorre na junta em que acontece a combinação crítica entre o maior momento aplicado e a menor aderência. Um outro método é o ensaio de arrancamento [ASTM C-1072 (1994)], em que também são utilizados prismas (Figura 4.2b). Nesse ensaio a unidade do topo do prisma é submetida a um momento enquanto a unidade logo abaixo é fixa, fazendo com que o momento solicite apenas uma junta de argamassa. Com esse método é possível avaliar a resistência de todas as juntas do prisma, com procedimento seqüencial.

b) Ruptura por cisalhamento

Um aspecto importante para determinação da resposta ao cisalhamento das juntas de argamassas é a capacidade do arranjo do ensaio em gerar um estado de tensão uniforme nas juntas. Esse objetivo é dificultado porque as condições de equilíbrio do ensaio introduzem tensões normais não-uniformes na junta. Existem na literatura 
técnica diferentes configurações de ensaios ilustrados brevemente na Figura 4.3; maiores detalhes podem ser encontrados em Jukes e Riddington (1997) e Drysdale et al. (1994).

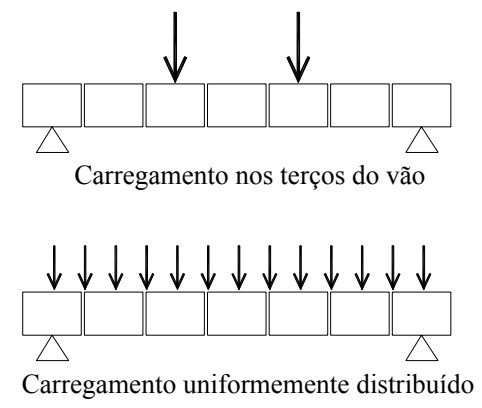

(a) Ensaio de flexão - ASTM E 518

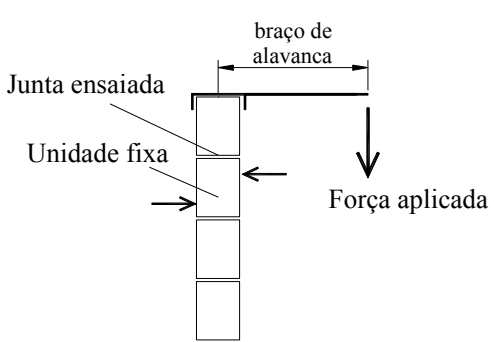

(b) Ensaio de arrancamento - ASTM C 1072

Figura 4.2- Ensaios de aderência da junta de argamassa.

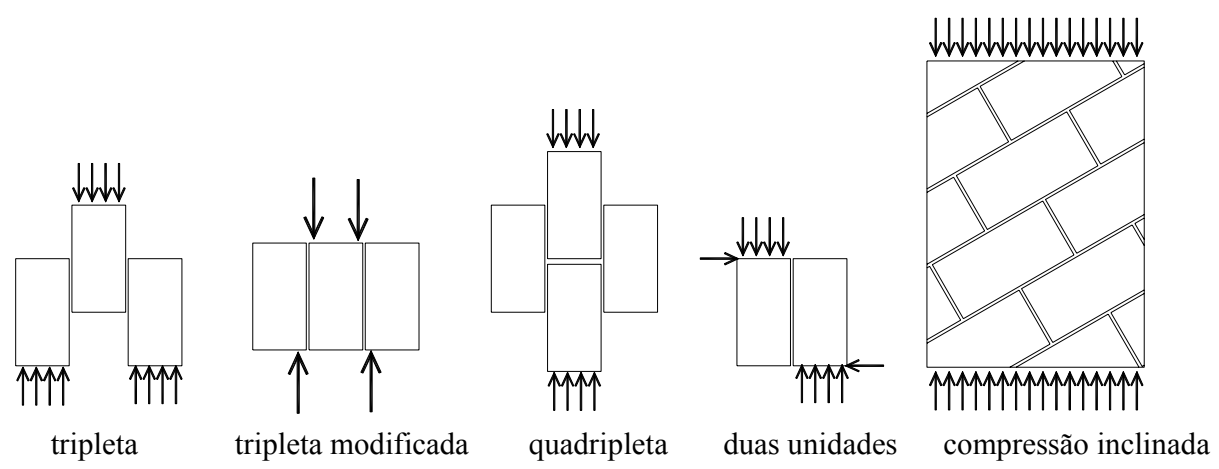

Figura 4.3 - Ensaios de cisalhamento na junta de argamassa.

Em todas as configurações de ensaios percebe-se que a tensão de cisalhamento correspondente ao deslizamento ao longo de uma ou mais juntas é diretamente relacionada à combinação de tensões de compressão e cisalhamento. A relação normalmente adotada para representar o fenômeno é o modelo de atrito de Coulomb. Vale ressaltar que parâmetros como o ângulo de atrito residual e o ângulo de dilatância são importantes para análises numéricas mais acuradas, não detalhados aqui por não estarem dentro do escopo deste trabalho.

\subsection{3 - Propriedades mecânicas do material composto}

a) Comportamento da alvenaria na compressão uniaxial

As normas de dimensionamento da alvenaria estrutural indicam a resistência à compressão em relação à direção normal à junta de assentamento como a propriedade mais relevante do material. A determinação dessa resistência pode ser obtida por ensaios de resistência à compressão uniaxial de prisma (Figura 4.4a), por exemplo NBR 
8215/1983, ASTM C 1314 (1997) entre outras. No entanto, devido aos efeitos de restrições das placas das prensas e do tipo de capeamento há a indicação de se utilizar fatores de correção de acordo com as dimensões do prisma [ASTM C 1314 (1997) e AS 3700 (1998)]. Outra forma de obtenção é através do ensaio de paredes em tamanho real, NBR 8949/1985 e BS 5628 (1992). Nesse caso não é necessário fazer correções da resistência, porém é um ensaio com grandes dimensões, necessitando de equipamentos de grande porte, o que eleva o seu custo. Um ensaio intermediário para se avaliar a resistência real à compressão da alvenaria na direção normal às juntas de assentamento é o procedimento indicado pela RILEM (Figura 4.4b), no entanto o exemplar ainda é relativamente grande e o custo do ensaio caro, principalmente quando comparados com os corpos de prova de concreto e os prismas.

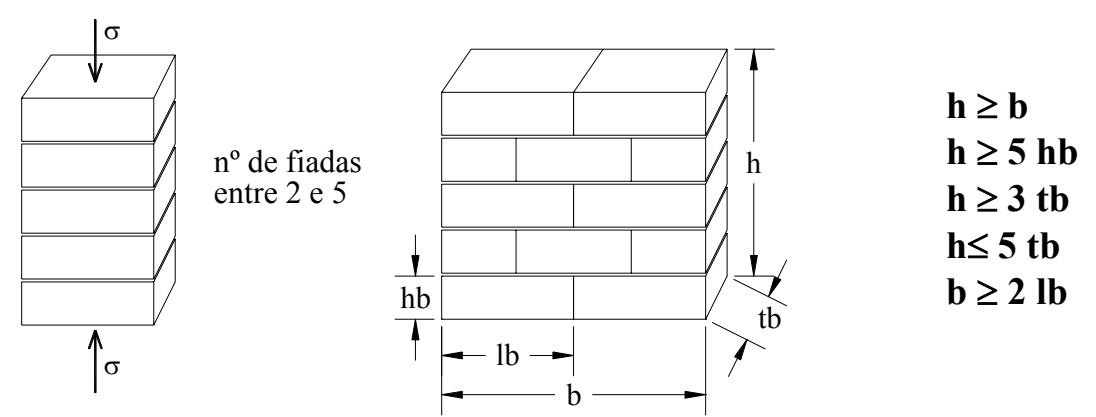

Figura 4.4 - Ensaio de prismas (a) Ensaio -RILEM (b). Adaptado de Lourenço (1996)

Com a introdução de análises numéricas para estruturas de alvenaria, observa-se a necessidade da obtenção de outras propriedades que possibilitem melhores modelagens. Verifica-se a pouca atenção dada aos ensaios de compressão na direção paralela à junta de assentamento. No entanto, como a alvenaria é um material anisotrópico, particularmente para unidades com perfurações e/ou vazios, a resistência à compressão na direção paralela às juntas pode ter um efeito decisivo na capacidade de carga da alvenaria. De acordo com Lourenço (1996), a razão entre a resistência uniaxial à compressão na direção paralela e na direção normal à junta de assentamento pode variar entre 0,2 e 0,8 , dependendo do tipo, da forma e do material da unidade.

b) Comportamento da alvenaria na tração uniaxial

Não é comum a realização de ensaios de tração perpendicular às juntas horizontais, apesar de existirem ensaios normalizados, NBR 14322/1999 e ASTM E 72 (1995). São ensaios de grandes dimensões e de custo elevado, pois utilizam paredes com dimensões reais para se obter a máxima tração na flexão. A ruptura obtida é 
geralmente causada pela perda da aderência entre a junta horizontal e a unidade. Dessa forma, como uma aproximação, a resistência à tração da alvenaria pode ser estimada pela a aderência unidade-argamassa.

Uma outra situação pode ocorrer em estruturas com unidades de baixas resistências e grande aderência entre a unidade e a argamassa, como por exemplo, nos casos de argamassa de alta resistência e unidades com pequenas e numerosas perfurações, que produzem um efeito de pino. Nesse caso pode acontecer a ruptura à tração da unidade. Novamente como uma aproximação, a resistência à tração da alvenaria pode ser estimada como igual à resistência à tração da unidade.

Para determinação da resistência à tração paralela à junta, Drysdale et al. (1994) comentam que diversos pesquisadores adaptam os procedimentos de ensaios indicados para a obtenção da resistência perpendicular à junta. Uma outra possibilidade é a realização de um ensaio de tração direta. No entanto, não é um ensaio padrão devido às dificuldades inerentes.

c) Comportamento biaxial da alvenaria

Diferentemente do concreto, o comportamento da alvenaria sob estados biaxiais de tensões não pode ser completamente descrito a partir do seu comportamento sob condições de carregamentos uniaxiais. A alvenaria é um material que apresenta diferentes propriedades de acordo com a direção escolhida, porque as juntas de argamassas funcionam como planos de fraqueza. Dessa forma, o estado biaxial não pode ser descrito apenas em termos de tensões principais, visto que a alvenaria é um material anisotrópico, sendo necessária uma superfície tridimensional para a descrição da resistência biaxial. Tanto a orientação das tensões principais com relação aos eixos materiais quanto a razão entre as tensões principais influenciam consideravelmente o modo de ruptura e a resistência.

\section{4- Tipo da análise: bidimensional ou tridimensional}

Uma das principais simplificações para a modelagem de paredes de alvenaria estrutural é a sua representação por suas superfícies médias. Existe uma quantidade substancial de trabalhos que simulam o comportamento de paredes utilizando elementos de estado plano de tensões. O sucesso do uso da análise bidimensional de painéis de alvenaria pode ser comprovado em diversos trabalhos consagrados [LOURENÇO (1996), DHANASEKAR et al. (1985), entre outros]. Vale ressaltar que grande parte dos 
estudos trata de paredes coplanares, carregamentos centrados na espessura da parede e outras situações onde a adoção dos elementos bidimensionais é perfeitamente adequada. No entanto, em certos casos é necessária a utilização de elementos tridimensionais, como por exemplo no estudo da distribuição tridimensional de tensões em prismas e paredes constituídos de blocos vazados de concreto [KHALIL et al. (1987), SAYEDAHMED e SHRIVE (1995,1996a e 1996b) e YI e SHRIVE (2000 e 2001)]. Outra situação em que é interessante a utilização de uma análise tridimensional é o caso de paredes em que o carregamento não é centrado na espessura da parede.

Vekemans e Arce (1993) consideram que o estudo da modelagem de paredes pertencentes a planos distintos, que é o caso de painéis com flanges, ainda é incipiente, havendo poucos trabalhos sobre o assunto. Por este motivo desenvolvem um trabalho onde investigam a influência do flange na rigidez de paredes de alvenaria estrutural não-armada. Inicialmente utilizam uma análise bidimensional, verificando, porém, que o modelo apresenta falhas na representatividade da parede " $\mathrm{T}$ ", pois como possui apenas duas dimensões, os flanges são modelados apenas com a mudança da espessura dos elementos em sua região. Desta forma, o modelo bidimensional não é capaz de prever as deformações reais da ligação parede-flange, além de não ser possível verificar a distribuição das tensões ao longo do flange ou mesmo sua possível fissuração. Já com um modelo tridimensional pode-se verificar a distribuição de tensões no flange, as concentrações de tensões de cisalhamento na ligação parede-flange e a influência da fissuração que eventualmente ocorra. Entretanto, os autores não apresentam resultados do modelo tridimensional, pois, devido ao seu maior grau de complexidade ainda estava em desenvolvimento.

Vekemans (1994) tenta desenvolver um modelo numérico mais simples que o tridimensional (3D), mas que represente o comportamento da parede " $\mathrm{T}$ " melhor do que o modelo bidimensional (2D). O modelo é denominado de $2 \frac{1}{2} \mathrm{D}$, sendo que a parede e o flange são modelados com os mesmos elementos planos de tensão, mas posicionados a $90^{\circ}$. No entanto, esse modelo ainda não permite verificar a distribuição de tensão ao longo da espessura do flange e não leva em consideração a fissuração em seu plano. $O$ autor, em suas conclusões, comenta sobre uma possível melhora no modelo caso utilizasse elementos planos para a parede e elementos tridimensionais para o flange.

Ali et al. (2000) realizam uma análise numérica de paredes de tijolos enrijecidas por paredes ortogonais considerando o comportamento não-linear da alvenaria. Com 
base nos estudos de Vekemans \& Arce (1993) e Vekemans (1994), decidem utilizar uma análise tridimensional empregando elementos sólidos para a modelagem numérica da parede enrijecida. Uma das formas utilizadas para reduzir o esforço computacional é consideração da alvenaria como homogênea (macro-modelagem). Observa-se uma boa correlação entre valores numéricos e experimentais para as forças de ruptura. $O$ padrão de fissuração obtido é compatível com os ensaios realizados anteriormente. Maiores detalhes sobre esse trabalho estão apresentados no capítulo 3.

Como já mostrado anteriormente, também no capítulo 3, Peleteiro (2002) realiza uma análise numérica de painéis " $\mathrm{H}$ " utilizando uma modelagem tridimensional (elementos de casca), com a inclusão do comportamento não-linear do bloco e da argamassa separadamente (micro-modelagem). Obtém valores coerentes para forças de ruptura e fissuração. No entanto, os deslocamentos relativos após a fissuração divergem dos obtidos experimentalmente. No modelo numérico não é possível observar a separação entre a parede central e os flanges verificada no ensaio. A autora também realiza a modelagem de paredes planas, verificando que tantos os modelos bidimensionais como os tridimensionais representam bem o comportamento experimental.

Em outro trabalho também já citado, Corrêa e Page (2001) fazem simulações de painéis " $\mathrm{H}$ " de alvenaria estrutural não-armada com o objetivo de estudar o comportamento global do painel. Dessa forma adotam o uso de elementos bidimensionais, pois os consideram suficientes para os objetivos da análise numérica desejada. Mesmo assim, o modelo continua a ter um caráter tridimensional, pois, como as paredes pertencem a planos distintos, os flanges são modelados por elementos rotacionados de $90^{\circ}$ em relação à parede central. Esse tipo de modelagem é a que Vekemans (1994) denomina de 2 1 12 D. A possibilidade da representação da parede por elementos planos confere ao problema uma simplificação conceitual e reduz o esforço computacional a ser utilizado.

\section{5- Natureza da análise: linear ou não-linear}

Segundo Page (1978), uma forma usual de simplificar a modelagem numérica da alvenaria estrutural é a consideração de um comportamento linear do material, desprezando-se a influência das juntas de argamassas como planos de fraqueza e a perda de rigidez da unidade com o aumento das tensões. De acordo com o autor, hipóteses dessa natureza são satisfatórias para simular deformações a baixos níveis de tensões 
com a estrutura em situação de serviço. Entretanto não se pode esperar bons resultados para altos níveis de tensões, em que deve ocorrer uma redistribuição de tensões.

Drysdale et al. (1994) indicam que prismas submetidos à compressão uniaxial possuem um comportamento linear até um nível de tensão por volta de $50 \%$ do valor último, especialmente para unidades de concreto, enquanto que em unidades cerâmicas esse valor é ainda maior. Hendry et al. (1981) comentam que pode ser considerado para a alvenaria de tijolos cerâmicos um comportamento linear até $75 \%$ da tensão de ruptura. Portanto, para situações em serviço, onde os níveis de tensões não ultrapassam usualmente $30 \%$ da resistência última, é perfeitamente aceitável o uso da análise linear para o estudo de distribuição de tensões, deformações e deslocamentos.

Segundo Riddington et al. (1997), a análise linear também é útil para realizar comparações de diferentes arranjos de ensaios (carregamento, geometria, restrições) indicando as vantagens e desvantagens relativas de cada um. Os autores utilizam a análise linear via elementos finitos para modelar diferentes ensaios de cisalhamento na junta encontrados na literatura técnica, com o objetivo de determinar qual deles é teoricamente melhor. Empregando a análise linear, desenvolvem um tipo de ensaio que produz resultados tão bons quanto os outros métodos estudados, porém utilizando dispositivos de ensaios mais simples e um arranjo de fácil execução.

Vale lembrar que a análise linear pode ser realizada considerando um material isotrópico, que é o modelo mais simples, ou então, um material ortotrópico, que é um modelo que representa a anisotropia observada na alvenaria, mas necessita de um maior número de parâmetros, que muitas vezes não são disponíveis.

Já a análise não-linear pode ser dividida em três grupos, em função de suas causas:

- não-linearidade geométrica: o equilíbrio é estabelecido na configuração deformada da estrutura, levando-se em conta os deslocamentos e as deformações, o que gera novos esforços na estrutura, os denominados efeitos de segunda ordem

- não-linearidade do material: relacionado à mudança das propriedades do material a um determinado estado de tensão. Pode ser considerada por diferentes teorias, por exemplo, plasticidade, mecânica do dano, mecânica da fratura.

- não-linearidade de contato: relacionado às mudanças nas condições de contorno de acordo com a evolução do carregamento. Essas mudanças podem ocorrer 
quando duas ou mais superfícies, da mesma estrutura ou de estruturas diferentes, fazem ou perdem contato entre elas. Outra situação é a de duas superfícies, da mesma estrutura ou de estruturas diferentes, que apresentam deslizamento relativo.

Analisando-se as propriedades mecânicas da alvenaria apresentadas no item 4.3 percebe-se o quão complexo deve ser uma análise não-linear detalhada de uma estrutura de alvenaria, visto a grande quantidade de parâmetros dependentes das propriedades da unidade e da argamassa e do conjunto dos materiais. Lourenço (1996) indica que um modelo acurado deve ser capaz de representar os seguintes mecanismos de ruptura característicos da alvenaria (Figura 4.5):

a) fissuração da junta por tração direta;

b) deslizamento ao longo da junta sob baixas compressões;

c) fissuração da unidade por tração;

d) fissuração por tração diagonal da unidade, sob compressão suficiente para desenvolver atrito nas juntas;

e) esmagamento da alvenaria, caracterizada pelo fendilhamento da unidade, induzida pela dilatância da argamassa sob alta compressão.

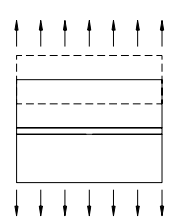

(a)

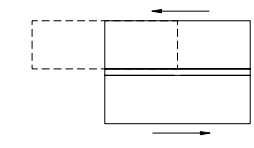

(b)

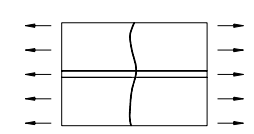

(c)

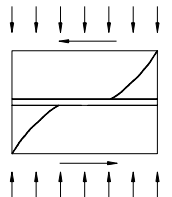

(d)

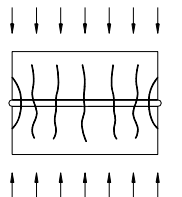

(e)

Figura 4.5- Mecanismos de ruptura da alvenaria. Lourenço (1996)

Observa-se que os mecanismos (a) e (b) estão associados à junta de argamassa, o (c) refere-se à unidade e os dois últimos, (d) e (e), são mistos. Também pode se definir que os mecanismo (c), (d) e (e) são relacionados as não-linearidades dos materiais. Já os mecanismos (a) e (b) são casos típicos de não-linearidade de contato. Portanto, para a consideração de um modelo que represente além do comportamento elástico é importante que os vários mecanismos estejam representados. No mínimo os mais relevantes para a situação estudada. Por exemplo, no caso da modelagem de um prisma 
à compressão uniaxial, a consideração apenas do mecanismo de esmagamento pode ser suficiente para uma boa representação.

Ressalta-se que todos os mecanismos apresentados estão relacionados apenas ao comportamento plano das paredes. Não existem indicações de mecanismos de ruptura para a alvenaria em planos diferentes, que é o caso da interseção de paredes.

A seguir são apresentadas as formas como as não-linearidades do material e de contato podem ser consideradas por meio da utilização do pacote computacional ABAQUS. O modelo para consideração da não-linearidade do material já é de uso consagrado na modelagem de estruturas de alvenaria. Já o emprego do modelo para a não-linearidade de contato não é usual para esse tipo de estrutura. O programa também permite simular a não-linearidade geométrica, no entanto, como esse comportamento não é considerado importante na análise do trabalho em questão, não se mostram detalhes sobre esse tema.

\subsection{1 - Modelo para a não-linearidade do material}

Apresenta-se brevemente o modelo elastoplástico para o concreto simples do programa ABAQUS. Segundo o manual do programa, o modelo é indicado para o comportamento do concreto submetido a carregamentos relativamente monotônicos sob baixas tensões de confinamento (menores que quatro ou cinco vezes a máxima tensão que pode ser admitida para o concreto na compressão uniaxial). A fissuração é adotada como o aspecto mais importante do material, sendo que seu aparecimento ocorre na estrutura quando a tensão atuante atinge uma superfície de ruptura, aqui denominada de superfície de fissuração. O modelo considera essa anisotropia introduzida pelo aparecimento das fissuras, visto sua importância para as simulações. A fissuração é levada em conta pelo modelo de fissuras dispersas, em que elas não são consideradas individualmente e sim no cálculo das tensões e rigidezes do material associadas a cada ponto de integração independemente.

As respostas do material à fissuração e à compressão que são incorporadas ao modelo estão ilustradas na resposta uniaxial apresentada na Figura 4.6. Quando o material é carregado em compressão, sua resposta inicial é elástica. À medida que a tensão aumenta, ocorrem algumas deformações inelásticas (não recuperáveis), e a resposta do material sofre um "amolecimento". Quando a tensão última do material é atingida, sua rigidez vai diminuindo até que não suporte nenhum acréscimo de tensão. Se o carregamento é retirado num estágio posterior ao aparecimento das deformações 
inelásticas, o descarregamento é menos rígido que a resposta elástica inicial, pois ocorre a danificação do material. No entanto, esse efeito é ignorado no modelo, visto que se assume que sua utilização é apenas para situações que envolvam principalmente um carregamento monotônico, com descarregamentos de pequena importância.

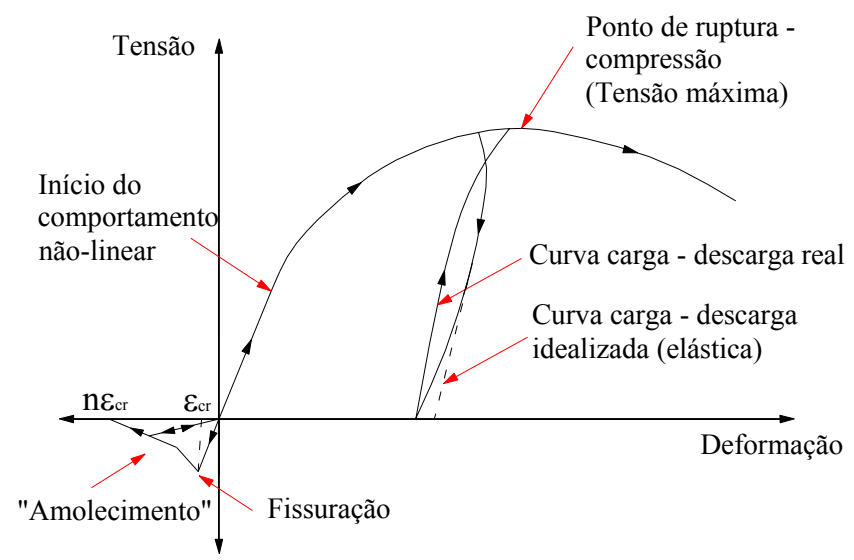

Figura 4.6 - Comportamento uniaxial do modelo. Adaptado do Manual do ABAQUS

O material quando submetido a uma tensão de tração, responde tipicamente de maneira elástica até uma tensão de 7 a $10 \%$ da máxima tensão de compressão, a partir desse nível ocorre a fissuração do material. As fissuras se formam tão rapidamente que, mesmo utilizando máquinas de ensaio com deformação controlada, é muito difícil observar o seu comportamento. O modelo assume que a fissuração causa uma danificação no material, assim as aberturas de fissuras são consideradas através da perda de rigidez (amolecimento). Também se admite que não há deformação permanente associada com a fissuração, permitindo que as fissuras se fechem completamente quando as tensões através delas se tornem de compressão. Essas observações podem ser generalizadas para o estado biaxial de tensões utilizando-se os conceitos de superfícies de ruptura e fluxo no espaço das tensões principais. As superfícies são ajustadas com dados experimentais, sendo que a Figura 4.7 ilustra um caso típico.

O programa ABAQUS permite que o usuário defina a forma dessa superfície de ruptura através de quatro dados de entrada:

- a razão entre a máxima tensão de compressão biaxial e a máxima tensão de compressão uniaxial;

- o valor absoluto da razão entre a tensão de ruptura para a tração uniaxial e a máxima tensão de compressão uniaxial; 
- a relação entre a componente principal da deformação plástica para a máxima tensão de compressão biaxial e a deformação plástica para a máxima tensão de compressão uniaxial;

- a relação entre a tensão de tração principal para fissuração (no estado plano de tensões é a que a outra tensão principal atinge o valor máximo de compressão) e a tensão de fissuração para a tração uniaxial.

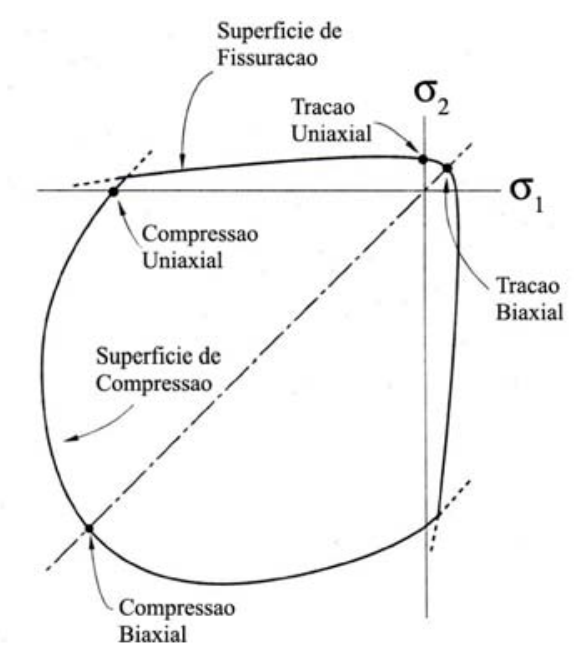

Figura 4.7 - Superficie de ruptura para o estado biaxial de tensões. Adaptado do Manual do ABAQUS

Vale ressaltar que valores referentes ao estado biaxial de tensão nem sempre são disponíveis ou de fácil obtenção, principalmente para a alvenaria como apresentado no item 4.3. Uma opção é utilizar os parâmetros sugeridos pelo programa, ou então realizar testes de calibração de forma a ajustar os resultados numéricos aos resultados experimentais.

O programa ABAQUS também permite como entrada de dados a própria curva experimental do diagrama de tensão versus deformação do material, sendo apenas necessária a transformação das tensões e deformações nominais em tensões e deformações atualizadas.

\subsection{2 - Modelo para a não-linearidade de contato (ABAQUS)}

O prograna ABAQUS permite diversas formas para considerar o comportamento não-linear do contato. Realiza-se, aqui, uma pequena revisão sobre o assunto, com o objetivo de encontrar indicações do melhor procedimento a ser utilizado. Observa-se que todos os trabalhos encontrados estão relacionados a uma única linha de pesquisa da Universidade de Calgary, Canadá. Sayed-Ahmed e Shrive (1995 e 1996) e Yi e Shrive 
(2000) utilizam o ABAQUS para simular uma fissuração discreta em blocos vazados de concreto. No caso, procuram representar a fissuração dos septos transversais, observando a sua evolução, verificada experimentalmente nos ensaios de compressão de prismas e paredes. Este padrão de ruptura é típico quando o assentamento da argamassa é realizado apenas sobre as faces laterais dos blocos vazados.

Para essa simulação, os autores utilizam elementos de contato na região central do septo transversal do bloco. O modelo adotado admite que a fissura ocorre quando a tensão normal ao elemento de contato supera a resistência à tração da alvenaria. Neste momento, ocorre a separação dos elementos em contato. Com esse desligamento, a rigidez do elemento é reduzida a zero. Uma vez iniciado esse processo, verificam-se os elementos de contato na vizinhança, com o intuito de considerar a propagação da fissura.

\section{6- Comentários}

Para se definir o tipo de modelagem a ser utilizada, é preciso que se determine inicialmente o objetivo que se deseja alcançar. No caso deste trabalho, como se mostra adiante, utiliza-se a micro-modelagem simplificada, sem a consideração do comportamento da interface unidade-argamassa, para se verificar a distribuição de tensões, em níveis de solicitação em que o comportamento do material ainda seja linear. O objetivo é utilizar essas distribuições de tensões para a definição do arranjo mais adequado para a estimativa das resistências ao cisalhamento no plano vertical da alvenaria. Outra opção consiste em empregar uma análise tridimensional em todos os casos, com o intuito de analisar a influência do uso de blocos com seus vazios e investigar o comportamento da interseção de paredes.

Também realizam-se análises do comportamento não-linear do material para a averiguação das resistências dos modelos, possibilitando a comparação com os resultados experimentais. Neste caso, para os modelos de menores dimensões, empregase, novamente, a micro-modelagem da alvenaria. Já para os modelos de grandes dimensões, utiliza-se a macro-modelagem da alvenaria, como forma de reduzir o esforço computacional. Em algumas situações específicas, inicia-se o estudo considerando-se a não-linearidade de contato.

Para a consideração do comportamento não-linear da alvenaria, tanto do material quanto de contato, utiliza-se o pacote computacional ABAQUS, que é 
empregado com sucesso em trabalhos no Brasil e no exterior. Entretanto, para que se obtenha sucesso nas análises numéricas, principalmente as não-lineares, observa-se a necessidade de uma boa caracterização dos materiais. Neste trabalho, como o intuito é a utilização de micro e macro-modelagens, é fundamental a realização de ensaios de caracterização da unidade, da argamassa, da junta bloco-argamassa e da alvenaria como um material composto. 


\section{Capítulo \\ 5 ENSAIOS DE CARACTERIZAÇÃO DOS MATERIAIS}

\section{1 - Generalidades}

Neste capítulo são apresentados os ensaios de caracterização do bloco cerâmico e da alvenaria em si, nas escalas natural (1:1) e reduzida (1:3). Todos os ensaios são realizados no Laboratório de Estruturas, do Departamento de Engenharia de Estruturas da EESC-USP.

O primeiro objetivo dos ensaios de caracterização é permitir a comparação das propriedades dos materiais nas diferentes escalas, procurando semelhanças e diferenças das suas propriedades físicas e mecânicas, estudando dessa forma a viabilidade da extrapolação do comportamento obtido nos ensaios em escala reduzida para a escala natural. Uma meta secundária é utilizar as técnicas de modelos físicos reduzidos visando obter fatores de escala que correlacionem os resultados das duas diferentes escalas.

Outro objetivo é a obtenção de algumas das principais propriedades mecânicas dos materiais, que viabilizam análises numéricas lineares e/ou não-lineares mais realistas, utilizando tanto técnicas de micro-modelagem quanto de macro-modelagem.

\section{2 - Caracterização dos blocos em escala natural e reduzida}

Para a caracterização dos blocos cerâmicos nas diferentes escalas são determinadas as dimensões reais, o desvio em relação ao esquadro, a planeza das faces, a resistência à compressão, bem como o índice de absorção e a área líquida. Para tanto, seguem-se as recomendações dispostas nas normas brasileiras, com as adaptações necessárias à escala. Para os ensaios de resistência à tração indireta dos blocos e de índice de absorção inicial (IRA), seguem-se os preceitos de normas americanas, visto a 
inexistência de norma brasileira similar. Também realizam-se os ensaios de resistência à compressão do bloco na direção paralela à junta de assentamento e de determinação do módulo de deformação do bloco, que não são normalizados.

Os procedimentos de ensaios, os equipamentos utilizados e as particularidades relacionadas a cada escala são detalhados em um item separado. Os resultados são apresentados de acordo com o tipo de ensaio, permitindo uma comparação imediata entre as escalas. Ao final é feita uma análise geral dos resultados obtidos, utilizando-se, inclusive, as técnicas de modelos físicos reduzidos.

\subsection{1- Procedimentos e equipamentos utilizados na caracterização dos blocos}

\subsubsection{1- Análise dimensional}

- Procedimentos:

De acordo com a NBR 7171/1992, as dimensões nominais correspondem às dimensões especificadas pelas arestas dos blocos. Já as dimensões reais correspondem às dimensões médias das arestas, medidas pelo alinhamento de 24 blocos escolhidos aleatoriamente. Segundo a mesma norma, as tolerâncias máximas de fabricação para as dimensões das arestas são de $\pm 3 \mathrm{~mm}$. Entretanto, adota-se para os blocos na escala reduzida (1:3) que a tolerância para as dimensões das arestas seja de $\pm 1 \mathrm{~mm}$, que é uma redução proporcional à escala, o que gera um critério excessivamente rigoroso. As mesmas 24 unidades utilizadas para determinar as dimensões reais são medidas individualmente.

A planeza das faces e o desvio em relação ao esquadro das unidades são também determinados segundo a NBR 7171/1992. Utiliza-se uma amostra com 12 unidades selecionadas aleatoriamente, uma a menos que a recomendada em norma. A tolerância para a planeza e o esquadro também é de $3 \mathrm{~mm}$ para os blocos na escala natural (1:1), e para a escala (1:3), devido à redução de escala, é considerada igual a $1 \mathrm{~mm}$.

- Equipamentos:

Para a escala natural $(1: 1)$ são utilizados trenas metálicas com graduação de $1 \mathrm{~mm}$ para leitura das dimensões reais, réguas metálicas com graduação de $0,5 \mathrm{~mm}$ para as leituras das medidas individuais e da planeza das faces; e esquadro metálico de $90 \pm$ $0,5^{\circ}$ para a medida do desvio em relação ao esquadro. Já para a escala reduzida (1:3) as modificações adotadas são a utilização de réguas metálicas para a leitura das dimensões 
reais e de um paquímetro com precisão de $0,1 \mathrm{~mm}$ para a leitura das medidas individuais.

\subsubsection{2- Absorção de água, massa específica e área líquida}

- Procedimentos:

A NBR 7171/1992 indica que a absorção de água dos blocos cerâmicos não deve ser inferior a $8 \%$ e nem superior a $25 \%$. Esse valor deve ser obtido seguindo os preceitos da NBR 8947 - Telha cerâmica - Determinação da massa e da absorção de água - Método de ensaio. Entretanto, pela dificuldade de deixar os blocos em água fervente durante 2 horas, opta-se por utilizar o método empregado para blocos de concreto, que é a imersão em água por um período mínimo de 24 horas.

Cabe ressaltar que o valor obtido por imersão é diferente do caso por fervura, pois, nessa última situação, a água fervente vence as tensões capilares dos poros do material cerâmico. No entanto, acredita-se que a diferença dos resultados não seja tão significativa, visto que Santos (2001), utilizando blocos cerâmicos semelhantes ao empregado na presente pesquisa, obteve para a absorção em água fervente durante 5 horas um resultado apenas 5\% superior à absorção por imersão em água por 24 horas.

Para determinação da área líquida dos blocos e meios-blocos segue-se a NBR 8043/1983, sendo que novamente utiliza-se a imersão dos blocos ao invés da fervura. Não existe nenhuma limitação de norma em relação a uma proporção mínima entre área líquida e bruta. Calcula-se, ainda, a massa específica dos blocos, que é a massa seca da unidade dividida por seu volume real.

A amostra utilizada em todos os casos é de 12 unidades.

- Equipamentos:

Neste caso empregam-se os mesmos equipamentos tanto para escala natural quanto para a reduzida. A estufa marca Quimis, modelo Q317 com precisão de $\pm 5^{\circ} \mathrm{C}$, e a balança marca Mettler Toledo, modelo SB24001 Delta Range com precisão de 1g e capacidade de $24.000 \mathrm{~g}$, adaptada para realizar medições de massas aparentes.

\section{$\underline{\text { 5.2.1.3- Resistência à compressão }}$}

- Procedimentos:

As resistências à compressão dos blocos e meios-blocos são determinadas seguindo os preceitos da NBR 6461/1983 com algumas modificações. Para o capeamento das unidades utiliza-se pasta de enxofre. Por esse motivo os blocos são 
ensaiados com sua umidade normal e não úmidos como menciona a norma, o que leva a superestimação da resistência quando comparados ao ensaio normalizado. Verifica-se que a velocidade de carregamento indicada na norma é muito baixa para os blocos estruturais, cerca de $0,5 \mathrm{kN} / \mathrm{s}$ independente da seção transversal. Caso se utilizasse tal velocidade, alguns blocos em escala natural levariam mais de 20 minutos para atingir a força de ruptura. Por esse motivo a velocidade de ensaio empregada é de $1 \mathrm{kN} / \mathrm{s}$.

As amostras utilizadas para os blocos e meios-blocos na escala natural (1:1) são de 18 e de 12 unidades, respectivamente. Já para a escala reduzida (1:3), a amostra dos blocos é de 29 unidades, e a dos meios-blocos é de 15 unidades. O resultado pode ser tanto em relação à área bruta quanto à área líquida, dependendo da finalidade desejada. Para as análises numéricas em que se considera o bloco vazado é interessante que as propriedades sejam referidas à área líquida

- Equipamentos:

Todas as unidades, independentemente da escala, são ensaiadas na máquina hidráulica para ensaio de compressão da marca ELE, modelo Autotest 2000.

\subsubsection{4- Resistência à tração indireta}

- Procedimentos:

A resistência à tração indireta do bloco é determinada segundo a ASTM C1006(1996), pois não existe nenhuma norma brasileira similar. O princípio do experimento é o mesmo do ensaio de compressão diametral de corpos-de-prova de concreto. De acordo com a norma americana deve-se utilizar barras cilíndricas para o apoio e a aplicação da força. No entanto, nos ensaios em escala natural (1:1) são utilizadas barras prismáticas por causa da dificuldade de posicionamento do bloco. Para corrigir as irregularidades das faces onde as barras são localizadas, empregam-se tiras de forro pacote (material bastante deformável).

$\mathrm{Na}$ escala natural (1:1) a região de aplicação da força e do apoio é um pouco deslocada do centro do bloco (Figura 5.1-a). Isso se deve a testes preliminares indicarem que ao aplicar o carregamento no centro do bloco ocorre ruptura por esmagamento e não por tração indireta. Acredita-se que isso ocorra devido à presença de paredes internas na mesma direção do carregamento. Desse modo desloca-se a aplicação da força para uma região onde só existam paredes ortogonais ao carregamento. 
Já para a escala reduzida (1:3) a aplicação de força e apoio é realizada numa região central em relação à cavidade do bloco (Figura 5.1-b). Isso porque nessa posição só existem paredes ortogonais ao carregamento, que parece ser uma situação mais favorável. Por meio de simulações numéricas são feitos estudos teóricos que comprovam ser esse o melhor posicionamento.

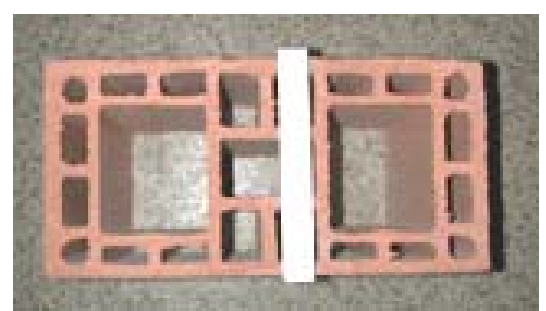

(a) Escala natural (1:1)

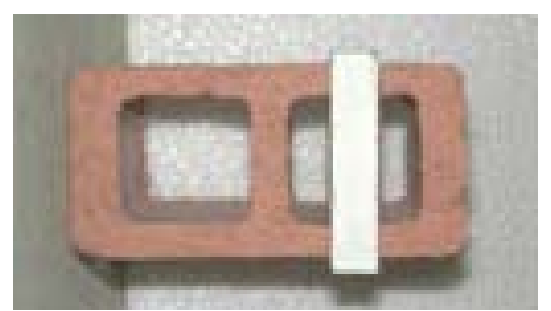

(b) Escala reduzida (1:3)

Figura 5.1- Região de aplicação da força no ensaio de tração indireta

Para o cálculo da resistência à tração, a ASTM C-1006 (1996) utiliza a seguinte expressão:

$$
\begin{aligned}
T & =\frac{2 P}{\pi L H}, \text { sendo: } \\
\mathrm{T} & =\text { resistência à tração indireta }(\mathrm{MPa}) ; \\
\mathrm{P} & =\text { força máxima aplicada pela máquina }(\mathrm{N}) ; \\
\mathrm{L} & =\text { espessura das paredes onde ocorre o carregamento }(\mathrm{mm}) ; \\
\mathrm{H} & =\text { altura da seção onde é aplicada a força }(\mathrm{mm}) .
\end{aligned}
$$

Como se observa, o cálculo da resistência à tração indireta depende da força máxima aplicada, da altura do bloco e da espessura das paredes onde ocorre o carregamento. Portanto, pode-se dizer que a tensão de tração obtida corresponde à área líquida.

A amostra utilizada para ambas as escalas é de 12 unidades

- Equipamentos:

Para os ensaios em escala natural (1:1) utiliza-se a máquina ELE - Autotest 2000. No entanto, para a escala reduzida (1:3), devido ao baixo valor da força de ruptura, o ensaio é realizado na máquina hidráulica para ensaio de compressão Soiltest.

\subsubsection{5- Taxa de absorção inicial (IRA)}

- Procedimentos:

A unidade de alvenaria (bloco ou tijolo) possui a propriedade de retirar a água presente na argamassa de assentamento e/ou no graute por um efeito de capilaridade, 
que produz uma ação de sucção. Esta característica é estimada pela taxa de absorção inicial, conhecida internacionalmente como IRA (Initial Rate of Absorption). De acordo com Drysdale et al. (1994) um valor muito alto ou muito baixo para essa taxa pode levar a uma baixa aderência entre unidade e argamassa. Os mesmos autores comentam que ensaios indicam que valores entre 0,25 a $1,5 \mathrm{~kg} / \mathrm{min} / \mathrm{m}^{2}$ produzem geralmente uma boa aderência com argamassas compatíveis. Como não existe uma norma nacional que trata do assunto, adota-se a norma americana ASTM C-67 (1997) para a determinação dessa propriedade.

A amostra utilizada em ambas as escalas é composta por cinco blocos, que corresponde ao número mínimo normalizado. Opta-se por realizar o ensaio com as unidades secas, ressaltando que tanto nos blocos em escala reduzida quanto nos reais utiliza-se a mesma lâmina d'água normalizada (cerca de $3 \mathrm{~mm}$ ).

- Equipamentos:

Empregam-se os mesmos equipamentos para as duas escalas: a estufa marca Quimis- Q317, a balança Mettler Toledo SB24001 Delta Range e um cronômetro com precisão de 1 segundo.

\subsubsection{6- Resistência à compressão do bloco na direção paralela à junta de assentamento}

- Procedimentos:

A determinação da resistência à compressão do bloco na direção paralela à junta de assentamento não é um ensaio usual, tanto que não possui uma norma própria. Isso acontece devido à alvenaria ser geralmente dimensionada para suportar ações verticais. Dessa forma, a característica principal é a resistência à compressão perpendicular a junta. Também não é comum a ação de forças uniaxiais de grande intensidade na direção horizontal. Apenas em algumas situações há uma maior influência dessa resistência, que é o caso de vigas e lintéis submetidos à flexão.

Para a realização dos ensaios, procura-se adaptar as recomendações da NBR 6461/1983 para esta situação. A principal modificação nos procedimentos é a adoção de uma velocidade de carregamento mais baixa, visto a natureza extremamente frágil da ruptura: $0,1 \mathrm{kN} / \mathrm{s}$ para o bloco na escala reduzida $(1: 3)$ e $0,5 \mathrm{kN} / \mathrm{s}$ para a escala natural (1:1). Emprega-se uma amostra de 6 unidades, sendo a pasta de enxofre a forma de capeamento utilizada.

Uma questão que deve ser ressaltada é que na direção paralela à junta de assentamento não há uma definição de área líquida, pois o bloco possui paredes 
paralelas e perpendiculares ao carregamento. Por esse motivo define-se apenas a tensão em relação à área bruta.

Cabe ressaltar que, a resistência à compressão na direção paralela à junta de assentamento é muito sensível ao tipo de capeamento, podendo haver diferenças acima de $600 \%$ (fato observado em ensaios preliminares).

- Equipamentos:

Todas as unidades, independente da escala, são ensaiadas na máquina hidráulica ELE -Autotest 2000.

\subsubsection{7- Módulo de deformação do bloco}

- Procedimentos:

Um parâmetro importante para caracterizar o comportamento do bloco cerâmico é a determinação do seu módulo de deformação na direção normal à junta de assentamento. É uma propriedade de interesse principalmente para a realização de futuras análises numéricas. Apesar disso, não se encontra nenhuma norma nacional que trate especificamente de sua obtenção. Geralmente, associa-se o módulo de deformação do bloco diretamente com a sua resistência à compressão.

O módulo de deformação é calculado de acordo com as recomendações do ACI 530-92 (1995), sendo a inclinação da secante do diagrama tensão versus deformação entre 5 e 33\% da tensão de ruptura. No caso, determina-se por regressão linear a melhor reta que se ajusta ao referido trecho. Novamente o valor pode ser tanto em relação à área bruta quanto à área líquida, visto que este último caso é importante para as futuras análises numéricas.

O capeamento utilizado é a pasta de enxofre, o mesmo do ensaio à compressão. Para as duas escalas são ensaiadas seis unidades, ressaltando que os resultados obtidos estão considerados no cálculo da resistência média do bloco.

- Equipamentos:

O experimento na escala natural (1:1) é realizado na máquina servo-controlada INSTRON. Utiliza-se este equipamento para possibilitar espaço suficiente para a instrumentação da unidade e, por meio do controle de deslocamento do pistão da máquina, evitar uma ruptura brusca que possa danificar os equipamentos. Os deslocamentos relativos do bloco são medidos por dois transdutores de deslocamento à base de extensômetro com curso de $10 \mathrm{~mm}$ (sensibilidade de $0,001 \mathrm{~mm}$ ), posicionados na meia altura da região central da cavidade, de forma a verificar possíveis 
excentricidades. As deformações específicas são calculadas com os deslocamentos relativos dos transdutores e a base de medida dos mesmos. Também são empregados outros dois transdutores do mesmo tipo para a medida do deslocamento entre os pratos da máquina para uma posterior comparação. As leituras e o armazenamento dos dados são feitos pelo sistema de aquisição SYSTEM 5000. Utiliza-se uma velocidade de imposição de deslocamento igual a $0,007 \mathrm{~mm} / \mathrm{s}$.

Já na escala reduzida (1:3) o procedimento para a aplicação de força é o mesmo utilizado para a determinação da resistência à compressão (máquina ELE - Autotest 2000 , velocidade de $1,0 \mathrm{kN} / \mathrm{s}$ ). As deformações específicas do bloco são medidas por dois extensômetros elétricos com base de $5 \mathrm{~mm}$ (sensibilidade de $10^{-6}$ ), posicionados na meia altura da região central da cavidade, de forma a verificar possíveis excentricidades. As leituras são realizadas a cada $5 \mathrm{kN}$ através do sistema de aquisição de dados (SYSTEM 5000). Também se procura registrar a deformação correspondente à força de ruptura.

\subsection{2- Resultados da análise dimensional}

A Figura 5.2 apresenta os blocos e meios-blocos em escala natural (1:1) empregados neste trabalho. As dimensões nominais e reais determinadas para os mesmos são indicadas nas tabelas 5.1 e 5.2. Percebe-se que a tolerância não é obedecida no caso do comprimento do meio-bloco (Tabela 5.2). Isso se deve ao fato do meiobloco ser produzido dois a dois, como apresentado na Figura 5.2, sendo que após sua separação para sua utilização sempre restam rebarbas, impedindo um perfeito alinhamento para a medição do comprimento.

Já os blocos, meios-blocos e blocos canaleta na escala (1:3) utilizados na pesquisa são mostrados na Figura 5.3. As tabelas 5.3, 5.4 e 5.5 apresentam, respectivamente, as dimensões nominais e reais dos blocos, meios-blocos e blocos canaleta. Nota-se nos valores exibidos que a largura do bloco comum, do canaleta e o comprimento do meio-bloco ultrapassam ligeiramente a tolerância. No entanto são diferenças da ordem de décimos de milímetros, podendo ser completamente aceitáveis visto a variabilidade natural do material cerâmico, e o rigor da tolerância adotada. 


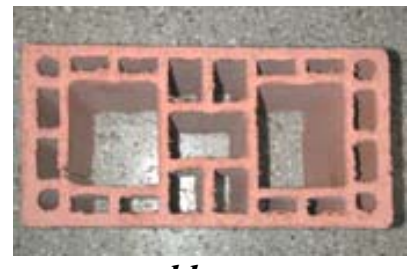

bloco

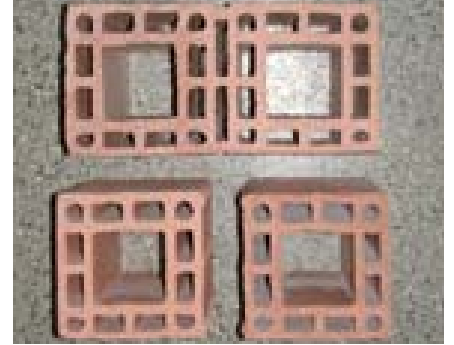

meio-bloco

Figura 5.2 - Blocos na escala natural utilizados na pesquisa
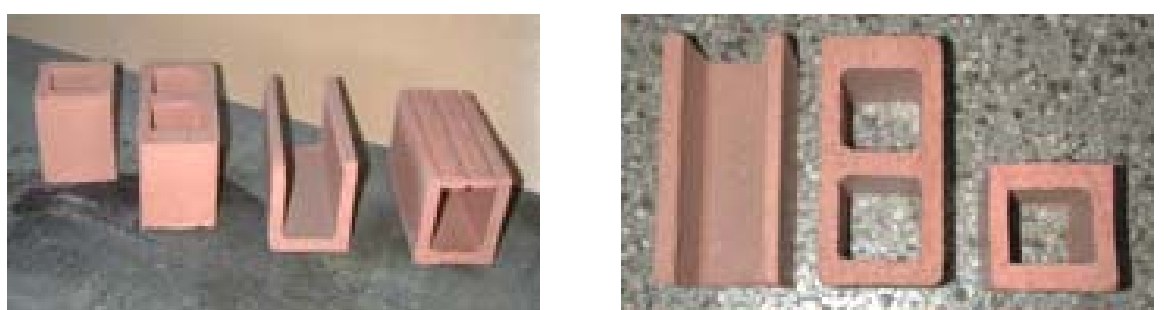

Figura 5.3 - Bloco, meio-bloco e bloco canaleta na escala (1:3)

Tabela 5.1 - Dimensões do bloco na escala (1:1)

\begin{tabular}{|c|c|c|c|}
\cline { 2 - 4 } \multicolumn{1}{c|}{} & \multicolumn{3}{c|}{ Dimensões - Bloco (1:1) } \\
\cline { 2 - 4 } \multicolumn{1}{c|}{} & Largura (cm) & Altura (cm) & Comprimento (cm) \\
\hline Nominal & 14,00 & 19,00 & 29,00 \\
\hline Real & 14,24 & 19,22 & 28,85 \\
\hline
\end{tabular}

Tabela 5.2 - Dimensões do meio-bloco na escala (1:1)

\begin{tabular}{|c|c|c|c|}
\cline { 2 - 4 } \multicolumn{1}{c|}{} & \multicolumn{3}{c|}{ Dimensões - Meio-Bloco (1:1) } \\
\cline { 2 - 4 } \multicolumn{1}{c|}{} & Largura (cm) & Altura (cm) & Comprimento (cm) \\
\hline Nominal & 14,00 & 19,00 & 14,00 \\
\hline Real & 14,02 & 19,20 & 14,36 \\
\hline
\end{tabular}

Tabela 5.3 - Dimensões do bloco na escala (1:3)

\begin{tabular}{|c|c|c|c|}
\cline { 2 - 4 } \multicolumn{1}{c|}{} & \multicolumn{3}{c|}{ Dimensões - Bloco (1:3) } \\
\cline { 2 - 4 } \multicolumn{1}{c|}{} & Largura (cm) & Altura (cm) & Comprimento (cm) \\
\hline Nominal & 4,70 & 6,30 & 9,70 \\
\hline Real & 4,81 & 6,27 & 9,65 \\
\hline
\end{tabular}

Tabela 5.4 - Dimensões do meio-bloco na escala (1:3)

\begin{tabular}{|c|c|c|c|}
\cline { 2 - 4 } \multicolumn{1}{c|}{} & \multicolumn{3}{c|}{ Dimensões - Meio-bloco (1:3) } \\
\cline { 2 - 4 } \multicolumn{1}{c|}{} & Largura (cm) & Altura (cm) & Comprimento (cm) \\
\hline Nominal & 4,70 & 6,30 & 4,70 \\
\hline Real & 4,78 & 6,29 & 4,83 \\
\hline
\end{tabular}

Tabela 5.5 - Dimensões do bloco canaleta na escala (1:3)

\begin{tabular}{|c|c|c|c|}
\cline { 2 - 4 } \multicolumn{1}{c|}{} & \multicolumn{3}{c|}{ Dimensões - Bloco Canaleta(1:3) } \\
\cline { 2 - 4 } \multicolumn{1}{c|}{} & Largura (cm) & Altura (cm) & Comprimento (cm) \\
\hline Nominal & 4,70 & 6,30 & 9,70 \\
\hline Real & 4,81 & 6,30 & 9,75 \\
\hline
\end{tabular}


Também são realizadas medidas individuais dos blocos e meios-blocos em escala natural (1:1), sendo que os resultados são apresentados nas tabelas 5.6 e 5.7. Já os valores encontrados para as medidas individuais dos blocos, dos meios-blocos e dos blocos canaletas estão, respectivamente, nas tabelas 5.8, 5.9 e 5.10. Percebe-se que em comparação com as dimensões reais há uma redução dos valores médios das arestas. Isso ocorre porque não se consideram os pequenos defeitos localizados, ao contrário do que acontece quando se realiza o alinhamento dos blocos. Verifica-se, também, que a variação dimensional é pequena, sendo o coeficiente de variação máximo de 1,51\%. Por esse procedimento apenas o comprimento do bloco na escala (1:3) estaria fora da tolerância, cerca de $0,6 \mathrm{~mm}$ a menos.

Tabela 5.6 - Medidas individuais de blocos na escala (1:1)

\begin{tabular}{|c|c|c|c|}
\cline { 2 - 4 } \multicolumn{1}{c|}{} & \multicolumn{3}{c|}{ Medições individuais dos blocos (1:1) } \\
\cline { 2 - 4 } \multicolumn{1}{c|}{} & Largura (cm) & Altura (cm) & Comprimento (cm) \\
\hline Média & 14,03 & 18,97 & 28,69 \\
\hline Máximo & 14,40 & 19,20 & 29,20 \\
\hline Mínimo & 13,50 & 18,30 & 28,10 \\
\hline Coef. Variação & $1,51 \%$ & $1,14 \%$ & $1,04 \%$ \\
\hline
\end{tabular}

Tabela 5.7 - Medidas individuais de meios-blocos na escala (1:1)

\begin{tabular}{|c|c|c|c|}
\cline { 2 - 4 } \multicolumn{1}{c|}{} & \multicolumn{3}{c|}{ Medições individuais dos meios-blocos (1:1) } \\
\cline { 2 - 4 } \multicolumn{1}{c|}{} & Largura (cm) & Altura (cm) & Comprimento (cm) \\
\hline Média & 13,88 & 18,83 & 14,03 \\
\hline Máximo & 14,10 & 19,10 & 14,20 \\
\hline Mínimo & 13,70 & 18,60 & 13,90 \\
\hline Coef. Variação & $0,85 \%$ & $0,69 \%$ & $0,77 \%$ \\
\hline
\end{tabular}

As tabelas 5.8, 5.9 e 5.10 ainda apresentam alguns valores de espessuras das paredes dos diferentes blocos na escala reduzida. No caso dos blocos e meios-blocos verificam-se que os septos transversais são mais espessos que as paredes laterais. Isso se deve às alterações necessárias nas dimensões das boquilhas durante a produção dos blocos em escala (1:3) visando viabilizar sua fabricação. Percebe-se também que as espessuras têm uma maior variabilidade que as dimensões das arestas, que ocorre pelas pequenas movimentações na parte interna das boquilhas durante o processo de produção.

Comparando-se os blocos nas escalas natural e reduzida nota-se a diferença das seções transversais. No bloco e no meio-bloco em escala natural as paredes são compostas por diversas cavidades; já na escala reduzida essas paredes são sólidas. Essas 
diferenças de geometria são facilmente percebidas na Figura 5.4, onde os blocos nas duas escalas são superpostos. Em relação às dimensões externas, verifica-se que os blocos em escala reduzida representam bem os blocos reais; as pequenas diferenças são inerentes à precisão do processo de produção.

Tabela 5.8 - Medidas individuais de blocos na escala (1:3)

\begin{tabular}{|c|c|c|c|c|c|}
\cline { 2 - 6 } \multicolumn{1}{c|}{} & \multicolumn{5}{c|}{ Medidas individuais do bloco (1:3) } \\
\cline { 2 - 6 } \multicolumn{1}{c|}{} & $\begin{array}{c}\text { Largura } \\
\text { (cm) }\end{array}$ & $\begin{array}{c}\text { Altura } \\
\text { (cm) }\end{array}$ & $\begin{array}{c}\text { Comp. } \\
\text { (cm) }\end{array}$ & $\begin{array}{c}\text { Septos transversais } \\
\text { Espessura (cm) }\end{array}$ & $\begin{array}{c}\text { Paredes laterais } \\
\text { Espessura (cm) }\end{array}$ \\
\hline Média & 4,70 & 6,23 & 9,54 & 1,00 & 0,72 \\
\hline Máximo & 4,74 & 6,33 & 9,65 & 1,28 & 0,84 \\
\hline Mínimo & 4,58 & 6,13 & 9,34 & 0,81 & 0,62 \\
\hline Coef. Variação & $0,78 \%$ & $0,89 \%$ & $0,76 \%$ & $13,75 \%$ & $7,00 \%$ \\
\hline
\end{tabular}

Tabela 5.9 - Medidas individuais de meios-blocos na escala (1:3)

\begin{tabular}{|c|c|c|c|c|c|}
\cline { 2 - 6 } \multicolumn{1}{c|}{} & \multicolumn{5}{c|}{ Medidas individuais do meio-bloco (1:3) } \\
\cline { 2 - 6 } & $\begin{array}{c}\text { Largura } \\
\text { (cm) }\end{array}$ & $\begin{array}{c}\text { Altura } \\
\text { (cm) }\end{array}$ & $\begin{array}{c}\text { Comp. } \\
\text { (cm) }\end{array}$ & $\begin{array}{c}\text { Septos transversais } \\
\text { Espessura (cm) }\end{array}$ & $\begin{array}{c}\text { Paredes laterais } \\
\text { Espessura (cm) }\end{array}$ \\
\hline Média & 4,68 & 6,26 & 4,75 & 0,91 & 0,69 \\
\hline Máximo & 4,71 & 6,43 & 4,81 & 0,95 & 0,77 \\
\hline Mínimo & 4,65 & 6,03 & 4,70 & 0,87 & 0,63 \\
\hline Coef. Variação & $0,42 \%$ & $1,47 \%$ & $0,52 \%$ & $1,61 \%$ & $7,55 \%$ \\
\hline
\end{tabular}

Tabela 5.10 - Medidas individuais de blocos canaleta na escala (1:3)

\begin{tabular}{|c|c|c|c|c|c|}
\cline { 2 - 6 } \multicolumn{1}{c|}{} & \multicolumn{5}{c|}{ Medidas individuais do bloco canaleta(1:3) } \\
\cline { 2 - 6 } & $\begin{array}{c}\text { Largura } \\
(\mathbf{c m})\end{array}$ & $\begin{array}{c}\text { Altura } \\
\mathbf{( c m )}\end{array}$ & $\begin{array}{c}\text { Comp. } \\
\mathbf{( c m )}\end{array}$ & $\begin{array}{c}\text { Fundo } \\
\text { Espessura (cm) }\end{array}$ & $\begin{array}{c}\text { Paredes laterais } \\
\text { Espessura (cm) }\end{array}$ \\
\hline Média & 4,72 & 6,25 & 9,68 & 0,83 & 0,71 \\
\hline Máximo & 4,74 & 6,35 & 9,75 & 0,89 & 0,77 \\
\hline Mínimo & 4,61 & 6,05 & 9,52 & 0,78 & 0,65 \\
\hline Coef. Variação & $0,61 \%$ & $0,90 \%$ & $0,56 \%$ & $3,12 \%$ & $4,09 \%$ \\
\hline
\end{tabular}

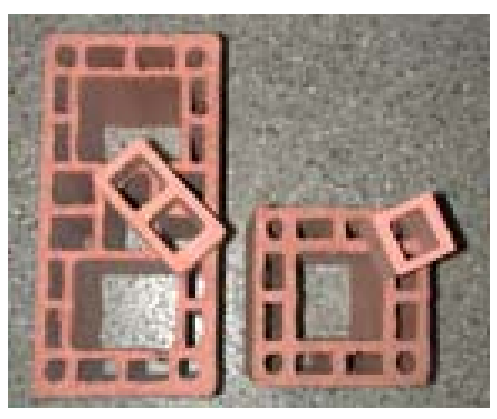

Figura 5.4 - Comparação das seções transversais dos blocos na escala (1:1) e (1:3)

Também são determinados a planeza das faces e o desvio em relação ao esquadro dos blocos e meios-blocos na escala (1:1), cujos resultados são apresentados nas tabelas 5.11 e 5.12 respectivamente. Percebe-se que no caso do bloco em tamanho natural, uma unidade excede a tolerância, no entanto a norma considera aceitável que 
até duas unidades superem esse valor. Portanto, tanto os blocos como os meios-blocos reais estão de acordo com as disposições normativas.

Tabela 5.11 - Medidas de planeza e esquadro dos blocos na escala (1:1)

\begin{tabular}{|c|c|c|}
\cline { 2 - 3 } \multicolumn{1}{c|}{} & \multicolumn{2}{c|}{ Bloco (1:1) } \\
\cline { 2 - 3 } \multicolumn{1}{c|}{} & Planeza (mm) & Esquadro (mm) \\
\hline Média & 2,13 & 2,75 \\
\hline Máximo & 3,00 & 3,50 \\
\hline Múnimo & 1,50 & 2,00 \\
\hline Coef. Variação & $22,7 \%$ & $19,8 \%$ \\
\hline
\end{tabular}

Tabela 5.12 - Medidas de planeza e esquadro dos meios-blocos na escala (1:1)

\begin{tabular}{|c|c|c|}
\cline { 2 - 3 } \multicolumn{1}{c|}{} & \multicolumn{2}{c|}{ Meio-Bloco (1:1) } \\
\cline { 2 - 3 } \multicolumn{1}{c|}{} & Planeza (mm) & Esquadro (mm) \\
\hline Média & 1,83 & 2,71 \\
\hline Máximo & 2,00 & 3,00 \\
\hline Múnimo & 1,50 & 2,00 \\
\hline Coef. Variação & $13,4 \%$ & $12,3 \%$ \\
\hline
\end{tabular}

Os resultados para os blocos, meios-blocos e blocos canaleta na escala (1:3) são apresentados nas tabelas 5.13, 5.14 e 5.15 respectivamente. Observa-se que as unidades em escala reduzida são problemáticas em relação a esses dois itens. O problema ocorre durante o corte das unidades, pois a guilhotina acaba provocando deformações que geram a perda de planeza e esquadro. Pelos valores apresentados, se observa o fato dos meios-blocos sofrerem as maiores deformações, apresentado as maiores perdas de planeza e esquadro.

Em relação aos parâmetros de planeza das faces e ao esquadro, os blocos em escala natural estão dentro da tolerância normalizada. Já as unidades em escala reduzida não respeitam a tolerância em grande parte dos casos, por causa do processo de corte, que gera certas deformidades, e da adoção da redução proporcional dos limites normalizados. Entretanto, não há possibilidade de uma nova produção de blocos na escala (1:3) para a correção desses defeitos. Também acredita-se que esse fato não traga grandes conseqüências.

Tabela 5.13 - Medidas de planeza e esquadro dos blocos na escala (1:3)

\begin{tabular}{|c|c|c|}
\cline { 2 - 3 } \multicolumn{1}{c|}{} & \multicolumn{2}{c|}{ Bloco (1:3) } \\
\cline { 2 - 3 } \multicolumn{1}{c|}{} & Planeza (mm) & Esquadro (mm) \\
\hline Média & 0,83 & 1,33 \\
\hline Máximo & 1,00 & 2,00 \\
\hline Mínimo & 0,50 & 1,00 \\
\hline Coef. Variação & $29,5 \%$ & $29,2 \%$ \\
\hline
\end{tabular}


Tabela 5.14 - Medidas de planeza e esquadro dos meios-blocos na escala (1:3)

\begin{tabular}{|c|c|c|}
\cline { 2 - 3 } \multicolumn{1}{c|}{} & \multicolumn{2}{c|}{ Meio-Bloco (1:3) } \\
\cline { 2 - 3 } \multicolumn{1}{c|}{} & Planeza $(\mathbf{m m})$ & Esquadro $(\mathbf{m m})$ \\
\hline Média & 1,38 & 1,83 \\
\hline Máximo & 2,50 & 3,00 \\
\hline Múnimo & 1,00 & 1,00 \\
\hline Coef. Variação & $38,4 \%$ & $44,0 \%$ \\
\hline
\end{tabular}

Tabela 5.15 - Medidas de planeza e esquadro dos blocos canaleta na escala (1:3)

\begin{tabular}{|c|c|c|}
\cline { 2 - 3 } \multicolumn{1}{c|}{} & \multicolumn{2}{c|}{ Bloco Canaleta (1:3) } \\
\cline { 2 - 3 } \multicolumn{1}{c|}{} & Planeza (mm) & Esquadro (mm) \\
\hline Média & 0,96 & 1,25 \\
\hline Máximo & 1,50 & 1,50 \\
\hline Mínimo & 0,50 & 1,00 \\
\hline Coef. Variação & $34,9 \%$ & $20,9 \%$ \\
\hline
\end{tabular}

5.2.3- Resultados dos ensaios de absorção de água, de massa específica e de área líquida

Os valores de absorção, massa específica, área líquida e porcentagem da área líquida em relação à área bruta dos blocos e meios-blocos em escala natural (1:1) são exibidos nas tabelas 5.16 e 5.17 respectivamente. Observa-se que para ambos os casos a absorção está dentro dos parâmetros de normas, sendo que os meios-blocos apresentaram valores ligeiramente superiores. Os valores de massa específica são bem próximos, com uma diferença de apenas $4 \%$, indicando que o material dos blocos e meios-blocos é praticamente o mesmo. Os meios-blocos apresentam uma área líquida proporcionalmente maior que a dos blocos, cerca de $20 \%$ superior.

Tabela 5.16 - Absorção, massa específica e área líquida dos blocos na escala (1:1)

\begin{tabular}{|c|c|c|c|c|}
\hline & \multicolumn{4}{|c|}{ Bloco (1:1) } \\
\hline & $\begin{array}{c}\text { Absorção } \\
\text { (\%) }\end{array}$ & $\begin{array}{c}\text { Massa específica } \\
\left(\mathrm{g} / \mathrm{cm}^{3}\right)\end{array}$ & $\begin{array}{l}\text { Área líquida } \\
\left(\mathrm{cm}^{2}\right)\end{array}$ & $\begin{array}{c}\mathbf{A}_{\text {liq }} / \mathbf{A}_{\text {bruta }} \\
(\%)\end{array}$ \\
\hline Média & 13,04 & 1,91 & 149,59 & 37,2 \\
\hline Máximo & 16,30 & 2,02 & 155,51 & 40,8 \\
\hline Mínimo & 9,60 & 1,83 & 144,28 & 36,6 \\
\hline Coef. Variação & $14,4 \%$ & $2,86 \%$ & $2,28 \%$ & $3,19 \%$ \\
\hline
\end{tabular}

Tabela 5.17 - Absorção, massa específica e área líquida dos meios-blocos na escala (1:1)

\begin{tabular}{|c|c|c|c|c|}
\hline & \multicolumn{4}{|c|}{ Meio-Bloco (1:1) } \\
\hline & $\begin{array}{l}\text { Absorção } \\
(\%)\end{array}$ & $\begin{array}{c}\text { Massa específica } \\
\left(\mathrm{g} / \mathrm{cm}^{3}\right)\end{array}$ & $\begin{array}{l}\text { Área líquida } \\
\left(\mathrm{cm}^{2}\right)\end{array}$ & $\begin{array}{c}\mathbf{A}_{\text {liq }} / \mathbf{A}_{\text {bruta }} \\
(\%)\end{array}$ \\
\hline Média & 15,44 & 1,84 & 86,82 & 44,5 \\
\hline Máximo & 18,40 & 1,93 & 89,18 & 45,5 \\
\hline Mínimo & 12,60 & 1,76 & 84,35 & 43,9 \\
\hline Coef. Variação & $11,6 \%$ & $2,67 \%$ & $1,93 \%$ & $1,01 \%$ \\
\hline
\end{tabular}


Os mesmos resultados dos blocos e meios-blocos na escala reduzida (1:3) são apresentados nas tabelas 5.18 e 5.19 respectivamente. Analisando-se os resultados da absorção de água verifica-se que tanto a absorção quanto a massa específica dos blocos e meios-blocos são idênticas. Isso confirma que o material utilizado nos dois tipos de unidades é o mesmo. Nota-se também que o valor da absorção está dentro dos limites estabelecidos pela NBR 7171/1992. Os meios-blocos apresentam uma proporção maior entre área líquida e bruta que os blocos inteiros, neste caso cerca de 7\% superior.

Tabela 5.18 - Absorção, massa específica e área líquida dos blocos na escala (1:3)

\begin{tabular}{|c|c|c|c|c|}
\hline & \multicolumn{4}{|c|}{ Bloco (1:3) } \\
\hline & $\begin{array}{l}\text { Absorção } \\
\text { (\%) }\end{array}$ & $\begin{array}{c}\text { Massa específica } \\
\left(\mathrm{g} / \mathrm{cm}^{3}\right)\end{array}$ & $\begin{array}{l}\text { Área líquida } \\
\left(\mathrm{cm}^{2}\right)\end{array}$ & $\begin{array}{c}A_{\text {liq }} / A_{\text {bruta }} \\
(\%)\end{array}$ \\
\hline Média & 15,00 & 1,88 & 22,73 & 50,7 \\
\hline Máximo & 16,30 & 1,96 & 23,00 & 51,1 \\
\hline Mínimo & 12,00 & 1,84 & 21,50 & 50,3 \\
\hline Coef. Variação & $7,44 \%$ & $1,70 \%$ & $1,82 \%$ & $0,57 \%$ \\
\hline
\end{tabular}

Tabela 5.19 - Absorção, massa específica e área líquida dos meios-blocos na escala (1:3)

\begin{tabular}{|c|c|c|c|c|}
\hline & \multicolumn{4}{|c|}{ Meio-Bloco (1:3) } \\
\hline & $\begin{array}{l}\text { Absorção } \\
(\%)\end{array}$ & $\begin{array}{c}\text { Massa específica } \\
\left(\mathrm{g} / \mathrm{cm}^{3}\right)\end{array}$ & $\begin{array}{l}\text { Área líquida } \\
\left(\mathrm{cm}^{2}\right)\end{array}$ & $\begin{array}{c}\mathbf{A}_{\text {liq }} / \mathbf{A}_{\text {bruta }} \\
(\%)\end{array}$ \\
\hline Média & 15,00 & 1,88 & 12,03 & 54,1 \\
\hline Máximo & 15,60 & 1,91 & 12,25 & 54,5 \\
\hline Mínimo & 14,30 & 1,86 & 11,89 & 53,7 \\
\hline Coef. Variação & $3,42 \%$ & $0,83 \%$ & $0,97 \%$ & $0,49 \%$ \\
\hline
\end{tabular}

As comparações dos valores médios de absorção de água, massa específica e relação entre área líquida e bruta, obtidos para os blocos e os meios-blocos das duas escalas, são apresentados nas tabelas 5.20 e 5.21, respectivamente. Percebe-se que os valores de absorção de água e massa específica das unidades em escala natural e reduzida se aproximam. Há apenas uma maior diferença entre os valores de absorção de água do bloco inteiro. No entanto, acredita-se que está dentro da variabilidade natural do material cerâmico. Portanto, tem-se uma forte indicação que o material cerâmico dos blocos nas diferentes escalas possuem as mesmas propriedades. Fato já esperado, visto que não há grandes diferenças no processo de produção dos mesmos.

Nas mesmas tabelas 5.20 e 5.21 fica clara a diferença das áreas das seções transversais nas duas escalas. Os blocos e os meios-blocos na escala reduzida possuem proporcionalmente uma maior área líquida que os correspondentes na escala natural. Lembra-se que isso acontece porque as seções transversais dos blocos são aumentadas 
durante a produção, com o intuito de viabilizar o processo e diminuir defeitos durante o corte das unidades. Nota-se, também, que os blocos apresentam maiores diferenças que os meios-blocos.

Tabela 5.20 - Comparações dos blocos (1:1) e (1:3)

\begin{tabular}{|l|c|c|c|}
\cline { 2 - 4 } \multicolumn{1}{c|}{} & Bloco (1:3) & Bloco (1:1) & $\mathbf{( 1 : 3 ) ~ / ~ ( 1 : 1 ) ~}$ \\
\hline Absorção (\%) & 15,00 & 13,04 & $+15,0 \%$ \\
\hline Massa específica (g/cm $\left.\mathbf{~}^{3}\right)$ & 1,88 & 1,91 & $-1,6 \%$ \\
\hline Área liq / Área bruta (\%) & 50,7 & 37,2 & $+36,3 \%$ \\
\hline
\end{tabular}

Tabela 5.21 - Comparações dos meios-blocos (1:1) e (1:3)

\begin{tabular}{|l|c|c|c|}
\cline { 2 - 4 } \multicolumn{1}{c|}{} & Meio-Bloco (1:3) & Meio-Bloco (1:1) & $\mathbf{( 1 : 3 ) / ( 1 : 1 ) ~}$ \\
\hline Absorção (\%) & 15,00 & 15,44 & $-2,9 \%$ \\
\hline Massa específica (g/cm & 1,88 & 1,84 & $+2,2 \%$ \\
\hline Área liq / Área bruta (\%) & 54,1 & 44,5 & $+21,6 \%$ \\
\hline
\end{tabular}

\subsection{4- Resultados dos ensaios de resistência à compressão}

As tabelas 5.22 e 5.23 apresentam a força de ruptura e a tensão última em relação à área bruta e a área líquida dos blocos e meios-blocos na escala natural, respectivamente. Percebe-se que a variabilidade da resistência das unidades está dentro de padrões aceitáveis, o coeficiente de variação máximo foi de 15,4\%.

Tabela 5.22 - Força de ruptura e tensão última dos blocos na escala (1:1)

\begin{tabular}{|c|c|c|c|}
\cline { 2 - 4 } \multicolumn{1}{c|}{} & \multicolumn{3}{c|}{ Bloco (1:1) } \\
\cline { 2 - 4 } \multicolumn{1}{c|}{} & Força (kN) & Tensão - A bruta (MPa) & Tensão - A líquida (MPa) \\
\hline Média & 580,8 & 14,44 & 38,82 \\
\hline Máximo & 738,2 & 19,18 & 51,53 \\
\hline Mínimo & 502,1 & 12,24 & 32,88 \\
\hline Coef. Variação & $13,7 \%$ & $15,4 \%$ & $15,4 \%$ \\
\hline
\end{tabular}

Tabela 5.23- Força de ruptura e tensão última dos meios-blocos na escala (1:1)

\begin{tabular}{|c|c|c|c|}
\cline { 2 - 4 } \multicolumn{1}{c|}{} & \multicolumn{3}{c|}{ Meio-Bloco (1:1) } \\
\cline { 2 - 4 } \multicolumn{1}{c|}{} & Força (kN) & Tensão - A bruta (MPa) & Tensão - A líquida (MPa) \\
\hline Média & 318,8 & 16,42 & 36,90 \\
\hline Máximo & 370,2 & 19,16 & 43,05 \\
\hline Mínimo & 237,4 & 12,03 & 27,02 \\
\hline Coef. Variação & $12,2 \%$ & $12,6 \%$ & $12,6 \%$ \\
\hline
\end{tabular}

Os resultados de força de ruptura e das tensões últimas, em relação à área bruta e líquida, dos blocos e meios-blocos na escala (1:3) são exibidos nas tabelas 5.24 e 5.25 respectivamente. Nota-se uma maior variabilidade dos resultados, sendo que os coeficientes de variação ficam em torno de $20 \%$. 
Tabela 5.24 - Força de ruptura e tensões última dos blocos na escala (1:3)

\begin{tabular}{|c|c|c|c|}
\cline { 2 - 4 } \multicolumn{1}{c|}{} & \multicolumn{3}{c|}{ Bloco (1:3) } \\
\cline { 2 - 4 } \multicolumn{1}{c|}{} & Força(kN) & Tensão - A bruta (MPa) & Tensão - A líquida (MPa) \\
\hline Média & 135,9 & 30,31 & 59,83 \\
\hline Máximo & 194,2 & 43,78 & 86,42 \\
\hline Mínimo & 74,2 & 16,50 & 32,57 \\
\hline Coef. Variação & $21,9 \%$ & $22,1 \%$ & $22,1 \%$ \\
\hline
\end{tabular}

Tabela 5.25 - Força de ruptura e tensões última dos meios-blocos na escala (1:3)

\begin{tabular}{|c|c|c|c|}
\cline { 2 - 4 } \multicolumn{1}{c|}{} & \multicolumn{3}{c|}{ Meio-Bloco (1:3) } \\
\cline { 2 - 4 } \multicolumn{1}{c|}{} & Força(kN) & Tensão - A bruta (MPa) & Tensão - A líquida (MPa) \\
\hline Média & 59,1 & 26,56 & 49,14 \\
\hline Máximo & 79,7 & 35,93 & 66,47 \\
\hline Mínimo & 42,7 & 19,05 & 35,24 \\
\hline Coef. Variação & $18,7 \%$ & $19,0 \%$ & $19,0 \%$ \\
\hline
\end{tabular}

A comparação das resistências dos blocos nas diferentes escalas, em relação à área bruta e líquida, é realizada na Tabela 5.26. Verifica-se que os blocos na escala reduzida apresentam uma resistência à compressão superior à do bloco na escala natural. $\mathrm{Na}$ área bruta é cerca de $110 \%$ maior e na área líquida essa diferença diminui para 54\%, visto que o bloco reduzido possui uma área líquida proporcionalmente maior que o bloco natural. Acredita-se que essa maior resistência esteja relacionada a uma melhor queima dos blocos na escala (1:3) devido ao seu menor volume e a própria geometria da seção transversal.

Tabela 5.26 - Comparações das resistências dos blocos (1:1) e (1:3)

\begin{tabular}{|c|c|c|c|}
\hline Tensão - Compressão (MPa) & Bloco (1:3) & Bloco (1:1) & (1:3) / (1:1) \\
\hline Área bruta & 30,31 & 14,44 & $+109,9 \%$ \\
\hline Área líquida & 59,83 & 38,82 & $+54,1 \%$ \\
\hline
\end{tabular}

Na Tabela 5.27 é apresentada a comparação da resistência dos meios-blocos na escala natural e reduzida. Nota-se que o meio-bloco na escala (1:3) também apresenta uma resistência à compressão superior ao do meio-bloco na escala (1:1), entretanto o valor é abaixo do verificado no caso do bloco inteiro. Por esses resultados nota-se que os meios-blocos em escala natural possuem uma resistência cerca de 13\% superior que os blocos, quando comparadas às tensões na área bruta. No entanto, como a quantidade de vazios dos meios-blocos é proporcionalmente menor que a dos blocos reais, a tensão de ruptura em relação à área líquida é cerca de 5\% inferior. No caso da escala reduzida, a tensão média em relação à área bruta dos meios-blocos é inferior a dos blocos, possuem uma diferença de cerca de $12 \%$. Já em relação à área líquida, a tensão última 
do meio-bloco é cerca de $18 \%$ inferior a do bloco reduzido, visto que este último tem um maior índice de vazios.

Tabela 5.27 - Comparações das resistências dos meios-blocos (1:1) e (1:3)

\begin{tabular}{|c|c|c|c|}
\cline { 2 - 4 } \multicolumn{1}{c|}{} & Meio-bloco (1:3) & Meio-bloco (1:1) & $(\mathbf{1 : 3 )} / \mathbf{( 1 : 1 )}$ \\
\hline Tensão (MPa) - Área bruta & 26,56 & 16,42 & $+61,7 \%$ \\
\hline $\begin{array}{c}\text { Resist. Meio-bloco / } \\
\text { Resist. bloco (\%) }\end{array}$ & $-12,4 \%$ & $+13,7 \%$ & -- \\
\hline Tensão (MPa) - Área líquida & 49,14 & 36,90 & $+33,2 \%$ \\
\hline $\begin{array}{c}\text { Resist. Meio-bloco / } \\
\text { Resist. bloco (\%) }\end{array}$ & $-17,9 \%$ & $-4,9 \%$ & -- \\
\hline
\end{tabular}

\subsection{5- Resultados dos ensaios de tração indireta}

Os ensaios de tração indireta dos blocos reais e reduzidos, juntamente com as suas formas de ruptura, são ilustrados nas figuras 5.5 e 5.6, respectivamente. Como apresentado no item 5.2.1.4, o cálculo da resistência à tração indireta depende da força máxima aplicada, da altura do bloco e da espessura das paredes onde ocorre carregamento.

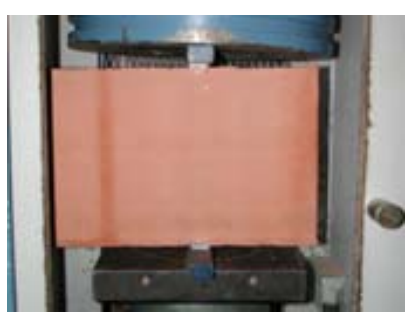

ensaio

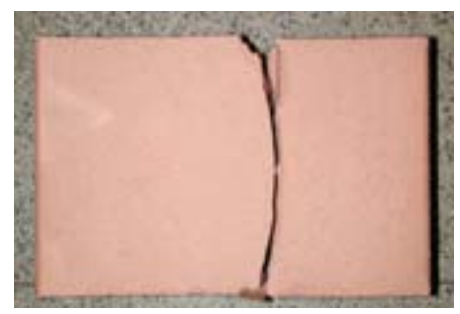

forma de ruptura

Figura 5.5 - Ensaio de tração indireta- escala (1:1)

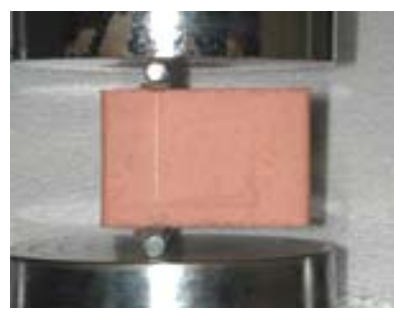

ensaio

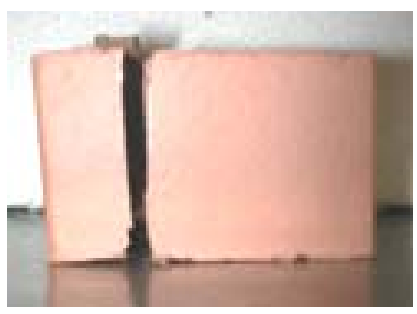

forma de ruptura

Figura 5.6 - Ensaio de tração indireta- escala (1:3)

Na Tabela 5.28 apresentam-se valores da altura, da soma das espessuras das paredes internas, da força máxima e o valor da tensão de tração para o bloco na escala natural. Entretanto, três resultados da amostra são descartados por ocorrer ruptura por esmagamento e não por tração indireta. $\mathrm{O}$ coeficiente de variação dos resultados pode ser considerado baixo, cerca de 6\%, quando comparado ao obtido no ensaio de compressão (15\%). Esses mesmos valores para o bloco na escala reduzida são exibidos 
na Tabela 5.29. Neste caso, apenas um resultado não é aproveitado devido a aplicação errônea do carregamento. Igualmente à escala (1:1), observa-se que o coeficiente de variação deste ensaio (10\%) é inferior ao obtido no ensaio de resistência à compressão $(22 \%)$.

Tabela 5.28 - Resistência à tração indireta dos blocos na escala (1:1)

\begin{tabular}{|c|c|c|c|c|}
\cline { 2 - 5 } \multicolumn{1}{c|}{} & \multicolumn{4}{c|}{ Resistência à tração (1:1) } \\
\cline { 2 - 5 } \multicolumn{1}{c|}{} & Altura (mm) & Espessura (mm) & Força (N) & Tensão (MPa) \\
\hline Média & 190,1 & 32,4 & 42810 & 4,43 \\
\hline Máximo & 192,0 & 33,4 & 46700 & 4,84 \\
\hline Mínimo & 189,0 & 31,7 & 38400 & 3,97 \\
\hline Coef. Variação & $0,5 \%$ & $1,8 \%$ & $5,9 \%$ & $6,2 \%$ \\
\hline
\end{tabular}

Tabela 5.29 - Resistência à tração indireta dos blocos na escala (1:3)

\begin{tabular}{|c|c|c|c|c|}
\cline { 2 - 5 } \multicolumn{1}{c|}{} & \multicolumn{4}{c|}{ Resistência à tração (1:3) } \\
\cline { 2 - 5 } \multicolumn{1}{c|}{} & Altura (mm) & Espessura (mm) & Força (N) & Tensão (MPa) \\
\hline Média & 62,1 & 14,3 & 8270 & 5,91 \\
\hline Máximo & 62,8 & 14,7 & 10000 & 7,00 \\
\hline Mínimo & 61,4 & 14,0 & 6500 & 4,61 \\
\hline Coef. Variação & $0,6 \%$ & $1,4 \%$ & $10,2 \%$ & $10,0 \%$ \\
\hline
\end{tabular}

Para uma melhor comparação do comportamento das diferentes escalas (Tabela 5.30), considera-se também a relação entre a resistência à tração e à compressão dos blocos, neste caso apenas relativa à área líquida. Nota-se que a razão entre resistência de tração indireta e resistência de compressão é próxima para as duas escalas. Isso é um fato importante, pois a alteração dessa razão pode modificar o comportamento e/ou o modo de ruptura de uma estrutura complexa. Verifica-se, também, que a diferença da resistência de tração das escalas natural e reduzida é inferior ao observado para a compressão.

Tabela 5.30 - Comparações das resistências na área líquida dos blocos (1:1) e (1:3)

\begin{tabular}{|l|c|c|c|}
\cline { 2 - 4 } \multicolumn{1}{c|}{} & Bloco (1:3) & Bloco (1:1) & $\mathbf{( 1 : 3 ) ~ / ~ ( 1 : 1 ) ~}$ \\
\hline Tensão - Compressão (MPa) & 59,83 & 38,82 & $+54,1 \%$ \\
\hline Tensão - Tração (MPa) & 5,91 & 4,43 & $+33,4 \%$ \\
\hline Tração / Compressão (\%) & $9,9 \%$ & $11,4 \%$ & $-13,1 \%$ \\
\hline
\end{tabular}

\subsection{6- Resultados dos ensaios de taxa de absorção inicial (IRA)}

Os resultados dos ensaios em escala natural (1:1) são apresentados na Tabela 5.31 , onde se observa que o valor médio $\left(1,75 \mathrm{~kg} / \mathrm{min} / \mathrm{m}^{2}\right)$ obtido para o IRA está acima do intervalo recomendado pela literatura técnica (entre 0,25 e $1,50 \mathrm{~kg} / \mathrm{min} / \mathrm{m}^{2}$ ). Verifica-se que o coeficiente de variação é relativamente pequeno, inferior a $6 \%$. Já a Tabela 5.32 exibe os valores obtidos para os blocos em escala reduzida (1:3). Nota-se 
que o valor médio $\left(1,42 \mathrm{~kg} / \mathrm{min} / \mathrm{m}^{2}\right)$ obtido para a taxa de absorção inicial está dentro do intervalo recomendado usualmente. Igualmente à escala natural o coeficiente de variação pode ser considerado pequeno, cerca de $7 \%$.

Um alto valor para a taxa de absorção inicial significa que o bloco em questão possui uma grande capacidade de absorção da água presente na argamassa e no graute no estado fresco. Este fato pode gerar uma baixa aderência caso se utilize juntas finas de argamassa seca, pois dessa forma o bloco pode retirar a água necessária para as reações de cimentação. Outro problema é que a perda de água da argamassa para o bloco faz com que se perca rapidamente a trabalhabilidade da mesma.

Tabela 5.31- Taxa de absorção inicial (IRA) dos blocos na escala(1:1)

\begin{tabular}{|c|c|}
\cline { 2 - 2 } \multicolumn{1}{c|}{} & IRA (kg/min/m $\mathbf{~}$ ) \\
\hline Média & 1,75 \\
\hline Máximo & 1,89 \\
\hline Mínimo & 1,62 \\
\hline Coef. Variação & $5,6 \%$ \\
\hline
\end{tabular}

Tabela 5.32- Taxa de absorção inicial (IRA) dos blocos na escala(1:3)

\begin{tabular}{|c|c|}
\cline { 2 - 2 } \multicolumn{1}{c|}{} & IRA (kg/min/m $\mathbf{m}^{\mathbf{2}}$ ) \\
\hline Média & 1,42 \\
\hline Máximo & 1,53 \\
\hline Mínimo & 1,29 \\
\hline Coef. Variação & $7,2 \%$ \\
\hline
\end{tabular}

Acredita-se que a diferença de valores observada nas duas escalas não seja devida aos blocos possuírem materiais diferentes, e sim pelas diferenças na geometria da seção transversal. Como o bloco na escala (1:1) possui diversas paredes de pequena espessura, o volume de material cerâmico em contato com a água é proporcionalmente maior que no caso do bloco na escala (1:3), em que as paredes das unidades são em número menor. Dessa forma, como o bloco na escala natural possui um maior contato com a água é de se esperar que sua capacidade de absorção seja superior à do bloco na escala reduzida.

\subsection{7- Resultados dos ensaios de resistência à compressão do bloco na direção paralela à junta de assentamento}

Os esquemas dos ensaios e as formas de ruptura dos blocos em escala natural e reduzida estão apresentados na Figura 5.7. Os resultados dos ensaios na escala (1:1) são exibidos na Tabela 5.33, verificando-se um coeficiente de variação regular, 
aproximadamente 8\%. Na Tabela 5.34 apresentam-se os resultados obtidos para a escala (1:3), onde se observa um coeficiente de variação relativamente alto (18\%).

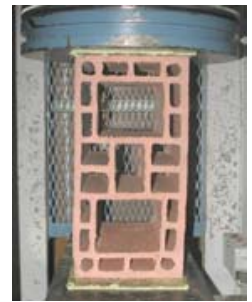

Ensaio (1:1)

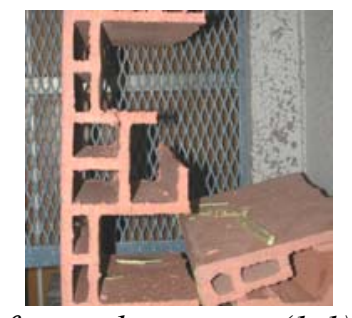

forma de ruptura $(1: 1)$

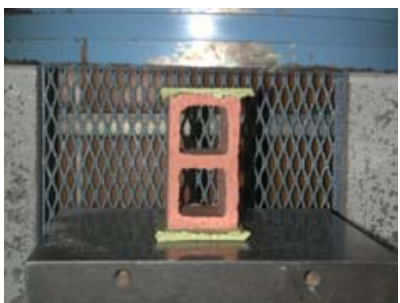

ensaio (1:3)

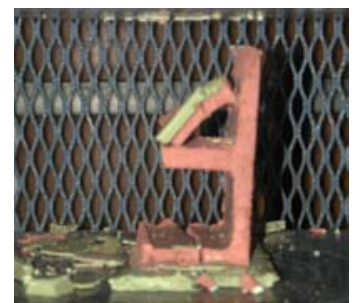

forma de ruptura $(1: 3)$

Figura 5.7- Ensaios nas escalas (1:1) e (1:3) na direção paralela à junta de assentamento

Tabela 5.33- Resistência à compressão do bloco na escala (1:1) na direção paralela à junta de assentamento

\begin{tabular}{|c|c|c|c|}
\cline { 2 - 4 } \multicolumn{1}{c|}{} & Força (kN) & Área bruta $\left(\mathbf{c m}^{2}\right)$ & Tensão (MPa) - A. bruta \\
\hline Média & 56,9 & 270,9 & 2,10 \\
\hline Máximo & 63,4 & 274,6 & 2,31 \\
\hline Mínimo & 50,8 & 266,0 & 1,89 \\
\hline Coef. Variação & $8,4 \%$ & $1,3 \%$ & $8,2 \%$ \\
\hline
\end{tabular}

Tabela 5.34 - Resistência à compressão do bloco na escala (1:3) na direção paralela à junta de assentamento

\begin{tabular}{|c|c|c|c|}
\cline { 2 - 4 } \multicolumn{1}{c|}{} & Força (kN) & Área bruta $\mathbf{( c m}^{\mathbf{2}}$ ) & Tensão (MPa) - A. bruta \\
\hline Média & 30,9 & 29,4 & 10,5 \\
\hline Máximo & 38,6 & 29,8 & 13,2 \\
\hline Mínimo & 24,8 & 28,7 & 8,6 \\
\hline Coef. Variação & $18,2 \%$ & $1,4 \%$ & $17,9 \%$ \\
\hline
\end{tabular}

No caso da resistência à compressão do bloco na direção paralela à junta de assentamento, só é possível a análise dos resultados em relação à área bruta dos blocos, fato anteriormente apresentado. Na Tabela 5.35 apresentam-se os valores para as duas escalas e a comparação com a resistência à compressão dos blocos na direção normal à junta (em relação à área bruta). Inicialmente verifica-se que a resistência do bloco na direção da junta de assentamento na escala reduzida é cerca de $400 \%$ superior à do bloco em tamanho natural. No entanto, ao se comparar a relação entre as resistências paralela e normal à junta, observa-se que a diferença passa a ser de 138\%. Acredita-se que caso fosse possível comparar as resistências em termos de área líquida os valores deveriam se aproximar mais, ficando talvez com uma diferença na mesma ordem de grandeza do caso da resistência à compressão. 
Tabela 5.35 - Comparações das resistências à compressão na direção paralela à junta de assentamento dos blocos (1:1) e (1:3)- área bruta

\begin{tabular}{|c|c|c|c|}
\cline { 2 - 4 } \multicolumn{1}{c|}{} & Bloco (1:3) & Bloco (1:1) & $\mathbf{( 1 : 3 ) / ( 1 : 1 )}$ \\
\hline Tensão (MPa) & 10,5 & 2,10 & $+400 \%$ \\
\hline $\begin{array}{c}\text { Resist. paralela à junta / } \\
\text { Resist. normal à junta }\end{array}$ & $34,6 \%$ & $14,5 \%$ & $+138 \%$ \\
\hline
\end{tabular}

\subsection{8- Resultados dos ensaios de módulo de deformação do bloco}

Os ensaios de módulo de deformação dos blocos na escala natural e reduzida, bem como a instrumentação utilizada em cada caso, estão ilustrados na Figura 5.8.

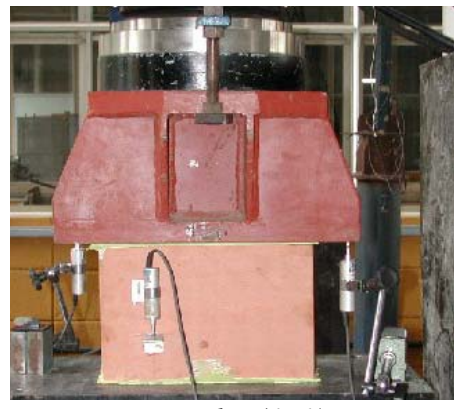

Escala (1:1)

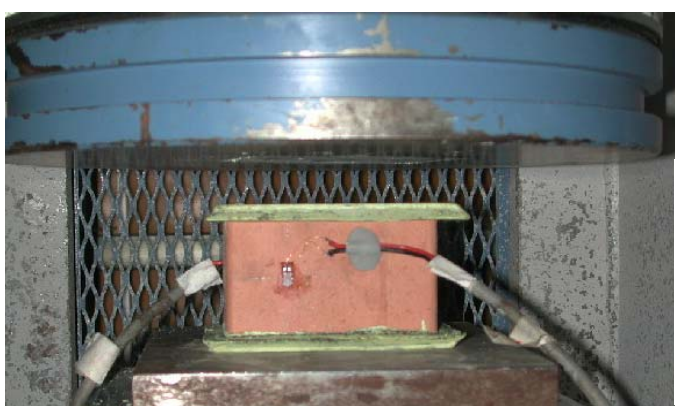

Escala (1:3) extensômetro 2

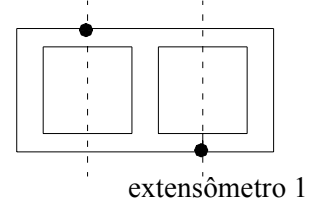

extensômetro 1

Figura 5.8 - Ensaios dos módulos de deformação dos blocos nas escalas (1:1) e (1:3)

Os resultados da força máxima aplicada, da tensão de ruptura e do módulo de deformação dos blocos na escala natural são apresentados na Tabela 5.36. Os valores são referidos tanto à área bruta quanto à área líquida (a ser utilizado nos modelos numéricos). Apesar da resistência à compressão não variar muito (menos de 12\%), o módulo de deformação possui um coeficiente de variação relativamente alto (mais de $22 \%$ ). Esses mesmos resultados para os blocos na escala (1:3) e ainda a deformação última estão na Tabela 5.37. Novamente, nota-se que o módulo de deformação possui um considerável coeficiente de variação, cerca de $18 \%$.

Ressalta-se que para os blocos na escala natural (1:1) não é apresentado o valor da deformação última, pois há uma grande perturbação das leituras dos transdutores nos estágios próximo à ruptura, tanto os que medem os deslocamentos relativos diretamente nas unidades quanto os posicionados para medir os deslocamentos dos pratos da máquina. Acredita-se que esse comportamento seja causado pela separação das paredes constituintes dos blocos, que pode ser visualizada na Figura 5.9.

- Adota-se que a deformação última é a deformação correspondente ao valor máximo da força aplicada (força última). 
Tabela 5.36 - Módulo de deformação do bloco na escala natural (1:1)

\begin{tabular}{|c|c|c|c|c|c|}
\cline { 2 - 6 } \multicolumn{1}{c|}{} & $\begin{array}{c}\text { Força } \\
\text { (kN) }\end{array}$ & $\begin{array}{c}\text { Tensão - } \\
\text { A.bruta(MPa) }\end{array}$ & $\begin{array}{c}\text { Módulo - } \\
\text { A.bruta(MPa) }\end{array}$ & $\begin{array}{c}\text { Tensão - } \\
\text { A.liq.(MPa) }\end{array}$ & $\begin{array}{c}\text { Módulo } \\
\text { A.liq.(MPa) }\end{array}$ \\
\hline Média & 580,8 & 14,43 & 5151,1 & 38,78 & 13847,1 \\
\hline Máximo & 647,3 & 16,00 & 6993,0 & 43,00 & 18798,4 \\
\hline Mínimo & 448,0 & 11,31 & 3505,2 & 30,40 & 9422,6 \\
\hline Coef. Var. & $12,4 \%$ & $11,9 \%$ & $22,8 \%$ & $11,9 \%$ & $22,8 \%$ \\
\hline
\end{tabular}

Tabela 5.37 - Módulo de deformação do bloco na escala (1:3)

\begin{tabular}{|c|c|c|c|c|c|c|}
\cline { 2 - 7 } \multicolumn{1}{c|}{} & $\begin{array}{c}\text { Força } \\
\text { (kN) }\end{array}$ & $\begin{array}{c}\text { Tensão - } \\
\text { A.bruta(MPa) }\end{array}$ & $\begin{array}{c}\text { Módulo - } \\
\text { A.bruta(MPa) }\end{array}$ & $\begin{array}{c}\text { Tensão - } \\
\text { A.liq.(MPa) }\end{array}$ & $\begin{array}{c}\text { Módulo } \\
\text { A.liq.(MPa) }\end{array}$ & $\begin{array}{c}\text { Deformação } \\
\text { última }\end{array}$ \\
\hline Média & 163,3 & 36,41 & 11147,7 & 71,88 & 22005,0 & $-2,87 \% \%_{\circ}$ \\
\hline Máximo & 193,4 & 43,13 & 14020,0 & 85,14 & 27674,7 & $-3,31 \% \%_{\circ}$ \\
\hline Mínimo & 135,2 & 30,15 & 8472,3 & 59,52 & 16723,8 & $-2,41 \% \%$ \\
\hline Coef. Var. & $12,1 \%$ & $12,1 \%$ & $18,4 \%$ & $12,1 \%$ & $18,4 \%$ & $14,0 \%$ \\
\hline
\end{tabular}

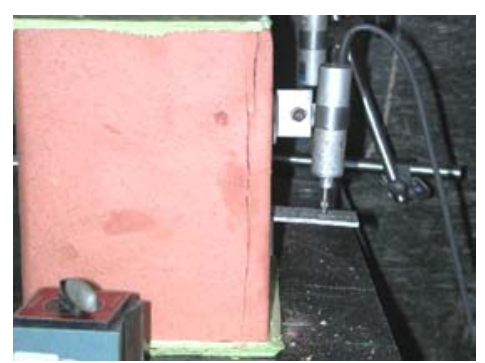

Figura 5.9 - Forma de ruptura do bloco na escala natural (1:1)

Os diagramas tensão x deformação do bloco em tamanho natural, considerandose apenas os transdutores posicionados na unidade, são apresentados na Figura 5.10. Mostram-se apenas os trechos em que o comportamento é considerado mais estável, sendo que em alguns blocos o diagrama é praticamente linear até o estágio próximo à ruptura. Para a escala reduzida, os diagramas tensão $\mathrm{x}$ deformação dos blocos são exibidos na Figura 5.11, sendo a tensão referida à área bruta. Neste caso, percebe-se claramente o comportamento linear dos blocos até as proximidades da ruptura.

Nos ensaios em escala natural, também é determinado o módulo de deformação do bloco, calculando-se a deformação específica a partir do deslocamento relativo dos pratos da máquina. Contudo, os valores obtidos são cerca da metade dos resultados correspondentes às deformações dos transdutores posicionados diretamente nos blocos. Julga-se que, neste caso, o procedimento de medição dos deslocamentos dos pratos da máquina não é adequado, tendo em vista que a ordem de grandeza das deformações obtidas é bem superior à esperada para um material cerâmico, chegando a ultrapassar o valor de $5 \%$. 


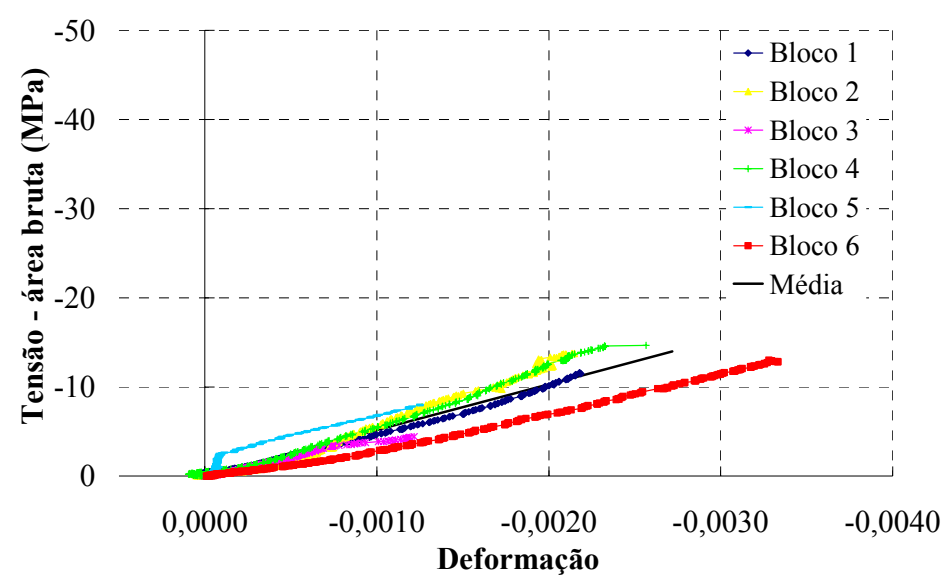

Figura 5.10 - Diagramas tensão x deformação dos blocos na escala natural (1:1)

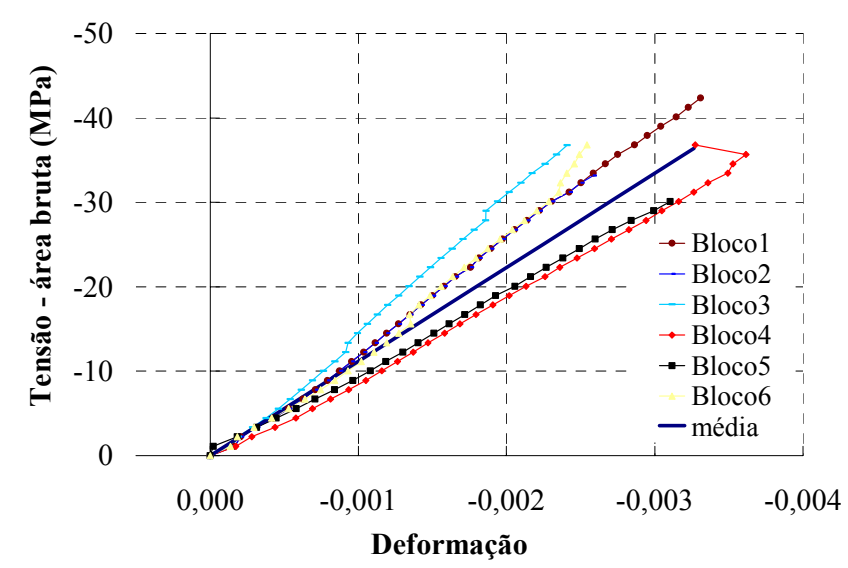

Figura 5.11- Diagramas tensão x deformação dos blocos na escala (1:3)

A comparação entre o módulo de deformação do bloco nas escalas (1:1) e (1:3) é realizada na Tabela 5.38. O valor obtido para a escala reduzida é superior ao caso do bloco em tamanho natural, entretanto apresenta aproximadamente o mesmo acréscimo observado para as resistências à compressão dos blocos nas duas escalas. Nota-se, ainda, que a proporção entre o módulo de deformação e a resistência do bloco é praticamente igual para os blocos nas diferentes escalas, o que traduz fato bastante importante devido à sua consistência.

Tabela 5.38 - Comparações dos módulos de deformação dos blocos (1:1) e (1:3)- área líquida

\begin{tabular}{|c|c|c|c|}
\cline { 2 - 4 } \multicolumn{1}{c|}{} & Bloco (1:3) & Bloco (1:1) & $\mathbf{( 1 : 3 ) / ( 1 : 1 )}$ \\
\hline $\begin{array}{c}\text { Módulo de deformação (MPa) } \\
\text { - Área bruta }\end{array}$ & 11147,7 & 5151,1 & $+116,4 \%$ \\
\hline $\begin{array}{c}\text { Módulo de deformação (MPa) } \\
\text { - Área líquida }\end{array}$ & 22005,0 & 13847,1 & $+58,9 \%$ \\
\hline $\begin{array}{c}\text { Módulo de deformação / } \\
\text { Resistência do bloco }\end{array}$ & 368 & 357 & $+3,1 \%$ \\
\hline
\end{tabular}




\subsection{9- Análise geral dos resultados dos blocos}

Acredita-se que apesar das diferenças na seção geométrica e na resistência à compressão dos blocos em escala reduzida, estes devem ser capazes de representar bem o comportamento da alvenaria com blocos na escala natural. Os valores de absorção, massa específica e razão entre as resistências de tração indireta e de compressão são próximos para as duas escalas, indicando que as características do material cerâmico são as mesmas. As diferenças entre as taxas de absorção inicial (IRA) estão mais ligadas ao tipo de seção transversal das unidades do que ao tipo de material dos blocos. Julga-se, também, que a grande desigualdade entre as resistências dos blocos na direção paralela à junta de assentamento não é um fator crítico, tendo em vista não ser usual a alvenaria estar submetida a altos níveis de tensões normais nessa direção. Um outro fator positivo é a manutenção da razão entre o módulo de deformação e a resistência do bloco para as duas escalas.

Em relação às técnicas de modelos reduzidos, classifica-se que o bloco na escala reduzida se encaixa no caso de modelos distorcidos, principalmente por causa das diferenças nas seções transversais dos blocos, que gera uma distorção da geometria. Ressalta-se que os fatores de escala são todos calculados em função das propriedades referidas à área bruta. $\mathrm{O}$ fator de escala de comprimento $\left(s_{L}\right)$ é direto e igual a 3 , o fator de escala de tensão $\left(s_{\sigma}\right)$ é igual 0,47 , que é a razão entre a resistência à compressão do bloco em tamanho natural e reduzido. Já o fator de escala de deformação $\left(s_{\varepsilon}\right)$ é considerado igual a 1, apesar de não ter sido possível obter as deformações últimas do bloco em tamanho natural. Todavia, a razão entre os módulos de deformação para as duas escalas, que é função de $\left(s_{\sigma} / s_{\varepsilon}\right)$, é igual a 0,46 ; praticamente o mesmo valor de $\left(s_{\sigma}\right)$. Portanto, é razoável a adoção de $\left(s_{\varepsilon}\right)=1$.

A Figura 5.12 exibe os diagramas tensão x deformação dos blocos reais em relação à área bruta e dos blocos reduzidos, sendo que estes últimos têm a tensão na área bruta multiplicada pelo fator de escala de tensão $\left(s_{\sigma}\right)$. Novamente, só são apresentados para os blocos reais os trechos anteriores à perturbação dos resultados anteriormente comentada. Percebe-se na figura uma grande similaridade entre os diagramas, indicando que o bloco na escala reduzida representa bem o comportamento do bloco em escala natural. 


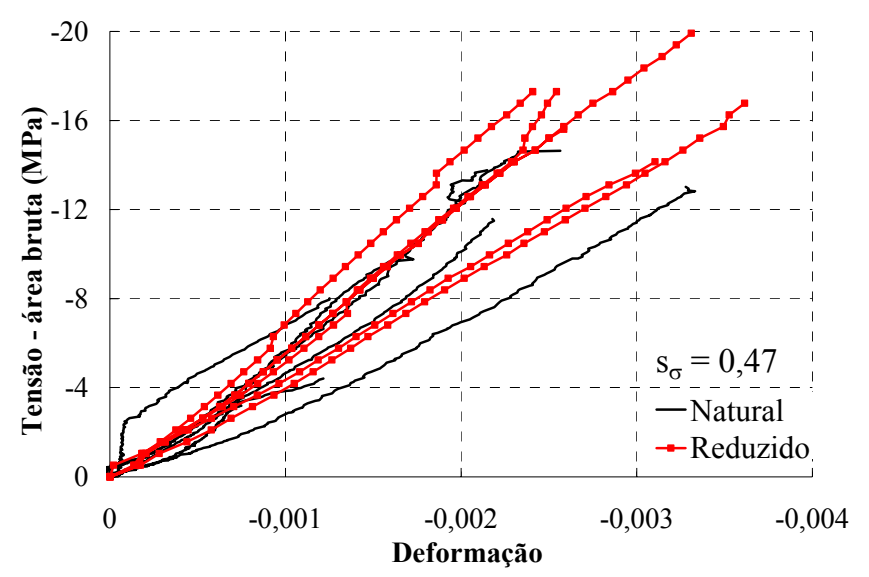

Figura 5.12 -Diagramas tensão $x$ deformação considerando os fatores de escala

\section{3- Caracterização da alvenaria em escala natural e reduzida}

Após a caracterização da unidade faz-se necessário o estudo do comportamento da alvenaria em si, isto é, o conjunto formado por blocos e juntas de argamassa. Para isso são realizados diversos ensaios com diferentes corpos-de-prova, sendo alguns deles usuais e outros não. Na Figura 5.13 estão alguns dos tipos de corpos-de-prova de alvenaria empregados para a escala natural e reduzida: o prisma de três blocos, o prisma de dois blocos (assentados na sua face menor) e a paredinha ${ }^{\star}$. Além desses utilizou-se numa etapa posterior o prisma de quatro blocos para o ensaio de flexão. Lembra-se que ainda são ensaiados os corpos-de-prova cilíndricos da argamassa utilizada. Em todos os casos procura-se manter a máxima semelhança possível nos procedimentos adotados para os ensaios nas diferentes escalas.

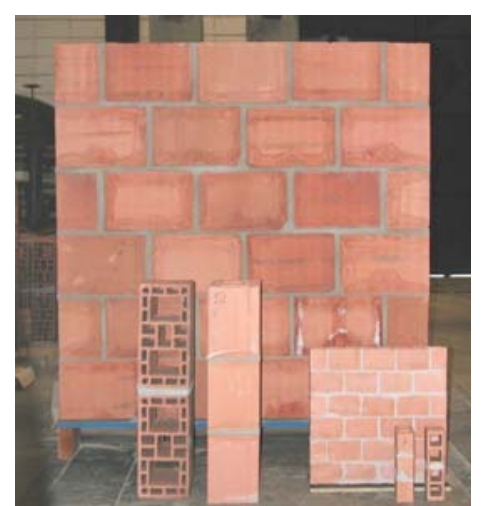

Figura 5.13 - Corpos-de-prova de alvenaria na escala natural (1:1) e reduzida (1:3)

Os cuidados tomados durante a execução e o transporte dos corpos-de-prova, bem como os procedimentos e equipamentos utilizados para os ensaios, são expostos no

- Termo difundido no meio técnico para designar corpos-de-prova de parede, normalmente com dimensões de $1,20 \mathrm{~m}$ $\mathrm{x} 1,20 \mathrm{~m}$ na escala real. 
item 5.3.1. Procura-se ressaltar as particularidades geradas pela utilização de blocos em escalas diferentes. Os resultados são apresentados por tipo de ensaio, possibilitando o confronto direto entre as escalas, além de algumas comparações das relações entre as propriedades mecânicas obtidas. Finalizando, faz-se uma análise geral da caracterização da alvenaria, empregando-se a teoria de modelos físicos reduzidos para o estudo do comportamento das diferentes escalas.

\subsection{1 - Procedimentos e equipamentos utilizados na caracterização da alvenaria}

\section{$\underline{\text { 5.3.1.1 - Modo de execução e transporte dos corpos-de-provas de alvenaria }}$}

- Procedimentos:

Os corpos-de-prova na escala natural (1:1) são executados por um pedreiro experiente, utilizando o prumo de pedreiro e o nível de bolha. A altura e o comprimento do corpo-de-prova são verificados com réguas metálicas, garantindo-se a espessura de $1 \mathrm{~cm}$ das juntas verticais e horizontais de argamassa. Os exemplares de alvenaria na escala (1:3) são construídos pelo mesmo pedreiro, no entanto com o auxílio de gabaritos de alumínio (Figura 5.14), para garantir o nível, o prumo e a espessura constante das juntas horizontais e verticais de argamassa (cerca de $3 \mathrm{~mm}$ ). As quantidades de corposde-prova são iguais em ambas as escalas: seis paredinhas, doze prismas de três blocos, seis prismas de dois blocos assentados na vertical e seis prismas de quatro blocos.

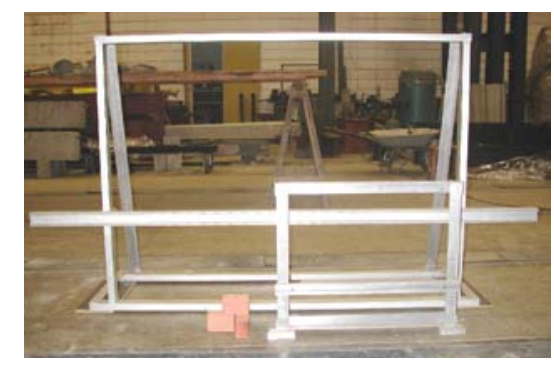

Figura 5.14 - Gabaritos utilizados na construção dos corpos-de-prova na escala (1:3)

Como visto no item 5.2.6, o bloco na escala natural (1:1) apresenta uma taxa de absorção inicial (IRA) acima dos limites recomendados. Assim, um procedimento indicado é a imersão dos blocos na água antes do seu assentamento. Entretanto, o pedreiro opta por aumentar a quantidade de água na argamassa, pois afirma existir uma grande dificuldade em assentar o bloco úmido na escala natural. Com relação à escala reduzida, apesar do bloco não apresentar uma taxa de absorção inicial (IRA) acima dos limites recomendados (item 5.2.6), os mesmos são imersos na água antes do seu 
assentamento, devido à dificuldade encontrada pelo pedreiro em trabalhar com a unidade na umidade natural. Acredita-se que por causa do pequeno volume da junta de argamassa, ela seja mais sensível à sucção de água pelo bloco, perdendo mais facilmente sua trabalhabilidade. Dessa forma, enquanto a unidade na escala natural é assentada na sua umidade natural, a unidade na escala reduzida é assentada úmida.

As paredinhas na escala (1:1) são construídas sobre uma base de madeira, o que possibilita o seu futuro transporte. Antes do assentamento da primeira fiada, é posicionada uma faixa de forro pacote sobre a base, com as mesmas dimensões do exemplar em planta. O objetivo primordial desse forro é impedir a adesão do corpo-deprova com a madeira; nos ensaios na direção normal à junta de assentamento, ele funciona como material de capeamento. Todas as paredinhas em escala natural são executadas na posição convencional, mesmo as que devem ser ensaiadas na direção paralela à junta de assentamento. Para esta última situação, a paredinha é girada para sua condição de ensaio com o auxílio da ponte rolante. Neste momento, também, se realiza o capeamento das faces laterais com uma massa tipo epóxi.

Para se evitarem problemas de danos durante a movimentação das paredinhas na escala (1:1), são utilizados tirantes externos ao exemplar, na direção normal à junta de assentamento. Com esses tirantes aplica-se uma pequena pré-compressão, diminuindo os riscos de aparecimentos de fissuras nas juntas de argamassas durante o transporte. Os exemplares são levados até o local de ensaio com o auxílio da ponte rolante (Figura 5.15) e de uma paleteira elétrica.

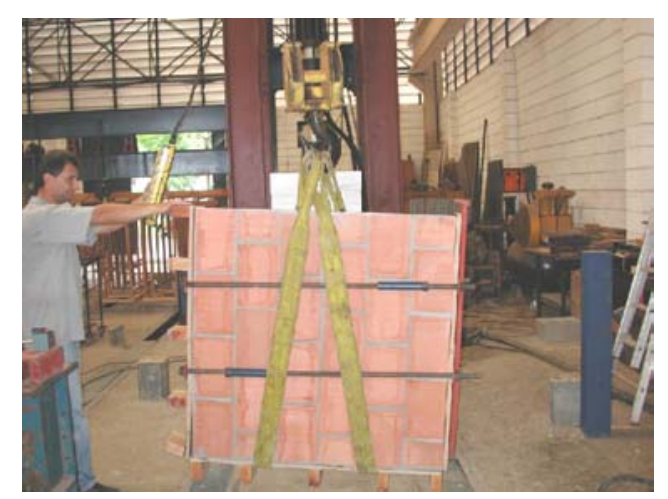

Figura 5.15 - Transporte da paredinha na escala natural (1:1)

Ainda com relação à escala natural, para cada paredinha construída são executados dois prismas de três blocos e um prisma de dois blocos. Ressalta-se que este último é construído em sua posição de ensaio. Numa etapa posterior, são construídos seis prismas de quatro blocos. Por suas menores dimensões e massa, todo o transporte é 
feito manualmente, tomando-se os cuidados necessários para não danificar a ligação bloco-argamassa.

Graças às pequenas dimensões e peso dos corpos-de-prova, os procedimentos para a escala reduzida são mais simples. As paredinhas são construídas utilizando-se o gabarito de maiores dimensões, permitindo que o pedreiro execute três delas simultaneamente. Ao término de cada três paredinhas é executada metade do número total de prismas de três e dois blocos, empregando-se agora o gabarito de menores dimensões. Novamente, os prismas de quatro blocos são executados posteriormente. Todo o transporte é feito manualmente. Toma-se apenas o cuidado de evitar movimentos bruscos e formas de carregar os exemplares que possam afetar a ligação bloco-argamassa.

A cura de todos os corpos-de-prova é feita nas condições do ambiente do laboratório. Também, salienta-se que em nenhum corpo-de-prova, de ambas as escalas, é verificado algum tipo de dano causado por sua movimentação, o que evidencia a adequação dos cuidados tomados durante o transporte.

\section{$\underline{5.3 .1 .2-\text { Ensaios relacionados à argamassa }}$}

- Procedimentos:

A areia empregada na confecção da argamassa para os corpos-de-prova de alvenaria na escala natural (1:1) é a utilizada em obras convencionais. No entanto, como em todo trabalho experimental em alvenaria em escala reduzida deve-se empregar uma areia mais fina do que a usual. Isso ocorre por causa das diferentes espessuras da junta de argamassa. Na escala (1:1) a junta é de $1 \mathrm{~cm}$, já na escala (1:3) essa junta se reduz para $0,3 \mathrm{~cm}$. E como há uma recomendação prática de que o diâmetro máximo do agregado seja inferior a $1 / 3$ da espessura da junta, a areia normalmente usada não é aplicável aos modelos reduzidos. A Figura 5.16 apresenta as curvas granulométricas obtidas de acordo com a NBR 7217/1987 para as areias utilizadas nos modelos reais e reduzidos.

Segundo a NBR 7211/1983, a areia para os modelos em escala natural praticamente se encaixa no intervalo da areia fina. Por outro lado, a areia empregada na execução dos corpos-de-prova na escala reduzida está no limite inferior da areia muito fina. Observa-se que o diâmetro máximo dos agregados, para ambas as escalas, é inferior a $1 / 3$ da espessura de suas respectivas juntas. Acredita-se que este cuidado é suficiente para a obtenção de argamassas adequadas à escala. 


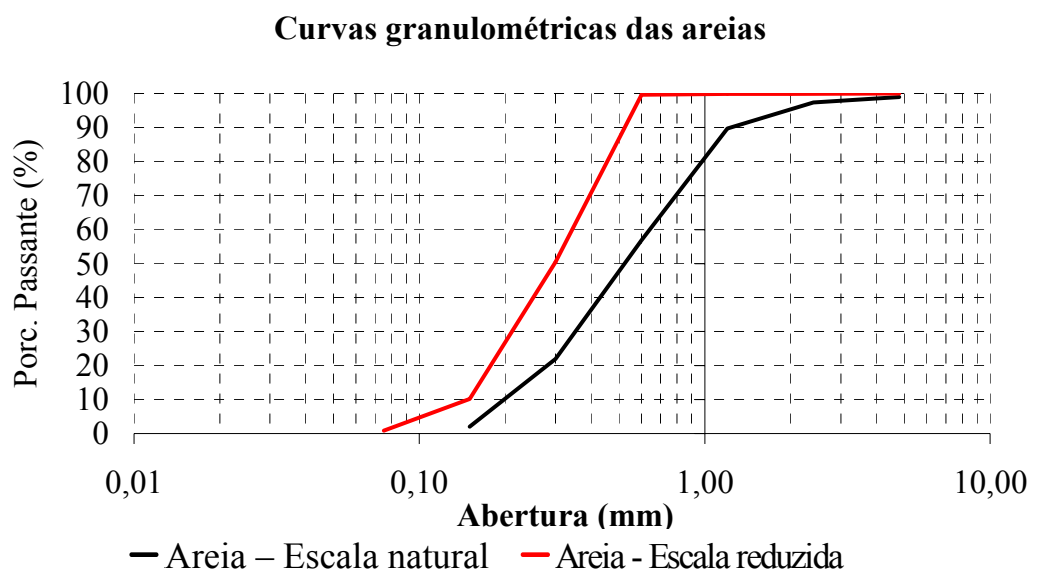

Figura 5.16- Curva granulométrica da areia utilizada nos corpos-de-prova da escala (1:3)

O traço em volume da argamassa adotada na pesquisa é 1: 0,5: 4,5 (cimento:cal:areia), usualmente empregada em diversos trabalhos científicos. O cimento utilizado é do tipo CP II E -32, a cal hidratada é a CH III. A relação água/cimento é determinada de modo a se obter a trabalhabilidade da argamassa desejada pelo pedreiro. Por causa da mudança do tipo de areia, da espessura da junta e da umidade em que os blocos são assentados, as relações água/cimento para as escalas natural e reduzida são diferentes. A Tabela 5.39 apresenta os traços em volume, as massas específicas reais e aparentes dos materiais, as relações água/cimento e os traços em massa das argamassas para a alvenaria nas escalas $(1: 1)$ e (1:3). Ressalta-se que toda a produção é realizada controlando-se as massas dos materiais secos.

Tabela 5.39- Traço da argamassa utilizada na escala (1:1) e (1:3)

\begin{tabular}{|c|c|c|c|c|c|c|c|c|}
\hline \multicolumn{9}{|c|}{ Argamassa - escala natural $(1: 1)$} \\
\hline \multirow{2}{*}{$\begin{array}{l}\text { Traço- } \\
\text { volume }\end{array}$} & \multicolumn{2}{|c|}{ Cimento } & \multicolumn{2}{|c|}{ Cal } & \multicolumn{2}{|c|}{ Areia } & \multirow{2}{*}{$\begin{array}{l}\text { Água/ } \\
\text { Cim. }\end{array}$} & \multirow{2}{*}{$\begin{array}{l}\text { Traço - } \\
\text { massa }\end{array}$} \\
\hline & $\gamma\left(\mathrm{g} / \mathrm{cm}^{3}\right)$ & $\delta\left(\mathrm{g} / \mathrm{cm}^{3}\right)$ & $\gamma\left(\mathrm{g} / \mathrm{cm}^{3}\right)$ & $\delta\left(\mathrm{g} / \mathrm{cm}^{3}\right)$ & $\gamma\left(\mathrm{g} / \mathrm{cm}^{3}\right)$ & $\delta\left(\mathrm{g} / \mathrm{cm}^{3}\right)$ & & \\
\hline $1: 0,5: 4,5$ & 3,13 & 1,18 & 2,65 & 0,72 & 2,61 & 1,51 & 1,23 & $1: 0,31: 5,76$ \\
\hline \multicolumn{9}{|c|}{ Argamassa - escala reduzida $(1: 3)$} \\
\hline \multirow{2}{*}{$\begin{array}{l}\text { Traço- } \\
\text { volume }\end{array}$} & \multicolumn{2}{|c|}{ Cimento } & \multicolumn{2}{|c|}{ Cal } & \multicolumn{2}{|c|}{ Areia } & \multirow{2}{*}{$\begin{array}{l}\text { Água/ } \\
\text { Cim. }\end{array}$} & \multirow{2}{*}{$\begin{array}{l}\text { Traço - } \\
\text { massa }\end{array}$} \\
\hline & $\gamma\left(\mathrm{g} / \mathrm{cm}^{3}\right)$ & $\delta\left(\mathrm{g} / \mathrm{cm}^{3}\right)$ & $\gamma\left(\mathrm{g} / \mathrm{cm}^{3}\right)$ & $\delta\left(\mathrm{g} / \mathrm{cm}^{3}\right)$ & $\gamma\left(\mathrm{g} / \mathrm{cm}^{3}\right)$ & $\delta\left(\mathrm{g} / \mathrm{cm}^{3}\right)$ & & \\
\hline $1: 0,5: 4,5$ & 3,13 & 1,18 & 2,65 & 0,72 & 2,63 & 1,57 & 1,16 & $1: 0,31: 5,99$ \\
\hline
\end{tabular}

A cada produção de argamassa determina-se a sua consistência de acordo com a NBR 7215/1991. Lembra-se que existe a recomendação para alvenaria de blocos de concreto que a argamassa deva possuir uma consistência de $23 \pm 1 \mathrm{~cm}$, NBR 8798/1985. Os corpos-de-prova são ensaiados à compressão, sempre que possível, na mesma data dos ensaios das paredinhas (em média aos 35 dias), utilizando-se a pasta de enxofre como capeamento. Também se determina o módulo de deformação da argamassa de acordo com a NBR 8522/1984, sendo um corpo-de-prova por argamassada. Opta-se 
pelo cálculo do módulo secante no intervalo entre $5 \%$ e $33 \%$ da tensão de ruptura (o mesmo utilizado no caso dos blocos).

Para a construção de cada paredinha em escala natural (1:1), com seus respectivos prismas, é efetuada uma única produção de argamassa, confeccionando-se quatro corpos-de-prova cilíndricos de $5 \mathrm{~cm}$ x $10 \mathrm{~cm}$ por produção, totalizando vinte e quatro exemplares. Para a escala reduzida (1:3) são executadas cinco argamassadas ao todo, sendo retirados três exemplares por produção, totalizando quinze corpos-de-prova cilíndricos.

- Equipamentos:

Devido aos baixos valores da força de ruptura, utiliza-se a máquina hidráulica Soiltest para os ensaios (Figura 5.17a), sendo as deformações medidas por extensômetros removíveis com base de 50mm (Figura 5.17b). As leituras são feitas a cada $0,5 \mathrm{kN}$ por meio do sistema de aquisição de dados (SYSTEM 5000). Ressalta-se, ainda, a opção de não realizar a redução proporcional à escala das dimensões do corpode-prova de argamassa, por causa dos problemas de moldagem gerados por essa diminuição.
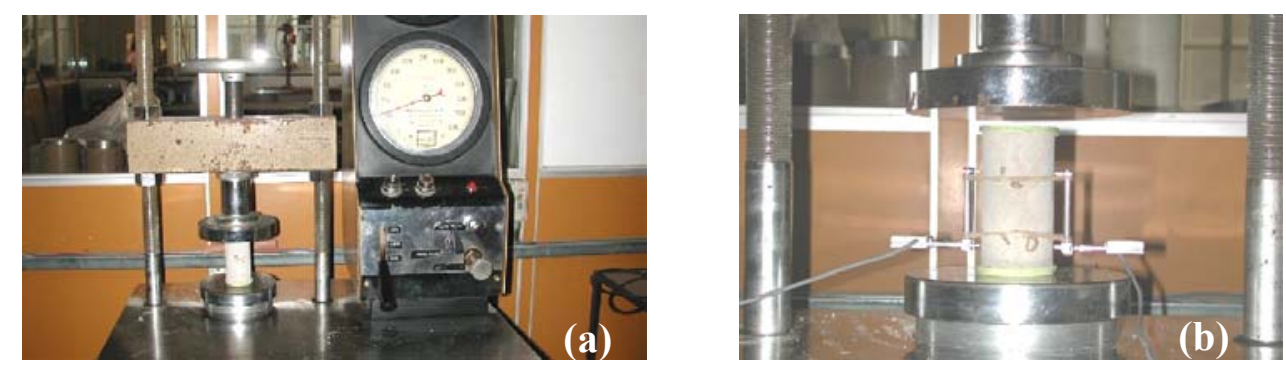

Figura 5.17- Ensaio de compressão e de módulo de deformação da argamassa

\section{$\underline{5.3 .1 .3 ~-~ E n s a i o s ~ d e ~ p r i s m a s ~ d e ~ t r e ̂ s ~ b l o c o s ~ a ̀ ~ c o m p r e s s a ̃ o ~}$}

- Procedimentos:

Opta-se pela utilização do prisma de três blocos para o ensaio de compressão, por sua relação entre altura e espessura ser próxima de cinco. Dessa forma, segundo diferentes normas [ASTM C 1314 (1997) e AS 3700 (1998)] a influência das restrições na resistência é pequena. Para cada paredinha executada são construídos dois prismas, totalizando doze exemplares, ensaiados segundo a NBR 8215/1983. Os resultados são apenas referidos à área bruta. $\mathrm{O}$ capeamento usado é o forro pacote, material bastante deformável e de grande facilidade de uso. 
Metade dos corpos-de-prova têm o bloco intermediário instrumentado, com o objetivo de se determinar o módulo de deformação da unidade numa condição mais próxima do bloco na parede. Adota-se novamente as indicações do ACI 530-92 (1995) para o seu cálculo.

- Equipamentos:

Por causa das dimensões do corpo-de-prova em escala natural utiliza-se a máquina servo-controlada INSTRON. A força é aplicada numa velocidade de carregamento de $0,01 \mathrm{~mm} / \mathrm{s}$. A Figura 5.18a apresenta as condições do ensaio do prisma na escala (1:1). A instrumentação é feita com quatro transdutores de deslocamento à base de extensômetro com curso de $10 \mathrm{~mm}$ (sensibilidade de $0,001 \mathrm{~mm}$ ), posicionados à meia altura da região central da cavidade do bloco intermediário (Figura 5.18b).
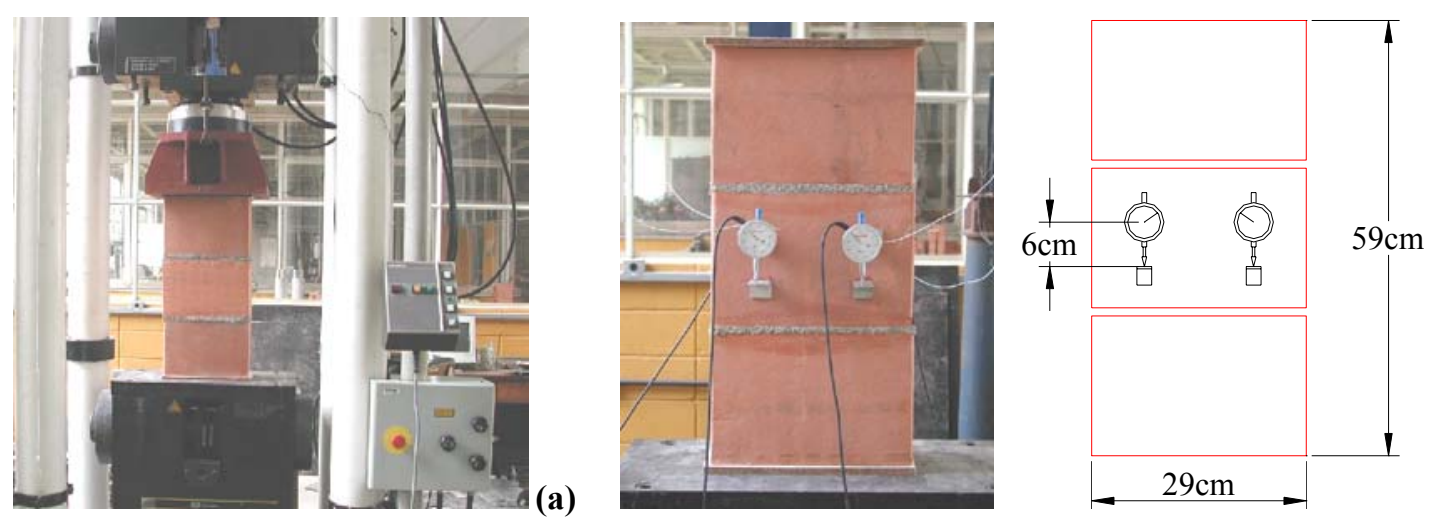

Figura 5.18 - Ensaio de compressão de prismas na escala natural(1:1)

(b)

Nos ensaios em escala (1:3) utiliza-se a máquina hidráulica ELE-Autotest 2000, empregando-se uma velocidade de carregamento de $1 \mathrm{kN} / \mathrm{s}$. A Figura $5.19 \mathrm{a}$ apresenta as condições do ensaio. Neste caso a instrumentação é realizada com dois extensômetros elétricos com $10 \mathrm{~mm}$ de base (sensibilidade de $10^{-6}$ ), posicionados à meia altura da região central da cavidade do bloco intermediário, de forma a verificar possíveis excentricidades (Figura 5.19b).

Em todos os ensaios utiliza-se o sistema de aquisição de dados SYSTEM 5000. Para a escala natural são armazenados continuamente a força aplicada e os deslocamentos medidos pelos transdutores. Para a escala reduzida, são realizadas leituras pontuais das deformações a cada $2,5 \mathrm{kN}$. 


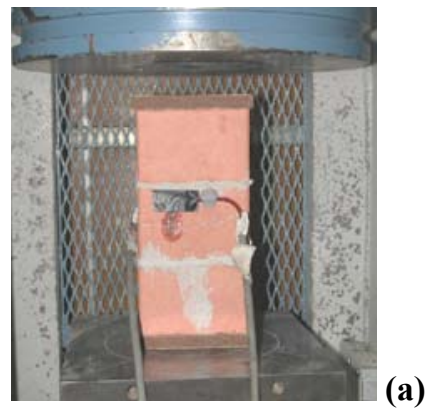

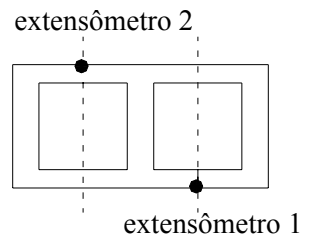

(b)

Figura 5.19- Ensaio de compressão de prismas na escala (1:3)

$\underline{\text { 5.3.1.4 - Ensaios de prismas de dois blocos à compressão paralela à junta de }}$ assentamento

- Procedimentos:

O uso de prismas para a determinação da resistência à compressão na direção paralela à junta de assentamento é indicado por Drysdale et al. (1994). Contudo, não é um ensaio usual, tanto que não há recomendações normativas nacionais ou internacionais. Dessa maneira, adota-se um prisma de dois blocos de altura construído na forma apresentada na Figura 5.20, obtendo uma razão entre altura e espessura próxima à do prisma de três blocos. Por ter o ensaio do bloco isolado nesta direção se mostrado muito sensível ao tipo de capeamento, emprega-se uma camada de massa epóxi para o nivelamento e a regularização das faces.

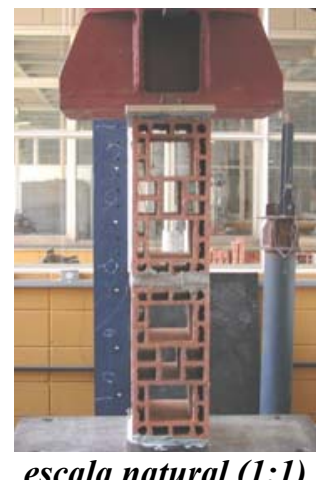

escala natural (1:1)

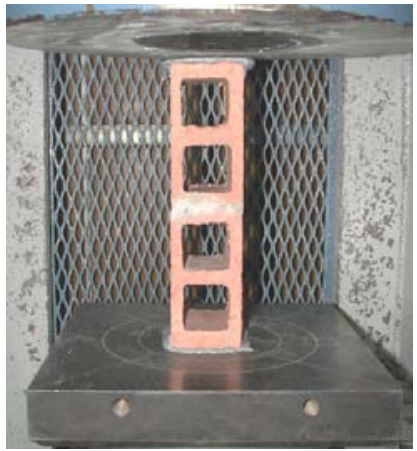

escala reduzida $(1: 3)$

Figura 5.20 - Ensaio de prismas de 2 blocos nas escalas (1:1) e (1:3)

Igualmente aos ensaios de blocos, não há como definir uma área líquida para os prismas nesta direção. Dessa forma todos os resultados são referidos à área bruta. Por ser um ensaio de caráter exploratório, é construído apenas um prisma por paredinha executada, totalizando seis exemplares.

- Equipamentos:

O ensaio na escala (1:1) é realizado na máquina INSTRON, com uma velocidade de apenas $0,002 \mathrm{~mm} / \mathrm{s}$. Para a escala reduzida utiliza-se a máquina hidráulica 
ELE-Autotest 2000, com um carregamento de $0,1 \mathrm{kN} / \mathrm{s}$. As velocidades de aplicação de força são baixas devido à ruptura do prisma ser extremamente frágil.

\section{$\underline{\text { 5.3.1.5 - Ensaios de prismas de quatro blocos à flexão }}$}

- Procedimentos:

$\mathrm{O}$ ensaio de prisma de quatro blocos à flexão tem o objetivo de determinar a resistência de aderência entre o bloco e a argamassa. Por não existir norma brasileira para tal corpo-de-prova, seguem-se as prescrições da norma americana ASTM E-518 (1993). Opta-se pelo ensaio com o carregamento nos terços dos vãos, vide Figura 5.21. O cálculo da resistência de aderência é feito utilizando-se a seguinte fórmula para a determinação da máxima tensão de tração:

$$
\sigma_{\text {aderência }}=\frac{P \cdot L}{6 \cdot W},
$$

Sendo:

$$
\begin{aligned}
\sigma_{\text {aderência }}= & \text { resistência de aderência }(\mathrm{MPa}) ; \\
\mathrm{P}= & \text { força aplicada para a ruptura }(\mathrm{N}), \text { incluindo o peso-próprio do } \\
& \text { corpo-de-prova } ; \\
\mathrm{L}= & \text { distância entre os apoios }(\mathrm{mm}) ; \\
\mathrm{W}= & \text { módulo de resistência à flexão do bloco }\left(\mathrm{mm}^{3}\right) .
\end{aligned}
$$

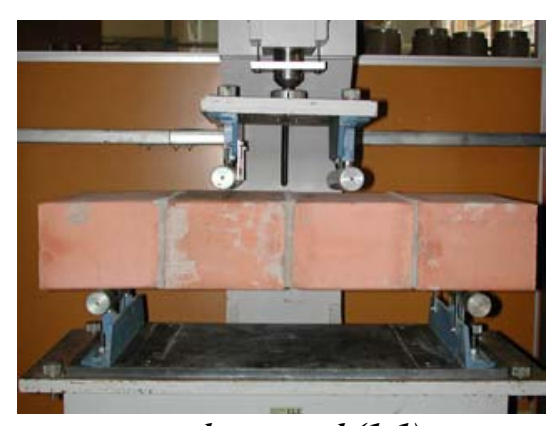

escala natural (1:1)

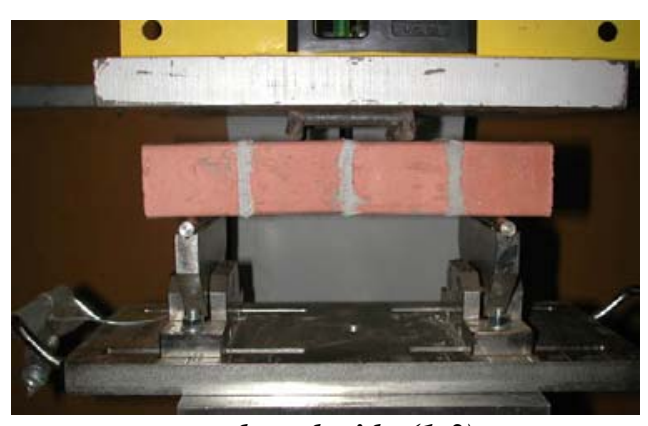

escala reduzida $(1: 3)$

Figura 5.21 - Ensaio deflexão de prismas de 4 blocos nas escalas (1:1) e (1:3)

O ensaio só é considerado válido quando a ruptura do prisma ocorre na junta de argamassa localizada entre os pontos de aplicação de força, que é a região de momento máximo. Caso a ruptura se dê em outro ponto, o ensaio desse exemplar deve ser descartado.

- Essa é uma simplificação da ASTM E-518 (1993), pois o peso-próprio deveria ser considerado como um carregamento distribuído. 
- Equipamentos:

Os corpos-de-prova, em ambas as escalas, são ensaiados no modo de flexão da máquina hidráulica ELE-Autotest 2000, com uma velocidade de carregamento de 0,10 $\mathrm{kN} / \mathrm{s}$ para a escala natural $(1: 1)$ e de $0,04 \mathrm{kN} / \mathrm{s}$ para a escala reduzida (1:3). As velocidades de aplicação de força são pequenas devido às baixas forças de ruptura do prisma.

\subsubsection{6 - Ensaios de "paredinhas" à compressão}

- Procedimentos:

Para a determinação da resistência à compressão e o módulo de deformação da alvenaria na direção normal à junta de assentamento é empregado o ensaio de paredinhas, no total de três exemplares para cada escala. Apesar de existir a norma brasileira NBR 8.949 /1985 para ensaios de paredes de alvenaria estrutural, decide-se por um corpo-de-prova de menores dimensões, recomendado pela RILEM. Por sua facilidade de uso, opta-se pelo forro pacote como material de capeamento.

O módulo de deformação é também calculado segundo as recomendações do ACI 530-92 (1995), da mesma maneira realizada para os blocos e prismas. O coeficiente de Poisson para a direção normal à junta de assentamento $\left(v_{\mathrm{x}}\right)$ é determinado através da relação entre as deformações verticais e horizontais. Para o seu cálculo admite-se o mesmo intervalo empregado no cálculo do módulo de deformação, entre $5 \%$ e $33 \%$ da tensão de ruptura.

Antes do ensaio propriamente dito, realiza-se o escorvamento do corpo-deprova, isto é, aplica-se uma força de aproximadamente $10 \%$ da esperada para a ruptura, objetivando a acomodação da instrumentação. Todos os resultados são dados em função da área bruta.

- Equipamentos:

Tanto os ensaios em escala natural quanto em escala reduzida são realizados na máquina INSTRON, apesar das dimensões da paredinha na escala (1:1) serem relativamente grandes. Os deslocamentos relativos na vertical e na horizontal são medidos por transdutores de deslocamentos. Para a realização das leituras dos dados é utilizado o sistema de aquisição SYSTEM 5000.

Na Figura 5.22 visualiza-se a condição de ensaio da paredinha na escala natural, indicando-se as dimensões médias e a instrumentação (igual para as duas faces). Na mesma figura, observa-se a existência de um perfil de aço, com rigidez suficiente, para 
a aplicação de um carregamento uniformemente distribuído. Para a escala (1:3) procurase representar as mesmas condições do ensaio em escala natural posicionando a instrumentação em pontos homólogos, como pode ser visto na Figura 5.23.
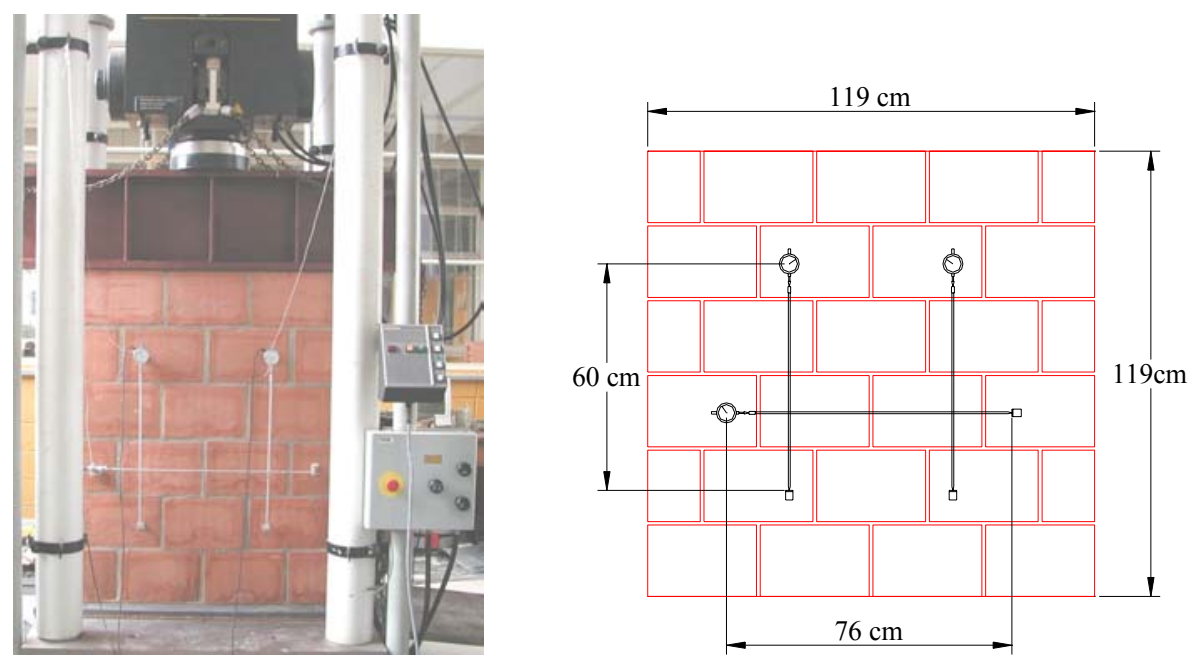

Figura 5.22 - Ensaio da paredinha na escala natural (1:1) na direção normal à junta.
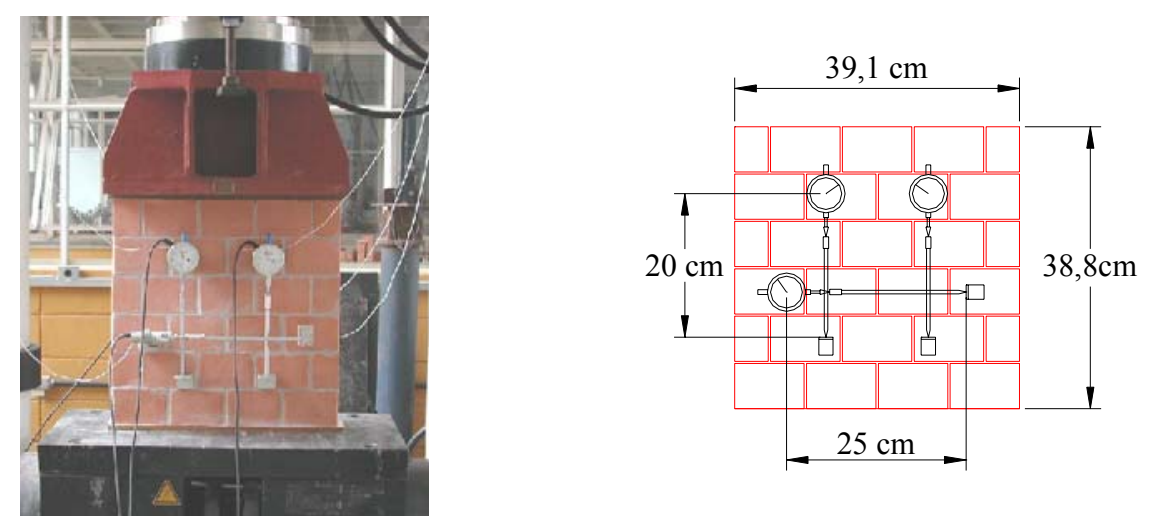

Figura 5.23 - Ensaio da paredinha na escala (1:3) na direção normal à junta.

A força é aplicada na paredinha, de ambas as escalas, de maneira que o pistão da máquina se desloque a uma velocidade de $0,01 \mathrm{~mm} / \mathrm{s}$. Com o intuito de se evitar uma ruptura brusca, a velocidade é reduzida à metade próximo à ruptura. Ressalva-se que não são realizadas marcações de fissuras durante a realização dos ensaios porque elas mesmas só se tornam visíveis próximo à ruptura. Como a aplicação do carregamento é contínua, o procedimento não seria seguro.

$\underline{\text { 5.3.1.7 - Ensaios de "paredinhas" à compressão na direção paralela à junta de }}$ assentamento

- Procedimentos:

No ensaio à compressão paralela à junta de assentamento, também utilizam-se as paredinhas como corpos-de-prova, com o mesmo número de exemplares (três). Elas 
possuem as mesmas dimensões do ensaio à compressão normal à junta, tendo como única diferença a posição em que se realiza o ensaio. Como não há nenhuma disposição normativa sobre este tipo de ensaio, procuram-se adotar procedimentos semelhantes ao ensaio anterior.

Para o capeamento, emprega-se uma massa tipo epóxi, gerando um trabalho bem maior que o uso do forro pacote. Entretanto, fez-se esta opção por se verificar que o bloco isolado nessa direção apresenta uma grande sensibilidade ao tipo de capeamento, como comentado anteriormente.

O módulo de deformação e o coeficiente de Poisson $\left(v_{\mathrm{y}}\right)$ para a direção paralela à junta de assentamento são determinados de modo análogo ao item anterior. Todos os resultados referem-se à área bruta. Neste caso, também se realiza o escorvamento do corpo-de-prova.

\section{- Equipamentos:}

As figuras 5.24 e 5.25 ilustram, respectivamente, as condições do experimento nas escalas natural e reduzida, apresentando as dimensões médias e o posicionamento da instrumentação (iguais para as faces opostas).
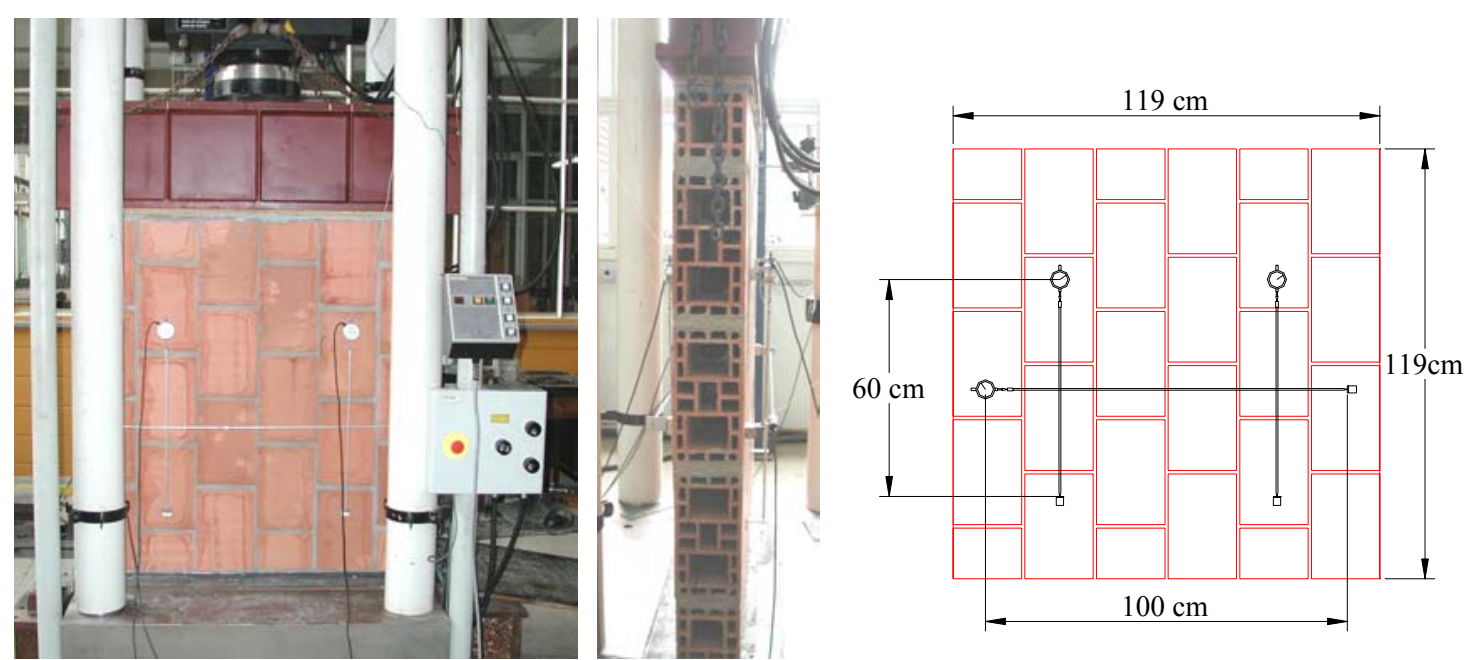

Figura 5.24 - Ensaio de paredinhas na escala natural (1:1) na direção paralela à junta
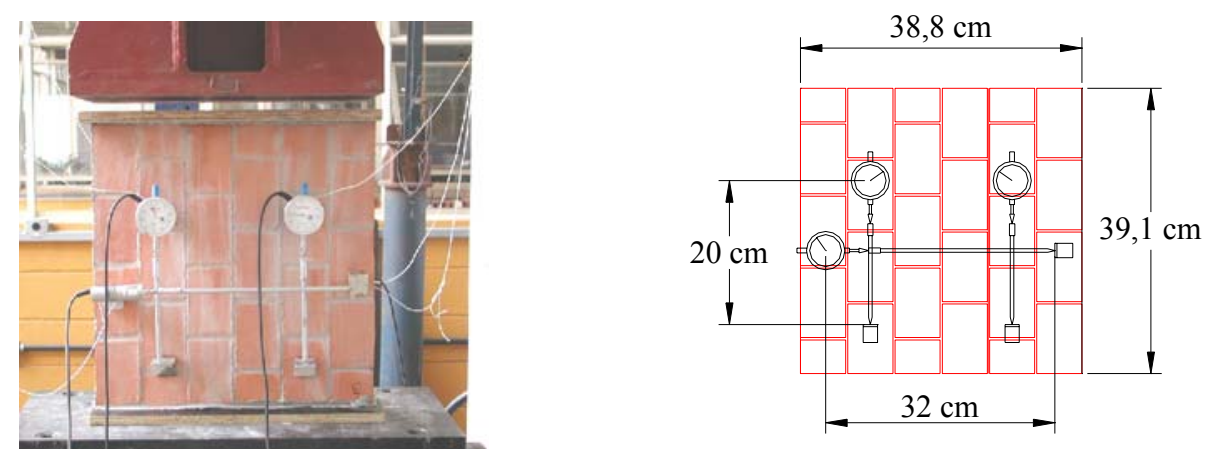

Figura 5.25- Ensaio de paredinhas na escala (1:3) na direção paralela à junta 
A única diferença em relação ao ensaio apresentado anteriormente é a velocidade de aplicação do carregamento. Por ser um tipo de ensaio não usual, há inicialmente o receio de uma ruptura extremamente frágil. Dessa maneira, utiliza-se uma velocidade baixa, sendo que o pistão da máquina se desloca a apenas $0,005 \mathrm{~mm} / \mathrm{s}$. Ainda assim, na iminência da ruína, a velocidade é reduzida para $0,002 \mathrm{~mm} / \mathrm{s}$. Devido à insegurança sobre a forma de ruptura, não é realizada a marcação de fissuras durante a execução do experimento.

\subsection{2 - Resultados dos ensaios de argamassa}

Em relação aos resultados obtidos para as argamassas em escala natural, que estão apresentados na Tabela 5.40, é necessário tecer alguns comentários. Os corpos-deprova de argamassa correspondentes à paredinha 6 não são levados em conta nos cálculos da média e nem do valor máximo, devido às suas grandes resistências quando comparados aos demais. A sua consideração elevaria o coeficiente de variação da resistência de $11 \%$ para $36 \%$. Não se acredita em algum tipo de erro no traço, visto que os materiais são controlados por massa e a consistência não foge à média obtida para as demais argamassas. A única modificação que ocorre é a abertura de novos sacos de cimento e cal, mas de mesmos tipos e marcas. Na Figura 5.26 percebe-se facilmente a discrepância de comportamento da argamassa considerada problemática (N6) em confronto com as demais.

Tabela 5.40 - Resultados dos ensaios da argamassa utilizada na escala natural (1:1)

\begin{tabular}{|c|c|c|c|c|}
\cline { 2 - 5 } \multicolumn{1}{c|}{} & $\begin{array}{c}\text { Tensão } \\
\text { (MPa) }\end{array}$ & $\begin{array}{c}\text { Módulo de } \\
\text { deformação (MPa) }\end{array}$ & $\begin{array}{c}\text { Deformação } \\
\text { última }\end{array}$ & $\begin{array}{c}\text { Consistência } \\
\text { (cm) }\end{array}$ \\
\hline Média & 3,68 & 5876,7 & $-1,84 \%$ & 22,5 \\
\hline Máximo & 4,38 & 6185,6 & $-2,28 \%$ & 24,0 \\
\hline Mínimo & 2,80 & 5373,5 & $-1,42 \%$ & 21,0 \\
\hline Coef. Variação & $11,2 \%$ & $6,2 \%$ & $17,1 \% \%$ & $5,4 \%$ \\
\hline
\end{tabular}

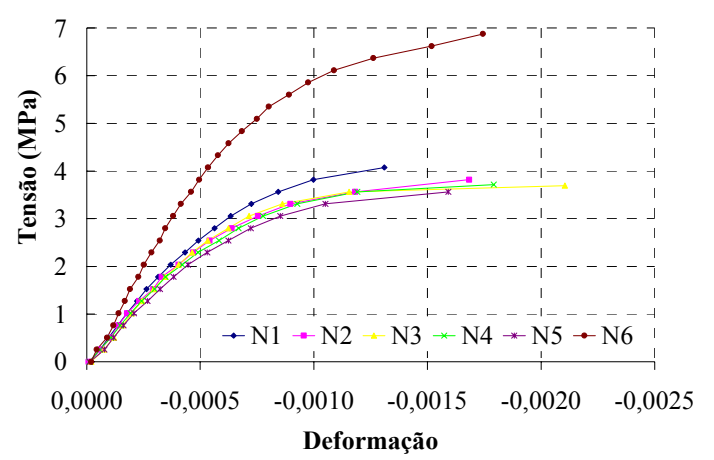

Figura 5.26 - Diagramas tensão x deformação da argamassa utilizada na escala natural (1:1) 
Os resultados obtidos para as argamassas na escala (1:3) são exibidos na Tabela 5.41, percebendo-se que os coeficientes de variação apresentam valores razoáveis, com exceção da deformação última da argamassa (20\%), em que as medidas individuais são valores muito pequenos. Isto também pode ser percebido nos diagramas tensão $\mathrm{x}$ deformação das argamassas mostrados na Figura 5.27.

Tabela 5.41- Resultados dos ensaios da argamassa utilizada na escala (1:3)

\begin{tabular}{|c|c|c|c|c|}
\cline { 2 - 5 } \multicolumn{1}{c|}{} & $\begin{array}{c}\text { Tensão } \\
\text { (MPa) }\end{array}$ & $\begin{array}{c}\text { Módulo de } \\
\text { deformação (MPa) }\end{array}$ & $\begin{array}{c}\text { Deformação } \\
\text { última }\end{array}$ & $\begin{array}{c}\text { Consistência } \\
(\mathbf{c m})\end{array}$ \\
\hline Média & 4,20 & 7057,8 & $-1,43 \%$ & 21,7 \\
\hline Máximo & 4,99 & 8063,0 & $-1,81 \%$ & 23,0 \\
\hline Mínimo & 3,31 & 6192,7 & $-1,09 \%$ & 20,0 \\
\hline Coef. Variação & $11 \%$ & $9,5 \%$ & $20 \%$ & $5,5 \%$ \\
\hline
\end{tabular}

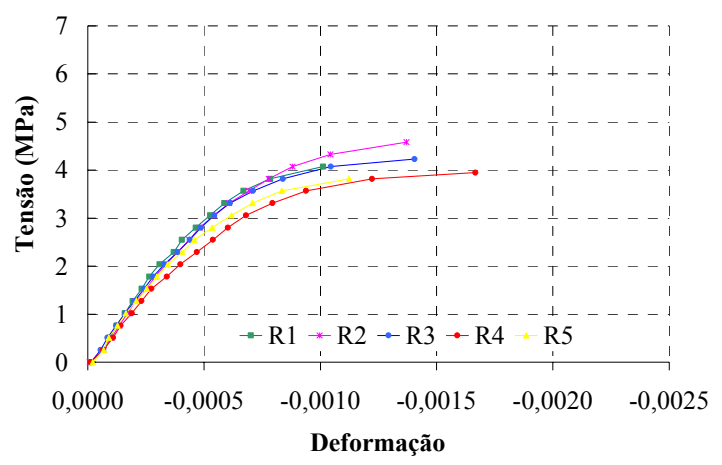

Figura 5.27- Diagramas tensão x deformação da argamassa utilizada na escala (1:3)

Observa-se que a consistência média das argamassas produzidas para os ensaios em escala (1:1) está dentro do valor recomendado pela NBR 8798/1985. Já as argamassas referentes à escala reduzida estão um pouco abaixo do valor estipulado em norma. Entretanto, em todos os casos a trabalhabilidade é considerada satisfatória pelo pedreiro.

Ressalta-se que a resistência à compressão também é inferior à de argamassas produzidas em outras pesquisas com o mesmo traço, relação água/cimento e tipo de cimento. Julga-se que isso ocorra porque os corpos-de-prova de argamassa não foram curados normalmente, ficando expostos às condições de umidade e temperatura do laboratório.

Na Tabela 5.42 realiza-se a comparação entre as resistências e módulos de deformação das argamassas utilizadas para as escala natural e reduzida. Observa-se que para a escala (1:3) a resistência e o módulo são superiores aos da escala (1:1), entretanto 
de uma maneira menos pronunciada que a observada na comparação das resistências e módulos dos blocos (itens 5.2.4 e 5.2.8).

Tabela 5.42- Comparação entre as argamassas para as escalas (1:1) e (1:3)

\begin{tabular}{|c|c|c|c|}
\hline Argamassa & Escala (1:3) & Escala (1:1) & $(\mathbf{1 : 3 )} /(\mathbf{1 : 1})$ \\
\hline Resistência (MPa) & 4,20 & 3,68 & $+14 \%$ \\
\hline Módulo (MPa) & 7057,8 & 5876,7 & $+20 \%$ \\
\hline
\end{tabular}

\subsection{3 - Resultados dos ensaios de compressão de prismas de três blocos}

Os resultados obtidos nos ensaios de prismas em escala natural são apresentados na Tabela 5.43. Observa-se que a variação dos resultados para a tensão de ruptura é da ordem de $17 \%$, enquanto que para a deformação última e o módulo de deformação os coeficientes de variação já são considerados altos (acima de 23\%).

Tabela 5.43 - Resultados dos ensaios dos prisma de 3 blocos na escala natural (1:1)

\begin{tabular}{|c|c|c|c|c|}
\cline { 2 - 5 } \multicolumn{1}{c|}{} & $\begin{array}{c}\text { Força } \\
(\mathbf{k N})\end{array}$ & $\begin{array}{c}\text { Tensão- } \\
\text { A.bruta(MPa) }\end{array}$ & $\begin{array}{c}\text { Módulo - } \\
\text { A.bruta(MPa) }\end{array}$ & $\begin{array}{c}\text { Deformação } \\
\text { de ruptura }\end{array}$ \\
\hline Média & 234,8 & 5,83 & 5644,6 & $-1,49 \%$ \\
\hline Máximo & 297,1 & 7,38 & 8058,9 & $-2,38 \%$ \\
\hline Mínimo & 182,1 & 4,52 & 4101,9 & $-0,72 \%$ \\
\hline Coef. Var. & $16,9 \%$ & $16,9 \%$ & $23,7 \%$ & $38,2 \%$ \\
\hline
\end{tabular}

A Tabela 5.44 exibe os resultados referentes à escala (1:3), sendo que os coeficientes de variação para a tensão de ruptura e o módulo de deformação são usuais. Todavia, para a deformação última a variação é considerada alta (cerca de 22\%), mas a diferença numérica é pequena, pois os valores individuais das medidas são muito pequenos.

Tabela 5.44- Resultados dos ensaios dos prisma de 3 blocos na escala reduzida (1:3)

\begin{tabular}{|c|c|c|c|c|}
\cline { 2 - 5 } \multicolumn{1}{c|}{} & $\begin{array}{c}\text { Força } \\
(\mathbf{k N )}\end{array}$ & $\begin{array}{c}\text { Tensão - } \\
\text { A.bruta(MPa) }\end{array}$ & $\begin{array}{c}\text { Módulo - } \\
\text { A.bruta(MPa) }\end{array}$ & $\begin{array}{c}\text { Deformação } \\
\text { última }\end{array}$ \\
\hline Média & 52,6 & 11,74 & 10793,8 & $-1,03 \%$ \\
\hline Máximo & 63,9 & 14,25 & 11488,0 & $-1,25 \%$ \\
\hline Mínimo & 39,1 & 8,72 & 10082,0 & $-0,67 \%$ \\
\hline Coef. Var. & $12,7 \%$ & $12,7 \%$ & $4,7 \%$ & $21,9 \%$ \\
\hline
\end{tabular}

A Figura 5.28 apresenta os diagramas tensão x deformação dos blocos presentes nos prismas na escala (1:1), indicando um comportamento praticamente linear do bloco intermediário até próximo à sua ruptura. Lembra-se que o bloco isolado apesar de possuir perturbações perto da ruptura, tem um comportamento linear para a faixa de tensões a que o bloco presente no prisma está submetido (ver item 5.2.8). 


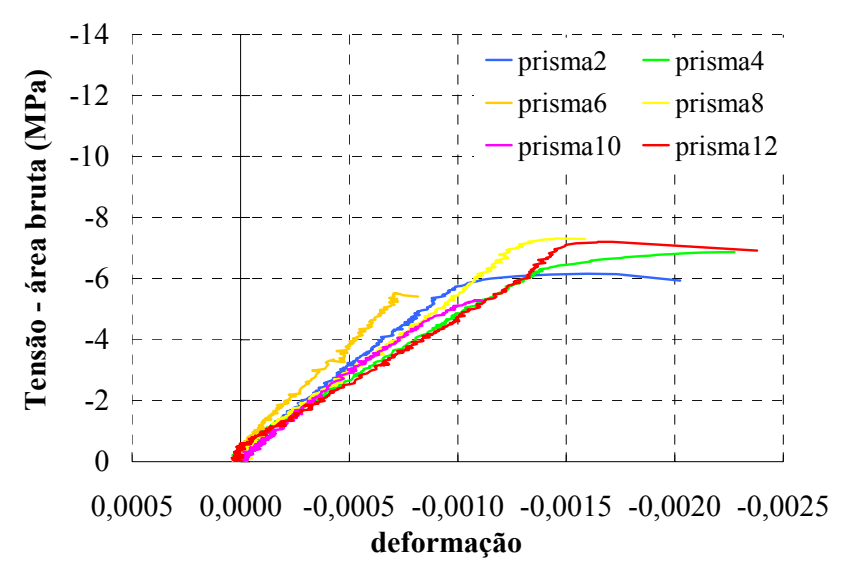

Figura 5.28 - Diagramas tensão x deformação dos blocos nos prismas na escala (1:1)

Os diagramas tensão x deformação dos blocos presentes nos prismas na escala reduzida também são praticamente lineares até a sua ruptura (Figura 5.29), indicando o mesmo comportamento observado na determinação do módulo de deformação do bloco isolado na mesma escala. Ressalta-se que um exemplar para determinação do módulo de deformação na escala (1:3) é perdido pela aplicação errônea do carregamento.

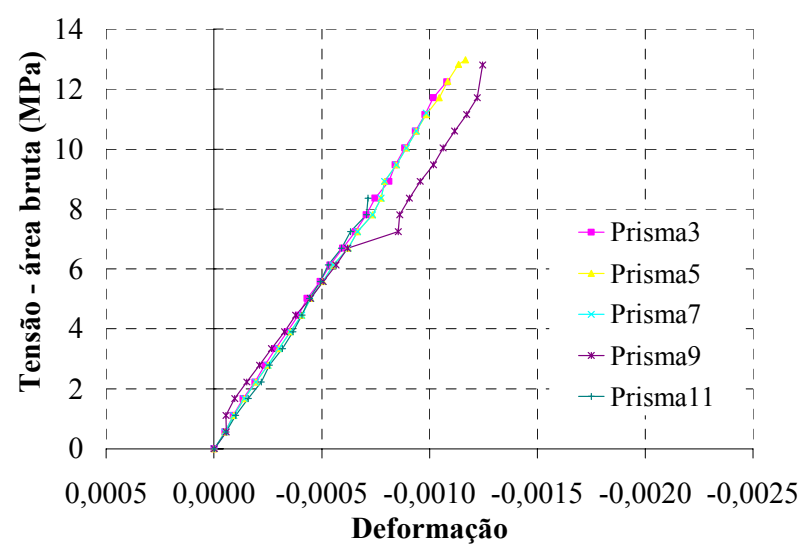

Figura 5.29- Diagramas tensão x deformação dos blocos nos prismas na escala (1:3)

As comparações entre os prismas nas diferentes escalas estão apresentadas na Tabela 5.45. Semelhante aos ensaios de blocos isolados (itens 5.2.4 e 5.2.8), a resistência e o módulo de deformação dos prismas em escala reduzida (1:3) são 91\% superiores aos da escala natural, aproximadamente da mesma ordem de grandeza observada nos blocos (116\%). Um fato a se ressaltar é que as relações entre o módulo e a resistência do prisma para ambas as escalas possuem valores próximos, com diferença de apenas $5 \%$. 
Tabela 5.45 - Comparações entre os prismas nas escalas (1:1) e (1:3) -área bruta

\begin{tabular}{|c|c|c|c|}
\hline Prisma & Escala (1:3) & Escala (1:1) & $\mathbf{( 1 : 3 ) ~ / ~ ( 1 : 1 ) ~}$ \\
\hline Resistência (MPa) & 11,74 & 5,83 & $+101,4 \%$ \\
\hline Módulo de deformação (MPa) & 10793,8 & 5644,6 & $+91,2 \%$ \\
\hline $\begin{array}{c}\text { Módulo de deformação - prisma / } \\
\text { Resistência do prisma }\end{array}$ & 919,4 & 968,2 & $-5,0 \%$ \\
\hline
\end{tabular}

Na Tabela 5.46 apresentam-se comparações envolvendo a resistência e o módulo de deformação dos prismas e dos blocos nas escalas natural e reduzida. Observa-se que as diferenças entre as razões são de no máximo $11,7 \%$, indicando uma boa representatividade dos modelos reduzidos. Cabe aqui relembrar que o módulo de deformação do prisma é na verdade o módulo de deformação do bloco medido no ensaio de prisma. Por isso, as relações entre os módulos de prismas e blocos devem mesmo ser próximas à unidade.

Tabela 5.46- Comparações das relações envolvendo prismas e blocos nas escalas (1:1) e (1:3)

\begin{tabular}{|c|c|c|c|}
\hline Relações & Escala (1:3) & Escala (1:1) & $(\mathbf{1 : 3 )} /(\mathbf{1 : 1 )}$ \\
\hline $\begin{array}{c}\text { Módulo de deformação - prisma / } \\
\text { Resistência do bloco }\end{array}$ & 356,1 & 390,9 & $-8,9 \%$ \\
\hline $\begin{array}{c}\text { Módulo de deformação - prisma / } \\
\text { Módulo de deformação - bloco }\end{array}$ & 0,968 & 1,096 & $-11,7 \%$ \\
\hline $\begin{array}{c}\text { Resistência do prisma / } \\
\text { Resistência do bloco }\end{array}$ & 0,387 & 0,404 & $-4,2 \%$ \\
\hline
\end{tabular}

\subsection{4 - Resultados dos ensaios de prismas de dois blocos submetidos à compressão} paralela à junta

Os resultados dos ensaios para a escala natural e reduzida são exibidos, respectivamente, nas tabelas 5.47 e 5.48. Para a escala (1:1) a variação é de $16 \%$, sendo da mesma ordem de grandeza do ensaio de prisma de três blocos. Contudo, para a escala (1:3) o coeficiente de variação é de $25 \%$, quase o dobro do observado no ensaio do prisma na direção normal à junta.

Tabela 5.47 - Resultados dos ensaios de prismas de 2 blocos na escala natural (1:1)

\begin{tabular}{|c|c|c|}
\cline { 2 - 3 } \multicolumn{1}{c|}{} & Força (kN) & Tensão-A.bruta(MPa) \\
\hline Média & 29,3 & 1,10 \\
\hline Máximo & 35,1 & 1,32 \\
\hline Mínimo & 22,9 & 0,86 \\
\hline Coef. Variação & $16,0 \%$ & $16,0 \%$ \\
\hline
\end{tabular}


Tabela 5.48 - Resultados dos ensaios de prismas de 2 blocos na escala (1:3)

\begin{tabular}{|c|c|c|}
\cline { 2 - 3 } \multicolumn{1}{c|}{} & Força (kN) & Tensão -A.bruta(MPa) \\
\hline Média & 10,7 & 3,66 \\
\hline Máximo & 15,8 & 5,40 \\
\hline Mínimo & 8,5 & 2,90 \\
\hline Coef. Variação & $25,1 \%$ & $25,1 \%$ \\
\hline
\end{tabular}

A forma de ruptura para a escala reduzida (1:3) está mostrada na Figura 5.30, onde visualizam-se as fissuras nas regiões de interseção dos septos. Nos corpos-deprova em escala (1:1) a ruptura se dá de maneira semelhante, todavia de maneira explosiva, não havendo por isso o seu registro fotográfico.

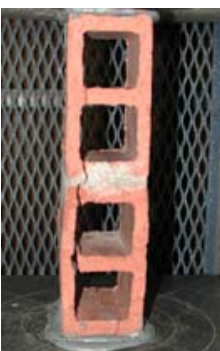

Figura 5.30 - Forma de ruptura do prisma de 2 blocos na escala (1:3)

Comparações entre os ensaios de prismas de 2 blocos e de blocos na direção paralela à junta de assentamento nas escalas natural e reduzida são apresentadas na Tabela 5.49. Percebe-se mais uma vez, que os valores obtidos para a escala (1:3) são superiores ao da escala $(1: 1)$, cerca de $230 \%$. Essa diferença é inferior a observada nos ensaios de blocos nessa mesma direção (item 5.2.7), aproximadamente 400\%. Como conseqüência, a eficiência entre a resistência do prisma de 2 blocos e do bloco nessa direção paralela à junta na escala natural é superior a obtida nos modelos reduzidos.

Tabela 5.49 - Comparações entre os ensaios de prismas e de blocos na direção paralela à junta de assentamento nas escalas (1:1) $e$ (1:3)

\begin{tabular}{|c|c|c|c|}
\hline Relações & Escala (1:3) & Escala (1:1) & $\mathbf{( 1 : 3 ) ~ / ~ ( 1 : 1 ) ~}$ \\
\hline Resistência - prisma(MPa) & 3,66 & 1,10 & $+232,7 \%$ \\
\hline $\begin{array}{c}\text { Resistência - prisma / } \\
\text { Resistência - bloco }\end{array}$ & 0,349 & 0,524 & $-33,3 \%$ \\
\hline
\end{tabular}

$\mathrm{Na}$ Tabela 5.50 faz-se uma tentativa de se correlacionar, para as duas escalas estudadas, as resistências dos prismas nas direções paralela e normal à junta de assentamento. Contudo, os valores exibem uma grande diferença, acima de $65 \%$, indicando que a influência da seção transversal dos blocos é mais acentuada para os ensaios nessa direção. 
Tabela 5.50 - Comparações entre as resistências dos prismas na direção paralela e normal à junta de assentamento nas escalas (1:1) e (1:3)

\begin{tabular}{|c|c|c|c|}
\hline Relações $^{*}$ & Escala (1:3) & Escala (1:1) & $(\mathbf{1 : 3 )} /(\mathbf{1 : 1 )}$ \\
\hline $\begin{array}{c}\text { Prisma (paralela) / } \\
\text { Prisma (normal) }\end{array}$ & 0,312 & 0,189 & $+65,4 \%$ \\
\hline
\end{tabular}

* Direção do ensaio entre parênteses

\subsection{5 - Resultados dos ensaios de prismas de quatro blocos à flexão}

Por meio dos ensaios de prismas de quatro blocos à flexão obtêm-se os valores da resistência de aderência bloco-argamassa. Os resultados para as escalas natural (1:1) e reduzida (1:3), em relação à seção bruta e líquida dos blocos, estão apresentados na Tabela 5.51 e na Tabela 5.52, respectivamente.

Tabela 5.51 -Resistência de aderência para a escala natural (1:1)

\begin{tabular}{|c|c|c|c|}
\cline { 2 - 4 } \multicolumn{1}{c|}{} & $\begin{array}{c}\text { Força total } \\
(\mathbf{k N})\end{array}$ & $\begin{array}{c}\text { Resist. de aderência - } \\
\text { Área bruta (MPa) }\end{array}$ & $\begin{array}{c}\text { Resist. de aderência - } \\
\text { Área líquida (MPa) }\end{array}$ \\
\hline Média & 2,23 & 0,235 & 0,406 \\
\hline Máximo & 2,31 & 0,243 & 0,420 \\
\hline Mínimo & 2,08 & 0,220 & 0,379 \\
\hline Coef. Variação & $4,5 \%$ & $4,5 \%$ & $4,5 \%$ \\
\hline \multicolumn{3}{|c|}{} & \multicolumn{2}{c|}{} \\
\hline
\end{tabular}

Tabela 5.52 - Resistência de aderência para a escala reduzida (1:3)

\begin{tabular}{|c|c|c|c|}
\cline { 2 - 4 } \multicolumn{1}{c|}{} & $\begin{array}{c}\text { Força total } \\
(\mathbf{k N})\end{array}$ & $\begin{array}{c}\text { Resist. de aderência - } \\
\text { Área bruta (MPa) }\end{array}$ & $\begin{array}{c}\text { Resist. de aderência - } \\
\text { Área líquida (MPa) }\end{array}$ \\
\hline Média & 0,42 & 0,388 & 0,510 \\
\hline Máximo & 0,51 & 0,467 & 0,613 \\
\hline Mínimo & 0,36 & 0,328 & 0,431 \\
\hline Coef. Variação & $16,2 \%$ & $16,2 \%$ & $16,2 \%$ \\
\hline \multicolumn{3}{|c|}{} \\
\hline
\end{tabular}

No caso dos ensaios em escala natural, dois prismas são descartados devido à ruptura fora da região central. Enquanto que apenas um corpo-de-prova em escala reduzida é descartado pelo mesmo motivo. As formas de ruptura corretas para as duas escalas estão ilustradas na Figura 5.31

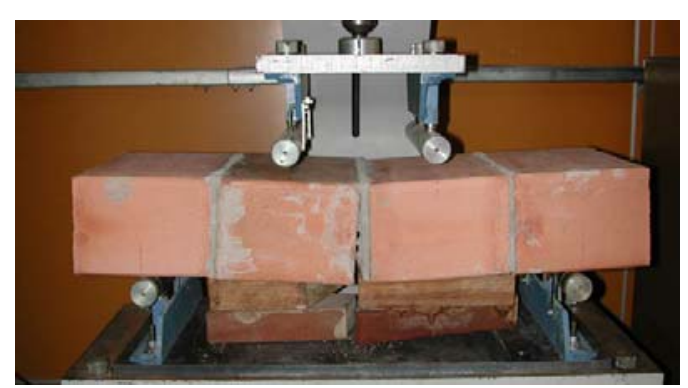

escala natural (1:1)

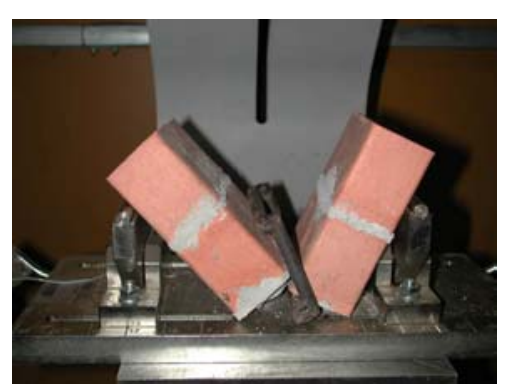

escala reduzida (1:3)

Figura 5.31 - Forma de ruptura do prisma de 4 blocos nas escalas (1:1) e (1:3) 
Ressalta-se que estes ensaios foram realizados posteriormente aos demais de caracterização, o que gerou diferenças nas resistências das argamassas, pois, apesar da manutenção do traço e da relação água/cimento, a condição de cura dos corpos-deprova variaram de acordo com as condições climáticas do laboratório durante o período de cada execução. Dessa forma, o objetivo do ensaio é analisar qualitativamente o comportamento da aderência bloco-argamassa nas escalas (1:1) e (1:3).

A Tabela 5.53 apresenta as comparações das tensões de aderência blocoargamassa nas escalas (1:1) e (1:3), tanto em relação à seção bruta quanto à líquida. Observa-se que a resistência de aderência para a escala reduzida (1:3), ao considerar a seção bruta, é $65 \%$ superior à escala natural (1:1). Porém, ao se considerar a seção líquida dos blocos esta diferença se reduz a $25 \%$.

Tabela 5.53 - Comparações entre as resistências de aderência nas escalas (1:1) e (1:3)

\begin{tabular}{|c|c|c|c|}
\cline { 2 - 4 } \multicolumn{1}{c|}{} & Escala (1:3) & Escala (1:1) & $(\mathbf{1 : 3 )} /(\mathbf{1 : 1 )}$ \\
\hline $\begin{array}{c}\text { Resist. de aderência - } \\
\text { Área bruta (MPa) }\end{array}$ & 0,388 & 0,235 & $+65,1 \%$ \\
\hline $\begin{array}{c}\text { Resist. de aderência - } \\
\text { Área líquida (MPa) }\end{array}$ & 0,510 & 0,406 & $+25,6 \%$ \\
\hline
\end{tabular}

Compara-se na Tabela 5.54 a aderência com as resistências dos blocos e dos prismas na direção normal à junta de assentamento nas escalas natural (1:1) e reduzida (1:3). As relações são feitas considerando-se os valores referidos à seção bruta dos blocos. Verifica-se que na escala reduzida as razões entre a aderência e as resistências dos blocos e dos prismas são cerca de $20 \%$ inferiores às obtidas na escala natural. Com isso, apesar dos corpos-de-prova em escala (1:3) apresentarem uma maior resistência de aderência em termos absolutos, o seu desempenho relativo à compressão é inferior ao dos corpos-de-prova em escala $(1: 1)$.

Tabela 5.54- Comparações entre as relações das tensões de aderência com as resistências dos blocos e dos prismas na direção normal à junta de assentamento nas escalas (1:1) e (1:3)

\begin{tabular}{|c|c|c|c|}
\cline { 2 - 4 } \multicolumn{1}{c|}{} & Escala (1:3) & Escala (1:1) & $(\mathbf{1 : 3 )} /(\mathbf{1 : 1 )}$ \\
\hline $\begin{array}{c}\text { Resit. de aderência / } \\
\text { Resistência dos blocos }\end{array}$ & $1,28 \%$ & $1,63 \%$ & $-21,5 \%$ \\
\hline $\begin{array}{c}\text { Resist. de aderência / } \\
\text { Resistência dos prismas }\end{array}$ & $3,30 \%$ & $4,03 \%$ & $-18,1 \%$ \\
\hline
\end{tabular}

Obs.: valores referidos à seção bruta dos blocos 


\subsection{6 - Resultados dos ensaios de "paredinhas" à compressão}

A força de ruptura, a tensão de ruptura, o módulo de deformação e a deformação última para as três paredinhas ensaiadas na escala natural $(1: 1)$ são exibidos na Tabela 5.55. Em todos os casos os coeficientes de variação podem ser considerados satisfatórios, destacando-se a pequena variação encontrada para a deformação última (abaixo dos $2 \%$ ).

Os resultados dos três experimentos na escala reduzida (1:3) são exibidos na Tabela 5.56. Percebe-se que, nesta escala, a tensão de ruptura e a deformação última apresentam uma grande variação de resultados, ao contrário do módulo de deformação que possui um coeficiente de variação relativamente pequeno. Essa grande variação dos resultados se deve à própria variabilidade dos blocos e à pequena quantidade de ensaios.

Tabela 5.55- Resultados dos ensaios de paredinhas na escala (1:1) na direção normal à junta

\begin{tabular}{|c|c|c|c|c|}
\cline { 2 - 5 } \multicolumn{1}{c|}{} & $\begin{array}{c}\text { Força } \\
(\mathbf{k N )}\end{array}$ & $\begin{array}{c}\text { Tensão - } \\
\text { A.bruta(MPa) }\end{array}$ & $\begin{array}{c}\text { Módulo - } \\
\text { A.bruta(MPa) }\end{array}$ & $\begin{array}{c}\text { Deformação } \\
\text { última }\end{array}$ \\
\hline Paredinha 1 & 644,3 & 3,87 & 5844,9 & $-0,71 \%$ \\
\hline Paredinha 2 & 593,7 & 3,56 & 7169,7 & $-0,71 \%$ \\
\hline Paredinha 3 & 464,4 & 2,79 & 6060,4 & $-0,69 \%$ \\
\hline Média & 567,5 & 3,41 & 6358,3 & $-0,70 \%$ \\
\hline Coef. Var. & $16,3 \%$ & $16,3 \%$ & $11,2 \%$ & $1,9 \%$ \\
\hline
\end{tabular}

Tabela 5.56- Resultados dos ensaios de paredinhas na escala (1:3) na direção normal à junta

\begin{tabular}{|c|c|c|c|c|}
\cline { 2 - 5 } \multicolumn{1}{c|}{} & $\begin{array}{c}\text { Força } \\
(\mathbf{k N})\end{array}$ & $\begin{array}{c}\text { Tensão - } \\
\text { A.bruta(MPa) }\end{array}$ & $\begin{array}{c}\text { Módulo - } \\
\text { A.bruta(MPa) }\end{array}$ & $\begin{array}{c}\text { Deformação } \\
\text { última }\end{array}$ \\
\hline Paredinha 1 & 102,3 & 5,57 & 8552,2 & $-0,77 \%$ \%o \\
\hline Paredinha 2 & 185,8 & 10,11 & 7509,7 & $-2,07 \%$ \%o \\
\hline Paredinha 3 & 124,8 & 6,79 & 7292,9 & $-1,41 \%$ \\
\hline Média & 137,6 & 7,49 & 7784,9 & $-1,42 \%$ \\
\hline Coef. Var. & $31,4 \%$ & $31,4 \%$ & $8,6 \%$ & $45,7 \%$ \\
\hline
\end{tabular}

As evoluções das deformações médias, nas direções vertical e horizontal, em relação à tensão média aplicada para cada paredinha ensaiada na escala natural estão ilustradas na Figura 5.32. Verifica-se que, em média, até 50\% da tensão de ruptura, o comportamento tensão x deformação vertical é linear, nível esse inferior ao indicado por Hendry (1981) como cerca de $75 \%$ para a alvenaria de unidades cerâmicas.

A Figura 5.33 mostra os diagramas tensão x deformação das três paredinhas ensaiadas na escala (1:3), ilustrando as deformações médias nas direções vertical e horizontal. Observa-se em todos os casos um comportamento praticamente linear até cerca de $45 \%$, em média, da tensão de ruptura, com perda de rigidez a partir desse nível de tensão. 


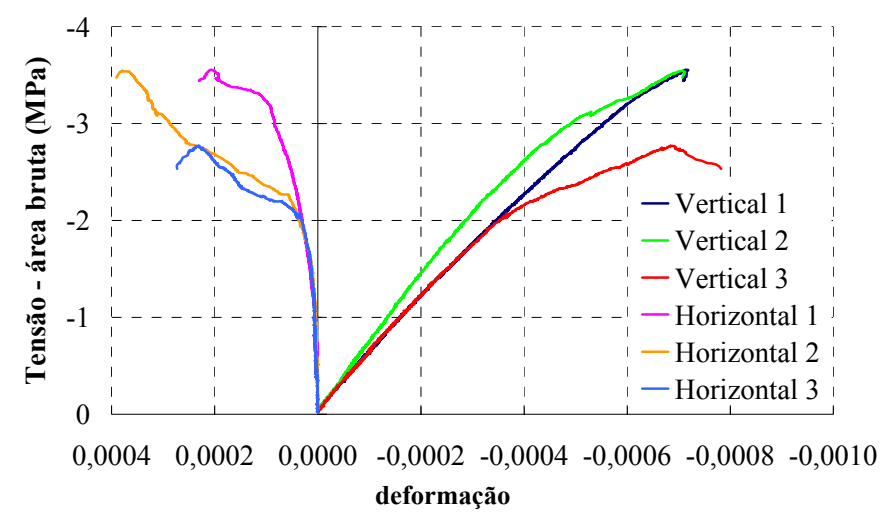

Figura 5.32 - Diagrama tensão x deformação das paredinhas na escala natural (1:1)

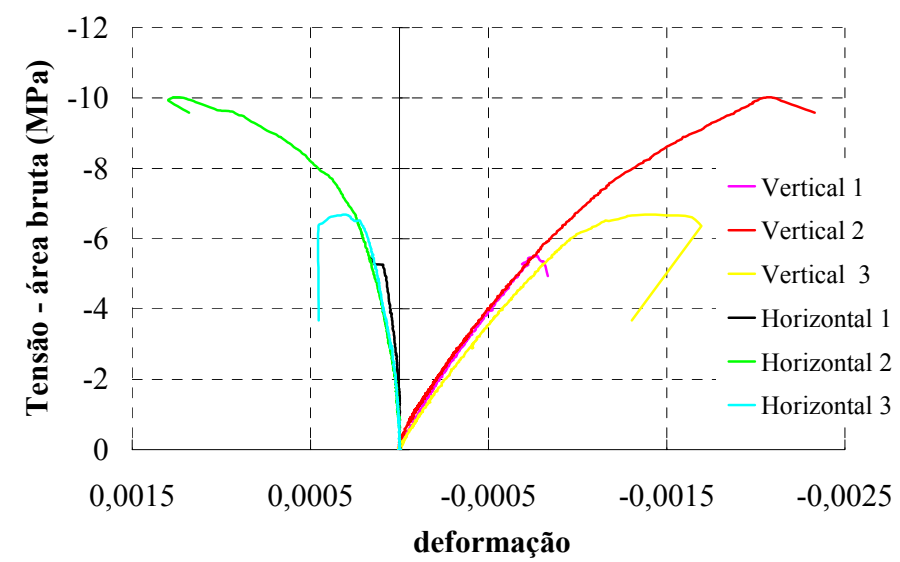

Figura 5.33 - Diagrama tensão $x$ deformação das paredinhas na escala (1:3)

$\mathrm{O}$ coeficiente de Poisson na direção normal à junta de assentamento $\left(v_{\mathrm{x}}\right)$ obtido para a escala (1:1) é igual a 0,06 , com um coeficiente de variação da mesma ordem de grandeza do encontrado para a resistência (cerca de 16\%). Ressalta-se que as leituras das deformações horizontais são bastante reduzidas, mesmo utilizando uma base de medida considerável $(76 \mathrm{~cm})$. Para a escala reduzida, o valor médio de $v_{\mathrm{x}}$ encontrado é igual a 0,12 , com um coeficiente de variação de quase 50\%. Acredita-se que essa grande divergência é causada tanto pela variabilidade do material, quanto pela pequena ordem de grandeza das leituras das deformações horizontais; neste caso a base de medida é de $25 \mathrm{~cm}$.

A Figura 5.34 mostra a forma de ruptura das paredinhas em escala natural, destacando-se as fissuras por meio de elementos gráficos. Todas apresentam fissuras verticais em sua extensão, sendo que as paredinhas 1 e 2 possuem um quadro de fissuração mais intenso. Considera-se que todas as paredinhas têm uma ruptura típica por compressão uniaxial, não ocorrendo fatores externos (excentricidade do carregamento) ou internos (variabilidade de rigidez do material) que levassem a uma ruptura excêntrica. 
Para a escala (1:3), as formas de ruptura das três paredinhas são ilustradas na Figura 5.35, observando-se que apenas o exemplar 2 apresenta uma fissuração intensa em seu todo. As paredinhas 1 e 3 têm um quadro de fissuração mais localizado em um dos seus lados, indicando excentricidade do carregamento. Entretanto, sempre no início do ensaio tomava-se o cuidado de centralizar os exemplares, de maneira que as leituras dos quatro transdutores verticais não possuíssem diferenças significativas. A divergência das leituras verticais inicia-se no mesmo estágio em que ocorre a perda de linearidade do comportamento do material. Por esse motivo, acredita-se que a excentricidade na ruptura tenha sido originada pela própria variabilidade do material e pelo progresso não uniforme da fissuração.

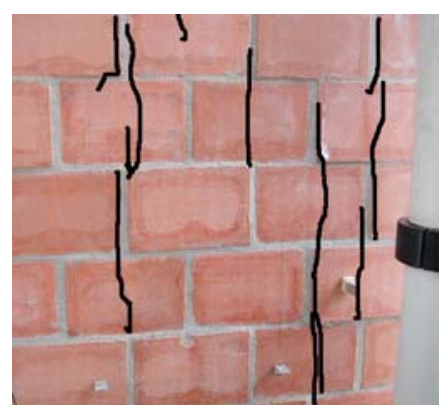

Paredinha 1

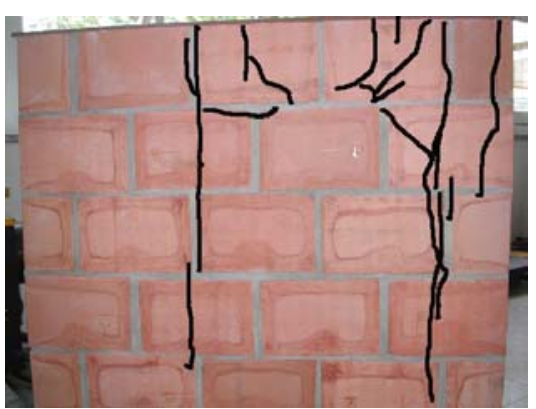

Paredinha 2

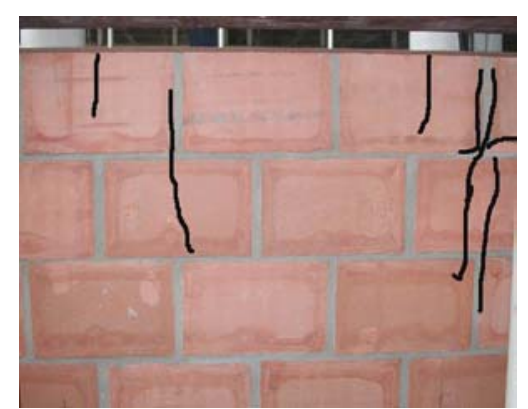

Paredinha 3

Figura 5.34- Formas de ruptura das paredinhas na escala natural (1:1)

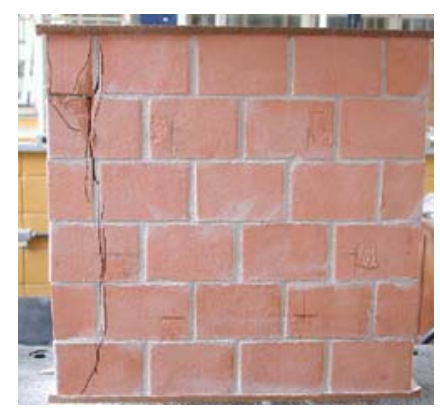

Paredinha 1

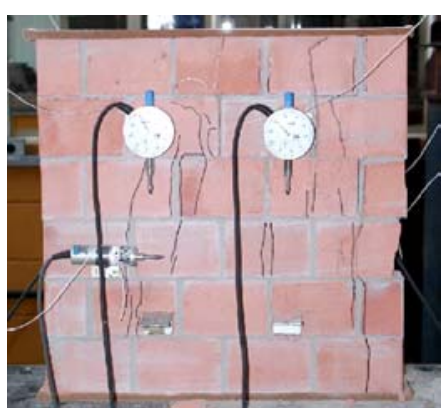

Paredinha 2

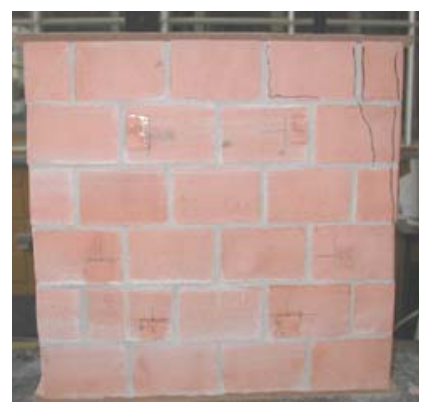

Paredinha 3

Figura 5.35 - Formas de ruptura das paredinhas na escala reduzida (1:3)

Comparações envolvendo as resistências das paredinhas e de diferentes corposde-provas ensaiados na direção normal à junta de assentamento, em ambas as escalas, são exibidas na Tabela 5.57. Verifica-se que os exemplares em escala reduzida apresentam resistências $120 \%$ superiores aos da escala (1:1), semelhantemente ao obtido para blocos e prismas, $110 \%$ e $101 \%$ respectivamente. Observa-se, em ambas as escalas, que o aumento da razão entre altura e espessura do corpo-de-prova gera uma redução da resistência, o que é um comportamento comum da alvenaria. Percebe-se que no caso dos ensaios na direção normal, as relações entre as resistências para os diversos 
corpos-de-prova nas escalas (1:1) e (1:3) são muito próximas, com diferenças inferiores a $10 \%$.

Tabela 5.57 - Comparações envolvendo as resistências das paredinhas e diferentes corpos-deprova nas escalas natural (1:1) e reduzida (1:3) na direção normal à junta

\begin{tabular}{|c|c|c|c|}
\hline Relações & Escala (1:3) & Escala (1:1) & $\mathbf{( 1 : 3 ) / ( 1 : 1 )}$ \\
\hline Resistência da paredinha (MPa) & 7,49 & 3,41 & $+119,6 \%$ \\
\hline $\begin{array}{c}\text { Resistência da paredinha / } \\
\text { Resistência do prisma }\end{array}$ & 0,638 & 0,585 & $+9,0 \%$ \\
\hline $\begin{array}{c}\text { Resistência da paredinha / } \\
\text { Resistência do bloco }\end{array}$ & 0,247 & 0,236 & $+4,7 \%$ \\
\hline
\end{tabular}

Ao contrário do ocorrido para os blocos e prismas, o módulo de deformação das paredinhas na escala reduzida apresenta uma diferença bem inferior em relação ao ensaio em escala natural $(+22,4 \%)$ quando comparada à obtida para a resistência $(+119,6 \%)$, ver tabelas 5.57 e 5.58. Com isso, as relações apresentadas na Tabela 5.58, envolvendo os módulos de paredinhas em comparação com os de prismas e de blocos ensaiados na direção normal à junta de assentamento, exibem valores até $43 \%$ inferiores. Verifica-se na mesma tabela que o módulo de deformação da paredinha na escala natural (1:1) é superior ao do bloco. Este fato é uma surpresa, pois o normal é que o módulo de deformação da paredinha seja inferior ao do bloco, por causa da maior deformabilidade da argamassa. Uma possível explicação para tal acontecimento é que a influência da variabilidade do módulo de deformação do bloco seja superior à da presença das juntas de argamassa na paredinha. Relembra-se que o valor referente ao prisma corresponde ao módulo de deformação do bloco obtido por meio do ensaio do prisma de três blocos.

Tabela 5.58 - Comparações envolvendo os módulos de deformação das paredinhas e de diferentes corpos-de-prova nas escalas (1:1) e (1:3) na direção normal à junta

\begin{tabular}{|c|c|c|c|}
\hline Relações & Escala (1:3) & Escala (1:1) & $(\mathbf{1 : 3 )} /(\mathbf{1 : 1 )}$ \\
\hline Módulo da paredinha (MPa) & 7784,9 & 6358,3 & $+22,4 \%$ \\
\hline $\begin{array}{c}\text { Módulo da paredinha / } \\
\text { Módulo do prisma }\end{array}$ & 0,721 & 1,126 & $-36,0 \%$ \\
\hline $\begin{array}{c}\text { Módulo da paredinha / } \\
\text { Módulo do bloco }\end{array}$ & 0,698 & 1,234 & $-43,4 \%$ \\
\hline
\end{tabular}

Na Tabela 5.59 realizam-se comparações entre os módulos de deformação das paredinhas e as resistências de diferentes corpos-de-prova, nas escalas natural (1:1) e reduzida (1:3), ensaiados na direção normal à junta de assentamento. Observa-se que, em ambas as escalas, os valores das razões decrescem de acordo com a diminuição da 
altura dos corpos-de-prova. Verifica-se, ainda, que as relações referentes à escala reduzida são cerca de $40 \%$ inferiores as da escala natural.

Tabela 5.59 - Comparações entre os módulos de deformação das paredinhas e resistências de corpos-de-prova nas escalas natural (1:1) e reduzida (1:3) na direção normal à junta

\begin{tabular}{|c|c|c|c|}
\hline Relações & Escala (1:3) & Escala (1:1) & $\mathbf{( 1 : 3 ) ~ / ~ ( 1 : 1 ) ~}$ \\
\hline $\begin{array}{c}\text { Módulo da paredinha / } \\
\text { Resistência da paredinha }\end{array}$ & 1039,4 & 1864,6 & $-44,3 \%$ \\
\hline $\begin{array}{c}\text { Módulo da paredinha / } \\
\text { resistência do prisma }\end{array}$ & 663,1 & 1090,6 & $-39,2 \%$ \\
\hline $\begin{array}{c}\text { Módulo da paredinha / } \\
\text { resistência do bloco }\end{array}$ & 256,8 & 440,3 & $-41,7 \%$ \\
\hline
\end{tabular}

5.3.7 - Ensaios de "paredinhas" à compressão na direção paralela à junta de assentamento - escala reduzida

Os resultados dos ensaios das paredinhas na escala natural (1:1) na direção paralela à junta de assentamento são apresentados na Tabela 5.60. Verifica-se uma pequena variabilidade para a força e para a tensão de ruptura $(1,5 \%)$ e um coeficiente de variação razoável para o módulo de deformação $(13,2 \%)$, sendo que apenas a deformação última possui uma variação maior $(25,2 \%)$.

A Tabela 5.61 apresenta os resultados dos ensaios das paredinhas na escala reduzida. Percebe-se que, ao contrário da escala natural, todos os resultados apresentam uma grande variabilidade, acima dos 29\%. A deformação última tem uma variação ainda maior $(63,5 \%)$, entretanto, isto ocorre porque a paredinha 5 possui um trecho em que para um pequeno acréscimo da força há um grande aumento da deformação (ver Figura 5.37).

Tabela 5.60 - Resultados dos ensaios das paredinhas na escala (1:1) na direção paralela à junta de assentamento

\begin{tabular}{|c|c|c|c|c|}
\cline { 2 - 5 } \multicolumn{1}{c|}{} & Força (kN) & $\begin{array}{c}\text { Tensão - } \\
\text { A.bruta(MPa) }\end{array}$ & $\begin{array}{c}\text { Módulo - } \\
\text { A.bruta(MPa) }\end{array}$ & $\begin{array}{c}\text { Deformação } \\
\text { última }\end{array}$ \\
\hline Paredinha 4 & 252,1 & 1,51 & 3188,6 & $-0,48 \%$ \\
\hline Paredinha 5 & 244,8 & 1,47 & 2536,9 & $-0,74 \%$ \\
\hline Paredinha 6 & 246,8 & 1,48 & 3219,4 & $-0,50 \%$ \\
\hline Média & 247,9 & 1,49 & 2981,6 & $-0,57 \%$ \\
\hline Coef. Var. & $1,5 \%$ & $1,5 \%$ & $12,9 \%$ & $25,2 \%$ \\
\hline
\end{tabular}


Tabela 5.61- Resultados dos ensaios das paredinhas na escala (1:3) na direção paralela à junta de assentamento

\begin{tabular}{|c|c|c|c|c|}
\cline { 2 - 5 } \multicolumn{1}{c|}{} & $\begin{array}{c}\text { Força } \\
\text { (kN) }\end{array}$ & $\begin{array}{c}\text { Tensão - } \\
\text { A.bruta(MPa) }\end{array}$ & $\begin{array}{c}\text { Módulo - } \\
\text { A.bruta(MPa) }\end{array}$ & $\begin{array}{c}\text { Deformação } \\
\text { última }\end{array}$ \\
\hline Paredinha 4 & 40,79 & 2,24 & 4375,5 & $-0,68 \%$ \% \\
\hline Paredinha 5 & 77,98 & 4,28 & 4652,3 & $-2,89 \%$ \\
\hline Paredinha 6 & 71,05 & 3,90 & 7203,9 & $-1,66 \%$ \\
\hline Média & 63,27 & 3,47 & 5410,6 & $-1,75 \%$ \\
\hline Coef. Var. & $31,3 \%$ & $31,3 \%$ & $28,8 \%$ & $63,5 \%$ \\
\hline
\end{tabular}

A Figura 5.36 apresenta os diagramas tensão x deformação média (vertical e horizontal) dos ensaios das paredinhas na escala natural para a direção paralela à junta de assentamento. Observa-se nos diagramas que para as deformações verticais as paredinhas 4 e 6 apresentam um comportamento praticamente linear até a ruptura. Já a paredinha 5 apresenta uma perturbação com uma tensão de cerca de $30 \%$ da tensão de ruptura, entretanto a curva mantém a mesma inclinação até próximo aos $75 \%$ da tensão de ruptura. Acredita-se que essa perturbação esteja relacionada com a abertura de uma fissura ao longo da junta de assentamento, visto que a partir do mesmo nível de tensão as deformações horizontais do exemplar 5 apresentam um grande acréscimo.

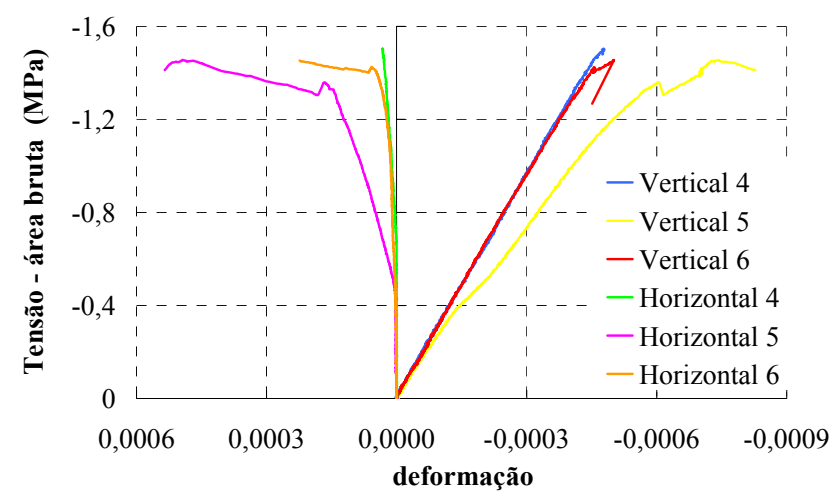

Figura 5.36 - Diagrama tensão $x$ deformação das paredinhas na escala natural (1:1) na direção paralela à junta de assentamento

Para a escala natural (1:1), as deformações horizontais são de pequena ordem de grandeza quando comparadas às deformações verticais (Figura 5.36). Nota-se que a ruptura da paredinha está associada ao grande aumento das deformações horizontais em pequenos acréscimos de força. O coeficiente de Poisson obtido para a direção paralela à junta de assentamento $\left(v_{\mathrm{y}}\right)$ é igual a 0,03 , com um coeficiente de variação de $27 \%$. Esse baixo valor indica que a deformação horizontal é inferior à vertical. Ressalva-se que este comportamento, em alguns exemplares, ocorre até praticamente a ruptura. 
Os mesmos diagramas para a escala (1:3) estão ilustrados na Figura 5.37. Percebe-se que para as deformações verticais a perda de linearidade ocorre em todos os exemplares em torno dos $2 \mathrm{MPa}$, cerca de $60 \%$, em média, da tensão de ruptura. Observa-se, também, a existência de patamares nos diagramas, que correspondem ao início da fissuração visível. Isso indica que existe dissipação de energia na abertura de fissuras, não havendo acréscimo na força aplicada.

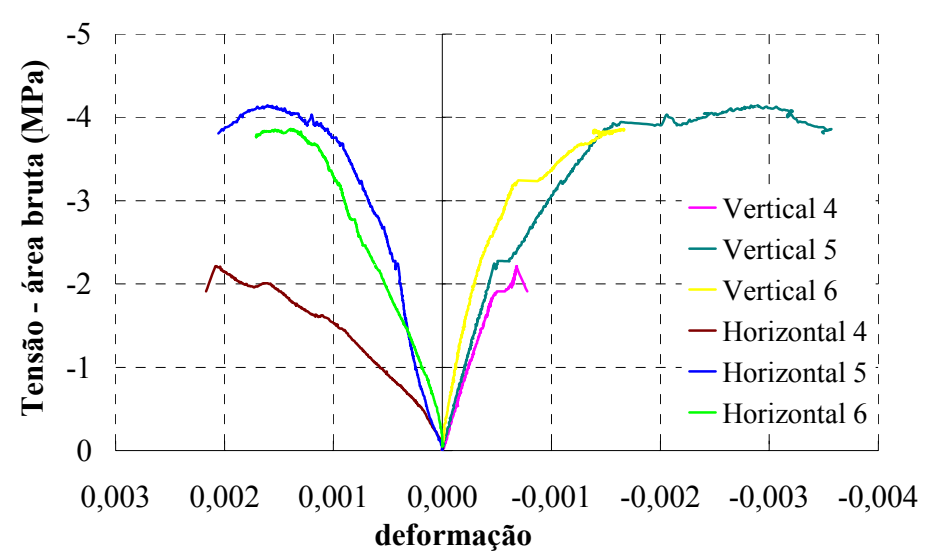

Figura 5.37 - Diagrama tensão x deformação das paredinhas na escala reduzida (1:3) na direção paralela à junta de assentamento

Verifica-se na escala reduzida (1:3) que as deformações horizontais são da mesma ordem de grandeza ou maiores que as deformações verticais (Figura 5.37). Calculando-se o coeficiente de Poisson para a direção paralela à junta de assentamento $\left(v_{\mathrm{y}}\right)$ obtém-se um valor médio igual a 1,77 , com um coeficiente de variação de $41 \%$. Isso quer dizer que a deformação horizontal é superior à vertical. Ressalta-se que desde o início do ensaio ocorre este comportamento, antes até da fissuração ou perda de linearidade das deformações verticais. No entanto, esse coeficiente de Poisson pode ser considerado como aparente, pois a maior parte da deformação horizontal está associada à separação das juntas de assentamento ao longo de seu comprimento e em diferentes fiadas (ver Figura 5.39). Acredita-se que essa fissuração seja originada por uma tendência de deslocamento relativo vertical entre as fiadas, visto que seu aparecimento ocorre em níveis inferiores à resistência de aderência bloco-argamassa.

A Figura 5.38 ilustra as rupturas das paredinhas na escala natural (1:1) nos ensaios na direção paralela à junta de assentamento, sendo que as fissuras estão destacadas por meio de elementos gráficos. No caso da paredinha 4, o ensaio é interrompido com um decréscimo da força aplicada e o aparecimento de fissuras visíveis na face lateral, indicativas da ruptura das paredes internas dos blocos. Nas 
paredinhas 5 e 6 observam-se, também, fissuras horizontais ao longo do comprimento da parede, sendo que no primeiro caso ocorrem junto à base e no segundo próximo ao topo. Também podem ser visualizadas fissuras ao longo da junta de assentamento.

As rupturas das paredinhas na escala (1:3) nos ensaios na direção paralela à junta de assentamento estão ilustradas na Figura 5.39. O quadro de fissuração de todas as paredes é bem parecido, com fissuras verticais em mais de uma fiada nas juntas de assentamento e fissuras horizontais na região de encontro do septo transversal com as paredes laterais dos blocos. A principal diferença é que na paredinha 4 a fissura horizontal ocorre junto ao topo, enquanto nos outros dois exemplares aparece junto à base. Observa-se que a fissuração é praticamente igual para as faces opostas de uma mesma paredinha.

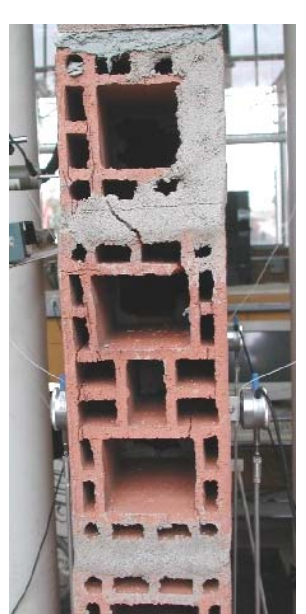

Paredinha 4

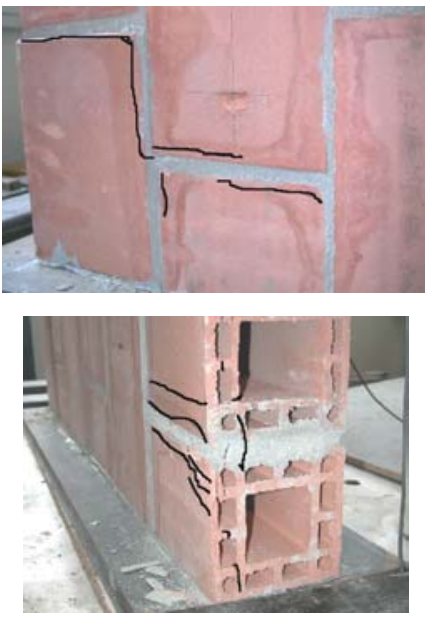

Paredinha 5

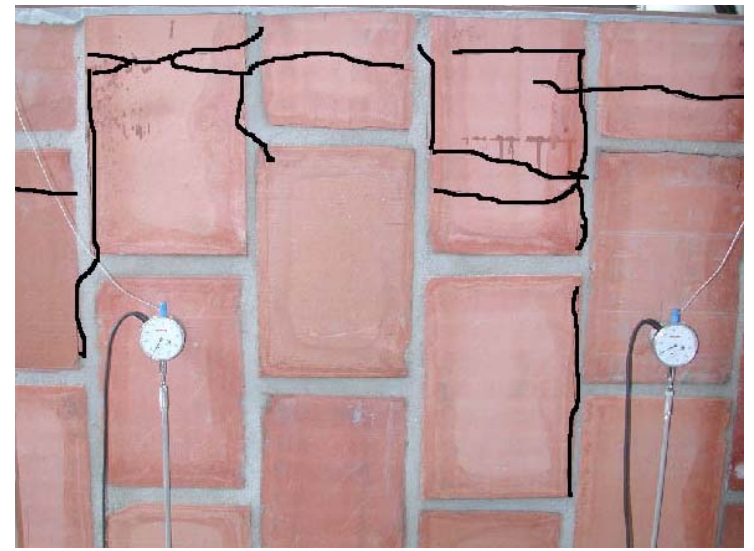

Paredinha 6

Figura 5.38 - Formas de rupturas das paredinhas na escala natural (1:1) - ensaio na direção paralela à junta de assentamento

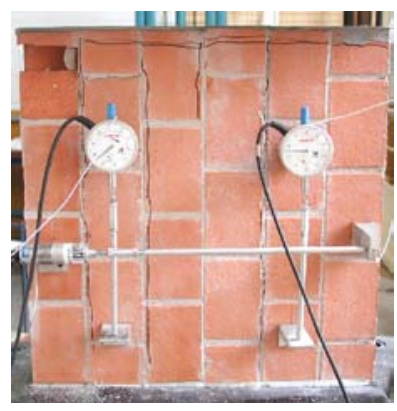

Paredinha 4

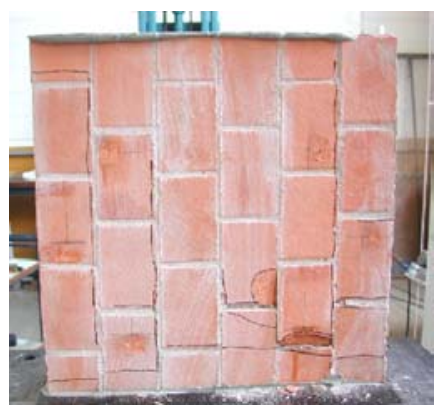

Paredinha 5

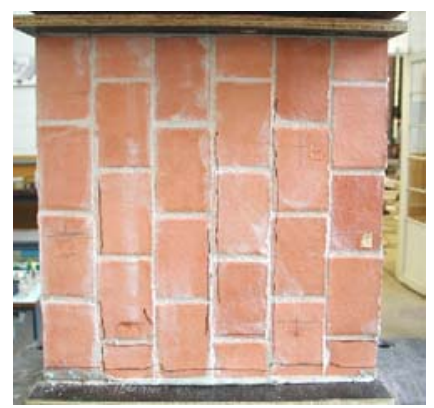

Paredinha 6

Figura 5.39 - Formas de rupturas das paredinhas na escala reduzida (1:3) - ensaio na direção paralela à junta de assentamento

$\mathrm{Na}$ Tabela 5.62 apresentam-se comparações envolvendo as paredinhas e diferentes corpos-de-prova na direção paralela à junta de assentamento nas diferentes 
escalas. Como em todos os casos anteriores os corpos-de-prova na escala (1:3) possuem maior resistência e módulo de deformação que na escala natural, entretanto as razões entre as propriedades obtidas são inferiores. Nas relações para os ensaios em escala (1:1) na direção paralela à junta de assentamento verifica-se um fato a princípio inusitado: a resistência da paredinha na direção paralela à junta é superior à do prisma de dois blocos. Todavia, acredita-se que essa diferença seja originada pelo efeito de pino na junta de assentamento, que ocorre graças à presença de diversas cavidades na seção transversal dos blocos em escala natural. Esse efeito levaria a uma condição benéfica da paredinha em relação ao prisma de dois blocos, visto que este último não apresenta junta de assentamento. Já para os modelos reduzidos, as resistências do prisma de dois blocos e da paredinha são praticamente iguais.

Tabela 5.62 - Comparações envolvendo as paredinhas e diferentes corpos-deprova nas escalas natural (1:1) e reduzida (1:3) na direção paralela à junta

\begin{tabular}{|c|c|c|c|}
\hline Relações & Escala (1:3) & Escala (1:1) & $\mathbf{( 1 : 3 ) / ( 1 : 1 )}$ \\
\hline Resistência da paredinha (MPa) & 3,47 & 1,49 & $+132,9 \%$ \\
\hline Módulo da paredinha (MPa) & 5410,6 & 2981,6 & $+81,5 \%$ \\
\hline $\begin{array}{c}\text { Módulo da paredinha/ } \\
\text { Resistência da paredinha }\end{array}$ & 1559,3 & 2001,1 & $-22,1 \%$ \\
\hline $\begin{array}{c}\text { Resistência da paredinha / } \\
\text { Resistência do prisma de 2 blocos }\end{array}$ & 0,948 & 1,355 & $-30,0 \%$ \\
\hline $\begin{array}{c}\text { Resistência da paredinha / } \\
\text { Resistência do bloco }\end{array}$ & 0,330 & 0,710 & $-53,5 \%$ \\
\hline $\begin{array}{c}\text { Resistência da paredinha / } \\
\text { Resist. de aderência }\end{array}$ & 8,94 & 6,34 & $+41,0 \%$ \\
\hline
\end{tabular}

As paredinhas em ambas as escalas ensaiadas na direção paralela à junta de assentamento são mais deformáveis que as demais ensaiadas na direção normal. Isso pode ser constatado na Tabela 5.63 e nas figuras 5.40 e 5.41. Na mesma tabela, nota-se que a razão entre as resistências das paredinhas nas direções paralela e normal são muito próximas para as duas escalas. Também na Figura 5.40 percebe-se que para as paredinhas na escala natural, as deformações horizontais nas duas direções são da mesma ordem de grandeza. Dessa maneira, os exemplares ensaiados na direção normal à junta possuem um coeficiente de Poisson $\left(v_{\mathrm{x}}\right)$ médio igual a 0,06 , já para as paredinhas ensaiadas na direção paralela à junta esse coeficiente $\left(v_{\mathrm{y}}\right)$ é igual a 0,03 . Julga-se que este comportamento demonstra a atuação do efeito de pino na junta de assentamento de argamassa. 
Já para a escala reduzida (1:3), Figura 5.41, verifica-se que o comportamento em relação às deformações horizontais é bastante diferente em função da direção de ensaio; a paredinha na direção normal à junta possui um coeficiente de Poisson $\left(v_{\mathrm{x}}\right)$ igual a 0,12 , já a paredinha na direção paralela à junta esse coeficiente $\left(v_{\mathrm{y}}\right)$ iguala-se a 1,77 .

Tabela 5.63 - Comparações envolvendo as paredinhas na direção paralela à junta e normal à junta de assentamento nas escalas natural (1:1) e reduzida (1:3)

\begin{tabular}{|c|c|c|c|}
\hline Relações $^{*}$ & Escala (1:3) & Escala (1:1) & $\mathbf{( 1 : 3 ) / ( 1 : 1 )}$ \\
\hline $\begin{array}{c}\text { Resistência da paredinha (paralela) / } \\
\text { Resistência da paredinha (normal) }\end{array}$ & 0,463 & 0,437 & $+5,9 \%$ \\
\hline $\begin{array}{c}\text { Módulo da paredinha (paralela)/ } \\
\text { Módulo da paredinha (normal) }\end{array}$ & 0,695 & 0,469 & $+48,2 \%$ \\
\hline
\end{tabular}

* Direção do ensaio entre parênteses

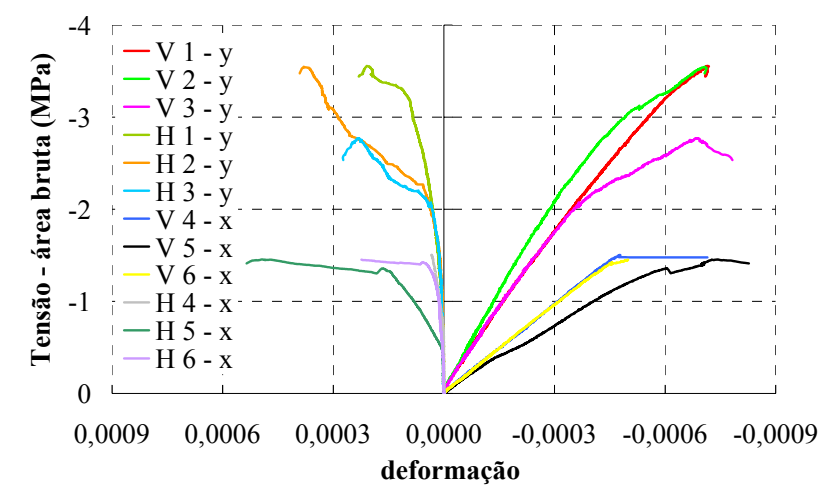

Figura 5.40 - Diagramas tensão $x$ deformação das paredinhas ensaiadas nas direções normal e paralela à junta de assentamento na escala natural (1:1)

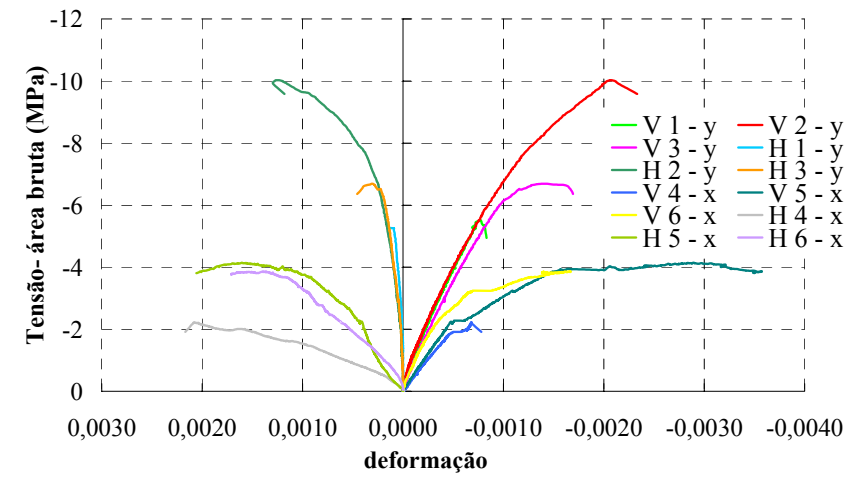

Figura 5.41 - Diagramas tensão $x$ deformação das paredinhas ensaiadas nas direções normal e paralela à junta de assentamento na escala reduzida (1:3)

\subsection{8 - Análise final dos ensaios da alvenaria}

Inicialmente apresenta-se na Tabela 5.64 um quadro resumo com os principais resultados obtidos nos ensaios de caracterização, em que todos os valores são referidos à área bruta. Observa-se que para os ensaios na direção normal à junta de assentamento 
as resistências dos corpos-de-prova (bloco, prisma de três blocos e paredinha) da escalas reduzida (1:3) são cerca de 105\% superiores às da escala natural (1:1), com exceção da argamassa $(+14 \%)$. As relações entre os módulos de deformação do bloco medidos nos ensaios do bloco isolado e do prisma estão na mesma faixa de valores que as obtidas para as resistências. Contudo, no ensaio das paredinhas, onde a base de medições da deformação considera a presença da argamassa, a relação entre os módulos de deformação nas duas escalas é inferior à verificada para a relação entre as resistências.Verifica-se, ainda, que a deformação última e o coeficiente de Poisson $\left(v_{\mathrm{x}}\right)$ da paredinha na escala reduzida são também cerca de $100 \%$ superiores aos da escala natural.

Para os ensaios na direção paralela à junta de assentamento, nota-se uma grande divergência das relações entre as resistências dos corpos-de-prova, que variam entre $+133 \%$ (paredinha) e $+400 \%$ (bloco). A maior diferença ocorre para o coeficiente de Poisson $\left(v_{\mathrm{y}}\right)$ cerca de $5800 \%$. Todavia vale lembrar que o coeficiente obtido para a escala reduzida é um valor aparente, conforme comentado anteriormente.

Tabela 5.64- Resumo dos resultados e comparações dos ensaios nas escalas reduzida (1:3) e natural (1:1)-referidos à área bruta

\begin{tabular}{|c|c|c|c|c|}
\hline \multicolumn{2}{|c|}{ Ensaio } & Escala $(1: 3)$ & Escala (1:1) & $(1: 3) /(1: 1)$ \\
\hline \multirow{2}{*}{$\begin{array}{l}\text { Bloco - Direção } \\
\text { normal à junta }\end{array}$} & Resistência (MPa) & 30,31 & 14,44 & $+109,9 \%$ \\
\hline & Módulo (MPa) & 11147,7 & 5151,1 & $+116,4 \%$ \\
\hline \multirow{2}{*}{ Argamassa } & Resistência (MPa) & 4,20 & 3,68 & $+14 \%$ \\
\hline & Módulo (MPa) & 7057,8 & 5876,7 & $+20 \%$ \\
\hline \multirow{2}{*}{$\begin{array}{c}\text { Prisma - Direção } \\
\text { normal à junta }\end{array}$} & Resistência (MPa) & 11,74 & 5,83 & $+101,4 \%$ \\
\hline & Módulo (MPa) & 10793,8 & 5644,6 & $+91,2 \%$ \\
\hline \multirow{4}{*}{$\begin{array}{c}\text { Paredinha - } \\
\text { Direção normal } \\
\text { à junta }\end{array}$} & Resistência (MPa) & 7,49 & 3,41 & $+119,6 \%$ \\
\hline & Módulo (MPa) & 7784,9 & 6358,3 & $+22,4 \%$ \\
\hline & Deformação última & $-1,42 \%$ & $-0,70 \%$ & $+102,8 \%$ \\
\hline & Poisson $\left(v_{x}\right)$ & 0,12 & 0,06 & $+100,0 \%$ \\
\hline $\begin{array}{l}\text { Bloco - Direção } \\
\text { paralela à junta }\end{array}$ & Resistência (MPa) & 10,5 & 2,10 & $+400,0 \%$ \\
\hline $\begin{array}{c}\text { Prisma - Direção } \\
\text { paralela à junta }\end{array}$ & Resistência (MPa) & 3,66 & 1,10 & $+232,7 \%$ \\
\hline $\begin{array}{l}\text { Prisma à flexão } \\
\text { (aderência) }\end{array}$ & Resistência (MPa) & 0,388 & 0,235 & $+65,1 \%$ \\
\hline \multirow{4}{*}{$\begin{array}{c}\text { Paredinha - } \\
\text { Direção paralela } \\
\text { à junta }\end{array}$} & Resistência (MPa) & 3,47 & 1,49 & $+132,9 \%$ \\
\hline & Módulo (MPa) & 5410,6 & 2981,6 & $+81,5 \%$ \\
\hline & Deformação última & $-1,75 \%$ & $-0,57 \%$ & $+207,0 \%$ \\
\hline & Poisson $\left(v_{y}\right)$ & 1,77 & 0,03 & $+5800 \%$ \\
\hline
\end{tabular}


Por tudo apresentado até aqui sobre a caracterização dos materiais na escala reduzida e natural, fica clara a boa representatividade dos modelos reduzidos para os ensaios na direção normal à junta de assentamento. As maiores diferenças observadas ocorrem nos ensaios na direção paralela à junta de assentamento, principalmente por causa das diferenças nas seções transversais dos blocos nas duas escalas. Contudo, deve-se ressaltar que as formas de ruptura de todos os ensaios na direção paralela (blocos, prismas de dois blocos e paredinhas) foram semelhantes. A única diferença destacada de comportamento está relacionada à junta de assentamento, pois existe no bloco na escala (1:1) uma série de cavidades na seção transversal que gera um mecanismo resistente não observado na escala reduzida, aqui denominado efeito de pino. Todavia, observa-se que esse comportamento não é um fator importante para os ensaios a serem realizados neste trabalho, visto que todos os carregamentos devem ser aplicados na direção normal à junta de assentamento e as tensões normais de flexão geradas devem ser de baixa intensidade.

Analisando-se os resultados de acordo com a teoria de modelos reduzidos, como já realizado para o caso do bloco isolado, a alvenaria na escala (1:3) é classificada como modelo do tipo distorcido, em função das diferenças geométricas das seções transversais dos blocos. Todas as propriedades são consideradas em função da área bruta. O fator de escala de comprimento $\left(s_{L}\right)$ é o único de obtenção direta, sendo igual a 3.

Examinando-se os resultados dos ensaios na direção normal à junta de assentamento, o fator de escala de tensão $\left(s_{\sigma}\right)$, que é a razão entre a resistência da alvenaria na escala natural e na reduzida, pode ser considerado igual a 0,48. Este valor corresponde à média das relações entre prismas e paredinhas, sendo idêntica à obtida para o bloco. Já o valor do fator de escala de deformação $\left(s_{\varepsilon}\right)$ é obtido indiretamente da relação entre os módulos de deformação, que é função de $\left(s_{\sigma} / s_{\varepsilon}\right)$. Dessa forma, como o fator de tensão $\left(s_{\sigma}\right)$ já é conhecido, a determinação do fator de deformação $\left(s_{\varepsilon}\right)$ é imediata. No caso do ensaio de prisma de três blocos, onde as medições são realizadas apenas no bloco intermediário, $\left(s_{\varepsilon}\right)$ é praticamente igual a 1 , fato que também ocorre na análise do bloco isolado.

A Figura 5.42 apresenta os diagramas tensão - deformação obtidos nos ensaios de prismas, considerando-se os fatores de escala de tensão e de deformação para os resultados obtidos na escala reduzida. Verifica-se uma ótima correlação dos resultados, 
sendo que as diferenças nas curvas estão relacionadas à forma dos ensaios. Na escala reduzida o carregamento é aplicado com controle de força e na escala natural é utilizado o controle de deslocamento, por isso é possível obter um patamar de deformações apenas para o último caso.

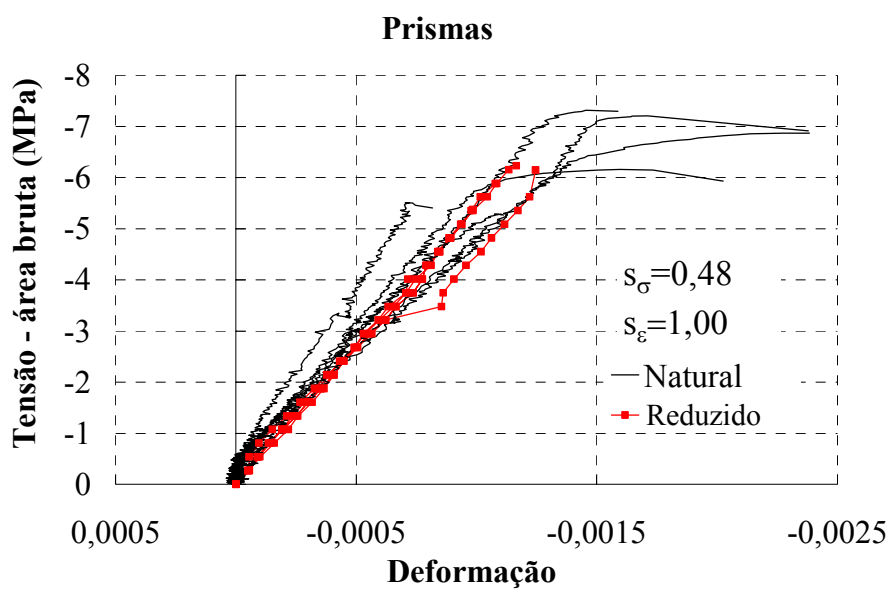

\section{Figura 5.42 - Diagramas tensão - deformação dos prismas na direção normal à junta de assentamento considerando-se os fatores de escala.}

No ensaio da paredinha na direção normal à junta de assentamento, as deformações englobam tanto os blocos quanto as juntas de argamassa. $\mathrm{O}$ fator de escala de deformação $\left(s_{\varepsilon}\right)$ obtido por meio da relação entre os módulos de deformação já não é igual a 1 , passando a valer 0,59 . Essa mudança no fator $\left(s_{\varepsilon}\right)$ é creditada às diferenças de confinamento das juntas de assentamento entre as paredinhas nas duas escalas. $\mathrm{Na}$ Figura 5.43 é possível observar que a utilização dos fatores de escala mostra novamente uma boa correlação entre os resultados das diferentes escalas, com as curvas possuindo uma mesma tendência.

Para os ensaios na direção paralela à junta, não é possível determinar um único fator de escala de tensão $\left(s_{\sigma}\right)$, pois este fator varia entre 0,20 e 0,43 dependendo do tipo de ensaio. Avalia-se que a seção transversal do bloco é determinante para o comportamento da alvenaria nessa direção. A mudança na seção do bloco leva a uma distorção que não é possível ser mensurada. O fator de escala de deformação $\left(s_{\varepsilon}\right)$ só pode ser obtido para o ensaio da paredinha, único que é instrumentado para tal fim, sendo igual a 0,78. A comparação entre as curvas de tensão - deformação das paredinhas nas diferentes escalas, considerando-se os fatores de escalas, está apresentada na Figura 5.44. Percebe-se que há uma correlação razoável entre o comportamento das deformações verticais nas duas escalas. Entretanto, para as 
deformações horizontais a divergência de comportamento é nítida, sendo causada pelas diferenças de comportamento das juntas de assentamento (existência do efeito de pino na escala natural).

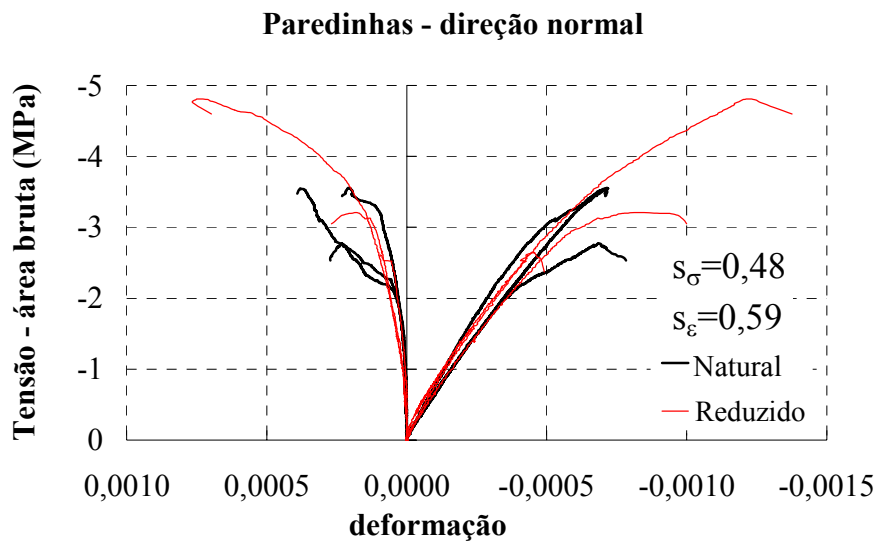

Figura 5.43-Diagramas tensão - deformação das paredinhas na direção normal à junta de assentamento considerando-se os fatores de escala.

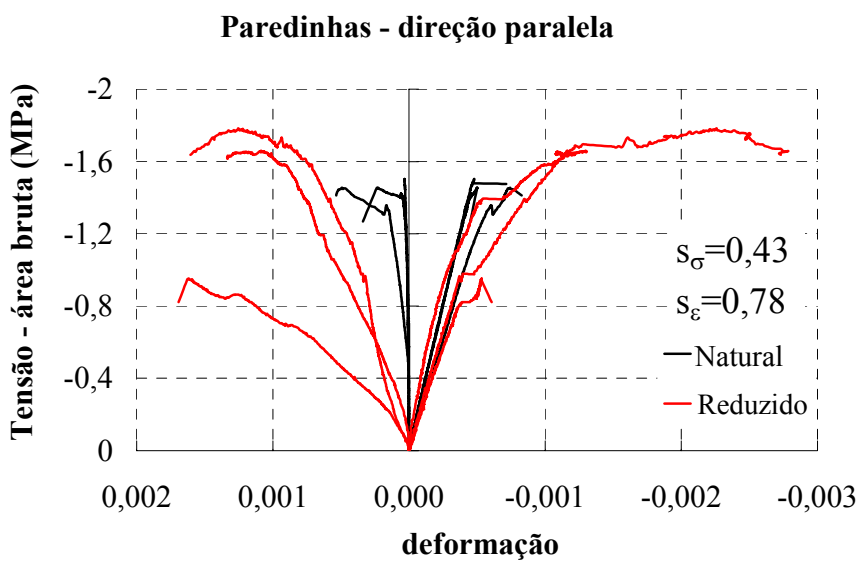

Figura 5.44-Diagramas tensão - deformação das paredinhas na direção paralela à junta de assentamento considerando-se os fatores de escala.

Conclui-se que a utilização dos fatores de escala para os ensaios na direção normal à junta de assentamento leva a uma excelente correlação dos resultados, como pode ser verificado nas figuras 5.12, 5.42 e 5.43. Contudo, para os ensaios na outra direção a utilização dos fatores de escala não leva a resultados tão bons, o que não é fator restritivo já que os principais esforços aos quais a alvenaria é submetida são na direção normal à junta de assentamento. 


\section{Capítulo \\ 6 ANÁLISES NUMÉRICAS INICIAIS}

\section{1- Generalidades}

Todas as análises numéricas desenvolvidas neste trabalho são referentes à alvenaria em escala reduzida (1:3). Essa decisão foi tomada porque a maioria dos ensaios aqui realizados são nessa escala, a geometria simplificada da seção transversal dos blocos reduzidos permite modelagens mais elaboradas e há uma redução significativa da quantidade de modelos numéricos. Além disso, ao se demonstrar que a análise numérica é capaz de representar o comportamento físico da alvenaria em escala (1:3), ela também o será para a alvenaria em escala natural (1:1), pois o fenômeno físico é o mesmo.

Nas modelagens numéricas opta-se por empregar as dimensões ideais das unidades como uma maneira de se garantir uma modulação perfeita. Os blocos e os meios-blocos podem ser modelados de três maneiras diferentes:

Com a presença das cavidades, onde são mantidas as características gerais como a tendência das espessuras das paredes dos blocos e uma aproximação da relação entre a área líquida e a área bruta (Figuras 6.1 - b e 6.2 - b);

$>$ Sólido, com as mesmas dimensões externas e conseqüentemente a mesma área bruta (Figuras 6.1 - c e 6.2 - c);

Sólido com espessura efetiva, onde se altera a espessura da unidade para se obter a mesma área líquida com o comprimento original (Figuras 6.1 - d e 6.2 - d).

Inicialmente, fazem-se estudos para a definição de um corpo-de-prova para a obtenção da resistência ao cisalhamento em plano vertical. Numa investigação preliminar os blocos são adotados como sólidos, o que simplifica as análises numéricas. 
Determinada a situação mais significativa, realiza-se uma nova modelagem considerando-se os blocos com suas cavidades.

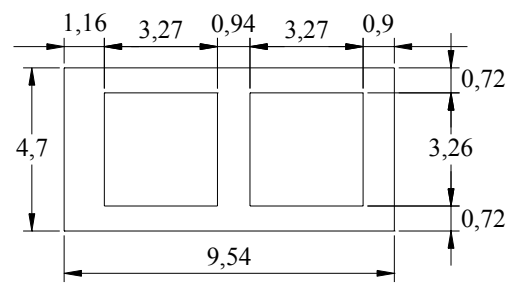

(a) - Dimensões reais médias (cm) altura $(\mathrm{h})=6,24 \mathrm{~cm}$

$\mathrm{A}_{\text {bruta }}=44,84 \mathrm{~cm}^{2}$

$\mathrm{A}_{\text {liquida }}=22,73 \mathrm{~cm}^{2}$

$\mathrm{A}_{\text {liquida }} / \mathrm{A}_{\text {bruta }}=50,7 \%$

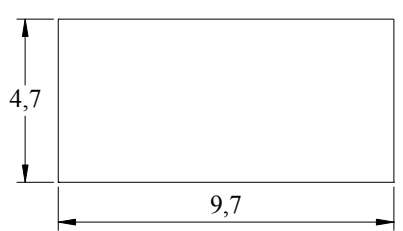

(c) Dimensões adotadas (cm) altura $(\mathrm{h})=6,30 \mathrm{~cm}$ $\mathrm{A}_{\text {bruta }}=45,59 \mathrm{~cm}^{2}$

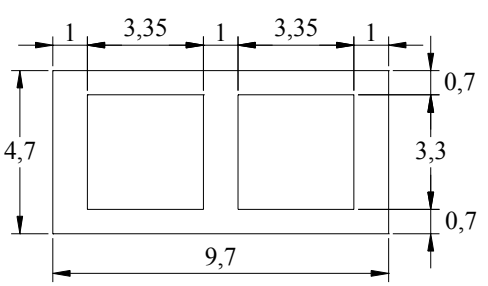

(b) - Dimensões adotadas (cm) altura $(\mathrm{h})=6,30 \mathrm{~cm}$

$$
\mathrm{A}_{\text {bruta }}=45,59 \mathrm{~cm}^{2}
$$

$\mathrm{A}_{\text {líquida }}=23,48 \mathrm{~cm}^{2}$

$\mathrm{A}_{\text {liquida }} / \mathrm{A}_{\text {bruta }}=51,5 \%$

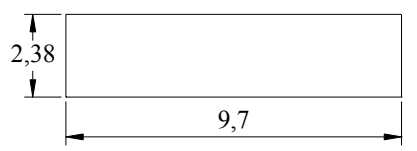

(d) Dimensões adotadas (cm) altura $(\mathrm{h})=6,30 \mathrm{~cm}$ $\mathrm{A}_{\text {bruta }}=23,09 \mathrm{~cm}^{2}$

Figura 6.1 - Dimensões do bloco

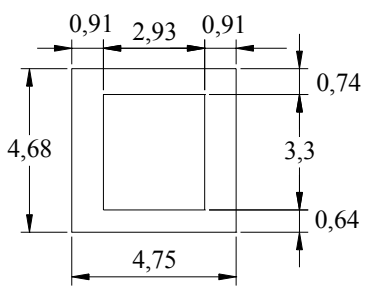

(a) - Dimensões reais médias $(\mathrm{cm})$ altura $(\mathrm{h})=6,26 \mathrm{~cm}$ $\mathrm{A}_{\text {bruta }}=22,23 \mathrm{~cm}^{2}$

$\mathrm{A}_{\text {líquida }}=12,03 \mathrm{~cm}^{2}$

$\mathrm{A}_{\text {líquida }} / \mathrm{A}_{\text {bruta }}=54,1 \%$

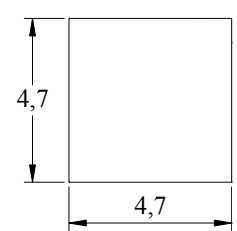

(c) - Dimensões reais médias (cm) altura $(\mathrm{h})=6,30 \mathrm{~cm}$ $\mathrm{A}_{\text {bruta }}=22,08 \mathrm{~cm}^{2}$

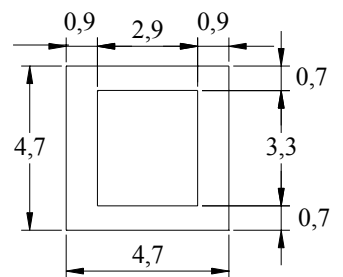

(b) - Dimensões adotadas (cm) altura $(\mathrm{h})=6,30 \mathrm{~cm}$ $\mathrm{A}_{\text {bruta }}=22,08 \mathrm{~cm}^{2}$ $\mathrm{A}_{\text {liquida }}=12,52 \mathrm{~cm}^{2}$ $\mathrm{A}_{\text {liquida }} / \mathrm{A}_{\text {bruta }}=56,7 \%$

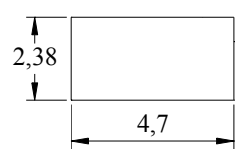

(d) - Dimensões adotadas (cm) altura $(\mathrm{h})=6,30 \mathrm{~cm}$ $\mathrm{A}_{\text {bruta }}=11,19 \mathrm{~cm}^{2}$

Figura 6.2 - Dimensões do meio-bloco 
Investiga-se a distribuição de ações verticais em painéis de alvenaria com diferentes plantas, auxiliando na definição de painéis para a futura investigação experimental. São analisados painéis com carregamentos centrados e excêntricos, em ambos os casos considerando-se a influência das restrições devidas à presença da laje. Ainda são modelados casos com um e dois pavimentos. Por suas grandes dimensões, a análise numérica dos painéis é realizada considerando-se apenas o bloco com sua seção sólida.

Apresentam-se, também, as modelagens numéricas não-lineares desenvolvidas para a pesquisa, comparando-se com os resultados da caracterização dos materiais. As análises desses ensaios têm o intuito de definir e calibrar o modelo numérico para representar a alvenaria. Os estudos são apresentados de acordo com a direção de aplicação de força no ensaio em relação à junta de assentamento (normal ou paralela). Todas as etapas seguintes serão realizadas com base nessas modelagens.

\section{2- Estudo de um corpo-de-prova para determinação da resistência ao cisalhamento vertical da alvenaria}

Na revisão bibliográfica realizada percebe-se a necessidade do desenvolvimento de um corpo-de-prova para a determinação da resistência ao cisalhamento vertical da alvenaria. As características desejáveis são que o espécime seja de pequeno porte, que o cisalhamento atuante tenda a uma distribuição uniforme e que a ruptura ocorra por cisalhamento da ligação.

A idéia inicial consiste em utilizar análises numéricas lineares para o estudo da geometria e dos tipos de apoio para a base do corpo-de-prova, de modo a obter a distribuição das tensões de cisalhamento mais adequada. Também pretende-se verificar a influência da utilização ou não do bloco de amarração na distribuição das tensões normais e cisalhantes. Os primeiros modelos são feitos adotando-se os blocos sem as cavidades, o que simplifica bastante a modelagem. Com base nesses primeiros modelos sólidos definem-se os mais representativos para a realização de outros onde os blocos são considerados com suas cavidades.

Escolhe-se um painel com seção " $\mathrm{H}$ " em planta, pois essa geometria permite a aplicação de um carregamento centrado em relação aos dois eixos de simetria, reduzindo os efeitos de excentricidade. As dimensões dos flanges e da parede são determinadas de forma a serem as mais reduzidas possíveis. Os modelos podem ter suas interseções feitas com o auxílio do bloco de amarração ou utilizando-se apenas o bloco 
e o meio-bloco. Para se analisar o efeito de três juntas a prumo na região da interseção, caso sem o bloco de amarração, considera-se que o número mínimo de fiadas deva ser igual a quatro. Com base nesses dados determinam-se quatro tipos diferentes de geometria para a análise numérica, apresentados na Figura 6.3.

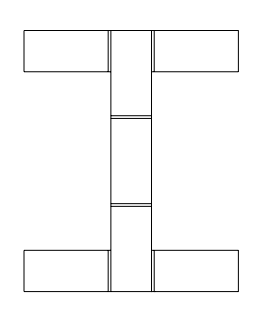

$1^{a}$ e $3^{a}$ fiadas

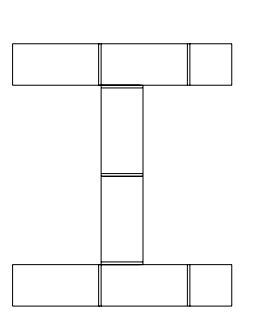

$1^{a}$ fiada

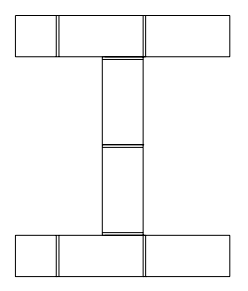

$2^{a}$ fiada

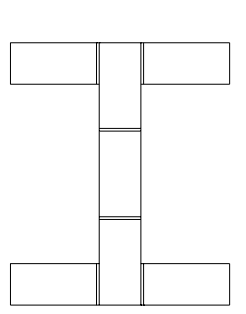

$2^{a}$ e $4^{a}$ fiadas

\section{GEOMETRIA 1}

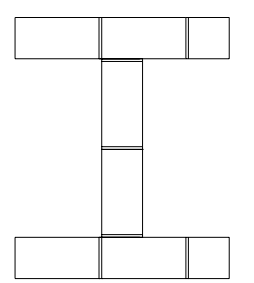

$4^{a}$ fiada

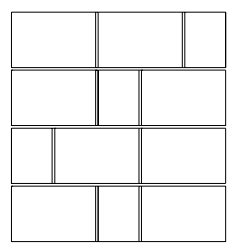

Vista frontal

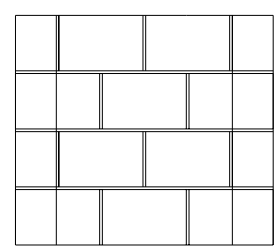

Vista lateral

GEOMETRIA la

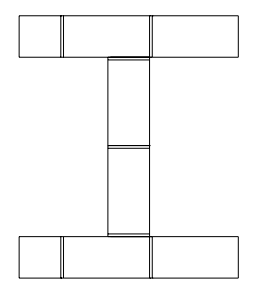

$3^{a}$ fiada

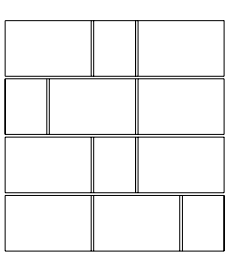

Vista frontal

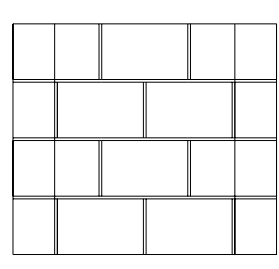

Vista lateral

GEOMETRIA 2

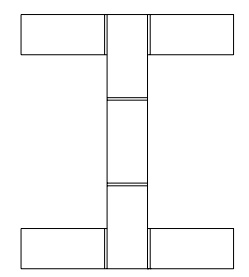

$1^{a}$ e $3^{a}$ fiadas

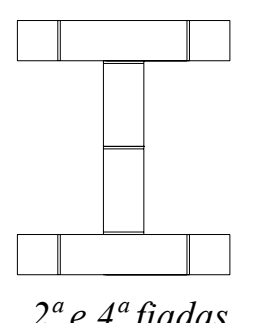

$2^{a}$ e $4^{a}$ fiadas

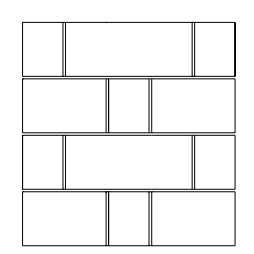

Vista frontal

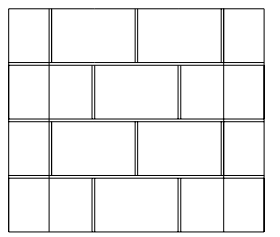

Vista lateral

GEOMETRIA $2 a$

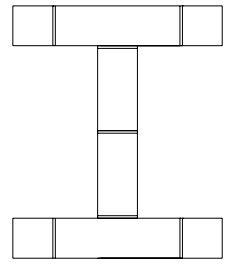

$1^{a}$ e $3^{a}$ fiadas

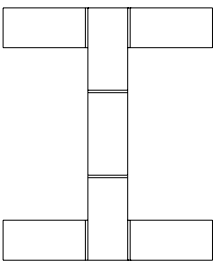

$2^{a}$ e $4^{a}$ fiadas

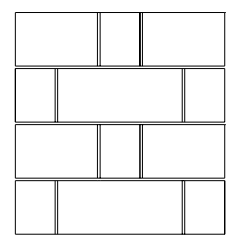

Vista frontal

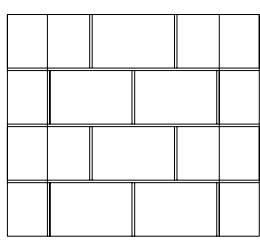

Vista lateral

Figura 6.3-Disposição das fiadas e vistas frontal e lateral para as diferentes geometrias.

São investigadas duas condições de restrições do painel: uma primeira onde todos os deslocamentos dos flanges e da parede central são restritos na base, e uma segunda onde todos os deslocamentos dos flanges são restritos e a base da parede central é livre (sem apoios). Dessa forma, são analisados oito tipos de modelos 
diferentes. Para que ocorra uma tendência de cisalhamento é aplicado uma pressão de 1 $\mathrm{MPa}$ apenas na parede central. Na Tabela 6.1 indicam-se as denominações de cada modelo, com o tipo de geometria e restrições.

Tabela 6.1 - Características dos modelos analisados.

\begin{tabular}{|c|c|c|}
\hline Modelo & Geometria & Restrições \\
\hline Int. 1 & geometria 1 (meio-bloco) & base toda restrita \\
\hline Int. 1a & geometria 1a (meio-bloco) & base toda restrita \\
\hline Int. 2 & geometria 2 (bloco amarração) & base toda restrita \\
\hline Int. 2a & geometria 2a (bloco amarração) & base toda restrita \\
\hline Int. 3 & geometria 1 (meio-bloco) & apenas flange restrito \\
\hline Int. 3a & geometria 1a (meio-bloco) & apenas flange restrito \\
\hline Int. 4 & geometria 2 (bloco amarração) & apenas flange restrito \\
\hline Int. 4a & geometria 2a (bloco amarração) & apenas flange restrito \\
\hline \multicolumn{2}{|c|}{ Carregamento = 1 MPa (apenas na parede central) } \\
\hline
\end{tabular}

Como se considera apenas o comportamento linear, utiliza-se nesta análise numérica o pacote computacional ANSYS, devido à maior facilidade de uso. Adota-se uma rede em que a dimensão máxima dos elementos é de $1 \mathrm{~cm}$, visto que uma rede mais refinada ultrapassaria o limite de número de nós e elementos do programa, além de não alterar o resultado final como verificado em testes iniciais. A Tabela 6.2 apresenta um resumo das características e propriedades utilizadas na análise numérica. Ressalta-se que as propriedades dos materiais são adotadas com base nos resultados de Holanda Jr. (2002), pois o estudo é apenas comparativo e anterior aos ensaios de caracterização.

Tabela 6.2 - Características e propriedades para os modelos de cisalhamento vertical

\begin{tabular}{|c|c|}
\hline Elemento & $\begin{array}{c}\text { Sólido }-8 \text { nós }-3 \text { graus de liberdade por nó } \\
\text { Integração reduzida }\end{array}$ \\
\hline Rede & Dimensão máxima de $1 \mathrm{~cm}$ \\
\hline Módulo de Elasticidade $-\operatorname{Bloco}\left(\mathbf{E}_{\mathbf{b}}\right)$ & $18500 \mathrm{MPa}$ \\
\hline Coeficiente de Poisson $-\operatorname{Bloco}\left(\boldsymbol{v}_{\mathbf{b}}\right)$ & 0,18 \\
\hline Módulo de Elasticidade $-\operatorname{Argamassa}\left(\mathbf{E}_{\mathbf{a}}\right)$ & $10000 \mathrm{MPa}$ \\
\hline Coeficiente de Poisson $-\operatorname{Argamassa}\left(\boldsymbol{v}_{\mathbf{a}}\right)$ & 0,20 \\
\hline Espessura das juntas de argamassa & $0,30 \mathrm{~cm}$ \\
\hline
\end{tabular}

Para diminuição do esforço computacional consideram-se as condições de simetria para se modelar apenas metade do corpo-de-prova. Não se modela apenas um quarto do corpo-de-prova porque há geometrias que não tem o segundo eixo de simetria. A rede típica utilizada nos modelos numéricos é ilustrada na Figura 6.4. Para cada caso estudado são exibidos os valores extremos da tensão normal vertical $\left(\sigma_{\mathrm{y}}\right) \mathrm{e}$ das tensões de cisalhamento no plano da parede central $\left(\sigma_{\mathrm{zy}}\right)$ e no plano do flange $\left(\sigma_{\mathrm{xy}}\right)$, ver Tabela 6.3. 
Para uma melhor visualização dos resultados também são analisadas as distribuições de tensão ao longo da altura do corpo-de-prova. A Figura 6.5a indica as seções verificadas para a distribuição das tensões de cisalhamento, enquanto que a Figura 6.5 b ilustra as seções verificadas para a tensão normal.

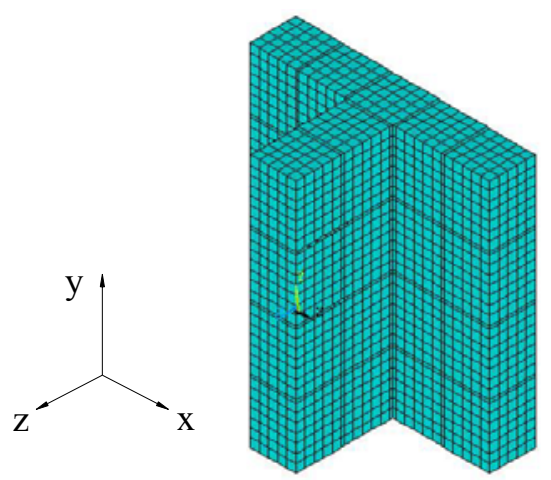

Figura 6.4 - Rede típica para os modelos de cisalhamento vertical

Tabela 6.3 - Valores extremos de tensões para os modelos de cisalhamento vertical - (MPa)

\begin{tabular}{|c|c|c|c|c|c|c|}
\hline Modelos & $\sigma_{\mathbf{v}}, \mathbf{m i n}$ & $\sigma_{\mathbf{v}}, \mathbf{m a x}$ & $\sigma_{\mathbf{x v}}, \mathbf{m i n}$ & $\sigma_{\mathbf{x y}}, \mathbf{m a x}$ & $\sigma_{\mathbf{z v}}, \mathbf{m i n}$ & $\sigma_{\mathbf{z v}}, \mathbf{m a x}$ \\
\hline Int. 1 & $-1,005$ & 0,075 & $-0,370$ & 0,336 & $-0,485$ & 0,017 \\
\hline Int. 1a & $-1,047$ & 0,077 & $-0,345$ & 0,343 & $-0,503$ & 0,026 \\
\hline Int. 2 & $-1,005$ & 0,074 & $-0,372$ & 0,372 & $-0,487$ & 0,017 \\
\hline Int. 2a & $-1,047$ & 0,076 & $-0,342$ & 0,342 & $-0,502$ & 0,026 \\
\hline Int. 3 & $-1,004$ & 0,082 & $-0,412$ & 0,375 & $-0,775$ & 0,018 \\
\hline Int. 3a & $-1,045$ & 0,085 & $-0,391$ & 0,388 & $-0,646$ & 0,020 \\
\hline Int. 4 & $-1,004$ & 0,081 & $-0,413$ & 0,413 & $-0,773$ & 0,018 \\
\hline Int. 4a & $-1,045$ & 0,084 & $-0,387$ & 0,387 & $-0,640$ & 0,020 \\
\hline
\end{tabular}

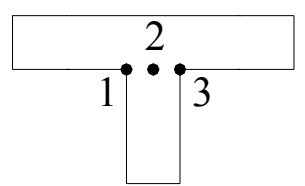

(a) Seções - cisalhamento

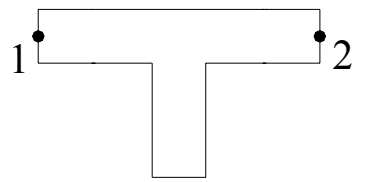

(b) Seções - tensão normal

Figura 6.5 - Seções analisadas nos modelos numéricos

Inicialmente comparam-se os comportamentos dos modelos que utilizam o bloco de amarração na interseção (Int. 2, 2a, 4 e 4a) e os modelos que utilizam o bloco e o meio-bloco (Int. 1, 1a , 3 e 3a). A princípio, na análise linear, os modelos apresentaram pequenas diferenças entre os valores máximos (ver Tabela 6.3) e as distribuições de tensões, vide exemplo na Figura 6.6. Portanto, isso indica um comportamento semelhante para os dois tipos de amarração, pelo menos para situações com baixos níveis de tensões, com a ligação ainda apresentando um comportamento linear. Entretanto, acredita-se que para níveis de tensões superiores as diferenças devam 
aumentar, por causa da menor resistência da junta da argamassa, tanto em relação à compressão como também à aderência.

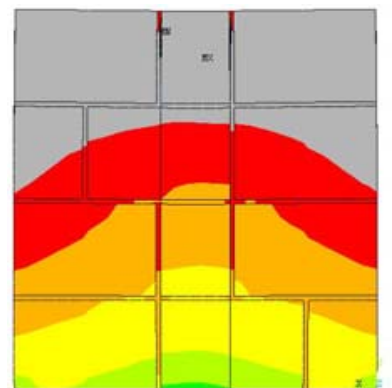

(a) Modelo Int. 1a-tensão $\sigma_{y}$ - flange

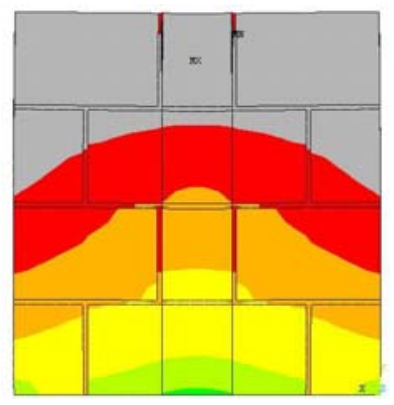

$\sigma \mathbf{y}(\mathbf{M P a})$

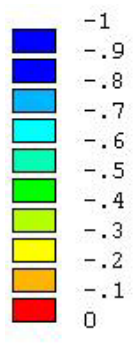

(b) Modelo Int. $2 a$-tensão $\sigma_{y}$ - flange

* Região em cinza corresponde às tensões de tração

Figura 6.6-Semelhança da distribuição de tensões para os dois tipos de amarração

Uma questão que pode ser levantada é em relação à simetria da distribuição das ações verticais nos casos dos modelos em que a interseção é feita apenas com blocos e meios-blocos. Porém, analisando-se a distribuição das tensões normais verticais $\left(\sigma_{y}\right)$, Figura 6.6, observa-se que a excentricidade causada pela não simetria das fiadas é pequena. Isso pode ser visualizado na Figura 6.7a, que exibe a distribuição dessa tensão para o modelo Int 1a. Contudo, a não-simetria gerada pelos meios-blocos pode ser percebida no caso das tensões de cisalhamento no plano do flange $\left(\sigma_{x y}\right)$, onde a diferença em cada lado do flange chega a 10\% no caso dos modelos Int 1 e 3 (Tabela 6.3 e Figura 6.7b). Entretanto, nos modelos Int 1a e Int 3a, as diferenças não ultrapassam $1 \%$.

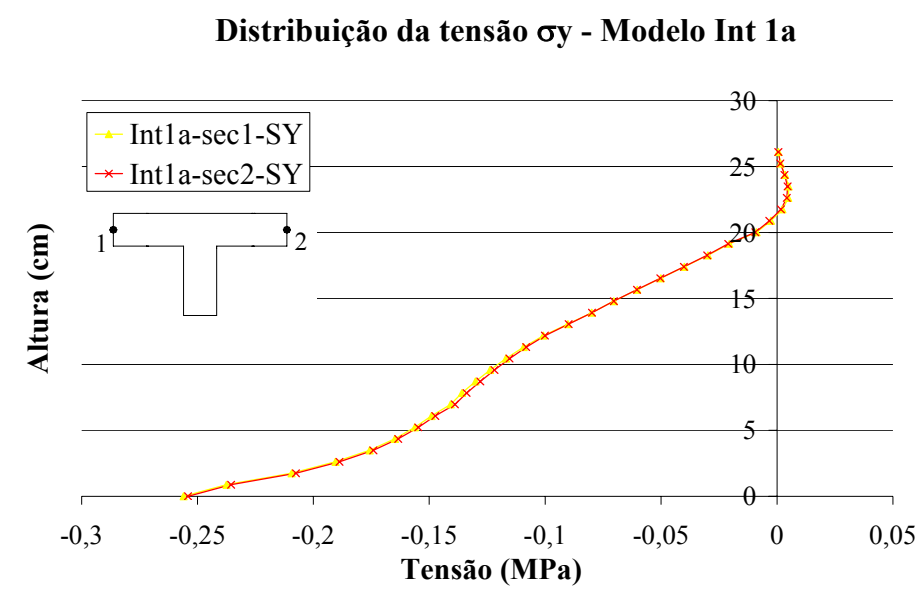

(a)

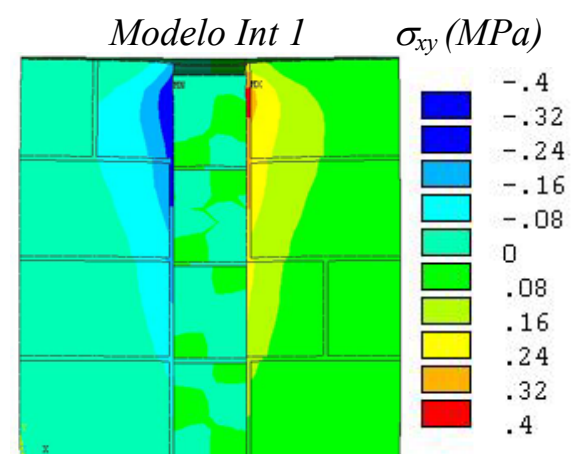

(b)

Figura 6.7- Verificação da excentricidade nos modelos sem bloco de amarração

Realizando-se comparações entre as geometrias adotadas, em relação à disposição das fiadas, percebe-se que a geometria 1a apresenta um comportamento mais 
simétrico que a geometria 1. Já para as geometrias 2 e 2 a não existe diferença, visto que ambas são simétricas. Em termos de tensões máximas, as mudanças de geometrias geram pequenas diferenças, não ultrapassando 7\%. Quanto à distribuição da tensão normal vertical, o comportamento é praticamente o mesmo, sendo difícil observar qualquer diferença. Já para as tensões cisalhantes existem pequenas diferenças que podem ser observadas na Figura 6.8, embora não sejam consideradas significativas. Entretanto, acredita-se que com o aumento dos níveis de tensão, as diferenças entre os modelos aumentem. Isso porque nos casos das geometrias 1 e 2 a análise numérica considera que a junta vertical de argamassa no topo da interseção seja capaz de transmitir as forças da parede central para o flange, o que não é verdade a partir de um determinado nível de tensão.

Tensão cisalhantes ao longo da altura da seção 1

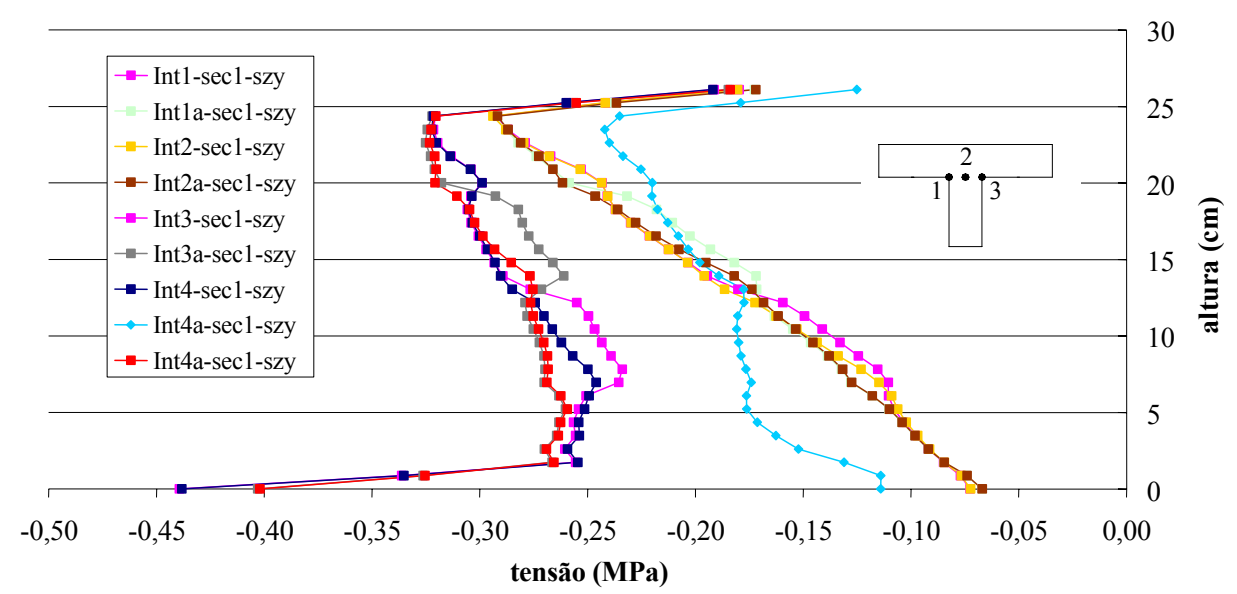

Figura 6.8 - Comparação da distribuição das tensões cisalhantes ao longo da altura para diferentes geometrias e apoios

De todas as comparações realizadas, a mais importante é a que investiga a influência da condição de apoio do corpo-de-prova: toda a base restrita ou apenas os flanges restritos. A princípio não se percebem diferenças significativas em relação aos valores extremos da tensão normal vertical $\left(\sigma_{\mathrm{y}}\right)$, entretanto, isso é devido aos valores extremos ocorrerem na região superior do corpo-de-prova, portanto, distantes das regiões com restrições. Já para as tensões cisalhantes, é possível verificar a mudança de comportamento. O modelo com apenas os flanges restritos apresenta valores de tensões superiores ao modelo com toda a base restrita. No primeiro caso todo o carregamento aplicado na parede central deve ser transferido para os flanges; dessa forma a tensão cisalhante chega a ser $60 \%$ superior à da segunda situação. Observa-se, também, que nos modelos em que a parede central é livre, as distribuições das tensões cisalhantes 
possuem um comportamento mais uniforme ao longo da altura, apesar de apresentar picos de tensões. (Figura 6.8 e Figura 6.9).
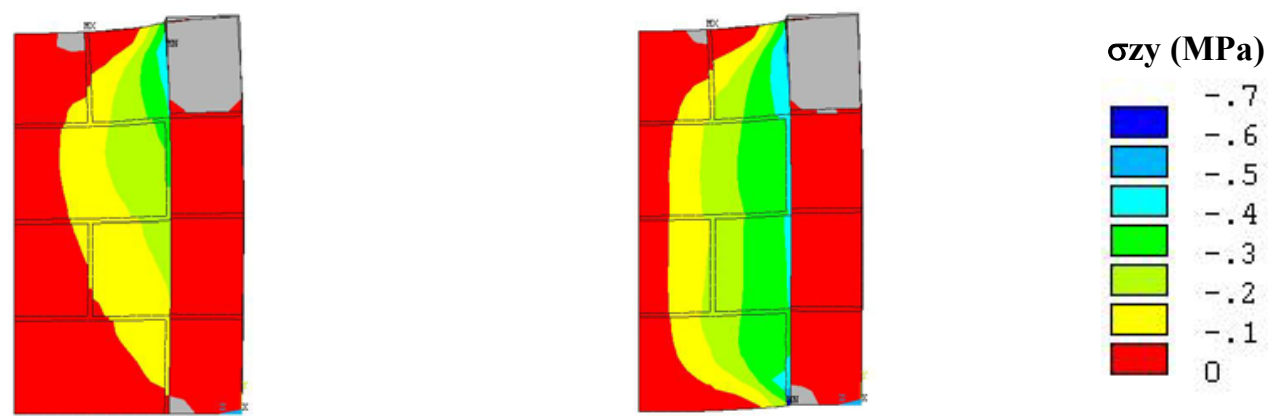

modelo Int $1 a$-base toda restrita modelo Int $3 a$-apenas o flange restrito

Figura 6.9-Distribuição das tensões cisalhantes para diferentes condições de apoios

Também se observa que os modelos com a base restrita e com apenas os flanges restritos possuem comportamentos semelhantes para a distribuição das tensões normais verticais $\left(\sigma_{\mathrm{y}}\right)$ ao longo da altura. No entanto, os valores de tensão para o modelo com a parede central livre são sempre superiores (vide Figura 6.10), visto que todo o carregamento deve ser transferido aos flanges.

\section{Distribuição da tensão $\sigma y$ ao longo da altura}

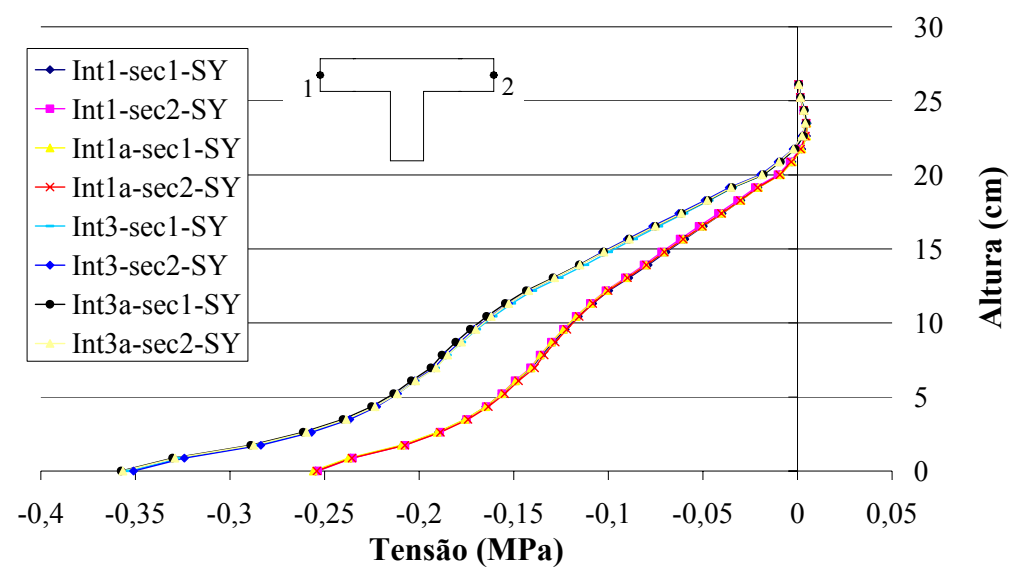

Figura 6.10 -Distribuição das tensões normais (бy) ao longo da altura para diferentes condições de apoios

Com base nesses resultados acredita-se que a não utilização do bloco de amarração na interseção não deva trazer maiores conseqüências para as transferências de forças entre as paredes do corpo-de-prova, pelo menos para baixos níveis de tensão onde o comportamento é linear. A amarração através de blocos e meios-blocos, apesar de não ser simétrica, não introduz excentricidades apreciáveis. Parece ser mais razoável utilizar disposições dos blocos de tal maneira que na fiada do topo já existam blocos para o intertravamento das paredes. E finalmente, a condição de apenas os flanges 
restritos com a parede central livre proporciona uma distribuição de tensões de cisalhamento mais uniforme, que é justamente um dos objetivos nesse corpo-de-prova. Portanto, de todos os modelos estudados, o que parece ser mais indicado para a obtenção da resistência ao cisalhamento vertical da alvenaria é o modelo Int $3 \mathrm{a}$ (vide Tabela 6.1).

Todavia, observa-se uma deficiência no corpo-de-prova de quatro fiadas: sua disposição das fiadas não é favorável ao estudo da influência da cinta de amarração à meia altura. Dessa forma, realiza-se um estudo numérico considerando o corpo-deprova com cinco fiadas, onde, além da possibilidade da análise da influência da cinta de amarração à meia altura ou no topo, obtém-se uma melhor situação de simetria para a amarração realizada com blocos e meios-blocos. Acredita-se, também, que o fato de existir um maior número de blocos intertravados seja uma situação mais favorável.

Assim, a análise numérica do modelo com cinco fiadas fica restrita a apenas uma geometria, que se fundamenta no modelo Int $3 \mathrm{a}$, sendo apenas adicionada uma fiada. A Figura 6.11 ilustra a geometria adotada, bem como as vistas frontal e lateral do corpo-de-prova.

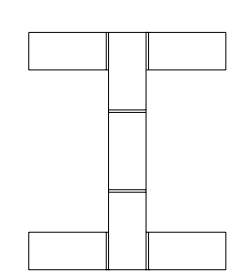

$1^{a}, 3^{a}$ e $5^{a}$ fiadas

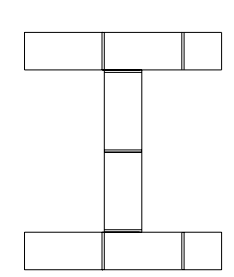

$2^{a}$ fiada

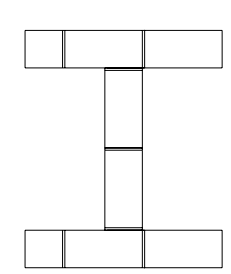

$4^{a}$ fiada

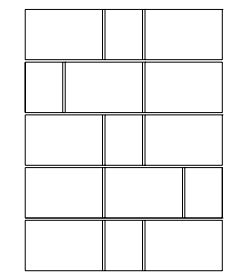

Vista frontal

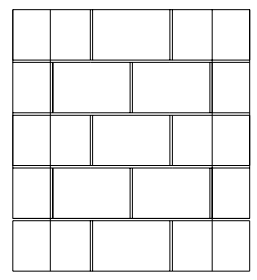

Vista lateral

Figura 6.11-Geometria do corpo-de-prova com cinco fiadas

As propriedades e características do modelo numérico são as mesmas do corpode-prova com quatro fiadas apresentadas anteriormente na Tabela 6.2. Também se utilizam as características da simetria para o estudo de apenas metade do painel. $\mathrm{O}$ carregamento de $1 \mathrm{MPa}$ é aplicado somente na parede central. A Figura 6.12 ilustra o modelo de cinco fiadas com sua discretização.

São investigadas duas situações de restrição: 1) flange restrito na base (restrições de deslocamento em x, y e z) com a parede central livre e 2) flange com apenas deslocamentos verticais (y) restritos na base e com a parede central livre. A Tabela 6.4 exibe os valores extremos das tensões normal vertical $\left(\sigma_{y}\right)$, de cisalhamento no plano da parede central $\left(\sigma_{\mathrm{zy}}\right)$ e principais $\left(\sigma_{1}\right.$ e $\left.\sigma_{3}\right)$ para as duas situações de restrições. Vale ressaltar que neste caso não é apresentada a tensão cisalhante no plano 
do flange $\left(\sigma_{\mathrm{xy}}\right)$, pois se verifica no modelo com quatro fiadas que não é uma situação crítica.

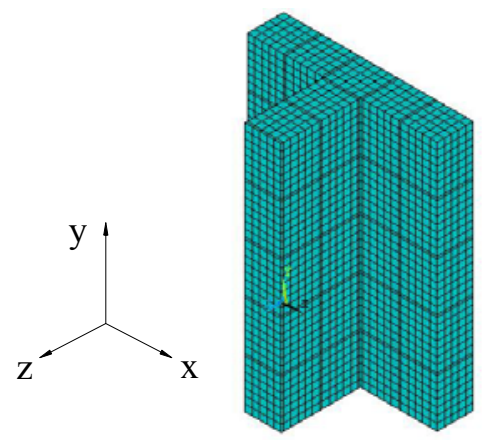

Figura 6.12 -Discretização do corpo-de-prova com cinco fiadas

Tabela 6.4 - Valores extremos de tensões para os modelos com cinco fiadas - (MPa)

\begin{tabular}{|c|c|c|c|c|c|c|c|c|}
\hline Modelos & $\sigma_{\mathrm{y}}, \mathbf{m i n}$ & $\sigma_{\mathbf{y}}, \mathbf{m a x}$ & $\sigma_{\mathbf{z y}}, \mathbf{m i n}$ & $\sigma_{\mathbf{z y}}, \mathbf{m a x}$ & $\sigma_{1}, \mathbf{m i n}$ & $\sigma_{\mathbf{1}}, \mathbf{m a x}$ & $\sigma_{3}, \mathbf{m i n}$ & $\sigma_{3}, \mathbf{m a x}$ \\
\hline Flange rest. (1) & $-1,049$ & 0,082 & $-0,678$ & 0,024 & $-0,247$ & 0,300 & $-1,627$ & 0,003 \\
\hline Flange uy rest.(2) & $-1,049$ & 0,083 & $-0,559$ & 0,060 & $-0,220$ & 0,495 & $-1,117$ & 0,030 \\
\hline $\mathbf{( 1 ) / ( 2 )}$ & 1,000 & 0,983 & 1,213 & 0,402 & 1,126 & 0,606 & 1,457 & 0,104 \\
\hline
\end{tabular}

Percebe-se que nos dois modelos as tensões normais verticais $\left(\sigma_{\mathrm{y}}\right)$, são muito próximas, com os valores máximos possuindo a mesma localização (região de aplicação do carregamento). Para as tensões de cisalhamento no plano da parede central $\left(\sigma_{z y}\right)$, observa-se na Figura 6.13 um pequeno efeito devido as mudanças nas restrições. O modelo com flange restrito exibe uma concentração dessa tensão na região próxima à base, fato que não ocorre com tal magnitude no outro modelo em que os deslocamentos horizontais estão livres. Os valores máximos absolutos se localizam em regiões diferentes. No modelo com o flange restrito o máximo ocorre na interseção numa região próxima à base (devido às restrições horizontais); já no outro modelo esse máximo ocorre próximo ao topo. Além disso, no modelo com a base do flange toda restrita esse valor crítico é cerca de $20 \%$ superior.
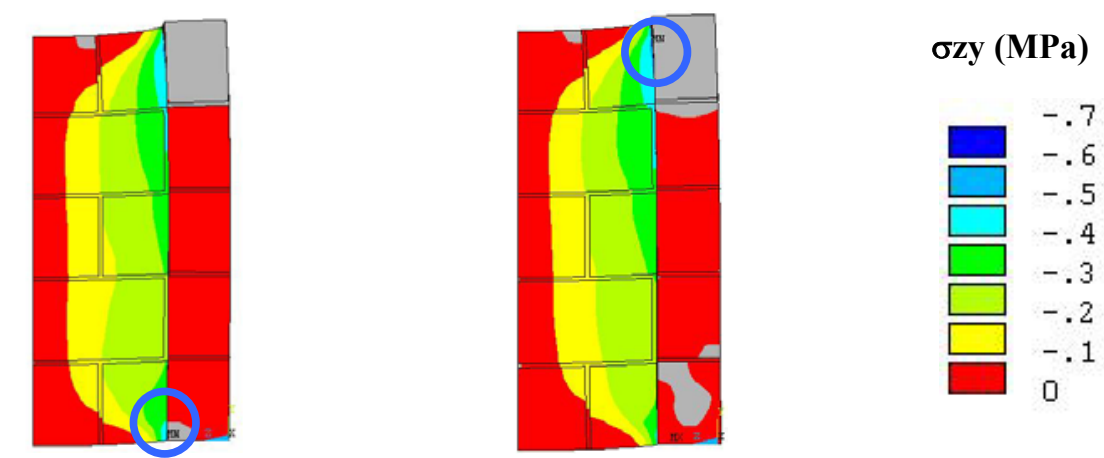

Modelo flange restrito Modelo flange com desl. hor. livres

Figura 6.13-Distribuição das tensões de cisalhamento no plano da parede central $\left(\sigma_{z y}\right)$ 
No caso das tensões principais $\left(\sigma_{1}\right)$, a mudança nas restrições gera significativas diferenças nos valores extremos. O modelo com o flange com os deslocamentos horizontais livres apresenta uma tensão máxima $65 \%$ maior que o caso restrito. Observa-se uma mudança na localização desses valores; no caso do flange restrito, a tensão máxima positiva ocorre na região da interseção na fiada abaixo do carregamento, enquanto que no outro caso ocorre na região central da base da parede central, indicando uma tendência de flexão desta (vide Figura 6.14).

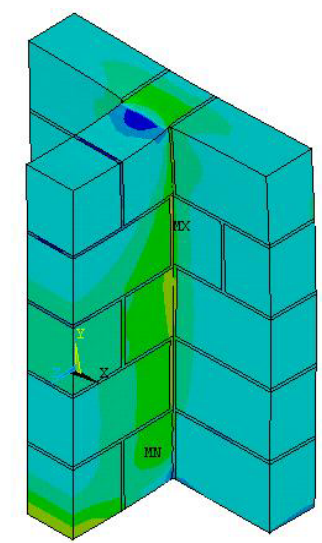

Modelo flange restrito

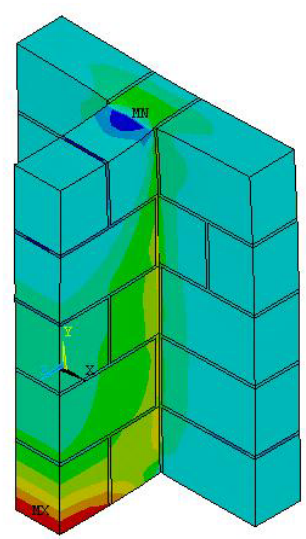

Modelo flange com desl. hor. livres
$\sigma_{1}(\mathbf{M P a})$

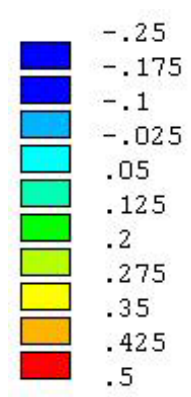

Figura 6.14-Distribuição das tensões principais $\left(\sigma_{I}\right)$

Para as tensões principais $\left(\sigma_{3}\right)$, também se observam diferenças dos valores e da localização dos seus extremos, mas não na distribuição das tensões. No modelo de flange restrito existe uma certa concentração de tensão na base devida às restrições, gerando altos valores de tensões negativas. Enquanto que no modelo onde os deslocamentos horizontais estão livres, não há uma concentração tão alta de tensões, contudo o valor mínimo também ocorre nessa mesma região. Em relação à tensão máxima positiva o primeiro modelo apresenta valor bem inferior, localizando-se no topo do flange. Para o modelo com apenas os deslocamentos verticais dos flanges restritos o valor máximo é muito superior, mas de pequena magnitude, ocorrendo na região inferior da parede central, apontando mais uma vez para a flexão desta região. $\mathrm{Na}$ Figura 6.15 é possível a visualização das distribuições dessas tensões e a localização das tensões máximas positivas.

Ao contrário dos valores extremos de tensão, as distribuições das tensões ao longo da altura do modelo não apresentam diferenças significativas. Pode-se considerar que o comportamento na região das três fiadas próximas ao topo é praticamente o 
mesmo. A tensão principal $\left(\sigma_{1}\right)$ é que apresenta a maior diferença, principalmente nas duas primeiras fiadas (Figura 6.16).
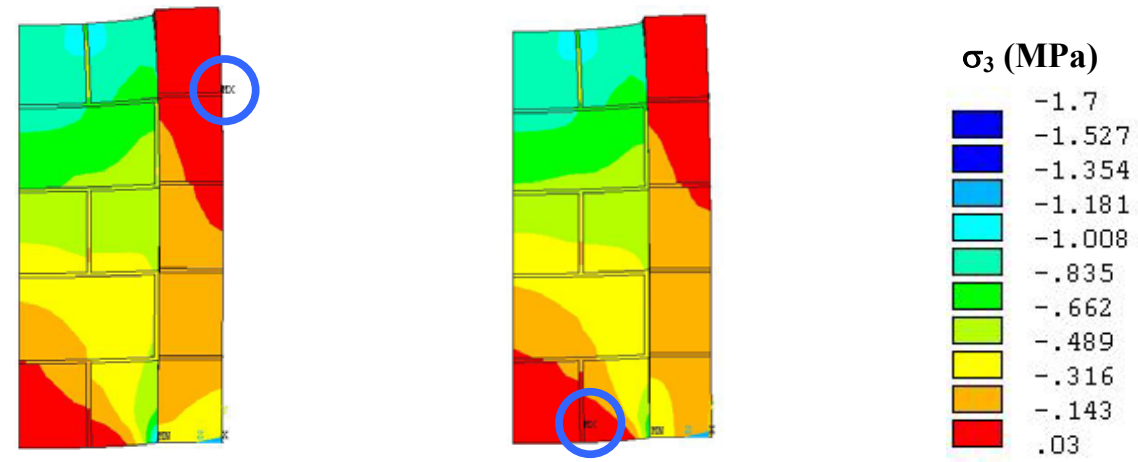

Modelo flange restrito Modelo flange com desl. hor. livres

Figura 6.15-Distribuição das tensões principais $\left(\sigma_{3}\right)$

Comparação dos modelos para a seção 3

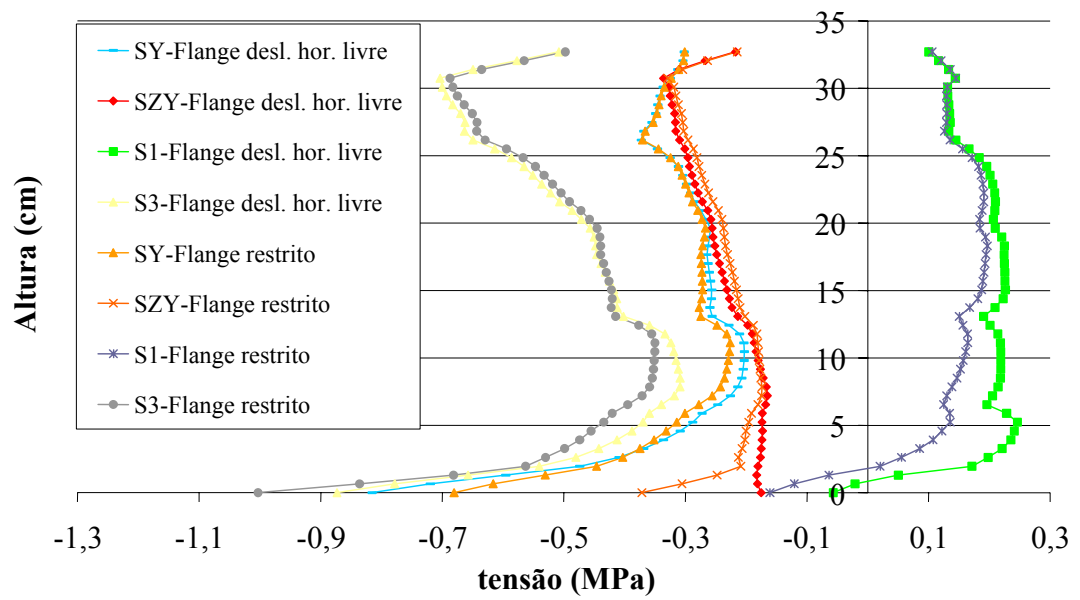

Seções

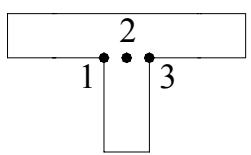

Figura 6.16 - Comparação das distribuiç̃̃es das tensões ao longo da altura- seção 3

Nas distribuições das tensões normais verticais $\left(\sigma_{\mathrm{y}}\right)$ ao longo da altura dos flanges (Figura 6.17) percebe-se que a liberação dos vínculos horizontais gera uma menor concentração de tensão na região próxima à base quando comparado ao caso restrito. Na região superior o comportamento dos dois modelos é semelhante, enquanto que numa posição intermediária os modelos com os flanges restritos exibem tensões inferiores. Em ambos os modelos observam-se excentricidades insignificantes.

Nas comparações entre os dois modelos com cinco fiadas acredita-se que o caso com os flanges restritos seja o mais realista, visto que na prática os deslocamentos horizontais da base dos mesmos possuem um certo grau de restrição, talvez não total, mas também não desimpedidos. Nos modelos com os deslocamentos horizontais livres, verificam-se pelas tensões principais $\left(\sigma_{1}\right.$ e $\left.\sigma_{3}\right)$ que a parede central está submetida à 
flexão, o que pode gerar uma ruptura indesejável do corpo-de-prova. Portanto, acreditase que o modelo com o flange restrito seja teoricamente o mais apropriado para a representação de um corpo-de-prova em que a ruptura ocorra por cisalhamento.

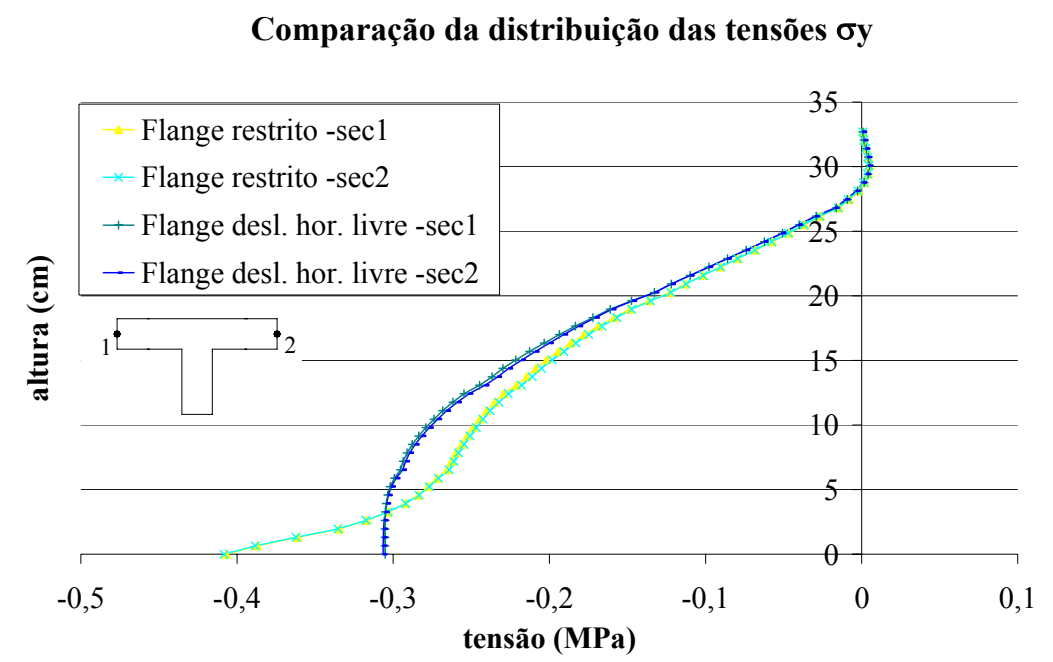

Figura 6.17 - Comparação das distribuições das tensões $\sigma_{y}$ ao longo da altura dos flanges

Definido o modelo com cinco fiadas, que se acredita ser o mais adequado para a determinação da resistência ao cisalhamento vertical, inicia-se uma nova etapa da investigação, a modelagem considerando-se os blocos com suas cavidades. As propriedades dos materiais são as mesmas utilizadas até aqui (Tabela 6.2), a geometria é a apresentada na Figura 6.11, as condições de restrições são flanges com deslocamentos restritos na base e parede central livre. $\mathrm{O}$ carregamento é de $1 \mathrm{MPa}$ em relação à área líquida dos blocos, com o objetivo de simular uma condição similar de tensões aos modelos com os blocos sólidos. Todavia, há a necessidade de mudar, ligeiramente, o tipo da discretização, para permitir a geração da rede do elemento utilizado (sólido com 8 nós), ver Figura 6.18.

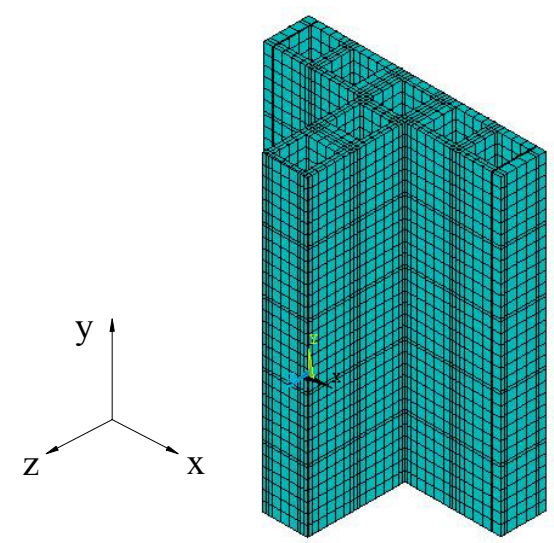

Figura 6.18 - Modelo considerando-se as cavidades dos blocos. 
Realiza-se uma comparação das tensões máximas obtidas pelos modelos sólido e vazado. Analisam-se as tensões normal vertical $\left(\sigma_{\mathrm{y}}\right)$, de cisalhamento no plano da parede central $\left(\sigma_{\mathrm{zy}}\right)$ e do flange $\left(\sigma_{\mathrm{xy}}\right)$, e principais $\left(\sigma_{1}\right.$ e $\left.\sigma_{3}\right)$. Os valores extremos dessas tensões estão apresentados na Tabela 6.5. Deve-se lembrar que como é mantida a mesma tensão em relação à área líquida, a força a ser transmitida pelo modelo sólido $(45,6 \mathrm{kN})$ é superior à do modelo vazado $(25,6 \mathrm{kN})$.

Tabela 6.5 - Valores extremos de tensões para os modelos com cinco fiadas -(MPa)

\begin{tabular}{|c|c|c|c|c|c|c|c|c|c|c|}
\hline \multirow{2}{*}{ Modelos } & \multicolumn{2}{|c|}{$\sigma_{\mathrm{y}}$} & \multicolumn{2}{c|}{$\sigma_{\mathrm{xy}}$} & \multicolumn{2}{c|}{$\sigma_{\mathbf{z y}}$} & \multicolumn{2}{c|}{$\sigma_{\mathbf{1}}$} & \multicolumn{2}{c|}{$\sigma_{\mathbf{3}}$} \\
\cline { 2 - 11 } & $\mathbf{m i n}$ & $\mathbf{m a x}$ & $\min$ & $\mathbf{m a x}$ & $\min$ & $\mathbf{m a x}$ & $\min$ & $\mathbf{m a x}$ & $\min$ & $\mathbf{m a x}$ \\
\hline Sólido & $-1,049$ & 0,082 & $-0,401$ & 0,398 & $-0,678$ & 0,024 & $-0,247$ & 0,300 & $-1,627$ & 0,003 \\
\hline Vazado & $-1,394$ & 0,099 & $-0,431$ & 0,431 & $-0,733$ & 0,167 & $-0,216$ & 0,676 & $-1,932$ & 0,012 \\
\hline
\end{tabular}

Pelos valores apresentados percebe-se que os modelos vazados apresentam maiores concentrações de tensões. Até mesmo as tensões de cisalhamento do modelo vazado são superiores às do modelo sólido. Para uma melhor comparação dos modelos é necessária uma investigação da distribuição das tensões ao longo da altura. Para isso são definidas as mesmas seções utilizadas na análise do modelo sólido, apresentadas anteriormente na Figura 6.5.

No caso da distribuição das tensões normais verticais $\left(\sigma_{y}\right)$ nos flanges observase que tanto o modelo sólido quanto o vazado apresentam um comportamento semelhante, como pode ser visualizado na Figura 6.19. A não simetria das fiadas fica mais evidente no modelo vazado, ver Figura 6.20. Já na distribuição ao longo da altura da interseção, Figura 6.21, percebe-se que o modelo vazado apresenta maiores perturbações que o modelo sólido. Entretanto, pode-se dizer que ambos os modelos apresentam uma mesma tendência de distribuição ao longo da maior parte da altura do corpo-de-prova.

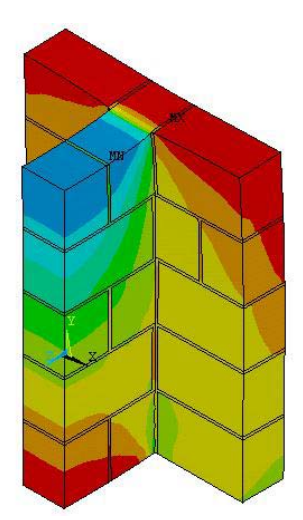

Modelo sólido

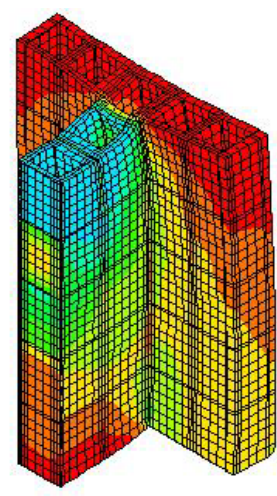

Modelo considerando os vazios

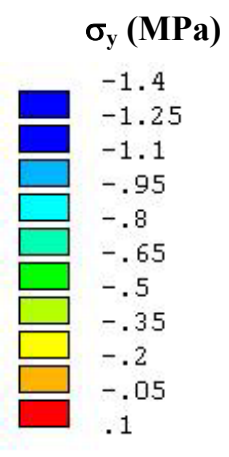

Figura 6.19 - Distribuição das tensões normais verticais (бy) 
Distribuição das tensões $\sigma \mathrm{y}$ ao longo da altura dos flanges

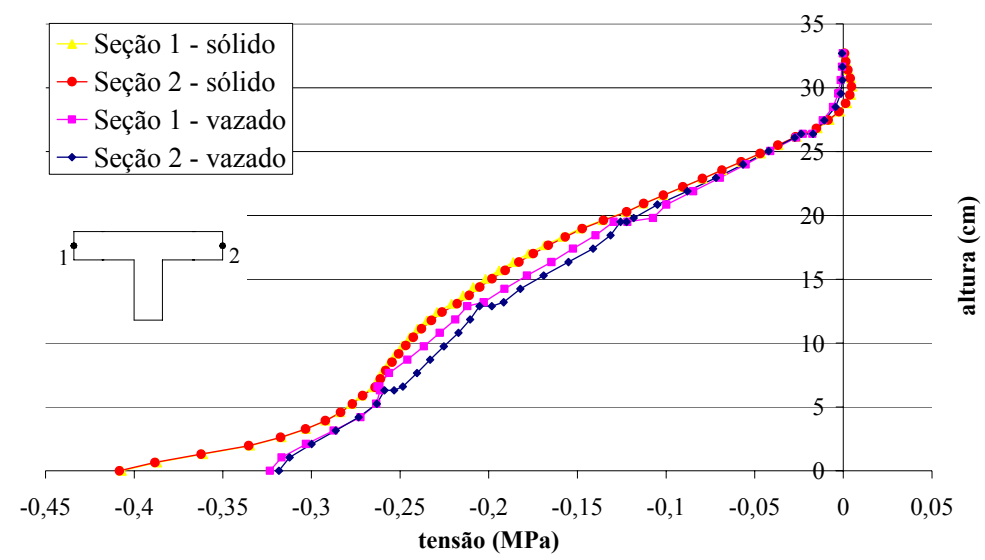

Figura 6.20 - Distribuição das tensões $\left(\sigma_{y}\right)$ ao longo da altura dos flanges

\section{Distribuição da tensão $\sigma y$ - Interseç̧ão}

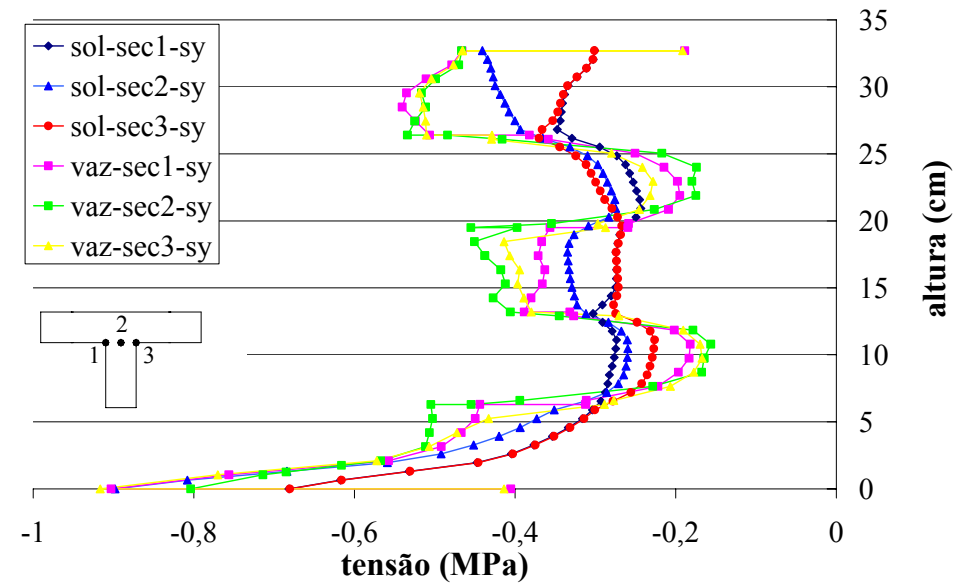

Figura 6.21 - Distribuição das tensões $\left(\sigma_{y}\right)$ ao longo da altura da interseção

Para a análise das tensões cisalhantes no plano da parede central $\left(\sigma_{\mathrm{zy}}\right)$, Figura 6.22, observa-se que a seção no centro da interseção (seção 2) é afetada pela presença dos vazios, não havendo comparação entre os modelos sólido e vazado. Contudo, notase para as outras seções (1 e 3), que os diferentes modelos apresentam uma mesma tendência de distribuição, com as maiores diferenças nas regiões referentes à junta de argamassa. Considerando-se que a tensão de cisalhamento média seja a força transferida dividida pela área da interseção (espessura do bloco x altura do corpo-de-prova), percebe-se que as tensões atuantes no modelo sólido são geralmente inferiores ao valor médio, enquanto que no modelo vazado ocorre o contrário, ou seja, as tensões são superiores à média.

Realiza-se, ainda, uma comparação entre as distribuições das tensões cisalhantes no plano do flange $\left(\sigma_{\mathrm{xy}}\right)$ e da parede central $\left(\sigma_{\mathrm{zy}}\right)$ para o modelo considerando os vazios, Figura 6.23. Percebe-se que os valores máximos das tensões relacionadas aos flanges 
$\left(\sigma_{\mathrm{xy}}\right)$ são inferiores aos observados na parede central $\left(\sigma_{\mathrm{zy}}\right)$. No caso da seção 2 , região central do bloco, as tensões de cisalhamento são inferiores às demais.

\section{Distribuição das tensões cisalhantes $\sigma_{\mathrm{zy}}$ - interseção}

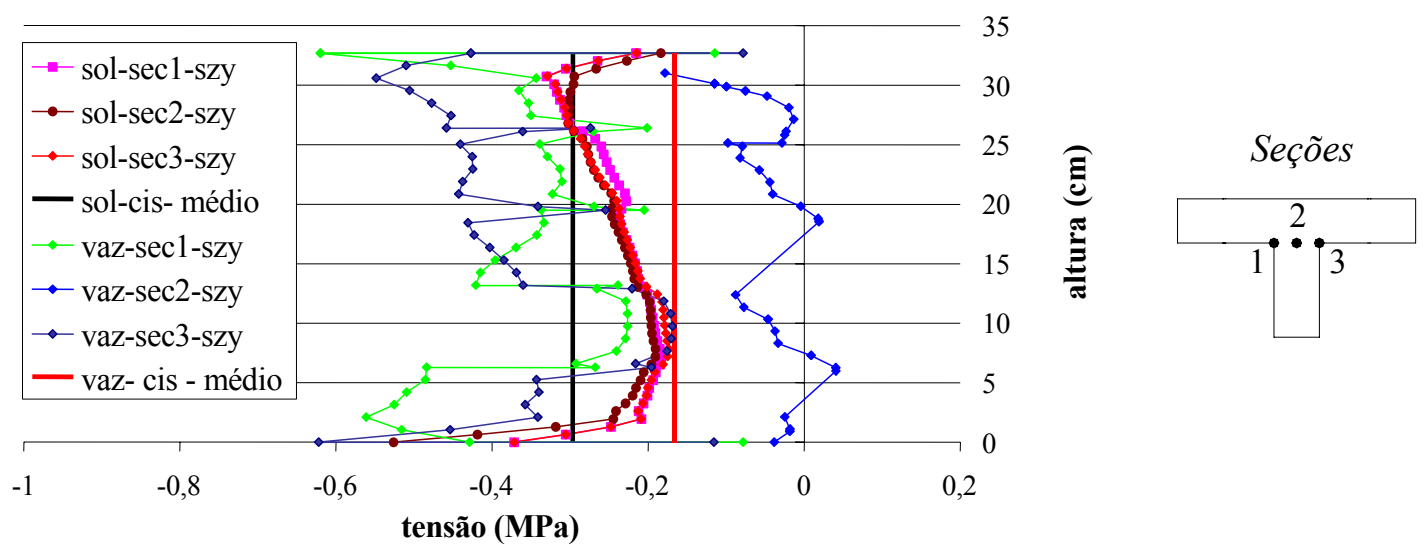

Figura 6.22 - Distribuição das tensões cisalhantes $\left(\sigma_{z y}\right)$ ao longo da altura da interseção

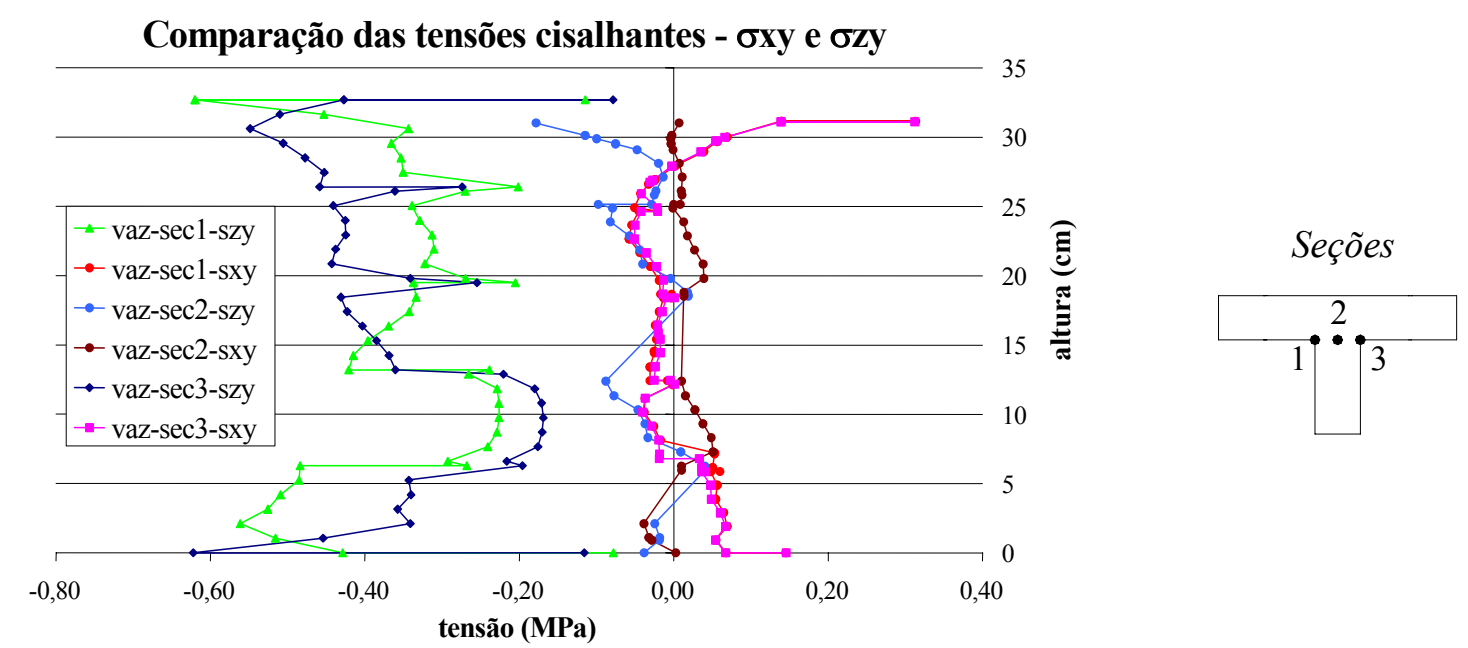

Figura 6.23 - Distribuição das tensões cisalhantes $\left(\sigma_{x y}\right)$ e $\left(\sigma_{z y}\right)$ ao longo da altura da interseção

Acredita-se que este modelo com cinco fiadas, com o flange restrito e parede central livre, seja o corpo-de-prova mais indicado para a obtenção do cisalhamento vertical, por causa da distribuição praticamente constante das tensões cisalhantes junto à interseção. Entretanto, ainda é necessária a realização de ensaios que indiquem se a ruptura ocorrerá mesmo por cisalhamento, ou se algum fator não considerado leve a um outro tipo de ruptura. Ressalta-se que não são analisados modelos numéricos com a presença de cintas, pois o objetivo inicial é a determinação da resistência da alvenaria ao cisalhamento vertical. 


\section{3- Estudo de painéis de alvenaria com diferentes seções em planta}

Neste item investiga-se a influência da seção em planta dos painéis de alvenaria estrutural na distribuição das ações verticais. Capuzzo Neto (2000), Parsekian e Franco (2002) e Corrêa e Page (2001) verificam a influência dessas dimensões dos painéis no processo de interação de paredes. Esta é uma etapa importante para a definição dos procedimentos mais indicados para o uso no projeto estrutural do edifício de alvenaria. Também é através deste estudo que se definem diretrizes para os futuros ensaios de painéis de alvenaria.

A escolha das dimensões dos painéis tem como base a proposta de Corrêa e Page (2001), na qual utilizam o Princípio de Saint Venant para se estudar a uniformização das tensões normais verticais. Esses autores consideram que, no caso de carregamentos centrados, a distância vertical mínima necessária para essa uniformização é igual ao diâmetro do círculo que circunscreve o painel em planta. Para carregamentos excêntricos verificam a necessidade de no mínimo dois pavimentos para que ocorra a uniformização, visto que neste caso depende da ação dos vínculos horizontais proporcionados pelas lajes.

São definidos dois tipos de seções em planta: o formato " $\mathrm{H}$ ", com dois eixos de simetria, e o formato " $Z$ ", adaptado do caso anterior (Figura 6.24). Dessa forma, podese analisar casos com carregamentos centrados e excêntricos. Ambas as seções em planta possuem círculos que as circunscrevem com o mesmo diâmetro. Para cada um desses formatos, escolhem-se duas situações de distribuição das ações verticais, uma onde a uniformização das tensões normais verticais ocorre em apenas um pavimento (somente para carregamentos centrados) e uma segunda onde sejam necessários dois andares para isso. Para a primeira situação adotam-se painéis de tal forma que o diâmetro seja igual à metade da altura do pavimento, enquanto para o segundo caso o diâmetro deve ser igual a uma vez e meia a distância entre pisos.

Assume-se que os painéis "H", independentemente do caso, possuem a mesma proporção entre os comprimentos dos flanges e da parede central (neste caso igual a 0,83 ). As dimensões aqui adotadas são todas relacionadas à utilização dos blocos em escala reduzida, visto que os ensaios devem ser realizados com este tipo de bloco. Define-se que a altura do pavimento seja igual a 78,9 $\mathrm{cm}$ (equivalente a $239 \mathrm{~cm}$ na escala 1:1), pois além da existência de ensaios na escala natural para essa dimensão [CAPUZZO NETO (2000)], é uma situação crítica para a uniformização das tensões. As 
figuras 6.25 a 6.28 apresentam as quatro geometrias escolhidas, com a disposição das fiadas e as vistas laterais e frontais para um pavimento. Os modelos são denominados de H1, Z1 (menores diâmetros) e H2 e Z2 (maiores diâmetros).

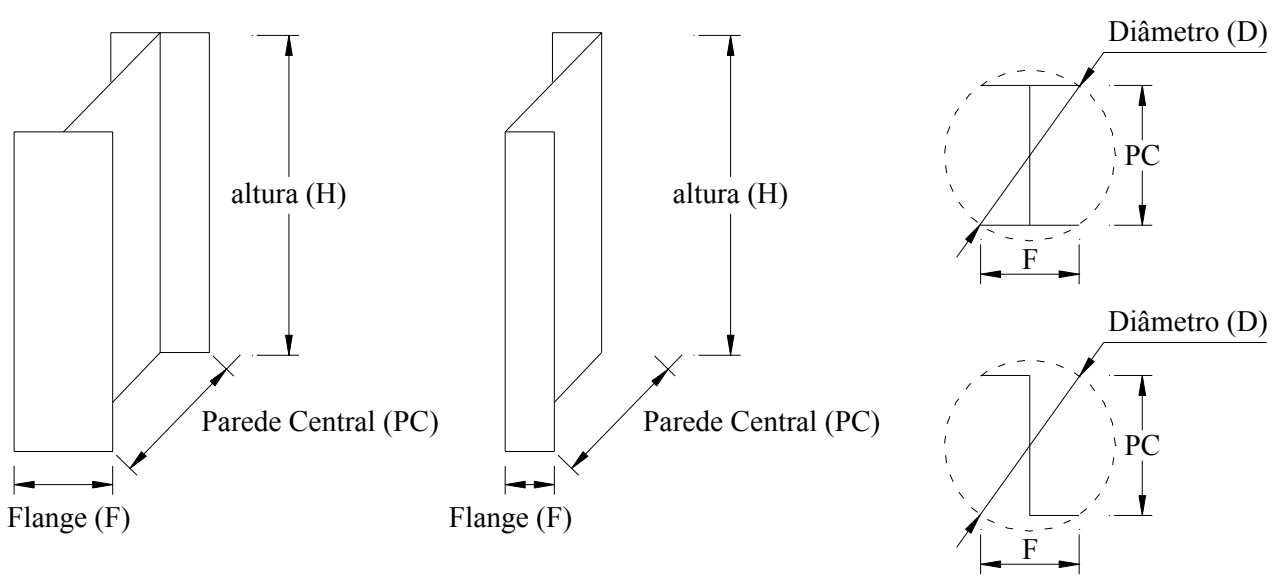

Figura 6.24 - Formatos adotados para as seções em planta.

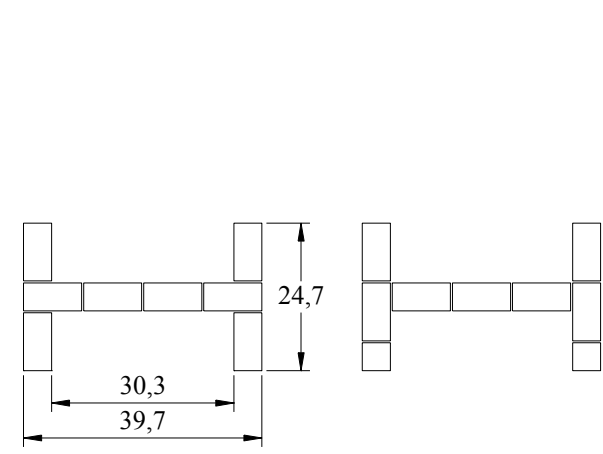

Disposições das fiadas

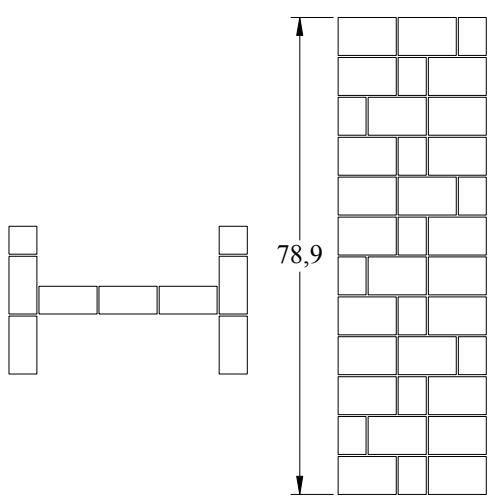

Vista lateral

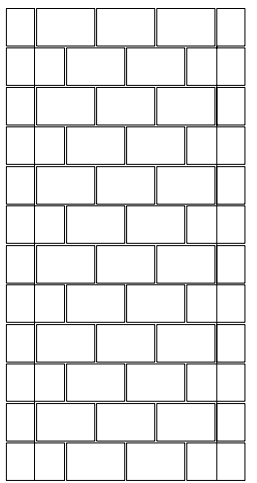

Vista frontal

Figura 6.25 - Geometria, fiadas e vistas do modelo H1
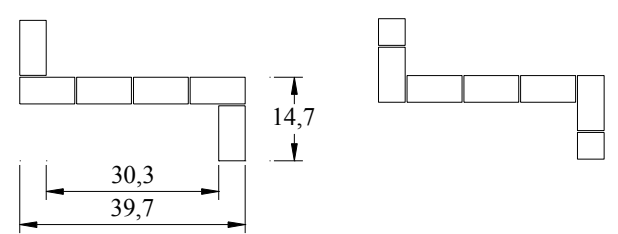

Disposições das fiadas

Figura 6.26 - Geometria, fiadas e vistas do modelo Z1
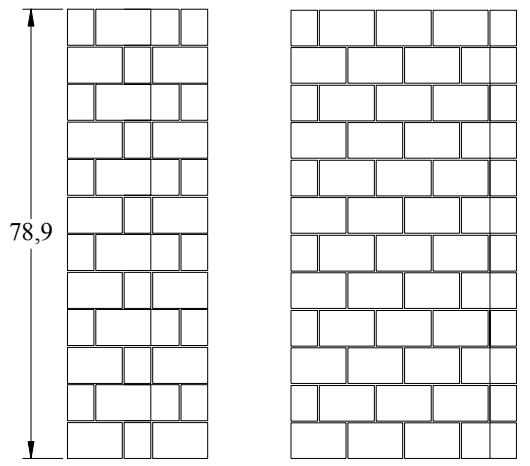

Vista lateral
Vista frontal 

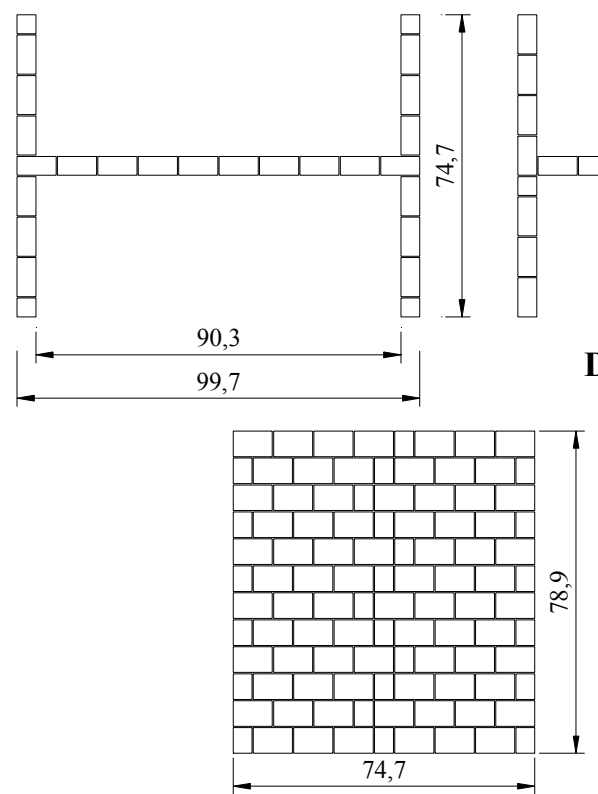

Vista lateral

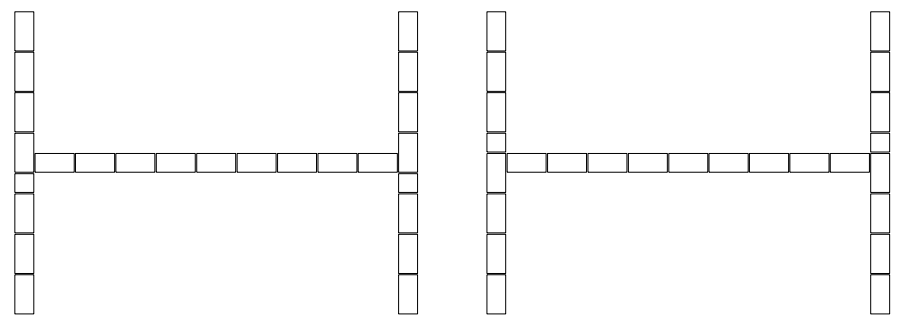

Disposições das fiadas

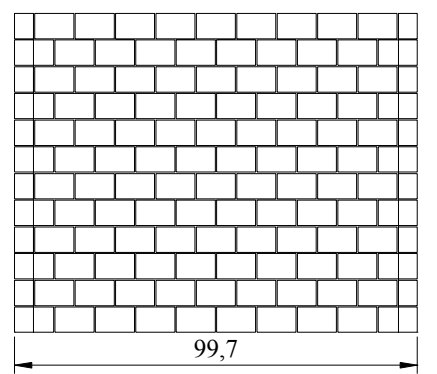

Vista frontal

Figura 6.27-Geometria, fiadas e vistas do modelo $\mathrm{H} 2$
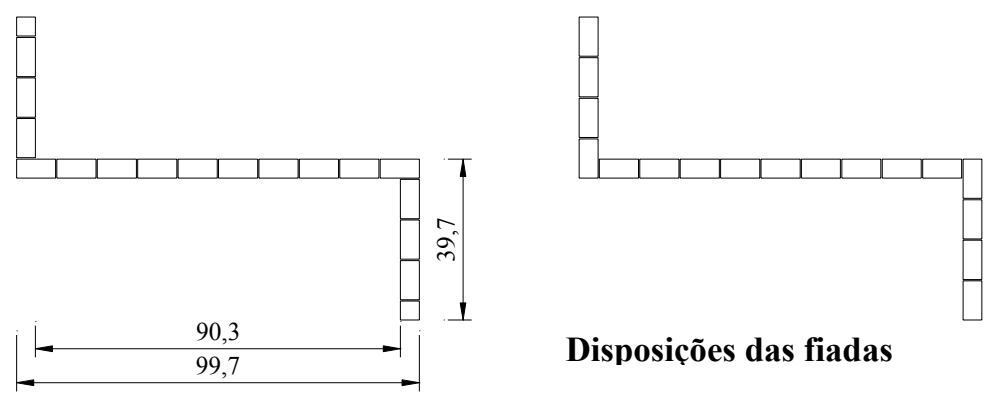

Disposições das fiadas

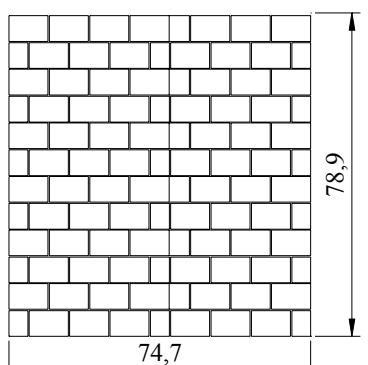

Vista lateral

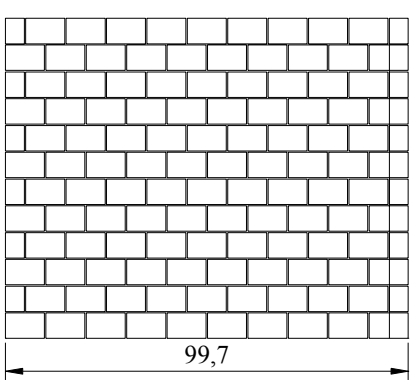

Vista frontal

Figura 6.28 - Geometria, fiadas e vistas do modelo Z2

A análise numérica é realizada considerando-se apenas o comportamento linear dos materiais, e com o emprego do pacote computacional ANSYS. Os blocos e as argamassas são modelados separadamente (micro-modelagem), sem a consideração do comportamento da interface bloco-junta, visto que é uma causa de não-linearidade. Utilizam-se as propriedades de simetria (painel H) e anti-simetria (painel Z), para representar apenas a metade dos painéis. Por causa das grandes dimensões, opta-se por considerar os blocos sólidos, como um modo de simplificação. Os painéis com menores dimensões (H1 e Z1) são discretizados tal que a dimensão máxima do elemento seja 
inferior a $1,6 \mathrm{~cm}$, enquanto que para os painéis de maiores dimensões (H2 e Z2), este limite é de 2,5 cm (vide Figura 6.29).

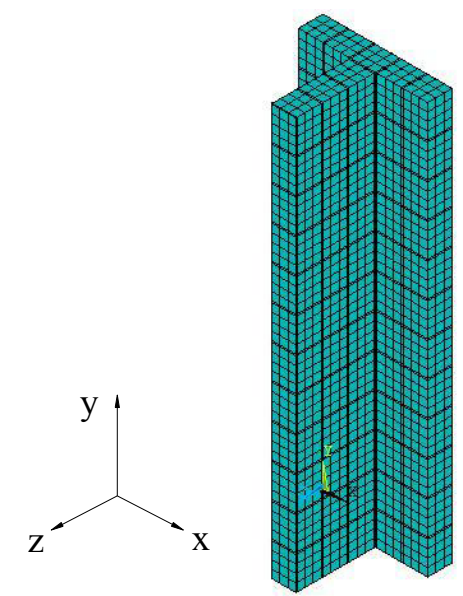

Modelo H1

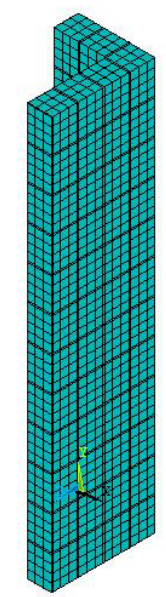

Modelo Z1

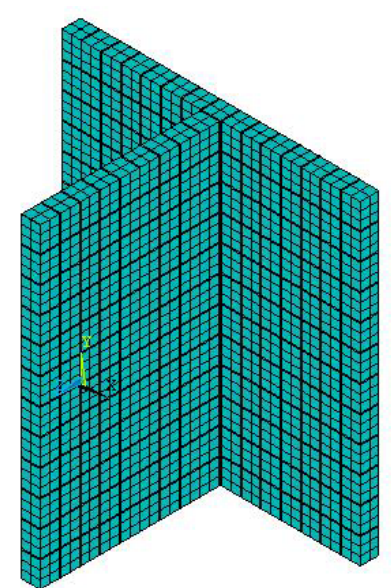

Modelo H2

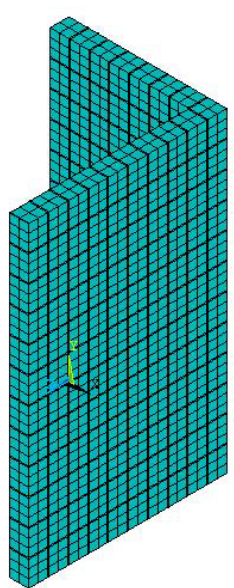

Modelo Z2

Figura 6.29 - Discretizações dos modelos investigados

As propriedades elásticas dos materiais são as mesmas adotadas no item anterior (Tabela 6.2). Em relação às restrições, toda a base dos painéis (parede central e flanges) têm seus deslocamentos restritos em $\mathrm{x}, \mathrm{y}$ e $\mathrm{z}$. Na tentativa de simular os vínculos providos pela presença das lajes, o topo de cada pavimento tem seus deslocamentos horizontais restritos (direção x e z). São considerados modelos com um e dois pavimentos. Nos painéis com um único andar, aplica-se apenas um carregamento de 1 $\mathrm{MPa}$ no topo da parede central. Para os modelos com dois pavimentos, há duas situações de carregamento. Na primeira, é aplicado todo o carregamento (1 MPa), apenas no topo da parede central do segundo pavimento. No segundo tipo, o carregamento é dividido pelo número de andares, adotando-se uma pressão de 0,5 $\mathrm{MPa}$ no topo da parede central de cada pavimento.

As tabelas de 6.6 a 6.9 exibem os valores extremos para as tensões normais verticais $\left(\sigma_{\mathrm{y}}\right)$, cisalhantes no plano do flange $\left(\sigma_{\mathrm{xy}}\right)$ e no plano da parede central $\left(\sigma_{\mathrm{zy}}\right)$, e principais $\left(\sigma_{1}\right.$ e $\left.\sigma_{3}\right)$ dos quatro modelos $(\mathrm{H} 1, \mathrm{Z} 1, \mathrm{H} 2$ e Z2). Apresentam-se, a seguir, observações válidas para todos os casos. Percebe-se que o cisalhamento na parede central $\left(\sigma_{\mathrm{zy}}\right)$ sempre é crítico se comparado ao cisalhamento nos flanges $\left(\sigma_{\mathrm{xy}}\right)$. Nota-se que os modelos com dois pavimentos e carregamento aplicado apenas no topo do segundo pavimento possuem valores extremos bastantes próximos aos obtidos no caso de um único pavimento. Dessa forma, acredita-se que a força de ruptura para ambas as situações sejam próximas. Já nos modelos com dois pavimentos e carregamento 
aplicado igualmente ao nível de cada andar, os valores são inferiores (de 25 a 50\%) ao modelo com um pavimento, indicando que a força necessária para a ruptura seja superior às dos dois outros modelos.

Tabela 6.6 - Valores extremos de tensões para os modelos H1 -( MPa)

\begin{tabular}{|c|c|c|c|c|c|c|c|c|c|c|}
\hline \multirow{2}{*}{ Modelos } & \multicolumn{2}{|c|}{$\sigma_{\mathbf{y}}$} & \multicolumn{2}{c|}{$\sigma_{\mathbf{x y}}$} & \multicolumn{2}{c|}{$\sigma_{\mathbf{z y}}$} & \multicolumn{2}{c|}{$\sigma_{\mathbf{1}}$} & \multicolumn{2}{c|}{$\sigma_{\mathbf{3}}$} \\
\cline { 2 - 11 } & $\mathbf{m i n}$ & $\mathbf{m a x}$ & $\mathbf{m i n}$ & $\mathbf{m a x}$ & $\mathbf{m i n}$ & $\mathbf{m a x}$ & $\mathbf{m i n}$ & $\mathbf{m a x}$ & $\min$ & $\mathbf{m a x}$ \\
\hline 1pav $^{*}-1,038$ & 0,008 & $-0,470$ & 0,436 & $-0,760$ & 0,033 & $-0,100$ & 0,537 & $-1,117$ & $-0,008$ \\
\hline 2pav-1 $^{*}$ & $-1,038$ & 0,008 & $-0,470$ & 0,436 & $-0,761$ & 0,038 & $-0,133$ & 0,537 & $-1,117$ & $-0,008$ \\
\hline 2pav-2 $^{* * *}$ & $-0,533$ & 0,004 & $-0,236$ & 0,218 & $-0,381$ & 0,030 & $-0,099$ & 0,269 & $-0,559$ & $-0,004$ \\
\hline
\end{tabular}

Tabela 6.7 - Valores extremos de tensões para os modelos Z1 -(MPa)

\begin{tabular}{|c|c|c|c|c|c|c|c|c|c|c|}
\hline \multirow{2}{*}{ Modelos } & \multicolumn{2}{|c|}{$\sigma_{\mathbf{y}}$} & \multicolumn{2}{c|}{$\sigma_{\mathbf{x y}}$} & \multicolumn{2}{c|}{$\sigma_{\mathbf{z y}}$} & \multicolumn{2}{|c|}{$\sigma_{\mathbf{1}}$} & \multicolumn{2}{|c|}{$\sigma_{\mathbf{3}}$} \\
\cline { 2 - 11 } & $\mathbf{m i n}$ & $\mathbf{m a x}$ & $\mathbf{m i n}$ & $\mathbf{m a x}$ & $\mathbf{m i n}$ & $\mathbf{m a x}$ & $\min$ & $\mathbf{m a x}$ & $\mathbf{m i n}$ & $\mathbf{m a x}$ \\
\hline 1pav $^{*}$ & $-1,043$ & 0,023 & $-0,496$ & 0,034 & $-0,737$ & 0,045 & $-0,147$ & 0,516 & $-1,100$ & $-0,006$ \\
\hline 2pav-1 $^{*}$ & $-1,043$ & 0,024 & $-0,500$ & 0,059 & $-0,741$ & 0,064 & $-0,184$ & 0,519 & $-1,102$ & $-0,005$ \\
\hline 2pav-2 $^{* *}$ & $-0,643$ & 0,010 & $-0,243$ & 0,051 & $-0,364$ & 0,044 & $-0,133$ & 0,253 & $-0,653$ & $-0,002$ \\
\hline
\end{tabular}

Tabela 6.8 - Valores extremos de tensões para os modelos H2 -(MPa)

\begin{tabular}{|c|c|c|c|c|c|c|c|c|c|c|}
\hline \multirow{2}{*}{ Modelos } & \multicolumn{2}{|c|}{$\sigma_{\mathbf{y}}$} & \multicolumn{2}{c|}{$\sigma_{\mathbf{x y}}$} & \multicolumn{2}{c|}{$\sigma_{\mathbf{z y}}$} & \multicolumn{2}{c|}{$\sigma_{\mathbf{1}}$} & \multicolumn{2}{c|}{$\sigma_{\mathbf{3}}$} \\
\cline { 2 - 11 } & $\mathbf{m i n}$ & $\mathbf{m a x}$ & $\mathbf{m i n}$ & $\mathbf{m a x}$ & $\mathbf{m i n}$ & $\mathbf{m a x}$ & $\mathbf{m i n}$ & $\mathbf{m a x}$ & $\mathbf{m i n}$ & $\mathbf{m a x}$ \\
\hline 1pav $^{*}$ & $-1,036$ & 0,025 & $-0,473$ & 0,498 & $-0,813$ & 0,078 & $-0,108$ & 0,590 & $-1,191$ & $-0,003$ \\
\hline 2pav-1 $^{*}$ & $-1,035$ & 0,025 & $-0,490$ & 0,516 & $-0,838$ & 0,075 & $-0,133$ & 0,614 & $-1,212$ & $-0,004$ \\
\hline 2pav-2 $^{* *}$ & $-0,599$ & 0,013 & $-0,278$ & 0,293 & $-0,468$ & 0,049 & $-0,093$ & 0,355 & $-0,649$ & $-0,004$ \\
\hline
\end{tabular}

Tabela 6.9 - Valores extremos de tensões para os modelos Z2 -(MPa)

\begin{tabular}{|c|c|c|c|c|c|c|c|c|c|c|}
\hline \multirow{2}{*}{ Modelos } & \multicolumn{2}{|c|}{$\sigma_{\mathbf{y}}$} & \multicolumn{2}{c|}{$\sigma_{\mathbf{x y}}$} & \multicolumn{2}{c|}{$\sigma_{\mathbf{z y}}$} & \multicolumn{2}{|c|}{$\sigma_{\mathbf{1}}$} & \multicolumn{3}{|c|}{$\sigma_{\mathbf{3}}$} \\
\cline { 2 - 11 } & $\mathbf{m i n}$ & $\mathbf{m a x}$ & $\mathbf{m i n}$ & $\mathbf{m a x}$ & $\mathbf{m i n}$ & $\mathbf{m a x}$ & $\min$ & $\mathbf{m a x}$ & $\mathbf{m i n}$ & $\mathbf{m a x}$ \\
\hline 1pav & $-1,064$ & 0,012 & $-0,548$ & 0,014 & $-0,764$ & 0,083 & $-0,234$ & 0,539 & $-1,125$ & 0,001 \\
\hline 2pav-1 $^{*}$ & $-1,063$ & 0,012 & $-0,567$ & 0,075 & $-0,783$ & 0,081 & $-0,233$ & 0,558 & $-1,139$ & $-0,001$ \\
\hline 2pav-2 $^{* *}$ & $-0,740$ & 0,007 & $-0,338$ & 0,056 & $-0,444$ & 0,060 & $-0,158$ & 0,331 & $-0,754$ & $-0,003$ \\
\hline
\end{tabular}

Analisando-se o modelo H1 verifica-se que o diâmetro do círculo que o circunscreve é de 46,7 cm (60\% da altura do pavimento), dessa forma, segundo Corrêa e Page (2001), esta é a altura necessária para a igualdade de tensões normais verticais $\left(\sigma_{y}\right)$. Essa suposição é comprovada na análise numérica, onde se observa, para o modelo com um único pavimento, que a uniformização das tensões ocorre aproximadamente à meia altura do painel (Figura 6.30a). Nos modelos com mais de um pavimento, também é facilmente visualizada a uniformização das tensões por meio das figuras $6.30 \mathrm{~b}$ e 6.30c. Ainda é possível verificar, por meio da Figura 6.31, que a transferência das forças se dá em apenas metade da altura do painel, notando-se que as tensões de 
cisalhamento se concentram em apenas meia distância entre pavimentos. No restante dos painéis o cisalhamento tende a um valor próximo de zero, o que indica que não há tendência de deslocamentos relativos entre as paredes, por causa da igualdade das tensões verticais.

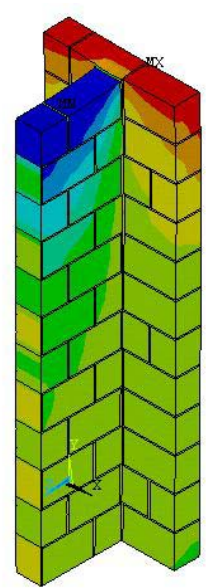

(a) 1 pav.

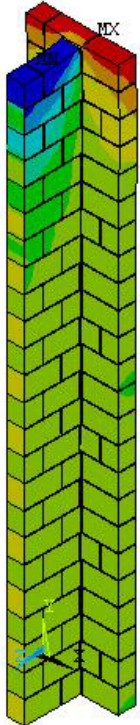

(b) 2 pav. - 1

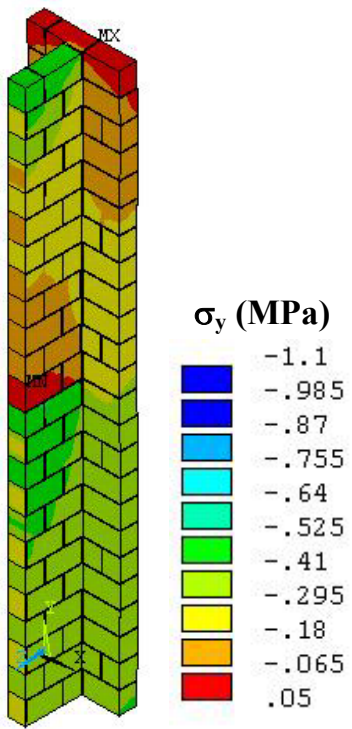

(c) 2 pav. -2

Figura 6.30-Distribuição das tensões normais verticais $\left(\sigma_{y}\right)$ - modelo H1

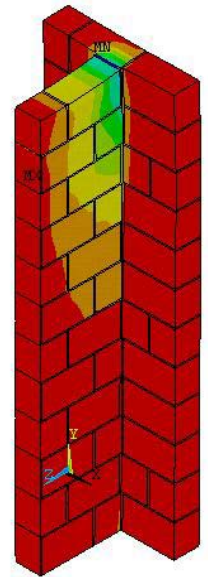

(a) 1 pav.

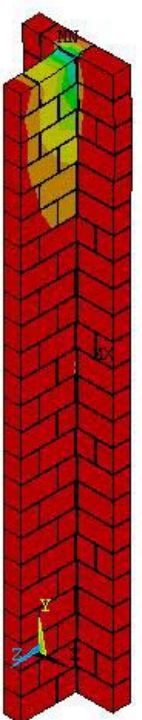

(b) 2 pav. -1
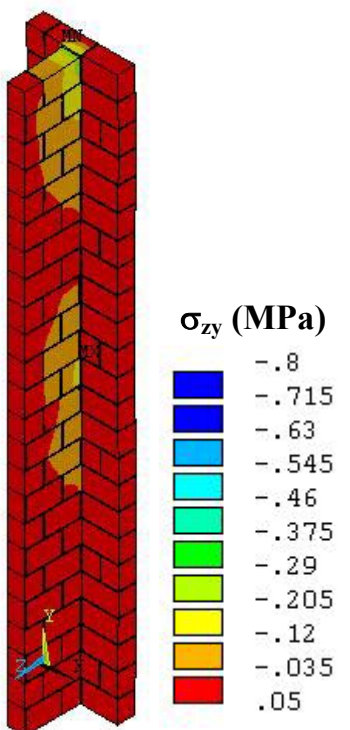

(c) 2 pav. -2

Figura 6.31 - Distribuição das tensões cisalhantes - modelo H1

Na Figura 6.32 averigua-se que a proposta de Corrêa e Page (2001), que consiste em estimar a tensão máxima de cisalhamento como sendo o triplo da tensão média, é razoável e segura para o modelo H1. Visto que, apenas na região próxima à aplicação dos carregamentos é que as tensões obtidas na análise numérica são superiores. Nessa 
mesma figura, nota-se como é favorável a situação em que o carregamento é dividido igualmente e aplicado em dois níveis diferentes.
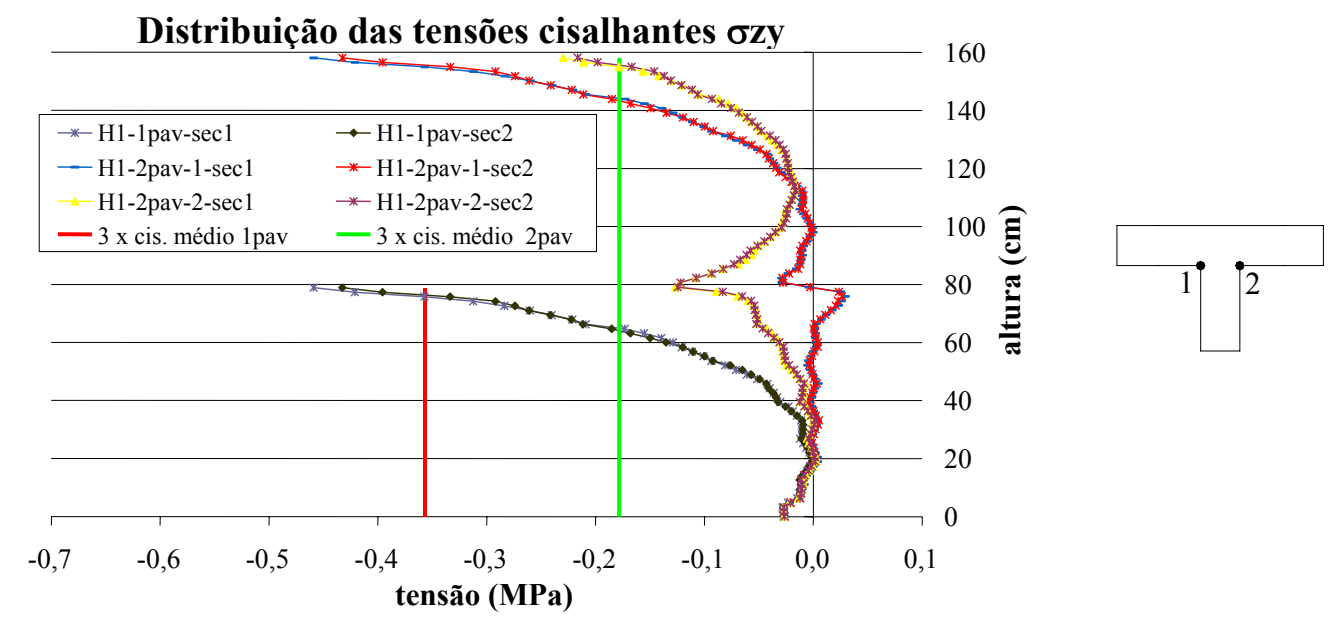

Figura 6.32 - Distribuição das tensões cisalhantes na interseção-modelo H1

O painel Z1 é circunscrito por um círculo de mesmo diâmetro do painel H1 $(46,7 \mathrm{~cm})$. No entanto, como a força transferida para os flanges não é centrada, esperase que a uniformização das tensões verticais não ocorra em apenas metade do pavimento. Contudo, a simulação da presença da laje, através do impedimento dos deslocamentos horizontais dos topos dos pavimentos, produz um efeito benéfico, fazendo com que haja praticamente a igualdade de tensões na base (Figura 6.33a). Corrêa e Page (2001) em seus estudos também verificam esse efeito da presença das lajes. Nos modelos com dois pavimentos, as condições para a uniformização das tensões são ainda mais favoráveis (Figura 6.33b e Figura 6.33c)

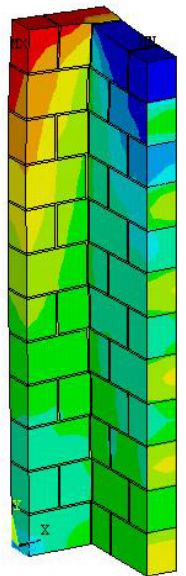

(a) 1 pav.

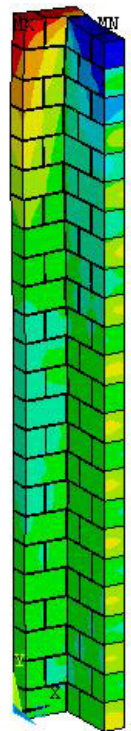

(b) 2 pav. - 1
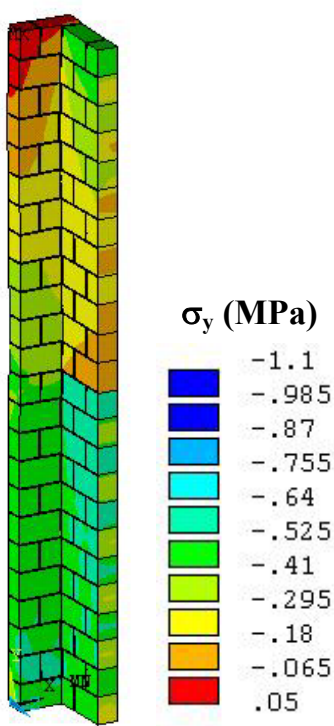

(c) 2 pav. -2

Figura 6.33-Distribuição das tensões normais verticais - modelo Z1 
Em relação ao cisalhamento do modelo Z1, verifica-se um comportamento semelhante ao observado no modelo $\mathrm{H} 1$, apenas com a diferença da excentricidade proporcionada pela geometria (Figura 6.34). Nessa mesma figura, percebe-se que o lado interno da parede central é submetido às maiores tensões de cisalhamento. A distribuição das tensões cisalhantes na interseção ao longo da altura (Figura 6.35) mostra comportamento semelhante ao obtido no modelo $\mathrm{H} 1$, excetuando-se a excentricidade verificada (vide diferenças entre as seções 1 e 2). Novamente, a proposta de Corrêa e Page (2001) para o cisalhamento máximo origina resultados compatíveis. Somente na região próxima ao topo é que os valores obtidos no modelo numérico superam o valor proposto.

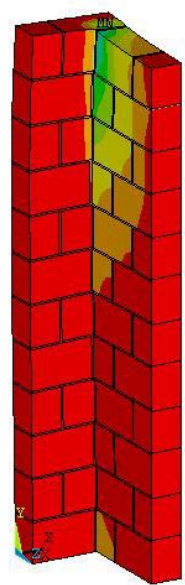

(a) 1 pav.

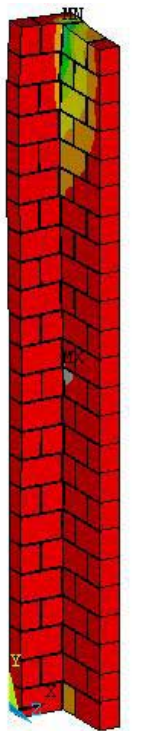

(b) 2 pav. - 1
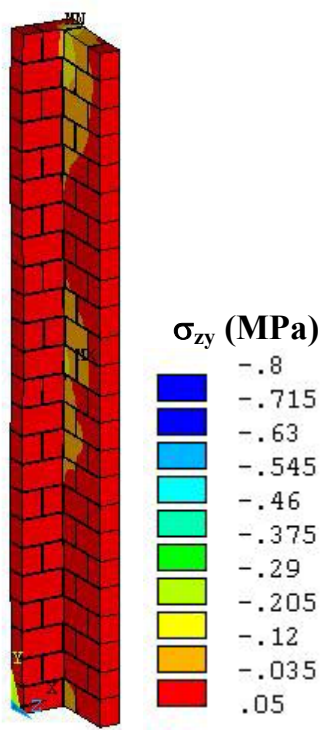

(c) 2 pav. -2

Figura 6.34 - Distribuição das tensões cisalhantes - modelo Z1
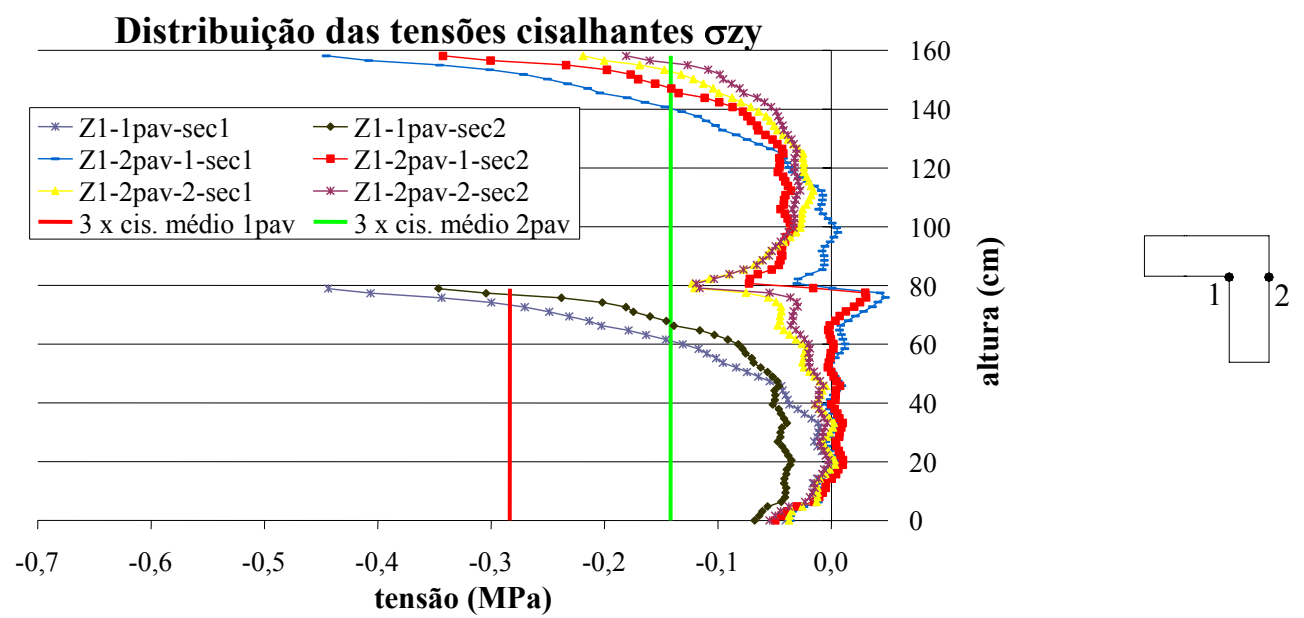

Figura 6.35 - Distribuição das tensões cisalhantes na interseção-modelo Z1 
$\mathrm{O}$ modelo $\mathrm{H} 2$ é o que possui as maiores dimensões em planta, sendo que o círculo que circunscreve sua geometria em planta tem um diâmetro de 124,6 cm, cerca de $60 \%$ maior que a altura do pavimento $(78,9 \mathrm{~cm})$. Portanto, de acordo com Corrêa e Page (2001) deve ser necessário mais que um pavimento para a uniformização das tensões normais verticais. Na Figura 6.36a observa-se que no modelo numérico com apenas um pavimento não ocorre a igualdade das tensões na região da base do painel. Já no modelo com dois pavimentos, em que o carregamento é aplicado somente no topo do segundo andar, nota-se que à meia altura do primeiro pavimento há a uniformização das tensões (Figura 6.36b). Isso pode ser melhor visualizado na Figura 6.37, que ilustra a distribuição das tensões normais verticais ao longo do comprimento da parede central (alma) e do flange, para uma seção à meia altura do primeiro pavimento. Verifica-se que as tensões do modelo com dois andares estão praticamente uniformizadas, enquanto que o caso de um único pavimento ainda apresenta diferentes tensões para a alma e o flange. No caso do modelo com dois pavimentos e carregamento aplicado em dois níveis diferentes (Figura 6.36c), também, não há a uniformização das tensões normais verticais na base do painel. Isso acontece porque o carregamento aplicado no primeiro andar não é uniformizado em apenas um pavimento, necessitando de uma maior altura.

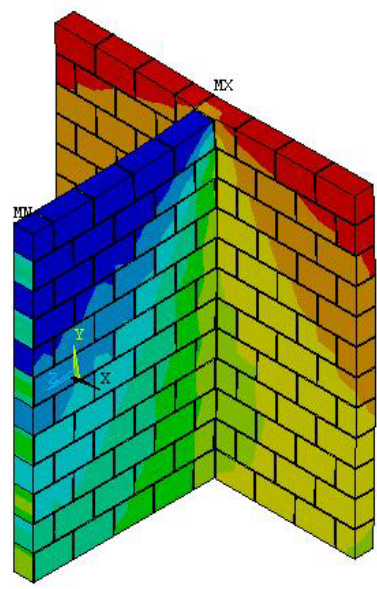

(a) 1 pav.

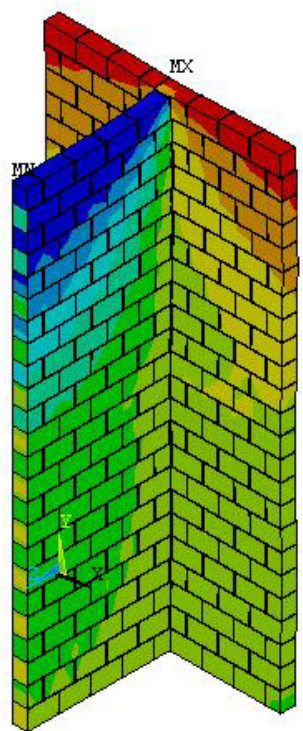

(b) 2 pav. - 1

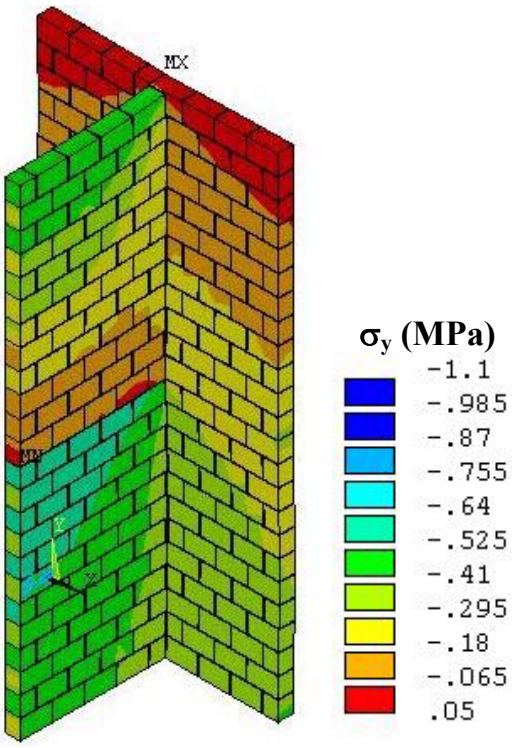

(c) 2 pav. -2

Figura 6.36-Distribuição das tensões normais verticais - modelo $\mathrm{H} 2$ 


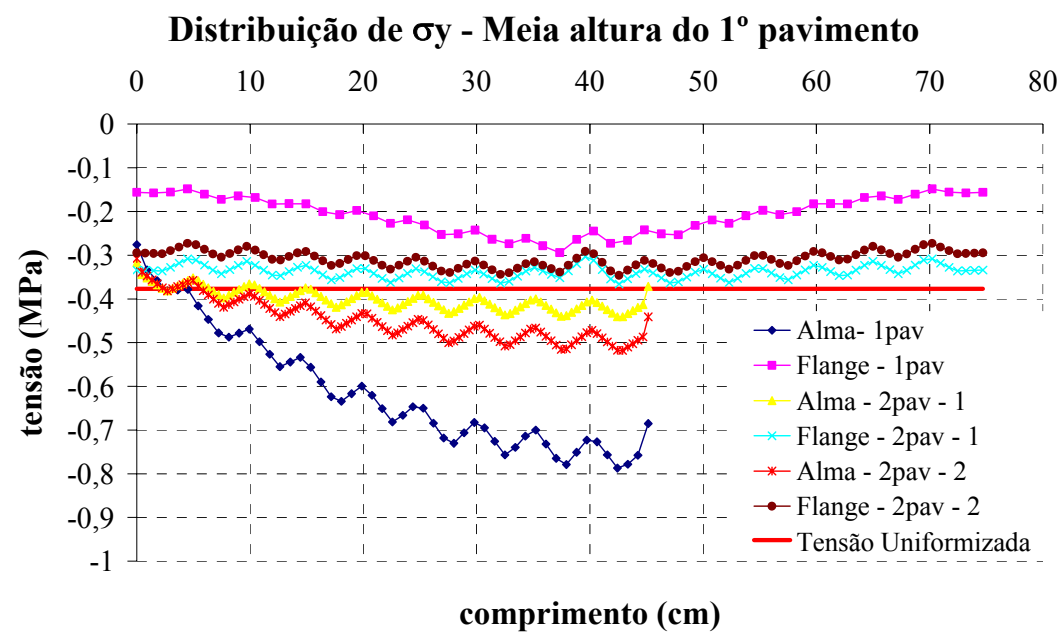

Figura 6.37 - Distribuição das tensões normais verticais ao longo do comprimento das paredes - modelo $\mathrm{H} 2$

Ainda sobre o modelo H2, percebe-se na Figura 6.38a que ao longo de toda a altura do modelo de um pavimento ocorrem tensões de cisalhamento, indicando que apenas um andar não é suficiente para toda a transferência de forças necessárias para a uniformização das tensões normais verticais. No caso de dois pavimentos, com o carregamento aplicado somente no topo do segundo andar (Figura 6.38b e Figura 6.39), observa-se o efeito benéfico da presença da laje na redução dos valores das tensões de cisalhamento atuantes no primeiro pavimento. Este efeito é menos pronunciado, como esperado, no caso do carregamento aplicado em dois níveis, como pode ser visto nas figuras $6.38 \mathrm{c}$ e 6.39 .

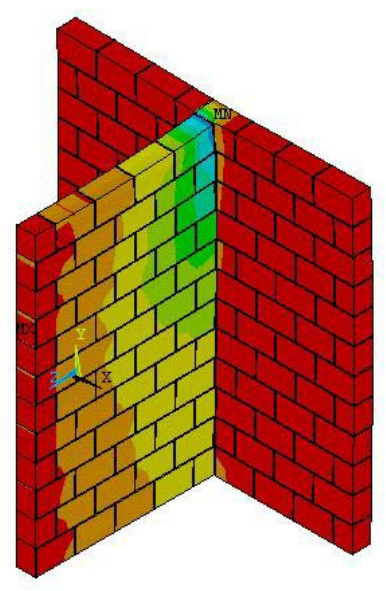

(a) 1 pav.

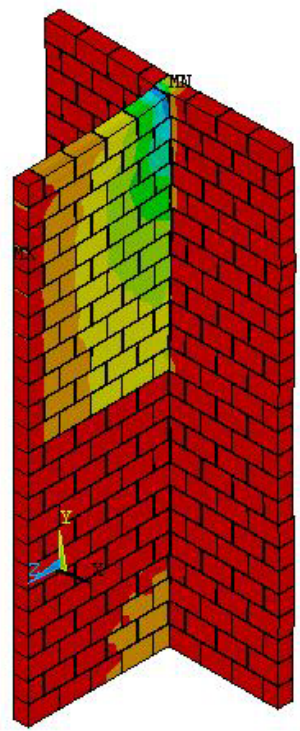

(b) 2 pav. - 1

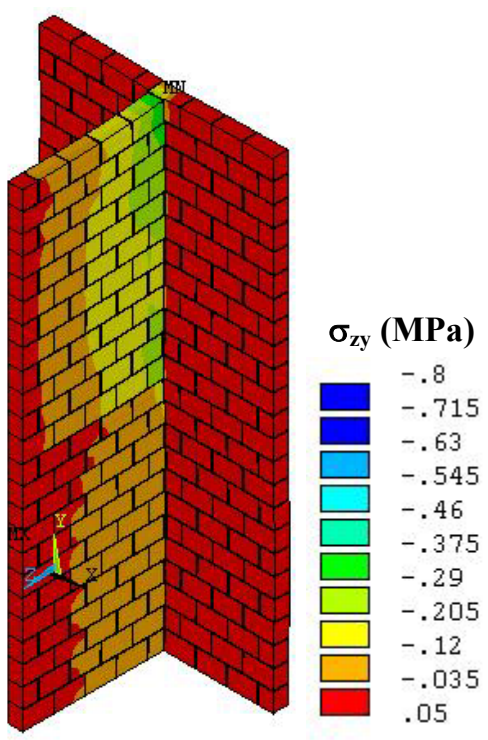

(c) 2 pav. -2

Figura 6.38- Distribuição das tensões cisalhantes na parede central para $\mathrm{H} 2$ 
Na Figura 6.39 nota-se que a hipótese de Corrêa e Page (2001) para a determinação da tensão máxima de cisalhamento é a favor da segurança em todos os casos. Os valores obtidos para o modelo com um pavimento são cerca de $40 \%$ superiores às tensões obtidas nos modelos numéricos. Enquanto isso, para os modelos com dois pavimentos, a hipótese para o cisalhamento máximo fornece bons resultados, cerca de $20 \%$ acima do valor obtido no modelo numérico. Neste caso, vale ressaltar que são determinadas diferentes tensões médias de cisalhamento para as duas situações de carregamento do modelo com dois pavimentos. Isto porque, para o carregamento aplicado apenas no topo do segundo pavimento, há altura suficiente para a uniformização das tensões. Já no caso do carregamento aplicado em dois níveis diferentes, a força aplicada no segundo pavimento não possui altura necessária para se uniformizar. Novamente fica visível a diminuição das tensões máximas de cisalhamento com a divisão do carregamento em mais de um pavimento.

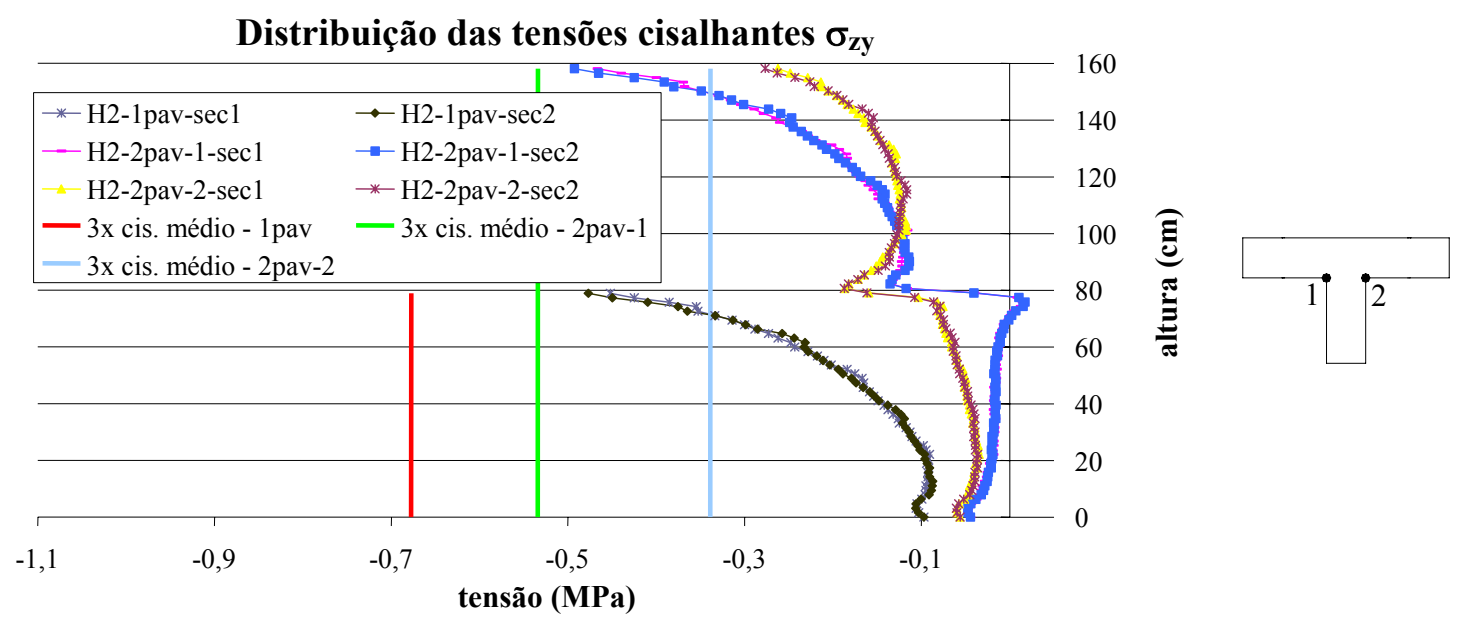

Figura 6.39-Distribuição das tensões cisalhantes na interseção- modelo H2

Examinando-se o modelo Z2, nota-se que o painel é circunscrito por um círculo de mesmo diâmetro que o caso H2 $(124,6 \mathrm{~cm})$, portanto, são necessários, no mínimo, dois pavimentos para a uniformização das tensões normais verticais. Para esta situação, ainda há a questão da força transferida para o flange ser excêntrica, atrapalhando ainda mais a uniformidade das tensões. Todavia, a simulação da presença das lajes, pelas restrições aos deslocamentos horizontais no topo dos pavimentos, atenua essa excentricidade. Na Figura 6.40a comprova-se que em um único pavimento não é possível a igualdade das tensões normais verticais da parede central e dos flanges. A uniformização só é obtida no caso do modelo com dois pavimentos e carregamento 
aplicado somente no segundo andar. Conforme as figuras $6.40 \mathrm{~b}$ e 6.41 , nota-se, para esse modelo, que à meia altura do primeiro pavimento, há praticamente a igualdade das tensões, enquanto que, para a situação de um único pavimento ainda há diferenças entre as tensões das diferentes paredes. Novamente, a não uniformização do carregamento em um pavimento é a causa da desigualdade das tensões no modelo com dois pavimentos e carregamento aplicado em dois níveis (Figura 6.40c).

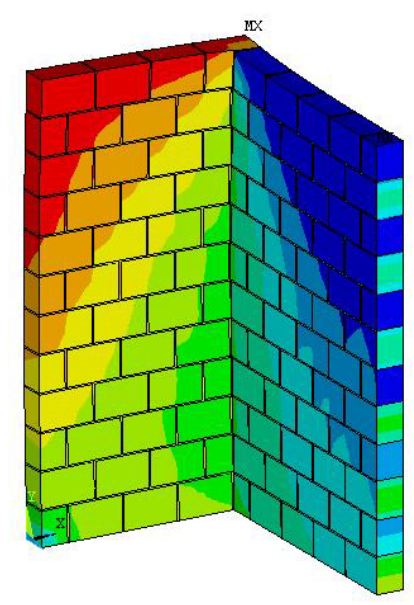

(a) 1 pav.

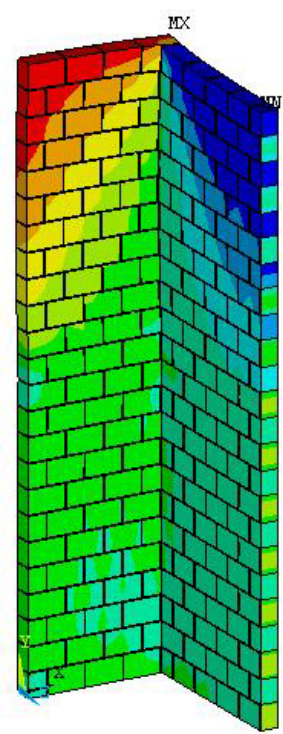

(b) 2 pav. -1

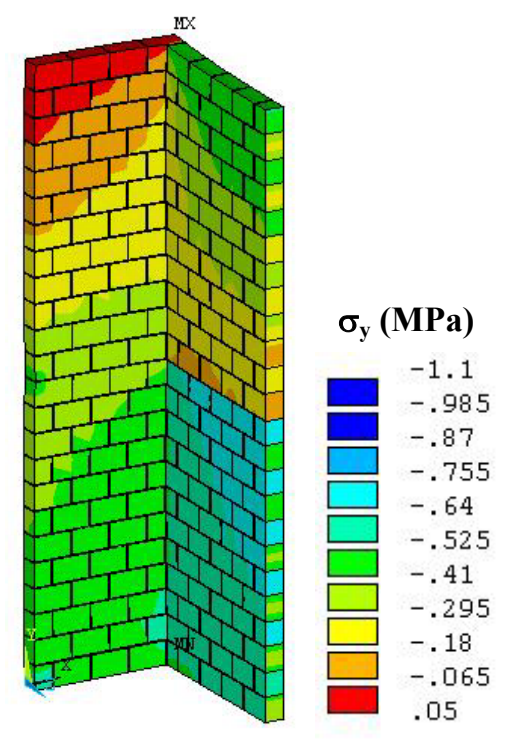

(c) 2 pav. -2

Figura 6.40 - Distribuição das tensões normais verticais para Z2

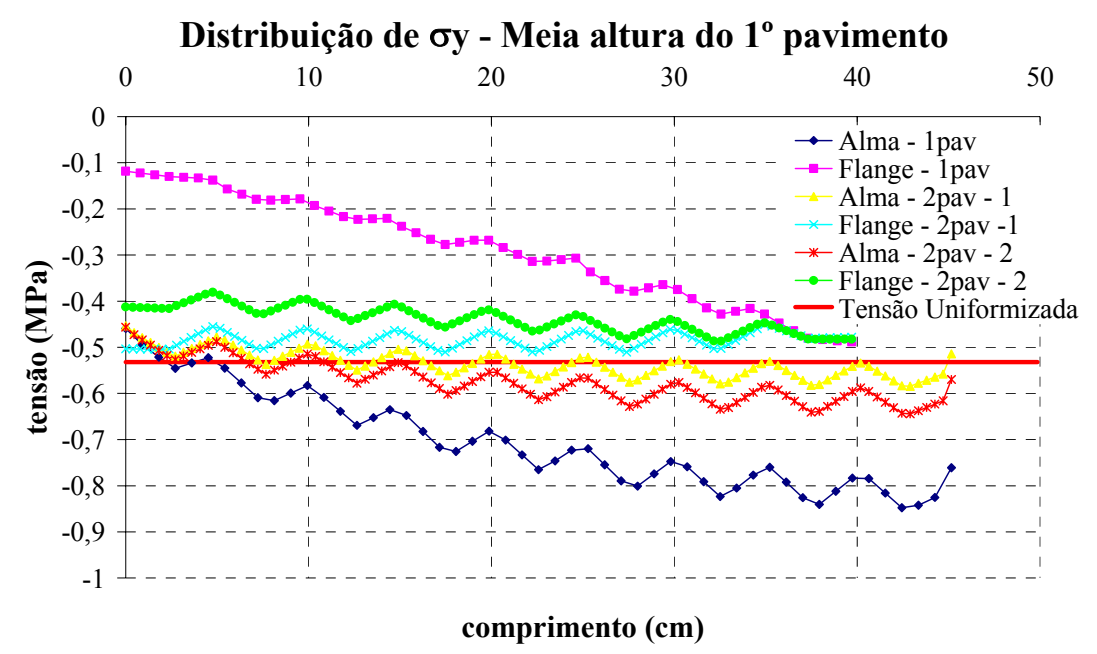

Figura 6.41 - Distribuição das tensões normais verticais ao longo do comprimento das paredes - modelo Z2

A respeito do cisalhamento, igualmente ao modelo $\mathrm{H} 2$, percebe-se nas figuras 6.42 e 6.43 o efeito benéfico da simulação da presença da laje, fazendo com que se reduzam os valores da tensão de cisalhamento referentes ao primeiro pavimento. Observa-se, também, uma boa correlação entre as tensões máximas de cisalhamento 
calculadas de acordo com a proposta de Corrêa e Page (2001) e os valores obtidos nas análises numéricas. A diferença máxima, cerca de 15\%, ocorre no caso do modelo com um pavimento. Analogamente ao modelo H2, são calculadas diferentes tensões médias de cisalhamento para as duas situações de carregamento do modelo com dois pavimentos.

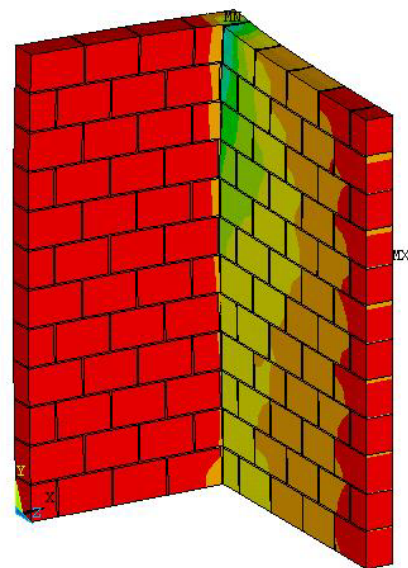

(a) 1 pav.

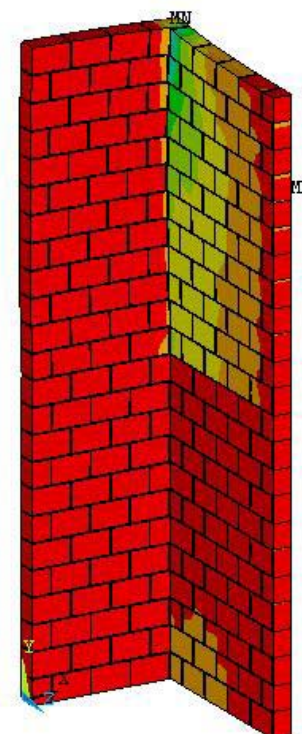

(b) 2 pav. - 1
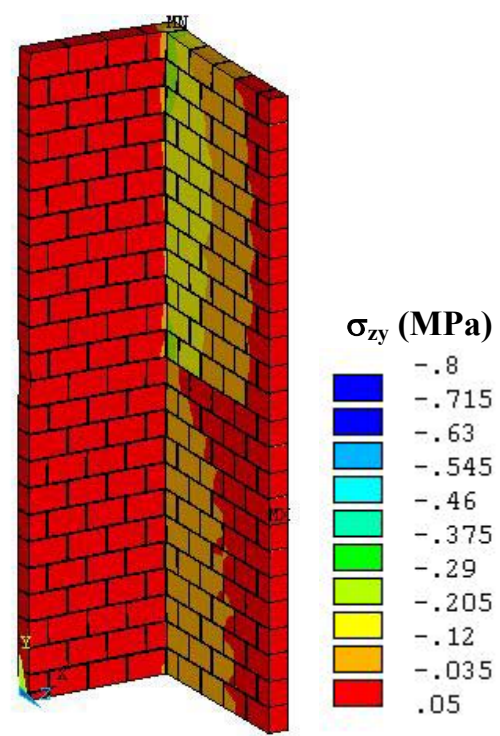

(c) 2 pav. -2

Figura 6.42 - Distribuição das tensões cisalhantes na parede central para Z2

Distribuição das tensões cisalhantes $\sigma z y$

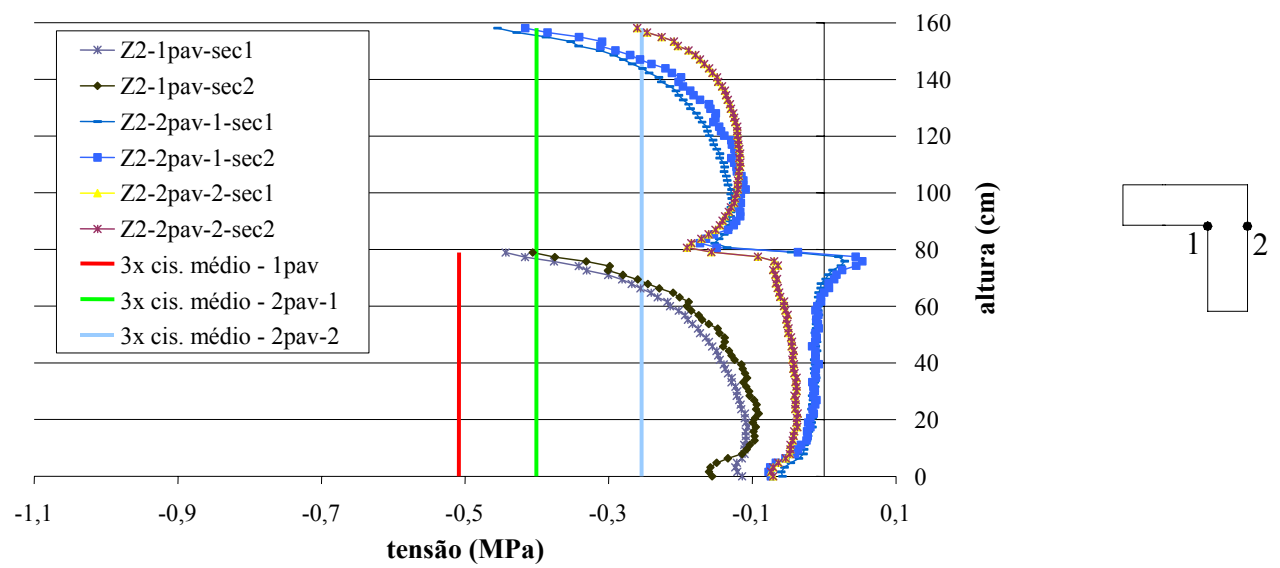

Figura 6.43-Distribuição das tensões cisalhantes na interseção-modelo Z2

Os modelos numéricos estudados confirmam o uso do Princípio de Saint Venant para se determinar a altura mínima necessária para a uniformização das tensões normais verticais. Também é observado o efeito da presença da laje em atenuar a excentricidade nos painéis tipo $\mathrm{Z}$ e na transmissão das tensões cisalhantes. A proposta de Corrêa e Page (2001), para a estimativa da tensão máxima cisalhante, se mostra válida para as todas as análises numéricas realizadas. Nas situações onde a uniformização das tensões ocorre 
em um único pavimento, os valores obtidos pela proposta são pouco inferiores ao modelo numérico, e apenas na região próxima ao topo. Nas demais situações a proposta é quase sempre a favor da segurança, com diferença máxima de 40\%. Verifica-se, ainda, a significativa diminuição das tensões máximas nos modelos com carregamentos aplicados em dois níveis, indicando um ganho de resistência em relação aos dois outros casos analisados.

Entretanto, para essas análises numéricas serem válidas não apenas para baixos níveis de tensões (comportamento linear), é necessário determinar a capacidade da interseção em resistir às tensões de cisalhamento impostas. Caso essa resistência seja superada, deve ocorrer a separação entre a parede central e os flanges. Desse modo, deixa de ocorrer a transferência de forças entre as paredes e, conseqüentemente, não há a possibilidade da uniformização das tensões de compressões verticais.

\section{4- Modelos dos ensaios de caracterização da alvenaria}

Os modelos numéricos dos ensaios de caracterização da alvenaria em escala reduzida são realizados considerando-se os blocos das três diferentes formas apresentadas no início do capítulo (figuras 6.1 e 6.2). Na maioria das situações emprega-se a micro-modelagem simplificada, isto é, os blocos e as juntas de argamassa são representados por elementos contínuos e a ligação entre bloco-argamassa é considerada perfeita. Apenas nos casos dos ensaios de paredinhas utilizam-se, também, a macro-modelagem, na qual se considera a alvenaria como um material homogêneo.

Na modelagem dos ensaios de caracterização, utiliza-se o pacote computacional ANSYS para a geração da geometria e da rede, por sua maior facilidade. No entanto, para o processamento dos modelos, onde se estuda o comportamento não-linear da alvenaria, utiliza-se o pacote computacional ABAQUS.

Utilizam-se elementos tipo sólido tridimensional para retratar a forma real do bloco. O elemento empregado é definido por oito nós, com três graus de liberdades em cada nó: translações nas direções x, y e z. Adota-se a integração reduzida para gerar um menor esforço computacional e evitar o "shear locking" e o "volumetric locking". No ANSYS o elemento é denominado de SOLID45 e no ABAQUS de C3D8R.

Emprega-se o modelo elastoplástico para o concreto existente no ABAQUS, maiores detalhes estão apresentados no capítulo 4. As propriedades dos blocos e das argamassas utilizadas têm como base os ensaios de caracterização desenvolvidos no 
Laboratório de Estruturas da EESC/USP (capítulo 5). As tabelas 6.10 e 6.11 apresentam as propriedades básicas empregadas para os modelos numéricos deste capítulo.

Tabela 6.10-Propriedades dos blocos para os modelos de caracterização da alvenaria

\begin{tabular}{|c|c|}
\hline \multicolumn{2}{|c|}{ Propriedades do Bloco* } \\
\hline Módulo de Elasticidade & $11148(22005) \mathrm{MPa}$ \\
\hline Resistência à compressão & $30,31(59,83) \mathrm{MPa}$ \\
\hline Resistência à tração & $(5,91) \mathrm{MPa}$ \\
\hline Coeficiente de Poisson (v) & 0,12 \\
\hline Curva tensão real $x$ deformação plástica & $\begin{array}{c}3,34(6,60) \mathrm{MPa} \\
30,19(59,60) \mathrm{MPa}\end{array}$ \\
\hline $\begin{array}{l}\text { Resistência à compressão. biaxial / } \\
\text { Resistência à compressão uniaxial }\end{array}$ & $1,20^{* *}$ \\
\hline $\begin{array}{c}\text { Resistência à tração uniaxial / } \\
\text { Resistência à compressão uniaxial }\end{array}$ & 0,099 \\
\hline $\begin{array}{c}\text { Deformação plástica. biaxial / } \\
\left.\text { Deformação plástica uniaxial ( }{ }^{\circ}\right)\end{array}$ & $1,28^{* *}$ \\
\hline $\begin{array}{c}\text { Tensão fissuração biaxial/ } \\
\text { tensão fissuração uniaxial (") }\end{array}$ & $0,33^{* *}$ \\
\hline Deslocamento último no "tension stiffening" & $0,008 \mathrm{~cm}^{* *}$ \\
\hline \multicolumn{2}{|c|}{$\begin{array}{l}\text { * Os valores entre parênteses referem-se à área líquida do bloco } \\
\text { - Correspondem aos valores últimos de tensão } \\
\text { - Com a outra tensão principal igual ao valor último de compressão } \\
{ }^{* *} \text { Valores recomendados pelo manual do ABAQUS }\end{array}$} \\
\hline
\end{tabular}

Tabela 6.11 - Propriedades da argamassa para os modelos de caracterização da alvenaria

\begin{tabular}{|c|c|c|}
\hline \multicolumn{3}{|c|}{ Propriedades da Argamassa } \\
\hline Módulo de Elasticidade & \multicolumn{2}{|c|}{$7058 \mathrm{MPa}$} \\
\hline Resistência à compressão & \multicolumn{2}{|c|}{$4,20 \mathrm{MPa}$} \\
\hline Resistência à tração & \multicolumn{2}{|c|}{$0,42 \mathrm{MPa}$} \\
\hline Coeficiente de Poisson (v) & \multicolumn{2}{|c|}{0,20} \\
\hline Curva tensão real x deformação plástica & $\begin{array}{l}\text { 1,40 MPa } \\
3,20 \mathrm{MPa} \\
3,80 \mathrm{MPa} \\
4,15 \mathrm{MPa} \\
4,20 \mathrm{MPa}\end{array}$ & $\begin{array}{c}0,0 \\
0,000143 \\
0,000377 \\
0,000557 \\
0,000830\end{array}$ \\
\hline Espessura da junta de argamassa & \multicolumn{2}{|c|}{$0,30 \mathrm{~cm}$} \\
\hline $\begin{array}{l}\text { Resistência à compressão. biaxial / } \\
\text { Resistência à compressão uniaxial }\end{array}$ & \multicolumn{2}{|c|}{$1,20^{* *}$} \\
\hline $\begin{array}{l}\text { Resistência à tração uniaxial / } \\
\text { Resistência à compressão uniaxial }\end{array}$ & \multicolumn{2}{|c|}{0,10} \\
\hline $\begin{array}{c}\text { Deformação plástica. biaxial / } \\
\text { Deformação plástica uniaxial }\left({ }^{\circ}\right)\end{array}$ & \multicolumn{2}{|c|}{$1,28^{* *}$} \\
\hline $\begin{array}{l}\text { Tensão fissuração biaxial/ } \\
\text { tensão fissuração uniaxial (") }\end{array}$ & \multicolumn{2}{|c|}{$0,33^{* *}$} \\
\hline Deslocamento último no "tension stiffening" & \multicolumn{2}{|c|}{$0,005 \mathrm{~cm}^{* *}$} \\
\hline \multicolumn{3}{|c|}{$\begin{array}{l}\text { - Correspondem aos valores últimos de tensão } \\
\text { - Com a outra tensão principal igual ao valor último de compressão } \\
\text { ** Valores recomendados pelo manual do ABAQUS }\end{array}$} \\
\hline
\end{tabular}




\subsection{1 - Modelos dos ensaios na direção normal à junta de assentamento}

\subsubsection{1 - Modelos dos ensaios de compressão do bloco}

A discretização do bloco é tal que possa ser utilizada nas demais modelagens de ensaios, sendo que a dimensão máxima do elemento é de $1 \mathrm{~cm}$, independente da geometria adotada (Figura 6.44). Em todos os casos considera-se a base com os deslocamentos impedidos nas três direções, sendo que no topo apenas os deslocamentos horizontais são restritos (deslocamentos em x e z). O carregamento é aplicado como uma pressão distribuída na face superior do bloco.
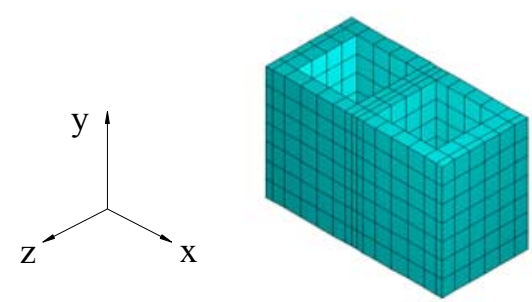

Bloco vazado

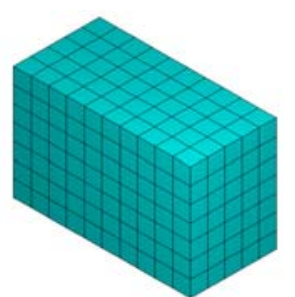

Bloco sólido

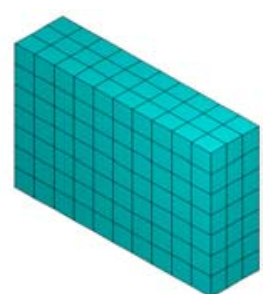

Bloco sólido c/ espessura efetiva

Figura 6.44 - Discretização dos blocos com diferentes geometrias

A Tabela 6.12 apresenta os resultados obtidos das tensões normais verticais máximas e dos módulos de deformação para os três modelos, além de realizar a comparação com os valores experimentais. Observa-se que o modelo com o bloco vazado é o que melhor representa o ensaio, com diferença de no máximo $10 \%$ em relação ao experimental. Os demais modelos também apresentam resultados razoáveis, com diferenças inferiores a $15 \%$. Todos os valores são em relação à área bruta.

Tabela 6.12 - Resultados numéricos do ensaio de compressão do bloco - área bruta

\begin{tabular}{|c|c|c|c|c|}
\hline Resultado & $\begin{array}{c}\text { Tensão } \\
\text { Máxima (MPa) }\end{array}$ & $\begin{array}{c}\text { Numérico/ } \\
\text { Experimental }\end{array}$ & $\begin{array}{c}\text { Módulo de } \\
\text { deformação (MPa) }\end{array}$ & $\begin{array}{c}\text { Numérico/ } \\
\text { experimental }\end{array}$ \\
\hline Experimental & 30,31 & -- & 11148 & -- \\
\hline Bloco Vazado & 30,64 & $+1,1 \%$ & 10037 & $-10,0 \%$ \\
\hline Bloco Sólido & 33,37 & $+10,1 \%$ & 9899 & $-11,2 \%$ \\
\hline $\begin{array}{c}\text { Bloco espessura } \\
\text { efetiva }\end{array}$ & $31,11(61,41)^{*}$ & $+2,6 \%$ & $9527(18806)^{*}$ & $-14,5 \%$ \\
\hline * Para a comparação com os valores dos outros modelos em relação à área bruta é necessário \\
multiplicar o resultado obtido (entre parênteses) pela razão $\mathrm{A}_{\text {liquida }} / \mathrm{A}_{\text {bruta }}=0,507$
\end{tabular}

Verifica-se na Figura 6.45 que a maior diferença entre os resultados experimentais e numéricos é a existência de um grande patamar de deformações nos modelos com blocos sólidos. Ressalta-se que os valores de deformações obtidos das análises numéricas correspondem aos pontos instrumentados no ensaio. A ruptura em 
todos os casos ocorre por esmagamento do bloco, conforme pode ser visualizado na Figura 6.46. As regiões negras nos modelos indicam que as tensões mínimas principais estão acima da resistência à compressão do material.

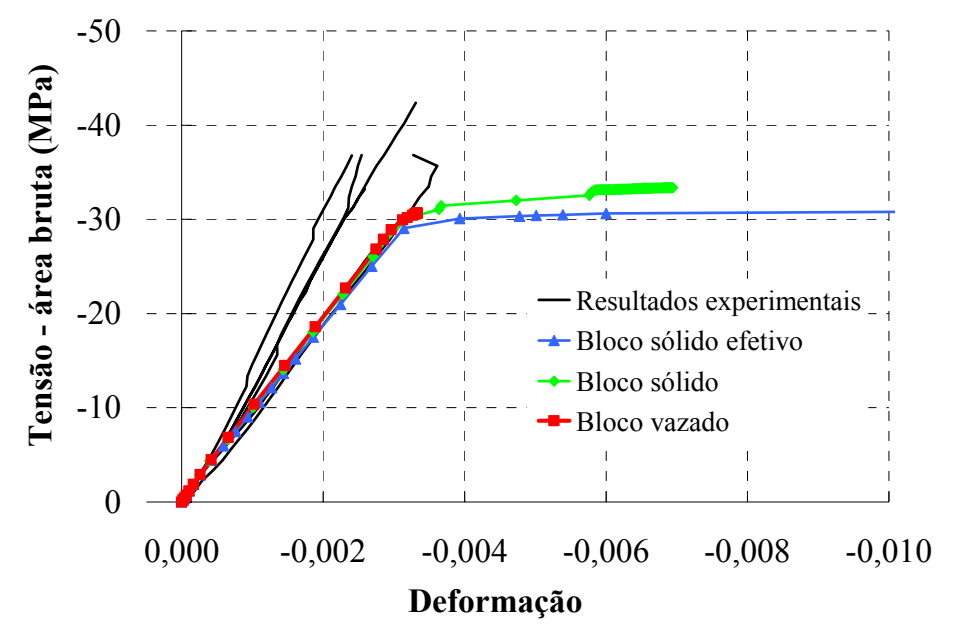

Figura 6.45 - Diagramas de tensão x deformação experimentais e numéricos - bloco

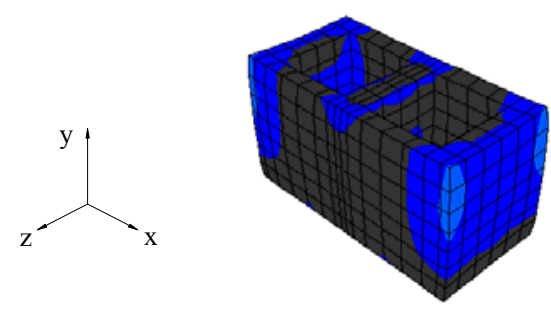

Bloco vazado

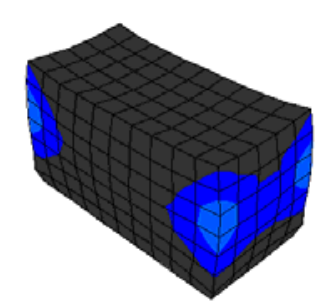

Bloco sólido

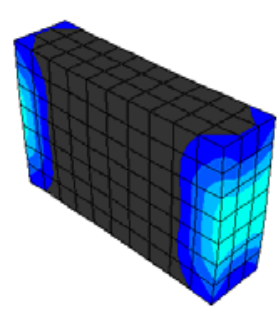

Bloco sólido c/ espessura efetiva

Figura 6.46 - Distribuições das tensões mínimas principais - bloco

\subsubsection{2 - Modelos dos ensaios de tração indireta do bloco}

Para a modelagem do ensaio de tração indireta do bloco, por causa da aplicação de uma força distribuída em uma região pequena, opta-se por refinar a rede, utilizandose elementos com dimensões máximas de $0,5 \mathrm{~cm}$. A região de aplicação do carregamento é aproximadamente a mesma do ensaio, sendo que na base impedem-se todos os deslocamentos e no topo permite-se apenas os deslocamentos na direção y. Nota-se que as restrições são realizadas apenas na região do carregamento. A Figura 6.47 ilustra a discretização, as restrições e o carregamento para os diferentes modelos.

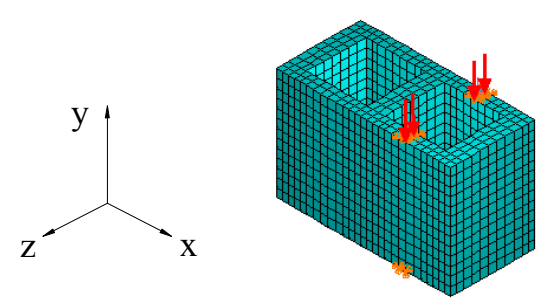

Bloco vazado

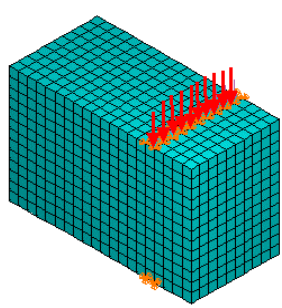

Bloco sólido

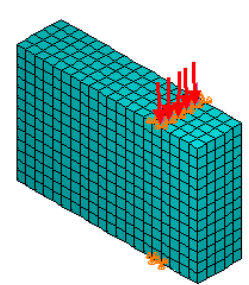

Bloco sólido c/ espessura efetiva

Figura 6.47 - Modelagem do ensaio de tração indireta 
As forças aplicadas e as tensões de tração indireta máximas para todos os modelos numéricos estão na Tabela 6.13. Observa-se que, para este ensaio, a região de carregamento varia de acordo com a modelagem, pois a espessura dos blocos é diferente em cada caso. Verifica-se que apenas o modelo com bloco vazado representa razoavelmente bem tanto a força quanto a tensão máxima, apresentando diferenças em torno de $15 \%$. O modelo com bloco sólido apesar de possuir uma redução na tensão máxima, apresenta uma força de ruptura cerca de $70 \%$ superior ao verificado no experimento. Já o modelo com bloco sólido com espessura efetiva que tem uma tensão de tração indireta próxima ao experimental, possui uma força de ruptura também $70 \%$ superior ao ensaio.

Tabela 6.13 - Resultados numéricos do ensaio de tração indireta do bloco - área líquida

\begin{tabular}{|c|c|c|c|c|}
\hline Resultado & $\begin{array}{c}\text { Força } \\
\text { Máxima ( kN) }\end{array}$ & $\begin{array}{c}\text { Numérico/ } \\
\text { Experimental }\end{array}$ & $\begin{array}{c}\text { Tensão } \\
\text { Máxima (MPa) }\end{array}$ & $\begin{array}{c}\text { Numérico/ } \\
\text { experimental }\end{array}$ \\
\hline Experimental & 8,27 & -- & 5,91 & -- \\
\hline Bloco Vazado & 6,96 & $-15,8 \%$ & 5,02 & $-15,1 \%$ \\
\hline Bloco Sólido & 14,37 & $+73,8 \%$ & 3,09 & $-47,7 \%$ \\
\hline $\begin{array}{c}\text { Bloco espessura } \\
\text { efetiva }\end{array}$ & 14,56 & $+76,1 \%$ & 6,18 & $+4,6 \%$ \\
\hline
\end{tabular}

As distribuições das tensões na direção $\mathrm{x}$ dos blocos para os diferentes casos estão ilustradas na Figura 6.48. As regiões em vermelho, abaixo da aplicação do carregamento, indicam tensões de tração que levam à ruptura do bloco. Lembra-se que esta é a forma de ruptura observada nos ensaios apresentados no capítulo 5.

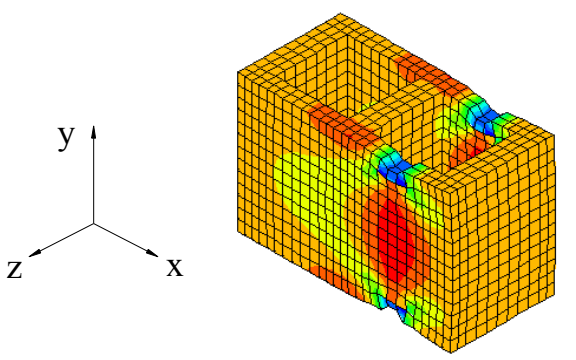

Bloco vazado

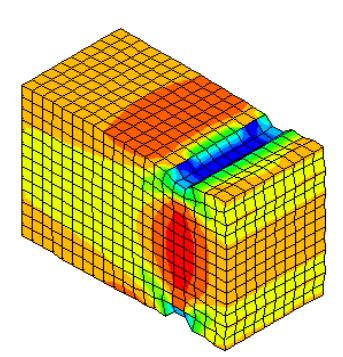

Bloco sólido

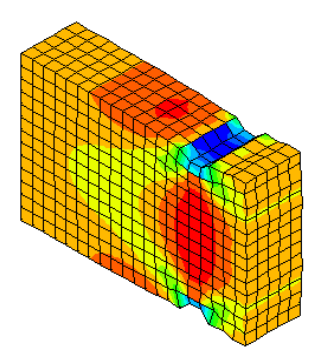

Bloco sólido c/ espessura efetiva Figura 6.48 - Distribuição das tensões normais na direção $x$ do bloco

\section{$\underline{\text { 6.4.1.3 - Modelos dos ensaios de prismas de } 3 \text { blocos }}$}

Os modelos dos ensaios de prismas de 3 blocos possuem as mesmas discretizações realizadas para os ensaios de blocos à compressão (item 6.4.1.1), sendo que o comprimento máximo do elemento é inferior a $1 \mathrm{~cm}$ (ver Figura 6.49). As bases têm todos os seus deslocamentos impedidos, enquanto os topos têm apenas os 
deslocamentos horizontais restritos (direções x e z). O carregamento em todos os casos também é aplicado no topo por meio de uma pressão uniformemente distribuída.

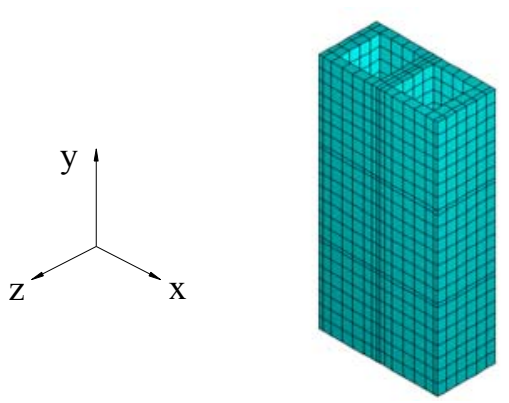

Prisma vazado

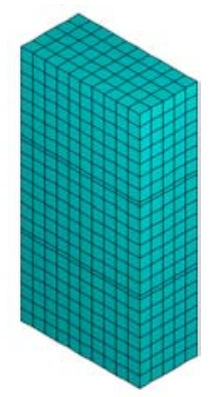

Prisma sólido Figura 6.49 - Discretização dos prismas com diferentes geometrias

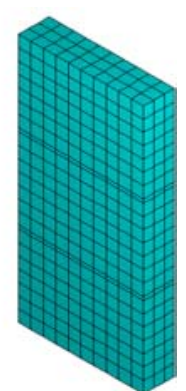

Prisma sólido c/ espessura efetiva

Os resultados das tensões máximas e dos módulos de deformação obtidos nas análises numéricas dos três modelos estão na Tabela 6.14. Neste caso, observa-se que o modelo sólido com espessura efetiva é o que mais se aproxima dos resultados experimentais, com diferenças inferiores a $2 \%$. O modelo vazado também apresenta bons resultados, sendo que a diferença entre o módulo de deformação experimental e numérico é inferior a $2 \%$ e a diferença entre as tensões máximas aplicadas é cerca de 13\%. Já o modelo sólido apresenta um resultado ruim para a tensão máxima aplicada, com uma diferença acima de $90 \%$.

Tabela 6.14- Resultados numéricos do ensaio de prisma de 3 blocos - área bruta

\begin{tabular}{|c|c|c|c|c|}
\hline Resultado & $\begin{array}{c}\text { Tensão } \\
\text { Máxima (MPa) }\end{array}$ & \begin{tabular}{|c|} 
Numérico/ \\
Experimental
\end{tabular} & $\begin{array}{c}\text { Módulo de } \\
\text { deformação (MPa) }\end{array}$ & $\begin{array}{c}\text { Numérico/ } \\
\text { experimental }\end{array}$ \\
\hline Experimental & 11,74 & -- & 10794 & -- \\
\hline Prisma Vazado & 10,15 & $-13,5 \%$ & 10991 & $+1,8 \%$ \\
\hline Prisma Sólido & 22,35 & $+90,4 \%$ & 10045 & $-6,9 \%$ \\
\hline $\begin{array}{c}\text { Prisma espessura } \\
\text { efetiva }\end{array}$ & $11,61(22,92)^{*}$ & $-1,1 \%$ & $10993(21700)^{*}$ & $+1,8 \%$ \\
\hline
\end{tabular}

As deformações dos modelos numéricos são determinadas nos pontos correspondentes à instrumentação utilizada. A Figura 6.50 ilustra as curvas tensão x deformação dos resultados experimentais e numéricos. Percebe-se que os três modelos representam bem o módulo de deformação, sendo que apenas o modelo sólido apresenta uma resistência discrepante dos demais casos. 


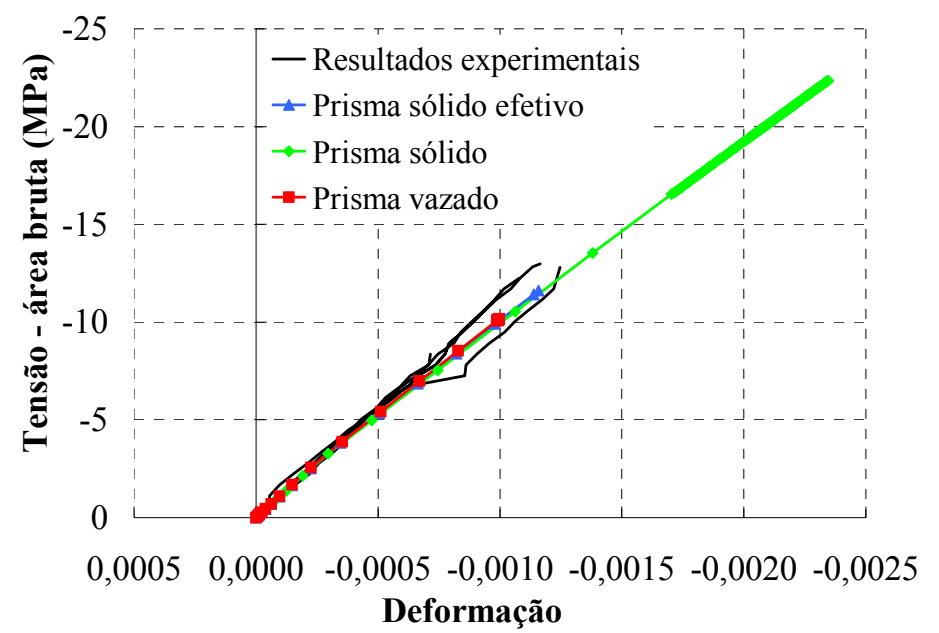

Figura 6.50 - Diagramas tensão $x$ deformação experimentais e numéricos prismas de 3 blocos

Examinando-se os resultados das análises numéricas, observa-se que a ruptura teórica do prisma de 3 blocos ocorre por esmagamento da argamassa. Com isso, explica-se a maior resistência alcançada pelo modelo sólido, pois nesse caso o confinamento da argamassa é superior aos outros dois modelos. Para se ter uma ordem de grandeza, a deformação plástica da argamassa na direção y no modelo sólido é mais de duas vezes superior aos modelos vazado e sólido com espessura efetiva. A Figura 6.51 apresenta a distribuição das deformações plásticas dos modelos na direção y, sendo que as regiões em azul indicam as zonas de maiores deformações por compressão.

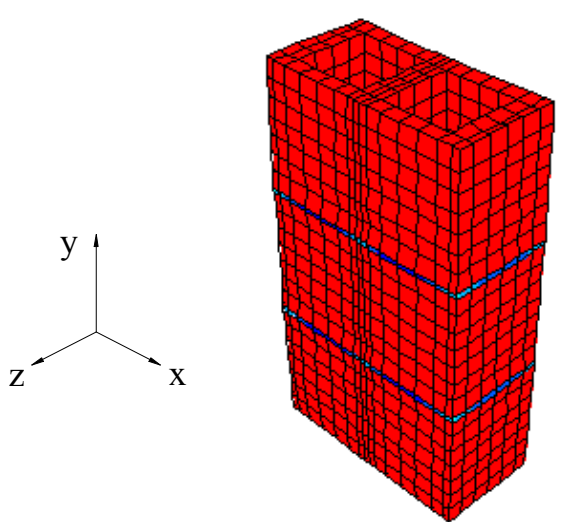

Prisma vazado

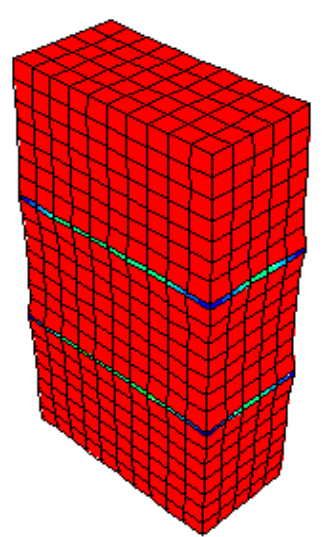

Prisma sólido

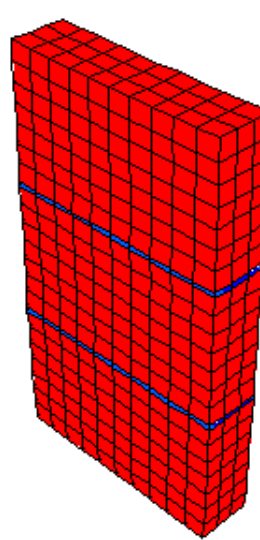

Prisma sólido c/ espessura efetiva

Figura 6.51 - Distribuição das deformaçães plásticas na direção y do prisma

\subsubsection{4 - Modelos dos ensaios de prismas de quatro blocos à flexão}

Para os modelos dos ensaios de prismas de quatro blocos à flexão emprega-se uma discretização de tal forma que o comprimento máximo do elemento é inferior a 0,5 cm para todas as situações, modelos vazado e sólido (ver Figura 6.52). Como o ensaio é realizado na condição de biapoiado, na região referente ao apoio fixo restringem-se os 
deslocamentos nas direções x e y, na região de apoio móvel apenas os deslocamentos na direção y são restritos. O carregamento, em todos os casos, é realizado por meio de forças concentradas aplicadas nos nós referentes aos terços dos vãos. Ressalta-se que, nestes modelos, utilizam-se as mesmas propriedades do bloco indicadas na tabela 6.10 , enquanto que as propriedades da argamassa são modificadas, pois seus ensaios apresentam uma resistência superior.
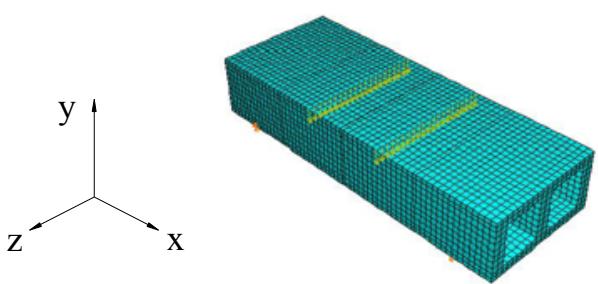

Prisma vazado

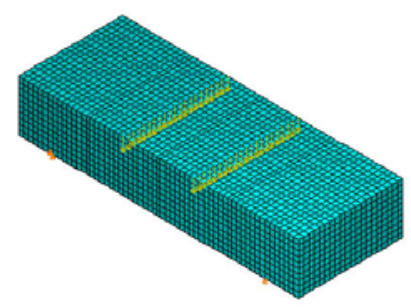

Prisma sólido

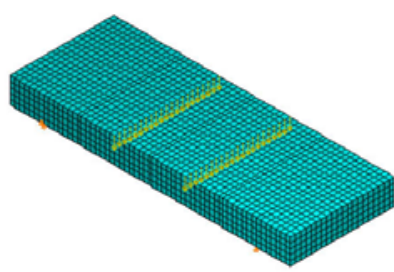

Prisma sólido c/ espessura efetiva

Figura 6.52 - Discretização dos prismas de 4 blocos com diferentes geometrias

Na Tabela 6.15 apresenta-se uma comparação dos resultados obtidos pela análise numérica para a força máxima aplicada e a tensão de tração máxima da junta central de argamassa na direção " $x$ " com os respectivos resultados experimentais. Notase que sem a consideração do comportamento da interface bloco-argamassa há uma superestimação da resistência à flexão da alvenaria, pois a argamassa possui uma resistência à tração superior à aderência. No entanto, apesar da diferença percentual ser alta, em termos absolutos o erro provocado por esta consideração não é tão expressivo.

Tabela 6.15-Resultados numéricos do ensaio de prisma de 4 blocos - área líquida

\begin{tabular}{|c|c|c|c|c|}
\hline Resultado & $\begin{array}{c}\text { Força } \\
\text { Máxima (kN) }\end{array}$ & $\begin{array}{c}\text { Numérico/ } \\
\text { Experimental }\end{array}$ & $\begin{array}{c}\text { Tensão de Tração } \\
\text { Máxima (MPa) }\end{array}$ & $\begin{array}{c}\text { Numérico/ } \\
\text { experimental }\end{array}$ \\
\hline Experimental & 0,42 & -- & 0,51 & -- \\
\hline Prisma Vazado & 1,16 & $+176 \%$ & 1,55 & $+204 \%$ \\
\hline Prisma Sólido & 1,68 & $+300 \%$ & 0,88 & $+73,1 \%$ \\
\hline $\begin{array}{c}\text { Prisma espessura } \\
\text { efetiva }\end{array}$ & 0,58 & $+38,1 \%$ & 1,60 & $+212 \%$ \\
\hline
\end{tabular}

Também existe a opção de se utilizar a não-linearidade de contato para a representação do comportamento da interface bloco-argamassa. Neste caso, emprega-se a própria resistência de aderência para definir a tensão a partir da qual ocorre a separação dos elementos em contato. Dessa maneira, os resultados numéricos e experimentais devem se aproximar bastante, pois o limite do modelo numérico é o próprio resultado experimental. 
Para a comprovação desse fato, realiza-se uma modelagem de um prisma vazado (ver Figura 6.53), com as mesmas propriedades e discretização anteriores, em que se considera os elementos de contato na interface da junta central de argamassa com o bloco, que é o local da ruptura típica do ensaio. Define-se que os elementos de contato admitem uma tração máxima de $0,51 \mathrm{MPa}$, que é o valor encontrado experimentalmente para a aderência bloco-argamassa. Como esperado, observa-se na Tabela 6.16 que os valores são praticamente coincidentes.

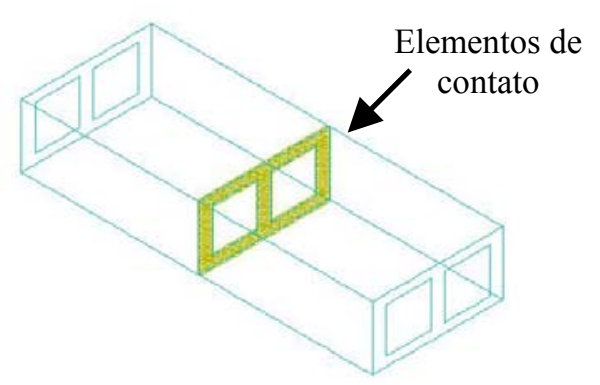

Figura 6.53 - Prisma vazado com elementos de contato na junta central de argamassa

Tabela 6.16 - Comparação entre o resultado experimental e a análise numérica considerando a não-linearidade de contato

\begin{tabular}{|c|c|c|c|c|}
\hline Resultado & $\begin{array}{c}\text { Força } \\
\text { Máxima (kN) }\end{array}$ & $\begin{array}{c}\text { Numérico/ } \\
\text { Experimental }\end{array}$ & $\begin{array}{c}\text { Tensão de Tração } \\
\text { Máxima (MPa) }\end{array}$ & $\begin{array}{c}\text { Numérico/ } \\
\text { experimental }\end{array}$ \\
\hline Experimental & 0,42 & -- & 0,51 & -- \\
\hline $\begin{array}{c}\text { Prisma Vazado } \\
\text { com Contato }\end{array}$ & 0,43 & $+2 \%$ & 0,51 & $0 \%$ \\
\hline
\end{tabular}

\subsubsection{5 - Modelos dos ensaios de compressão de paredinhas}

Como já adiantado, no caso da análise numérica das paredinhas, realiza-se também um modelo utilizando-se a macro-modelagem. Dessa forma é necessário apresentar as propriedades adotadas para o material alvenaria, que tem como base os resultados do próprio ensaio das paredinhas (ver Tabela 6.17).

A Figura 6.54 apresenta as discretizações das paredinhas para os diferentes modelos numéricos adotados. A dimensão do elemento é sempre inferior a $1 \mathrm{~cm}$, da mesma maneira que nas modelagens dos ensaios anteriores. Os deslocamentos das bases são impedidos nas três direções, enquanto no topo restrigem-se apenas os deslocamentos horizontais. O carregamento é aplicado por meio de uma pressão uniformemente distribuída no topo das paredinhas. Os deslocamentos relativos, para o cálculo das deformações, são determinados nos pontos homólogos ao ensaio. 
Tabela 6.17 - Propriedades do material alvenaria para a macro-modelagem - área bruta

\begin{tabular}{|c|c|c|}
\hline \multicolumn{3}{|c|}{ Propriedades do material alvenaria - direção normal } \\
\hline Módulo de Elasticidade & \multicolumn{2}{|c|}{$7786 \mathrm{MPa}$} \\
\hline Resistência à compressão & \multicolumn{2}{|c|}{ 7,42 MPa } \\
\hline Resistência à tração & \multicolumn{2}{|c|}{$0,74 \mathrm{MPa}$} \\
\hline Coeficiente de Poisson $(v)$ & \multicolumn{2}{|c|}{0,12} \\
\hline Curva tensão real $x$ deformação plástica & $\begin{array}{l}\text { 3,34 MPa } \\
5,29 \mathrm{MPa} \\
6,62 \mathrm{MPa} \\
\text { 7,42 MPa }\end{array}$ & $\begin{array}{c}0,0 \\
0,00007 \\
0,00020 \\
0,00035\end{array}$ \\
\hline $\begin{array}{l}\text { Resistência à compressão. biaxial / } \\
\text { Resistência à compressão uniaxial }\end{array}$ & \multicolumn{2}{|c|}{$1,20^{* *}$} \\
\hline $\begin{array}{c}\text { Resistência à tração uniaxial / } \\
\text { Resistência à compressão uniaxial }\end{array}$ & \multicolumn{2}{|c|}{$0,10^{* *}$} \\
\hline $\begin{array}{c}\text { Deformação plástica. biaxial / } \\
\left.\text { Deformação plástica uniaxial ( }{ }^{\circ}\right)\end{array}$ & \multicolumn{2}{|c|}{$1,28^{* *}$} \\
\hline $\begin{array}{l}\text { Tensão fissuração biaxial/ } \\
\text { tensão fissuração uniaxial (") }\end{array}$ & \multicolumn{2}{|c|}{$0,33^{* *}$} \\
\hline Deslocamento último no "tension stiffening" & \multicolumn{2}{|c|}{$0,008 \mathrm{~cm}^{* *}$} \\
\hline \multicolumn{3}{|c|}{$\begin{array}{l}\text { - Correspondem aos valores últimos de tensão } \\
\text { - Com a outra tensão principal igual ao valor último de compressão } \\
{ }^{* *} \text { Valores recomendados pelo manual do ABAQUS }\end{array}$} \\
\hline
\end{tabular}

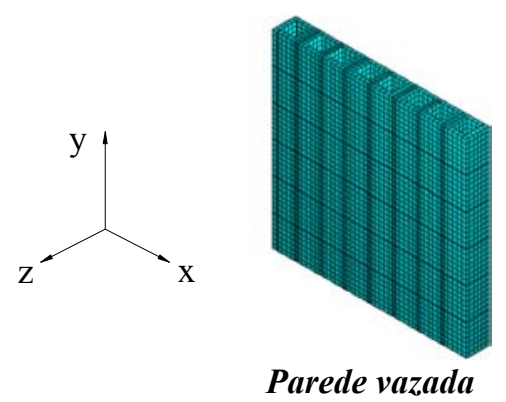

Parede vazada

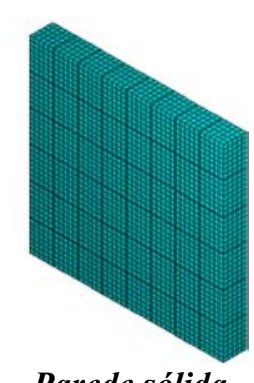

Parede sólida

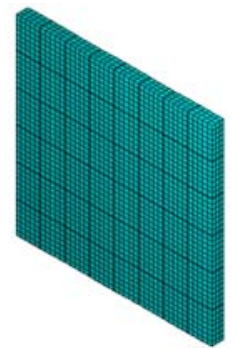

Parede sólida c/ espessura efetiva

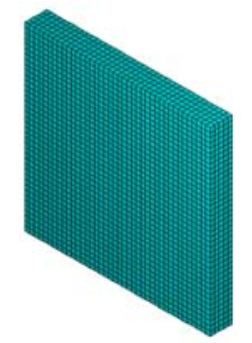

Parede sólida macro-modelagem

Figura 6.54-Discretização das paredinhas com diferentes geometrias

A comparação dos resultados experimentais com os resultados dos modelos numéricos estão apresentados na Tabela 6.18, em que apresentam-se os valores das tensões máximas e dos módulos de deformação. Nota-se que as maiores diferenças ocorrem em termos das tensões máximas nos modelos de parede sólida $(+190 \%)$ e parede sólida com espessura efetiva $(+52,5 \%)$. Já para os modelos de parede vazada e parede com macro-modelagem os valores se aproximam do resultado experimental, com diferenças de $+13,9 \%$ e $-0,7 \%$, respectivamente. Com relação ao módulo de deformação, todos os modelos apresentam resultados razoáveis, com diferenças inferiores a $20 \%$. Destaca-se que a boa representatividade da parede com macromodelagem é um fato esperado, pois as propriedades do material utilizadas são retiradas do próprio ensaio das paredinhas. 
Tabela 6.18 - Resultados numéricos do ensaio de paredinha - área bruta

\begin{tabular}{|c|c|c|c|c|}
\hline Resultado & $\begin{array}{c}\text { Tensão } \\
\text { Máxima (MPa) }\end{array}$ & $\begin{array}{c}\text { Numérico/ } \\
\text { Experimental }\end{array}$ & $\begin{array}{c}\text { Módulo de } \\
\text { deformação (MPa) }\end{array}$ & $\begin{array}{c}\text { Numérico/ } \\
\text { experimental }\end{array}$ \\
\hline Experimental & 7,49 & -- & 7785 & -- \\
\hline Parede Vazada & 8,53 & $+13,9 \%$ & 8771 & $+12,7 \%$ \\
\hline Parede Sólida & 21,78 & $+190 \%$ & 9320 & $+19,7 \%$ \\
\hline $\begin{array}{c}\text { Parede espessura } \\
\text { efetiva }\end{array}$ & $11,42(22,54)^{*}$ & $+52,5 \%$ & $9232(18223)^{*}$ & $+18,5 \%$ \\
\hline $\begin{array}{c}\text { Parede sólida - } \\
\text { macromodelagem }\end{array}$ & 7,44 & $-0,7 \%$ & 7814 & $+0,4 \%$ \\
\hline $\begin{array}{r}{ }^{*} \text { Para a compacação com os valores dos outros modelos em relação à área bruta é necessário } \\
\text { multiplicar o resultado obtido (entre parênteses) pela relação } \mathrm{A}_{\text {liquida }} / \mathrm{A}_{\text {bruta }}=0,507\end{array}$ \\
\hline \multicolumn{5}{|l}{}
\end{tabular}

Observa-se nos gráficos da Figura 6.55 que todos os modelos de parede utilizando a micro-modelagem possuem um comportamento mais rígido que $\mathrm{o}$ experimental. Nota-se também que as diferenças das curvas numéricas e experimentais têm a tendência de aumentar para maiores níveis de tensão. $\mathrm{O}$ modelo de parede utilizando a macro-modelagem representa bem o comportamento médio dos ensaios, com exceção do alto valor da deformação última. Verifica-se, em todos os casos, que as deformações horizontais são bem representadas até a tensão de $6 \mathrm{MPa}$.

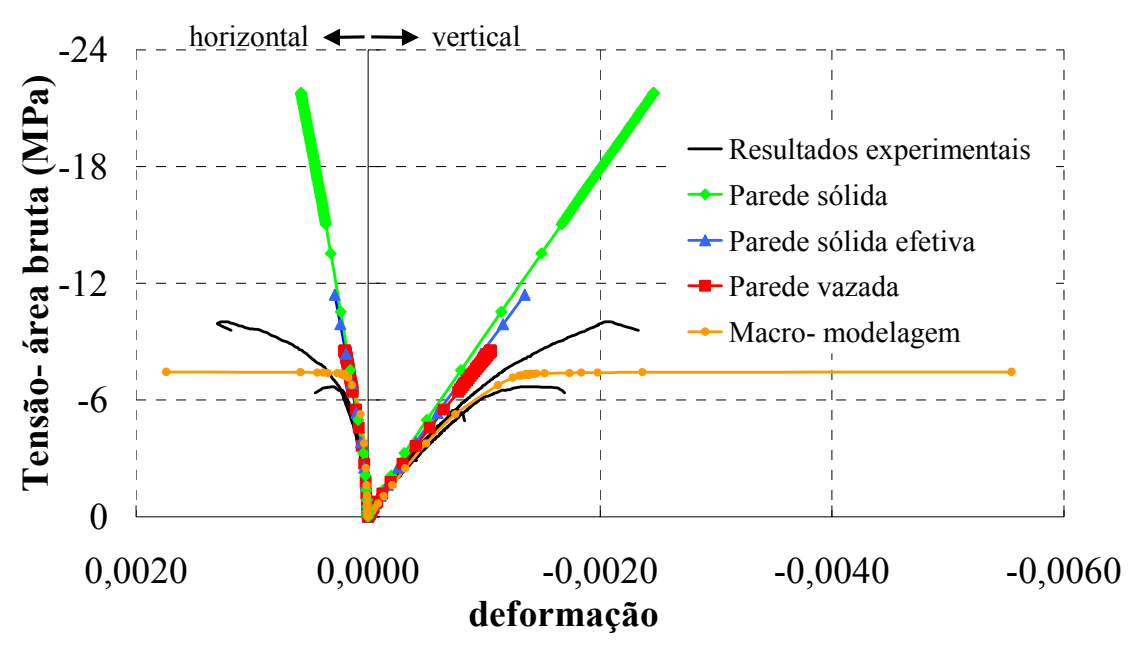

Figura 6.55-Diagramas tensão x deformação experimentais e numéricos-paredinhas

Analisando-se os resultados numéricos, percebe-se que o modo de ruptura é dependente do tipo de modelagem. No modelo de parede vazada, ocorre o esmagamento da argamassa em conjunto com a ruptura por tração indireta nos blocos. Nos modelos de parede sólida e sólida com espessura efetiva a ruptura se dá apenas pelo esmagamento da argamassa. Já no modelo de parede empregando-se a macro-modelagem alcança-se a resistência à compressão do material. 
São apresentadas na Tabela 6.19 comparações das relações entre as resistências de paredinhas, prismas e blocos obtidas experimental e numericamente. Observa-se que as menores diferenças ocorrem para os modelos considerando-se as cavidades dos blocos, indicando uma melhor representatividade dos ensaios. Verifica-se nos casos dos modelos sólido e sólido com espessura efetiva que as resistências das paredinhas são muito próximas às dos prismas. Isso pode ser explicado pela forma de ruptura dos mesmos, já que, em ambos os casos e modelos, ocorre o esmagamento da argamassa.

Tabela 6.19- Comparações das relações entre as resistência de paredinhas, prismas e blocos

\begin{tabular}{|c|c|c|c|c|}
\hline Resultado & $\begin{array}{c}\text { Paredinha/ } \\
\text { Bloco }\end{array}$ & $\begin{array}{c}\text { Numérico/ } \\
\text { experimental }\end{array}$ & $\begin{array}{c}\text { Paredinha/ } \\
\text { prisma }\end{array}$ & $\begin{array}{c}\text { Numérico/ } \\
\text { experimental }\end{array}$ \\
\hline Experimental & 0,247 & -- & 0,638 & -- \\
\hline Parede Vazada & 0,278 & $+12,6 \%$ & 0,840 & $+31,7 \%$ \\
\hline Parede Sólida & 0,653 & $+164,4 \%$ & 0,974 & $+52,7 \%$ \\
\hline $\begin{array}{c}\text { Parede espessura } \\
\text { efetiva }\end{array}$ & 0,367 & $+48,6 \%$ & 0,984 & $+54,2 \%$ \\
\hline
\end{tabular}

\subsection{2 - Modelos dos ensaios na direção paralela à junta de assentamento}

A modelagem dos ensaios na direção paralela à junta de assentamento possui uma particularidade em relação aos modelos de ensaios apresentados anteriormente. Acredita-se que a utilização de modelos em que não se consideram as cavidades dos blocos não forneçam resultados coerentes. Nesta direção, a seção transversal do bloco é fator determinante para resistência tanto quanto o tipo de material utilizado. Outro detalhe importante é que, durante o ensaio, a aplicação do carregamento gera um estado de deformação do bloco (vide Figura 6.56), que leva à separação entre a superfície do bloco e o dispositivo de aplicação de força, fazendo com que a força aplicada se concentre nas faces laterais.

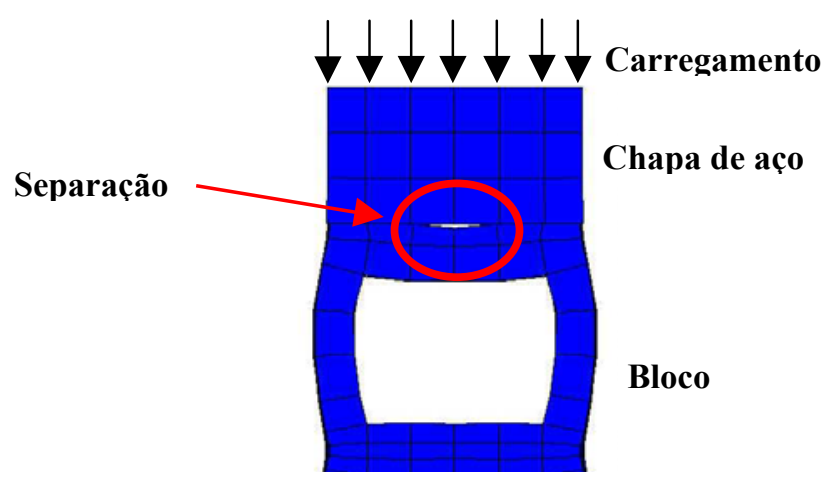

Figura 6.56 - Detalhe da aplicação do carregamento e a deformação do bloco 


\subsubsection{1 - Modelos dos ensaios de blocos}

Para a modelagem dos ensaios de blocos na direção paralela à junta de assentamento empregam-se as mesmas discretizações utilizadas para as análises dos ensaios na direção normal (item 6.4.1.1). A principal diferença é que no caso do modelo com bloco vazado também se discretizam chapas de aço para simular a forma de aplicação de força. Essas chapas são conectadas aos blocos por elementos de contato que permitem a separação dos dois materiais caso ocorram tensões de tração na interface aço-bloco, representando melhor as condições de ensaio. Nos modelos sólidos, a deformação dos blocos não é crítica devido à ausência das cavidades; assim, opta-se por impor as restrições e as forças diretamente nas unidades. A Figura 6.57 ilustra o carregamento e as restrições aplicados nos diferentes modelos numéricos. Numa face lateral aplica-se uma pressão uniformemente distribuída na direção x, restringindo-se os deslocamentos em y e $z$, na face oposta os deslocamentos são impedidos em todas as direções.
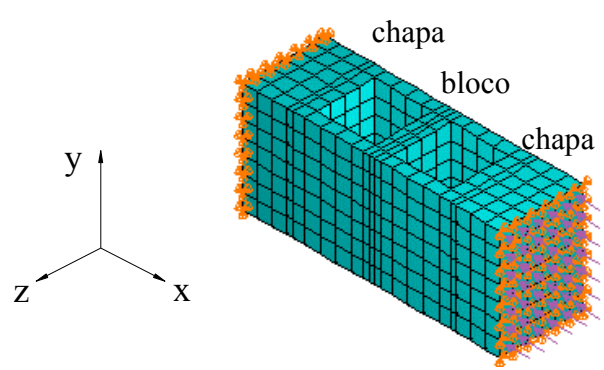

Bloco vazado

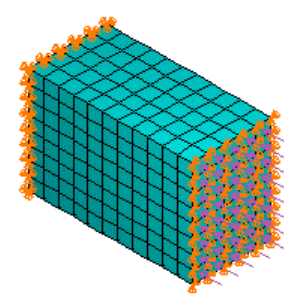

Bloco sólido

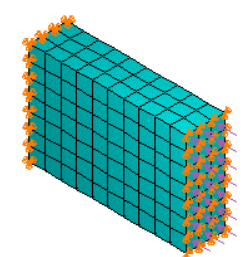

Bloco sólido c/ espessura efetiva

Figura 6.57 - Aplicação de forças e restrições nos modelos do ensaio de blocos na direção paralela

Os resultados da força e da tensão máxima dos modelos numéricos e sua comparação com os valores experimentais estão na Tabela 6.20. Verifica-se que todos os modelos apresentam resultados bem superiores ao ensaio, sendo que as menores diferenças, cerca de $73 \%$, são para o caso em que se considera o bloco vazado. As discrepâncias dos blocos sólido e sólido com espessura efetiva são ainda mais significativas, com valores acima de $180 \%$.

Examinado-se os resultados, verifica-se que todos os modelos atingem tensões normais na direção " $\mathrm{x}$ ” superiores à resistência à compressão do material, regiões em azul da Figura 6.58, indicando uma ruptura por esmagamento do bloco. Contudo, no modelo com bloco vazado, os septos transversais ultrapassam simultaneamente a resistência à tração do material, regiões em vermelho da Figura 6.58-a, apontando uma 
melhor representatividade deste modelo. Lembra-se que nos ensaios a ruptura se dá por tração nos septos.

Tabela 6.20-Resultados numéricos do ensaio de compressão do bloco na direção paralela - área bruta

\begin{tabular}{|c|c|c|c|c|}
\hline Resultado & $\begin{array}{c}\text { Força } \\
\text { Máxima (kN) }\end{array}$ & $\begin{array}{c}\text { Numérico/ } \\
\text { Experimental }\end{array}$ & $\begin{array}{c}\text { Tensão } \\
\text { Máxima (MPa) }\end{array}$ & $\begin{array}{c}\text { Numérico/ } \\
\text { Experimental }\end{array}$ \\
\hline Experimental & 30,9 & -- & 10,50 & -- \\
\hline Bloco Vazado & 53,7 & $+73,8 \%$ & 18,12 & $+72,6 \%$ \\
\hline Bloco Sólido & 89,3 & $+189,0 \%$ & 30,16 & $+187,2 \%$ \\
\hline $\begin{array}{c}\text { Bloco espessura } \\
\text { efetiva }\end{array}$ & 89,5 & $+189,6 \%$ & 59,64 & $+468,0 \%$ \\
\hline
\end{tabular}
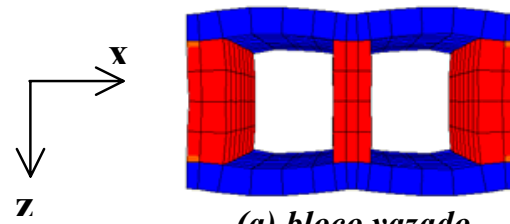

(a) bloco vazado

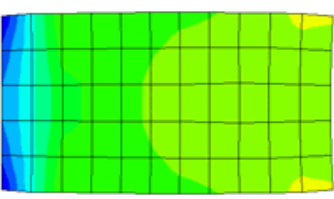

(b) bloco sólido

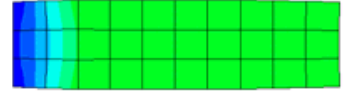

(c) bloco sólido c/ espessura efetiva

Figura 6.58 - Distribuição das tensões normais na direção $x$ - vista de topo

$\mathrm{Na}$ Tabela 6.21 apresentam-se as razões entre as resistências do bloco nas direções paralela e normal à junta de assentamento, comparando-se os resultados numéricos e experimentais. Percebe-se, novamente, que o modelo considerando o bloco vazado apresenta a menor diferença entre os demais, cerca de $71 \%$, entretanto, é ainda uma grande divergência.

Tabela 6.21 - Relações entre as resistências dos blocos nas diferentes direções

\begin{tabular}{|c|c|c|}
\hline Resultado & $\begin{array}{c}\text { Resistência (direção paralela)/ } \\
\text { Resistência (direção normal) }\end{array}$ & $\begin{array}{c}\text { Numérico/ } \\
\text { Experimental }\end{array}$ \\
\hline Experimental & 0,346 & -- \\
\hline Bloco Vazado & 0,591 & $+70,8 \%$ \\
\hline Bloco Sólido & 0,904 & $+161,3 \%$ \\
\hline $\begin{array}{c}\text { Bloco espessura } \\
\text { efetiva }\end{array}$ & $0,971^{*}$ & $+180,6 \%$ \\
\hline
\end{tabular}

* Comparação feita com as resistências em relação à área líquida

\section{$\underline{\text { 6.4.2.2 - Modelos dos ensaios de prismas de } 2 \text { blocos }}$}

A análise numérica dos ensaios de prismas de 2 blocos é similar à modelagem realizada para o ensaio de bloco na direção paralela à junta de assentamento (item 6.4.2.1). As discretizações, as formas de aplicação de carregamento e das restrições são bem semelhantes; a única diferença é que são modelados dois blocos e uma junta de argamassa. Novamente, no modelo que considera as cavidades dos blocos utilizam-se 
chapas de aço para simular a forma de carregamento e restrições. A Figura 6.59 ilustra os diferentes modelos com suas restrições e carregamentos.
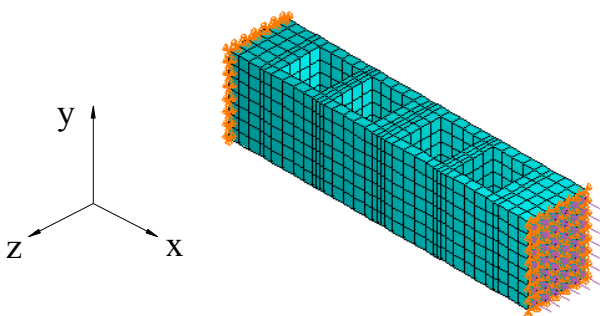

Prisma vazado

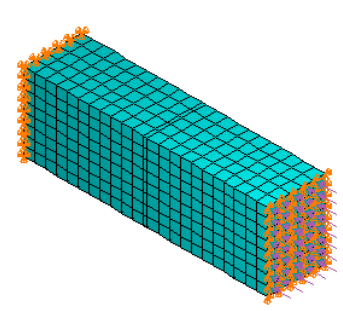

Prisma sólido

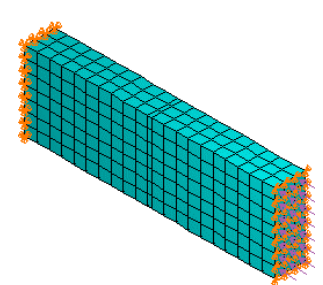

Prisma sólido c/ espessura efetiva

Figura 6.59 - Aplicação de forças e restrições nos modelos do ensaio de prismas na direção paralela

Os valores experimentais e numéricos obtidos para a força e a tensão máxima estão na Tabela 6.22. Observa-se, mais uma vez, que os modelos numéricos apresentam resultados bem superiores aos dos ensaios, sendo que a menor diferença, que ocorre na análise do prisma vazado, é acima de 92\%. Os demais modelos exibem valores totalmente discrepantes do experimento.

Tabela 6.22-Resultados numéricos do ensaio de prisma de 2 blocos na direção paralela - área bruta

\begin{tabular}{|c|c|c|c|c|}
\hline Resultado & $\begin{array}{c}\text { Força } \\
\text { Máxima (kN) }\end{array}$ & $\begin{array}{c}\text { Numérico/ } \\
\text { Experimental }\end{array}$ & $\begin{array}{c}\text { Tensão } \\
\text { Máxima (MPa) }\end{array}$ & $\begin{array}{c}\text { Numérico/ } \\
\text { Experimental }\end{array}$ \\
\hline Experimental & 10,7 & -- & 3,66 & -- \\
\hline Prisma Vazado & 20,8 & $+94,8 \%$ & 7,04 & $+92,3 \%$ \\
\hline Prisma Sólido & 68,3 & $+538,3 \%$ & 23,07 & $+530,3 \%$ \\
\hline $\begin{array}{c}\text { Prisma espessura } \\
\text { efetiva }\end{array}$ & 56,6 & $+429,0 \%$ & 37,73 & $+930,9 \%$ \\
\hline
\end{tabular}

Nos modelos de prisma sólido e prisma sólido com espessura efetiva ocorre o esmagamento da junta de argamassa, de forma similar ao ensaio de prisma na direção normal à junta de assentamento. Já no modelo de prisma vazado a ruptura ocorre por tração na região central dos septos. Na Figura 6.60 as áreas que estão em vermelho indicam que as tensões máximas principais são superiores à resistência à tração do material. Essa forma de ruína é próxima à observada nos ensaios, em que a ruptura se dá por tração nos septos, contudo, na região de interseção das paredes dos blocos.

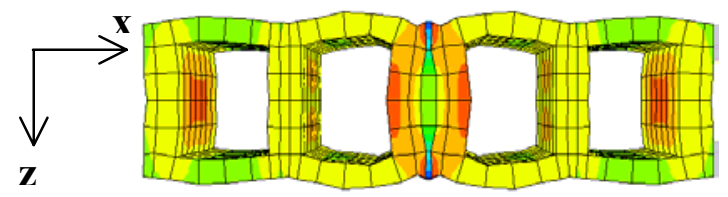

Prisma vazado

Figura 6.60 - Distribuição das tensões máximas principais no modelo de prisma vazado 
Avaliam-se na Tabela 6.23 as relações entre as resistências de prismas e blocos na direção paralela à junta de assentamento, tanto os valores experimentais quanto os numéricos. Neste caso, nota-se que apesar dos modelos vazados apresentarem resistências superiores aos ensaios, a relação entre os resultados de prisma e de bloco é próxima à verificada experimentalmente, com uma diferença de apenas 11,5\%. Entretanto, os modelos sólido e sólido com espessura efetiva não apresentam uma boa correlação com o experimental, com diferenças acima de $80 \%$.

Tabela 6.23-Relações entre os resultados dos ensaios de prismas e blocos na direção paralela

\begin{tabular}{|c|c|c|}
\hline Resultado & $\begin{array}{c}\text { Resistência (Prisma) / } \\
\text { Resistência (bloco) }\end{array}$ & $\begin{array}{c}\text { Numérico/ } \\
\text { Experimental }\end{array}$ \\
\hline Experimental & 0,349 & -- \\
\hline Modelo Vazado & 0,389 & $+11,5 \%$ \\
\hline Modelo Sólido & 0,765 & $+119,2 \%$ \\
\hline $\begin{array}{c}\text { Modelo espessura } \\
\text { efetiva }\end{array}$ & 0,633 & $+81,4 \%$ \\
\hline
\end{tabular}

6.4.2.3 - Modelos dos ensaios de paredinhas na direção paralela à junta de assentamento

Nos itens anteriores (6.4.2.1 e 6.4.2.2) verifica-se que a micro-modelagem com os modelos sólido e sólido com espessura efetiva não apresenta bons resultados para as análises numéricas dos ensaios na direção paralela à junta de assentamento. Dessa forma, decide-se não realizar esses tipos de modelos na análise numérica do ensaio das paredinhas nessa direção. São estudados apenas os casos em que se consideram as cavidades dos blocos (paredinha vazada) e a macro-modelagem. As propriedades empregadas para o material alvenaria na direção paralela têm como base os resultados do próprio ensaio (ver Tabela 6.24), diferentes das adotadas na modelagem do ensaio na direção normal (item 6.4.1.5).

Resolve-se investigar duas situações utilizando o modelo da paredinha com cavidades. Uma primeira na qual as juntas verticais e horizontais de argamassa são discretizadas de forma usual (Figura 6.61-a). E uma outra em que não se considera a presença de argamassa nas juntas horizontais (Figura 6.61-b), isto na tentativa de simular simplificadamente a separação das fiadas, observada nos ensaios. Em ambos os casos, o carregamento e as restrições são impostos indiretamente por chapas de aço, de modo semelhante ao apresentado nas modelagens dos ensaios de bloco e de prismas na direção paralela. No modelo em que se emprega a macro-modelagem, tanto a aplicação de força quanto as restrições são feitas diretamente na paredinha (Figura 6.61-c). Numa 
face lateral aplica-se uma pressão uniformemente distribuída na direção x, restringindose os deslocamentos em y e $z$, sendo que na face oposta os deslocamentos são impedidos em todas as direções. Para a determinação das deformações, utilizam-se os deslocamentos relativos dos pontos homólogos à instrumentação empregada.

Tabela 6.24- Propriedades do material alvenaria na direção paralela para a macro-modelagem

\begin{tabular}{|c|c|c|}
\hline \multicolumn{3}{|c|}{ Propriedades do material alvenaria - direção paralela } \\
\hline Módulo de Elasticidade & \multicolumn{2}{|c|}{$5411 \mathrm{MPa}$} \\
\hline Resistência à compressão & \multicolumn{2}{|c|}{$3,47 \mathrm{MPa}$} \\
\hline Resistência à tração & \multicolumn{2}{|c|}{$0,347 \mathrm{MPa}$} \\
\hline Coeficiente de Poisson (v) & \multicolumn{2}{|c|}{0,12} \\
\hline $\begin{array}{l}\text { Curva tensão real } x \\
\text { deformação plástica }\end{array}$ & $\begin{array}{l}2,08 \mathrm{MPa} \\
3,00 \mathrm{MPa} \\
3,35 \mathrm{MPa} \\
3,47 \mathrm{MPa}\end{array}$ & $\begin{array}{c}0,0 \\
0,00010 \\
0,00088 \\
0,00175\end{array}$ \\
\hline $\begin{array}{l}\text { Resistência à compressão. biaxial / } \\
\text { Resistência à compressão uniaxial }\end{array}$ & \multicolumn{2}{|c|}{$1,20^{* *}$} \\
\hline $\begin{array}{c}\text { Resistência à tração uniaxial / } \\
\text { Resistência à compressão uniaxial }\end{array}$ & \multicolumn{2}{|c|}{$0,10^{* *}$} \\
\hline $\begin{array}{c}\text { Deformação plástica. biaxial / } \\
\left.\text { Deformação plástica uniaxial ( }{ }^{\circ}\right)\end{array}$ & \multicolumn{2}{|c|}{$1,28^{* *}$} \\
\hline $\begin{array}{c}\text { Tensão fissuração biaxial/ } \\
\text { tensão fissuração uniaxial (") }\end{array}$ & \multicolumn{2}{|c|}{$0,33 * *$} \\
\hline Deslocamento último no "tension stiffening" & \multicolumn{2}{|c|}{$0,008 \mathrm{~cm}^{* *}$} \\
\hline $\begin{array}{l}\text { Correspondem aos valores últimos de tensão } \\
\text { Com a outra tensão principal igual ao valor último } \\
\text { Valores recomendados pelo manual do ABAQUS }\end{array}$ & apress & \\
\hline
\end{tabular}

Vista

de topo
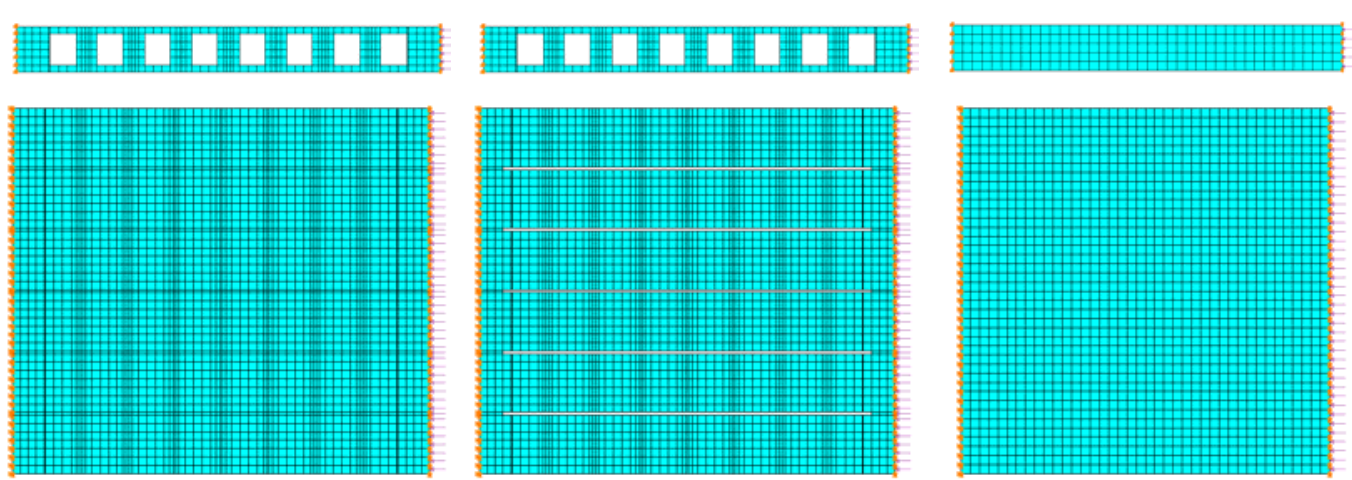

(a) Paredinha Vazada

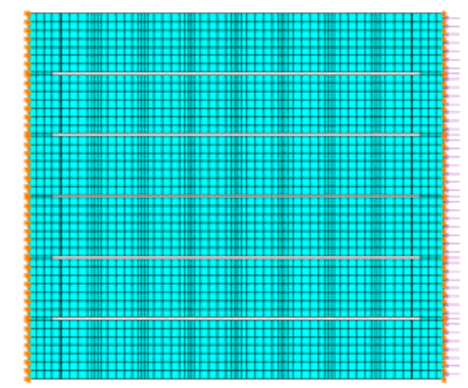

(b) Paredinha vazada sem junta de assentamento (c) Paredinha macro-modelagem

Figura 6.61 - Modelagens do ensaio de paredinhas na direção paralela à junta de assentamento

Os valores experimentais e numéricos da tensão máxima e do módulo de deformação da paredinha estão apresentados na Tabela 6.25. Como esperado, o modelo utilizando a macro-modelagem é o que apresenta os melhores resultados, pois suas 
propriedades são retiradas diretamente do ensaio. A análise da paredinha vazada leva a uma baixa resistência, mas seu módulo de deformação é compatível com o experimental, com diferença inferior a $15 \%$. Já no caso em que não se considera a existência das juntas horizontais obtém-se um alto valor para a tensão máxima $(89 \%$ superior ao ensaio), no entanto seu módulo de deformação é bastante próximo ao do experimento. As mesmas observações podem ser obtidas por meio das curvas tensão $\mathrm{X}$ deformação experimentais e numéricas (Figura 6.62). Ressalta-se que não são feitas comparações entre as medidas relacionadas ao coeficiente de Poisson, pois os valores experimentais são considerados aparentes devido à ocorrência da separação das fiadas.

Tabela 6.25-Resultados numéricos do ensaio de paredinhas na direção paralela - área bruta

\begin{tabular}{|c|c|c|c|c|}
\hline Resultado & $\begin{array}{c}\text { Tensão } \\
\text { Máxima (kN) }\end{array}$ & $\begin{array}{c}\text { Numérico/ } \\
\text { Experimental }\end{array}$ & $\begin{array}{c}\text { Módulo de } \\
\text { deformação (MPa) }\end{array}$ & $\begin{array}{c}\text { Numérico/ } \\
\text { Experimental }\end{array}$ \\
\hline Experimental & 3,47 & -- & 5411 & -- \\
\hline Paredinha vazada & 1,24 & $-64,3 \%$ & 6204 & $+14,7 \%$ \\
\hline $\begin{array}{c}\text { Paredinha vazada sem } \\
\text { junta horizontal }\end{array}$ & 6,56 & $+89,0 \%$ & 5705 & $+5,4 \%$ \\
\hline $\begin{array}{c}\text { Paredinha Macro- } \\
\text { modelagem }\end{array}$ & 3,28 & $-5,5 \%$ & 5437 & $+0,5 \%$ \\
\hline
\end{tabular}

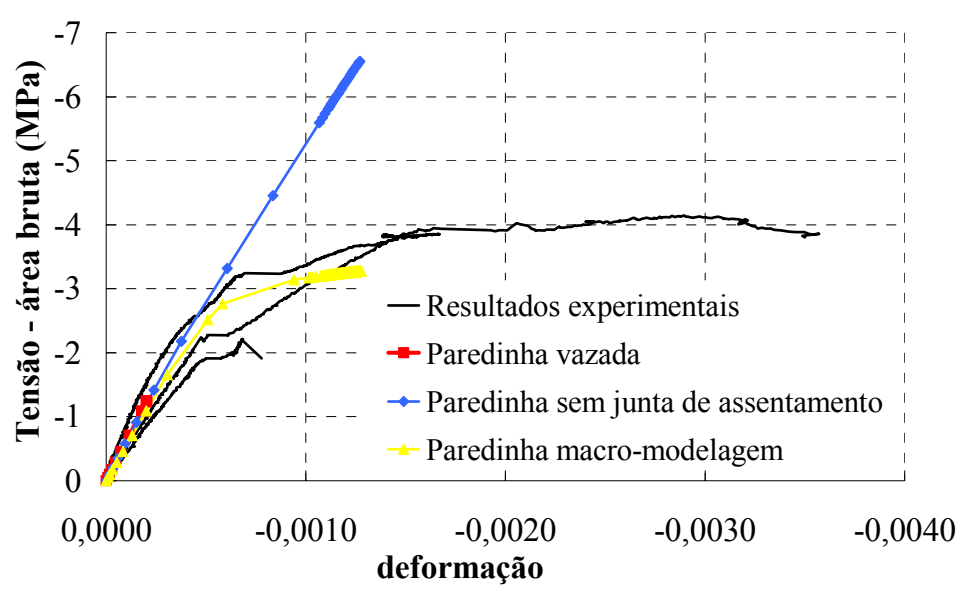

Figura 6.62 - Diagramas tensão x deformação experimentais e numéricos-paredinhas na direção paralela à junta de assentamento

Novamente a forma de ruptura é dependente do tipo de modelagem. Para o caso da paredinha vazada o processamento pára quando a resistência à tração das juntas de assentamento é alcançada, o que não acontece no experimento, pois mesmo com as fiadas separadas a paredinha continua resistindo. No modelo em que não existem juntas horizontais de argamassa, a ruína ocorre por tração nos septos dos blocos. As regiões em vermelho da Figura 6.63 indicam tensões máximas principais superiores à resistência à tração do material cerâmico. Cabe ressaltar que nos ensaios a ruptura 
realmente se dá por tração do bloco, entretanto em regiões próximas às interseções das paredes dos blocos. Na macro-modelagem da paredinha a força de ruptura corresponde à resistência à compressão do material alvenaria na direção paralela à junta de assentamento.
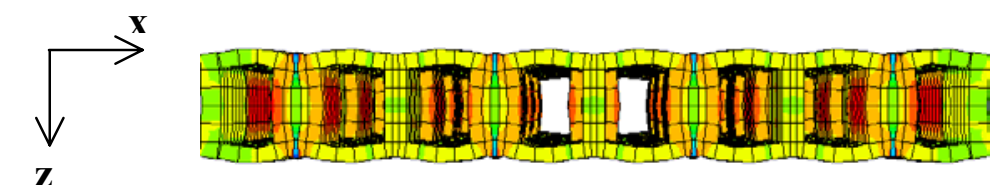

Figura 6.63 - Distribuição das tensões máximas principais no modelo de paredinha vazada sem junta horizontal de argamassa

$\mathrm{Na}$ Tabela 6.26 apresentam-se as relações entre resistências de paredinhas, prismas e blocos na direção paralela, tanto para os modelos numéricos quanto para os resultados dos ensaios. Nota-se que o modelo vazado não consegue representar a resistência do ensaio de paredinha por causa da ruptura prematura gerada pela junta horizontal de argamassa, o que leva a relações cerca de $80 \%$ inferiores. Já no modelo vazado em que não se considera a junta de assentamento, a tensão máxima é superior à experimental, mas as relações entre resistência são bem próximas às verificadas nos ensaios, com diferenças de no máximo $10 \%$.

Tabela 6.26 - Relações entre as resistências dos diferentes ensaios - direção paralela

\begin{tabular}{|c|c|c|c|c|}
\hline Resultado & $\begin{array}{c}\text { Paredinha / } \\
\text { prisma }\end{array}$ & $\begin{array}{c}\text { Numérico/ } \\
\text { Experimental }\end{array}$ & $\begin{array}{c}\text { Paredinha / } \\
\text { bloco }\end{array}$ & $\begin{array}{c}\text { Numérico/ } \\
\text { Experimental }\end{array}$ \\
\hline Experimental & 0,948 & -- & 0,330 & -- \\
\hline Modelo Vazado & 0,176 & $-81,4 \%$ & 0,068 & $-79,4 \%$ \\
\hline $\begin{array}{c}\text { Modelo vazado sem } \\
\text { junta horizontal }\end{array}$ & 0,932 & $-1,7 \%$ & 0,362 & $+9,7 \%$ \\
\hline
\end{tabular}

\subsection{3 - Análise final da modelagem numérica dos ensaios de caracterização}

Com relação aos tipos de modelagem realizados para os ensaios na direção normal à junta, verifica-se que a micro-modelagem considerando-se os blocos com suas cavidades apresentam os melhores resultados como um todo, com diferenças inferiores a $15 \%$ em termos de resultados individuais. Os modelos sólidos não se mostram representativos para a obtenção das resistências, no entanto têm valores razoáveis em termos da deformabilidade. Já os modelos sólidos com espessura efetiva têm resultados razoáveis tanto para as resistências quanto para os módulos de deformação, com uma maior diferença para a resistência à compressão da paredinha (cerca de 53\%). Entretanto, julga-se que modificações em alguns parâmetros das análises possam levar a uma melhoraria desse resultado. A macro-modelagem da paredinha também demonstra 
uma boa correlação com os resultados das paredinhas, visto que suas propriedades são retiradas diretamente dos ensaios.

Nas análises numéricas dos ensaios na direção paralela à junta de assentamento observa-se que as micro-modelagens não representam as resistências obtidas experimentalmente, com valores sempre muito superiores (acima de 70\%). Contudo, nos modelos considerando-se os vazios dos blocos obtém-se relações entre as resistências dos diferentes corpos-de-prova na direção paralela próximas às verificadas experimentalmente. Esses modelos também apresentam formas de ruptura mais condizentes com as obtidas nos ensaios. Acredita-se que as tensões de tração nas interseções dos septos dos blocos estejam subestimadas nos modelos numéricos, o que leva a uma maior resistência do corpo-deprova. Na direção paralela apenas a macro-modelagem das paredinhas apresenta resultados compatíveis tanto para a resistência quanto para o módulo de deformação.

Com base em todos os resultados apresentados, conclui-se que os modelos considerando a micro-modelagem com os blocos vazados e a macro-modelagem são os mais indicados para retratar a resistência e a deformabilidade da alvenaria, sendo por isso empregados daqui por diante. Ressalta-se que todas as micro-modelagens empregando modelos sólidos são aptas para representar o comportamento linear da alvenaria, visto que produziram correlação razoável entre os módulos de deformação. Julga-se, também, que os modelos sólidos com espessura efetiva podem ser calibrados para obtenção de resultados mais consistentes.

De uma maneira geral, pode-se concluir que as análises numéricas dos ensaios na direção normal à junta de assentamento (item 6.4.1) apresentam melhores resultados que as análises na direção paralela. Considera-se que o fato das propriedades dos blocos terem sido obtidas na direção normal tenha influenciado a representatividade dos modelos nessa direção. Outra questão a ser analisada é que a seção geométrica do bloco é fator determinante para os ensaios na direção paralela. Assim, as variações das espessuras dos septos transversais, a existência de tensões residuais provenientes do processo de queima, entre outras razões, são mais destacadas nos ensaios nessa direção. Conseqüentemente, como esses fatores são difíceis de serem considerados nos modelos numéricos, os resultados alcançados são limitados. Como no presente trabalho as ações atuantes na direção paralela à junta de assentamento não são significativas, não houve uma preocupação maior em se atingir bons resultados para as análises numéricas nessa direção. Contudo, o estudo realizado pode servir de balizamento para futuras pesquisas. 


\section{Capítulo \\ 7 ENSAIOS DOS CORPOS-DE-PROVA DE CISALHAMENTO}

\section{1- Generalidades}

De acordo com as análises numéricas desenvolvidas no capítulo 6 define-se um corpo-de-prova com cinco fiadas de altura, com seção em planta em formato " $\mathrm{H}$ " e com a parede central não apoiada, para a determinação da resistência ao cisalhamento vertical da alvenaria. Como os ensaios de caracterização de blocos e da alvenaria, apresentados no capítulo 5, indicam a viabilidade dos modelos reduzidos, opta-se por realizar a quase totalidade dos ensaios em escala reduzida (1:3), por sua maior simplicidade e agilidade. Contudo, também é realizado um ensaio em escala natural (1:1) para comprovar que os modelos reduzidos são também capazes de representar o cisalhamento da alvenaria.

Os corpos-de-prova em escala reduzida (1:3) possuem as mesmas dimensões e disposições das fiadas determinadas nas análises numéricas iniciais. Entretanto, estudase também a influência da presença da cinta de amarração. Assim, consideram-se três situações diferentes: uma primeira onde não há cinta de amarração (Figura 7.1-a), uma segunda na qual a última fiada do corpo-de-prova é uma cinta de amarração (Figura 7.1b) e uma terceira em que a cinta localiza-se na fiada intermediária (Figura 7.1-c).

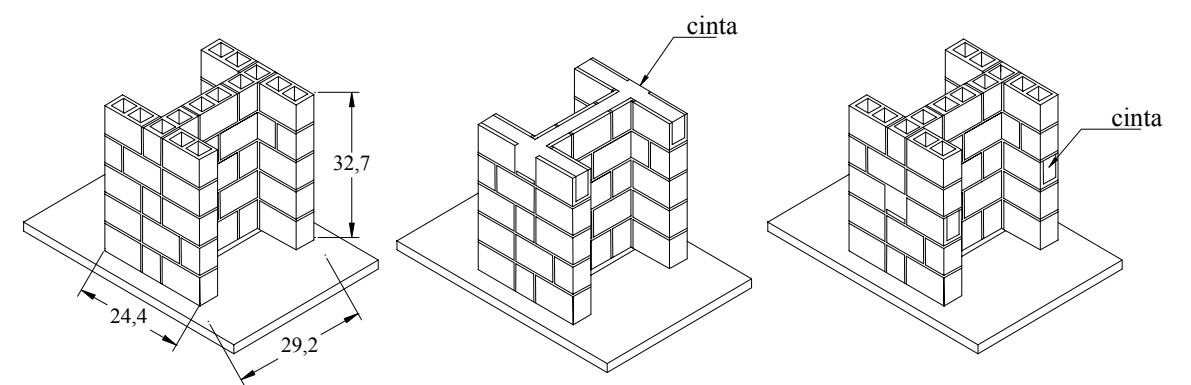

$\begin{array}{ll}\text { (a) Sem cinta de amarração } & \text { (b) Cinta de amarração no topo }\end{array}$

(c) Cinta intermediária Figura 7.1- Tipos de corpos-de-prova de cisalhamento em escala reduzida (1:3). 
Já para o corpo-de-prova em escala natural (1:1), é investigado apenas o exemplar sem cinta de amarração, pois é a situação mais simples de ser executada e também a mais representativa. Ressalta-se que os procedimentos utilizados são homólogos aos da escala reduzida, permitindo a utilização da teoria de modelos reduzidos na análise comparativa de resultados. A Figura 7.2 ilustra a disposição das fiadas, iguais às dos corpos-de-prova em escala reduzida, e as principais dimensões do exemplar em escala natural.
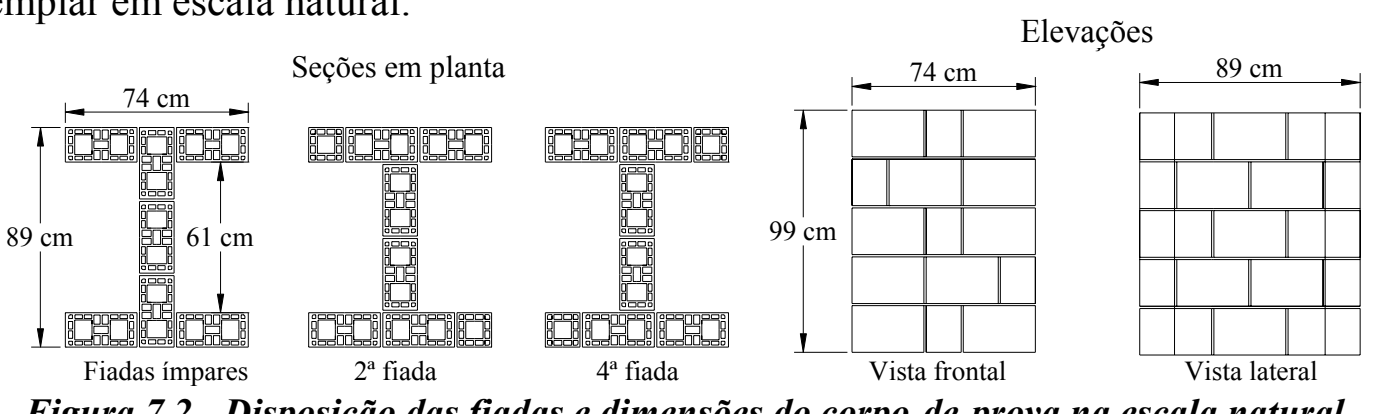

Figura 7.2 - Disposição das fiadas e dimensões do corpo-de-prova na escala natural

Ao final do capítulo realiza-se uma análise numérica considerando-se diferentes não-linearidades. Ressalta-se que é uma investigação preliminar, com o objetivo de fornecer subsídios para estudos numéricos posteriores e comparar qualitativamente com os resultados experimentais.

\section{2- Modo de execução dos corpos-de-prova de cisalhamento}

- Procedimentos:

Para a execução dos corpos-de-prova de cisalhamento e dos painéis de alvenaria, todos em escala reduzida, desenvolveu-se um conjunto de gabaritos em alumínio para garantir as dimensões, o esquadro, o nível e o prumo para todas as paredes. São dois gabaritos idênticos para a execução dos flanges (Figura 7.3-a), sendo interligados por réguas de acordo com o tamanho da parede central (Figura 7.3-b). A Figura 7.3-c proporciona uma idéia do posicionamento dos gabaritos para a construção de um painel de alvenaria.

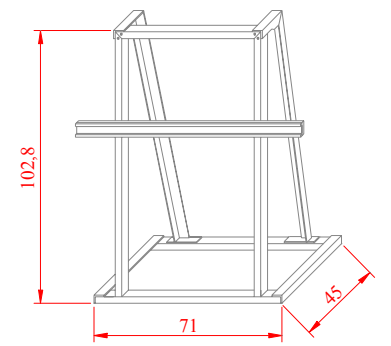

(a) Gabarito para os flanges

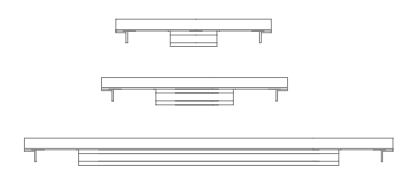

(b) Réguas para a parede central

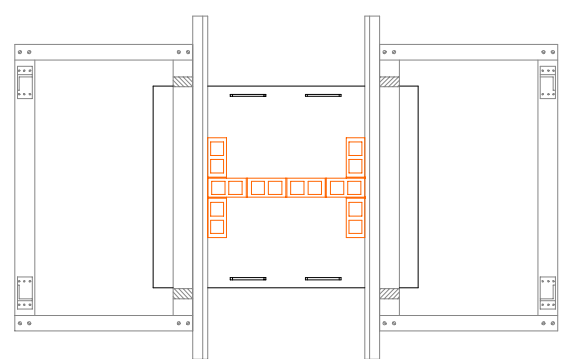

(c) Posicionamento dos gabaritos

Figura 7.3 - Conjunto de gabaritos em alumínio desenvolvidos 
Os corpos-de-prova de cisalhamento em escala reduzida (1:3) são construídos sobre lajes com uma abertura para possibilitar que a parede central tenha os deslocamentos livres (Figura 7.4). O concreto utilizado para essas lajes que servem de base possuem o traço em massa de 1:1,94:2,06 (cimento;areia;pedrisco) com relação água/cimento igual a 0,65. O cimento é do tipo ARI-Plus, a areia é a mesma dos ensaios de caracterização em escala natural e o pedrisco é de $6,3 \mathrm{~mm}$ de origem basáltica. Para a armadura longitudinal emprega-se a tela soldada de malha quadrada (espaçamento $=5$ $\mathrm{cm}$ ) e fios com diâmetro de 2,5mm. Para cada concretagem foram moldadas três lajes e retirados seis corpos-de-prova cilíndricos $(5 \mathrm{~cm}$ x $10 \mathrm{~cm})$ para controle da resistência.

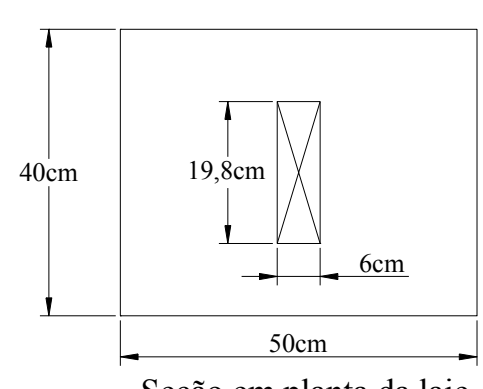

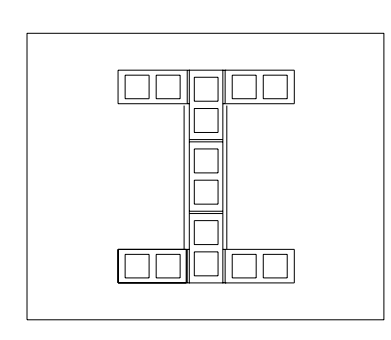

Vista do topo

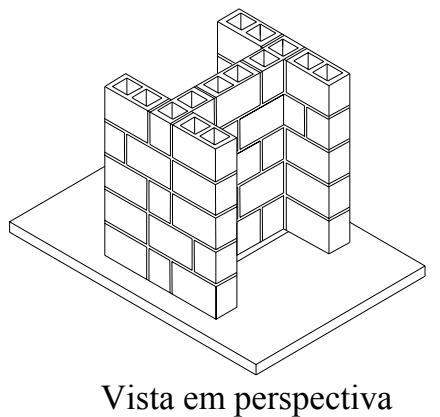

Vista em perspectiva

Figura 7.4 - Laje vazada e posição para a construção do corpo-de-prova

Antes de iniciar a construção de um exemplar preenche-se a abertura da laje com areia úmida, fornecendo apoio para a parede central apenas na fase de execução. Para a realização do ensaio, essa areia é facilmente retirada permitindo o deslocamento livre da base da parede. Os corpos-de-prova são executados pelo mesmo pedreiro dos ensaios de caracterização. Para cada uma das três situações investigadas em escala reduzida (1:3) são construídos cinco exemplares, além de dois prismas de três blocos por exemplar para controle da resistência à compressão da alvenaria.

O traço em volume da argamassa utilizado é 1:0,5:4,5 (cimento : cal : areia), igual aos dos ensaios de caracterização (capítulo 5). Emprega-se o mesmo cimento (CP II E - 32), a mesma cal (CH III) e a areia de mesma granulometria (muito fina), contudo aumenta-se a relação água / cimento de 1,16 para 1,21. Essa mudança na quantidade de água é necessária para se atingir uma trabalhabilidade adequada para as condições climáticas do período de construção. Todas as juntas têm apenas $3 \mathrm{~mm}$ de espessura. $\mathrm{O}$ volume de argamassa realizado por vez corresponde ao necessário para a construção de um exemplar, de dois prismas de três blocos, de três corpos-de-prova cilíndricos $(5 \mathrm{~cm} \mathrm{x}$ $10 \mathrm{~cm}$ ) e de um ensaio de consistência. 
O graute para as cintas de amarração possui o traço em massa de 1:0,76:1,24 (cimento : areia : pedrisco) com relação água/cimento igual a 0,37 , além de $0,7 \%$ de aditivo superplastificante. O cimento é do tipo ARI - Plus, a areia é de granulometria fina, o pedrisco $(6,3 \mathrm{~mm})$ é de origem basáltica e o aditivo é o Glenium 51. Este é um traço empregado em outros programas de pesquisa em que se obtém uma resistência acima de $50 \mathrm{MPa}$ aos 14 dias. A necessidade de tal valor justifica-se pela opção de se empregar um graute com resistência próxima à do material cerâmico, cerca de $59 \mathrm{MPa}$ na área líquida do bloco em escala reduzida. São grauteadas duas ou três cintas por vez, sendo retirados seis corpos-de-prova cilíndricos $(5 \mathrm{~cm} \mathrm{x} 10 \mathrm{~cm})$ apenas para controle qualitativo.

Em geral, na armação das cintas de amarração em construções usuais utilizam-se duas barras de $8 \mathrm{~mm}$, ou uma barra de $10 \mathrm{~mm}$. Na escala reduzida isso é equivalente a duas barras de $2,5 \mathrm{~mm}$ e uma barra de $3,2 \mathrm{~mm}$, respectivamente. Contudo, a barra de menor diâmetro encontrada na região é de 4,2 $\mathrm{mm}$. Dessa forma, utiliza-se nas cintas em modelo reduzido apenas uma barra de aço $\mathrm{CA}-60$ de $4,2 \mathrm{~mm}$, o que corresponderia na escala natural a uma barra de $12,5 \mathrm{~mm}$.

A Figura 7.5 ilustra todas as etapas de construção para os diferentes corpos-deprova em escala reduzida (1:3). Para o caso com cinta intermediária, é necessário que a construção se dê em duas etapas devido ao grauteamento da cinta. Os demais tipos são construídos ininterruptamente, sendo apenas necessária uma pequena espera para o grauteamento dos exemplares com cinta de amarração no topo.

Apresentam-se em destaque na Figura 7.6 os diferentes tipos de corpos-de-prova de cisalhamento na escala (1:3). Vale ressaltar que também há a tentativa de se controlar a resistência à compressão das cintas de amarração através de ensaios de compressão de blocos canaletas preenchidos com os grautes utilizados.

O corpo-de-prova na escala natural (1:1) é executado com a mesma mão-deobra, só que utilizando o prumo de pedreiro, esquadro metálico e o nível de bolha para controle ao invés dos gabaritos anteriormente descritos. A altura e o comprimento do corpo-de-prova são verificados com réguas metálicas, garantindo-se a espessura de $1 \mathrm{~cm}$ das juntas verticais e horizontais de argamassa. 


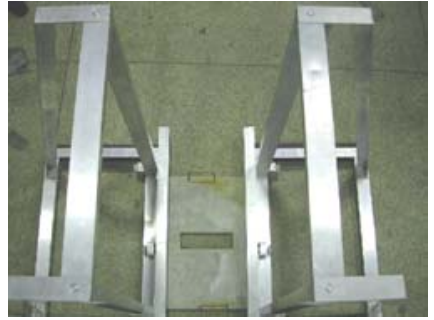

(a) Posicionamento do gabarito

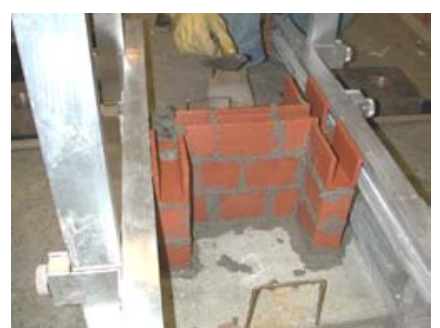

(d) Construção do exemplar com cinta intermediária

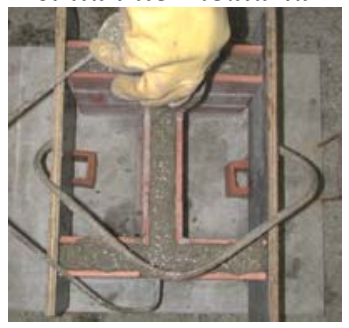

(g) Grauteamento da cinta

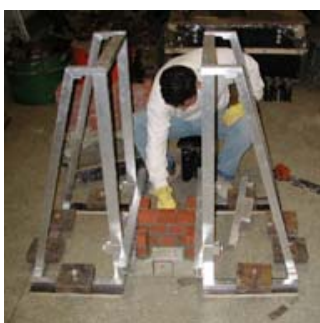

(j) Vista geral

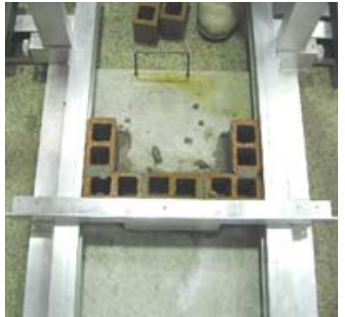

(b) Régua para construção da parede central

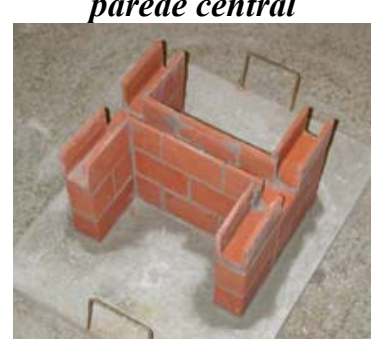

(e) Espera para o grauteamento da cinta

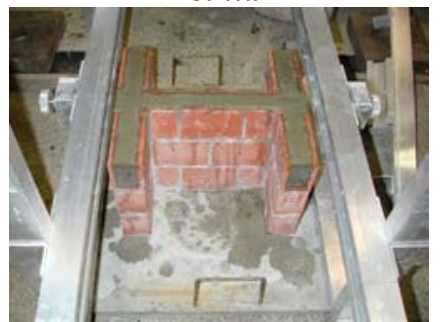

(h) Espera para o endurecimento do graute

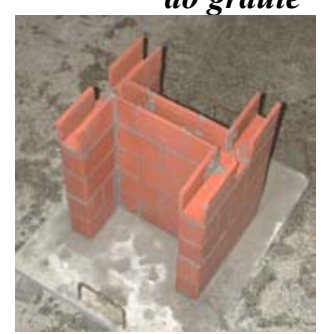

(k) Espera do exemplar com cinta no topo para o grauteamento

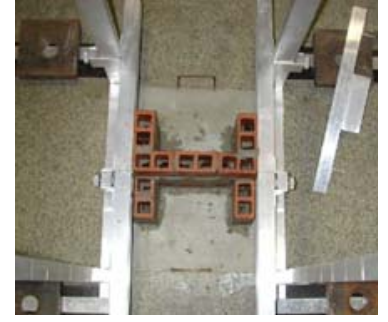

(c) Evolução da construção

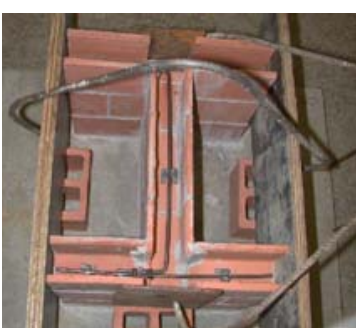

(f) Armadura da cinta intermediária

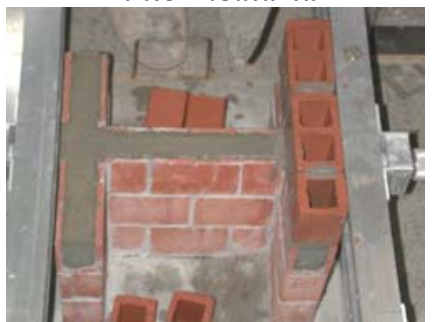

(i) Início da construção das

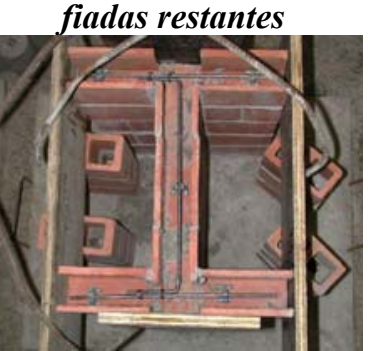

(l) Armadura da cinta no topo

Figura 7.5 - Etapas da construção dos corpos-de-prova de cisalhamento em escala (1:3)

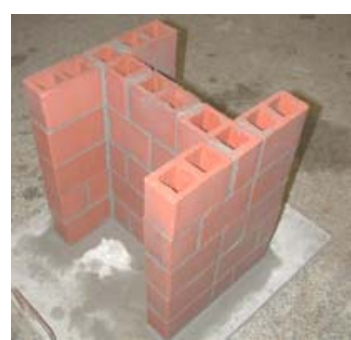

(a) Sem cinta de amarração

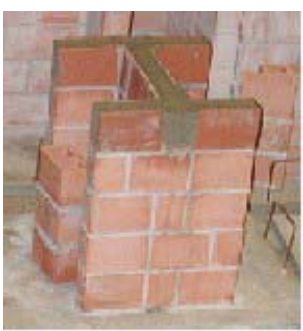

(b) Cinta de amarração no topo

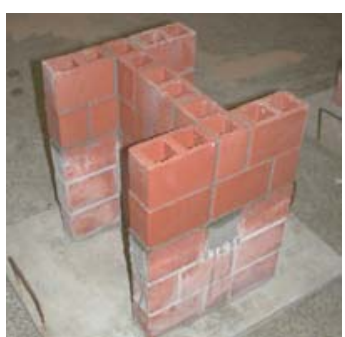

(c) Cinta intermediária Figura 7.6 - Corpos-de-prova de cisalhamento em escala reduzida (1;3)

O exemplar na escala natural é construído de tal maneira que os flanges fiquem apoiados sobre bases de concreto independentes (ver Figura 7.7), enquanto a parede central apóia-se numa base de isopor, possibilitando a sua retirada antes da realização 
do ensaio. Esse procedimento garante que durante o ensaio a face inferior da parede central do corpo-de-prova fique com os deslocamentos livres. Ressalta-se que tanto na base de concreto quanto na base de isopor é colocada uma camada de argamassa para assentamento do bloco. Neste caso não há transporte do corpo-de-prova, que é construído já na posição do ensaio.

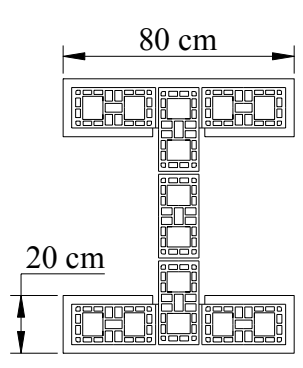

Vista do topo

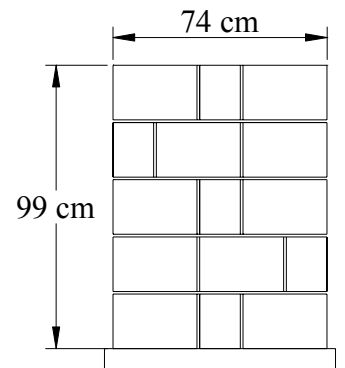

Vista frontal

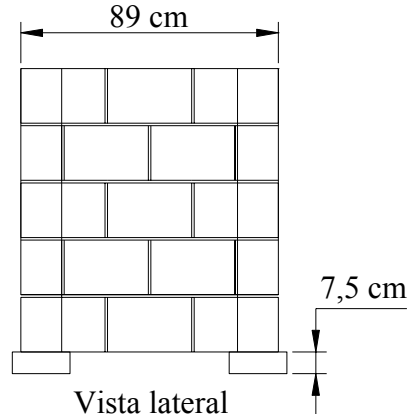

Vista lateral

Figura 7.7 - Esquema das bases de concreto do corpo-de-prova em escala natural

A argamassa e os materiais empregados para sua preparação são os mesmos dos ensaios de caracterização para a alvenaria em escala natural. O traço em volume da argamassa é 1: 0,5: 4,5 (cimento:cal:areia), com uma relação água/cimento igual a 1,23. O cimento utilizado é do tipo CP II E -32, a cal hidratada é a CH III e areia é classificada como fina pela NBR 7211(1983). São necessárias duas produções de argamassa, sendo que em cada uma são retirados três corpos-de-prova cilíndricos $(5 \mathrm{~cm}$ x $10 \mathrm{~cm}$ ) para controle de sua resistência. Também, para cada produção de argamassa, são construídos três prismas de três blocos para controle da resistência à compressão da alvenaria.

O concreto utilizado para a base do exemplar possui o traço em massa de 1:1,94:2,06 (cimento;areia;pedrisco) com relação água/cimento igual a 0,65. O cimento é do tipo ARI-Plus, a areia é a mesma utilizada na argamassa e o pedrisco de origem basáltica tem diâmetro de $6,3 \mathrm{~mm}$. Retiram-se três corpos-de-prova cilíndricos $(5 \mathrm{~cm} \times$ $10 \mathrm{~cm}$ ) para controle da resistência do concreto. Para a armadura longitudinal empregam-se barras de $5 \mathrm{~mm}$ de diâmetro, com espaçamento de $5 \mathrm{~cm}$, junto a ambas as faces.

\section{3- Procedimentos e equipamentos utilizados nos ensaios}

- Procedimentos:

A finalidade do ensaio é a determinação da resistência ao cisalhamento vertical da alvenaria com amarração direta. Para tanto o carregamento é aplicado apenas na 
parede central, que não é apoiada em sua base; com isso todo o carregamento deve ser transferido para os flanges (ver Figura 7.8). Considera-se que a resistência média ao cisalhamento seja igual à razão da força de ruptura do corpo-de-prova pela área das interseções conforme a seguinte equação:

$\tau_{\text {vert }}=\frac{\mathrm{F}_{\text {ruptura }}}{\mathrm{A}_{\text {int erseção }}}=\frac{\mathrm{F}_{\text {ruptura }}}{2 \cdot \mathrm{h} \cdot \mathrm{e}}$, sendo:

$\tau_{\mathrm{vert}}=$ resistência média ao cisalhamento vertical da alvenaria;

$\mathrm{F}_{\text {ruptura }}=$ força de ruptura do corpo-de-prova;

$\mathrm{A}_{\text {interseção }}=$ área das interseções;

$\mathrm{h}=$ altura do corpo-de-prova;

$\mathrm{e}=$ espessura da parede.

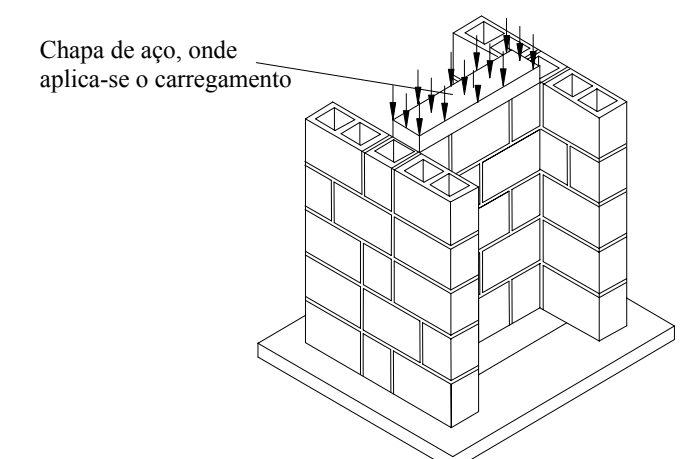

Figura 7.8- Forma de aplicação do carregamento

Em ambas as escalas utilizam-se o forro pacote para o capeamento da face de aplicação do carregamento, sendo que em alguns casos ainda é necessária a utilização adicional de massa plástica para regularizar defeitos localizados. Na região de aplicação da força nos ensaios nas escalas (1:3) e (1:1) emprega-se, respectivamente, uma placa de aço de 2,5 cm e de 3,8 cm de espessura para possibilitar uma distribuição uniforme do carregamento. É realizado o escorvamento prévio do corpo-de-prova, com o intuito de promover a acomodação da estrutura. Para o ensaio ser considerado válido, a ruptura deve ocorrer por cisalhamento das ligações das paredes. Durante o ensaio não há marcação de fissuras, devido ao pequeno espaço físico disponível.

- Equipamentos:

Os ensaios em modelos reduzidos são realizados utilizando-se pórtico de reação e um atuador hidráulico servo-controlado da marca INSTRON, que permite a aplicação do carregamento através de controle de deslocamento do pistão. A velocidade inicial de carregamento é de $0,01 \mathrm{~mm} / \mathrm{s}$. Ao se aproximar de $50 \%$ da força de ruptura prevista, a 
velocidade é reduzida para $0,005 \mathrm{~mm} / \mathrm{s}$, sendo que próximo à ruptura reduz-se novamente para $0,002 \mathrm{~mm} / \mathrm{s}$. Utiliza-se uma baixa velocidade de carregamento para permitir a retirada da força aplicada imediatamente após o momento da ruptura (modo frágil), evitando-se danificar os equipamentos instalados nos exemplares. Os deslocamentos relativos são medidos por transdutores de deslocamentos à base de extensômetros com curso de $10 \mathrm{~mm}$. Para a realização das leituras dos dados é utilizado o sistema de aquisição SYSTEM 5000.

A instrumentação do corpo-de-prova de cisalhamento é idêntica para as três situações estudadas (sem cinta de amarração, com cinta na última fiada e com cinta na fiada intermediária). Na Figura 7.9 visualizam-se o esquema da instrumentação utilizado nos corpos-de-prova na escala reduzida (1:3) em todas as suas faces, bem como as fotos representando a realização do ensaio.
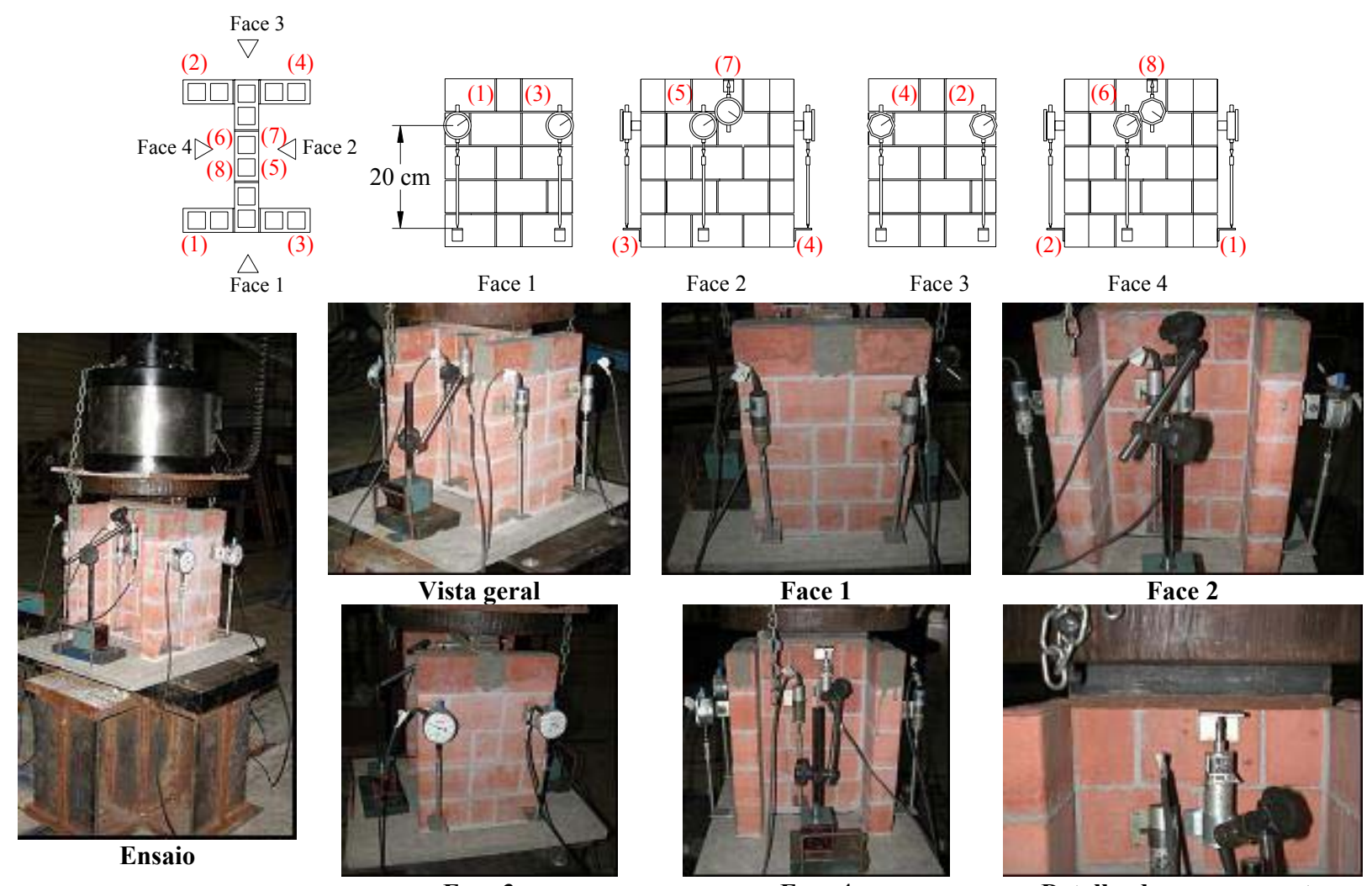

Face 3

Face 4

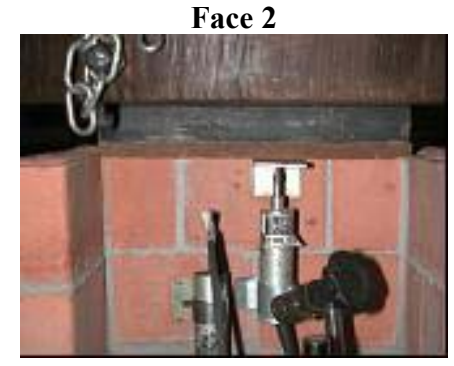

Figura 7.9 - Esquema da instrumentação dos ensaios dos corpos-de-prova na escala (1:3)

Para o ensaio em escala natural (1:1), devido à alta taxa de ocupação dos atuadores servo-controlados, que permitem o ensaio com controle de deslocamentos, fez-se a opção se realizar um ensaio com controle de força. Dessa forma, o ensaio em escala natural é realizado utilizando-se pórticos de reação e um macaco hidráulico comum de $1000 \mathrm{kN}$ de capacidade. Os deslocamentos relativos são medidos por 
transdutores de deslocamentos à base de extensômetros com curso de $10 \mathrm{~mm}$, os mesmos empregados nos ensaios em escala reduzida. Para a realização das leituras dos dados também é utilizado o sistema de aquisição SYSTEM 5000. O carregamento é aplicado a uma taxa de $10 \mathrm{kN}$ por minuto, esperando-se a estabilização das leituras em cada etapa.

O esquema da instrumentação do corpo-de-prova na escala natural (1:1) é homólogo ao dos ensaios em escala reduzida (1:3), visando permitir a comparação dos resultados. A instrumentação utilizada nos corpos-de-prova em todas as suas faces, bem como as fotos ilustrativas da realização do ensaio, estão representadas na Figura 7.10.

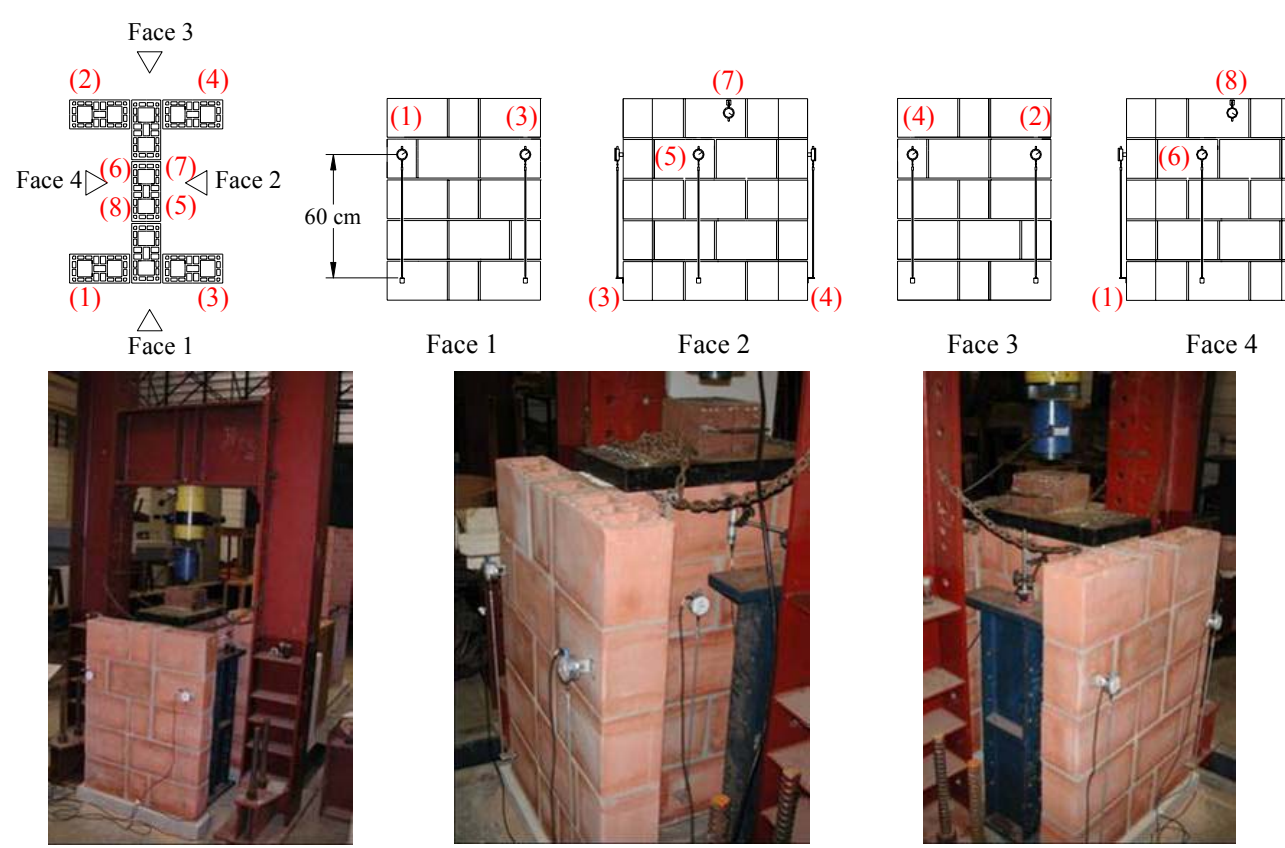

Figura 7.10 - Esquema do ensaio co corpo-de-prova em escala natural (1:1)

\section{4- Resultados dos corpos-de-prova de cisalhamento sem cinta de amarração em} escala reduzida $(1: 3)$ e natural $(1: 1)$

A Tabela 7.1 apresenta os resultados relativos aos ensaios em modelos reduzidos dos cinco corpos-de-prova de cisalhamento sem cinta de amarração (CP-SC): a força de ruptura, a resistência ao cisalhamento $\left(\tau_{\text {vert }}\right)$, a resistência média da argamassa e do prisma de três blocos referente a cada exemplar ensaiado. Para este caso, a resistência média ao cisalhamento da alvenaria em escala reduzida é de 2,35 $\mathrm{MPa}$, um valor relativamente alto quando comparado ao valor de $0,96 \mathrm{MPa}$ obtido por CAMACHO et al (2001) para blocos cerâmicos reduzidos. Nota-se, ainda, que o máximo coeficiente de variação obtido foi em torno de $11 \%$ no caso das resistências dos prismas, sendo um coeficiente aceitável para estruturas de alvenaria. 
Tabela 7.1 - Resultados dos ensaios em escala (1:3) dos corpos-de-prova sem cinta de amarração

\begin{tabular}{|c|c|c|c|c|}
\hline Corpo-de-prova & $\begin{array}{c}\text { Força de } \\
\text { ruptura } \\
(\mathbf{k N})\end{array}$ & $\begin{array}{c}\tau_{\text {vert }}-\text { Resistência ao } \\
\text { cisalhamento (MPa) }\end{array}$ & Argamassa (MPa) & Prisma (MPa) \\
\hline CP-1 SC & $51,06^{*}$ & $1,66^{*}$ & 8,74 & 10,08 \\
\hline CP-2 SC & 69,53 & 2,26 & 8,32 & 8,52 \\
\hline CP-3 SC & 74,33 & 2,42 & 9,17 & 10,06 \\
\hline CP-4 SC & 71,21 & 2,32 & 9,59 & 11,50 \\
\hline CP-5 SC & 74,29 & 2,42 & 9,17 & 10,84 \\
\hline Média & $\mathbf{7 2 , 3 4}$ & $\mathbf{2 , 3 5}$ & $\mathbf{9 , 0 6}$ & $\mathbf{1 0 , 2 0}$ \\
\hline Coef. Var. & $\mathbf{3 , 3 \%}$ & $\mathbf{3 , 3 \%}$ & $\mathbf{5 , 9 \%}$ & $\mathbf{1 0 , 9} \%$ \\
\hline
\end{tabular}

*não considerado no cálculo das médias, visto que houve uma ruptura prematura devida a uma imperfeição no apoio da laje de base.

- Todos valores de resistência são em relação à área bruta

As formas de ruptura nas principais faces de todos os dos corpos-de-prova de cisalhamento sem cinta de amarração (CP - SC) na escala (1:3) estão apresentadas na Figura 7.11. Observa-se, nessa mesma figura, que os tipos de fissuração são similares para todos exemplares: fissuras inclinadas na parede central junto à interseção das paredes, indicando o cisalhamento, e fissuras verticais e horizontais ao longo das juntas de argamassas nos flanges, devido à sua flexão. Pode-se concluir que a ruptura dos corpos-de-prova ocorre pelo cisalhamento da ligação das paredes. Apenas no exemplar CP - 1 SC há a presença de fissuras na laje de apoio, ocorridas devido à falha no esquema de apoio, proporcionando uma flexão não desejada.

Para realizar uma melhor análise do comportamento dos corpos-de-prova durante a aplicação do carregamento, constroem-se diferentes gráficos mostrados na Figura 7.12. O comportamento da parede central está ilustrado na Figura 7.12-a, considerando as médias das leituras realizadas pelos transdutores de deslocamentos dispostos na mesma. Neste caso, as deformações são negativas (encurtamentos) ao longo de todo o ensaio, visto que é a região onde o carregamento é diretamente aplicado. A única exceção é o CP - 1 SC, sendo mais uma evidência para se descartar esse corpo de prova.

O carregamento aplicado é naturalmente excêntrico em relação aos flanges. Dessa maneira, apesar das deformações iniciais serem de encurtamento, a flexão passa a ser predominante, explicando a ocorrência dos alongamentos registrados (Figura 7.12b). Acredita-se que a maior parcela referente aos alongamentos é devida à abertura das fissuras nas juntas horizontais de assentamento. 

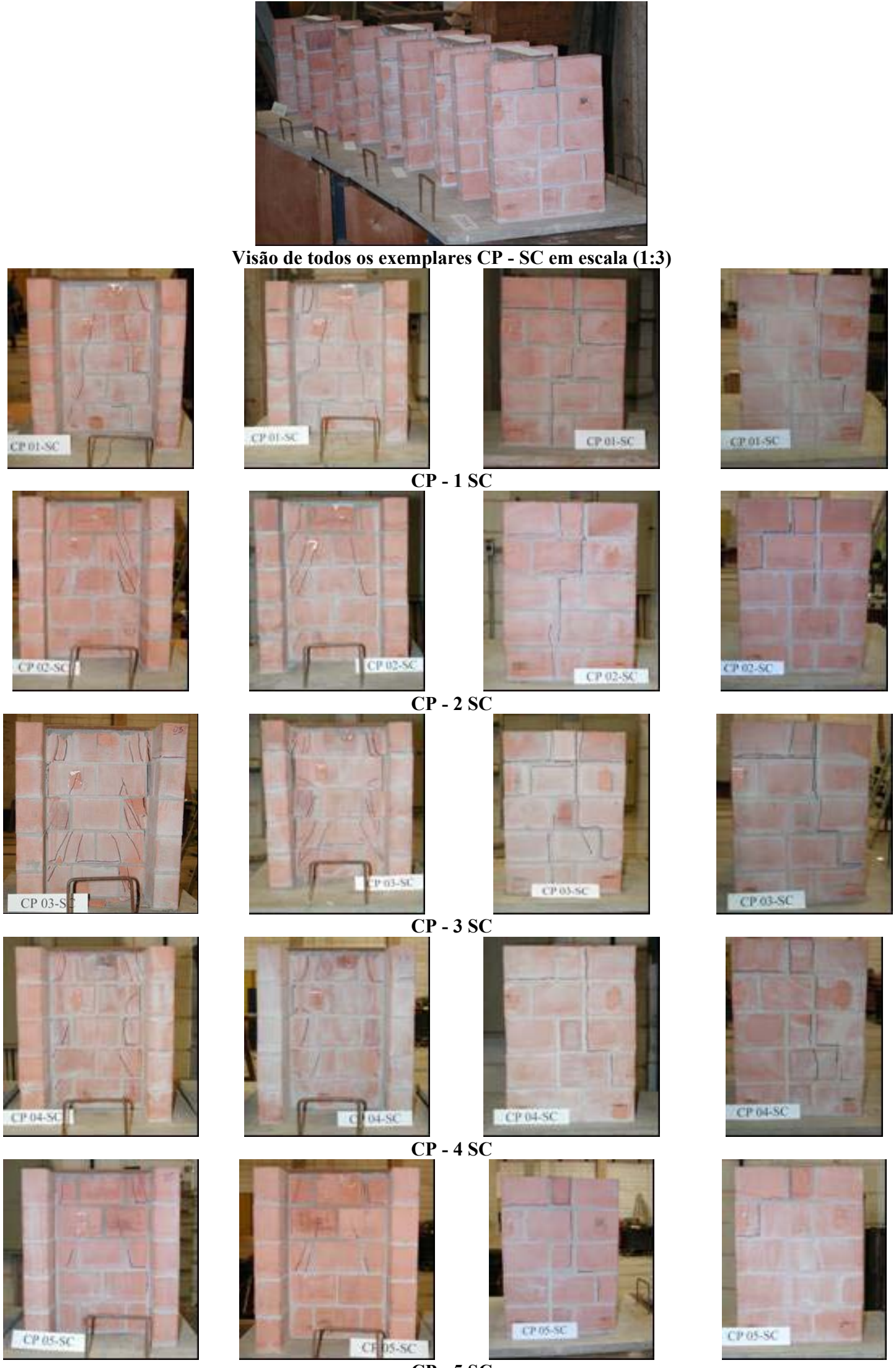

Figura 7.11- Forma de ruptura dos corpos-de-prova de cisalhamento sem cinta de amarração em escala reduzida (1:3) 


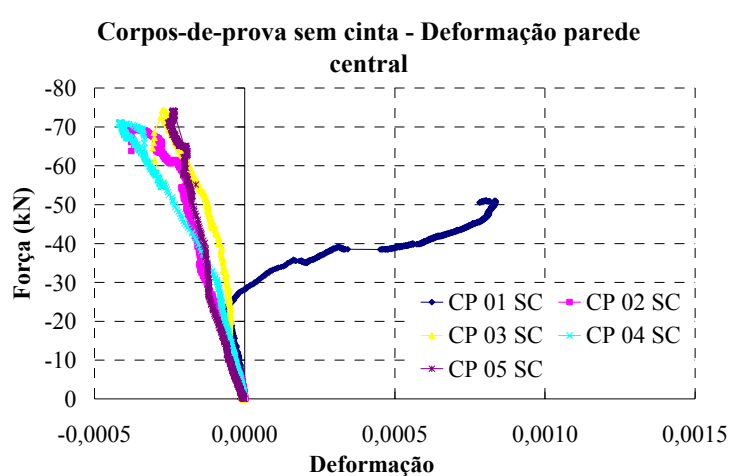

(a)

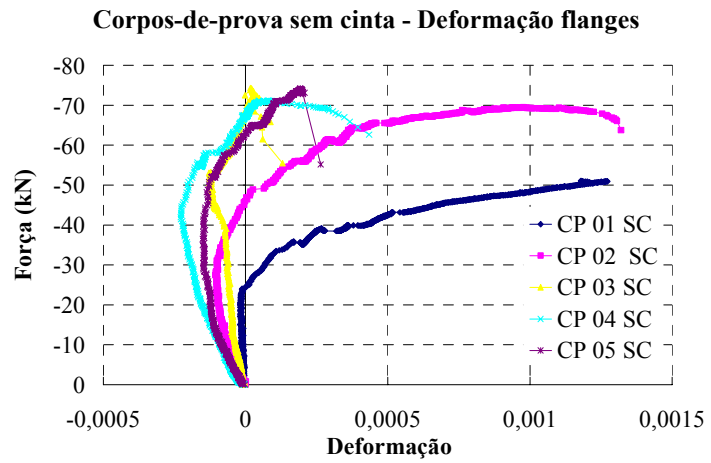

(b)

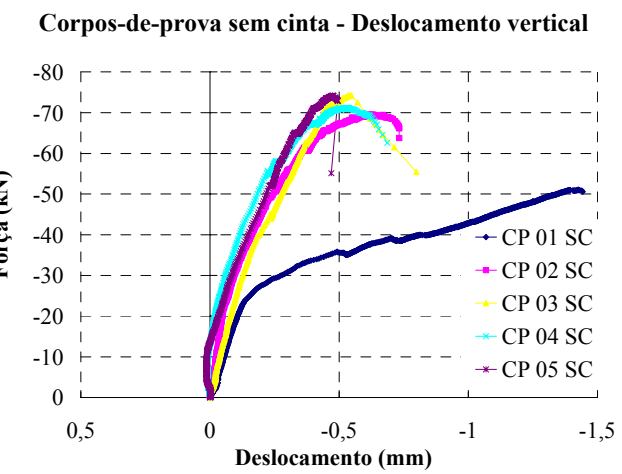

(c)

Figura 7.12 - Comportamento dos corpos-de-prova sem cinta de amarração em escala reduzida

O deslocamento vertical do topo da parede central (Figura 7.12-c) apresenta um comportamento muito próximo para a maioria dos exemplares. Verifica-se uma certa tendência linear na fase inicial do ensaio e não se observa nenhuma variação brusca até o colapso. Novamente, o CP- 1 SC é o único discrepante dos demais.

A Tabela 7.2 apresenta os resultados relacionados ao ensaio do corpo-de-prova de cisalhamento sem cinta de amarração na escala natural: a força de ruptura, a resistência ao cisalhamento $\left(\tau_{\text {vert }}\right)$, a resistência média da argamassa e do concreto da base. Observa-se que o valor obtido para a resistência ao cisalhamento na escala natural $(1,21 \mathrm{MPa})$ é inferior ao obtido para os corpos-de-prova em escala reduzida (2,35MPa). Uma comparação mais detalhada será realizada a seguir. Verifica-se, também, que a resistência obtida se aproxima ao valor de 0,90 MPa encontrado por Silva (2003) em ensaios em escala natural de bloco cerâmico.

A forma de ruptura do exemplar em escala (1:1) está ilustrada na Figura 7.13. Observam-se fissuras inclinadas ao longo da altura da parede central, próximas à interseção das paredes, que indicam o cisalhamento vertical. No instante da ruptura ocorre a separação de um dos flanges. Percebe-se, também, que na escala natural as fissuras nos flanges são de pequena abertura e visíveis apenas no flange em que se dá a separação. 
Tabela 7.2- Resultado dos ensaios referentes ao corpo-de-prova sem cinta de amarração em escala natural (1:1)

\begin{tabular}{|c|c|c|c|c|}
\hline $\begin{array}{c}\text { Força de } \\
\text { ruptura } \\
(\mathbf{k N})\end{array}$ & $\begin{array}{c}\tau_{\text {vert }}-\text { Resistência } \\
\text { ao cisalhamento (MPa) }\end{array}$ & $\begin{array}{c}\text { Argamassa } \\
\mathbf{( M P a )}\end{array}$ & $\begin{array}{c}\text { Prisma } \\
\mathbf{( M P a )}\end{array}$ & $\begin{array}{c}\text { Concreto da } \\
\text { base (MPa) }\end{array}$ \\
\hline 334 & 1,21 & 9,94 & 5,47 & 27,94 \\
\hline
\end{tabular}
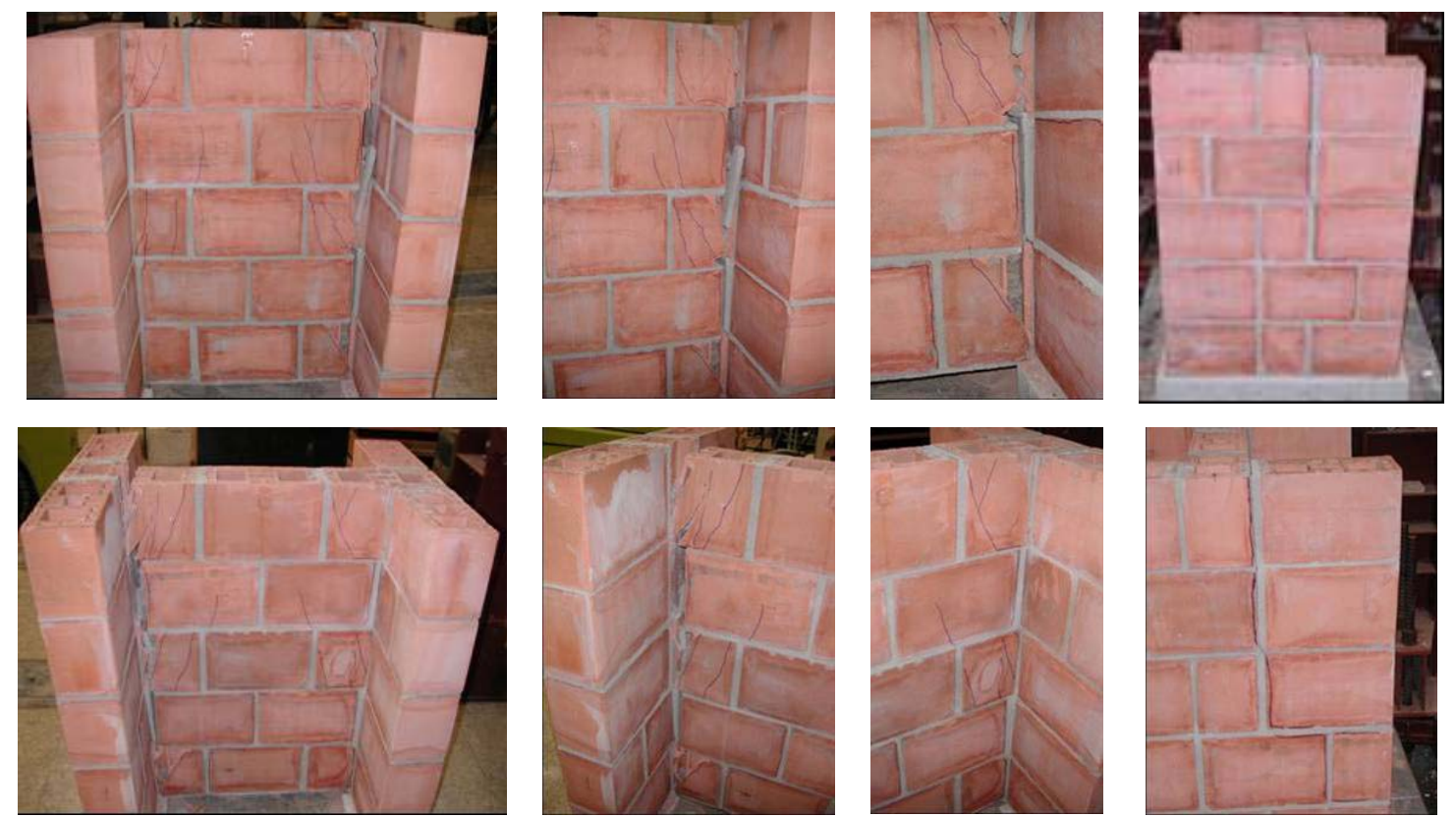

Figura 7.13 - Forma de ruptura do corpo de prova de cisalhamento em escala natural

O comportamento do corpo-de-prova na escala natural pode ser visualizado na Figura 7.14, onde são apresentadas as deformações médias na parede central e nos flanges, bem como o deslocamento médio do topo da parede central. Ressalta-se que para se garantir a integridade dos transdutores de deslocamentos no caso de uma ruptura frágil, os mesmos foram retirados quando a força aplicada atingiu $250 \mathrm{kN}$.

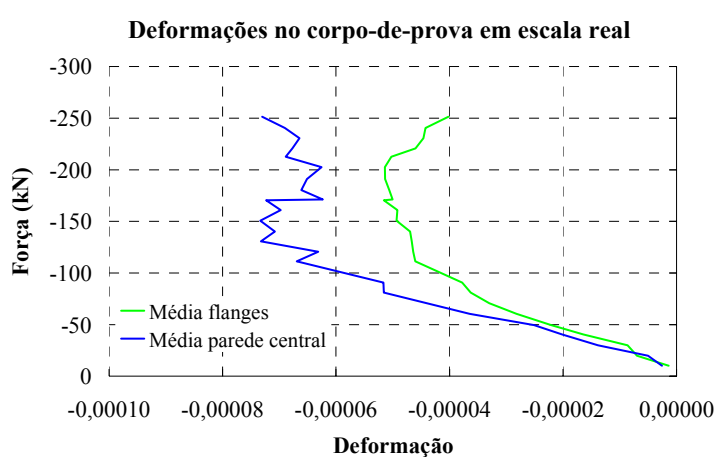

(a)

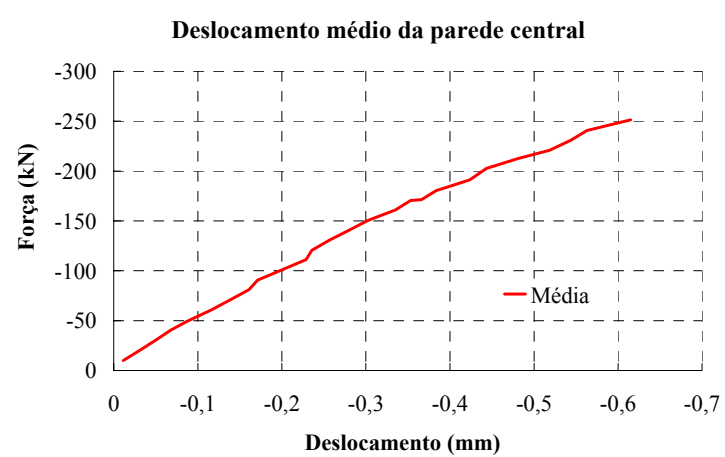

(b)

Figura 7.14 - Comportamento do corpo-de-prova na escala (1:1) sem cinta de amarração 
Nota-se na Figura 7.14-a que as deformações tanto da parede central quanto dos flanges são de encurtamento. Contudo, percebe-se que nos flanges há uma tendência de reversão do encurtamento para uma força superior a $200 \mathrm{kN}$. Até o momento da retirada dos transdutores de deslocamento não se observava a ocorrência de fissuras nos flanges. Em relação aos deslocamentos do topo da parede central (Figura 7.14-b) pode-se verificar o comportamento praticamente linear até a retirada dos equipamentos.

$\mathrm{Na}$ Tabela 7.3, ao se comparar a resistência ao cisalhamento dos corpos-deprova sem cinta de amarração nas escalas natural (1:1) e reduzida (1:3) percebe-se que a relação obtida é muito próxima do valor do fator de escala $\left(\mathrm{s}_{\sigma}\right)$ para a resistência à compressão (vide capítulo 5). Essa proximidade de valores pode ser explicada devido à resistência à tração do material ser o fator limitante tanto da resistência à compressão quanto da resistência ao cisalhamento da alvenaria. Em ambos os casos, a ruptura está ligada ao surgimento das fissuras, que por sua vez são naturalmente dependentes da resistência à tração do material.

Tabela 7.3 - Comparação dos corpos-de-prova sem cinta de amarração nas escalas natural (1:1) e reduzida (1:3)

\begin{tabular}{|c|c|c|c|}
\hline $\begin{array}{c}\text { Corpo-de- } \\
\text { prova }\end{array}$ & $\begin{array}{c}\tau_{\text {vert }} \text { - Resistência } \\
\text { ao cisalhamento (MPa) }\end{array}$ & $\frac{\tau_{\text {vert }}(1: 1)}{\tau_{\text {vert }}(1: 3)}$ & $\begin{array}{c}\mathrm{s}_{\sigma} \text { - Fator de escala para } \\
\text { a resistência à } \\
\text { compressão }\end{array}$ \\
\cline { 1 - 2 } Escala $(1: 1)$ & 1,21 & 0,51 & 0,48 \\
\hline Escala $(1: 3)$ & 2,35 & 0,45 \\
\hline
\end{tabular}

A forma de ruptura para as duas escalas é semelhante quanto à fissuração da parede central,apresentando fissuras inclinadas ao longo da altura e próximas à interseção (Figura 7.15). Nos flanges também há uma similaridade; as fissuras ocorrem nas juntas de argamassa vertical e horizontal, contudo as aberturas de fissuras na escala reduzida são superiores às verificadas no modelo em escala natural. Acredita-se que essa diferença de abertura esteja relacionada ao fato da razão entre a resistência de aderência e de compressão do bloco em escala reduzida (1:3) ser superior a do bloco em escala natural (1:1), conforme comentado no capítulo 5 .

Para a comparação do comportamento dos corpos-de-prova em escala natural (1:1) e reduzida (1:3) emprega-se a teoria de modelos físicos reduzidos. Assim, os valores obtidos nos modelos reduzidos serão multiplicados por fatores de escala. Para as deformações e tensões utilizam-se os valores obtidos nos ensaios de caracterização de compressão normal à junta de assentamento, $\mathrm{s}_{\varepsilon}=0,59$ e $\mathrm{s}_{\sigma}=0,48$ respectivamente. São 
adotados esses últimos valores por dois motivos: primeiro porque o carregamento aplicado é de compressão normal à junta de assentamento; segundo porque a relação entre as tensões de cisalhamento na escala natural e reduzida é próxima ao fator de escala de tensão $\left(\mathrm{s}_{\sigma}\right)$ obtido nos ensaios de caracterização. No caso de medidas relacionadas ao deslocamento, o fator de escala $\left(\mathrm{s}_{\text {desl }}\right)$ é obtido, conforme apresentado no capítulo 3, por $\mathrm{s}_{\text {desl }}=\mathrm{s}_{\varepsilon} \cdot \mathrm{s}_{\mathrm{L}}=1,77$. Já o fator de escala para força $\left(\mathrm{s}_{\mathrm{F}}\right)$ é dado pela relação $\mathrm{s}_{\mathrm{F}}=\mathrm{s}_{\sigma} \cdot \mathrm{s}_{\mathrm{L}}^{2}$, que é igual a 4,32 .
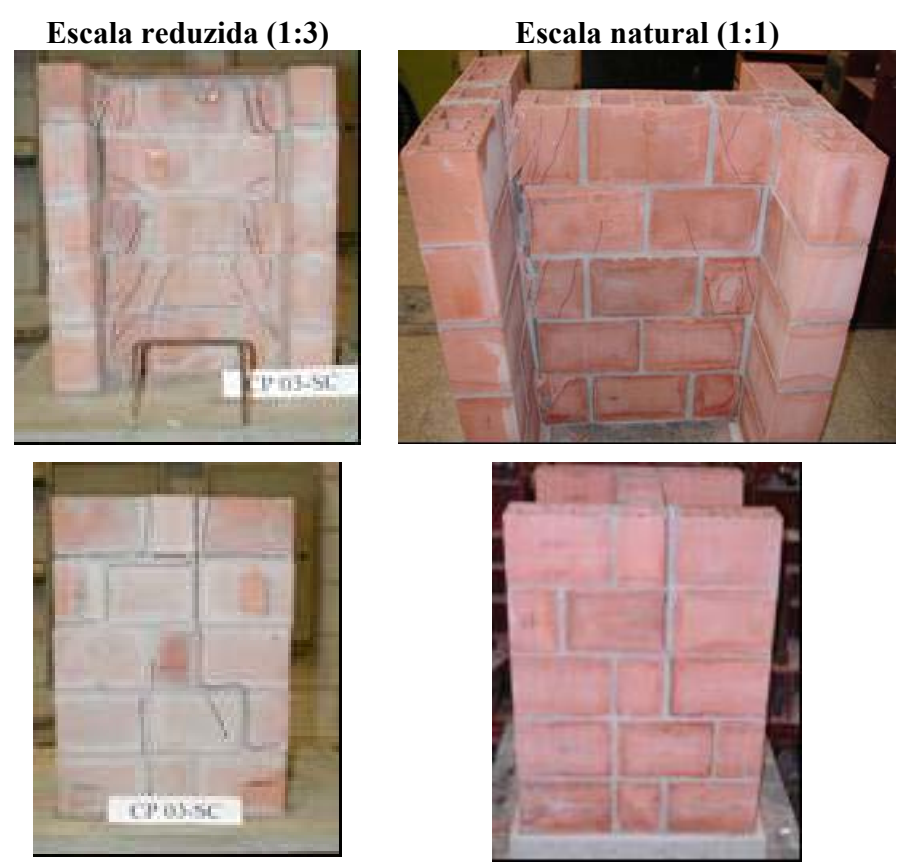

\section{Figura 7.15 - Comparação entre as formas de ruptura para as diferentes escalas}

Na Figura 7.16, empregando-se as técnicas de modelos reduzidos, são ilustrados em conjunto os comportamentos dos corpos-de-prova em escala reduzida, com exceção do CP - 01 SC, e o exemplar em escala natural. Lembra-se que no caso do corpo-deprova na escala $(1: 1)$ os transdutores de deslocamentos são retirados antes da ruptura, portanto não se dispõe de resultados correspondentes à parte final do ensaio. Contudo, na figura percebe-se que os modelos reduzidos fornecem uma ótima representação do comportamento do corpo-de-prova de cisalhamento em escala natural, tanto para as deformações dos flanges e da parede central quanto do deslocamento vertical do topo da parede central.

Dessa forma, comprova-se que os modelos de alvenaria estrutural em escala reduzida são aptos para representar a resistência e o comportamento da alvenaria em escala natural submetida ao cisalhamento vertical. 


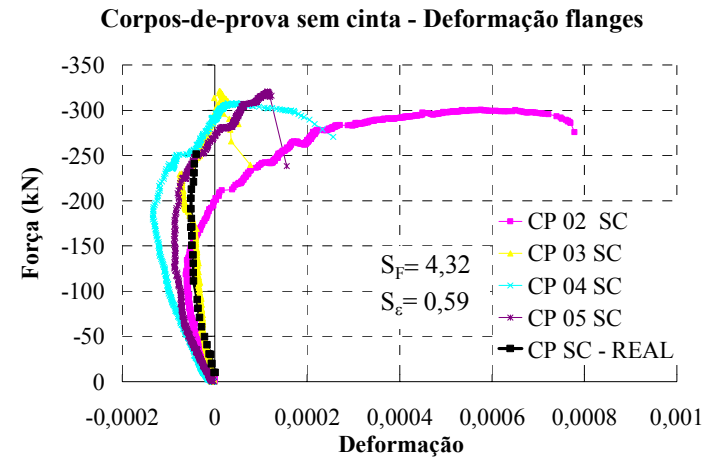

(a)

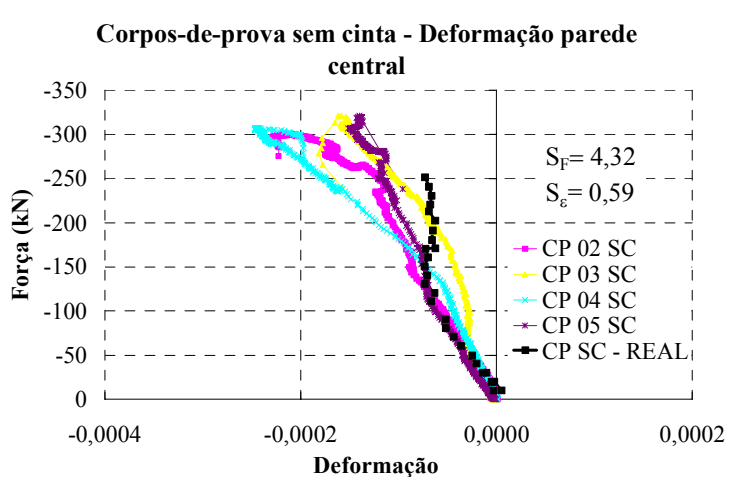

(b)

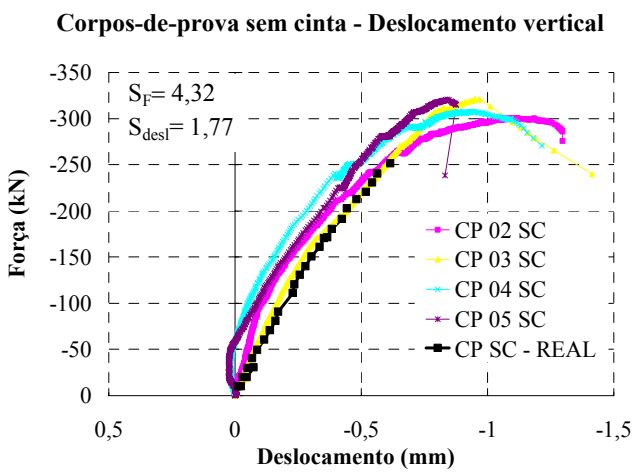

(c)

Figura 7.16 - Comparação do comportamento dos corpos-de-prova nas escalas natural e reduzida

\section{5- Resultados dos corpos-de-prova de cisalhamento com cinta de amarração no topo do exemplar em escala reduzida (1:3)}

Os resultados relativos aos ensaios em escala reduzida (1:3) dos cinco corposde-prova de cisalhamento com cinta de amarração no topo (CP - CT) estão apresentados na Tabela 7.4. A princípio, seria de se imaginar que haveria um ganho razoável em relação à resistência ao cisalhamento, devido à presença da cinta de amarração. Contudo, observa-se uma resistência média de 2,76 $\mathrm{MPa}$, cerca de $17 \%$ superior ao corpo-de-prova sem cinta de amarração. Observa-se que apesar da argamassa possuir uma resistência muito próxima aos dos corpos-de-prova sem cinta de amarração, a resistência dos prismas de três blocos é cerca de 15\% inferior, indicando uma certa variabilidade da resistência dos blocos utilizados. Novamente o máximo coeficiente de variação obtido foi em torno de $11 \%$ no caso das resistências dos prismas, aceitável para estruturas de alvenaria. Como idealizado inicialmente, a resistência à compressão do bloco canaleta preenchido com graute é superior à resistência do bloco inteiro, sendo realmente um elemento de reforço na estrutura. 
Tabela 7.4 - Resultados dos ensaios em escala reduzida (1:3) dos corpos-de-prova com cinta de amarração no topo

\begin{tabular}{|c|c|c|c|c|c|c|}
\hline $\begin{array}{c}\text { Corpo- } \\
\text { de-prova }\end{array}$ & $\begin{array}{c}\text { Força de } \\
\text { ruptura } \\
(\mathbf{k N})\end{array}$ & $\begin{array}{c}\tau_{\text {vert }}-\text { Resistência } \\
\text { ao cisalhamento }(\mathbf{M P a})\end{array}$ & $\begin{array}{c}\text { Argamassa } \\
\mathbf{( M P a )}\end{array}$ & $\begin{array}{c}\text { Prisma } \\
\mathbf{( M P a )}\end{array}$ & $\begin{array}{c}\text { Graute } \\
(\mathbf{M P a})\end{array}$ & $\begin{array}{c}\text { Canaletas } \\
(\mathbf{M P a})\end{array}$ \\
\hline CP-6 CT & 85,34 & 2,78 & 10,91 & 10,58 & 62,07 & 39,47 \\
\hline CP-7 CT & 94,04 & 3,06 & 8,11 & 8,42 & 55,03 & 45,96 \\
\hline CP-8 CT & 90,11 & 2,93 & 9,04 & 8,51 & 55,03 & 45,96 \\
\hline CP-13 CT & 78,85 & 2,57 & 9,85 & 8,40 & 55,03 & 45,96 \\
\hline CP-14 CT & 75,8 & 2,47 & 9,46 & 7,97 & 55,12 & 38,11 \\
\hline Média & $\mathbf{8 4 , 8 3}$ & $\mathbf{2 , 7 6}$ & $\mathbf{9 , 1 1}$ & $\mathbf{8 , 7 8}$ & $\mathbf{5 6 , 4 6}$ & $\mathbf{4 3 , 0 9}$ \\
\hline Coef. Var. & $\mathbf{8 , 9 \%}$ & $\mathbf{8 , 9 \%}$ & $\mathbf{8 , 2 \%}$ & $\mathbf{1 1 , 7 \%}$ & $\mathbf{5 , 6 \%}$ & $\mathbf{9 , 2 \%}$ \\
\hline - Todos valores de resistência são em relação à área bruta \\
\hline
\end{tabular}

A Figura 7.17 ilustra as rupturas dos corpos-de-prova com cinta de amarração no topo (CP - CT) em escala reduzida (1:3). Na parede central as fissuras predominantes são as diagonais, ocorridas pelo cisalhamento da interseção das paredes em todas as cinco fiadas. Portanto, admite-se, mais uma vez, que a ruptura do corpo-deprova é devida ao cisalhamento no plano vertical. Já nos flanges, as fissuras são em sua grande maioria verticais, passando não só pelas juntas de argamassa, mas também pelos próprios blocos. Nota-se, que há uma tendência das fissuras se concentrarem em um determinado lado do exemplar, apesar de todos os cuidados na centralização do carregamento.

A Figura 7.18-a ilustra o comportamento da deformação da parede central dos corpos-de-prova com cinta na fiada de topo. Em todos os casos ocorrem apenas encurtamentos, o que já era de se esperar, pois é nessa região que a compressão é aplicada. Para este caso, a maioria dos exemplares em modelos reduzidos apresenta curvas semelhantes até os $40 \mathrm{kN}$.

Os flanges (Figura 7.18-b) apresentam dois comportamentos distintos, um em que os encurtamentos são mais significativas (CP- 6 CT e CP- 13 CT) e outro em que os encurtamentos são de pequena magnitude, ocorrendo alongamentos significativos (demais exemplares). Todavia, não há diferenças no padrão de fissuração dos flanges que expliquem tal desigualdade.

O deslocamento do topo da parede central, para os diferentes exemplares, está ilustrado na Figura 7.18-c. Há uma certa semelhança entre as curvas para todos os corpos-de-prova. Novamente, não há grandes perturbações ao longo do ensaio. 

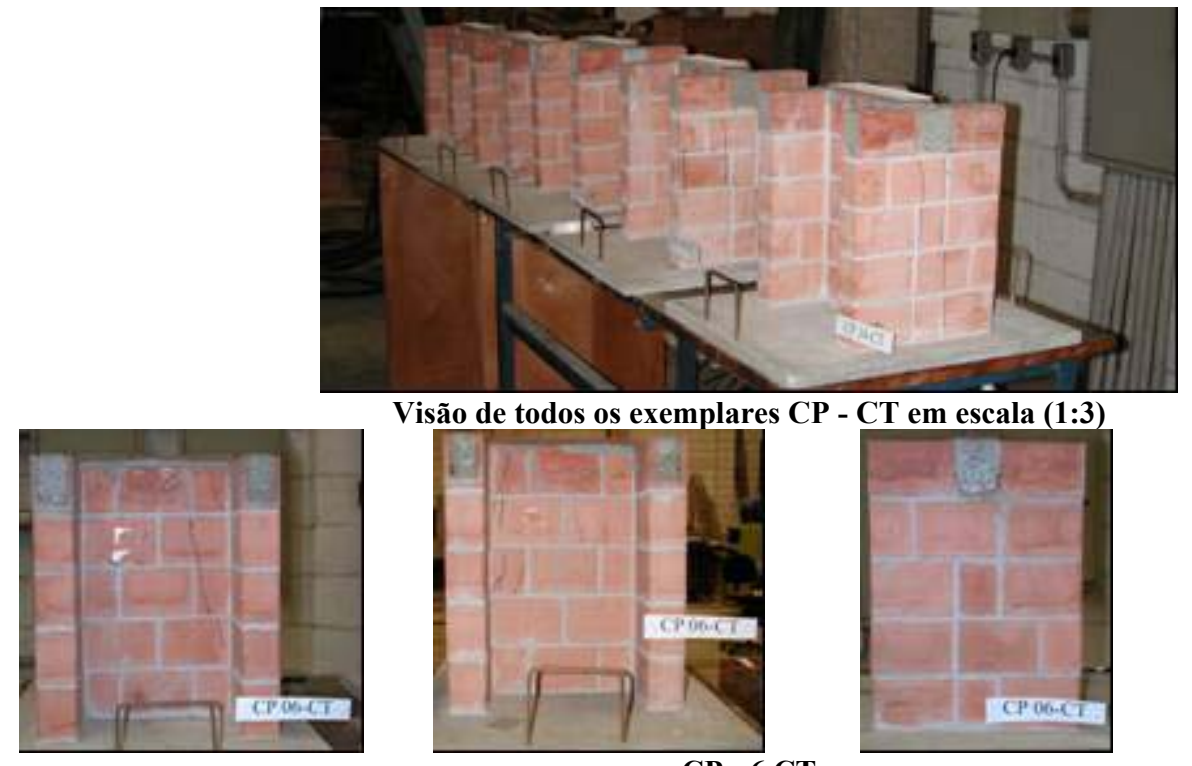

Visão de todos os exemplares CP - CT em escala (1:3)
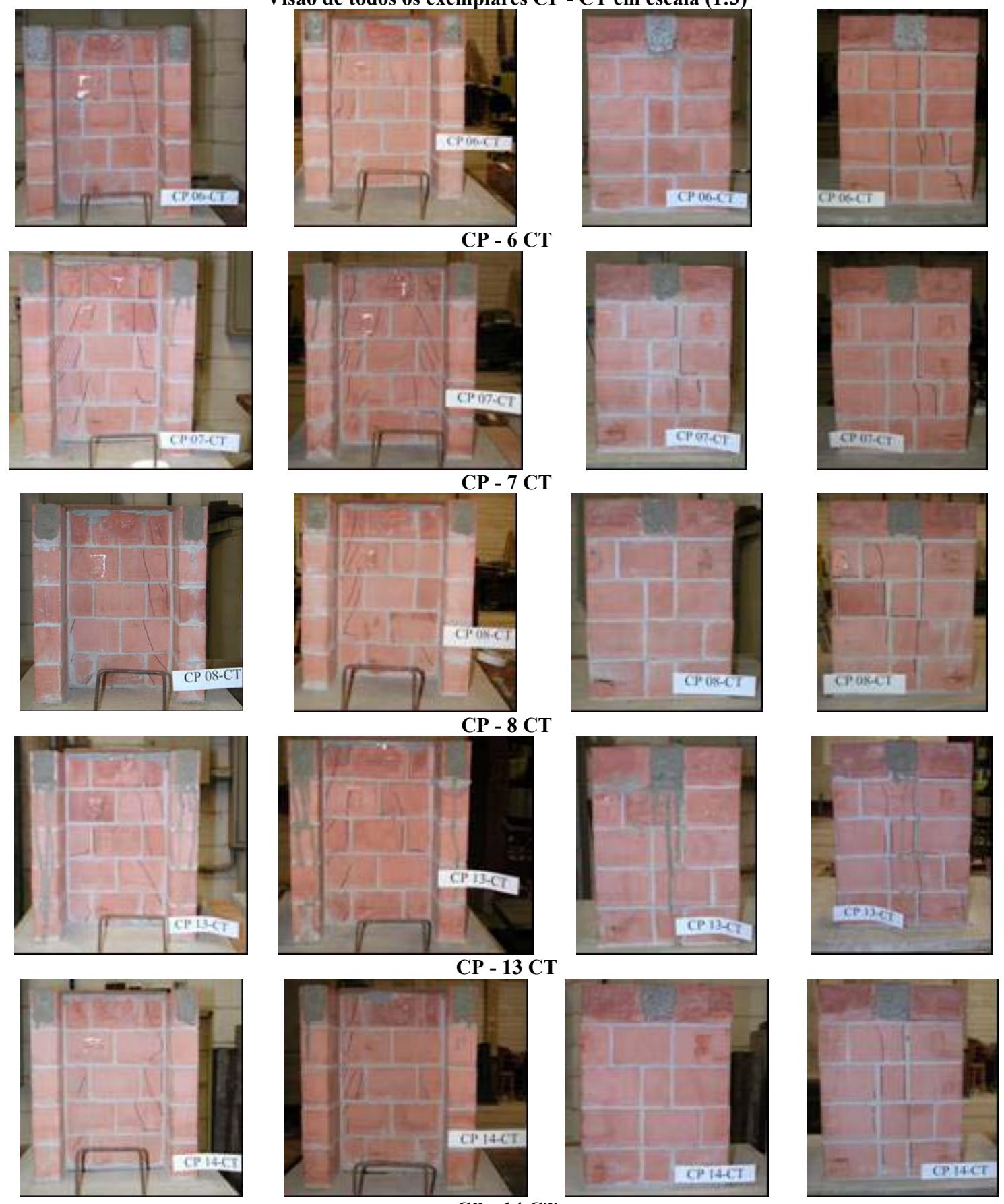

CP - 14 CT
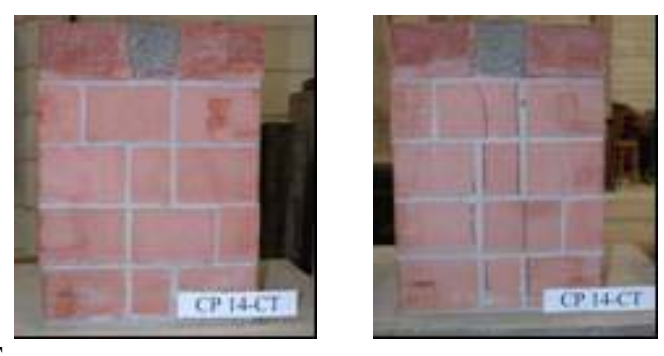

Figura 7.17 - Forma de ruptura dos corpos-de-prova de cisalhamento com cinta de amarração no topo 


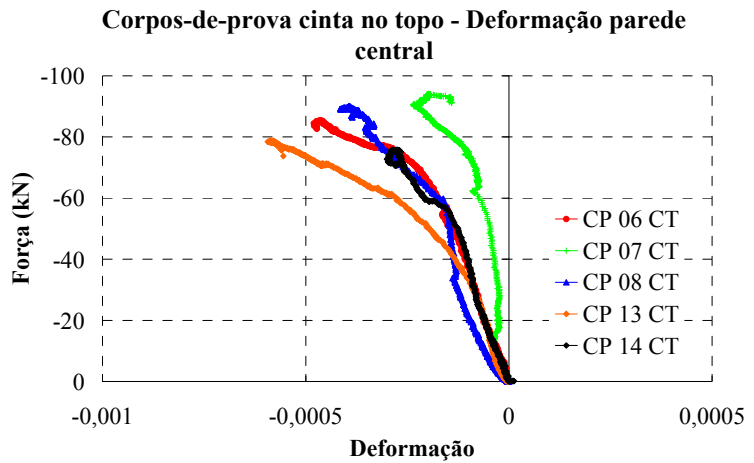

(a)

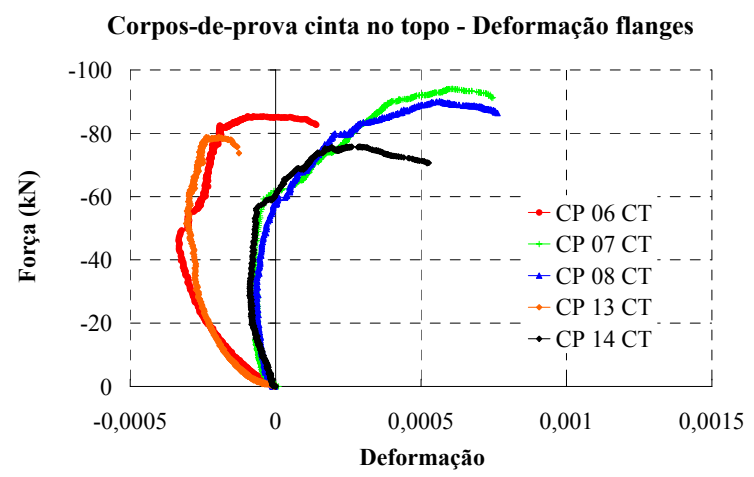

(b)

Corpos-de-prova cinta no topo - Deslocamento vertical

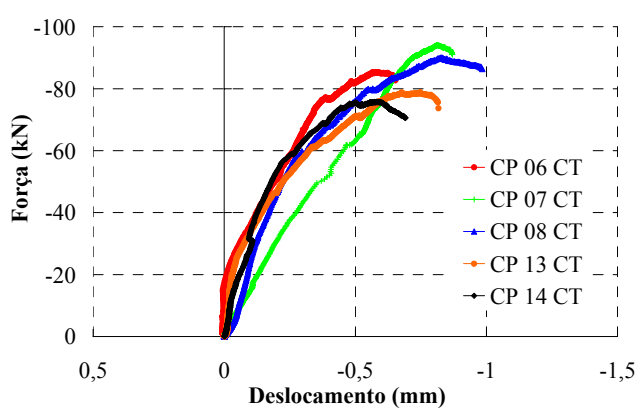

(c)

Figura 7.18 - Comportamento dos corpos-de-prova com cinta de amarração no topo em escala reduzida $(1: 3)$

\section{6- Resultados dos corpos-de-prova de cisalhamento com cinta de amarração na}

\section{fiada intermediária do exemplar em escala reduzida (1:3)}

Os resultados referentes aos corpos-de-prova em escala reduzida (1:3) com cinta de amarração na fiada intermediária(CP - CI) estão apresentados na Tabela 7.5. Ressalta-se que como são necessárias duas produções de argamassas por exemplar, são indicados separadamente os resultados das resistências das argamassas e dos respectivos prismas. Neste caso, o coeficiente de variação máximo, cerca de $15 \%$, é maior do que os observados nos ensaios anteriores (11\%). Todavia, ainda é uma variação aceitável para o estudo de estruturas de alvenaria. A resistência ao cisalhamento obtida, 2,65 MPa, é cerca de 13\% superior aos corpos-de-prova sem cinta de amarração e apenas 4\% inferior aos exemplares com cinta no topo. Apesar da resistência do graute ser ligeiramente superior à obtida para os CP - CT, os blocos canaletas preenchidos apresentam uma resistência à compressão $10 \%$ inferior aos referentes blocos dos CP CT, indicando a variabilidade da resistência do bloco canaleta.

As rupturas dos corpos-de-prova em escala (1:3) com cinta na fiada intermediária (CP -CI) estão ilustradas na Figura 7.19. De uma maneira geral, a forma de ruptura é semelhante para todos os exemplares. O padrão de fissuração na parede central continua o mesmo dos corpos-de-prova anteriores. Já nos flanges, há uma certa 
modificação no padrão de fissuração, visto que as fissuras verticais e horizontais nas juntas de argamassa se concentram apenas na fiada de topo.

Tabela 7.5 - Resultados dos ensaios dos corpos-de-prova com cinta intermediária em escala reduzida (1:3)

\begin{tabular}{|c|c|c|c|c|c|c|}
\hline $\begin{array}{l}\text { Corpo- } \\
\text { de-prova }\end{array}$ & $\begin{array}{c}\text { Força de } \\
\text { ruptura } \\
(\mathbf{k N})\end{array}$ & $\begin{array}{c}\tau_{\text {vert }}-\text { Resistência } \\
\text { ao cisalhamento (MPa) }\end{array}$ & $\begin{array}{c}\text { Argamassa }^{1)} \\
\text { (MPa) }\end{array}$ & $\begin{array}{c}\text { Prisma }^{1)} \\
\text { (MPa) }\end{array}$ & $\begin{array}{l}\text { Graute } \\
\text { (MPa) }\end{array}$ & $\begin{array}{c}\text { Canaleta } \\
\text { (MPa) }\end{array}$ \\
\hline CP-9 CI & 90,13 & 2,93 & $\begin{array}{l}9,23 \\
7,86\end{array}$ & $\begin{array}{l}9,32 \\
8,80\end{array}$ & 55,12 & 38,11 \\
\hline CP-10 CI & 85,23 & 2,77 & $\begin{array}{l}7,13 \\
7,19\end{array}$ & $\begin{array}{l}8,88 \\
7,95\end{array}$ & 62,07 & 39,47 \\
\hline CP-11 CI & 66,77 & 2,17 & $\begin{array}{l}7,13 \\
7,64\end{array}$ & $\begin{array}{l}8,88 \\
9,26\end{array}$ & 55,12 & 38,11 \\
\hline CP-12 CI & 72,75 & 2,37 & $\begin{array}{l}5,92 \\
7,19\end{array}$ & $\begin{array}{l}8,72 \\
7,95\end{array}$ & 62,07 & 39,47 \\
\hline CP-15 CI & 92,83 & 3,02 & $\begin{array}{l}8,79 \\
7,86\end{array}$ & $\begin{array}{l}7,65 \\
8,80\end{array}$ & 62,07 & 39,47 \\
\hline Média & 81,54 & 2,65 & 7,68 & 8,65 & 59,29 & 38,93 \\
\hline Coef. Var. & $13,9 \%$ & $13,9 \%$ & $14,4 \%$ & $7,3 \%$ & $6,4 \%$ & $1,9 \%$ \\
\hline
\end{tabular}

As deformações médias nas paredes centrais dos corpos-de-prova com cinta na fiada intermediária são apresentadas na Figura 7.20-a. Observa-se para todos os exemplares um comportamento típico, com um trecho inicial de tendência linear seguido de um patamar quase horizontal, onde um pequeno acréscimo de força leva a um grande aumento na deformação.

A Figura 7.20-b mostra as curvas das deformações médias dos flanges dos corpos-de-prova com a presença da cinta intermediária. Ao contrário dos casos anteriores, na maioria dos exemplares não há o aparecimento nem mesmo de uma tendência de alongamento. Todavia, isso pode ser explicado pelo tipo de fissuração que ocorre nos flanges. Nestes exemplares a fissuração se dá na fiada de topo (ver Figura 7.19), portanto acima da região instrumentada.

Observa-se na Figura 7.20-c que, na maioria dos exemplares, o deslocamento vertical do topo da parede central tem uma tendência linear até os $50 \mathrm{kN}$. Apenas o $\mathrm{CP}$ $11 \mathrm{CI}$ apresenta um comportamento diferente. Contudo acredita-se que isso se deva a um problema localizado na fiada de topo, pois nas análises das deformações não se nota nenhuma discrepância. Como nos casos anteriores, não se percebe nenhuma perturbação significativa. 


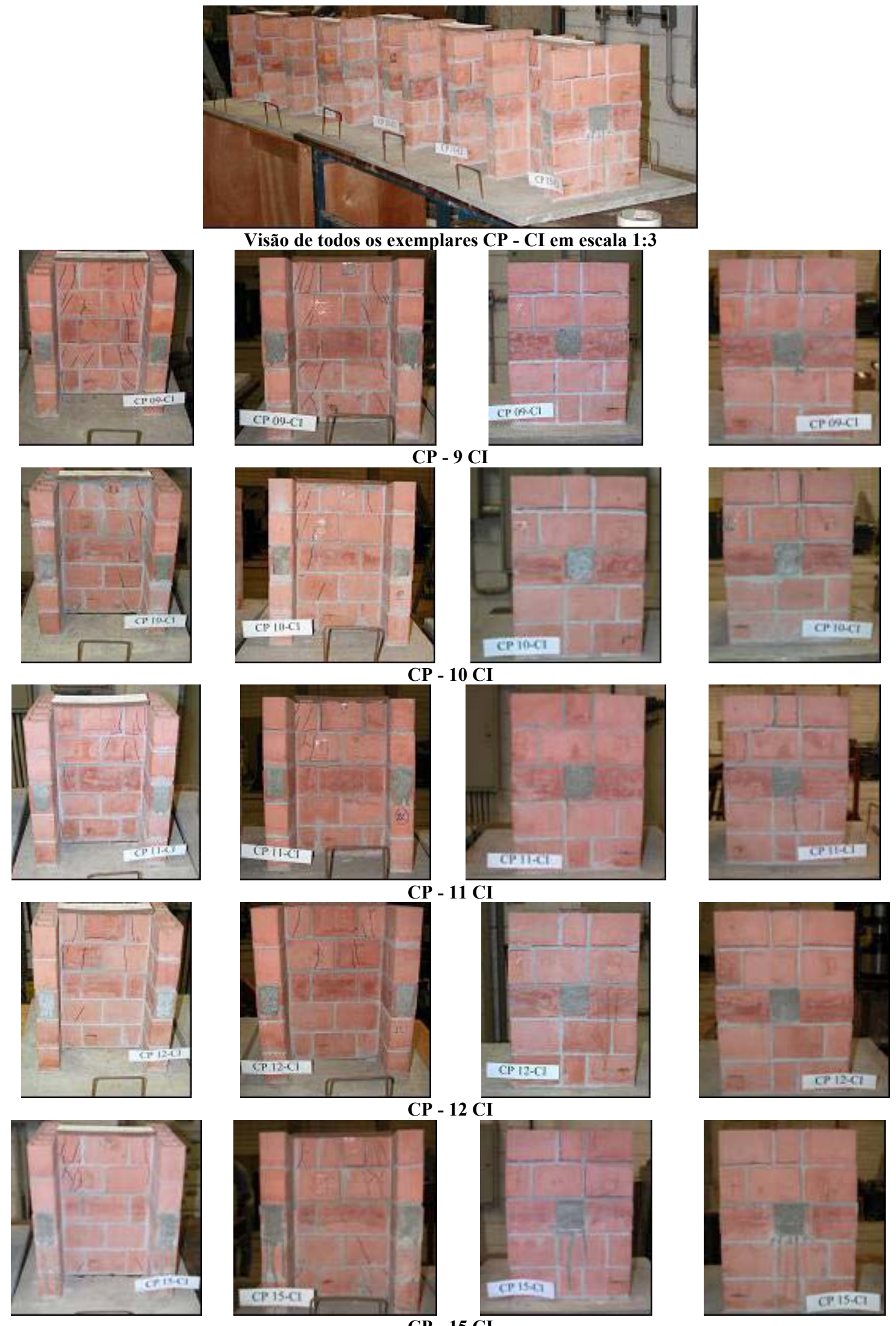

Figura 7.19 - Forma de ruptura dos corpos-de-prova de cisalhamento com cinta de amarração na fiada intermediária em escala reduzida (1:3) 


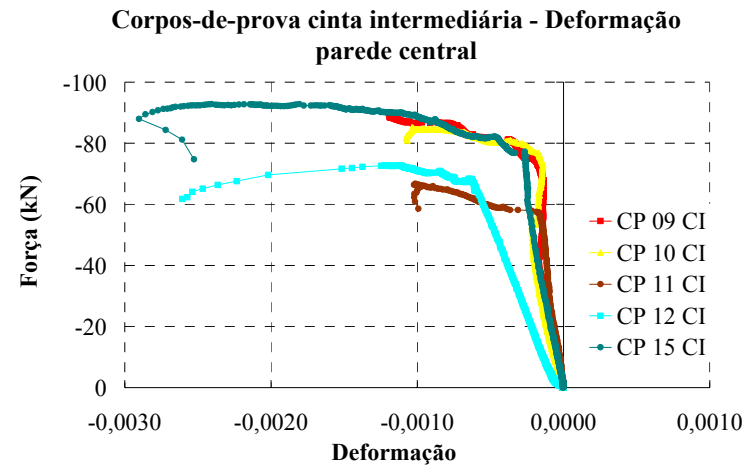

(a)

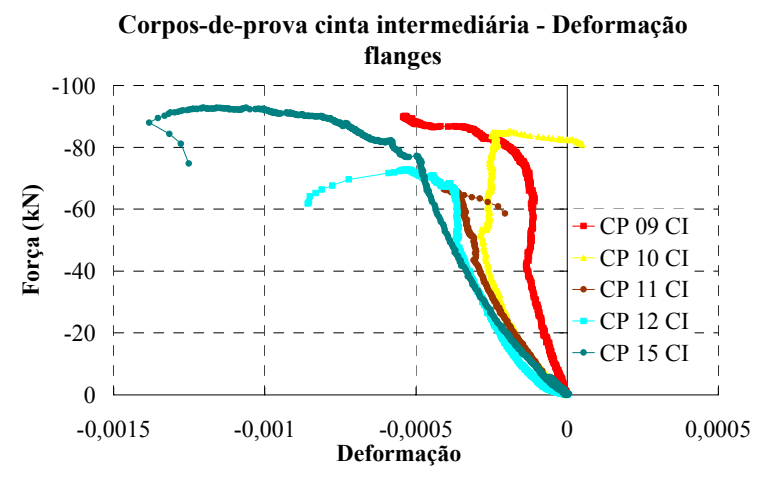

(b)

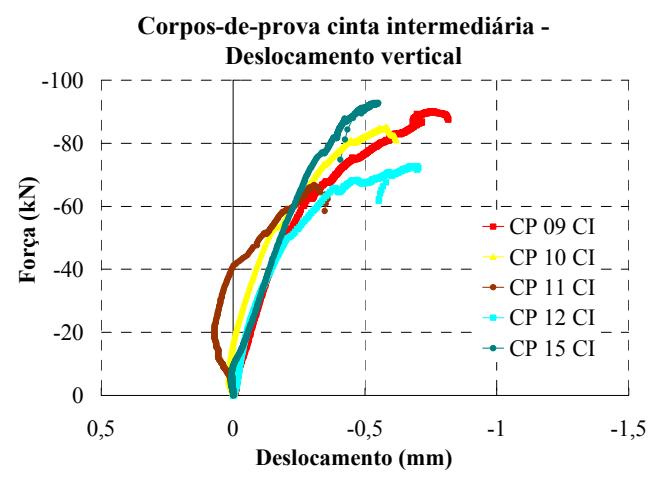

(c)

Figura 7.20 - Comportamento dos corpos-de-prova com cinta intermediária em escala reduzida

\section{7- Comparação dos resultados dos diferentes corpos-de-prova em escala} reduzida

Comparando-se as resistências ao cisalhamento dos diferentes corpos-de-prova em escala reduzida (Tabela 7.6), percebe-se que o ganho de resistência devido à presença da cinta de amarração é inferior a 20\%. Acredita-se que o principal efeito da cinta-de-amarração é propiciar uma transferência de forças mais uniforme, pois a resistência ao cisalhamento da alvenaria está limitada pela resistência ao cisalhamento dos blocos. Não basta que a cinta de amarração resista a uma maior tensão de cisalhamento, pois os blocos logo abaixo da cinta não irão suportar esse acréscimo de tensão.

Tabela 7.6 - Comparação das resistências ao cisalhamento para os diferentes corpos-de-prova em escala reduzida (1:3)

\begin{tabular}{|c|c|c|}
\hline Corpo-de-prova & $\begin{array}{c}\tau_{\text {vert }}-\text { Resistência } \\
\text { ao cisalhamento } \\
\text { (MPa) }\end{array}$ & $\frac{\tau_{\text {vert }}}{\tau_{\text {vert }}(\mathrm{CP}-\mathrm{SC})}$ \\
\hline Sem cinta (CP-SC) & 2,35 & 1,00 \\
\hline Com cinta no topo (CP-CT) & 2,76 & 1,17 \\
\hline Com cinta intermediária (CP-CI) & 2,65 & 1,13 \\
\hline
\end{tabular}


Na Figura 7.21 faz-se a comparação das formas de ruptura típica dos corpos-deprova de cisalhamento em escala reduzida. Observa-se que a fissuração da parede central é similar para todos os casos, indicando uma ruptura típica de cisalhamento, o que comprova que é a resistência ao cisalhamento dos blocos que comanda a ruptura. Já em relação aos flanges, percebe-se um comportamento distinto para cada situação. Para os corpos-de-prova sem cinta (CP-SC) há uma série de fissuras de flexão em boa parte dos flanges, sendo que praticamente todas elas estão localizadas na interface bloco argamassa. Nos corpos-de-prova com cinta no topo (CP-CT) predominam as fissuras verticais nos flanges, concentrando-se na ligação das paredes, tanto na interface blocoargamassa quanto no próprio bloco. Já para os exemplares com cinta intermediária (CPCI), as fissuras nos flanges ocorrem principalmente na fiada de topo, nas juntas de argamassa.
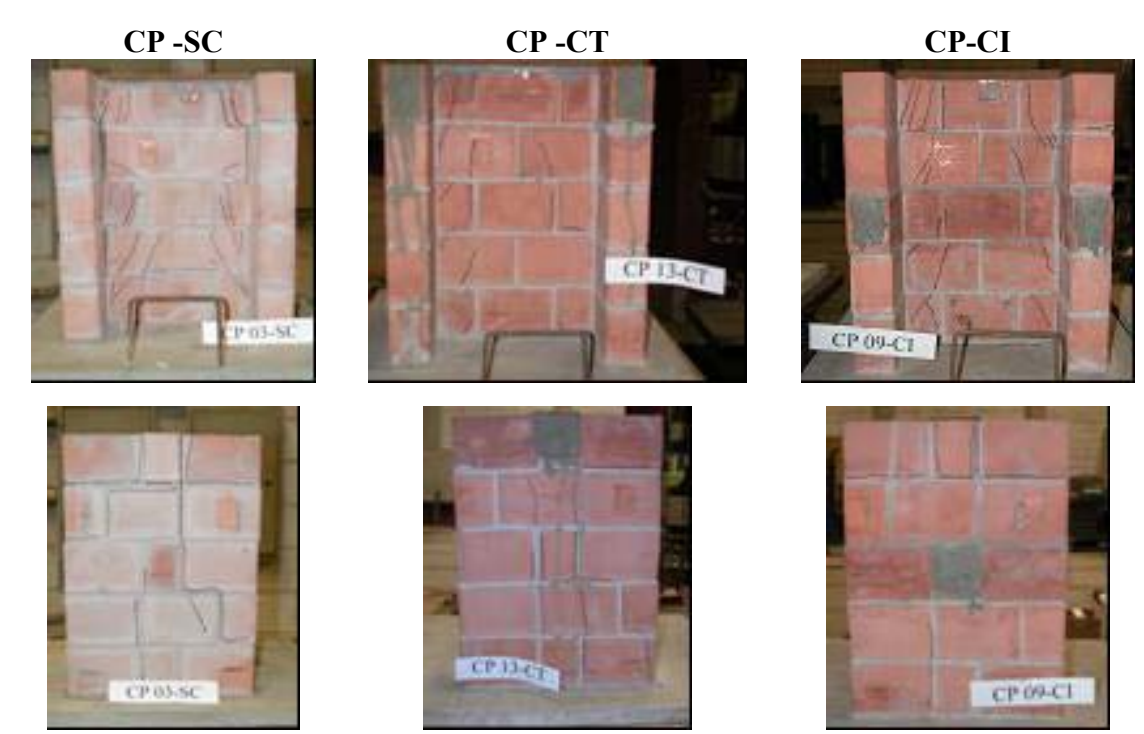

Figura 7.21 - Comparação das formas de ruptura dos corpos-de-prova de cisalhamento

As curvas dos diferentes corpos-de-prova em relação ao deslocamento vertical do topo da parede central e às deformações médias da parede central e dos flanges estão apresentados na Figura 7.22. As deformações médias da parede central, Figura 7.22-a, indicam tendências semelhantes para os diferentes exemplares até próximo à ruptura; a partir desse ponto os corpos-de-prova com cinta intermediária apresentam grandes deformações, não verificadas nos demais tipos de corpos-de-prova. Em relação às deformações médias dos flanges, Figura 7.22-b, confirma-se a divergência de comportamentos verificada nas formas de ruptura, sendo que cada tipo de exemplar possui curvas peculiares. Observa-se na Figura 7.22-c que o comportamento do deslocamento no topo da parede central é semelhante para todos os tipos de corpos-de- 
prova, com exceção dos exemplares CP-1SC e CP-11CI que apresentam divergências comentadas nos itens anteriores.

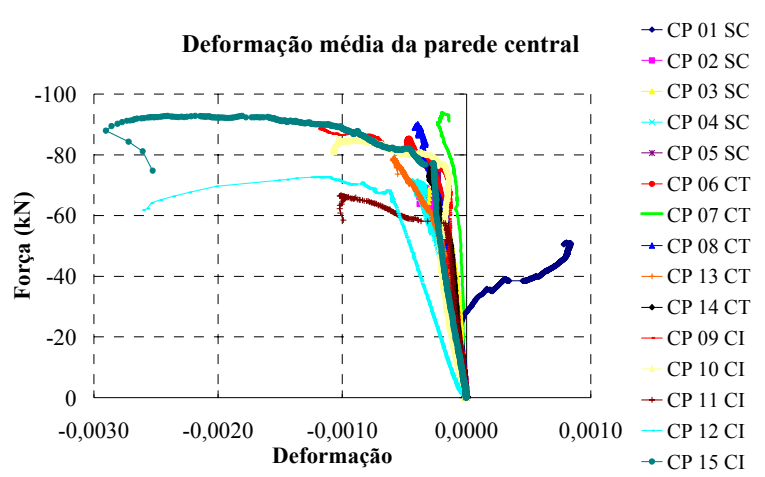

(a)

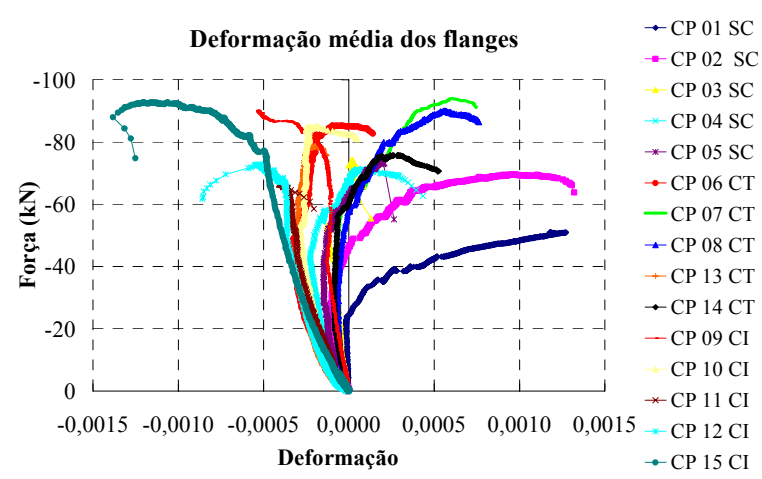

(b)

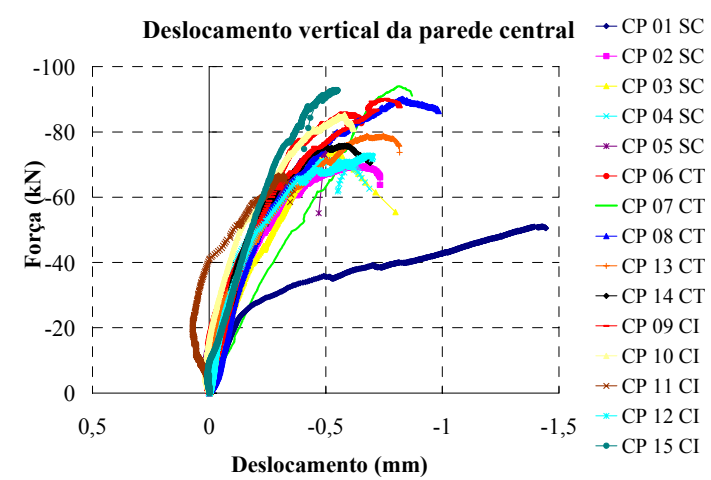

(c)

Figura 7.22 - Comportamento de todos os diferentes corpos-de-prova em escala reduzida

Percebe-se por essa análise comparativa que a maior influência da presença da cinta de amarração está relacionada ao comportamento dos flanges, enquanto que sua atuação na parede central é menos significativa.

\section{8- Análise numérica dos corpos-de-prova de cisalhamento em escala reduzida}

Dentre os corpos-de-prova de cisalhamento, o ensaio mais simples de se modelar numericamente é aquele sem a presença de cinta de amarração. Por essa maior simplicidade, define-se por realizar diferentes testes numéricos apenas para esta situação. Empregam-se a micro-modelagem, considerando-se os vazios dos blocos, e a macro-modelagem, admitindo os blocos com sua seção bruta, que demonstraram, no capítulo 6, serem as melhores técnicas para a representação do comportamento da alvenaria.

A não-linearidade do material é considerada de maneira análoga à apresentada no item 6.4.1, utilizando, inclusive, as mesmas propriedades para os blocos (tabela 6.10) e para a alvenaria como conjunto (tabela 6.16). Para as propriedades da argamassa, 
empregam-se os valores médios obtidos nos ensaios das argamassas referentes aos corpos-de-prova de cisalhamento, ver Tabela 7.7.

Tabela 7.7 - Propriedades da argamassa para os modelos dos corpos-de-prova de cisalhamento

\begin{tabular}{|c|c|c|}
\hline \multicolumn{3}{|c|}{ Propriedades da Argamassa } \\
\hline Módulo de Elasticidade & \multicolumn{2}{|c|}{$13604 \mathrm{MPa}$} \\
\hline Resistência à compressão & \multicolumn{2}{|c|}{$9,29 \mathrm{MPa}$} \\
\hline Resistência à tração & \multicolumn{2}{|c|}{$0,93 \mathrm{MPa}$} \\
\hline Coeficiente de Poisson (v) & \multicolumn{2}{|c|}{0,20} \\
\hline Curva tensão real $x$ deformação plástica & $\begin{array}{l}4,07 \mathrm{MPa} \\
5,09 \mathrm{MPa} \\
6,62 \mathrm{MPa} \\
9,29 \mathrm{MPa}\end{array}$ & $\begin{array}{c}0,0 \\
0,00001 \\
0,00005 \\
0,00132\end{array}$ \\
\hline Espessura da junta de argamassa & \multicolumn{2}{|c|}{$0,30 \mathrm{~cm}$} \\
\hline $\begin{array}{l}\text { Resistência à compressão. biaxial / } \\
\text { Resistência à compressão uniaxial }\end{array}$ & \multicolumn{2}{|c|}{$1,20^{* *}$} \\
\hline $\begin{array}{c}\text { Resistência à tração uniaxial / } \\
\text { Resistência à compressão uniaxial }\end{array}$ & \multicolumn{2}{|c|}{0,10} \\
\hline $\begin{array}{c}\text { Deformação plástica. biaxial / } \\
\text { Deformação plástica uniaxial ( } \\
\text { ( })\end{array}$ & \multicolumn{2}{|c|}{$1,28^{* *}$} \\
\hline $\begin{array}{l}\text { Tensão fissuração biaxial/ } \\
\text { tensão fissuração uniaxial (") }\end{array}$ & \multicolumn{2}{|c|}{$0,33^{* *}$} \\
\hline Deslocamento último no "Tension stiffening" & \multicolumn{2}{|c|}{$0,005 \mathrm{~cm}^{* *}$} \\
\hline
\end{tabular}

Para a não-linearidade de contato, utilizam-se os procedimentos apresentados no capítulo 4. A idéia inicial seria empregar os elementos de contato para representar o comportamento da interface bloco-argamassa tanto nas juntas verticais quanto nas horizontais. Contudo, encontraram-se dificuldades na consideração das juntas verticais: os modelos não processavam ou levavam a resultados incoerentes. Dessa forma, no presente trabalho, utilizam-se os elementos de contato apenas para a consideração das juntas horizontais.

São desenvolvidos modelos numéricos com diferentes considerações: tipo de modelagem, não-linearidade física e de contato. Na Tabela 7.8 apresenta-se a denominação de cada modelo, oito no total, com suas principais características. A discretização empregada é idêntica à do capítulo 6. As restrições e os carregamentos, bem como a localização dos elementos de contato, tanto da macro-modelagem quanto da micro-modelagem, estão ilustrados na Figura 7.23. 
Tabela 7.8 - Diferentes modelos numéricos do corpo-de-prova de cisalhamento

\begin{tabular}{|c|c|c|c|}
\hline Denominação & Tipo de modelagem & $\begin{array}{c}\text { Não-linearidade } \\
\text { f́́sica }\end{array}$ & $\begin{array}{c}\text { Não-linearidade } \\
\text { de contato }\end{array}$ \\
\hline Vaz-linear & Micro-modelagem & não & não \\
\hline Macro-linear & Macro-modelagem & não & não \\
\hline Vaz-não-linear & Micro-modelagem & sim & não \\
\hline Macro-não-linear & Macro-modelagem & sim & não \\
\hline Vaz-linear-cont & Micro-modelagem & não & Juntas horizontais \\
\hline Macro-linear-cont & Macro-modelagem & não & Juntas horizontais \\
\hline Vaz-não-linear-cont & Micro-modelagem & sim & Juntas horizontais \\
\hline Macro-não-linear-cont & Macro-modelagem & sim & Juntas horizontais \\
\hline
\end{tabular}

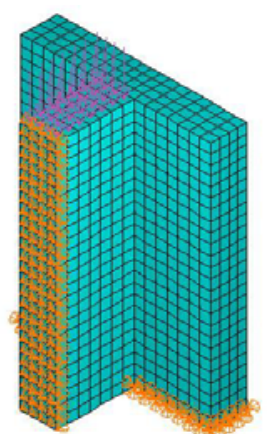

(a) restrições e carregamento do macro-modelo

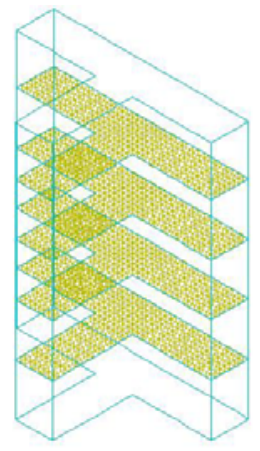

(b) elementos de contato do macromodelo

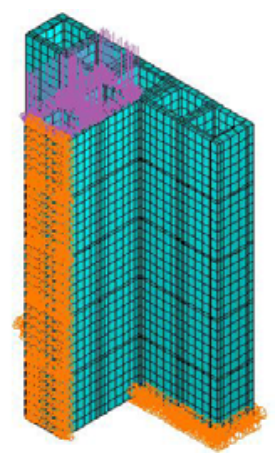

(c) restrições e carregamento do micro-modelo

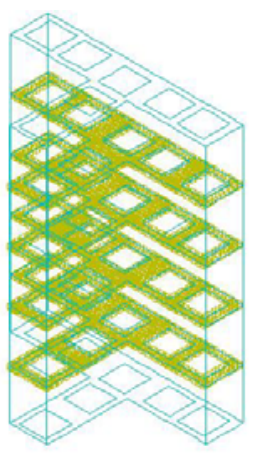

(d) elementos de contato do micromodelo

Figura 7.23 - Modelos numéricos dos corpos-de-prova de cisalhamento

$\mathrm{Na}$ Figura 7.24 realiza-se a comparação entre os resultados numéricos e experimentais para o corpo-de-prova de cisalhamento sem cinta de amarração. No caso da parede central (Figura 7.24-a e -c), nota-se que todos os modelos representam a tendência observada nos ensaios, porém sem as perturbações verificadas. A nãolinearidade de contato nas juntas horizontais não gera diferenças significativas em nenhum dos tipos de modelagem. Já a não-linearidade física leva a problemas de convergência numérica na micro-modelagem, fazendo com que a análise seja interrompida em baixos níveis de carregamento, inferiores a 50\% da força de ruptura. No caso dos flanges (Figura 7.24-b), observa-se que nenhum dos modelos numéricos é capaz de representar bem o comportamento obtido nos ensaios; apenas os macromodelos com a consideração da não-linearidade física indicam uma tendência de alongamento nas faces externas dos flanges. 


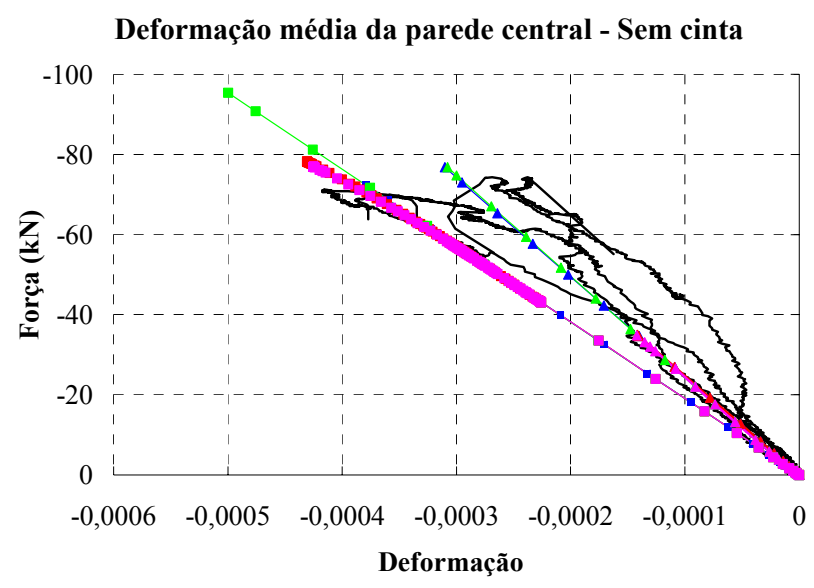

(a)

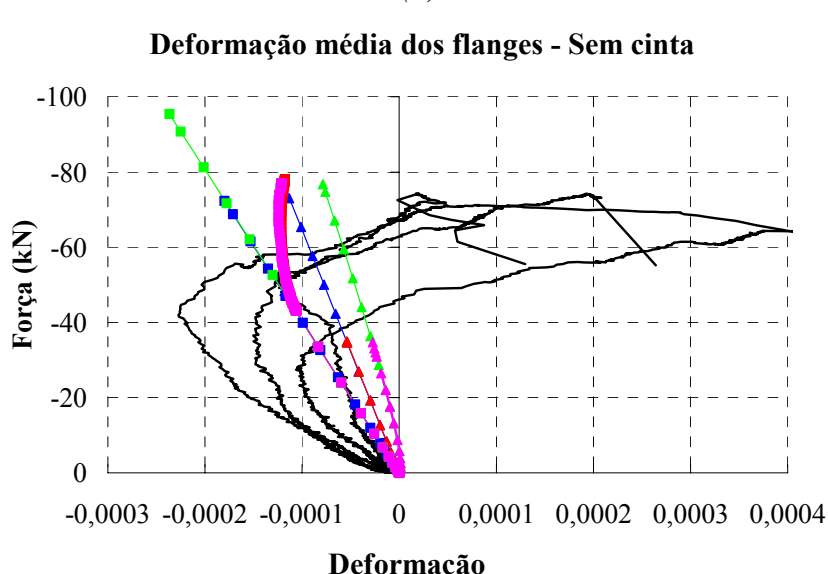

(b)

Deslocamento vertical da parede central - Sem cinta

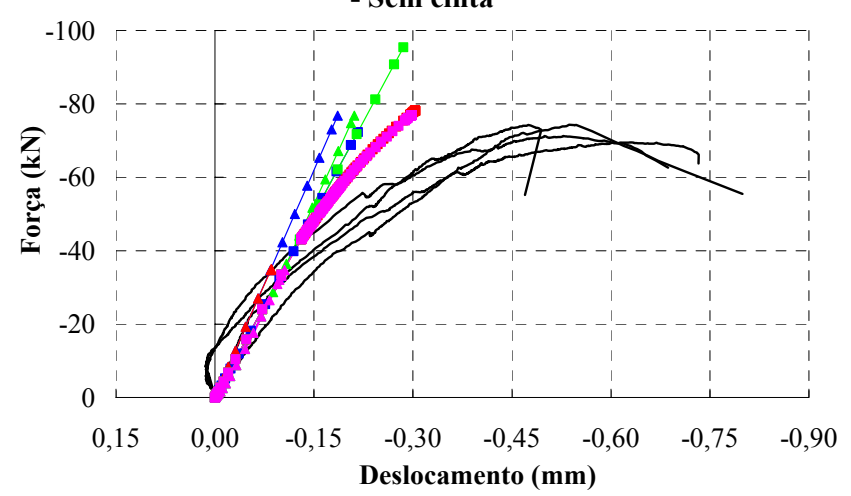

(c)

Legenda
- Ensaios
$\rightarrow$ Vaz-linear
$\rightarrow$ Vacro-linear
$\rightarrow$ - Macro-não-linear
- Vaz-linear-cont
$\rightarrow-$ Macro-linear-cont
$\rightarrow$ Vaz-não-linear-cont
$\rightarrow-$ Macro-não-linear-cont

Figura 7.24 - Comparação entre os resultados numéricos e experimentais para o corpo-deprova sem cinta de amarração

Para a análise numérica dos corpos-de-prova de cisalhamento, com cinta de amarração no topo ou na fiada intermediária, consideram-se apenas os macro-modelos com não-linearidade física, pois verificou-se no caso anterior que foi a situação que mais se aproximou do comportamento do ensaio, apesar de não representá-lo perfeitamente. Na Figura 7.25 estão ilustrados os modelos referentes aos corpos-de- 
prova de cisalhamento com cinta de amarração, em que se percebe que a discretização é a mesma utilizada nos modelos anteriores. Para as regiões sem cinta de amarração empregam-se as propriedades da alvenaria como conjunto, as mesmas do item 6.4.1 (Tabela 6.16). Já para as cintas de amarração considera-se apenas o comportamento elástico-linear do conjunto bloco canaleta - graute, com módulo de elasticidade de $21470 \mathrm{MPa}$ e coeficiente de Poisson de 0,12 (adotado igual ao da alvenaria). Tal simplificação é adotada por ser a cinta um elemento de reforço com a função de amarrar as paredes e distribuir as forças aplicadas de maneira mais uniforme. Portanto, sua ruptura não deve ocorrer antes da ruína das demais partes da alvenaria.

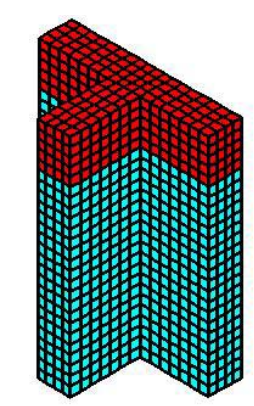

(a) Cinta no topo

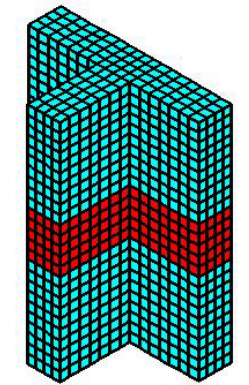

(b) Cinta intermediária

Figura 7.25 - Macro-modelos dos corpos-de-prova de cisalhamento com a presença de cintas de amarração

As comparações entre as análises numéricas e os resultados experimentais dos corpos-de-prova com cinta de amarração estão apresentadas na Figura 7.26. Observa-se que os modelos numéricos representam melhor as tendências de comportamento da parede central (Figuras 7.26- a- b- e- f) do que dos flanges (Figuras 7.26- c- d). Contudo, em nenhum dos casos, os modelos numéricos estudados foram capazes de representar as perturbações verificadas nos ensaios.

Com os resultados analisados até aqui, acredita-se que, para a obtenção de modelos numéricos mais realistas, seria necessário representar o comportamento da interseção das paredes de forma alternativa. Desse modo, ao longo dessa interface haveria regiões com grande resistência à tração (blocos intertravados) e outras regiões com pequenas resistências (juntas verticais de argamassa), além de ocorrer o aparecimento de fissuras de grande magnitude. Uma possível solução para esse caso seria a utilização dos elementos de contatos para reproduzir essas diferenças de resistência e permitir o surgimento das fissuras. Todavia, como comentado anteriormente, ainda não se obteve sucesso nas tentativas de se realizar tal representação. Tais insucessos podem ser devidos a alguma falha não detectada na 
modelagem ou o elemento de contato do Abaqus não ser o mais indicado para representar o comportamento desejado. Estudos adicionais deverão ser realizados em trabalhos futuros para avaliar essa questão.

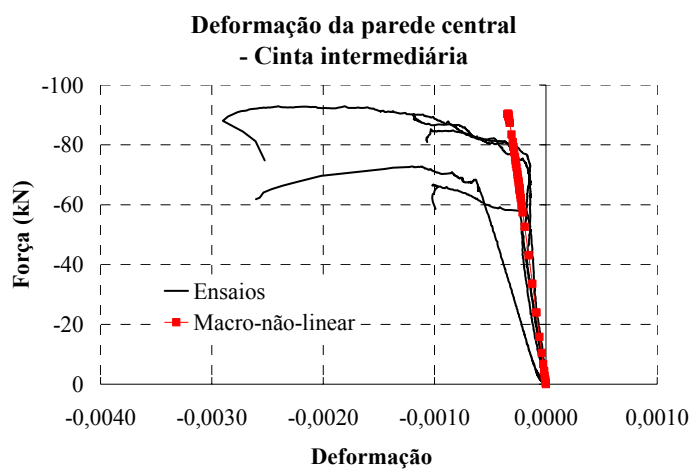

(a)

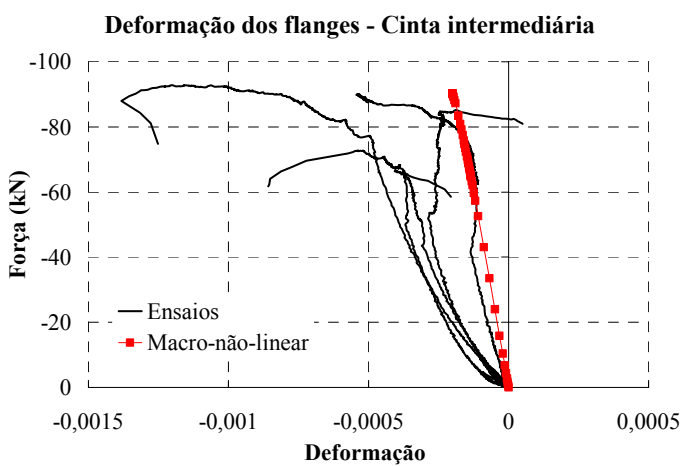

(c)

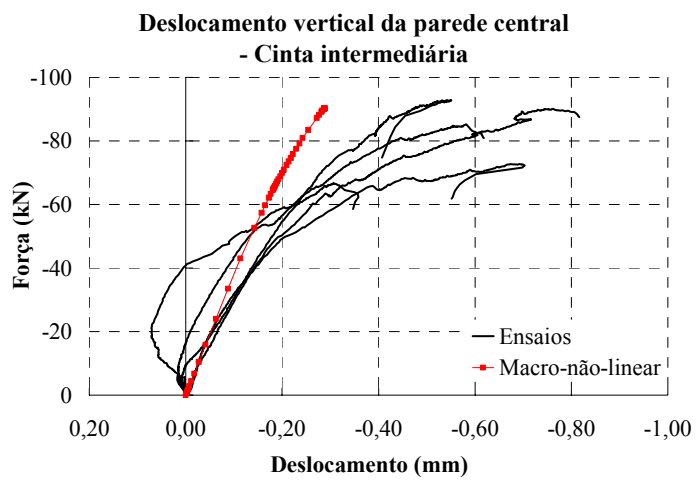

(e)

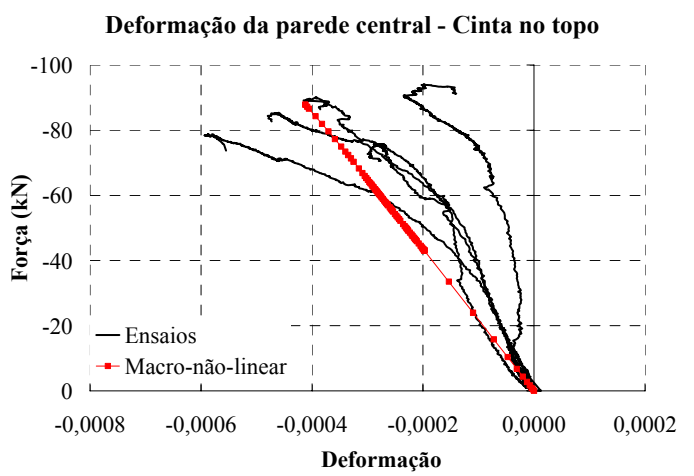

(b)

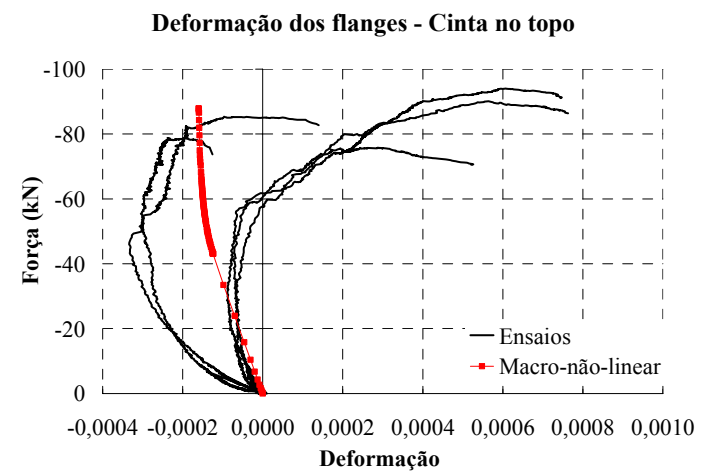

(d)

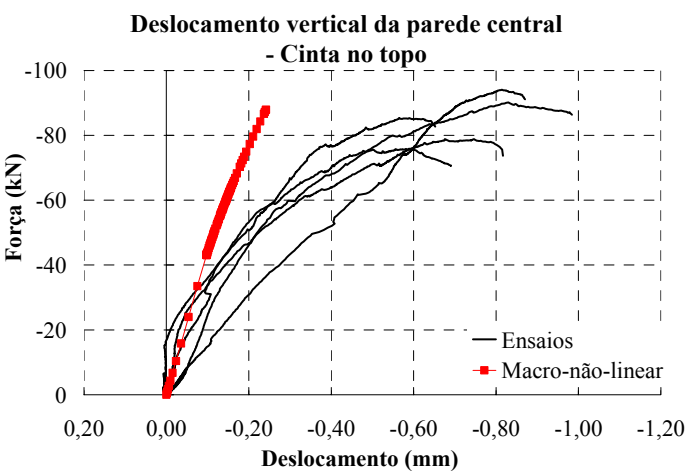

(f)

Figura 7.26 - Comparação entre os resultados numéricos e experimentais para os corpos-de-prova com cinta de amarração

Apesar dos modelos numéricos não simularem as perturbações verificadas nos ensaios, eles são capazes de representar o comportamento global dos ensaios dos diferentes corpos-de-prova. Na Figura 7.27 percebe-se que há uma concentração de tensões normais verticais de compressão no topo da parede central, enquanto que na região externa dos flanges ocorrem tensões de tração, que levam ao aparecimento das fissuras nas juntas de assentamento. Já a Figura 7.28 ilustra que as tensões de 
cisalhamento se concentram na região junto a interseção, mesmo local onde ocorrem as fissuras de cisalhamento observadas nos ensaios.

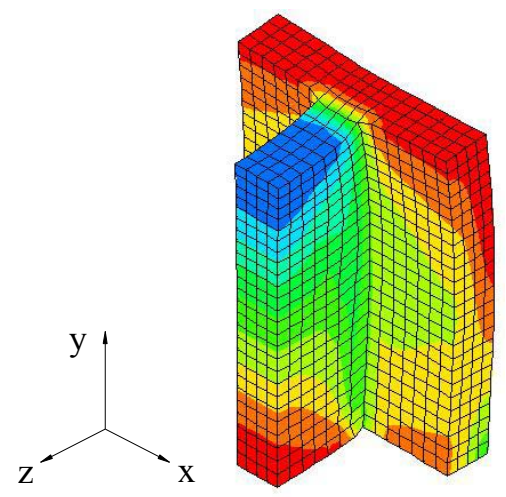

(a) Sem cinta

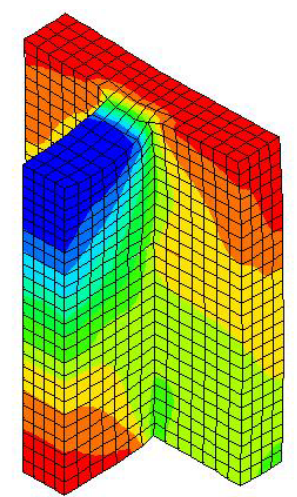

(b) Cinta

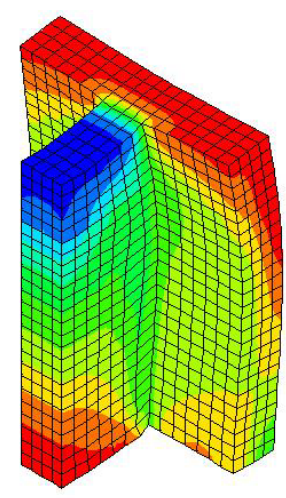

(c) Cinta no topo

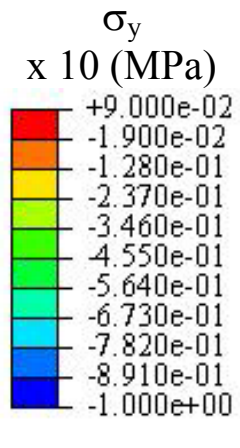

intermediária

Figura 7.27 - Distribuição das tensões normais verticais dos macro-modelos dos corpos-deprova de cislahamento

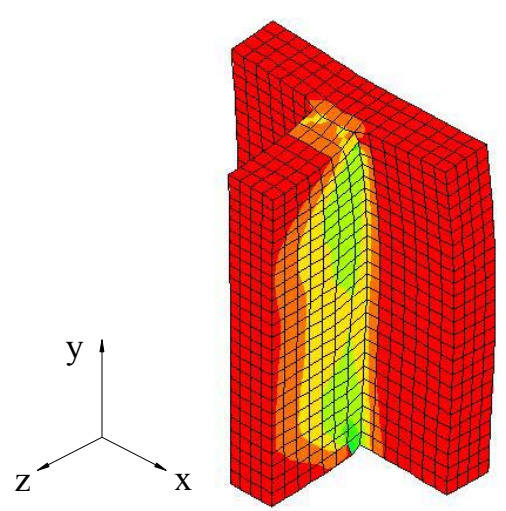

(a) Sem cinta

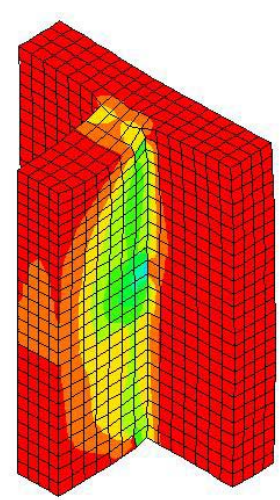

(b) Cinta intermediária

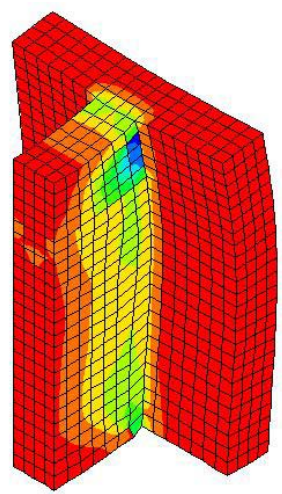

(c) Cinta no topo

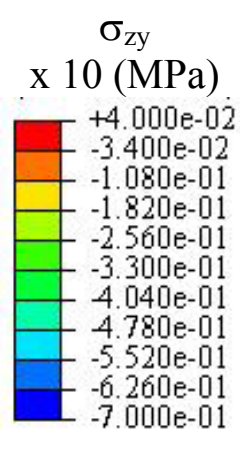

Figura 7.28 - Distribuição das tensões de cisalhamento no plano "zy" dos macro-modelos dos corpos-de-prova de cislahamento

\section{9- Comentários}

Nos ensaios dos corpos-de-prova para determinação da resistência ao cisalhamento vertical da alvenaria em escala reduzida verificou-se que a influência das cintas de amarração em termos de resistência total do corpo-de-prova não foi apreciável, pois levaram a um aumento da força de ruptura inferior a 20\%. No entanto, supondo que o acréscimo na força de ruptura seja devido apenas à cinta de amarração, isso indica que a mesma possui uma resistência $45 \%$ superior à amarração direta. A resistência da cinta foi estimada do seguinte modo: no ensaio do corpo-de-prova sem cinta de amarração a força de ruptura média foi de $72,34 \mathrm{kN}$, como existiam três fiadas de intertravamento, cada fiada resiste a $24,11 \mathrm{kN}$; nos ensaios com cinta-de-amarração a força de ruptura média foi de $83,19 \mathrm{kN}$, como existiam duas fiadas de intertravamento e 
uma cinta de amarração tem-se que a resistência da cinta $=83,19 \mathrm{kN}-2 \times 24,11 \mathrm{kN}=$ $34,97 \mathrm{kN}$. As cintas, também, provocaram modificações no comportamento dos flanges, diminuindo a tendência do surgimento de tensões de tração nos mesmos.

Com a realização do ensaio de corpo-de-prova de cisalhamento em escala natural (1:1) comprovou-se que os modelos reduzidos também foram capazes de representar convenientemente a alvenaria submetida ao cisalhamento.

As análises numéricas desenvolvidas neste capítulo foram capazes de representar qualitativamente o comportamento global dos corpos-de-prova de cisalhamento, todavia não se conseguiu simular as perturbações observadas nos ensaios. Acredita-se que o estudo realizado até aqui servirá como ponto de partida para próximas pesquisas sobre o tema, sabendo-se das limitações de cada tipo de modelagem. 


\section{Capítulo}

\section{ENSAIOS DOS PAINÉIS DE ALVENARIA}

\section{1- Generalidades}

Nos capítulos anteriores observaram-se as influências das dimensões em planta dos painéis de alvenaria e do número de andares nos quais o carregamento é aplicado na distribuição das ações verticais. Dessa forma, verifica-se a necessidade de executar e ensaiar modelos de painéis com diferentes seções em planta e com mais de um pavimento para comprovação desse comportamento. Estuda-se, ainda, qual o efeito proporcionado pela presença das lajes de concreto.

Devido às dimensões e aos equipamentos de aplicação de força necessários, os ensaios de painéis em escala natural seriam onerosos e alguns seriam até mesmo impraticáveis para as condições disponíveis no Laboratório de Estruturas da EESC/USP, com isso todos os ensaios de painéis são realizados em escala reduzida (1:3). Todavia, é feita uma comparação de um tipo de painel ensaiado com os ensaios em escala natural realizados anteriormente por Capuzzo Neto (2000), para efeito de controle.

Por fim realizam-se análises numéricas dos painéis ensaiados considerando-se apenas a não-linearidade física e empregando-se as técnicas de macro-modelagem. Salienta-se que é uma investigação preliminar, pois, como visto no capítulo anterior, é necessária uma melhor representação numérica do comportamento das interseções das paredes. A finalidade desta investigação é verificar se os modelos numéricos são capazes de representar qualitativamente o comportamento verificado nos experimentos.

\section{2- Ensaios dos painéis em escala reduzida tipo $\mathrm{H1}$}

Efetua-se inicialmente o ensaio do painel em formato " $\mathrm{H}$ " com menores dimensões na escala (1:3) na tentativa de se comparar com os resultados obtidos com os 
encontrados por Capuzzo Neto (2000) em painéis em escala natural. Este caso corresponde ao modelo numérico H1 estudado anteriormente.

Investiga-se, também, a influência da presença de uma laje no topo, visando simular uma condição mais próxima à de um painel de alvenaria pertencente a um edifício, impedindo parcialmente a flexão dos flanges. Com isso, ensaia-se um painel H1 sem a presença da laje de topo e um segundo com a sua presença (Figura 8.1).

Em ambos os casos emprega-se a cinta de amarração de respaldo (última fiada). Ressalta-se que toda a base do painel é apoiada e que o carregamento é aplicado apenas na região correspondente à parede central.

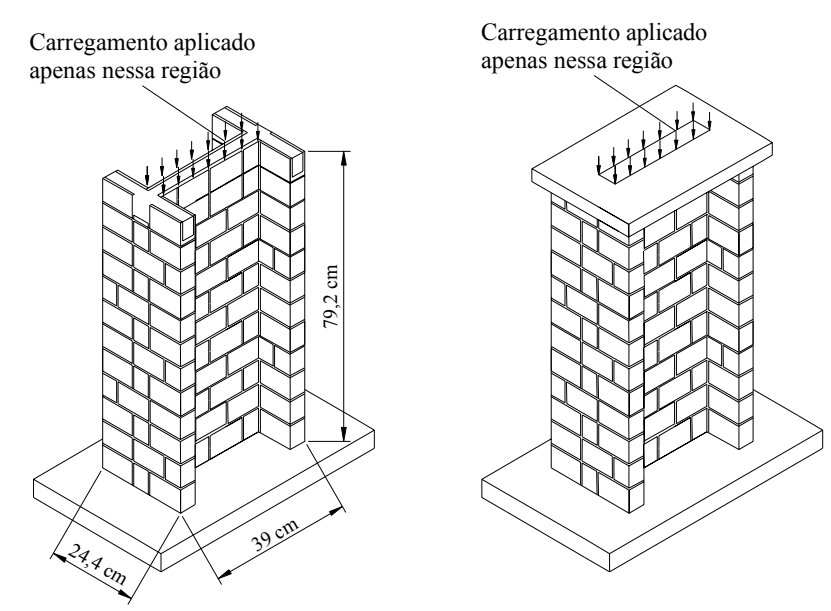

Figura 8.1 - Painéis H1 com e sem laje de topo

\subsection{1- Modo de execução dos painéis}

- Procedimentos:

A geometria, as dimensões e a disposição das fiadas dos painéis H1 estão ilustradas na Figura 8.2. Eles são construídos sobre uma laje de concreto com $5 \mathrm{~cm}$ de altura para permitir o transporte para o local de ensaio (Figura 8.3-a). Nessa laje é utilizada uma armadura dupla de barras de aço CA 50 com $5 \mathrm{~mm}$ de diâmetro, com espaçamento máximo de $9,5 \mathrm{~cm}$, que dá uma taxa de armadura de $2,4 \mathrm{~cm}^{2} / \mathrm{m}$ (Figura 8.3-b). Ressalta-se que é uma taxa de armadura bem superior à necessária, porém optase por um valor maior para reduzir a chance de ruptura ou dano da laje de apoio. $\mathrm{O}$ concreto utilizado é o mesmo das lajes utilizadas no ensaio de cisalhamento, o traço em massa de 1:1,94:2,06 (cimento;areia;pedrisco) com relação água/cimento igual a 0,65. Retiram-se três corpos-de-prova cilíndricos $(5 \mathrm{~cm} \times 10 \mathrm{~cm})$ para controle de sua resistência. A Figura 8.3-c mostra uma das lajes logo após a sua concretagem. 


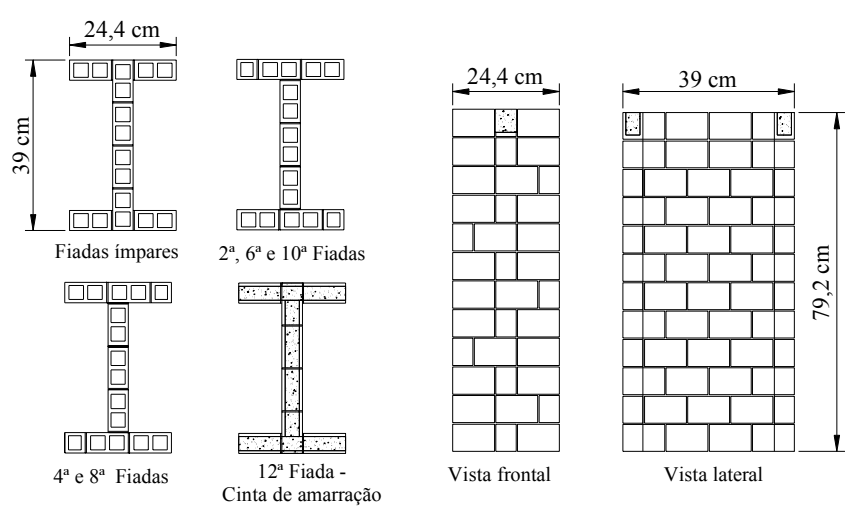

Figura 8.2 - Geometria e dimensões dos painéis H1

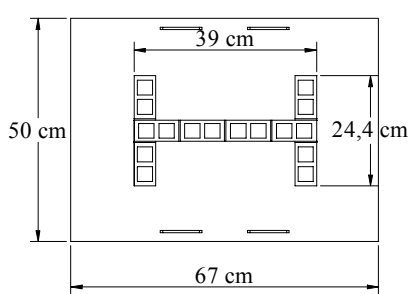

(a) Esquema

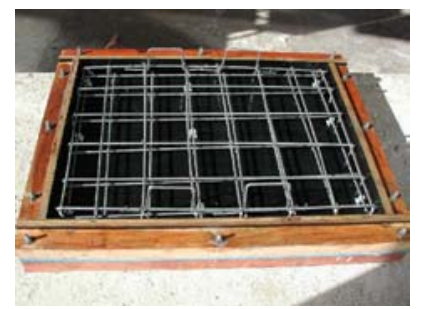

(b) Armadura

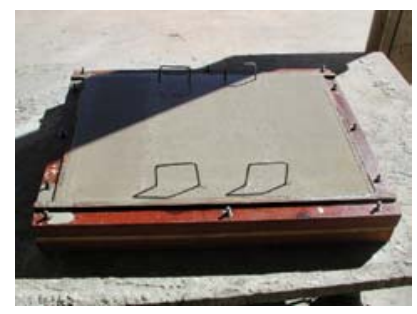

(c) Concretagem

Figura 8.3 - Laje de base para o painel $\mathrm{H} 1$

A execução e os procedimentos utilizados na construção dos painéis H1 são bem semelhantes aos empregados no item anterior para os corpos-de-prova de cisalhamento. Os traços da argamassa e do graute são os mesmos, modificando-se apenas as quantidades de corpos-de-prova retirados. Cada produção de argamassa é dimensionada para assentar seis fiadas (metade de um painel), construir dois prismas de três blocos e três corpos-de-prova cilíndricos de $5 \mathrm{~cm}$ x $10 \mathrm{~cm}$. As cintas dos dois painéis H1 são grauteadas simultaneamente, recolhendo-se seis corpos-de-prova de cilíndricos de $5 \mathrm{~cm}$ x $10 \mathrm{~cm}$ e preenchendo-se quatro blocos canaletas para controle de resistência. A armadura da cinta de amarração também é uma barra de aço CA 60 de 4,2mm. A Figura 8.4 mostra algumas etapas da construção dos painéis $\mathrm{H} 1$.

Lembra-se que em um dos painéis H1 é colocada uma laje no topo, no entanto as dimensões serão diferentes da laje de base e com altura de $3,5 \mathrm{~cm}$ (Figura 8.5). Isto acontece porque a intenção é representar uma laje com espessura usual em escala natural. Neste caso corresponderia a uma laje com $10,5 \mathrm{~cm}$ de altura. Procura-se também utilizar uma taxa de armadura mais baixa em ambas as faces $\left(0,98 \mathrm{~cm}^{2} / \mathrm{m}\right)$, que é obtida pelo uso de tela soldada com fio de $2,5 \mathrm{~mm}$ e malha quadrada de $5 \mathrm{~cm}$ (Figura 8.5). O concreto a ser empregado será o mesmo da laje de base. Opta-se por fixar a laje de topo com uma argamassa igual à de assentamento dos blocos, diferindo-se apenas o tipo de cimento, pois neste caso será utilizado um com ganho de resistência rápida (ARI-Plus). 


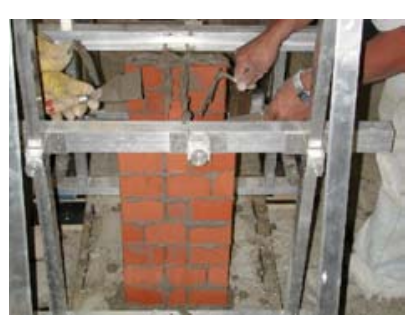

(a) Colocação da argamassa

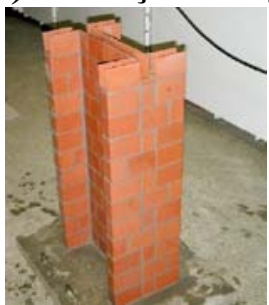

(d) Painel todo construído

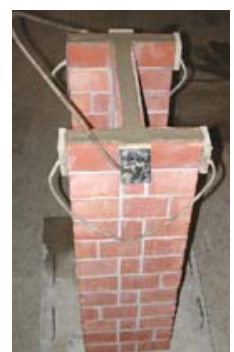

(g) Vistas do painel H1 já grauteado

Figura 8.4 - Construção do painel H1
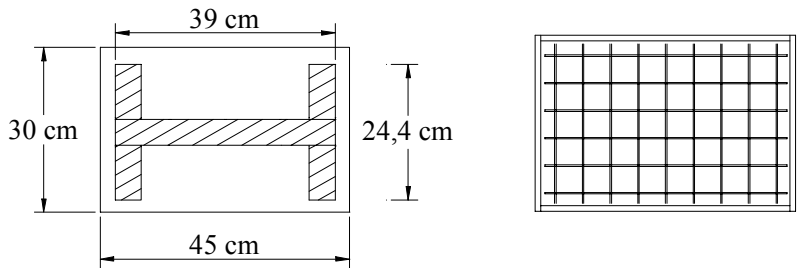

Armadura dupla

Tela soldada $\phi=2,5 \mathrm{~mm}$ malha quadrada de $5 \mathrm{~cm}$

Figura 8.5 - Laje de topo para o painel $\mathrm{H} 1$

\subsection{2- Procedimentos e equipamentos utilizados nos ensaios dos painéis H1}

- Procedimentos:

O objetivo do ensaio é analisar a distribuição das ações verticais em paredes de alvenaria interligadas por amarração direta. Para isso o carregamento é aplicado apenas na região da parede central de modo que haja a possibilidade da transferência de força para os flanges. Essa transferência será estimada por meio de medidas das deformações das paredes em dois níveis diferentes, numa região superior, próxima ao carregamento, e numa inferior, próxima à base.

De acordo com os ensaios de Capuzzo Neto (2000), em painéis em escala natural com as mesmas proporções, ocorre a tendência de uniformização das tensões normais verticais a partir da meia altura do painel. Isto é, as deformações medidas nos flanges e na parede central são próximas. 
- Equipamentos:

Devido às pequenas dimensões externas dos painéis H1, eles são ensaiados na máquina hidráulica servo-controlada INSTRON. Dessa forma é possível aplicar o carregamento por meio de controle de deslocamento do pistão da máquina, o que leva a uma melhor condição de ensaio e principalmente de segurança em relação a uma ruptura frágil. O carregamento é inicialmente aplicado de maneira que o pistão se desloque a $0,01 \mathrm{~mm} / \mathrm{s}$, reduzindo até $0,001 \mathrm{~mm} / \mathrm{s}$ quando próximo à ruptura.

Para a verificação da transferência do carregamento para os flanges opta-se por uma instrumentação que permita avaliar as deformações das diferentes paredes em dois níveis (metade superior e inferior). Também são controlados os deslocamentos horizontais da parede central e dos flanges. A Figura 8.6 ilustra a instrumentação utilizada, que é a mesma para os dois ensaios. São utilizados transdutores de deslocamento à base de extensômetros com cursos de 10, 20 e $50 \mathrm{~mm}$. Ressalta-se que o número de transdutores de 10 e $20 \mathrm{~mm}$, que possuem uma maior sensibilidade, é limitado pela quantidade disponível no laboratório. Observa-se, também, que na região superior da parede central, devido ao pequeno espaço físico, é necessária uma defasagem entre os transdutores. Para o registro dos dados utiliza-se o sistema de aquisição de dados SYSTEM 5000. O detalhe da aplicação do carregamento nos painéis com e sem laje de topo está na Figura 8.7.
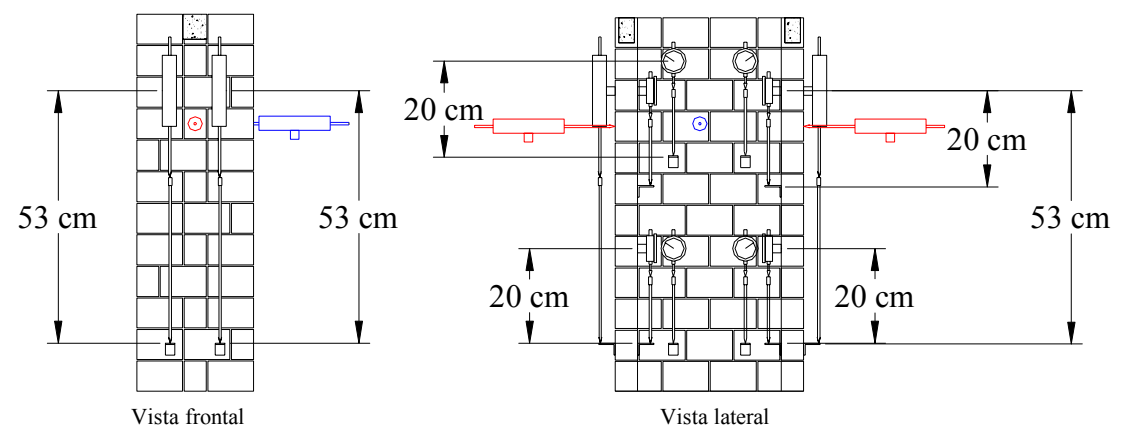

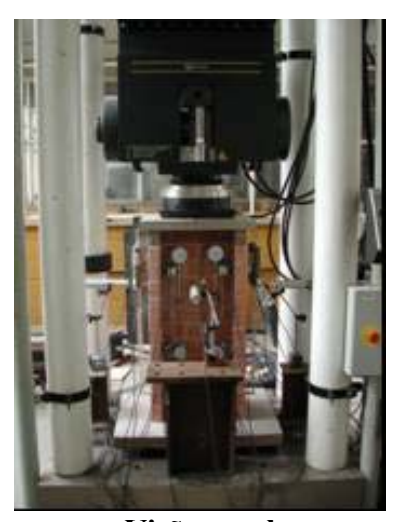

Visão geral

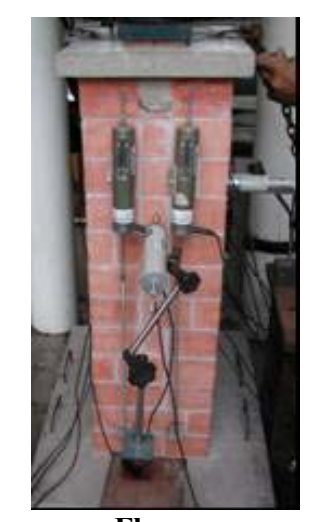

Flanges

éis $\mathrm{H} 1$

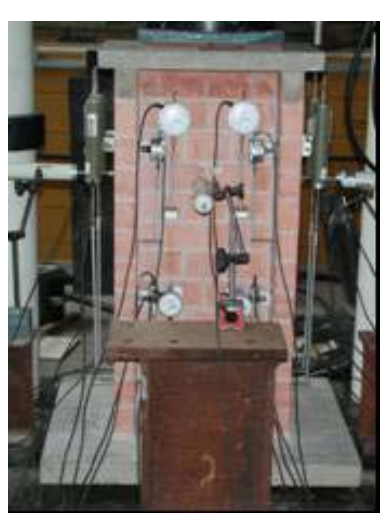

Parede Central 


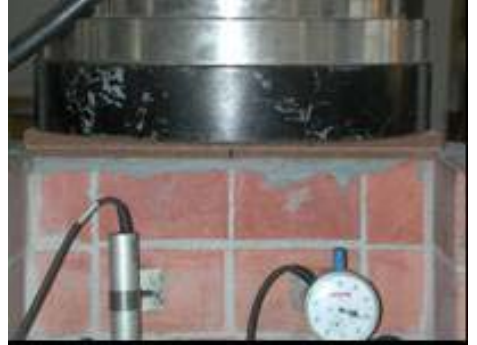

Sem laje de topo

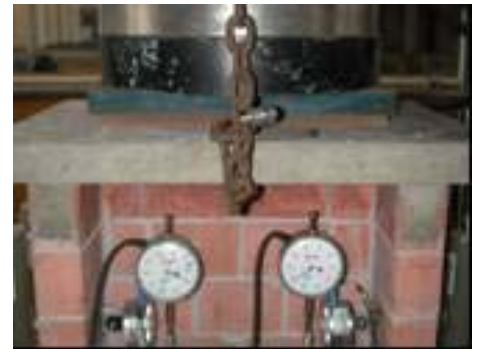

Com laje de topo

Figura 8.7- Detalhe da aplicação da força nos painéis tipo H1

\subsection{3- Resultados do painel H1 sem laje de topo (Painel H1-1)}

Os valores médios obtidos nos ensaios dos corpos-de-prova referentes ao painel H1-1, estão na Tabela 8.1. Verifica-se que a resistência da argamassa é inferior às obtidas nos ensaios de corpos-de-prova de cisalhamento, no entanto superior ao obtido nos ensaios de caracterização. Contudo, a resistência dos prismas neste caso é superior aos valores obtidos nos ensaios de corpos-de-prova de cisalhamento. As resistências do graute, bloco canaleta e o concreto da base são inferiores às resistências obtidas nos ensaios anteriores. Acredita-se que essa variação de resistência esteja relacionada à variação das condições de cura, visto que os corpos-de-prova cilíndricos são curados nas condições ambientes do laboratório, portanto sujeitos às variações de temperatura e umidade. Na mesma tabela são apresentados os valores de módulo de deformação da argamassa, do graute e do concreto da base, que poderão ser utilizados nas futuras análises numéricas.

Tabela 8.1 - Resultados dos ensaios dos corpos-de-prova do painel H1-1

\begin{tabular}{|c|c|c|c|c|c|}
\hline $\begin{array}{c}\text { Ensaios } \\
\text { (valores médios) }\end{array}$ & Argamassa & Prisma & Graute & Canaletas & $\begin{array}{c}\text { Concreto } \\
\text { base }\end{array}$ \\
\hline Resistência (MPa) & 5,34 & 10,39 & 43,96 & 35,28 & 22,87 \\
\hline $\begin{array}{c}\text { Módulo de } \\
\text { deformação (MPa) }\end{array}$ & 9035 & -- & 24860 & -- & 25465 \\
\hline
\end{tabular}

Na Tabela 8.2 apresentam-se a força de ruptura do painel H1 sem laje de topo (H1-1), as tensões de ruptura calculadas por meio de diferentes considerações e as previsões da resistência à compressão da alvenaria. Observa-se que a tensão de ruptura calculada considerando-se apenas a área da parede central $(8,9 \mathrm{MPa})$ é cerca de $18 \%$ superior à resistência da alvenaria obtida no ensaio de caracterização $(7,49 \mathrm{MPa})$, e cerca de 34\% superior à previsão de resistência estimada por meio da eficiência de prisma $(6,62 \mathrm{MPa})$. Admitindo-se que a tensão de ruptura seja determinada considerando a área total do painel, obtém-se uma tensão de 3,33 $\mathrm{MPa}$, que é no mínimo 50\% inferior às estimativas de resistência. Portanto, pode-se concluir que o 
limitante da resistência do painel H1 é a parede central, sendo que a contribuição dos flanges para a capacidade de carga do painel é relativamente pequena.

As formas de ruptura do painel H1 sem laje de topo (painel H1-1) estão ilustradas na Figura 8.8. As fissuras na parede central têm uma leve inclinação, são localizadas próximas à interseção das paredes e ocorrem ao longo de quase toda a altura, indicando serem originadas pelo cisalhamento. Observa-se que mesmo com todos os cuidados na centralização do carregamento, a fissuração da parede central se concentra em apenas um dos seus lados, mas de maneira simétrica às faces. Com relação aos flanges, as fissuras ocorrem apenas no flange que está interligado ao lado com maior grau de fissuração da parede central, o que é consistente. Neste caso, aparecem fissuras horizontais ao longo das juntas de assentamento e fissuras verticais que passam ao longo das juntas verticais de argamassa e, inclusive, por alguns blocos.

Tabela 8.2 - Resultados do ensaio do Painel H1-1

\begin{tabular}{|c|c|c|c|c|}
\hline $\begin{array}{c}\text { Força de } \\
\text { Ruptura } \\
\text { (kN) }\end{array}$ & $\begin{array}{c}\text { Tensão de } \\
\text { ruptura 1) } \\
(\mathrm{MPa})\end{array}$ & $\begin{array}{c}\text { Tensão de } \\
\text { ruptura 2) } \\
\text { (MPa) }\end{array}$ & $\begin{array}{l}\text { Resistência da } \\
\text { alvenaria } \\
\text { (MPa) }\end{array}$ & $\begin{array}{c}\text { Previsão da } \\
\text { resistência da } \\
\text { alvenaria } \\
\text { (MPa) }\end{array}$ \\
\hline 121,32 & 8,90 & 3,33 & 7,49 & 6,62 \\
\hline \multicolumn{5}{|c|}{$\begin{array}{l}\text { 1) Tensão considerando apenas a área da parede central em planta; } \\
\text { 2) Tensão considerando a área de todo o painel em planta; } \\
\text { }{ }^{3)} \text { Resistência obtida nos ensaios de paredinhas (ensaios de caracterização); } \\
\text { 4) Previsão da resistência da alvenaria considerando a eficiência entre as resistências da paredinha e prismas } \\
\text { obtida nos ensaios de caracterização }(0,637) \text {. } \\
\text { Obs: Todas as resistências e tensões são relacionadas à área bruta. }\end{array}$} \\
\hline
\end{tabular}
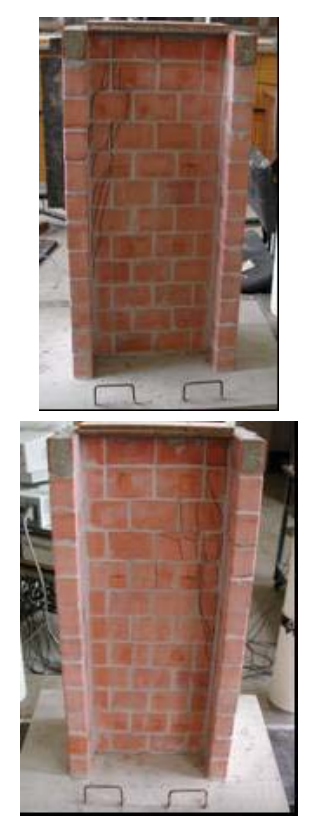

Figura 8.8 - Formas de ruptura do painel H1-1

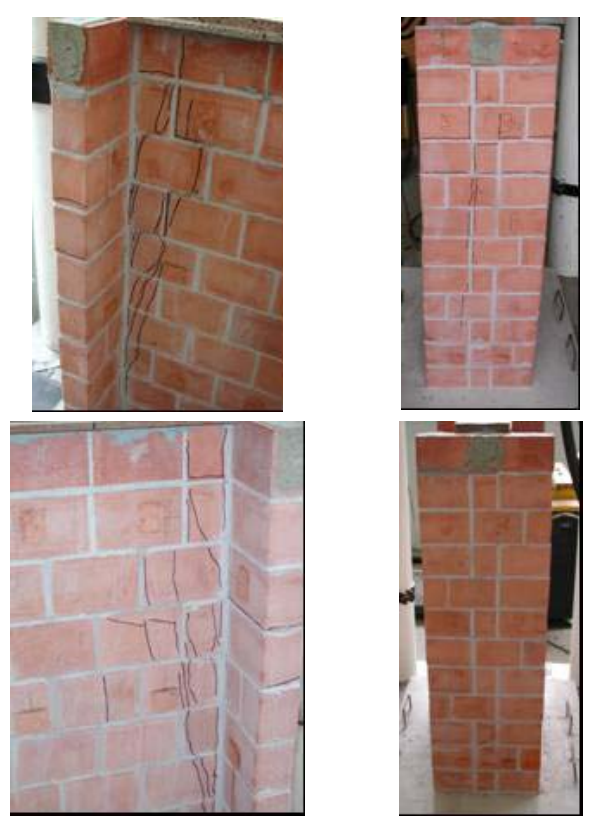

\section{1}


Para a análise do comportamento do painel H1-1 são utilizadas as deformações médias calculadas através das leituras de determinados grupos de transdutores. Os grupos são definidos em relação à sua disposição no painel. O grupo alma inferior corresponde aos transdutores localizados na região inferior da parede central. Os transdutores posicionados na região superior da parede central são denominados de grupo alma superior. Em relação aos flanges, podem-se ter transdutores nas faces externas e internas. Como na face externa dos flanges há uma única disposição, esses transdutores são pertencentes ao grupo flange externo. Na face interna os transdutores são divididos em dois grupos, flange superior e flange inferior, que correspondem respectivamente à região superior e inferior da face interna dos flanges do painel. A Figura 8.9 apresenta o comportamento de todos esses grupos ao longo do carregamento. Ressalva-se que não são apresentados os resultados dos deslocamentos horizontais da parede central e dos flanges porque são apenas medições de controle e todos os seus resultados são inferiores a $0,5 \mathrm{~mm}$.

Observa-se na Figura 8.9 que apenas a alma superior apresenta um nível de deformação superior aos demais, inclusive à alma inferior. A diferença entre os níveis de deformação na região superior e inferior da parede central (alma) pode ser explicada pela transferência de parte do carregamento para os flanges. Verifica-se, também, que as deformações na alma inferior e nos flanges (externo, superior e inferior) são aparentemente do mesmo nível de intensidade, indicando uma tendência de uniformização das tensões normais verticais. Percebe-se que na maioria dos casos o comportamento é praticamente linear até aproximadamente $90 \mathrm{kN}$, o que corresponde a cerca de $74 \%$ da força de ruptura.

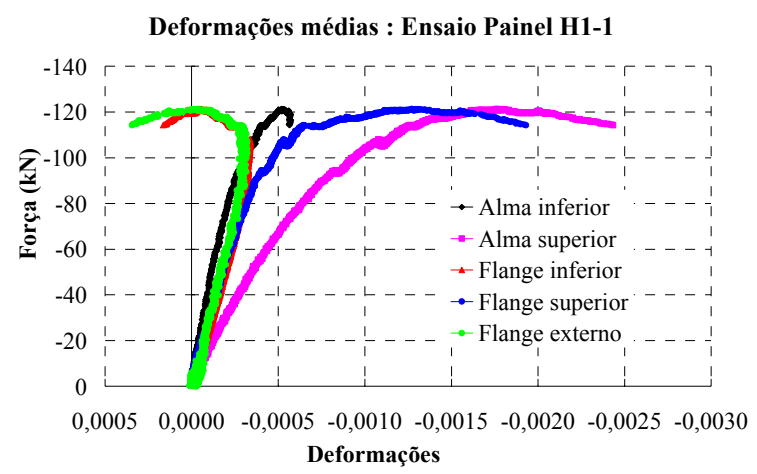

Figura 8.9 - Comportamento do painel H1-1

Ainda na Figura 8.9, nota-se que no estágio próximo à ruptura, as deformações na alma superior aumentam consideravelmente, isto porque, com o aparecimento das 
fissuras na interseção das paredes, não há mais transferência de força para os flanges na região superior. Na região da alma inferior o aumento das deformações não é tão pronunciado, visto que a interseção das paredes nesse trecho ainda permanece praticamente íntegra, portanto ocorrendo a transferência de forças para os flanges. No trecho superior dos flanges a flexão passa a predominar; dessa forma há o surgimento de fissuras horizontais na face externa, fazendo com que os valores dos encurtamentos na face interna se elevem rapidamente. Nos flanges externo e inferior, devido à fissuração na interseção e nos flanges, ocorre o alívio da força aplicada na região onde estão posicionados os transdutores. Contudo, na região próxima à base dos flanges, que serve de referencial para o cálculo da deformação de ambos, ainda há a transferência de forças provenientes da parede central. Dessa forma, como os pontos que servem de referência se deslocam em sentidos contrários, as leituras dos transdutores dos flanges inferior e externo indicam um alongamento.

Para uma melhor análise do comportamento do painel são construídos dois gráficos força $\mathrm{x}$ deformação considerando o trecho linear inicial $(50 \%$ da força de ruptura) e separando-se as deformações da parede central e dos flanges (Figura 8.10). Utiliza-se a inclinação da reta força versus deslocamento como uma medida de comparação entre as regiões do painel. Observa-se na Figura 8.10-a que a inclinação da reta correspondente à parede central na região superior é cerca de $33 \%$ do valor obtido na região inferior. Considerando que as características mecânicas da alvenaria não variam ao longo da altura e que o material está em regime elástico linear, pode-se concluir que a tensão atuante na região superior é cerca de três vezes o valor da região inferior. Essa diferença é explicada tanto pela transferência de forças para os flanges, o que diminui a tensão na região inferior, quanto pela concentração de tensão na região próxima ao carregamento, o que eleva a tensão na região superior.

Os trechos lineares das deformações dos flanges estão ilustrados na Figura 8.10b. Nota-se que as inclinações das retas dos flanges tendem para um valor próximo, indicando que as tensões atuantes também o são. Todavia, seria de se esperar que a tensão na região inferior dos flanges fosse maior que a verificada no trecho superior, visto que a transferência de força entre a parede central e os flanges se dá ao longo da altura. Observa-se, também, que o nível de deformação médio dos flanges é quase 50\% maior que na região inferior da parede central, isto é, as tensões nos flanges são superiores às tensões no trecho inferior da alma. 


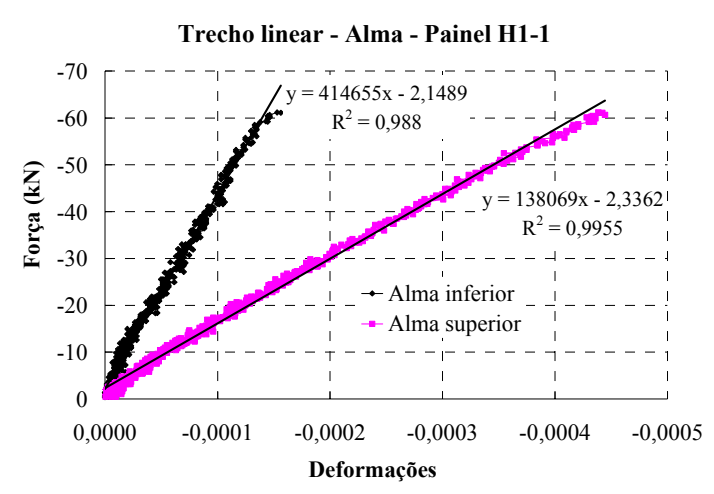

(a)

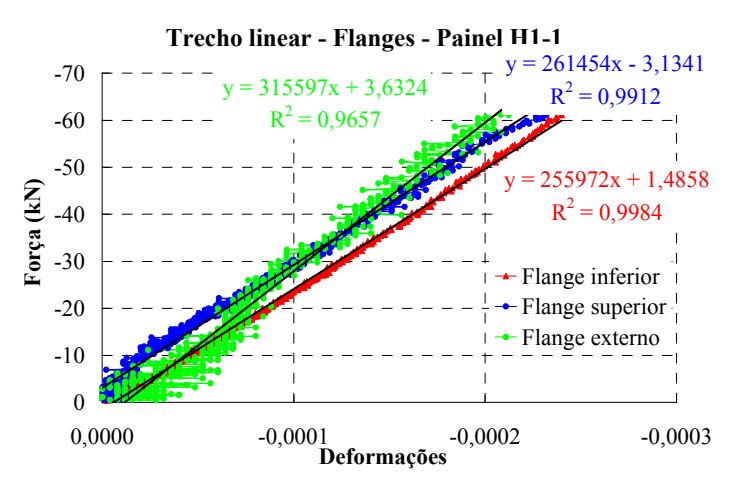

(b)

Figura 8.10 - Análise dos trechos lineares das deformaçães no painel H1-1

\subsection{4- Resultados do painel H1 com laje de topo (Painel H1-1a)}

A Tabela 8.3 apresenta os valores médios dos ensaios de corpos-de-prova referente ao painel H1 com laje de topo (painel H1-1a). Neste caso há também os resultados relacionados à laje de topo. Observa-se que a resistência média da argamassa é próxima da obtida no painel H1-1, contudo a resistência do prisma é cerca de $30 \%$ inferior. Os demais resultados são próximos aos do item anterior. Novamente apresentam-se os resultados dos módulos de deformação que serão utilizados em futuras análises numéricas.

Tabela 8.3- Resultados dos ensaios dos corpos-de-prova do painel H1-1a

\begin{tabular}{|c|c|c|c|c|c|c|}
\hline $\begin{array}{c}\text { Ensaios } \\
\text { (valores médios) }\end{array}$ & Argamassa & Prisma & Graute & Canaletas & $\begin{array}{c}\text { Concreto } \\
\text { base }\end{array}$ & $\begin{array}{c}\text { Concreto } \\
\text { topo }\end{array}$ \\
\hline Resistência (MPa) & 5,03 & 7,42 & 43,96 & 35,28 & 23,46 & 32,67 \\
\hline $\begin{array}{c}\text { Módulo de } \\
\text { deformação (MPa) }\end{array}$ & 8359 & -- & 24860 & -- & 27221 & 26949 \\
\hline
\end{tabular}

A força de ruptura do painel $\mathrm{H} 1$ com laje de topo (painel H1-1a), as tensões de ruptura calculadas por diferentes considerações e as estimativas das resistências da alvenaria estão na Tabela 8.4. Observa-se que a tensão de ruptura calculada adotando apenas a área da parede central $(12,19 \mathrm{MPa})$ é cerca de $63 \%$ superior à resistência à compressão da alvenaria obtida nos ensaios de caracterização $(7,49 \mathrm{MPa})$ e $158 \%$ superior à previsão da resistência da alvenaria por meio dos ensaios de prismas $(4,73)$. Já a tensão de ruptura determinada considerando toda a área do painel (4,56 $\mathrm{MPa})$ é $40 \%$ inferior ao valor do ensaio de caracterização $(7,49 \mathrm{MPa})$ e apenas $4 \%$ inferior ao valor estimado pela resistência dos prismas (4,73MPa). Então, pode-se concluir que neste caso, em que está presente a laje de topo, a resistência do painel não é limitada apenas pela capacidade da parede central, mas que os flanges também contribuem para 
a resistência final do painel, apesar do carregamento ser aplicado somente na região correspondente à alma do painel.

Tabela 8.4 - Resultados do ensaio do Painel H1-1 a

\begin{tabular}{|c|c|c|c|c|}
\hline $\begin{array}{c}\text { Força de } \\
\text { Ruptura } \\
\text { (kN) }\end{array}$ & $\begin{array}{l}\text { Tensão de } \\
\text { ruptura }{ }^{1)} \\
\text { (MPa) }\end{array}$ & $\begin{array}{l}\text { Tensão de } \\
\text { ruptura } \\
\text { (MPa) }\end{array}$ & $\begin{array}{l}\text { Resistência da } \\
\text { alvenaria }^{3)} \\
\text { (MPa) }\end{array}$ & $\begin{array}{l}\text { Previsão da } \\
\text { resistência da } \\
\text { alvenaria }{ }^{4)} \\
\text { (MPa) }\end{array}$ \\
\hline 166,18 & 12,19 & 4,56 & 7,49 & 4,73 \\
\hline \multicolumn{5}{|c|}{$\begin{array}{l}\text { 1) Tensão considerando apenas a área da parede central em planta; } \\
\text { 2) Tensão considerando a área de todo o painel em planta; } \\
\text { 3) Resistência obtida nos ensaios de paredinhas (ensaios de caracterização); } \\
\text { 4) Previsão da resistência da alvenaria considerando a eficiência entre as resistências da paredinha } \\
\text { prismas obtida nos ensaios de caracterização }(0,637) \text {. } \\
\text { Obs: Todas as resistências e tensões são relacionadas à área bruta. }\end{array}$} \\
\hline
\end{tabular}

As formas de ruptura do painel H1 com a presença da laje de topo (painel H11a) estão ilustradas na Figura 8.11. As primeiras fissuras percebidas nos ensaios, para uma força aplicada acima de $100 \mathrm{kN}$, são inclinadas e próximas à interseção, indicando o cisalhamento. Até um carregamento de $120 \mathrm{kN}$, há uma forte propagação dessas fissuras inclinadas ao longo da altura, havendo depois uma estabilização da fissuração até próximo de $140 \mathrm{kN}$. A partir desse ponto começam a surgir fissuras verticais na parede central que são típicas de compressão. Desse modo, com o aumento da força atuante, ocorre a ruptura por compressão da parede central e conseqüentemente do painel. Na ruptura também aparecem fissuras horizontais nos flanges originadas da sua flexão.
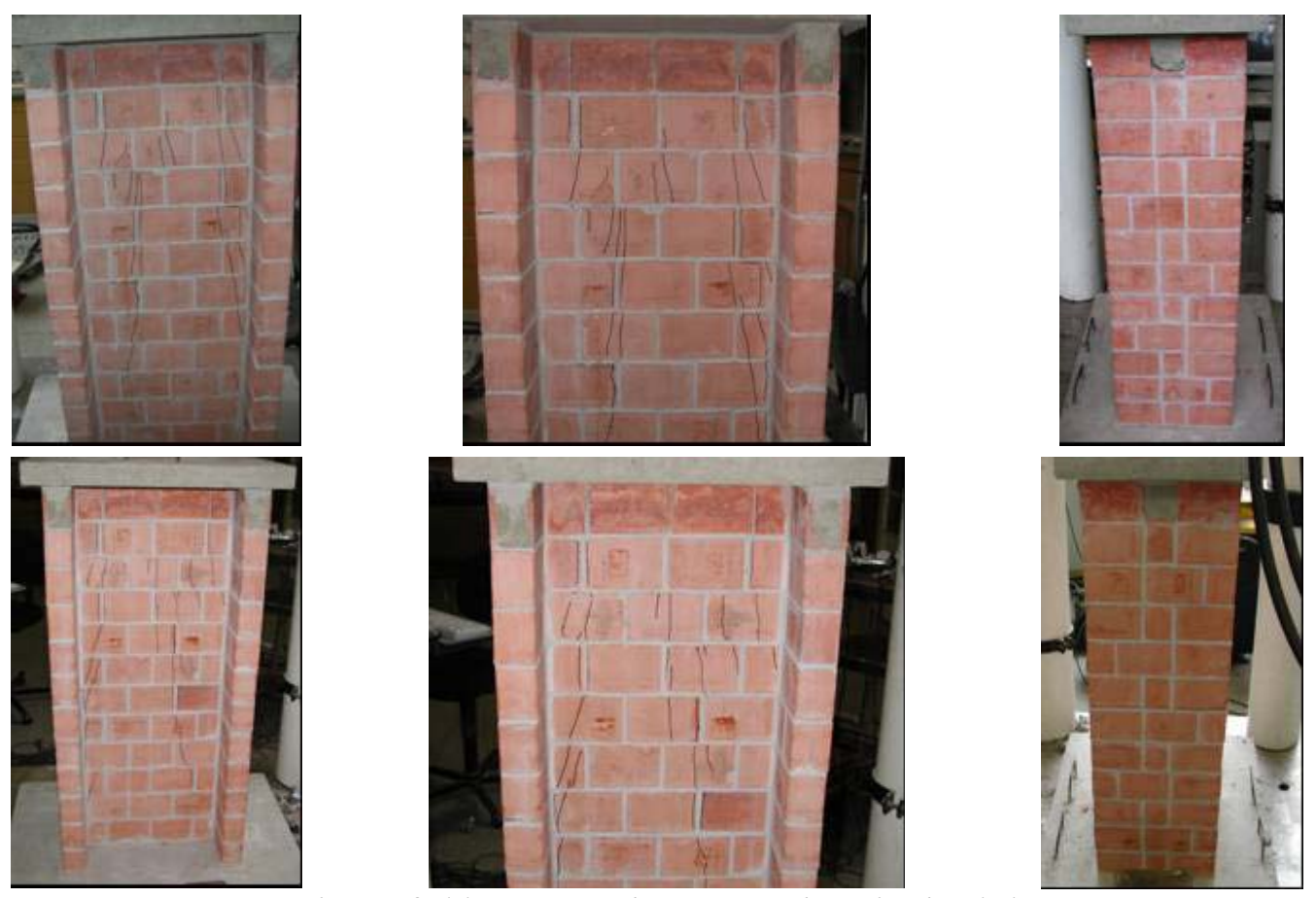

Figura 8.11 - Forma de ruptura do painel H1-1a 
De maneira análoga ao painel anterior, constrói-se um gráfico força versus deformações das diferentes regiões da parede central e dos flanges (Figura 8.12). Percebe-se que as deformações na região superior da parede central (alma) são maiores que na região inferior, indicando uma transferência do carregamento da parede central para os flanges. Nota-se que as deformações nos flanges são um pouco superiores que a deformação da região inferior da parede central. Observa-se ainda que há uma perturbação nas deformações para uma força de 120 kN, o que gera um comportamento diferente entre os flanges e a parede central.

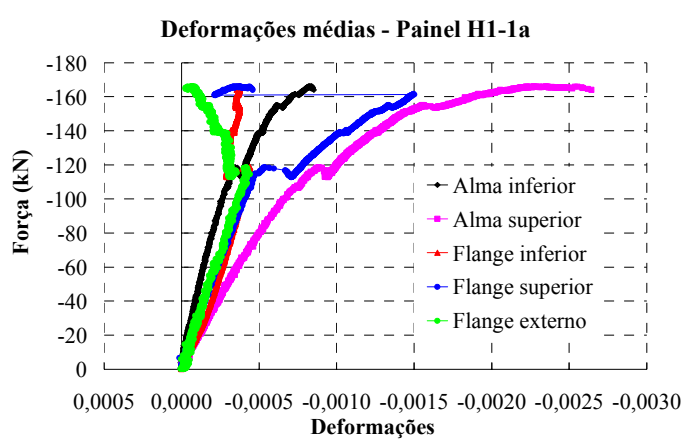

Figura 8.12 - Comportamento do painel H1-1a

A Figura 8.13 apresenta os trechos lineares (até 50\% da força de ruptura) das deformações da parede central e dos flanges separadamente. Similarmente ao item anterior, utiliza-se a inclinação das retas como forma de comparação. Neste caso, a inclinação da reta referente à região superior da parede central é cerca de $40 \%$ do valor correspondente à região inferior. Admitindo-se que o material está no regime elásticolinear e que não há variação das características mecânicas da alvenaria, pode-se dizer que a tensão atuante na região superior da alma é 2,5 vezes o valor da tensão na região inferior. Esse fato sugere mais uma vez a transferência do carregamento da parede central para os flanges. Nota-se, também, que as inclinações das retas relacionadas aos flanges são próximas, apontando que as tensões atuantes nas diferentes regiões dos flanges são similares.

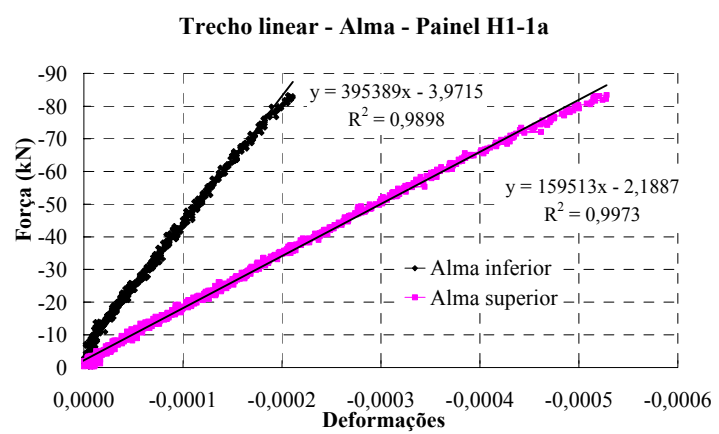

(a)

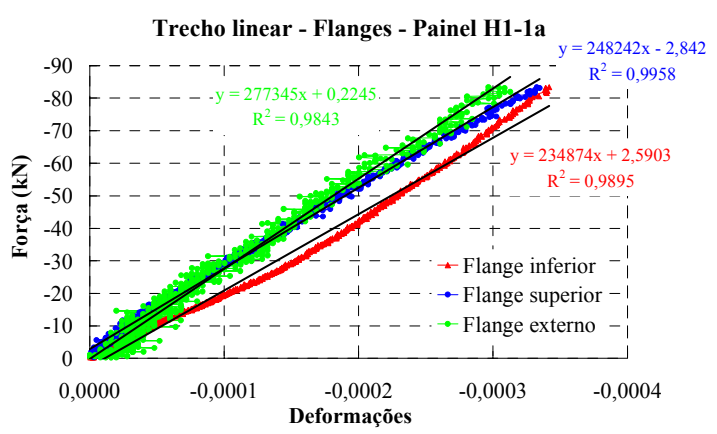

(b)

Figura 8.13 - Análise dos trechos lineares das deformações no painel H1-1a 


\subsection{5- Comparação dos resultados dos painéis H1 com e sem laje de topo}

A única diferença entre os painéis $\mathrm{H} 1$ é a presença ou não da laje no topo do painel. Conseqüentemente, uma comparação entre os resultados dos ensaios fornece a influência da presença da laje no comportamento do painel. A comparação das forças de ruptura dos painéis H1-1 (sem laje no topo) e H1-1a (com laje no topo) está na Tabela 8.5 , onde percebe-se que a laje promove um aumento de $37 \%$ na força de ruptura, mesmo tendo apresentado uma resistência de prisma 30\% inferior. No painel H1-1 (sem laje) a ruptura do painel ocorre quando o grau de fissuração da interseção das paredes é alto. Nesse instante há um alívio de forças nos flanges e apenas a parede central passa a resistir à força aplicada. Dessa forma, a resistência do painel H1-1 fica limitada à resistência da parede central. No Painel H1-1a (com laje) também ocorre um alto grau de fissuração na interseção das paredes. No entanto a laje de topo não permite o alívio total de força nos flanges, além de transmitir diretamente para eles uma parcela do carregamento. Com isso, a capacidade resistente do painel é composta pela capacidade da parede central mais a força transferida para os flanges.

Tabela 8.5 - Comparação das forças de ruptura dos painéis H1

\begin{tabular}{|c|c|c|}
\hline Tipo do painel & Força de ruptura (kN) & $\begin{array}{c}\text { Força Painel / Força } \\
\text { Painel H1-1 }\end{array}$ \\
\hline H1-1 (sem laje no topo) & 121,32 & 1,00 \\
\hline H1-1a (com laje no topo) & 166,18 & 1,37 \\
\hline
\end{tabular}

Observa-se na Figura 8.14 que a presença da laje de topo leva a modificações na forma de ruptura do painel. No painel H1-1 (sem laje) a fissuração ocorre principalmente na região da interseção das paredes (Figura 8.14-a). Já no painel H1-1a (com laje), ocorrem fissuras verticais, que indicam a ruptura por compressão, além das fissuras na interseção da parede (Figura 8.14-b).

Verifica-se, também, que o comportamento global dos painéis H1-1 e H1-1a são semelhantes até aproximadamente a força de $100 \mathrm{kN}$ (Figura 8.15). A partir desse valor, no painel H1-1 ocorre um alívio de forças nos flanges, culminando na ruptura do painel para uma força de $122 \mathrm{kN}$ (Figura 8.15-a). Já no painel H1-1a (com laje) ocorre uma perturbação quando o carregamento atinge os $120 \mathrm{kN}$. No entanto, o painel continua a resistir até os $166 \mathrm{kN}$ (Figura 8.15-b). Observa-se, também, que as deformações nos flanges externo e inferior permanecem ao final praticamente constantes, enquanto no flange superior continua a ocorrer o acréscimo das deformações. 


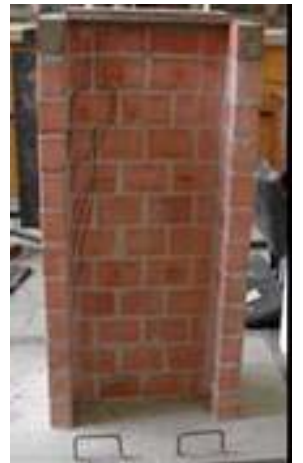

(a) Painel H1-1

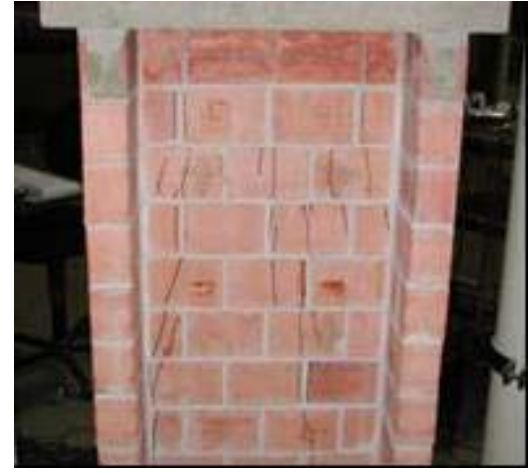

(b) Painel H1-1a

Figura 8.14 - Comparação das formas de ruptura dos painéis H1-1 e H1-1a

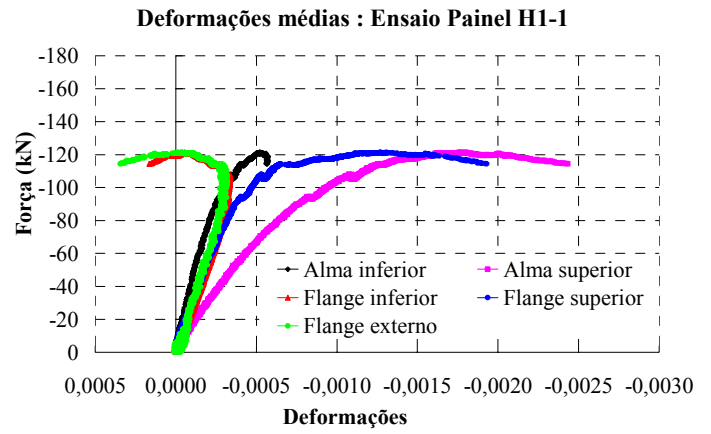

(a)

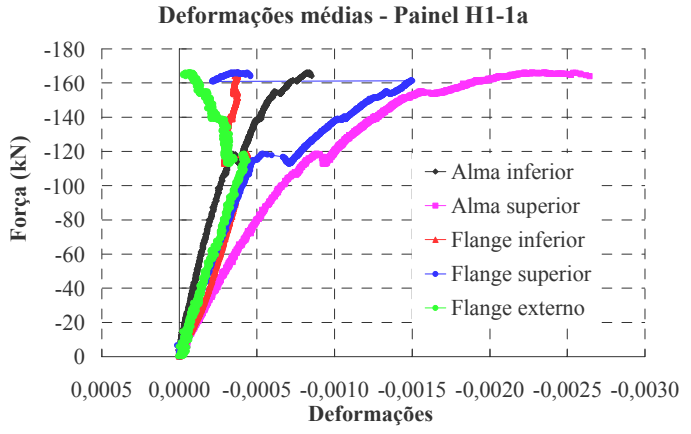

(b)

Figura 8.15 - Comparação dos comportamentos dos painéis H1

Comparando-se, na Figura 8.16, os trechos lineares das deformações da parede central dos painéis H1-1 (sem laje) e H1-1a (com laje) observa-se uma grande semelhança dos seus comportamentos. As diferenças nas inclinações das retas são inferiores a 13\%, o que sugere que a influência da laje seja pequena para baixos carregamentos. Por meio da Figura 8.17, que apresenta os trechos lineares das deformações dos flanges dos dois painéis, também é possível chegar à mesma conclusão.

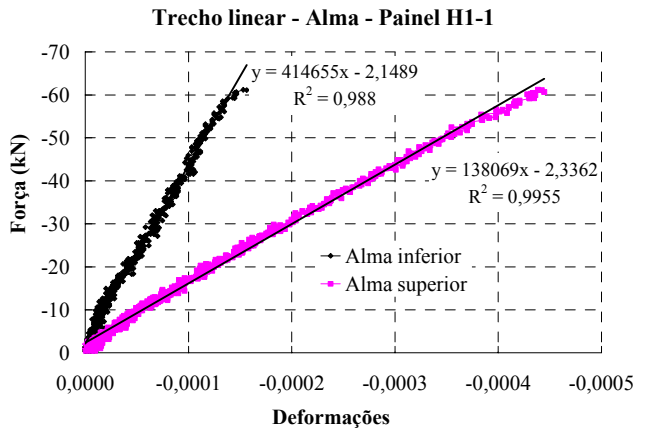

(a)

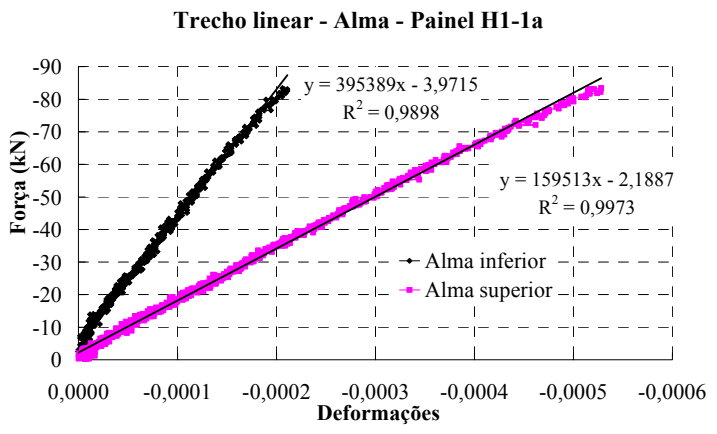

(b)

Figura 8.16 - Comparação das deformações na parede central dos painéis H1 


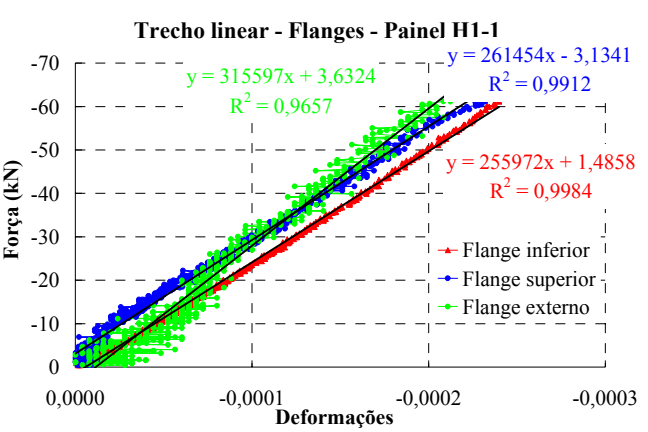

(a)

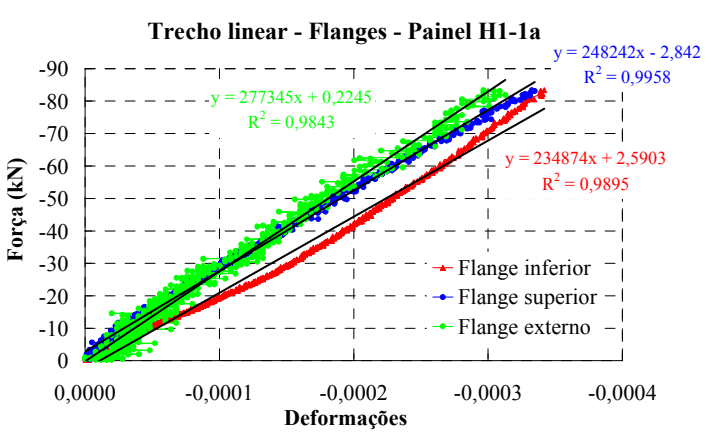

(b)

Figura 8.17 - Comparação das deformações nos flanges dos painéis H1

Neste caso, com base nas comparações feitas, pode-se concluir que a contribuição da laje no topo além de aumentar a capacidade máxima do painel, também prolonga o trecho de comportamento linear do material. Entretanto, são necessários mais ensaios para uma posição definitiva.

\subsection{6- Comparação dos resultados do painel H1-1 em escala reduzida (1:3) com os ensaios de painéis em escala natural de Capuzzo Neto (2000).}

Capuzzo Neto (2000) realizou ensaios de painéis $H$ de alvenaria estrutural de blocos cerâmicos em escala natural (capítulo 2). Lembra-se que as condições de carregamento e as dimensões do painel H1 em escala reduzida são definidas em função das dimensões desses ensaios. Portanto são painéis similares. Contudo, a disposição das fiadas possui uma diferença, pois no caso dos ensaios em escala natural existia o bloco de amarração (Figura 8.18-a).

Ressalta-se que os blocos cerâmicos utilizados por Capuzzo Neto (2000) não são do mesmo fabricante dos blocos utilizados nesta pesquisa. Entretanto, possuem as mesmas dimensões nominais, uma seção transversal semelhante e uma resistência à compressão um pouco inferior, cerca de $11 \mathrm{MPa}$ na área bruta (Figura 8.18).

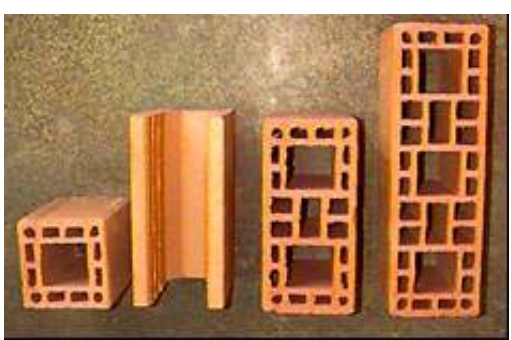

a) Blocos - Capuzzo Neto (2000)
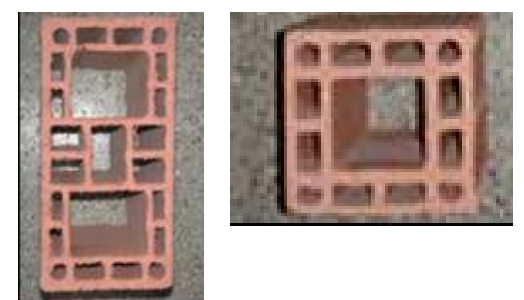

b) Blocos - pesquisa atual

Figura 8.18 - Comparação dos tipos de blocos

Os painéis tinham as bases todas apoiadas, sendo que o carregamento era aplicado apenas na parede central. Na Figura 8.19 apresenta-se novamente a 
instrumentação utilizada nos ensaios, onde se percebe a semelhança com a disposição dos transdutores nos modelos em escala reduzida (ver Figura 8.6). A principal diferença entre as instrumentações ocorre em relação à face externa dos flanges. Nos ensaios de Capuzzo Neto (2000) há transdutores em dois níveis ao longo da altura (trecho superior e inferior), enquanto que nos ensaios em modelos reduzidos há um único nível de transdutores, englobando os trechos superior e inferior. Outra diferença percebida é que nos painéis H1-1 em escala reduzida, devido ao pequeno espaço físico, há a necessidade de os transdutores referentes ao trecho superior da parede central serem deslocados um bloco na altura, fato desnecessário nos ensaios em escala natural.

Para realizar a comparação entre os resultados dos ensaios em escala natural (1:1) e do ensaio do painel H1-1 em escala reduzida (1:3) emprega-se a teoria de modelos físicos reduzidos. Contudo, os fatores de escala para este caso não são conhecidos, pois os blocos utilizados por Capuzzo Neto (2000) são diferentes da atual pesquisa. Porém, ao se utilizarem os fatores de escala referentes aos blocos reais dessa pesquisa e multiplicá-los pelos resultados do painel H1-1 em escala reduzida obtém-se, teoricamente, o comportamento de um painel H1-1 na escala (1:1). Desse modo, é possível realizar uma comparação dos resultados dos ensaios dos painéis de Capuzzo Neto (2000) com o resultado do painel H1-1 na escala (1:1), determinado pela teoria dos modelos reduzidos. Assim, a principal diferença entre os dois painéis é que os blocos possuem propriedades mecânicas diferentes.

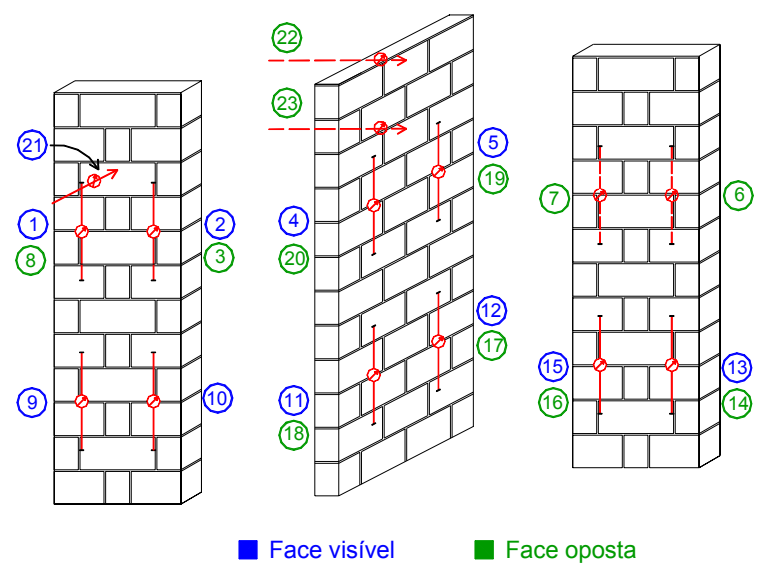

Figura 8.19 - Instrumentaçấo utilizada por Capuzzo Neto (2000)

Para a obtenção do comportamento do painel H1 na escala natural (1:1) os valores obtidos no modelo reduzido serão multiplicados pelos fatores de escala. No caso de medidas relacionadas ao comprimento, o fator $\left(\mathrm{s}_{\mathrm{L}}\right)$ é direto e igual a 3. Para as deformações e tensões utilizam-se o valores obtidos nos ensaios de caracterização de 
compressão normal à junta de assentamento, $\mathrm{s}_{\varepsilon}=0,59$ e $\mathrm{s}_{\sigma}=0,48$ respectivamente. Já $\mathrm{o}$ fator de escala para força $\left(\mathrm{s}_{\mathrm{F}}\right)$ é dado pela relação $\mathrm{s}_{\mathrm{F}}=\mathrm{s}_{\sigma} \cdot \mathrm{s}_{\mathrm{L}}^{2}$, que é igual a 4,32.

A Tabela 8.6 apresenta uma comparação das forças de ruptura e das resistência à compressão dos prismas de três blocos entre o painel H1-1, transformado por meio dos fatores de escala para a escala natural (1:1), e o valor médio dos ensaios da série 1 de Capuzzo Neto (2000). Observa-se que a força de ruptura nos dois casos é bastante próxima, com uma diferença inferior a 3\%. Nota-se, também, que a resistência dos prismas de Capuzzo Neto (2000) é cerca de 12\% superior. Portanto, estão dentro da faixa de variação obtida usualmente para estruturas de alvenaria estrutural.

Tabela 8.6 - Comparação entre o painel H1-1 na escala (1:1) e os painéis de Capuzzo Neto (2000)

\begin{tabular}{|c|c|c|}
\hline Tipo & Força de Ruptura (kN) & Resistência dos prismas (MPa) \\
\hline Painel H1-1 escala (1:1) & $524,1^{*}$ & $4,99^{*}$ \\
\hline $\begin{array}{c}\text { Painéis Série 1- } \\
\text { Capuzzo Neto (2000) }\end{array}$ & 510,0 & 5,60 \\
\hline${ }^{*}$ Resultado obtido pela multiplicação do resultado do ensaio na escala (1:3) pelos fatores de escala \\
\hline
\end{tabular}

As formas de ruptura do painel H1-1 em escala reduzida e dos painéis da série 1 de Capuzzo Neto (2000) também são semelhantes como pode ser visto na Figura 8.20, com fissuras ao longo da altura na região da interseção da parede central com os flanges.

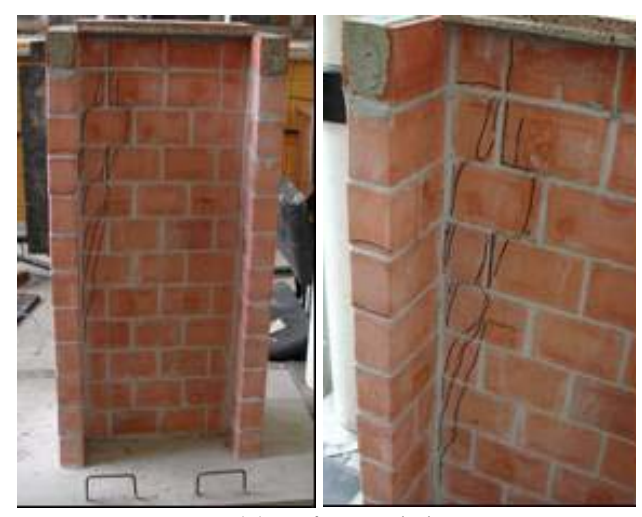

(a) Painel H1-1

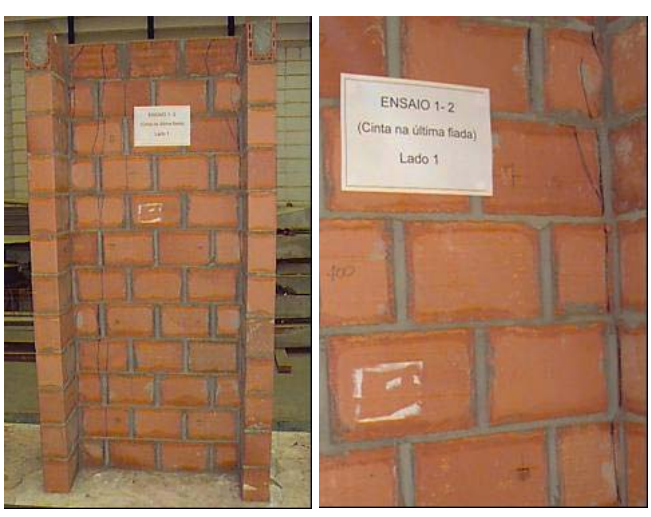

(b) Painel Série 1

Figura 8.20 - Comparação das formas de ruptura

Ainda são realizadas as comparações das evoluções das deformações na parede central (Figura 8.21-a e -b) e nos flanges (Figura 8.21-c e -d). Lembra-se que não é possível fazer a comparação das medidas relacionadas ao flange externo e que há uma pequena diferença no posicionamento dos transdutores na região superior da parede central. Ressalta-se, também, que no caso dos ensaios de Capuzzo Neto (2000) os 
transdutores são retirados antes da ruptura dos painéis. Portanto não há leituras que representem sua ruína.

Observa-se, na Figura 8.21-a, que a tendência do comportamento da parede central na região superior é bem próxima para todos os casos. Já para a região inferior (Figura 8.21-b), apenas o painel em tamanho natural série 1-3 se aproxima do comportamento do painel H1-1 transformado para a escala natural (1:1). Em relação aos flanges (Figura 8.21-c e d), nota-se um comportamento praticamente idêntico em grande parte do carregamento, inclusive na região do flange inferior, em que os painéis série 11 e série 1-3 apresentam uma tendência de inversão das deformações também registrada no caso do painel H1-1.

Desse modo, conclui-se que o painel H1-1 na escala (1:3) é capaz de representar bem o comportamento e, até mesmo, a ruptura de um painel em escala natural (1:1).

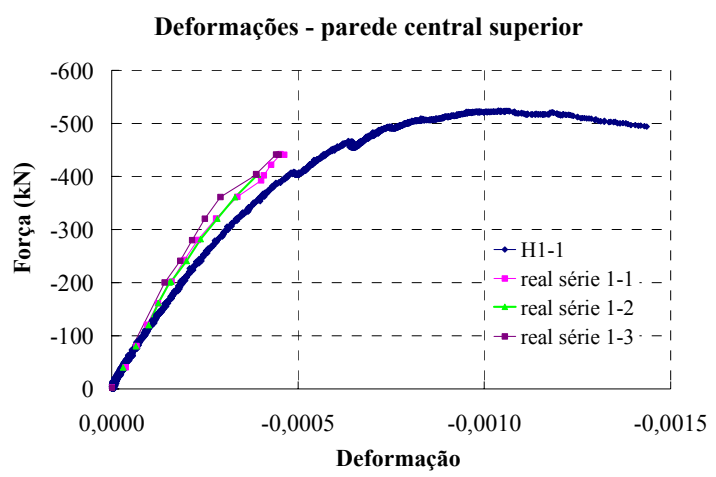

(a)

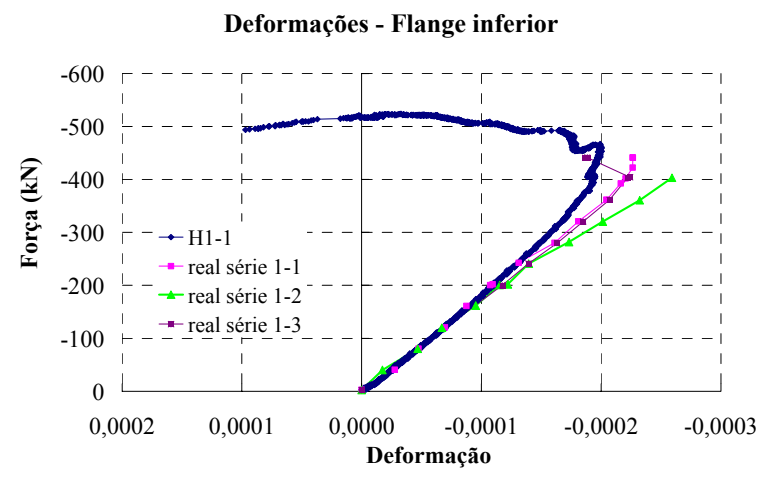

(c)

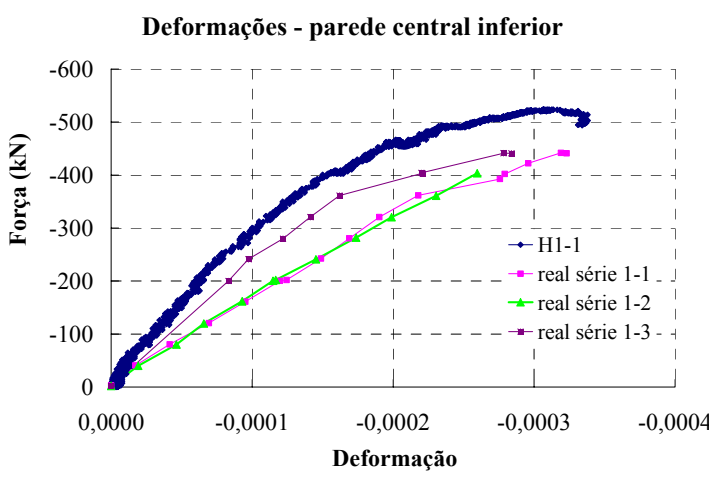

(b)

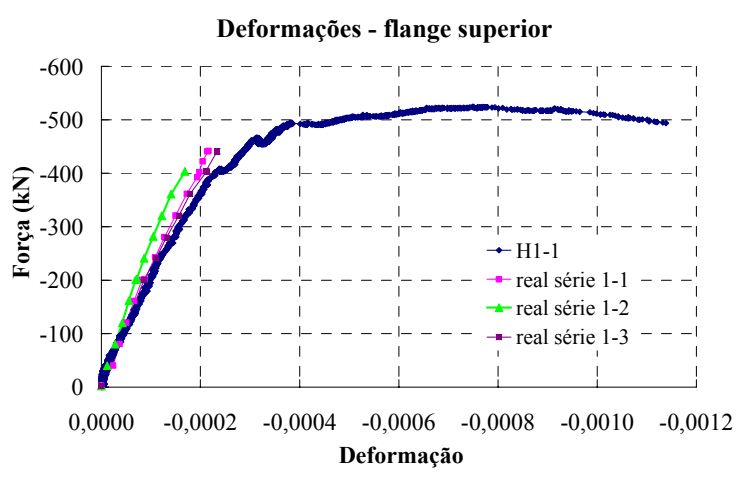

(d)

Figura 8.21 - Comparação das deformaçães da parede central e dos flanges

\section{3- Ensaios dos painéis em escala reduzida tipo $\mathrm{H2}$}

Além do painel H1 apresentado no item anterior, ensaia-se um segundo caso que é o do painel H2, também analisado no capítulo 6, sendo que os exemplares são novamente em escala reduzida (1:3). O objetivo deste ensaio é comprovar que a uniformização das tensões não ocorre em um único pavimento, assim o carregamento é 
aplicado apenas na região da parede central. Além da cinta de respaldo presente em todos os painéis, estuda-se o efeito da cinta intermediária, pois, neste caso, a transferência de força se dá ao longo de toda a altura do painel; dessa forma, a presença dessa cinta pode ter um efeito benéfico. Similarmente ao painel H1, investiga-se o efeito da presença de uma laje no topo do painel (Figura 8.22). Dessa maneira, são ensaiados no total quatro painéis do tipo H2. Ressalta-se que não serão realizados ensaios de painéis com formato em " $Z$ ", por se acreditar que a excentricidade do carregamento leve a dificuldades na condução do ensaio.

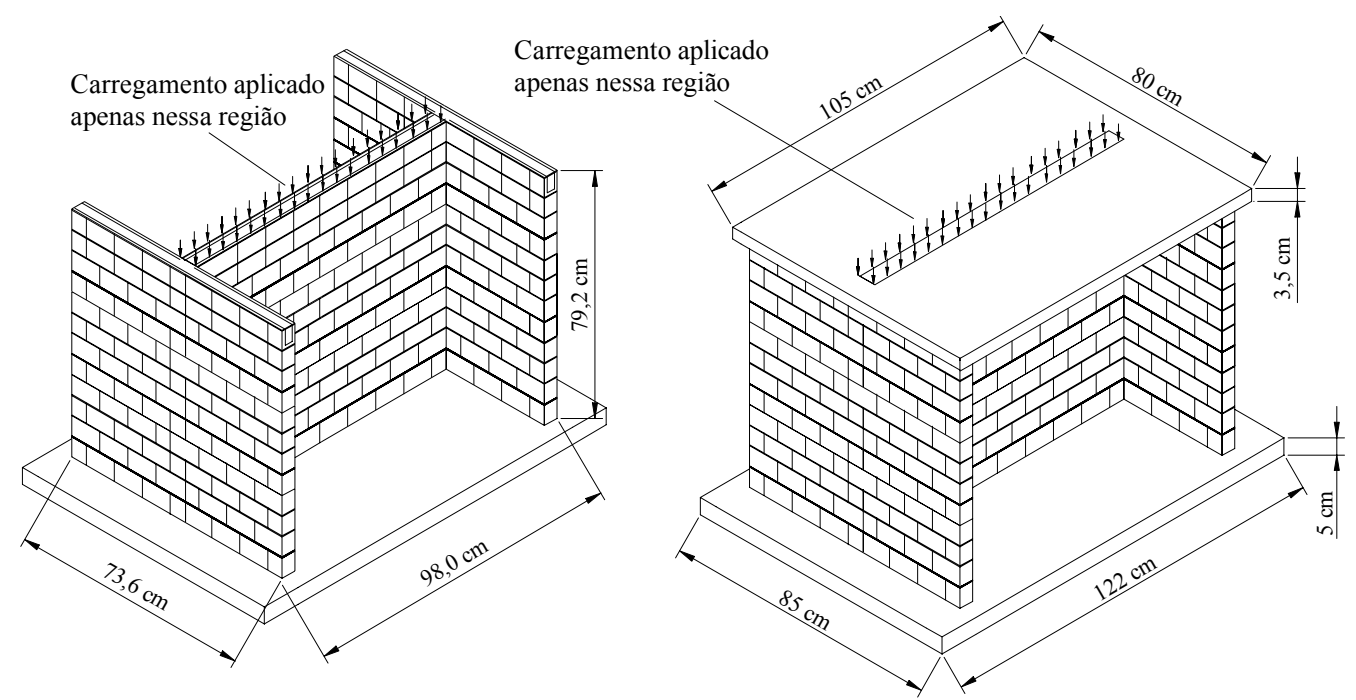

Figura 8.22 - Painéis H2 com e sem laje no topo

\subsection{1- Modo de execução dos painéis}

- Procedimentos:

Nas figuras 8.23 e 8.24 estão apresentadas a geometria, as dimensões e a disposição das fiadas das diferentes configurações dos painéis H2. Eles são construídos sobre uma laje de concreto com $5 \mathrm{~cm}$ de altura para permitir o transporte para o local de ensaio. Nessa laje é utilizada uma armadura dupla de barras de aço CA $50 \mathrm{com} 5 \mathrm{~mm}$ de diâmetro, com espaçamento máximo de $9,5 \mathrm{~cm}$, que dá uma taxa de armadura de 2,4 $\mathrm{cm}^{2} / \mathrm{m}$ (Figura 8.25-a). Novamente é uma taxa de armadura bem superior à necessária. O concreto utilizado é o mesmo das lajes anteriores, o traço em massa de 1:1,94:2,06 (cimento;areia;pedrisco) com relação água/cimento igual a 0,65. Retiram-se três corposde-prova cilíndricos $(5 \mathrm{~cm} \times 10 \mathrm{~cm})$ para controle de sua resistência. 


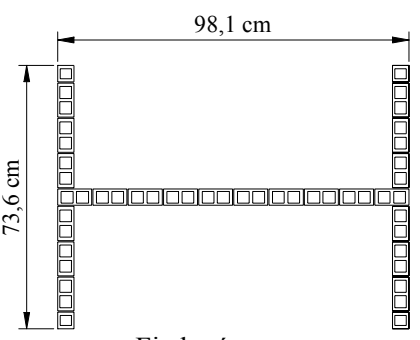

Fiadas ímpares

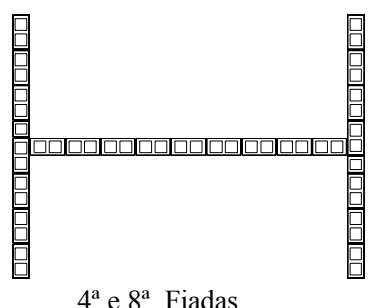

$4^{\mathrm{a}}$ e $8^{\mathrm{a}}$ Fiadas

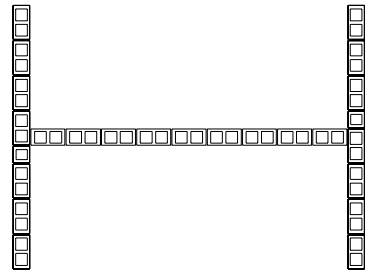

$2^{\mathrm{a}}, 6^{\mathrm{a}}$ e $10^{\mathrm{a}}$ Fiadas

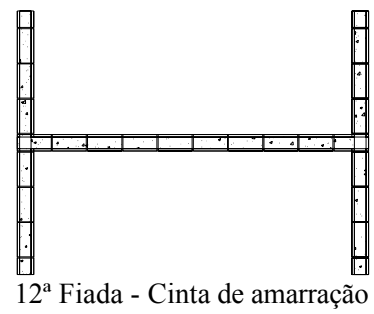

Cinta de respaldo

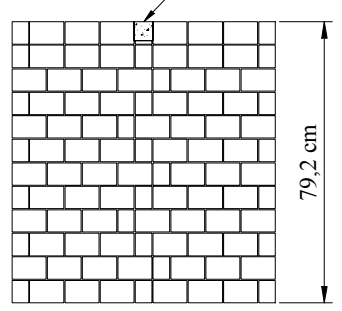

Vista lateral

Cinta de respaldo

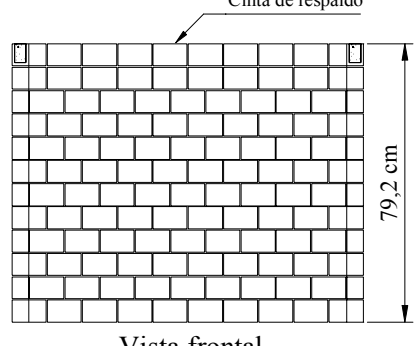

Vista frontal

Figura 8.23 - Painéis H2 apenas com cinta de amarração no topo

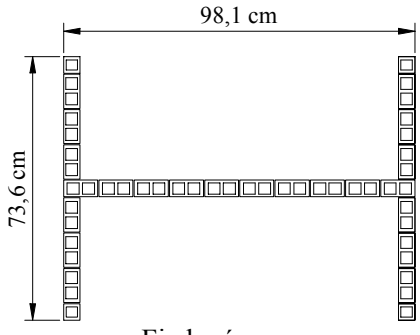

Fiadas ímpares

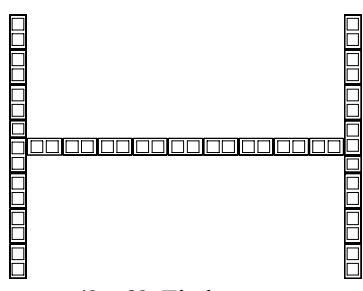

$4^{\mathrm{a}}$ e $8^{\mathrm{a}}$ Fiadas

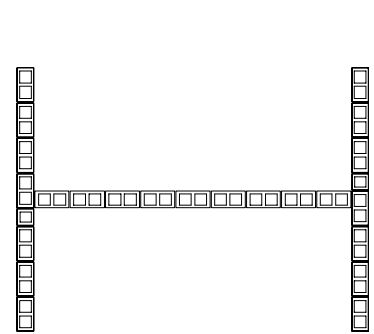

$2^{\mathrm{a}}$ e $10^{\mathrm{a}}$ Fiadas

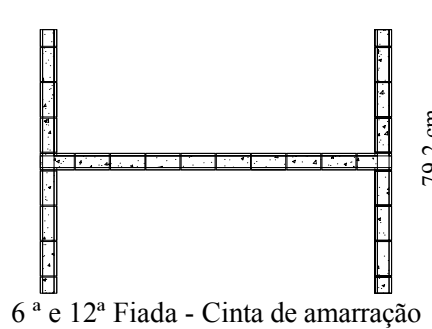

Cinta de respaldo

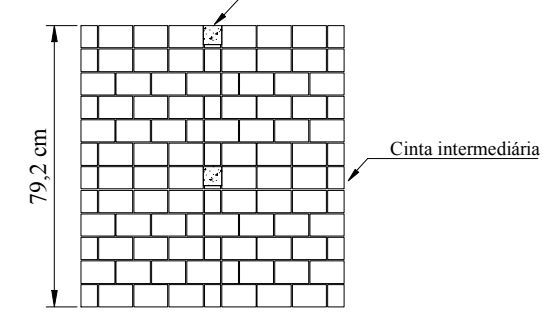

Vista lateral

Cinta de respaldo

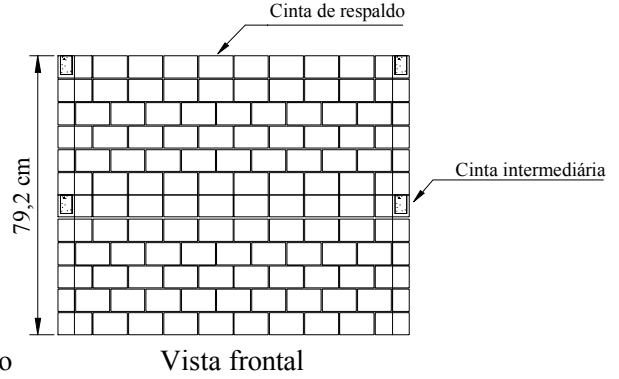

Figura 8.24 - Painéis H2 apenas com cinta de amarração intermediária e no topo

Similarmente ao painel H1, a laje no topo possui dimensões diferentes da laje de base, possuindo uma altura de $3,5 \mathrm{~cm}$ (Figura 8.22). Isto acontece porque a intenção é representar uma laje com espessura usual em escala natural, com cerca de 10,5 cm de altura. Também se utiliza uma taxa de armadura mais baixa em ambas as faces $(0,98$ $\mathrm{cm}^{2} / \mathrm{m}$ ), que é obtida pelo uso de tela soldada com fio de $2,5 \mathrm{~mm}$ e malha quadrada de 5 $\mathrm{cm}$. O concreto empregado é o mesmo da laje de base.

A execução e os procedimentos utilizados na construção dos painéis H2 são semelhantes aos empregados na construção dos corpos-de-prova de cisalhamento e dos painéis H1. A principal diferença na construção é a utilização de uma régua, que une os 
dois gabaritos, compatível com a dimensão da parede central. Os traços e os materiais da argamassa e do graute também são os mesmos. Cada produção de argamassa é dimensionada para assentar quatro fiadas, construir dois prismas de três blocos e três corpos-de-prova cilíndricos de $5 \mathrm{~cm} \times 10 \mathrm{~cm}$.

No grauteamento das cintas dos painéis H2, recolhem-se seis corpos-de-prova cilíndricos de $5 \mathrm{~cm} \times 10 \mathrm{~cm}$ e preenchem-se seis blocos canaleta para controle de resistência. A armadura da cinta de amarração também é uma barra de aço CA 60 de 4,2mm. A Figura 8.25 mostra algumas etapas da construção dos painéis H2, bem como uma visão geral dos exemplares construídos. Ressalta-se que na construção dos painéis H2 com cintas intermediárias, o gabarito não é movimentado para que se evite qualquer descontinuidade (Figura 8.25-g).

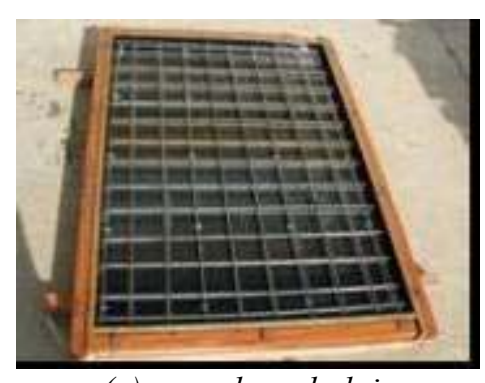

(a) armadura da laje

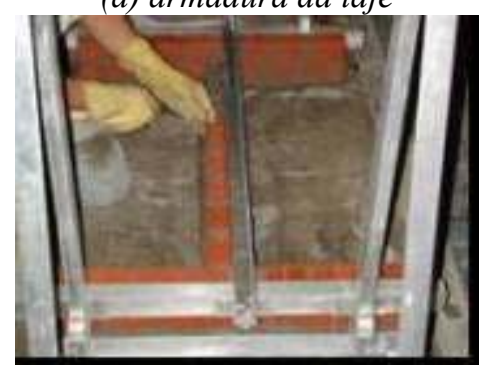

(d) utilização

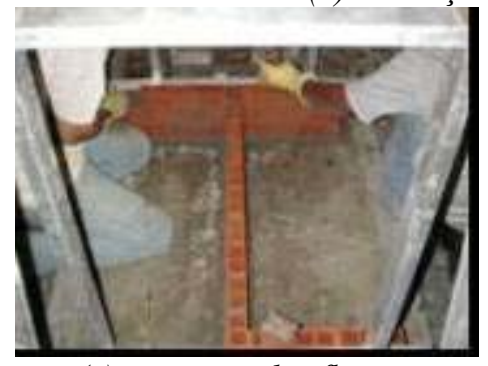

(e) execução dos flanges

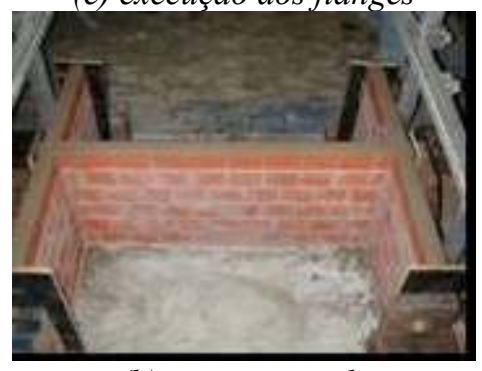

(h) cinta grauteda

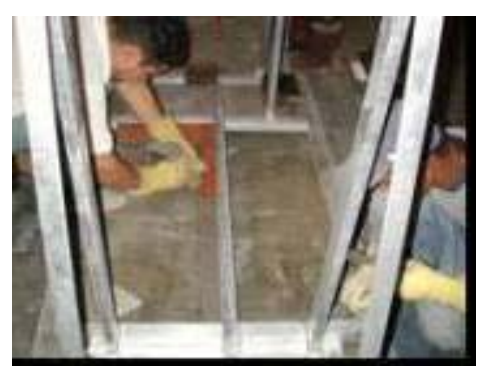

(b) assentamento $1^{a}$ fiada

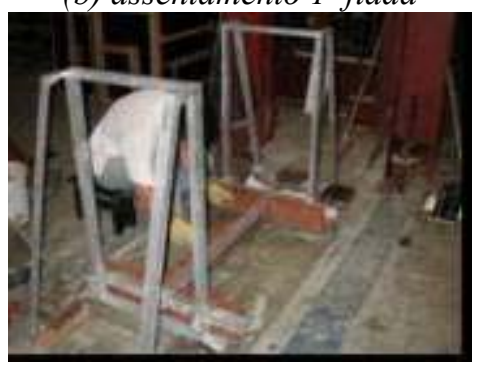

do gabarito para a construção da parede central

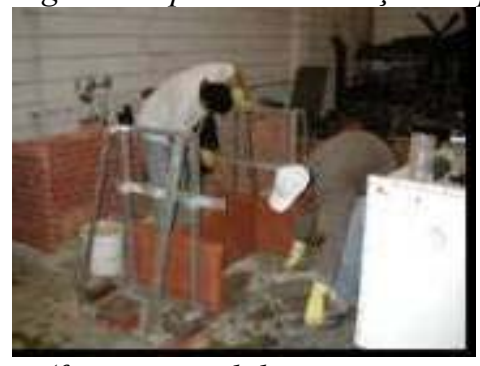

(f) visão geral da construção

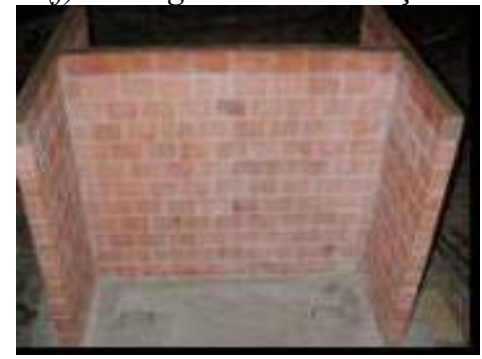

(i) painel H2 com cinta de topo

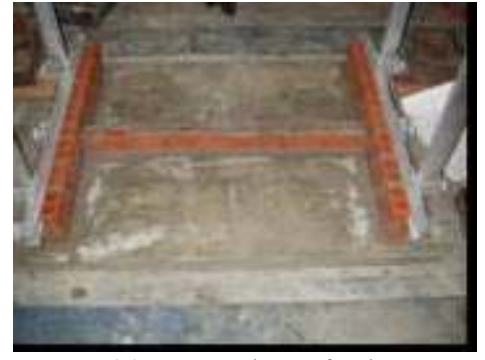

(c) início da $2^{a}$ fiada
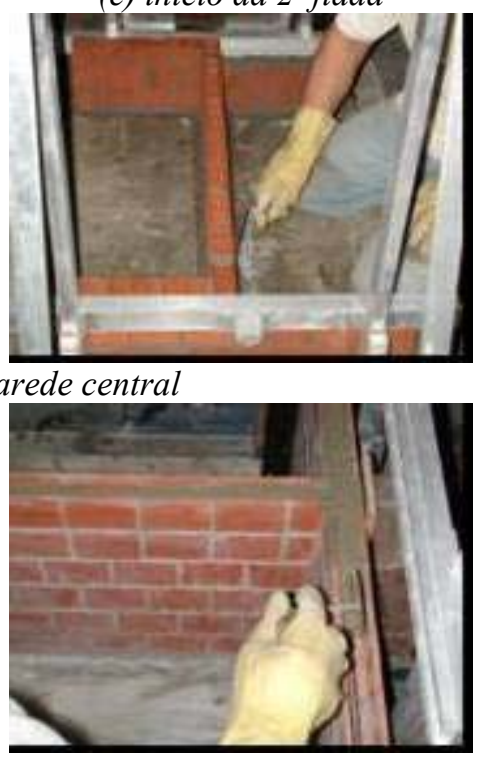

(g) grauteamento da cinta

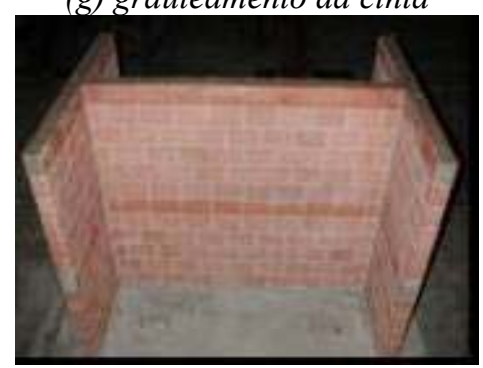

(j) Painel H2 com 2 cintas

Figura 8.25 - Execução dos painéis H2 


\subsection{2- Procedimentos e equipamentos utilizados nos ensaios}

- Procedimentos:

Os procedimentos são idênticos ao apresentado para o painel H1, item 8.2.2.

- Equipamentos:

Devido às maiores dimensões externas dos painéis H2, eles são ensaiados utilizando-se pórticos de reação e um atuador hidráulico servo-controlado da marca INSTRON, com capacidade máxima de $500 \mathrm{kN}$, que também permite a aplicação do carregamento através de controle de deslocamento do pistão. Desse modo, há uma melhor condição de ensaio, principalmente de segurança em relação a uma ruptura frágil. $\mathrm{O}$ carregamento é inicialmente aplicado de maneira que o pistão se desloque a $0,01 \mathrm{~mm} / \mathrm{s}$, reduzindo até $0,001 \mathrm{~mm} / \mathrm{s}$ quando próximo à ruptura. Para a distribuição da força sobre a parede central se utiliza um perfil metálico.

Novamente a instrumentação empregada permite avaliar as deformações das diferentes paredes em dois níveis, na metade superior e inferior do painel (Figura 8.26). Também são controlados os deslocamentos horizontais da parede central e dos flanges. Ressalta-se que a instrumentação é a mesma para todos os ensaios. São utilizados os mesmos transdutores e a mesma quantidade dos ensaios dos painéis H1. Observa-se que, neste caso, não há a necessidade da defasagem entre os transdutores da região superior da parede central. Para o registro automático dos dados utiliza-se o sistema de aquisição SYSTEM 500.

Para facilitar a desenvoltura do texto são utilizadas denominações para os painéis H2 ensaiados, que estão indicadas na Tabela 8.7.

Tabela 8.7 - Denominaç̃̃es dos painéis H2

\begin{tabular}{|c|c|c|c|}
\hline Painel & $\begin{array}{c}\text { Cinta de amarração } \\
\text { no topo }\end{array}$ & $\begin{array}{c}\text { Cinta de amarração } \\
\text { intermediária }\end{array}$ & Laje no topo \\
\hline Painel H2-1 & Sim & Não & Não \\
\hline Painel H2-1a & Sim & Não & Sim \\
\hline Painel H2-2 & Sim & Sim & Não \\
\hline Painel H2-2a & Sim & Sim & Sim \\
\hline
\end{tabular}




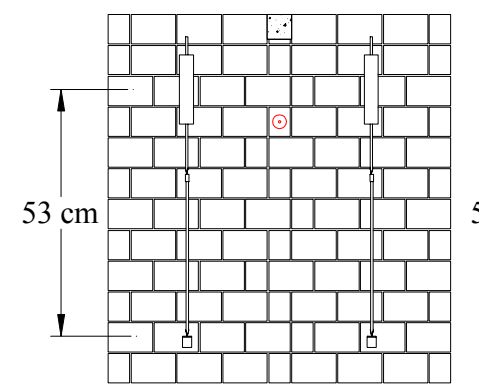

Flanges
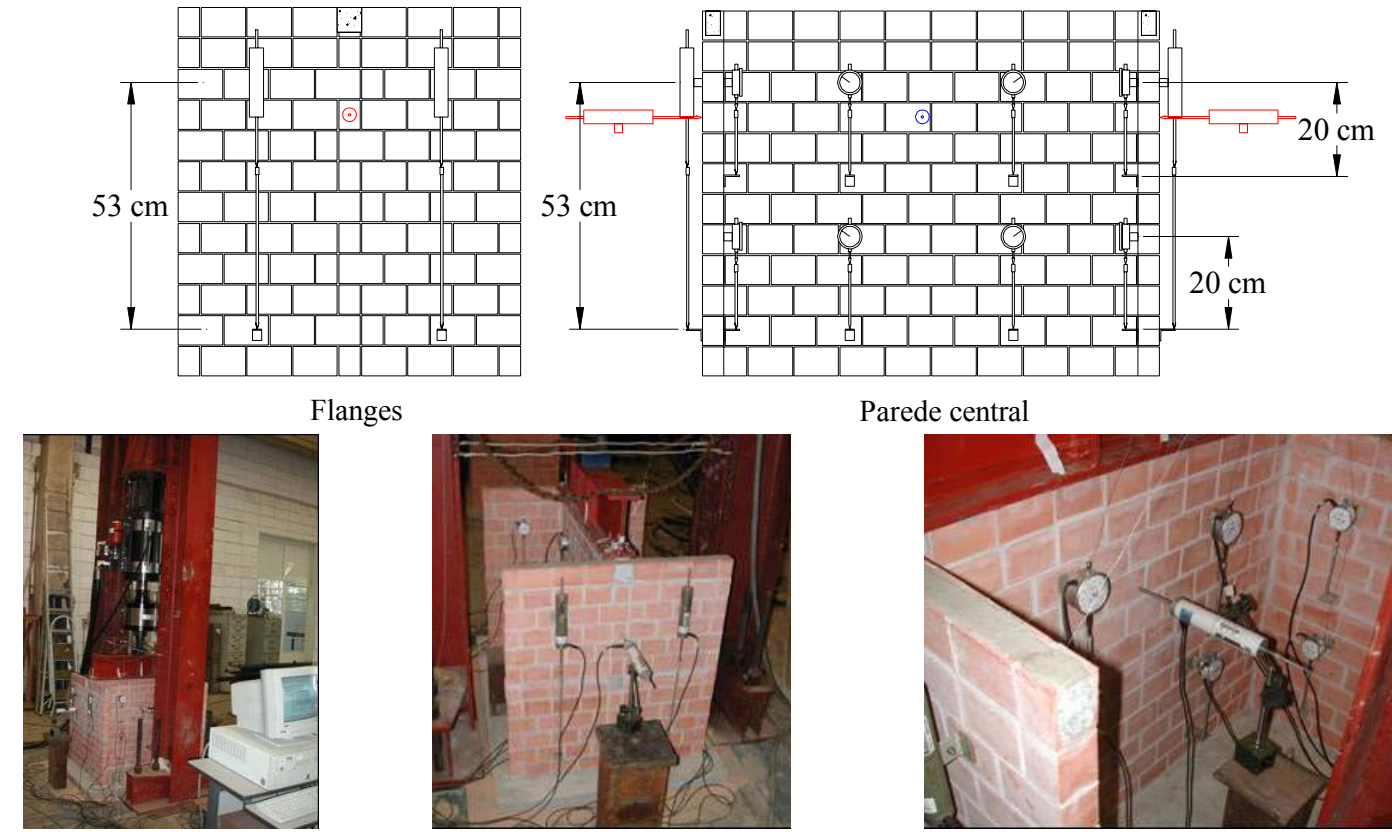

Parede central

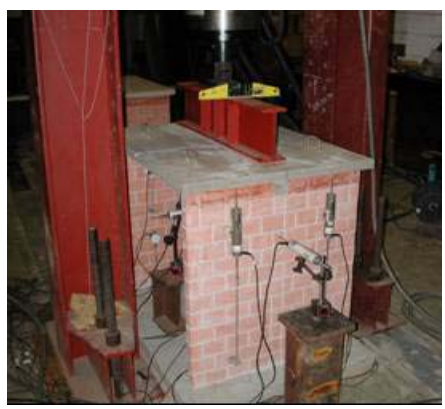

Figura 8.26 - Esquema e instrumentação dos ensaios dos painéis H2

\subsection{3- Resultados do painel $\mathrm{H} 2$ com cinta de respaldo e sem laje de topo (Painel} H2-1)

Os valores médios da resistência e do módulo de deformação dos corpos-deprova referentes ao painel H2-1 estão apresentados na Tabela 8.8. Observa-se que os resultados estão dentro da faixa de valores encontrados anteriormente.

Tabela 8.8 - Resultados dos ensaios dos corpos-de-prova do painel H2-1

\begin{tabular}{|c|c|c|c|c|c|}
\hline $\begin{array}{c}\text { Ensaios } \\
\text { (valores médios) }\end{array}$ & Argamassa & Prisma & Graute & Canaletas & $\begin{array}{c}\text { Concreto } \\
\text { base }\end{array}$ \\
\hline Resistência (MPa) & 6,56 & 10,72 & 53,58 & 50,00 & 40,68 \\
\hline $\begin{array}{c}\text { Módulo de } \\
\text { deformação (MPa) }\end{array}$ & 10129 & -- & 29090 & -- & 25720 \\
\hline
\end{tabular}

$\mathrm{Na}$ Tabela 8.9 apresentam-se a força de ruptura do painel H2-1, as estimativas da tensão de ruptura e da resistência da alvenaria. A tensão de ruptura calculada com apenas a área da parede central $(8,88 \mathrm{MPa})$ é cerca de $18 \%$ superior à resistência da alvenaria no ensaio de paredinhas $(7,49 \mathrm{MPa})$ e 30\% superior à estimativa da resistência da alvenaria considerando as resistências dos prismas (6,83 MPa). Já a tensão de ruptura 
calculada considerando toda a área do painel $(3,33 \mathrm{MPa})$ é muito inferior a qualquer das previsões de resistência da alvenaria. Com isso, pode-se concluir que a capacidade do painel está limitada à resistência da parede central, com uma pequena contribuição dos flanges. Observa-se que é a mesma conclusão obtida no ensaio do painel H1-1, além do que, as tensões de ruptura em relação à parede central são praticamente idênticas nos dois casos.

Tabela 8.9 - Resultados do painel H2-1

\begin{tabular}{|c|c|c|c|c|}
\hline $\begin{array}{c}\text { Força de } \\
\text { Ruptura }(k N)\end{array}$ & ${ }^{1)}$ & & $\begin{array}{l}\text { la da } \\
\text { ia } 3) \\
\text { ) } \\
\end{array}$ & $\begin{array}{l}\text { Pre } \\
\text { resist }\end{array}$ \\
\hline & & & & \\
\hline \multicolumn{5}{|c|}{$\begin{array}{l}\text { a; } \\
\text { iterização); } \\
\text { a. entre as resistências da paredinha e prismas }\end{array}$} \\
\hline
\end{tabular}

As formas de ruptura do painel H2-1 estão ilustradas na Figura 8.27. Observa-se um alto grau de fissuração ao longo da altura da parede central na região da interseção das paredes, com fissuras inclinadas através dos blocos e fissuras escalonadas nas juntas de argamassa, indicando o cisalhamento. Na região superior dos flanges, aparecem fissuras horizontais ao longo das juntas de assentamento e algumas fissuras verticais na interface bloco-argamassa, o que indica a flexão deles.
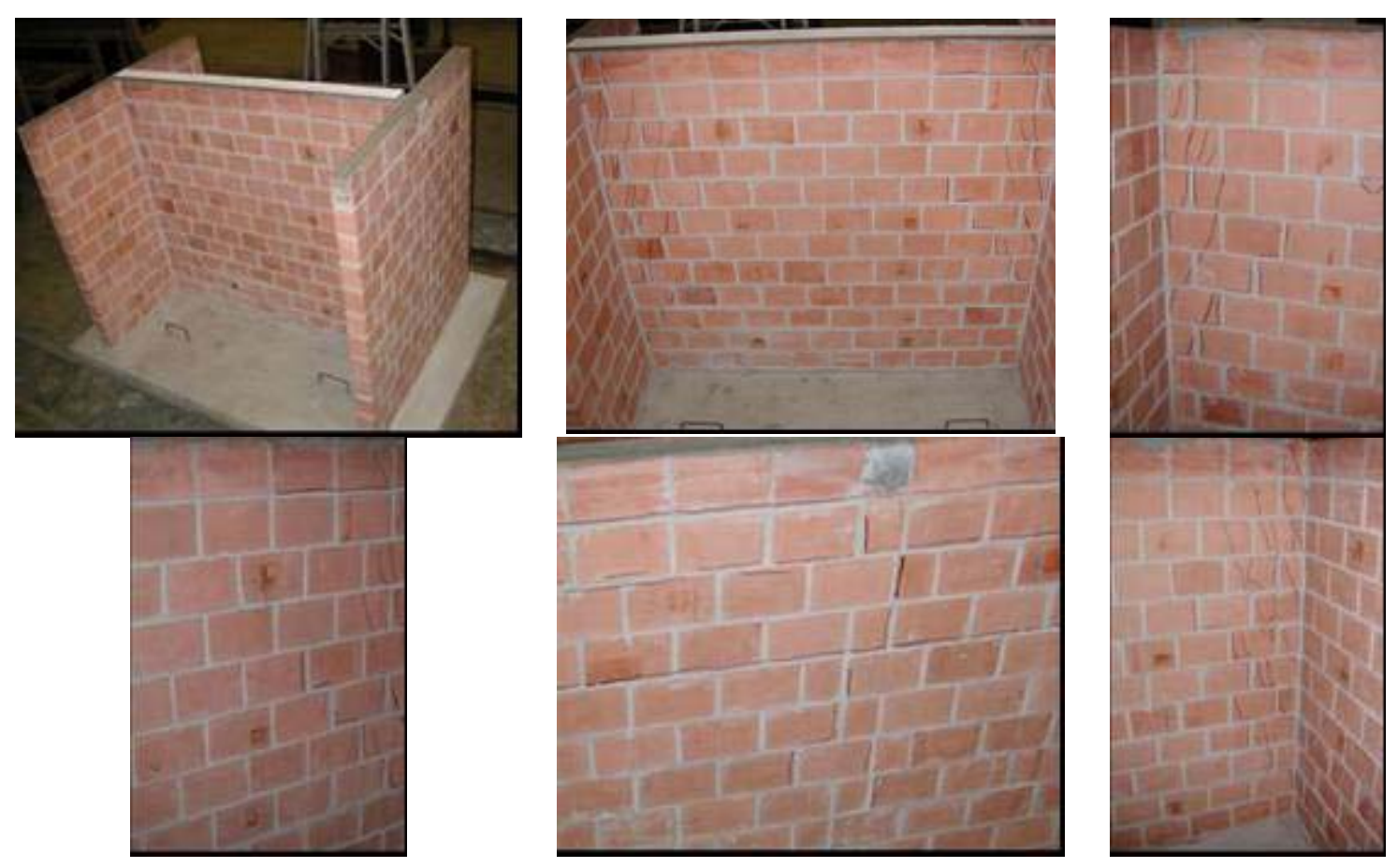

Figura 8.27 - Formas de ruptura do painel H2-1 
Utilizando-se a mesma metodologia empregada na análise dos painéis $\mathrm{H} 1$, constrói-se um gráfico das deformações médias referentes as diferentes regiões do painel H2 (Figura 8.28). Percebe-se que até os $50 \mathrm{kN}$ há uma certa acomodação das leituras, apesar de ter sido realizado o escorvamento da estrutura. Observa-se, que similarmente ao painel $\mathrm{H} 1$, as deformações na região superior da parede central são maiores que na região inferior, indicando uma certa transferência de forças para os flanges. Devido à flexão nos flanges, as medidas de deformação na face externa indicam, desde o início do ensaio, uma tendência de alongamento. As deformações do flange interno na região inferior são praticamente constantes ao longo de todo ensaio. Já a região superior do flange tem um comportamento próximo ao verificado na região inferior da parede central.

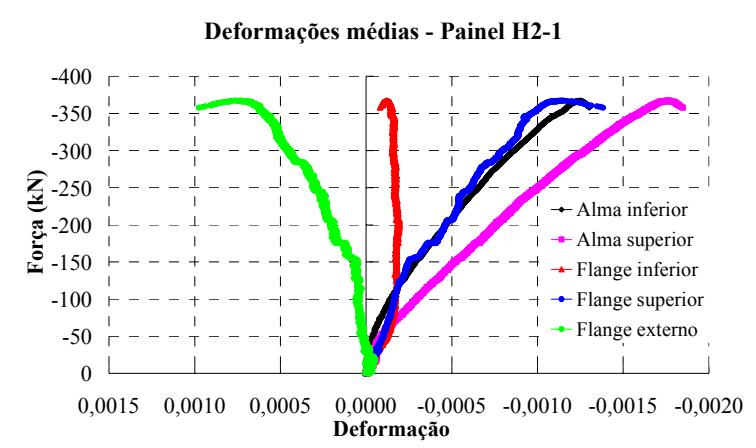

Figura 8.28 - Comportamento do painel H2-1

Para uma melhor análise do ensaio, constroem-se gráficos das deformações da parede central e dos flanges para forças inferiores a 50\% do carregamento de ruptura (Figura 8.29). Ressalta-se que são excluídas as regiões com perturbações. Na parede central (alma), a inclinação da reta referente à região superior é cerca de 64\% do valor obtido na região inferior (Figura 8.29-a). Admitindo-se que o material está em regime elástico-linear, pode-se dizer que a tensão na região superior é 1,55 vezes a tensão no trecho inferior. Isso mais uma vez confirma a transferência de parte do carregamento para os flanges. Já em relação aos flanges (Figura 8.29-b), ao contrário do painel H1-1, os comportamentos de cada região são díspares, não se admitindo um trecho linear para o flange inferior. 


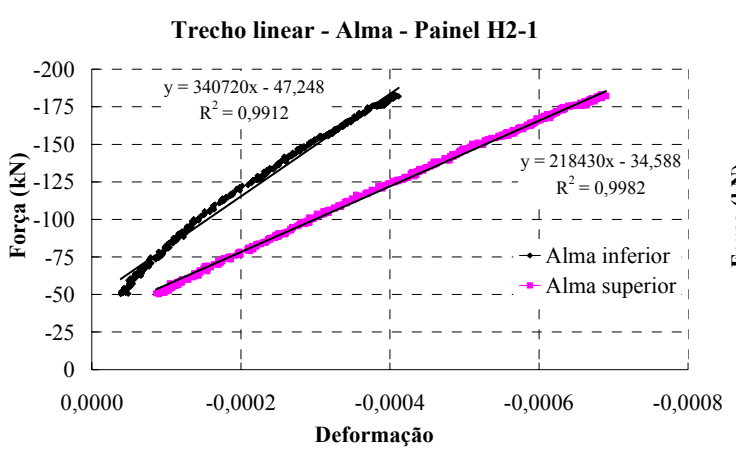

(a)

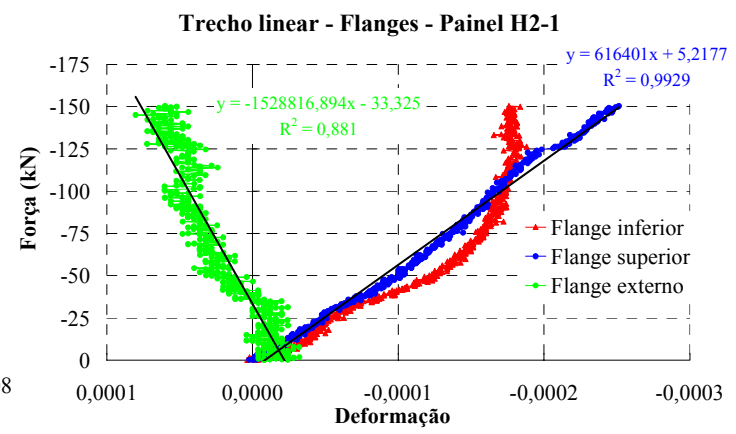

(b)

Figura 8.29 - Comportamento linear do painel H2-1

\subsection{4- Resultados do painel $\mathrm{H} 2$ com cinta de respaldo e com laje de topo (Painel H2-1a)}

A Tabela 8.10 apresenta os resultados dos corpos-de-prova relacionados ao painel H2-1a; indica-se os valores médios das resistências e em alguns casos os módulos de deformação. Neste caso, a resistência da argamassa é superior ao do painel anterior, no entanto os valores das resistências dos prismas para os dois casos são praticamente iguais. Observa-se, também, que apesar da resistência do graute ser superior a do painel H2-1, a resistência dos blocos canaletas preenchidos são cerca de $20 \%$ inferiores aos do painel anterior, mostrando a variabilidade da resistência isolada do bloco canaleta.

Tabela 8.10 - Resultados dos ensaios dos corpos-de-prova do painel H2-1a

\begin{tabular}{|c|c|c|c|c|c|c|}
\hline $\begin{array}{c}\text { Ensaios } \\
\text { (valores médios) }\end{array}$ & Argamassa & Prisma & Graute & Canaletas & $\begin{array}{c}\text { Concreto } \\
\text { base }\end{array}$ & $\begin{array}{c}\text { Concreto } \\
\text { topo }\end{array}$ \\
\hline Resistência (MPa) & 10,56 & 10,66 & 57,47 & 41,79 & 25,92 & 32,67 \\
\hline $\begin{array}{c}\text { Módulo de } \\
\text { deformação (MPa) }\end{array}$ & 12475 & -- & 32749 & -- & 20322 & 26949 \\
\hline
\end{tabular}

Os resultados da força de ruptura e das estimativas da tensão de ruptura e da resistência da alvenaria estão na Tabela 8.11. Ressalta-se que a força de ruptura obtida é praticamente a capacidade máxima do atuador utilizado. A tensão de ruptura referida apenas à área da parede central $(11,29 \mathrm{MPa})$ é cerca de $50 \%$ superior à resistência à compressão obtida nos ensaios de caracterização $(7,49 \mathrm{MPa})$ e $66 \%$ superior à estimativa feita com a resistência dos prismas $(6,79 \mathrm{MPa})$. Analisando-se a tensão calculada considerando a área toda do painel H2-1a (4,23 MPa), nota-se que essa tensão é no mínimo $44 \%$ inferior às resistências estimadas para a alvenaria. Desse modo, conclui-se que a capacidade do painel com a laje no topo não é restrita à parede central, havendo uma contribuição dos flanges. Observa-se que é a mesma conclusão obtida no 
ensaio do painel H1- 1a, além do que, em ambos os painéis, as tensões de ruptura referidas apenas à parede central são próximas, com uma diferença inferior a $8 \%$. Comparando-se os resultados dos painéis H2-1 e H2-1a, percebe-se que a presença da laje no topo do painel proporciona um aumento de $27 \%$ na capacidade de carga. Esse ganho é um pouco inferior ao obtido nessa mesma comparação para os painéis H1, que é de $37 \%$.

Tabela 8.11 - Resultados do painel H2-1a

\begin{tabular}{|c|c|c|c|c|}
\hline $\begin{array}{c}\text { Força de } \\
\text { Ruptura } \\
(\mathrm{kN})\end{array}$ & $\begin{array}{c}\text { Tensão de } \\
\text { ruptura } 1) \\
\text { (MPa) }\end{array}$ & $\begin{array}{c}\text { Tensão de } \\
\text { ruptura }{ }^{2)} \\
\text { (MPa) }\end{array}$ & $\begin{array}{l}\text { Resistência da } \\
\left.\text { alvenaria }{ }^{3}\right) \\
\text { (MPa) }\end{array}$ & $\begin{array}{c}\text { Previsão da } \\
\text { resistência da } \\
\text { alvenaria }^{4)}(\mathrm{MPa})\end{array}$ \\
\hline 467,05 & & & 7,4 & \\
\hline \multicolumn{5}{|c|}{$\begin{array}{l}\text { 1) Tensão considerando apenas a área da parede central em planta; } \\
\text { 2) Tensão considerando a área de todo o painel em planta; } \\
\text { 3) Resistência obtida nos ensaios de paredinhas (ensaios de caracterização); } \\
{ }^{4)} \text { Previsão da resistência da alvenaria considerando a eficiência entre as resistências da paredinha e prismas } \\
\text { obtida nos ensaios de caracterização }(0,637) \text {. } \\
\text { Obs: Todas as resistências e tensões são relacionadas à área bruta. }\end{array}$} \\
\hline
\end{tabular}

As fissuras iniciais no painel H2-1a, que ocorrem para um carregamento de aproximadamente de $300 \mathrm{kN}$, são inclinadas e se localizam próximas à ligação da parede central com os flanges. Essa fissuração corresponde ao cisalhamento causado pela transferência da força aplicada na parede central para os flanges. A fissuração na interseção teria a tendência de provocar um alívio nas tensões dos flanges, no entanto a presença da laje no topo restringe esse alívio. Com isso, a parcela de força transferida para os flanges permanece constante. Assim, após a fissuração da interseção das paredes, o carregamento adicional é resistido principalmente pela parede central. A partir desse instante inicia-se um comportamento típico de ensaio de compressão, com o aparecimento de fissuras verticais ao longo da parede central. Observa-se que, nos flanges, predominam as fissuras de flexão nas fiadas próximas ao topo. A ruptura do painel H2-1a é típica de compressão na parede central. A Figura 8.30 ilustra as formas de ruptura do painel.

O comportamento do painel H2-1a pode ser analisado com o auxílio das deformações médias que ocorrem nas suas diferentes regiões (Figura 8.31). Nota-se que a diferença no comportamento da parede central na região superior e inferior é menor que a verificada no caso anterior (painel H2-1). Observa-se, também, que inicialmente os flanges estão todos comprimidos, ocorrendo uma mudança no comportamento apenas a partir dos $300 \mathrm{kN}$, que é a força em que se inicia a fissuração na interseção. Percebe- 
se que os flanges na região inferior permanecem com uma deformação praticamente constante, enquanto que nas regiões superior e externa há um aumento das deformações, que é provocado pelas aberturas de fissuras de flexão.
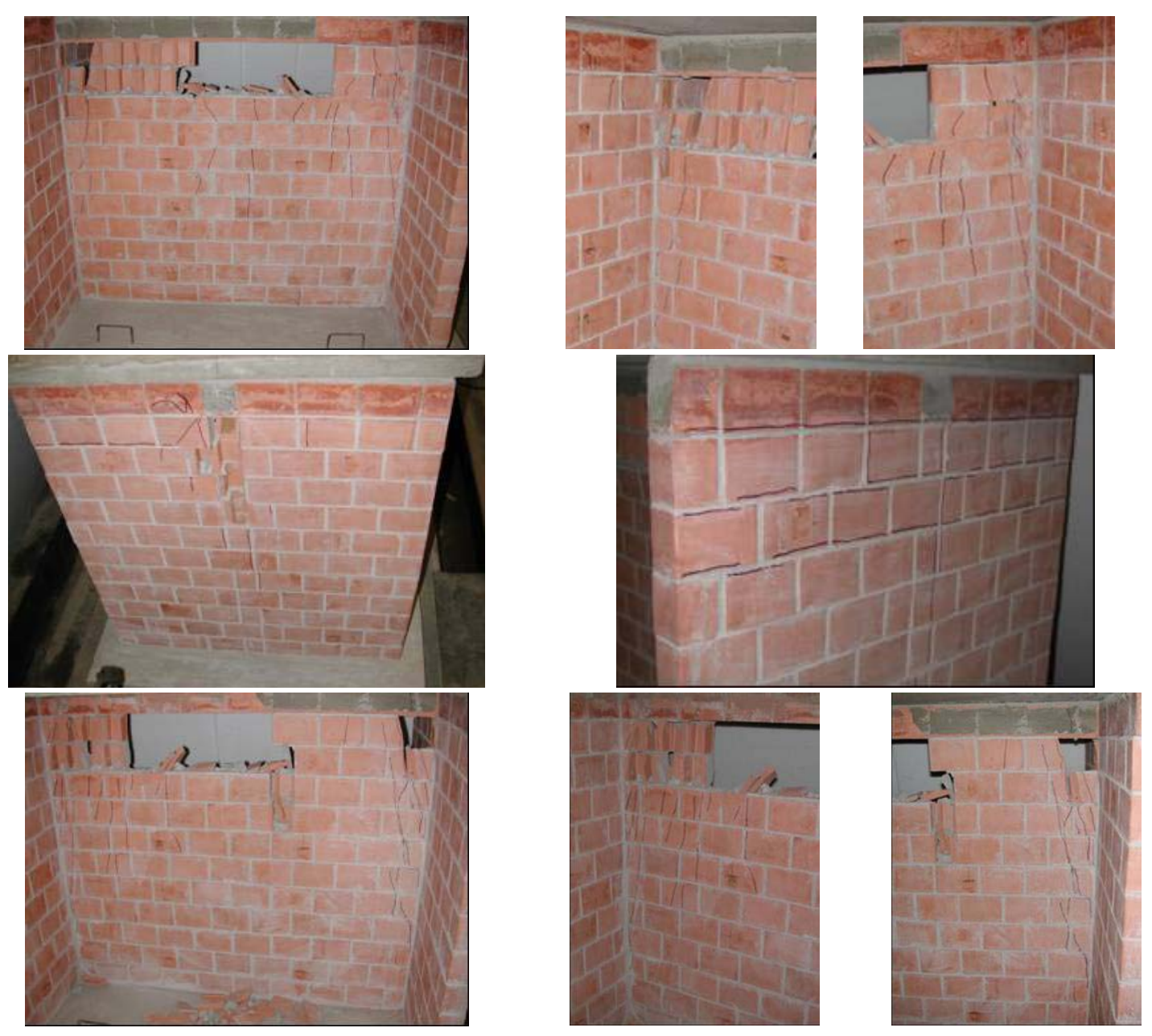

Figura 8.30 - Formas de ruptura do painel H2-1a

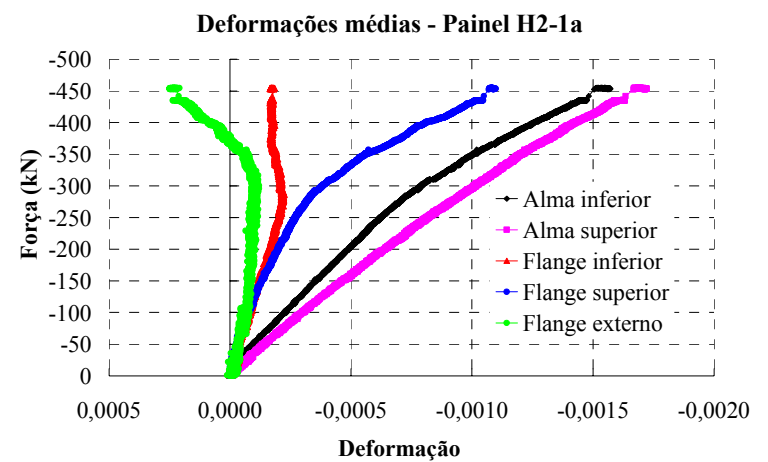

Figura 8.31 - Comportamento do Painel H2-1a

Na Figura 8.32 apresentam-se os trechos de comportamento linear das deformações na parede central (alma) e nos flanges. Observa-se na Figura 8.32-a que a inclinação referente à região superior da parede central é $75 \%$ do valor da região inferior. Considerando o comportamento elástico linear, isso corresponde a dizer que a 
tensão na região superior é cerca de 33\% maior que na região inferior. A diferença nas tensões é devida à transferência de parte do carregamento para os flanges. Percebe-se que os flanges possuem uma tendência de comportamento linear. No entanto, os valores de suas inclinações são bastante variáveis. Nota-se que as suas deformações são bem inferiores às verificadas na parede central, portanto submetidos a um nível de tensão bem inferior.

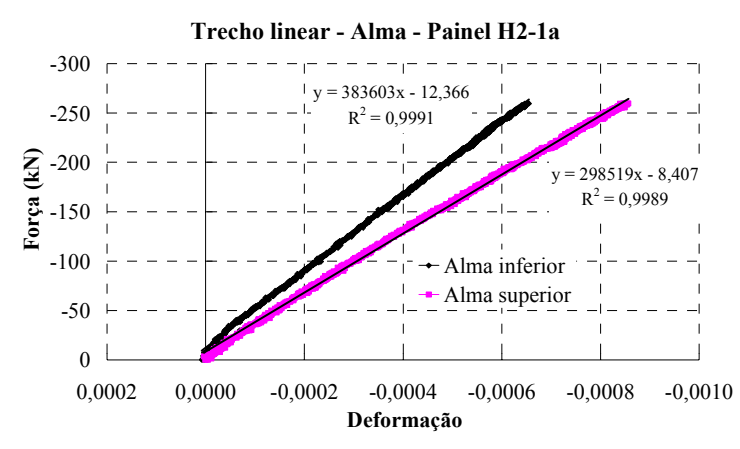

(a)

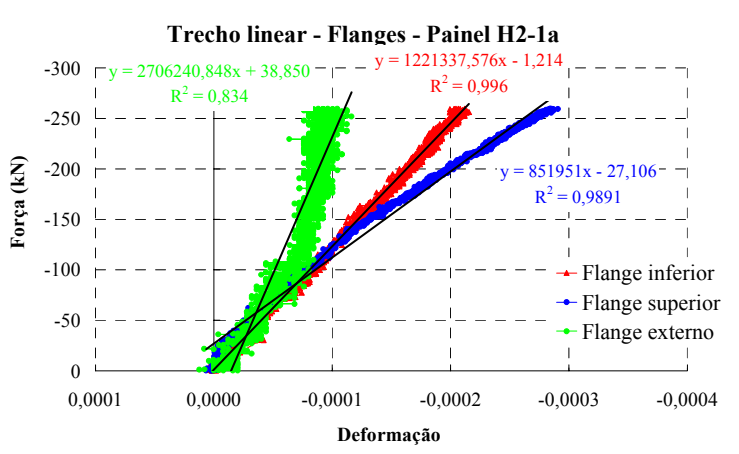

(b)

Figura 8.32 - Comportamento linear do painel H2-1

\subsection{5- Resultados do painel $\mathrm{H} 2$ com cintas intermediária e de respaldo e sem laje de topo (Painel H2-2)}

Os resultados, relacionados ao painel $\mathrm{H} 2-2$, dos ensaios das argamassas, dos prismas, dos grautes, dos blocos canaletas preenchidos e do concreto da base estão na Tabela 8.12. Novamente, os valores estão dentro da faixa dos resultados obtidos para os painéis anteriores.

Tabela 8.12 - Resultados dos ensaios dos corpos-de-prova do painel H2-2

\begin{tabular}{|c|c|c|c|c|c|}
\hline $\begin{array}{c}\text { Ensaios } \\
\text { (valores médios) }\end{array}$ & Argamassa & Prisma & Graute & Canaletas & $\begin{array}{c}\text { Concreto } \\
\text { base }\end{array}$ \\
\hline Resistência (MPa) & 6,57 & 10,02 & $\begin{array}{c}51,17^{1)} \\
52,06^{2)}\end{array}$ & $\begin{array}{c}50,62^{1)} \\
44,62^{2)}\end{array}$ & 29,33 \\
\hline $\begin{array}{c}\text { Módulo de } \\
\text { deformação (MPa) }\end{array}$ & 10015 & -- & $\begin{array}{c}28238^{1)} \\
30494^{2)}\end{array}$ & -- & 27209 \\
\hline $\begin{array}{l}\text { 1) Referente à cinta intermediária; } \\
\text { 2) Referente à cinta de topo (respaldo) }\end{array}$ & \\
\hline
\end{tabular}

Na Tabela 8.13 estão apresentadas a força de ruptura do painel, as estimativas das tensões de ruptura e das resistências da alvenaria. Observa-se que a tensão de ruptura calculada considerando apenas a área da parede central $(9,17 \mathrm{MPa})$ é $22 \%$ superior à resistência à compressão obtida nos ensaios de caracterização $(7,49 \mathrm{MPa})$ e $44 \%$ maior que à resistência estimada por meio dos prismas. Já a tensão de ruptura calculada admitindo-se toda a área do painel é no mínimo $44 \%$ inferior às resistências 
estimadas da alvenaria. Desse modo, conclui-se que a capacidade resistente do painel, para este tipo de carregamento, está diretamente ligada à resistência da parede central, com uma pequena contribuição dos flanges. Essa é a mesma conclusão obtida para os painéis H1-1 e H2-1. Verifica-se, também, que a presença da cinta intermediária praticamente não influi na resistência do painel, a diferença da força de ruptura em relação ao painel H2-1 é de apenas 3\%.

Tabela 8.13 - Resultados do painel H2-2

\begin{tabular}{|c|c|c|c|c|}
\hline $\begin{array}{c}\text { Força de } \\
\text { Ruptura } \\
\text { (kN) }\end{array}$ & $\begin{array}{l}\text { Tensão de } \\
\text { ruptura } 1) \\
\text { (MPa) }\end{array}$ & $\begin{array}{l}\text { Tensão de } \\
\text { ruptura } \\
\text { (MPa) }\end{array}$ & $\begin{array}{l}\text { Resistência da } \\
\text { alvenaria }^{3)} \\
\text { (MPa) }\end{array}$ & $\begin{array}{c}\text { Previsão da } \\
\text { resistência da } \\
\text { alvenaria }^{4)}(\mathrm{MPa})\end{array}$ \\
\hline 379 & & & & \\
\hline \multicolumn{5}{|c|}{$\begin{array}{l}\text { 1) Tensão considerando apenas a área da parede central em planta; } \\
\text { 2) Tensão considerando a área de todo o painel em planta; } \\
\text { }{ }^{3)} \text { Resistência obtida nos ensaios de paredinhas (ensaios de caracterização); } \\
{ }^{4)} \text { Previsão da resistência da alvenaria considerando a eficiência entre as resistências da paredinha e prisma } \\
\text { obtida nos ensaios de caracterização }(0,637) \text {. } \\
\text { Obs: Todas as resistências e tensões são relacionadas à área bruta. }\end{array}$} \\
\hline
\end{tabular}

As formas de ruptura do painel H2-2 estão ilustradas na Figura 8.33. Verifica-se que na parede central há o aparecimento de fissuras inclinadas junto à interseção das paredes, indicando o cisalhamento. Essa fissuração se concentra na região superior à cinta intermediária, contudo existem fissuras também na região inferior, só que em menor intensidade. No instante em que as fissuras na interseção promovem a separação física entre a parede central e os flanges na região superior, ocorre a ruptura frágil da parede central por compressão. Percebe-se, também, que nos flanges, além da fissuração devida à flexão, há uma fissuração escalonada nos flanges.

O gráfico da Figura 8.34 permite a visualização do comportamento em diferentes regiões do painel H2-2. Percebe-se que até os $50 \mathrm{kN}$ ocorre uma acomodação do painel. Verifica-se, também, a diferença entre os níveis de deformação da parede central na região superior e inferior. Essa diferença é devida à transferência de parte do carregamento da parede central para os flanges. Observa-se que na região externa dos flanges, por causa da flexão, há a tendência, desde o início do ensaio, de alongamentos. No flange inferior, a deformação se mantém constante em boa parte do ensaio. Já no flange superior, o nível de deformação é bem próximo ao trecho inferior da parede central. Nota-se que este comportamento se assemelha ao verificado no ensaio do painel H2-1 (Figura 8.28). 

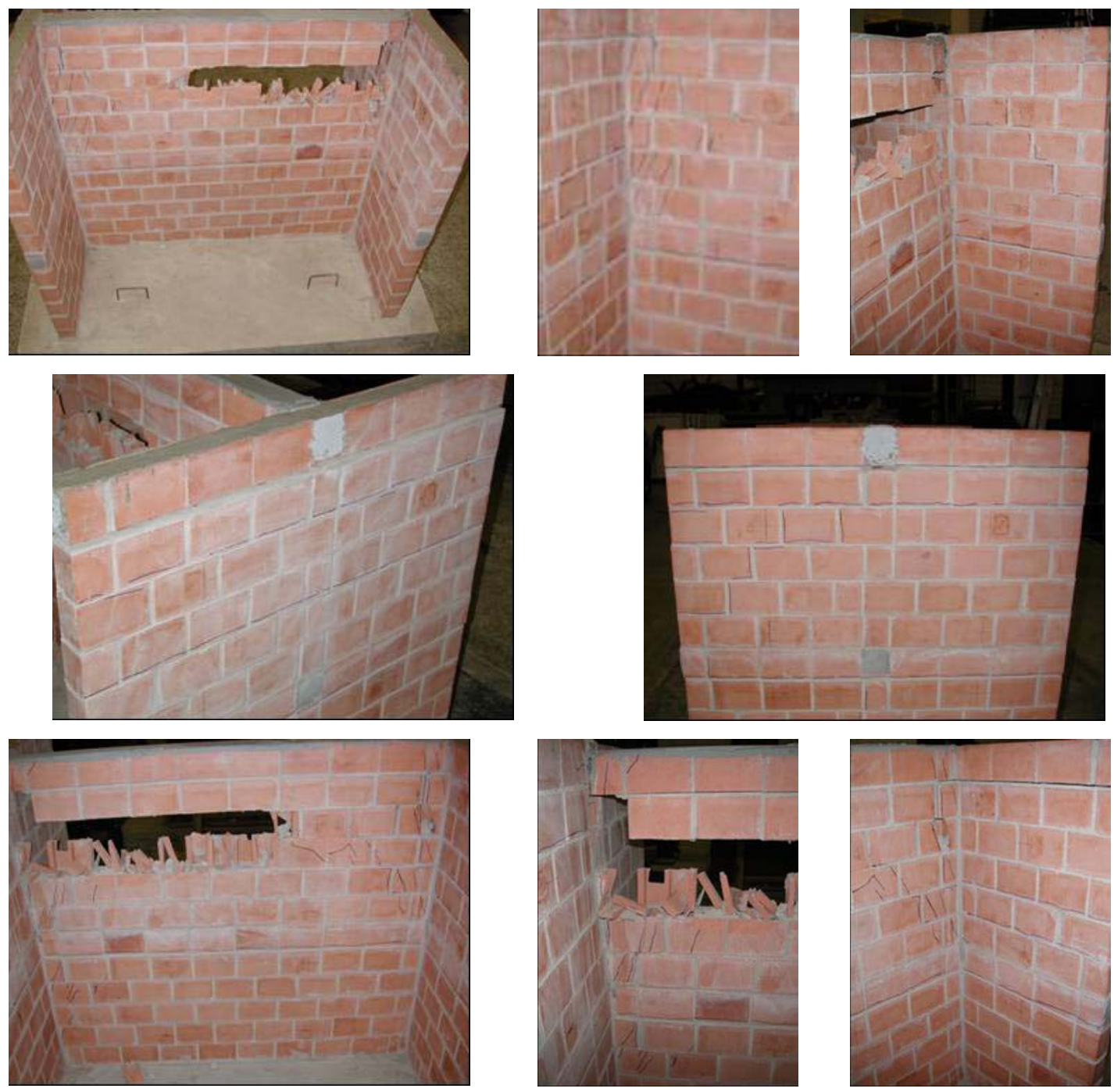

Figura 8.33 - Formas de ruptura do painel H2-2

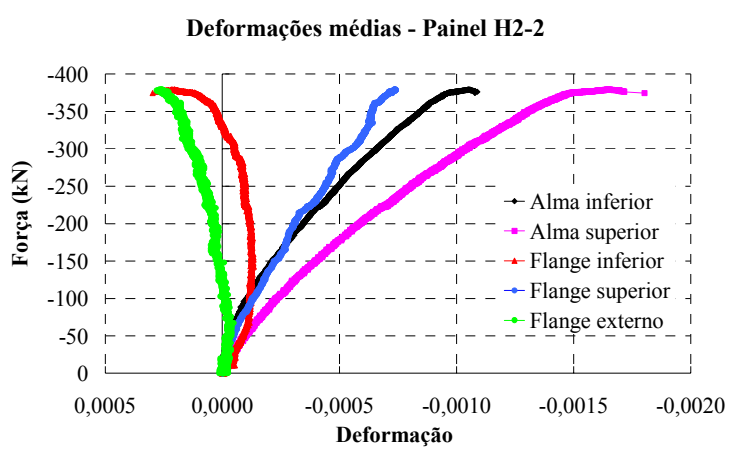

Figura 8.34 - Comportamento do painel H2-2

Na Figura 8.35 procura-se analisar o comportamento linear do painel H2-2. Para isso adota-se o trecho com carregamento inferior a 50\% da força de ruptura. No caso da parede central retira-se, também, a perturbação inicial (Figura 8.35-a). Comparando-se as inclinações das diferentes regiões da parede central, nota-se que a inclinação da região superior é $65 \%$ do valor da região inferior. Desse modo, admitindo o material em 
regime elástico linear, a tensão na região superior da parede central é 1,54 vezes a da região inferior. Esse é praticamente o mesmo valor encontrado na análise do painel H21. Nos flanges (Figura 8.35-b), o comportamento é diferente para cada região, não havendo trechos lineares bem definidos.

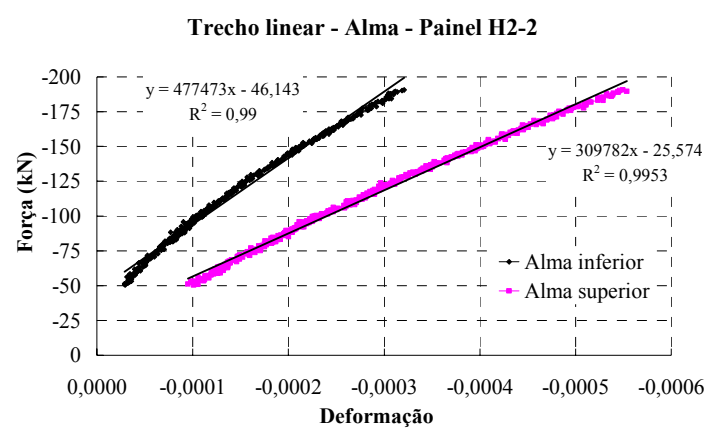

(a)

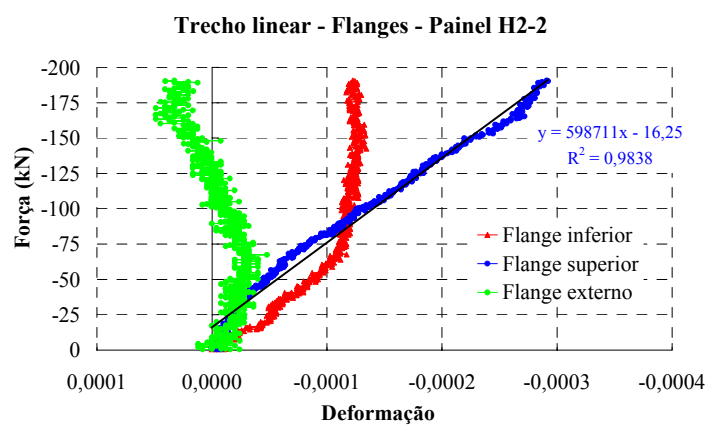

(b)

Figura 8.35 - Comportamento do trecho linear do painel H2-2

\subsection{6- Resultados do painel $\mathrm{H} 2$ com cintas intermediária e de respaldo e com laje} de topo (Painel H2-2a)

Na Tabela 8.14 apresentam-se os valores médios das resistências e dos módulos de deformação dos corpos-de-prova referentes ao painel H2-2a. Nota-se que apesar da resistência da argamassa ser inferior à dos ensaios anteriores, a resistência de prisma é praticamente a mesma. Os demais resultados estão todos dentro da faixa de valores já encontrados.

Tabela 8.14 - Resultados dos ensaios dos corpos-de-prova do painel H2-2a

\begin{tabular}{|l|c|c|c|c|c|c|}
\hline $\begin{array}{c}\text { Ensaios } \\
\text { (valores médios) }\end{array}$ & Argamassa & Prisma & Graute & Canaletas & $\begin{array}{c}\text { Concreto } \\
\text { base }\end{array}$ & $\begin{array}{c}\text { Concreto } \\
\text { topo }\end{array}$ \\
\hline Resistência (MPa) & 5,61 & 10,60 & $\begin{array}{c}52,06^{1)} \\
57,47^{2)}\end{array}$ & $\begin{array}{c}44,62^{1)} \\
41,79^{2)}\end{array}$ & 25,29 & 21,10 \\
\hline $\begin{array}{c}\text { Módulo de } \\
\text { deformação (MPa) }\end{array}$ & 8450 & -- & $\begin{array}{c}30494^{1)} \\
32749^{2)}\end{array}$ & -- & 29103 & 21376 \\
\hline $\begin{array}{l}{ }^{1)} \text { Referente à cinta intermediária; } \\
{ }^{2)} \text { Referente à cinta de topo (respaldo) }\end{array}$
\end{tabular}

Os resultados da força de ruptura, das tensões de ruptura e das resistências à compressão do painel H2-2a estão na Tabela 8.15. Verifica-se que nesse caso a tensão de ruptura calculada considerando apenas a área da parede central $(7,32 \mathrm{MPa})$ é cerca de $2 \%$ inferior à resistência à compressão das paredinhas e $8 \%$ superior à resistência estimada da alvenaria por meio dos prismas. Já a tensão de ruptura calculada com toda a área do painel em planta é no mínimo $60 \%$ inferior às resistências estimadas da alvenaria. Ressalta-se que, no entanto, a força de ruptura do painel H2-2a é cerca de $20 \%$ inferior ao menor dos valores obtidos nos demais ensaios de painéis H2. Acredita- 
se que essa diminuição da força de ruptura tenha ocorrido devido a uma falha no apoio da laje de base, visto que após os ensaios verificou-se a presença de duas fissuras, ortogonais à parede central, junto à sua interseção com os flanges. Esse fato, na visão do autor, invalida o resultado correspondente à força de ruptura do painel.

Tabela 8.15 - Resultados do painel H2-2a

\begin{tabular}{|c|c|c|c|c|}
\hline $\begin{array}{l}\text { Força de } \\
\text { Ruptura } \\
(\mathbf{k N})\end{array}$ & $\begin{array}{c}\text { Tensão de } \\
\text { ruptura 1) } \\
\text { (MPa) }\end{array}$ & $\begin{array}{l}\text { Tensão de } \\
\text { ruptura 2) } \\
\text { (MPa) }\end{array}$ & $\begin{array}{l}\text { Resistência da } \\
\text { alvenaria }^{3)} \\
\text { (MPa) }\end{array}$ & $\begin{array}{c}\text { Previsão da } \\
\text { resistência da } \\
\text { alvenaria }^{4)}(\mathrm{MPa})\end{array}$ \\
\hline & 7,32 & 2,14 & 1,4 & \\
\hline \multicolumn{5}{|c|}{$\begin{array}{l}\text { 1) Tensão considerando apenas a área da parede central em planta; } \\
\text { 2) Tensão considerando a área de todo o painel em planta; } \\
{ }^{3)} \text { Resistência obtida nos ensaios de paredinhas (ensaios de caracterização); } \\
\text { 4) Previsão da resistência da alvenaria considerando a eficiência entre as resistências da paredinha e prismas } \\
\text { obtida nos ensaios de caracterização ( } 0,637) \text {. } \\
\text { Obs: Todas as resistências e tensões são relacionadas à área bruta. }\end{array}$} \\
\hline
\end{tabular}

As formas de ruptura apresentadas na Figura 8.36 apontam um comportamento diferente dos verificados nos ensaios anteriores. Apesar de haver uma fissuração típica de cisalhamento próxima à interseção das paredes, as fissuras iniciaram-se com baixos valores de carregamento $(150 \mathrm{kN})$. Observa-se, também, que há uma forte fissuração associada à compressão na região inferior da parede central, que levou à ruptura do painel. Nos flanges, além das fissuras de flexão, verificam-se várias fissuras escalonadas, típicas de cisalhamento. Acredita-se que essa ruptura prematura esteja relacionada a uma flexão da laje de base, provocando um acréscimo nas tensões de compressão no centro da região inferior da parede central (local da ruptura por compressão).

A evolução das deformações no painel H2-2a está ilustrada na Figura 8.37. Nota-se que ocorre uma acomodação da estrutura até a força aplicada alcançar os 50 $\mathrm{kN}$. Novamente, na região superior da parede central aparecem maiores deformações que na região inferior. Contudo, acontece uma inversão desses valores para um carregamento acima de $250 \mathrm{kN}$, fato não ocorrido nos ensaios anteriores. Observa-se que os flanges apresentam encurtamentos praticamente constantes ao longo da maior parte do ensaio, indicando a influência da presença da laje no topo. 

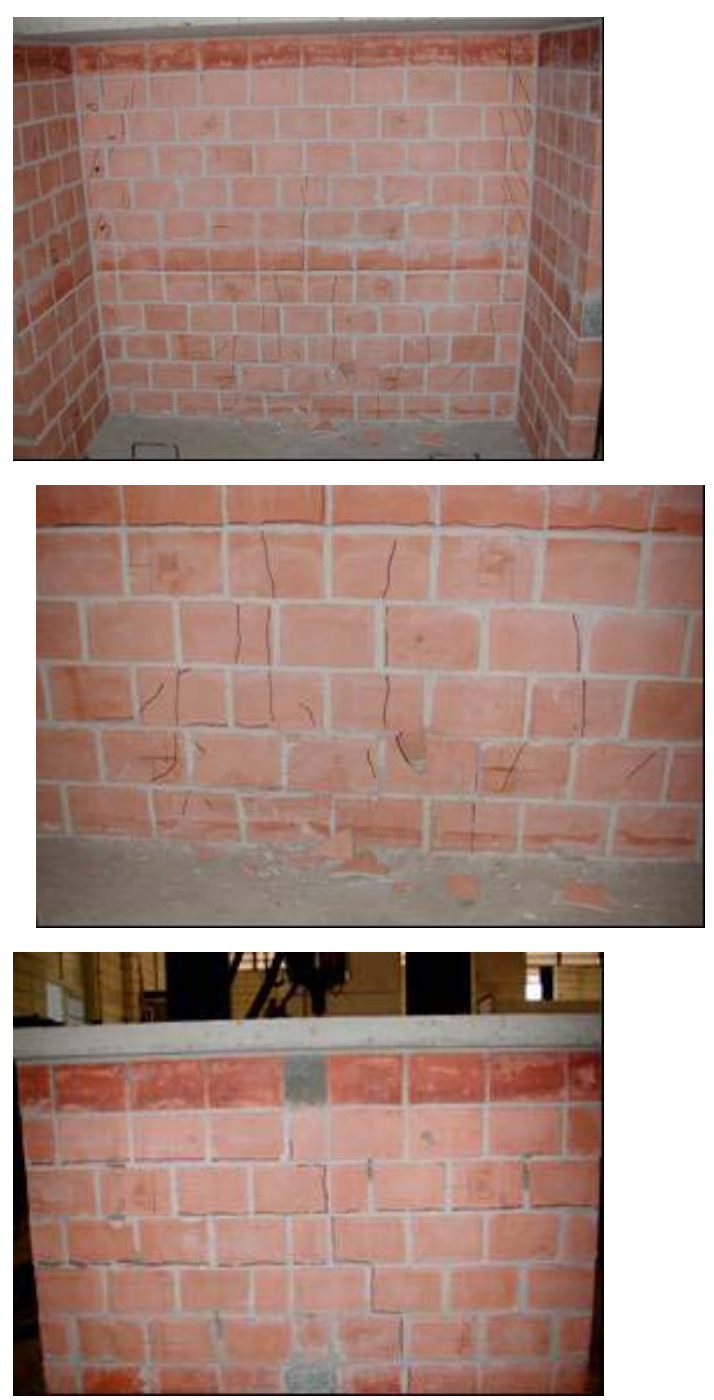
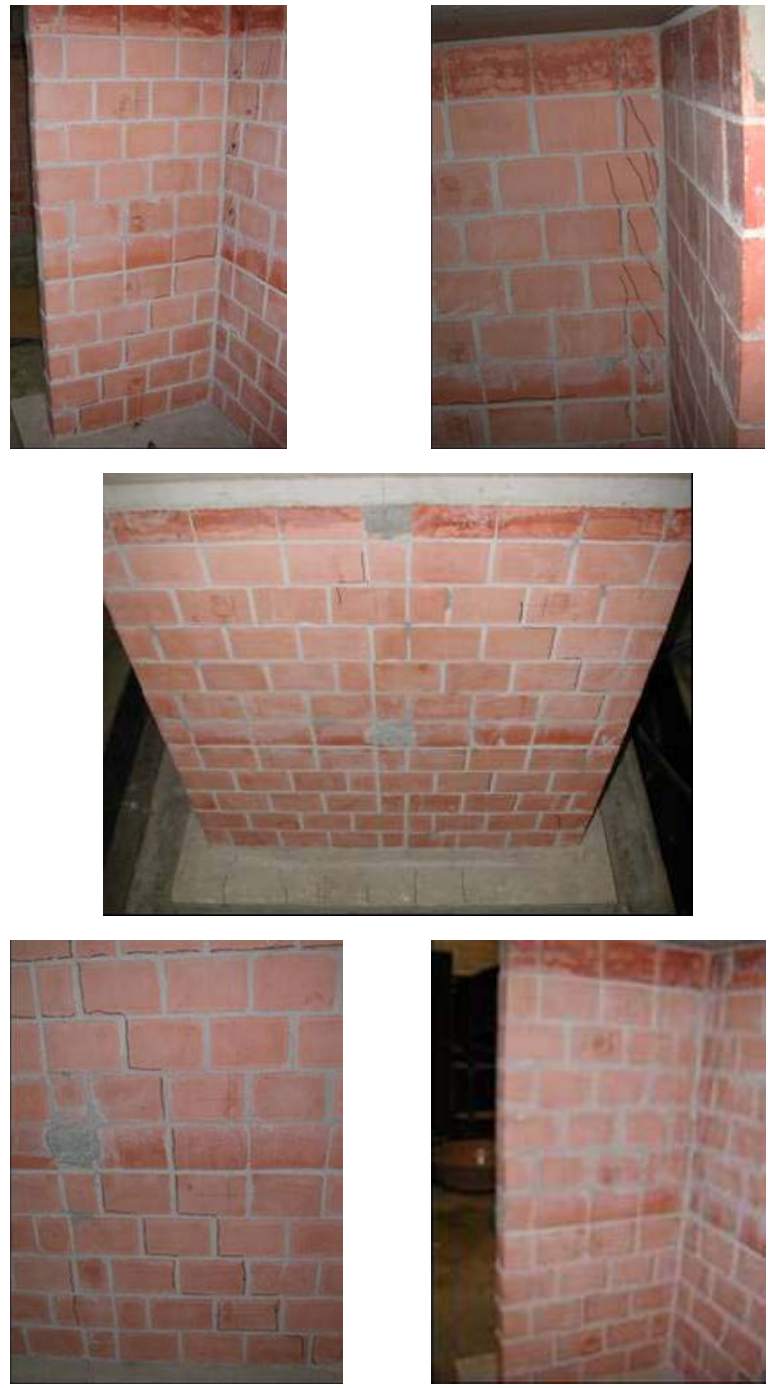

Figura 8.36 - Formas de ruptura do painel H2-2a

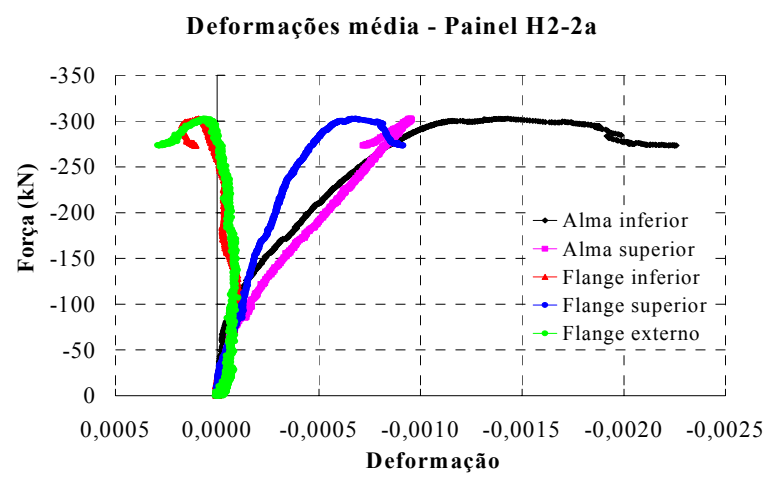

Figura 8.37 - Comportamento do painel H2-2a

As análises dos trechos teoricamente lineares, valores inferiores à $50 \%$ da força de ruptura, estão na Figura 8.38. Verifica-se que a inclinação correspondente à região superior da parede central (alma) é 77\% do valor da região inferior (Figura 8.38-a), valor muito próximo ao encontrado para o painel H2-1a (75\%). Assumindo o regime elástico-linear, isso corresponde a dizer que a tensão na região superior da alma é $30 \%$ 
maior que na região inferior. Observa-se, também, que o comportamento dos flanges do painel H2-2a (Figura 8.38-b) é similar ao obtido para o painel H2-1a (Figura 8.32-b). Portanto, pode-se concluir que os comportamentos para situações de serviço dos painéis H2-1a e H2-2a são semelhantes. Desse modo, verifica-se que a cinta de amarração intermediária, para essa condição de ensaio, influencia pouco o comportamento do painel.

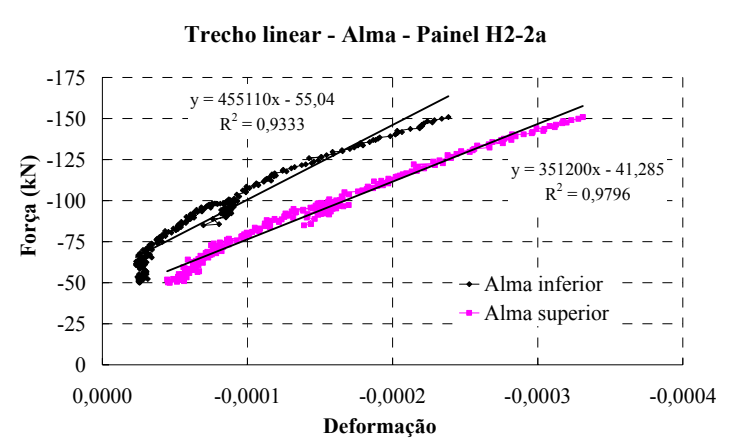

(a)

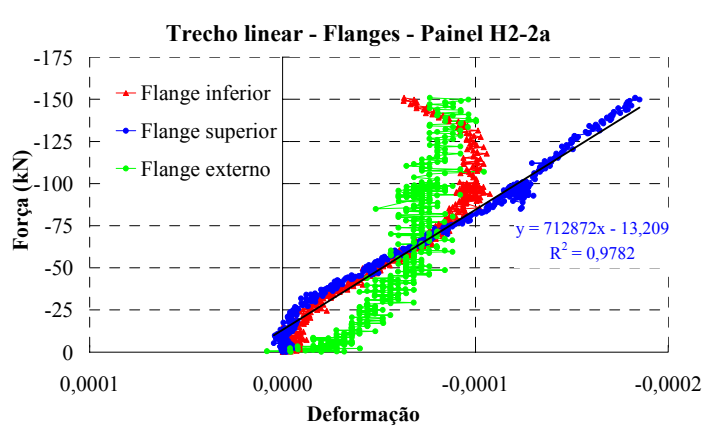

(b)

Figura 8.38 - Comportamento do trecho linear do Painel H2-2a

\subsection{7- Comparações entre os resultados dos painéis $\mathbf{H 2}$}

As comparações entre os resultados dos ensaios dos diferentes painéis $\mathrm{H} 2$ fornecem uma idéia da influência da presença da cinta intermediária e da laje de topo. Nos itens anteriores já se comentaram algumas semelhanças e diferenças entre os resultados dos ensaios, porém nesse item será feita a análise comparativa dos resultados dos quatro painéis $\mathrm{H} 2$.

A Tabela 8.16 apresenta os resultados das forças de ruptura de cada painel, bem como uma comparação com o valor obtido no ensaio do painel H2-1, tomado como referência. Como comentado no item anterior, o valor da força de ruptura do Painel H22a é descartado devido à ocorrência de uma ruptura atípica. Analisando-se os resultados percebe-se que a influência da cinta de amarração intermediária é pequena, fato também verificado nos ensaios dos corpos-de-prova de cisalhamento. Já a laje de topo proporciona um ganho de resistência, comprovado nos ensaios dos painéis H1, pois sua presença física impede que as ações transferidas pelos flanges sejam dissipadas no momento em que ocorre a ruptura da ligação com a parede central.

As formas de ruptura da parede central dos painéis H2 estão apresentadas na Figura 8.39. Ressalta-se que no caso do painel H2-1 o carregamento foi retirado de maneira que não ocorresse a ruptura explosiva da parede central. Já nos demais painéis, mesmo aplicando-se o carregamento por controle de deslocamento, não se conseguiu 
evitar a ruptura frágil dos painéis. Observa-se que em todos os casos ocorre uma intensa fissuração inclinada na região do encontro das paredes gerada pelo cisalhamento vertical, o que provoca a separação entre a parede central e os flanges. A partir desse momento todo o carregamento aplicado passa a ser resistido pela parede central, até que ela rompa por compressão. Acredita-se que no caso do painel H2-2a tenha ocorrido uma falha no apoio da laje da base, pois a ruptura se deu na região inferior do painel e com um carregamento bem inferior ao seu similar (painel H2-1a).

Tabela 8.16 - Comparação das forças de ruptura dos painéis H2

\begin{tabular}{|c|c|c|c|c|}
\hline $\begin{array}{c}\text { Tipo do } \\
\text { painel }\end{array}$ & $\begin{array}{c}\text { Laje de } \\
\text { topo }\end{array}$ & $\begin{array}{c}\text { Cinta } \\
\text { intermediária }\end{array}$ & $\begin{array}{c}\text { Força de } \\
\text { ruptura } \\
\text { (kN) }\end{array}$ & $\begin{array}{c}\text { Força Painel / Força } \\
\text { Painel H2-1 }\end{array}$ \\
\hline H2-1 & não & não & 367,15 & 1,00 \\
\hline H2-1a & sim & não & 467,05 & 1,27 \\
\hline H2-2 & não & sim & 379,15 & 1,03 \\
\hline H2-2a & sim & sim & $302,64 *$ & $*$ \\
\hline \multicolumn{7}{|r}{} \\
\hline \multicolumn{7}{|r}{} \\
\hline
\end{tabular}

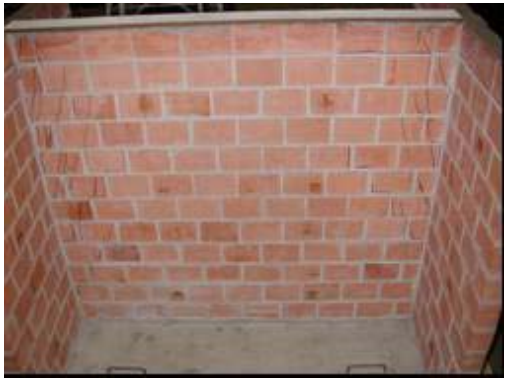

(a) Painel H2-1

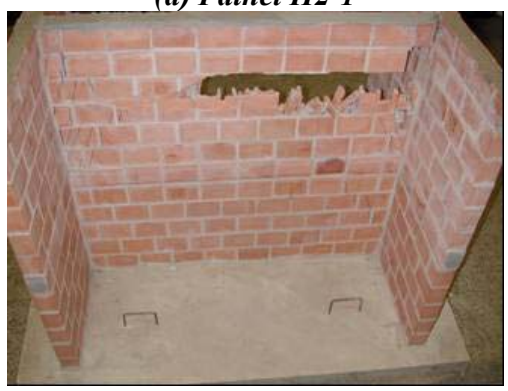

(c) Painel H2-2

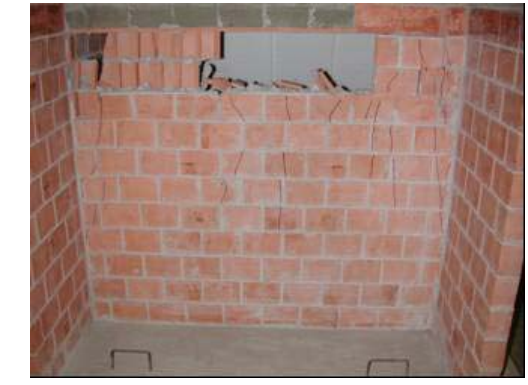

(b) Painel H2-1a

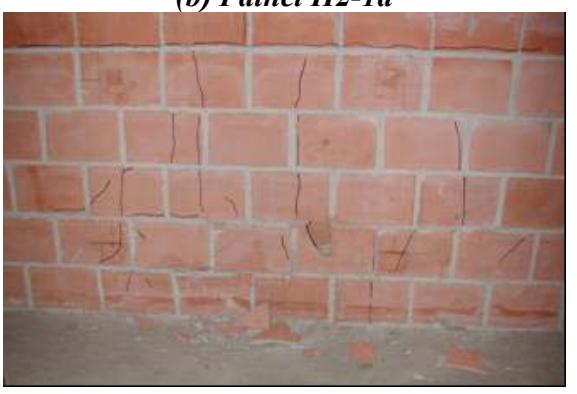

(d) Painel H2-2a

Figura 8.39 - Comparação das formas de ruptura da parede central (alma) dos painéis H2

Apresentam-se na Figura 8.40 as fissurações típicas dos flanges dos quatro painéis H2. Verifica-se que em todos os casos a forma principal é a de flexão, com a tendência de giro das fiadas, separando-se os blocos das juntas de argamassa de assentamento. Nos painéis H2-1, H2-1a e H2-2 a fissuração por flexão se concentra nas quatro últimas fiadas. Já no painel H2-2a ocorrem fissuras de flexão em fiadas inferiores e fissuras escalonadas relacionadas ao cisalhamento do painel, indicando novamente um comportamento atípico. 


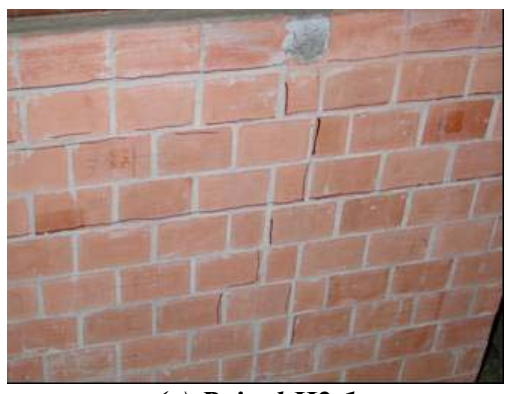

(a) Painel H2-1

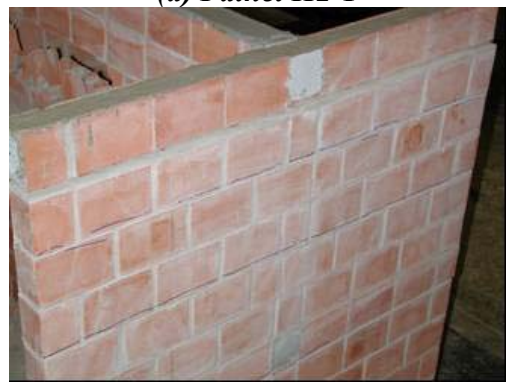

(c) Painel H2-2

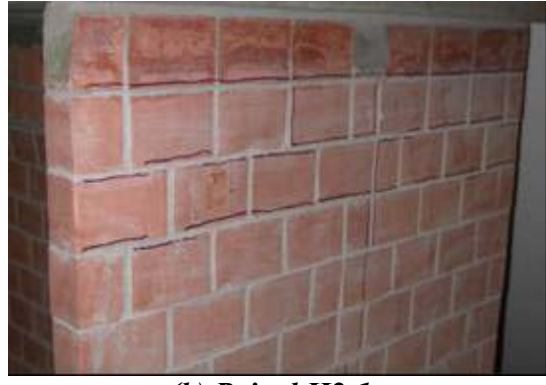

(b) Painel H2-1a

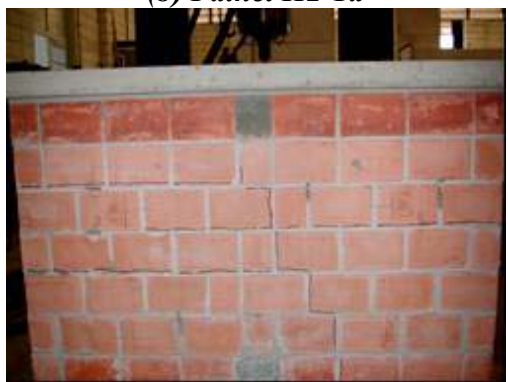

(d) Painel H2-2a

Figura 8.40 - Comparação das formas de ruptura dos flanges dos painéis $\mathrm{H} 2$

O comportamento em diferentes porções dos quatro painéis $\mathrm{H} 2$ ao longo do ensaio estão apresentados na Figura 8.41. Observa-se que nos painéis sem laje de topo (H2-1 e H2-2) as diferenças entre as deformações da região superior e inferior da parede central (alma) são superiores às constatadas nos painéis com laje de topo (H2-1a e H22a). Em relação aos flanges verifica-se que quando não há presença da laje de topo ocorre uma flexão pronunciada do flange externo, com deformações de tração desde o início dos ensaios. Nos painéis com laje de topo os flanges possuem uma tendência de estarem todos comprimidos até o momento em que ocorre a fissuração na interseção das paredes. A partir desse ponto a flexão torna-se dominante e, na região externa dos flanges, chegam a ocorrer alongamentos. Comparando-se os painéis H2-1 e H2-2 verifica-se que a influência da cinta intermediária nas deformações dos painéis não é tão significativa, apenas há uma redução dos valores máximos dos alongamentos no flange externo.

Na Figura 8.42 comparam-se os trechos lineares das paredes centrais dos painéis H2. Observa-se que as deformações da região superior das paredes centrais dos painéis sem laje de topo são cerca de 55\% maiores que da região inferior, indicando uma transferência do carregamento aplicado na alma para os flanges. Já para os painéis com laje de topo a região superior da parede central apresenta valores cerca de $28 \%$ maiores que a região inferior. Acredita-se que essa redução das diferenças entre as deformações na região superior e inferior se deva ao fato da laje de topo transmitir parte do carregamento diretamente para os flanges antes de comprimir a região superior da alma. 
Nota-se, ainda na mesma figura, que a influência da cinta de amarração intermediária é pequena em termos de comportamento. Porém, percebe-se que os painéis com a presença dessa cinta apresentam uma rigidez superior à daqueles sem cintas, com um aumento entre $20 \%$ e $40 \%$.

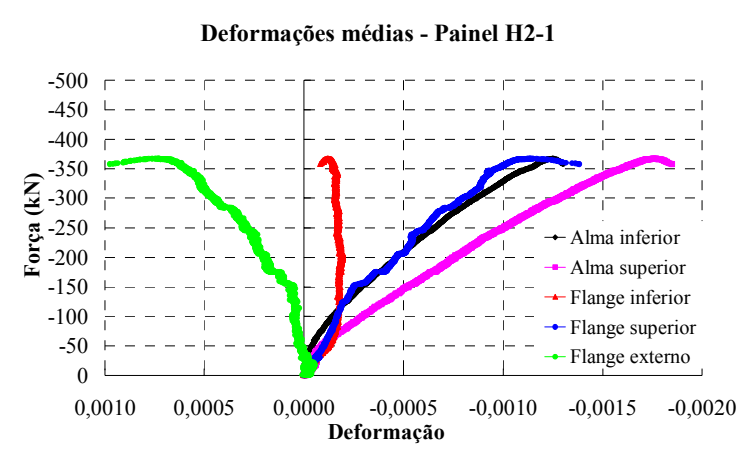

(a) Painel H2-1

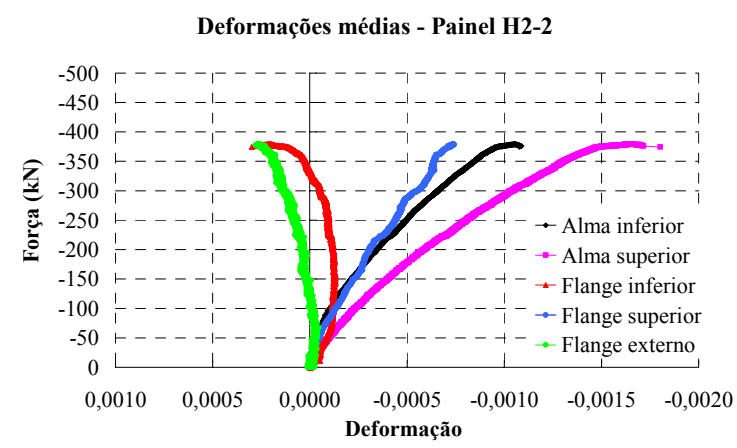

(c) Painel H2-2

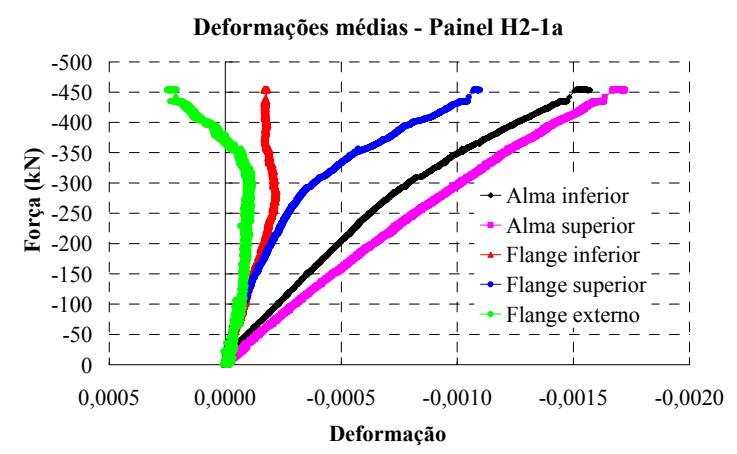

(b) Painel H2-1a

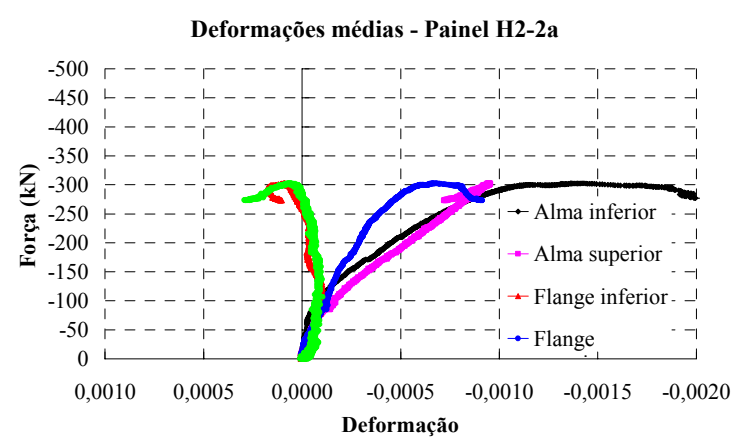

(d) Painel H2-2a

Figura 8.41 - Comparação dos comportamentos dos painéis $\mathrm{H2}$

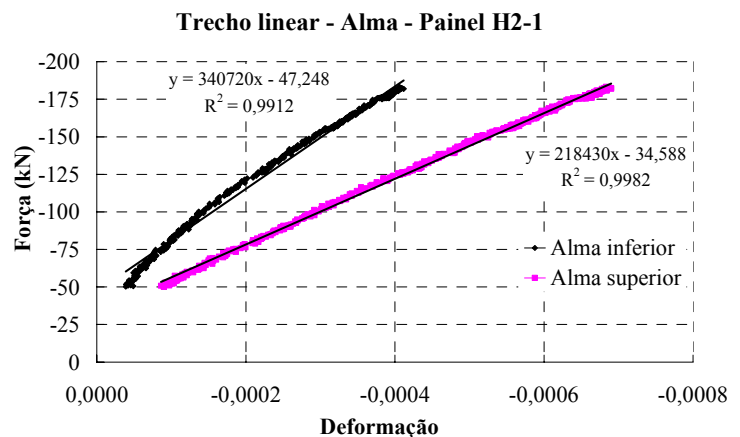

(a) Painel H2-1

Trecho linear - Alma - Painel H2-2

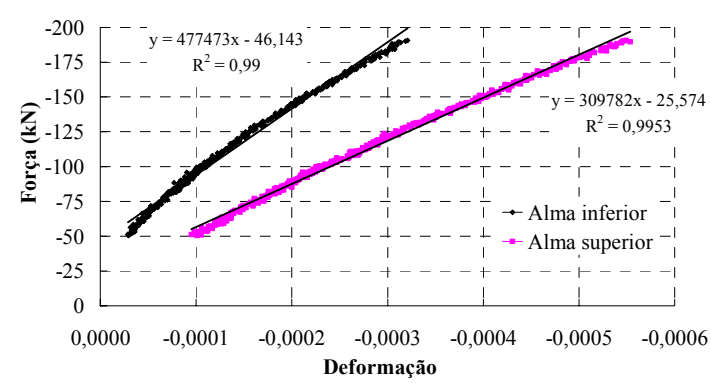

(c) Painel H2-2

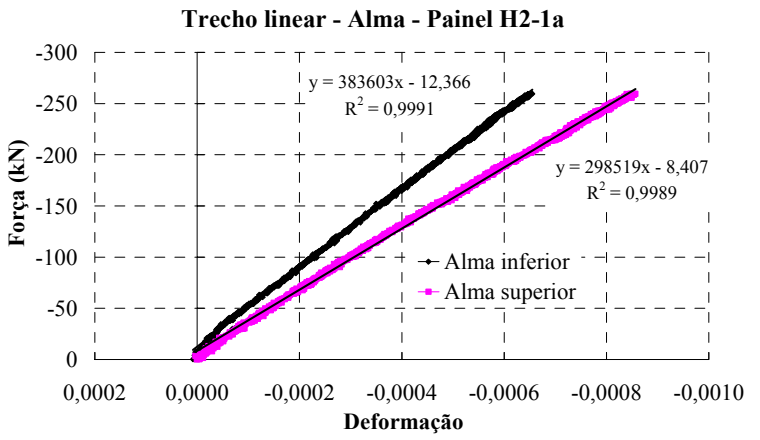

(b) Painel H2-1a

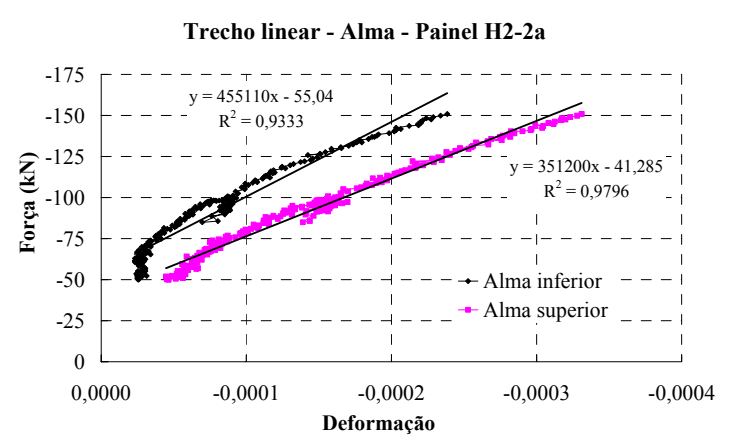

(d) Painel H2-2a

Figura 8.42 - Comparação dos trechos lineares das almas dos painéis H2 
Os comportamentos dos trechos iniciais das curvas para os flanges dos painéis H2 estão ilustrados na Figura 8.43. Percebe-se que os flanges possuem perturbações mesmo para baixos carregamentos, o que dificulta a análise dos resultados. Entretanto, nota-se claramente uma diferença entre os painéis sem e com laje de topo. Nos painéis sem laje de topo (H2-1 e H2-2) a flexão dos flanges é predominante, sendo que o flange externo apresenta tendência de alongamentos desde o início dos ensaios. Nos painéis com laje de topo (H2-1a e H2-2a) verifica-se uma tendência de flexão, sendo que até mesmo o flange externo permanece comprimido nessa fase inicial do ensaio. Em relação à presença da cinta intermediária não se observa nenhuma influência significativa no comportamento dos painéis.

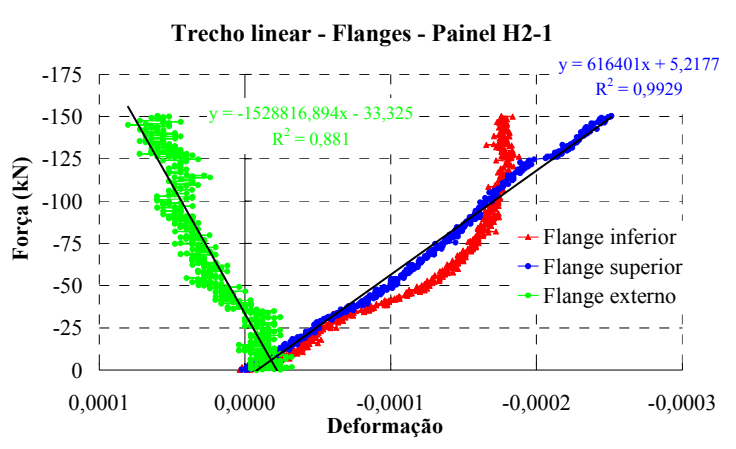

(a) Painel H2-1

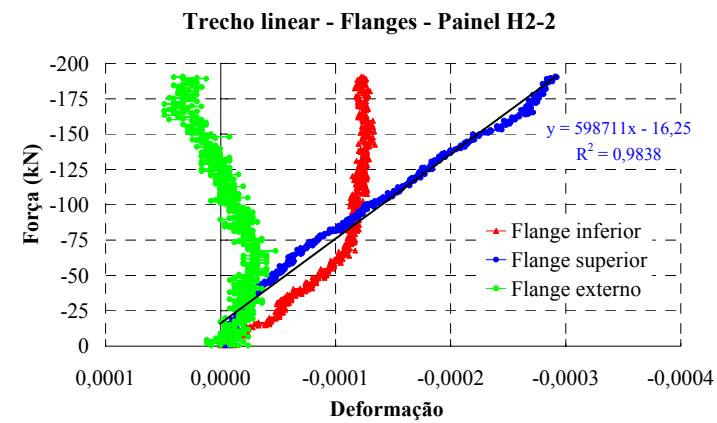

(c) Painel H2-2

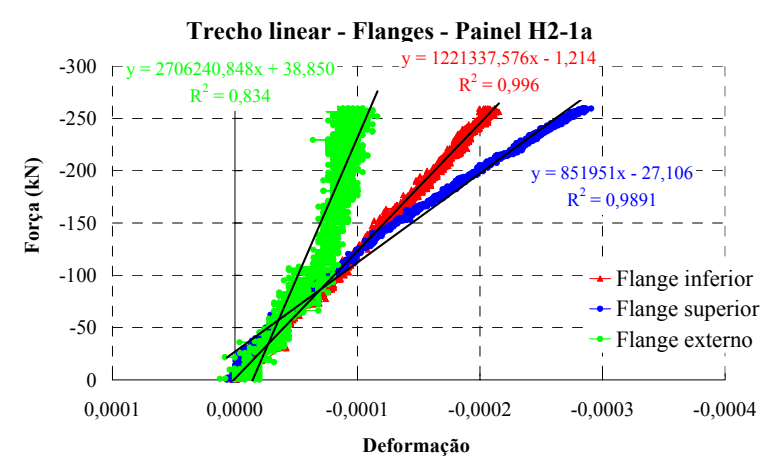

(b) Painel H2-1a

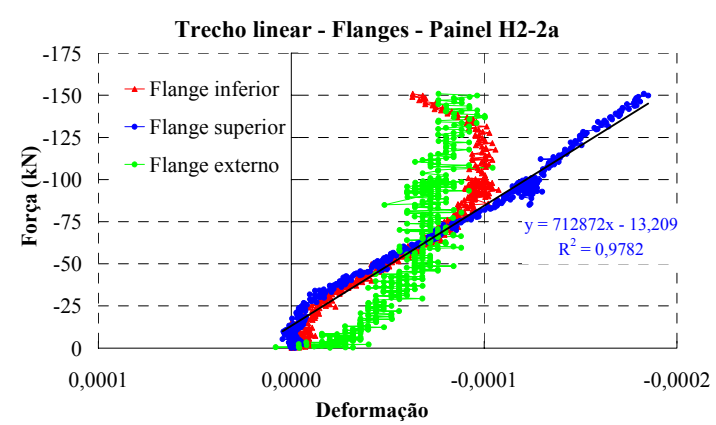

(d) Painel H2-2a

Figura 8.43 - Comparação dos trechos iniciais das deformaçães nos flanges dos painéis H2

\section{4- Ensaio do painel em escala reduzida tipo $\mathrm{H} 2 \mathrm{com}$ dois pavimentos}

Uma questão importante para o estudo da distribuição das ações verticais é o comportamento de painéis " $\mathrm{H}$ " com mais de um pavimento e com o carregamento aplicado em níveis diferentes. Neste caso o principal objetivo é verificar se há o aumento da força de ruptura quando o carregamento é aplicado em níveis diferentes, fato indicado nas análises numéricas iniciais (capítulo 6). Assim, dentro das possibilidades oferecidas pelo Laboratório de Estruturas da EESC-USP realiza-se o ensaio de um painel com dois pavimentos. 
Opta-se por uma geometria igual à do painel H2 com cintas de amarração no topo de cada pavimento, sendo a disposição das fiadas igual à da Figura 8.23. Por simplificação, não será considerada a presença da laje no topo dos pavimentos.

\subsection{1- Modo de execução do painel}

- Procedimentos:

Os materiais, os traços de argamassa, de graute e de concreto, as cintas de amarração e a elevação das paredes são idênticos aos utilizados na execução dos painéis H2. O primeiro pavimento é construído sobre uma laje de concreto igual à utilizada no item anterior. As diferenças no modo de execução estão relacionadas à construção do segundo pavimento, pois há a necessidade de dispositivos de apoio para o posicionamento dos gabaritos de alumínio e o painel é executado sobre um conjunto de placas de aço. Essas placas são assentadas utilizando-se a mesma argamassa de assentamento. Cabe ressaltar ainda que as placas sobre os flanges são independentes da placa de aço sobre a parede central. A Figura 8.44 mostra um esquema com as dimensões do painel de alvenaria com dois pavimentos, bem como fotos do painel já executado. O painel, por suas maiores dimensões, é construído na sua posição de ensaio para evitar movimentações.

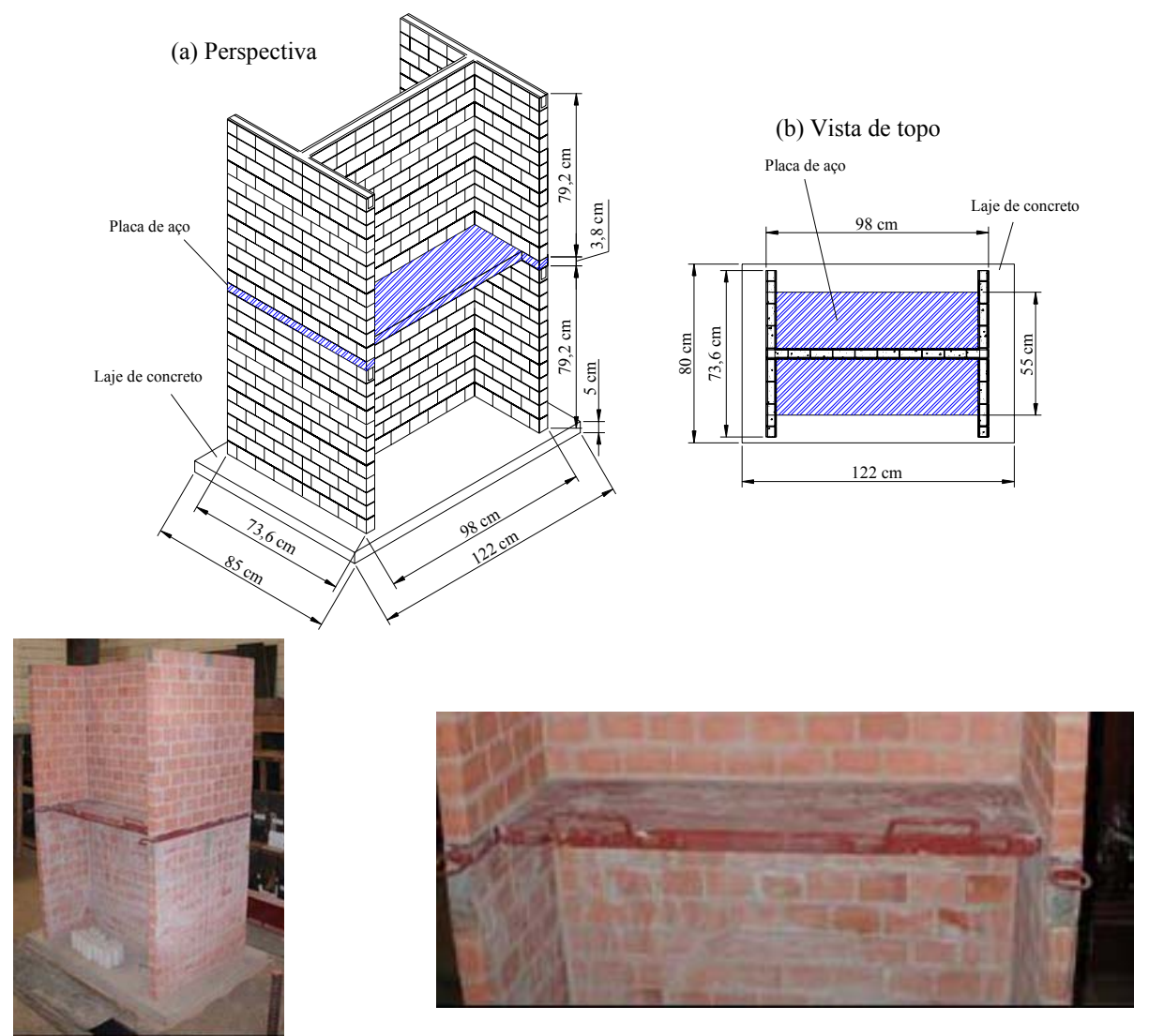

Figura 8.44 - Painel de alvenaria com dois pavimentos 


\subsection{2- Procedimentos e equipamentos utilizados no ensaio}

- Procedimentos:

O objetivo do ensaio é analisar a influência do número de pavimentos na distribuição das ações verticais em paredes de alvenaria interligadas por amarração direta. Para isso o carregamento é aplicado no topo de cada um dos pavimentos, apenas na região da parede central, similarmente ao efetuado nos ensaios dos painéis com um único pavimento.

- Equipamentos:

A principal dificuldade do ensaio é justamente a aplicação do carregamento apenas na região da parede central no topo do primeiro e segundo pavimento, sendo que os acréscimos de forças sejam iguais para os níveis diferentes. Para que se consiga esse aumento de carregamento por igual, são utilizados quatro macacos hidráulicos de 300 $\mathrm{kN}$ (dois em cada nível) ligados a uma mesma bomba, na tentativa de se garantir que a pressão em todos seja a mesma. Todos os macacos hidráulicos estão fixados no mesmo pórtico de reação. São utilizados perfis metálicos para a distribuição do carregamento ao longo do comprimento da parede central. No topo do primeiro pavimento as placas de aço dos flanges e da parede central não são contínuas, não havendo assim a transferência do carregamento aplicado da parede central para os flanges por meio dessas placas. Na verdade as placas de aço sobre os flanges têm o objetivo apenas de ajustar a modulação para a construção do segundo pavimento. A Figura 8.45 mostra um desenho esquemático do ensaio do painel com dois pavimentos.
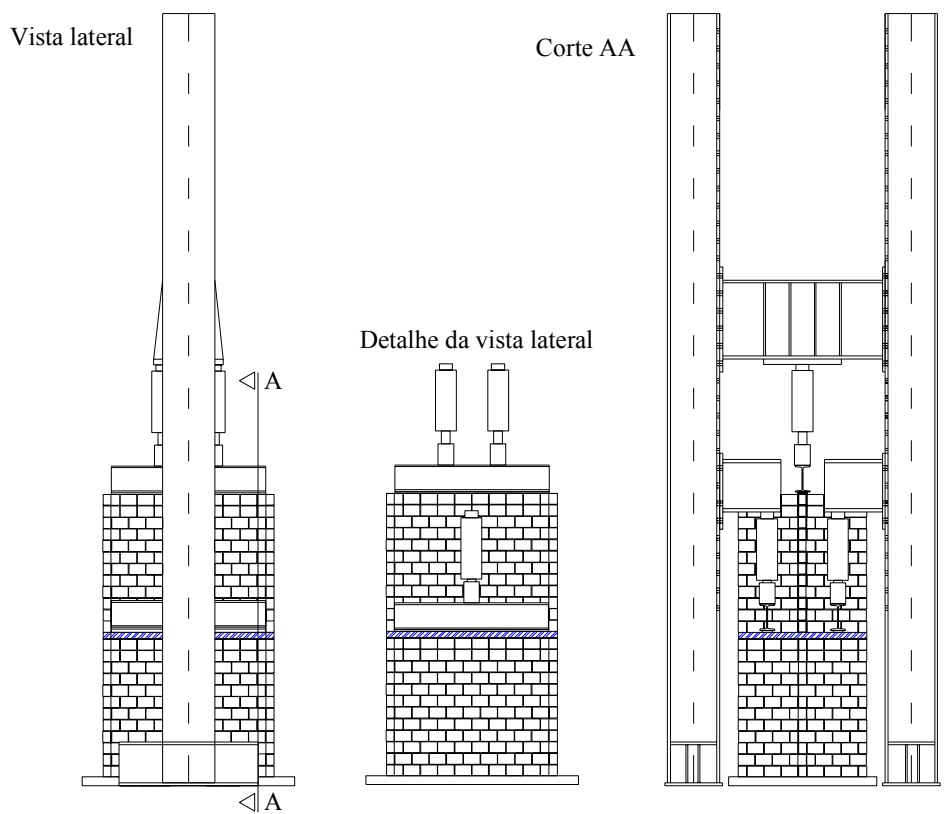

Figura 8.45 - Esquema de ensaio do painel com dois pavimentos 
$\mathrm{Na}$ aplicação do carregamento é feito o controle de força, pois se utilizam macacos hidraúlicos. Antes do ensaio propriamente dito é feito o escorvamento, isto é, aplica-se um carregamento inicial de $60 \mathrm{kN}$ para acomodação da estrutura e equipamentos. O carregamento é aplicado em etapas de $20 \mathrm{kN}$ (cerca de $5 \mathrm{kN}$ por macaco) esperando-se a estabilização da força total e das leituras da instrumentação utilizada. O ponto negativo de se utilizar o controle de força está relacionado à segurança do ensaio, pois a ruptura da alvenaria à compressão é frágil.

A instrumentação empregada no primeiro pavimento é idêntica aos dos painéis H2, para permitir a comparação entre os comportamentos. Já para o segundo pavimento, são utilizados apenas transdutores de deslocamentos com base de $50 \mathrm{~mm}$, visto que todos os demais transdutores de menores cursos e conseqüentemente maiores sensibilidade já estavam sendo utilizados no pavimento inferior. Com isso, a instrumentação do pavimento superior tem o objetivo apenas de registrar o seu comportamento geral. A Figura 8.46 apresenta o esquema da instrumentação utilizada, enquanto na Figura 8.47 têm-se fotos do esquema ensaio.

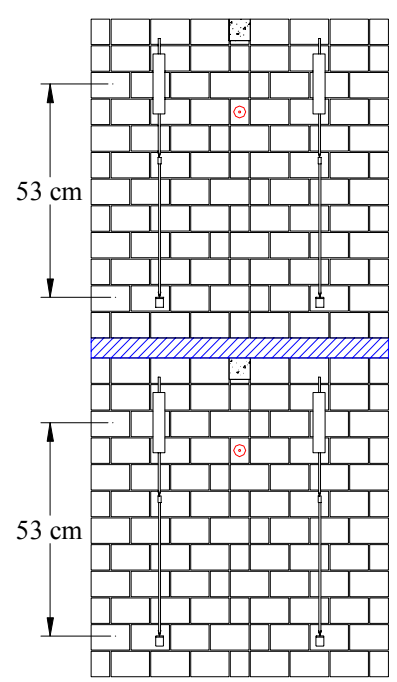

Flanges

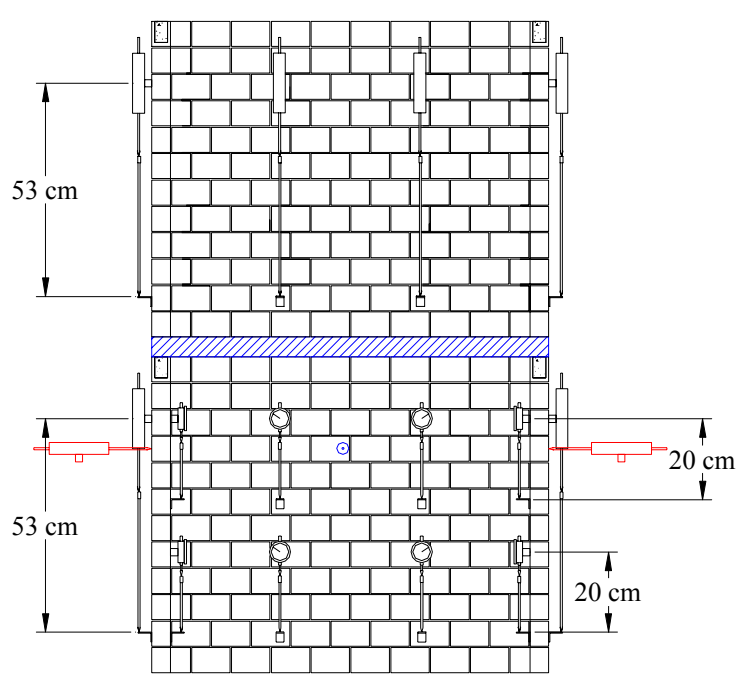

Parede central

Figura 8.46 - Instrumentação do painel H2 com 2 pavimentos 

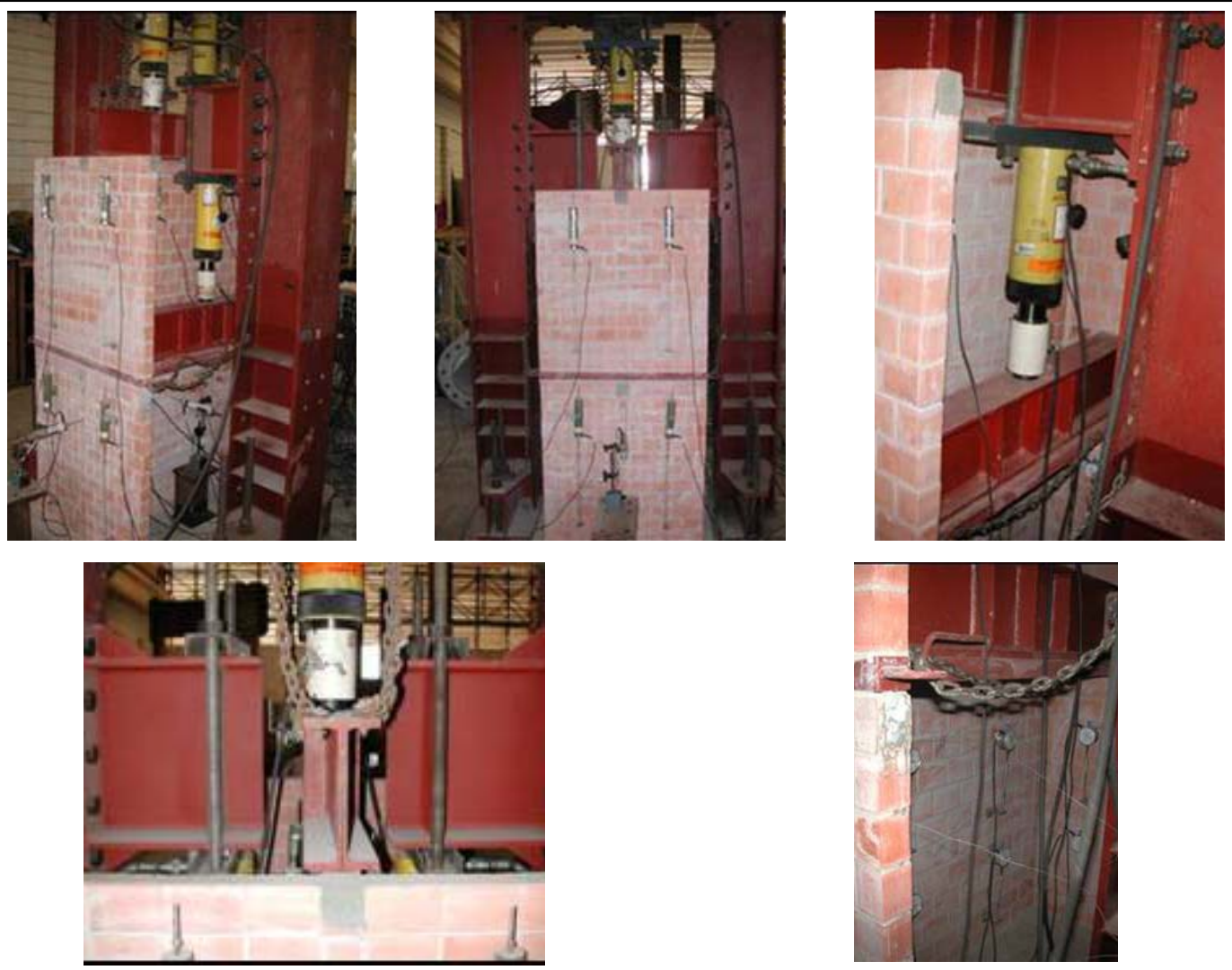

Figura 8.47 - Fotos do esquema do ensaio do painel H2 com 2 pavimentos

\subsection{3- Resultados do painel $\mathrm{H} 2$ com dois pavimentos}

Inicialmente deve-se ressaltar que por motivos alheios à pesquisa o ensaio do painel $\mathrm{H} 2$ com dois pavimentos foi realizado sete meses após sua construção, período muito superior aos observados nos ensaios anteriores. Esse fato gera uma distorção nos resultados dos corpos-de-prova, levando a valores superiores aos obtidos nos demais painéis ensaiados.

Na Tabela 8.17 apresentam-se os resultados dos corpos-de-prova, separando-se os valores referentes aos painéis do primeiro e do segundo pavimentos. A resistência da argamassa é praticamente o dobro das resistências verificadas nos painéis H2-1, H2-2 e $\mathrm{H} 2-2 \mathrm{a}$ e cerca de $20 \%$ superior a do painel H2-1a. Os prismas apresentam valores $80 \%$ superiores aos observados em todos os painéis $\mathrm{H} 2$, indicando que neste caso o conjunto bloco-argamassa (alvenaria) é mais resistente que os demais. Apesar do graute possuir uma resistência cerca de 30\% superior aos dos valores obtidos nos ensaios anteriores, os blocos canaletas preenchidos possuem resistências próximas às já encontradas. Isso demonstra mais uma vez que o limitante do bloco canaleta preenchido é o material cerâmico. 
Tabela 8.17 - Resultados dos ensaios dos corpos-de-prova do painel H2 com 2 pavimentos

\begin{tabular}{|c|c|c|c|c|c|}
\hline $\begin{array}{c}\text { Ensaios } \\
\text { (valores médios) }\end{array}$ & Argamassa & Prisma & Graute & Canaletas & $\begin{array}{c}\text { Concreto } \\
\text { base }\end{array}$ \\
\hline Resistência (MPa) & $\begin{array}{l}12,56^{1)} \\
11,40^{2)}\end{array}$ & $\begin{array}{l}18,40^{1)} \\
17,62^{2)}\end{array}$ & $\begin{array}{l}73,42^{1)} \\
68,89^{2)}\end{array}$ & $\begin{array}{l}51,92^{1)} \\
44,55^{2)}\end{array}$ & 31,81 \\
\hline
\end{tabular}

Na Tabela 8.18 são apresentados os resultados da força de ruptura, das tensões de ruptura e das resistências à compressão do painel H2 com dois pavimentos. Analisando-se a tensão de ruptura e considerando-se apenas a área da parede central, observa-se que o valor encontrado é $84 \%$ superior ao valor encontrado nos ensaios de caracterização, no entanto é apenas $20 \%$ superior à previsão da resistência da alvenaria por meio dos prismas de três blocos. Ao se calcular a tensão de ruptura em relação a toda a seção transversal do painel obtém-se um valor cerca de $30 \%$ inferior à resistência dos ensaios de caracterização e 55\% inferior à estimativa da resistência por meio dos prismas. As comparações com a previsão da resistência pelos prismas demonstram um comportamento semelhante aos painéis anteriores. Desse modo, não se pode afirmar que a maior força de ruptura em relação aos painéis $\mathrm{H} 2$ de um pavimento seja originada pela aplicação do carregamento em dois níveis diferentes ou se devido à maior resistência do conjunto bloco-argamassa.

Tabela 8.18 - Resultados do painel H2 com 2 pavimentos

\begin{tabular}{|c|c|c|c|c|}
\hline $\begin{array}{c}\text { Força de } \\
\text { Ruptura } \\
(\mathrm{kN})\end{array}$ & $\begin{array}{c}\text { Tensão de } \\
\text { ruptura } 1) \\
\text { (MPa) }\end{array}$ & $\begin{array}{c}\text { Tensão de } \\
\text { ruptura }{ }^{2)} \\
(\mathrm{MPa})\end{array}$ & $\begin{array}{l}\text { Resistência da } \\
\text { alvenaria } \\
\text { (MPa) }\end{array}$ & $\begin{array}{c}\text { Previsão da } \\
\text { resistência da } \\
\text { alvenaria }^{4)}(\mathrm{MPa})\end{array}$ \\
\hline 570,8 & 13,80 & 5,17 & 7,49 & \\
\hline \multicolumn{5}{|c|}{$\begin{array}{l}\text { 1) Tensão considerando apenas a área da parede central em planta; } \\
\text { 2) Tensão considerando a área de todo o painel em planta; } \\
\text { }{ }^{3)} \text { Resistência obtida nos ensaios de paredinhas (ensaios de caracterização); } \\
\text { }{ }^{4} \text { Previsão da resistência da alvenaria considerando a eficiência entre as resistências da paredinha e prismas } \\
\text { obtida nos ensaios de caracterização }(0,637) \text {. } \\
\text { Obs: Todas as resistências e tensões são relacionadas à área bruta. }\end{array}$} \\
\hline
\end{tabular}

A fissuração do painel com dois pavimentos iniciou-se pelo $2^{\circ}$ pavimento na região próxima à interseção das paredes, para um carregamento total de $280 \mathrm{kN}$, indicando o cisalhamento vertical da alvenaria. Com o aumento do carregamento as fissuras se estenderam ao longo de toda a altura da parede central do $2^{\circ}$ pavimento. Percebeu-se também o aparecimento de fissuras horizontais de flexão nos flanges desse mesmo pavimento (Figura 8.48-a). A fissuração no painel referente ao $1^{\mathrm{o}}$ pavimento só teve início após a interseção da parede central do $2^{\circ}$ pavimento estar com um grau 
elevado de deterioração, o que ocorreu para uma força total de $390 \mathrm{kN}$. As fissuras no $1^{\mathrm{o}}$ pavimento também se deram na região de interseção da parede central com os flanges, propagando-se ao longo da altura com o aumento do carregamento aplicado (Figura 8.48-b).

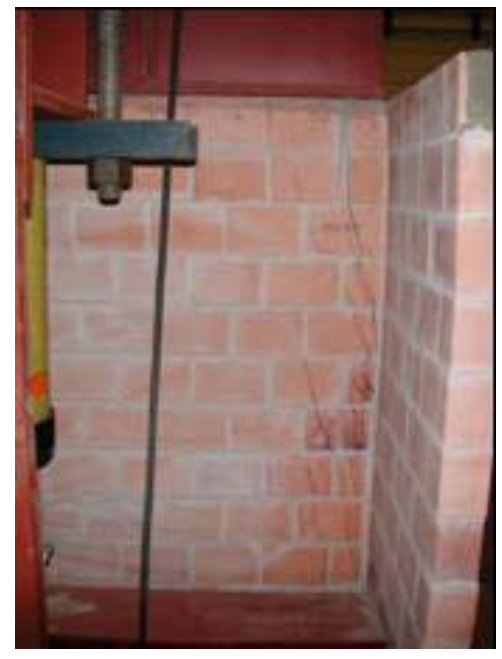

(a) $2^{\circ}$ pavimento

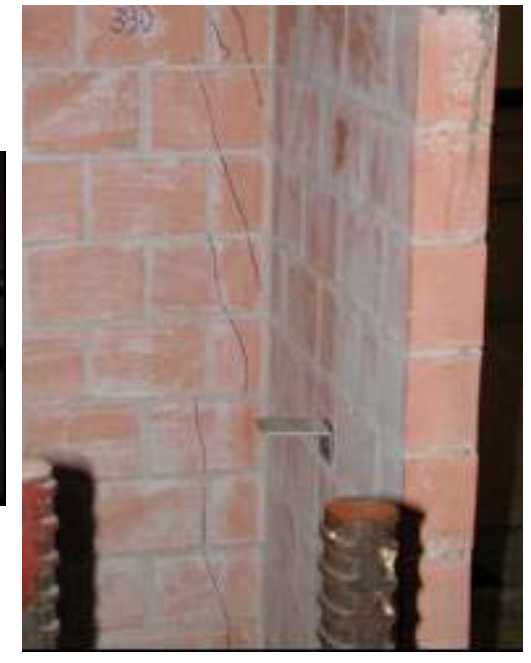

(b) $1^{\circ}$ pavimento

Figura 8.48 - Fissuração no painel $\mathrm{H} 2$ com 2 pavimentos

A forma de ruptura do painel $\mathrm{H} 2$ com dois pavimentos está ilustrada na Figura 8.49. Percebe-se que o carregamento se concentra na parede central devido a fissuração da interseção da parede central com os flanges em ambos os pavimentos. Ao final do ensaio, no $2^{\circ}$ pavimento chega a ocorrer a separação total dos flanges. A concentração de tensão na parede central do $1^{\circ}$ pavimento leva a uma ruptura por compressão, visto que além do carregamento aplicado em seu topo também resiste ao carregamento aplicado no nível superior.

Uma questão importante no ensaio do painel $\mathrm{H} 2$ com dois pavimentos é a aplicação do carregamento em dois níveis diferentes. Os macacos hidráulicos do $1^{\circ}$ e $2^{\circ}$ pavimento estavam interligados à mesma bomba, na tentativa de se aplicar carregamentos iguais aos dois níveis. Percebe-se na Figura 8.50 que em grande parte do ensaio esse objetivo é alcançado, pois a razão entre a força aplicada no $2^{\circ}$ pavimento e a aplicada no $1^{\circ}$ pavimento fica em torno de $95 \%$. Entretanto, ao se atingir uma força total de $440 \mathrm{kN}$, há uma queda brusca da força no $2^{\circ}$ pavimento o que abaixa a razão entre os dois níveis para cerca de $75 \%$. Essa diminuição da força aplicada no $2^{\circ}$ pavimento é devida à separação dos flanges da parede central, provocando a dissipação da força a eles transferida. Após esse alívio a parede central do $2^{\circ}$ pavimento continua a absorver o carregamento aplicado, mas a diferença entre os níveis permanece. 

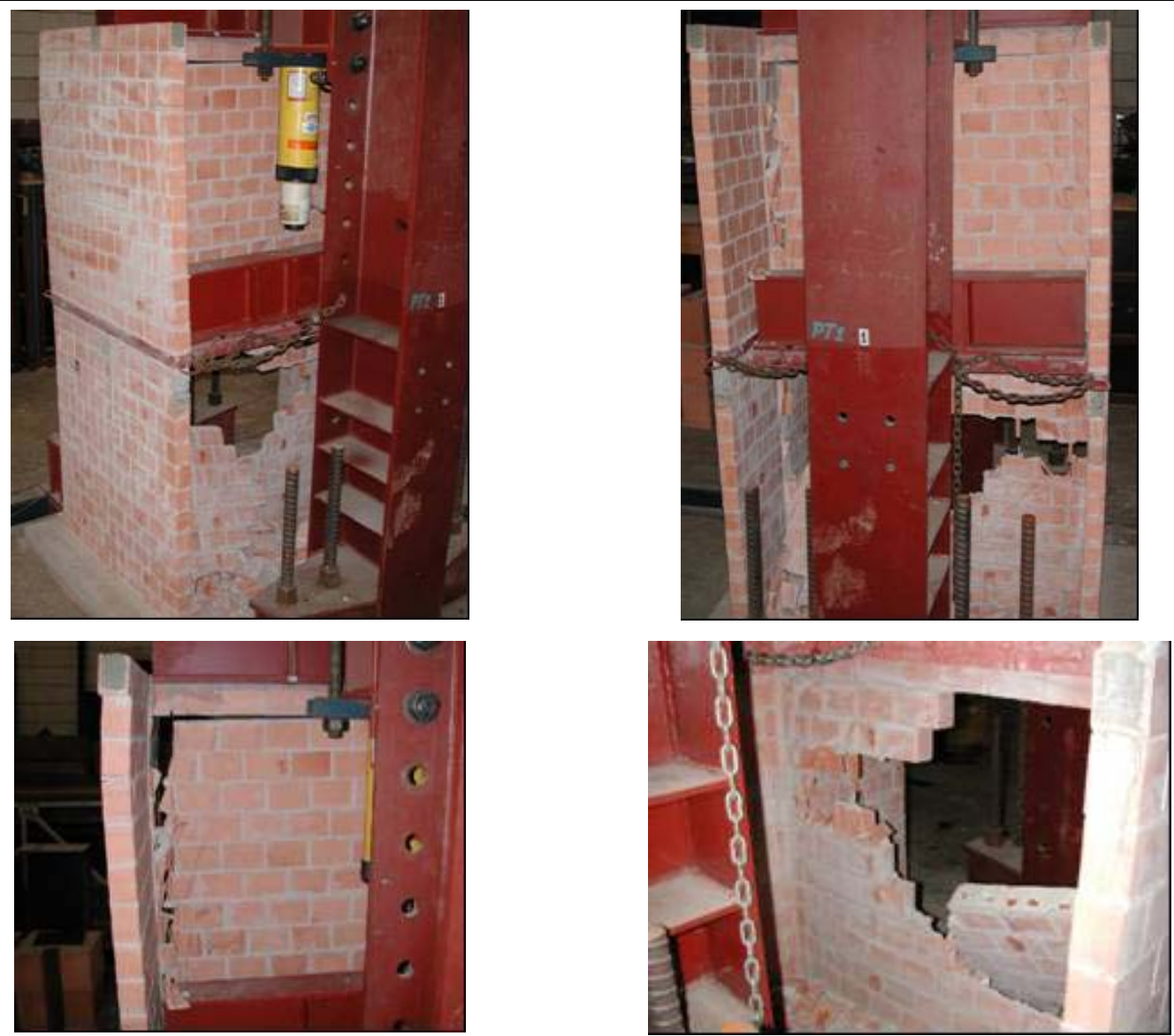

Figura 8.49 - Forma de ruptura do painel $\mathrm{H} 2$ com 2 pavimentos

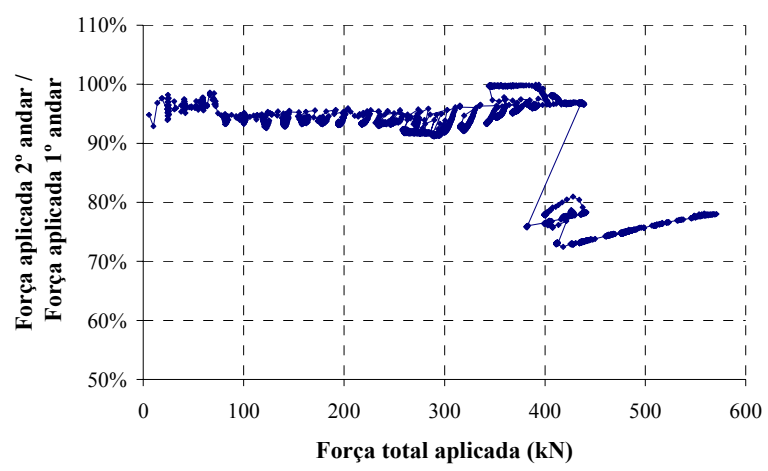

Figura 8.50 - Razão entre a força aplicada no $2^{\circ}$ pavimento e a aplicada no $1^{\circ}$ pavimento

Para visualizar o comportamento dos painéis referentes aos $1^{\circ}$ e $2^{\circ}$ pavimentos ao longo do carregamento constroem-se os gráficos da Figura 8.51. Ressalta-se que, como o $1^{\circ}$ pavimento possui instrumentação idêntica aos painéis $\mathrm{H} 2$ ensaiados anteriormente, utiliza-se a mesma sistemática de análise, dividindo-se o comportamento do painel em regiões: alma superior e inferior, flange interno superior e inferior e flange externo. Nessa situação o carregamento atuante no painel é a força total aplicada. No $2^{\circ}$ pavimento, como a instrumentação é mais simples, tem-se apenas o comportamento médio da alma (parede central) e do flange externo. Nesse caso considera-se que o 
carregamento atuante é somente a força aplicada no próprio $2^{\circ}$ pavimento. Para se evitarem danos aos equipamentos, toda a instrumentação é retirada para um carregamento total de $450 \mathrm{kN}$.

Observa-se na Figura 8.51-a que o $1^{\circ}$ pavimento é todo comprimido e seu comportamento é praticamente linear até os $280 \mathrm{kN}$, momento que iniciou-se a fissuração no pavimento superior. A partir desse ponto há um certo alívio nos flanges, enquanto na parede central (alma) ocorre uma tendência de maiores deformações. Na Figura 8.51-b verifica-se que a parede central do $2^{\circ}$ pavimento é sempre comprimida e apresenta comportamento linear até a retirada da instrumentação. Já nos flanges há a predominância da flexão, levando ao aparecimento de tensões de tração e conseqüentemente a abertura de fissuras, que geram o aumento expressivo dos alongamentos medidos.

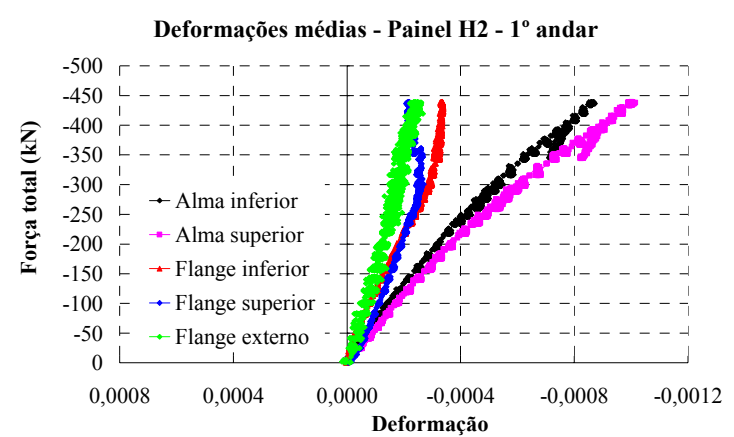

(a) $1^{\circ}$ pavimento

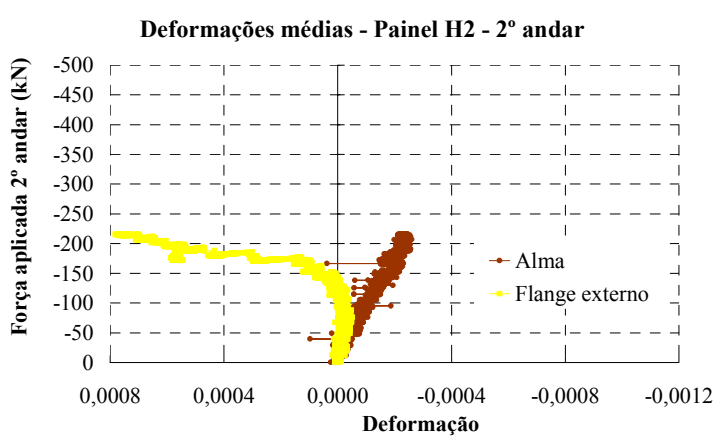

(b) $2^{\circ}$ pavimento

Figura 8.51 - Comportamento do painel $\mathrm{H} 2$ com 2 pavimentos

Para a análise do trecho linear do painel H2 com dois pavimentos consideraramse as deformações correspondentes a valores de força aplicada inferiores a 50\% do valor de ruptura. Na Figura 8.52 estão ilustrados os comportamentos referentes aos dois pavimentos. Observa-se que as medidas relacionadas ao $1^{\circ}$ pavimento (Figura 8.52-a) não apresentam perturbações, indicando um comportamento linear. Percebe-se que as diferenças entre as deformações da parede central (alma) superior e inferior são pequenas, da ordem de $11 \%$, apontando um comportamento distinto do verificado nos ensaios de painéis com um único pavimento. Acredita-se que essa tendência de uniformidade das deformações na alma seja gerada pela distribuição das ações aplicadas no pavimento superior para os flanges, levando a uma menor concentração de tensões no topo da parede central do pavimento inferior. Em relação aos flanges do $1^{\circ}$ pavimento nota-se que eles estão comprimidos, sem tendência de flexão, sendo mais uma demonstração que a parcela da força aplicada no $2^{\circ}$ pavimento transferiu-se 
diretamente para os flanges. Desse modo, há um efeito de pré-compressão nos flanges do pavimento inferior, diminuindo-se a possibilidade do aparecimento de fissuras de flexão e aumentando-se a resistência ao cisalhamento das juntas de argamassa. Verifica-se, Figura 8.52-b, que apenas a parede central (alma) do $2^{\circ}$ pavimento apresenta uma tendência de comportamento linear. Já nos flanges, nota-se uma forte tendência à flexão a partir de um carregamento superior aos $60 \mathrm{kN}$, o que explica as fissuras de flexão observadas no ensaio.
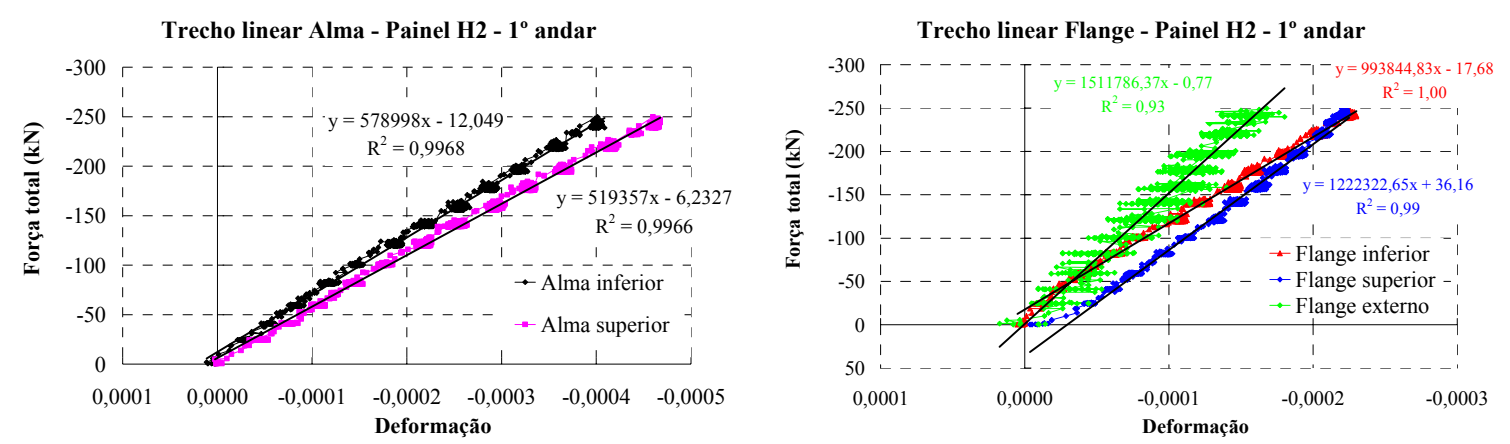

(a) $1^{o}$ pavimento

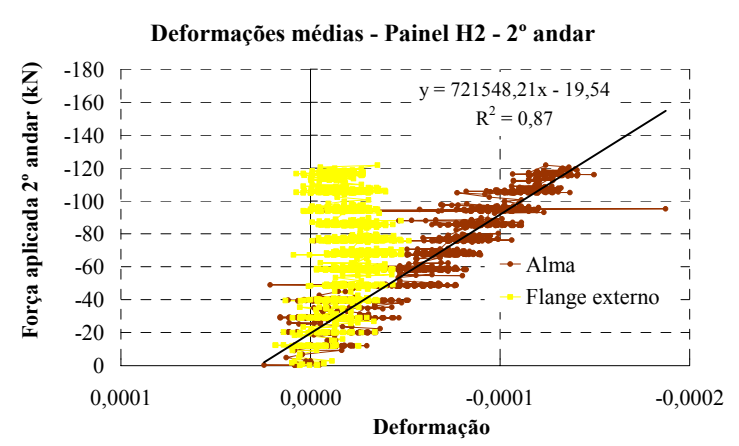

(b) $2^{\circ}$ pavimento

Figura 8.52 - Comportamento do trecho linear do Painel H2 com 2 pavimentos

\subsection{4- Comparação entre os resultados do painel $\mathrm{H} 2$ com dois pavimentos e dos painéis $\mathrm{H} 2$ com um pavimento}

Para uma melhor análise do comportamento do painel H2 com dois pavimentos realizam-se diversas comparações entre os seus resultados e dos painéis $\mathrm{H} 2$ com um pavimento. Ressalta-se que no ensaio de dois pavimentos, as chapas de aço sobre os flanges não têm ligação com a da parede central, não ocorrendo a restrição dos deslocamentos dos flanges como no caso dos ensaios com laje de topo. Portanto, consideram-se nessa comparação apenas os painéis H2 sem laje de topo, que correspondem à situação observada no ensaio de dois pavimentos. Como não foi verificada uma influência significativa da presença da cinta intermediária, item 7.4.7, analisam-se nesse estudo tanto os resultados do painel H2-1 quanto do painel H2-2. 
$\mathrm{Na}$ Tabela 8.19 realizam-se comparações entre as forças de ruptura dos diferentes painéis e seus respectivos prismas. Como já comentado anteriormente, a força de ruptura do painel com dois pavimentos é cerca de $50 \%$ superior aos valores encontrados nos ensaios de um pavimento. Todavia, a resistência dos prismas também é cerca de $70 \%$ superior. Dessa forma, não se pode afirmar que a maior força de ruptura do painel de dois pavimentos seja originada pelo fato do carregamento ser aplicado em níveis diferentes ou se pela maior resistência à compressão da alvenaria.

Tabela 8.19 - Comparação das forças de ruptura dos painéis com 1 e 2 pavimentos

\begin{tabular}{|c|c|c|c|c|}
\hline $\begin{array}{c}\text { Tipo do } \\
\text { painel }\end{array}$ & $\begin{array}{c}\text { Força de } \\
\text { ruptura (kN) }\end{array}$ & $\begin{array}{c}\text { Força Painel / } \\
\text { Força Painel H2-1 }\end{array}$ & $\begin{array}{c}\text { Prisma } \\
\text { (MPa) }\end{array}$ & $\begin{array}{c}\text { Prisma Painel / } \\
\text { Prisma Painel H2-1 }\end{array}$ \\
\hline H2-1 & 367,15 & 1,00 & 10,7 & 1,00 \\
\hline H2-2 & 379,15 & 1,03 & 10,0 & 0,93 \\
\hline H2 - 2pav. & 570,80 & 1,55 & $18,0^{*}$ & 1,68 \\
\hline \multicolumn{5}{|c}{ Valor médio dos dois pavimentos } \\
\hline
\end{tabular}

Com relação ao comportamento dos flanges dos diferentes painéis, observa-se na Figura 8.53-a que apesar do aparecimento de fissuras de flexão nos flanges do $2^{\circ}$ pavimento, tal fissuração é menos intensa que as constatadas nos painéis de um pavimento Figura 8.53-b e Figura 8.53-c. Essa menor intensidade se deve ao fato do $2^{\circ}$ pavimento estar submetido a um menor carregamento, pois apenas metade da ação é aplicada no topo deste pavimento. Já nos flanges do $1^{\circ}$ pavimento não se observa nenhum tipo de fissuração, isso porque parte do carregamento aplicado na parede central do pavimento superior é transferido para os flanges, fazendo com que fiquem comprimidos.

A ruptura do painel $\mathrm{H} 2$ de dois pavimentos ocorre pelo esgotamento da capacidade resistente à compressão da parede central do pavimento inferior (Figura 8.54-b). Nessa região ocorre uma concentração de tensão, pois além do carregamento diretamente aplicado, também atua uma parcela do carregamento proveniente do pavimento superior. Já no pavimento superior há apenas a ruptura da ligação entre a parede central e os flanges (Figura 8.54-a), continuando a parede central a resistir ao carregamento até se atingir a capacidade máxima do pavimento inferior. Nos painéis com um único pavimento, também ocorre a separação entre as paredes, sendo que, a partir desse instante, o carregamento passa a ser resistido apenas pela parede central, o que leva à sua ruptura por compressão (Figura 8.54-c e Figura 8.54-d). 


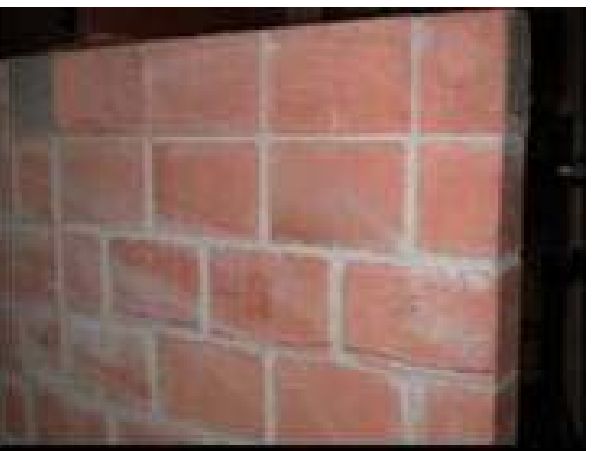

(a) flange do $2^{\circ}$ pavimento do painel de 2 andares

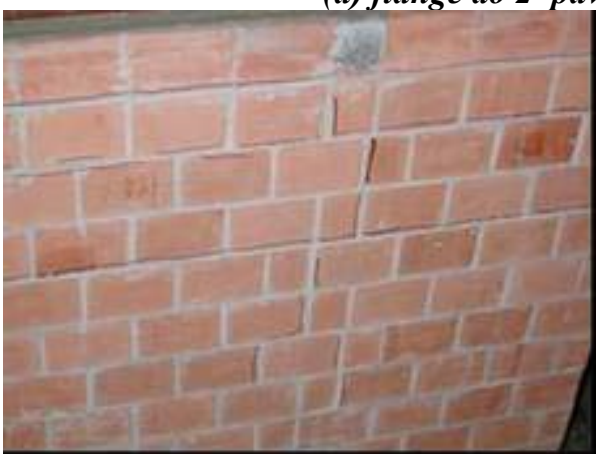

(b) flange do painel H2-1

Figura 8.53 - Fissuração dos flanges dos painéis

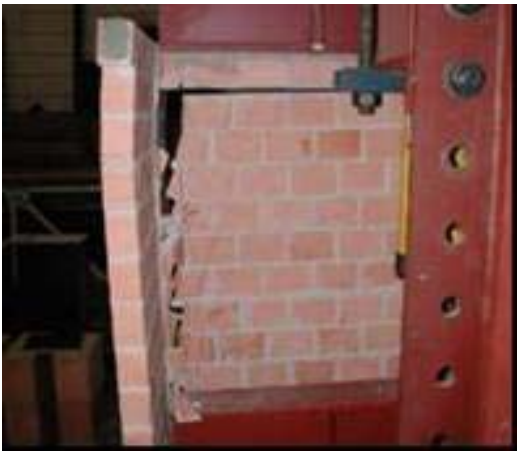

(a) Parede central do $2^{\circ}$ pavimento - painel 2 andares

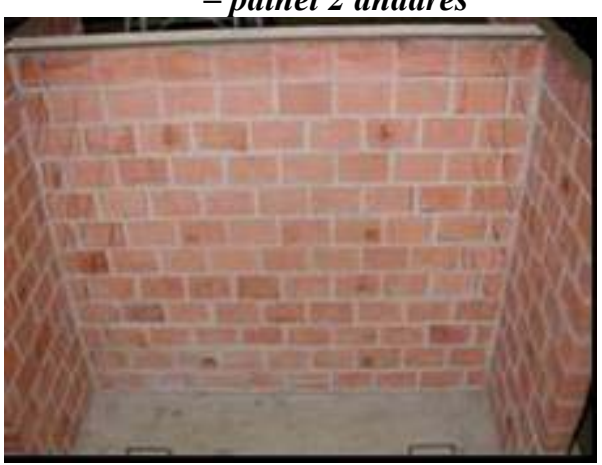

(c) Parede central do painel $\mathrm{H} 2-1$

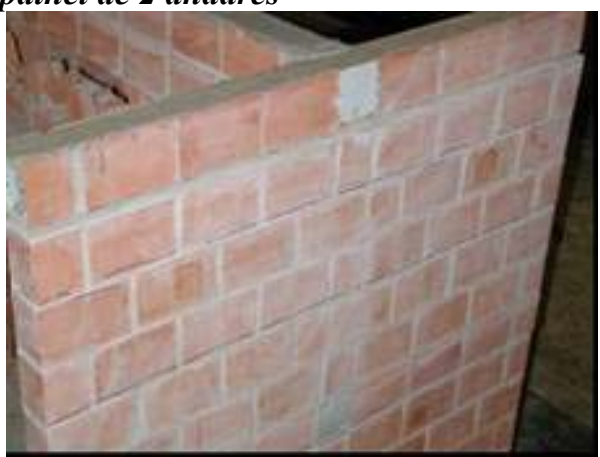

(c) flange do painel $\mathrm{H} 2-2$

(c) flange painéis

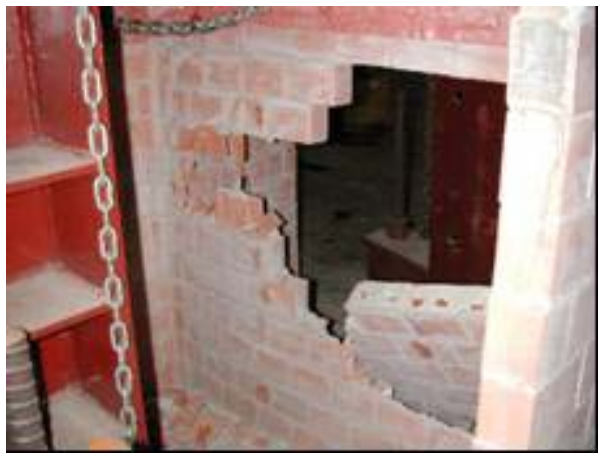

(b) Parede central do $1^{\circ}$ pavimento - painel 2 andadres

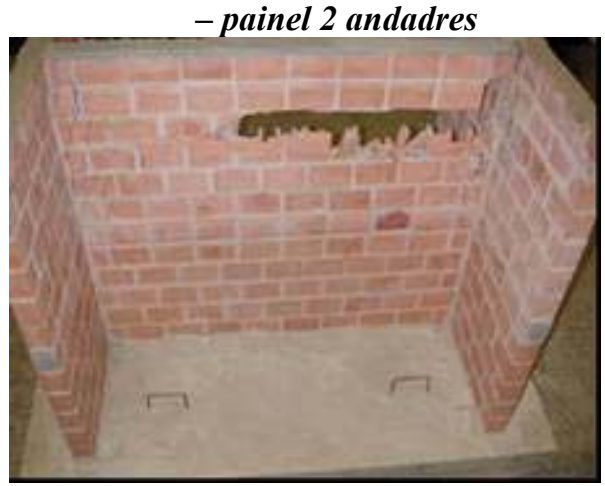

(d) Parede central do painel $\mathrm{H} 2-2$

Figura 8.54 - Formas de ruptura dos painéis

Pela Figura 8.55 pode-se comparar os comportamentos gerais do ensaio de dois pavimentos e dos painéis H2-1 e H2-2, lembrando que a instrumentação do $1^{\circ}$ pavimento é idêntica à utilizada nos ensaios dos painéis anteriores. Nota-se que a diferença das deformações entre a região da parede central (alma) superior e inferior no 
ensaio de dois pavimentos é menor que a observada nos ensaios dos painéis com um único pavimento. Nos flanges, observa-se que no andar inferior do ensaio de dois pavimentos as deformações são todas de compressão, enquanto no andar superior observa-se uma tendência de flexão semelhante a verificada nos ensaios com um único pavimento. Isso indica, mais uma vez, que no ensaio de dois pavimentos há uma transferência da parcela do carregamento aplicada no $2^{\circ}$ pavimento diretamente para os flanges, o que explica uma menor concentração de tensões normais verticais na parede central do pavimento inferior e a compressão a que os flanges estão submetidos.

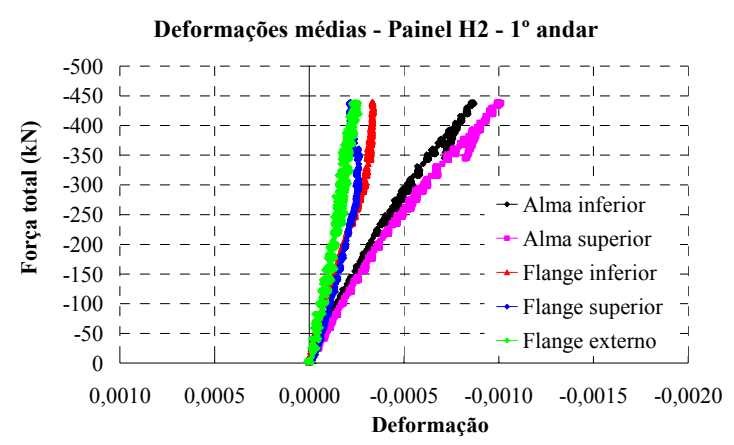

(a) Comportamento geral do $1^{\circ}$ pavimento - painel 2 andares

Deformações médias - Painel H2-1

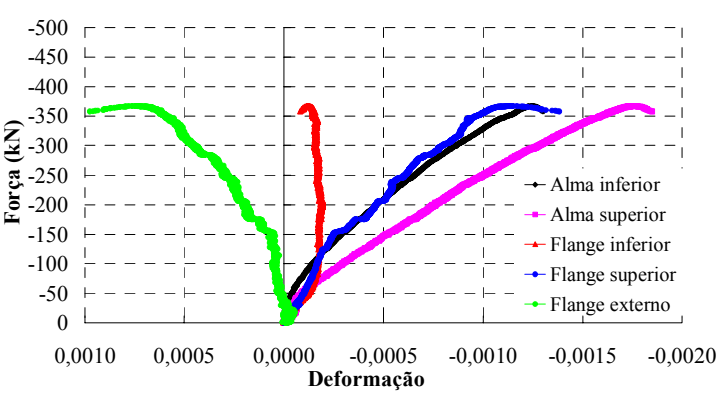

(c) Comportamento do painel $\mathrm{H} 2-1$

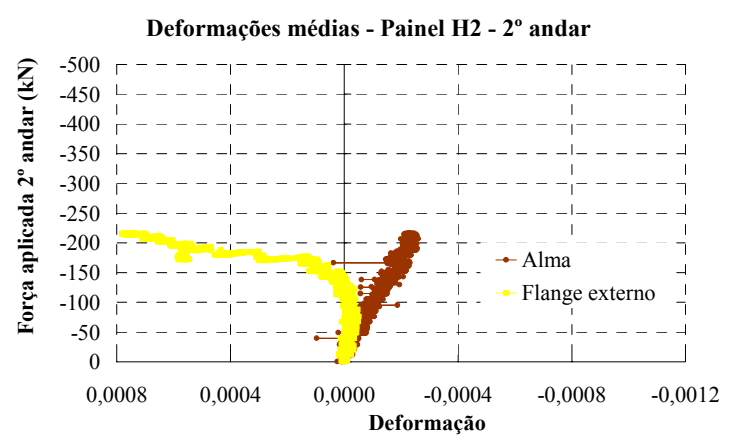

(b) Comportamento geral do $2^{\circ}$ pavimento - painel 2 andares

Deformações médias - Painel H2-2

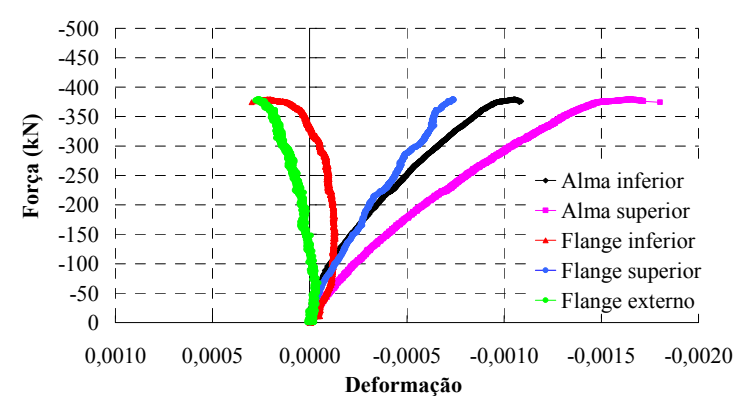

(d) Comportamento do painel $\mathrm{H} 2-2$

Figura 8.55 - Comportamento global dos painéis

Para a análise do comportamento do trecho linear das paredes centrais dos painéis têm-se os gráficos apresentados na Figura 8.56. Observa-se que na parede central (alma) do $1^{\circ}$ pavimento, a inclinação da reta referente à região superior é $90 \%$ do valor obtido na região inferior (Figura 8.56-a). Admitindo-se que o material está em regime elástico-linear, pode-se dizer que a tensão na região superior é cerca de $11 \%$ maior que a tensão no trecho inferior. Já nos ensaios dos painéis H2-1 e H2-2 (Figura 8.56-b e c), observa-se que a inclinação da região superior equivale a $64 \%$ do valor obtido para região inferior, indicando que as tensões na região próxima ao topo são $55 \%$ superiores as tensões próximas a base. Dessa maneira, verifica-se que ao aplicar-se o carregamento em dois níveis diferentes, diminui-se a concentração de tensões na parede 
central. Nota-se, ainda, que o painel H2 com dois pavimentos apresenta uma rigidez superior aos demais painéis.

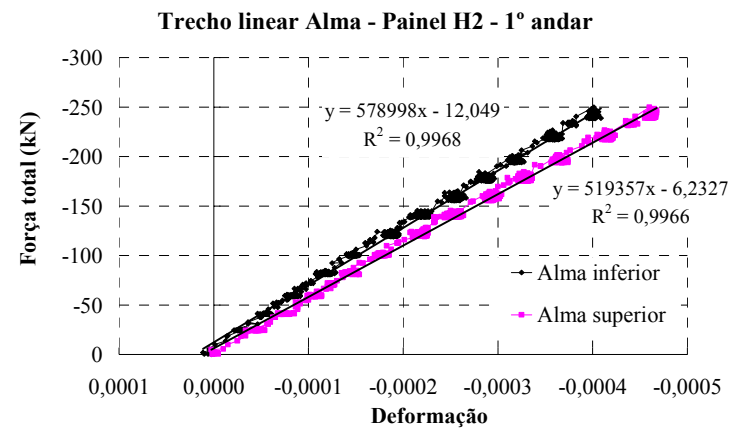

(a) Parede central do $1^{\circ}$ pavimento - painel 2 andares

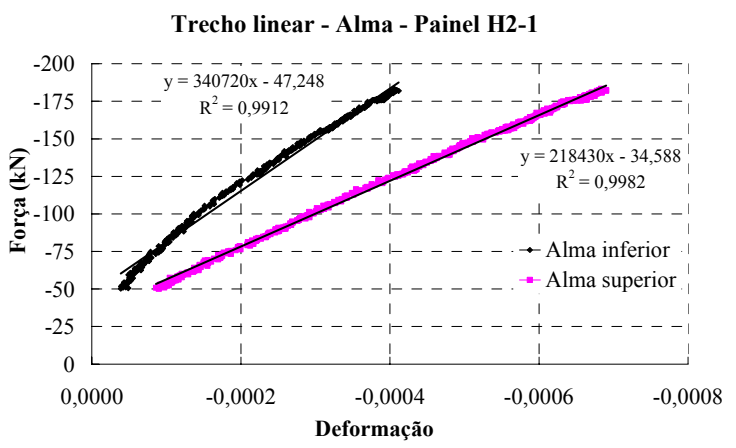

(b) Parede central do painel H2-1

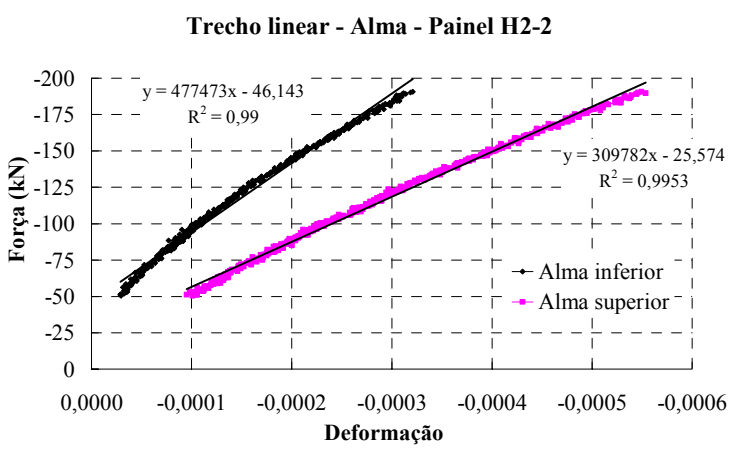

(c) Parede central do painel H2-2

Figura 8.56 - Comportamento do trecho linear das paredes centrais dos painéis

O comportamento dos trechos iniciais das curvas para os flanges dos painéis está apresentado na Figura 8.57. Nota-se uma tendência linear das deformações apenas nos flanges do $1^{\mathrm{o}}$ pavimento, enquanto que nos demais painéis percebem-se nãolinearidades para baixos valores de carregamento. Destaca-se a diferença verificada entre o comportamento dos flanges do ensaio de dois pavimentos e dos ensaios com um único pavimento. No primeiro caso os flanges permanecem comprimidos em regime linear, enquanto que nos ensaios dos painéis H2-1 e H2-2 observa-se uma forte tendência à flexão dos flanges. No caso do painel H2-1 os alongamentos da região externa dos flanges ocorrem desde o início do ensaio. Já no painel H2-2, há encurtamento da região externa no início do ensaio, que reverte-se para uma tendência de alongamento quando o carregamento atinge $50 \mathrm{kN}$. 


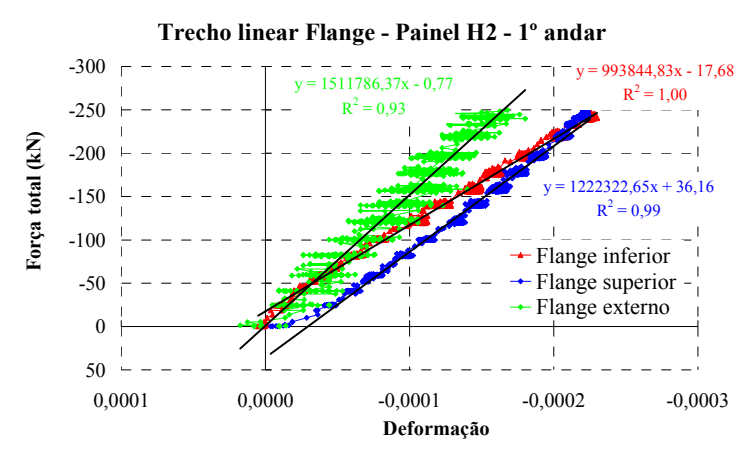

(a) Flanges do $1^{o}$ pavimento

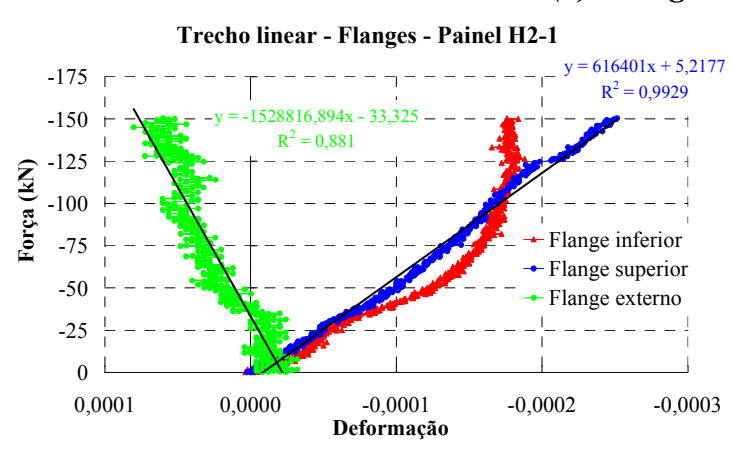

(b) Flanges do painel $\mathrm{H} 2-1$

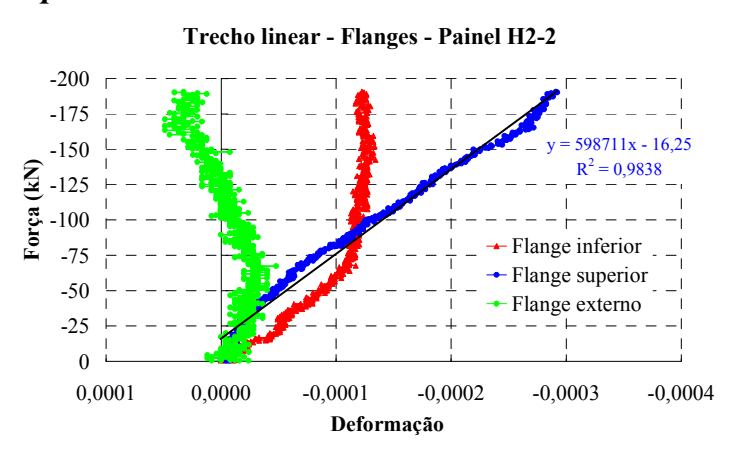

(c) Flanges do painel $\mathrm{H} 2-2$

Figura 8.57 - Comportamento dos trechos iniciais das deformações nos flanges dos painéis

\section{5- Análise numérica dos painéis de alvenaria}

Nos modelos numéricos dos ensaios dos painéis de alvenaria, com um e dois pavimentos, emprega-se apenas a macro-modelagem, considerando os blocos sem os vazios, com a não-linearidade física, pois este procedimento foi o que mais se aproximou do comportamento dos corpos-de-prova de cisalhamento. Salienta-se, como observado no capítulo 7, que para melhores resultados são necessários maiores estudos para o emprego da não-linearidade de contato para representação da interseção das paredes.

Nas situações em que existe a presença de lajes de concreto no topo, ou de placas de aço, elas são discretizadas na tentativa de se obter uma representação mais realista dos ensaios. Ressalta-se que nas análises numéricas deste item são empregados os procedimentos desenvolvidos no capítulo 6 , onde se realizou um estudo inicial dos modelos numéricos de alvenaria.

Em todas as modelagens dos painéis utilizam-se propriedades idênticas do conjunto bloco-argamassa, apresentadas na tabela 6.16. Semelhantemente à modelagem dos corpos-de-prova de cisalhamento (capítulo 7), considera-se apenas o comportamento elástico-linear das cintas de amarração, com módulo de elasticidade de $21470 \mathrm{MPa}$ e coeficiente de Poisson de 0,12 . No caso dos painéis com laje de concreto no topo, também, adota-se, por simplificação, apenas o comportamento elástico-linear 
do material, procedimento semelhante ao empregado para a consideração das placas de aço. Para o concreto da laje utiliza-se o módulo de elasticidade determinado experimentalmente para cada um dos painéis, enquanto para o aço emprega-se o módulo de elasticidade convencional (210.000 MPa).

Nas discretizações de todos os painéis emprega-se uma rede de elementos de tal forma que a máxima dimensão do elemento é de $2,5 \mathrm{~cm}$. Ressalta-se que na macromodelagem seria possível a utilização de simetrias para representação de apenas um quarto dos painéis. Entretanto, opta-se por manter o padrão de representação dos capítulos anteriores, isto é, emprega-se apenas a técnica de simetria em relação a um único eixo.

Na Figura 8.58 apresenta-se a modelagem numérica dos painéis tipo H1. Observa-se que os diferentes componentes constituintes dos painéis (alvenaria, cinta de amarração e laje de concreto no topo) estão representados por cores diferentes. Nota-se, também, que os carregamentos dos modelos numéricos estão de acordo com os respectivos ensaios.

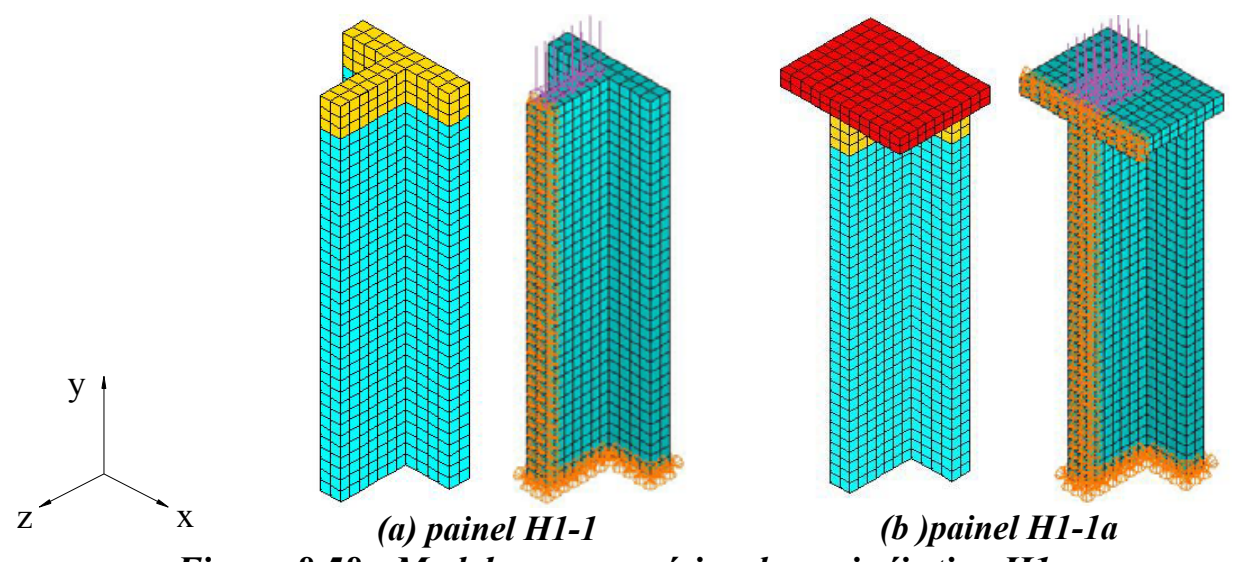

Figura 8.58 - Modelagem numérica dos painéis tipo $\mathrm{H} 1$.

Como pode ser observado na Tabela 8.20, os modelos numéricos empregados são capazes de representar qualitativamente a força de ruptura dos painéis ensaiados. Percebe-se que a análise numérica indica, como verificado nos ensaios, que o painel H1-1a, com laje no topo, tem uma força de ruptura maior que o painel H1, sem laje no topo. Entretanto, os modelos numéricos não são aptos para predizer o valor da força de ruptura dos painéis ensaiados, pois os valores das análises numéricas são cerca de $70 \%$ dos valores experimentais. Acredita-se que essa diferença ocorra por não serem os modelos numéricos desenvolvidos capazes de representar perfeitamente $o$ comportamento da interseção das paredes. 
Tabela 8.20 - Comparação entre forças de ruptura numérica e experimental - painéis H1

\begin{tabular}{|c|c|c|c|}
\hline Painel & $\begin{array}{c}\text { Força de ruptura } \\
\text { numérica }\left(\mathbf{F}_{\text {num }}\right)\end{array}$ & $\begin{array}{c}\text { Força de ruptura } \\
\text { experimental }\left(\mathbf{F}_{\text {exp }}\right)\end{array}$ & $\mathbf{F}_{\text {num }} / \mathbf{F}_{\exp }$ \\
\hline Painel H1-1 & $84,6 \mathrm{kN}$ & $121,3 \mathrm{kN}$ & $69,7 \%$ \\
\hline Painel H1-1a & $128,0 \mathrm{kN}$ & $166,2 \mathrm{kN}$ & $77,0 \%$ \\
\hline
\end{tabular}

As distribuições das tensões normais verticais na ruptura dos painéis tipo H1 estão ilustradas na Figura 8.59. Ressalva-se que para melhor visualização omite-se a representação da laje de concreto. Nota-se que o painel H1-1a que atingiu uma maior força de ruptura está, conseqüentemente, submetido a um nível de tensões de compressão superior ao painel H1-1. Percebe-se, também, que o flange do painel com laje no topo (H1-1a) está praticamente todo comprimido, enquanto que no flange do painel sem laje no topo (H1-1) a flexão é mais acentuada. Lembra-se que essa diferença nos comportamentos entre os painéis $\mathrm{H} 1$ é verificada nos ensaios e é devida à laje no topo. Portanto, os modelos numéricos são aptos a representar a influência da presença da laje de concreto no topo do painel H1.

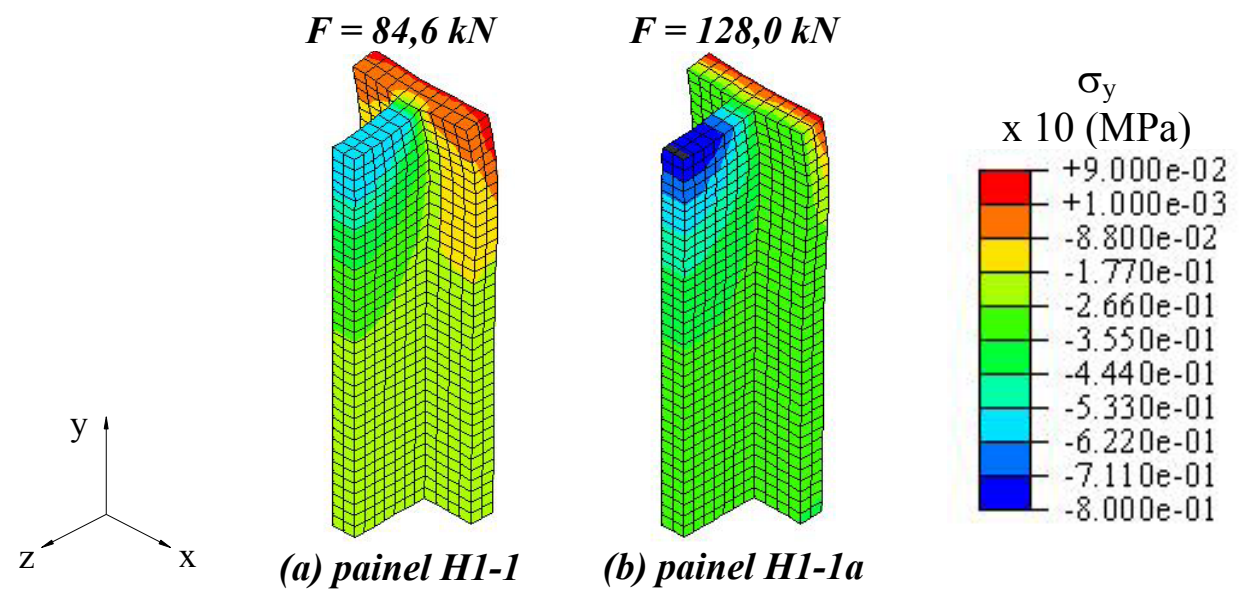

Figura 8.59 - Distribuição das tensões normais verticais nos painéis tipo H1

Na Figura 8.60 estão apresentadas as distribuições das tensões cisalhantes no plano "zy" correspondentes à ruptura dos painéis tipo H1. Como esperado, o painel H11a apresenta tensões cisalhantes superiores às do painel H1-1, pois a força atuante é maior. Todavia, essas maiores tensões ocorrem na região da cinta de amarração, que possue uma maior capacidade de resistir ao cisalhamento, como visto no capítulo anterior. Ressalta-se que os níveis das tensões de cisalhamento na alvenaria nos dois painéis H1 são próximos e concentram-se na região próxima à interseção das paredes, como verificado nos ensaios. Dessa forma, pode-se concluir que os modelos numéricos são capazes de representar qualitativamente a distribuição de tensões cisalhantes no painel H1. 


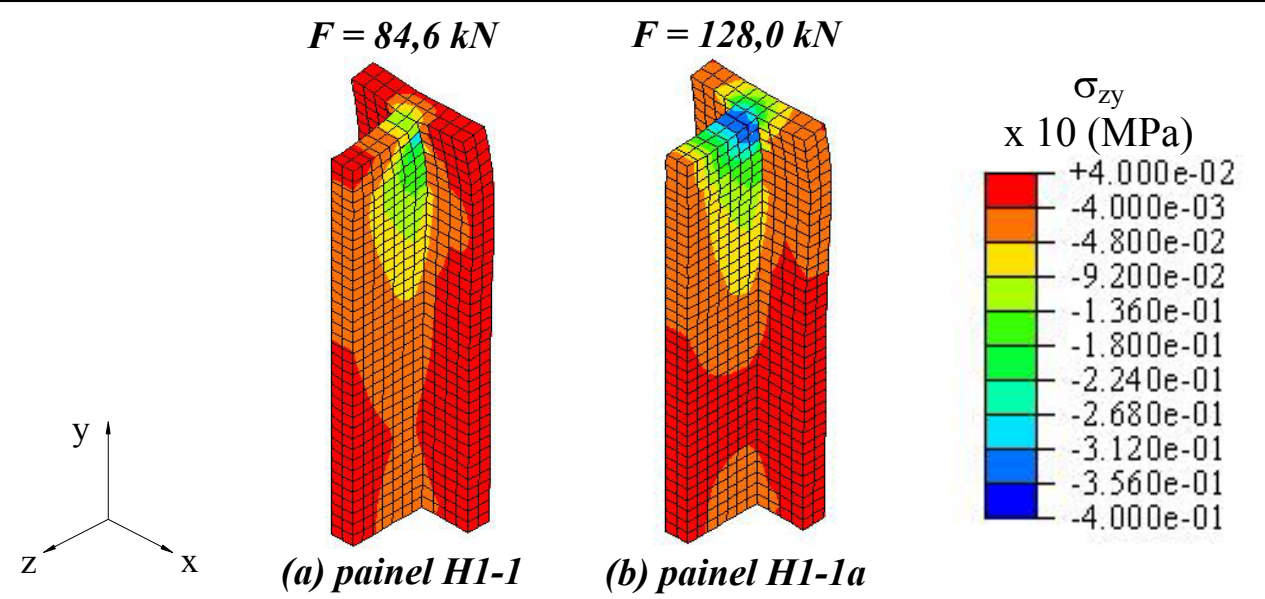

Figura 8.60 - Distribuição das tensões cisalhantes no plano “zy” nos painéis tipo H1

Algumas comparações entre as deformações obtidas nas análises numéricas, lineares e não-lineares, com os valores experimentais estão apresentadas nos gráficos da Figura 8.61. Observa-se que o comportamento linear dos painéis tipo H1 é relativamente bem representado pelos modelos numéricos. Contudo, percebe-se, nas Figuras 8.61-c e -d, que no momento em que ocorre a tendência de alongamento dos flanges externos, devido à fissuração da interseção das paredes, os modelos numéricos não são capazes de representá-lo. Como já comentado anteriormente, essa inabilidade está associada à falta de adequação na representação do comportamento da interseção das paredes pelos modelos numéricos.

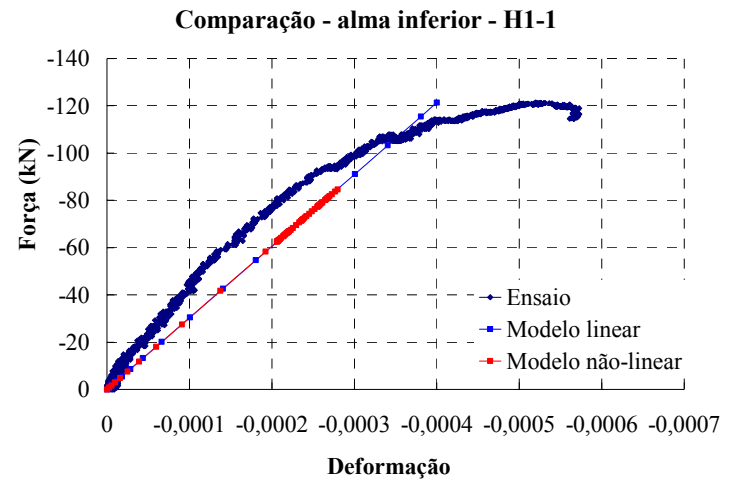

(a)

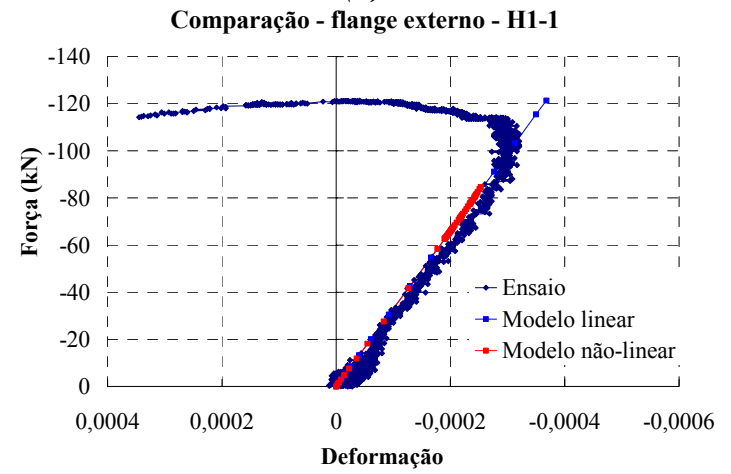

(c)

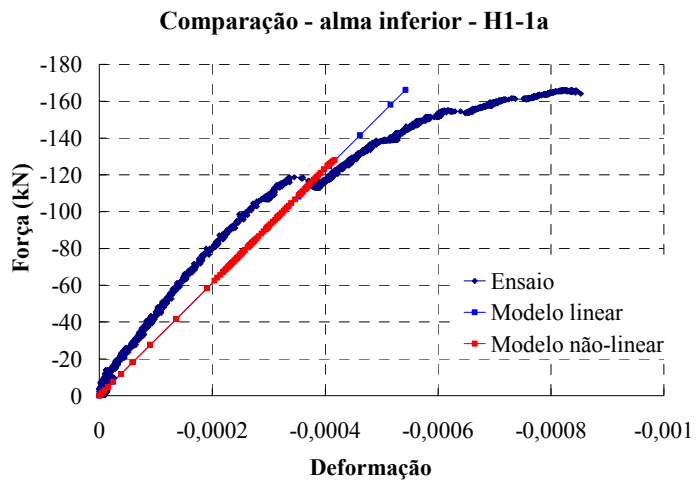

(b)

Comparação - flange externo - H1-1a

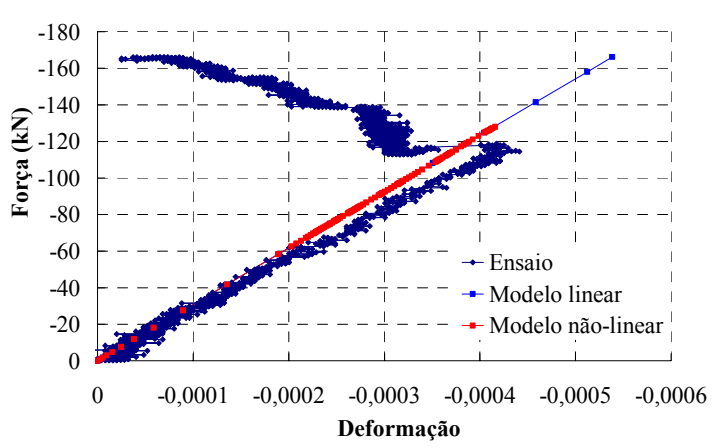

(d)

Figura 8.61 - Comparação entre os resultados numéricos e experimentais dos painéis tipo H1 
Os modelos numéricos e as formas de carregamento dos painéis tipo H2 estão apresentados na Figura 8.62, onde é possível distinguir, pelas diferentes cores, os materiais utilizados (alvenaria, cinta de amarração e laje de concreto). Percebe-se que os carregamentos dos modelos numéricos estão de acordo com os respectivos ensaios.

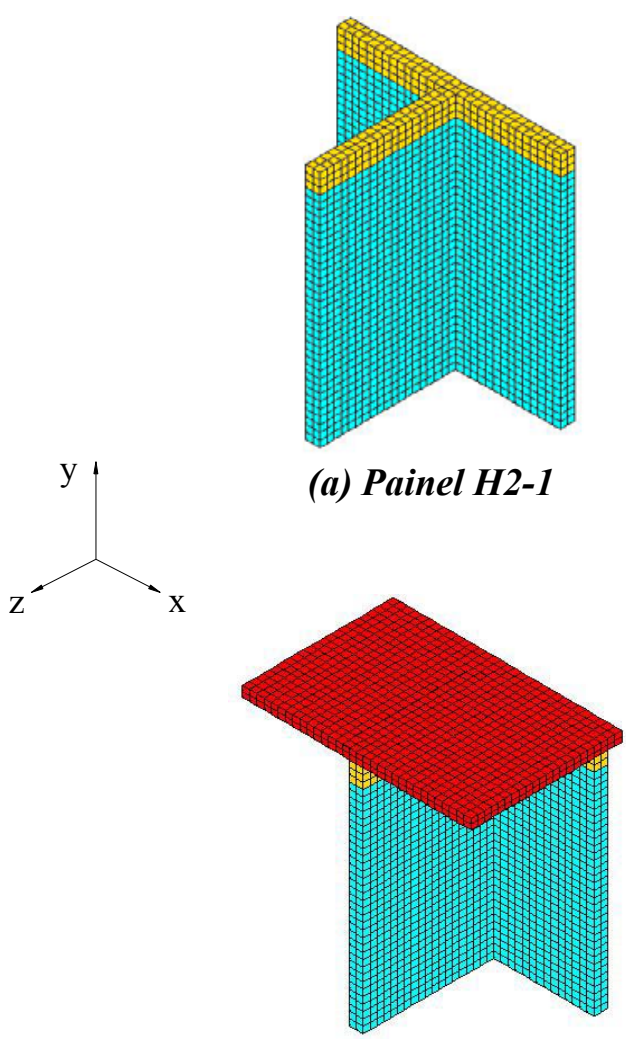

(d) Painel H2-1a

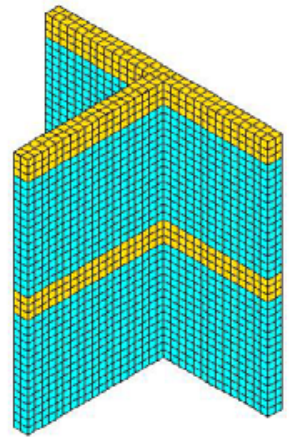

(b) Painel H2-2

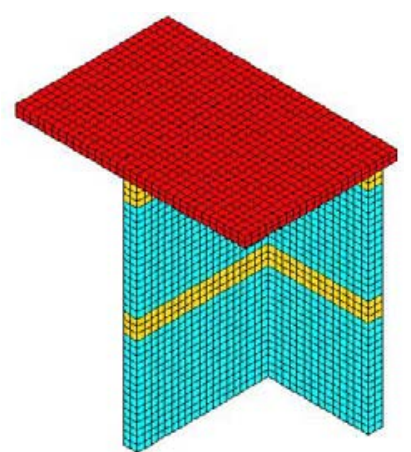

(e) Painel H2-2a

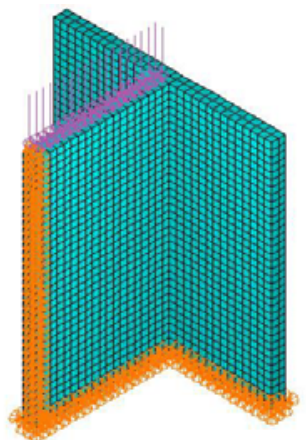

(c) Carregamento sem

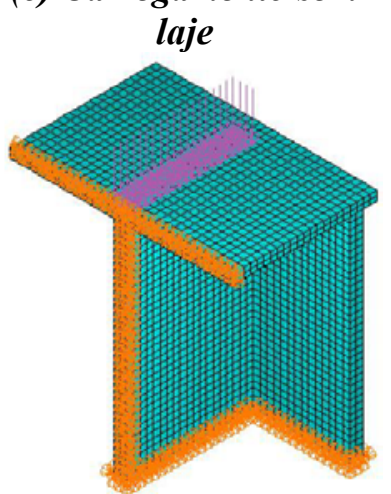

(f) Carregamento com laje

Figura 8.62 - Modelagem numérica dos painéis tipo $\mathrm{H} 2$.

Na Tabela 8.21 verifica-se que, novamente, os modelos numéricos empregados são capazes de representar qualitativamente a força de ruptura dos painéis tipo H2. Nota-se que a análise numérica indica que a presença da cinta de amarração na fiada intermediária não traz ganho em relação à força de ruptura, fato observado nos ensaios. $\mathrm{O}$ aumento da força de ruptura devido à presença da laje no topo também é representado pelos modelos numéricos. Contudo, outra vez, os modelos numéricos não são aptos para predizer o valor da força de ruptura dos painéis ensaiados, sendo, neste caso, os valores das análises numéricas cerca de $45 \%$ dos valores experimentais.

Tabela 8.21 - Comparação entre as forças de ruptura numérica e experimental - painéis H2

\begin{tabular}{|c|c|c|c|}
\hline Painel & $\begin{array}{c}\text { Força de ruptura } \\
\text { numérica }\left(F_{\text {num }}\right)\end{array}$ & $\begin{array}{c}\text { Força de ruptura } \\
\text { experimental }\left(F_{\text {exp }}\right)\end{array}$ & $\mathbf{F}_{\text {num }} / \mathbf{F}_{\exp }$ \\
\hline Painel H2-1 & $164,1 \mathrm{kN}$ & $367,2 \mathrm{kN}$ & $44,7 \%$ \\
\hline Painel H2-2 & $164,1 \mathrm{kN}$ & $379,2 \mathrm{kN}$ & $43,3 \%$ \\
\hline Painel H2-1a & $210,6 \mathrm{kN}$ & $467,1 \mathrm{kN}$ & $45,1 \%$ \\
\hline Painel H2-2a & $211,6 \mathrm{kN}$ & $302,6 \mathrm{kN}^{*}$ & -- \\
\hline
\end{tabular}

* Obs.: Ruptura atípica, o valor não deve ser considerado para comparações 
Para a comparação dos comportamentos das tensões normais verticais no instante da ruptura dos painéis tipo $\mathrm{H} 2$ utiliza-se a Figura 8.63. Similarmente aos modelos dos painéis $\mathrm{H} 1$, para melhor vizualização omite-se a representação das lajes de concreto. Nota-se que a presença das cintas de amarração intermediárias tem apenas uma pequena influência na distribuição das tensões normais nos flanges, fato também observado nos ensaios. Na mesma figura percebe-se que a presença da laje no topo do painel permite a aplicação de um maior carregamento. Outro efeito da presença das lajes é que os flanges permanecem em grande parte comprimidos, ao contrário dos flanges dos painéis sem laje no topo. Essas influências das lajes são comprovadas pelos ensaios dos painéis tipo H2. Desse modo, confirma-se a capacidade dos modelos numéricos em representar qualitativamente a influência das presenças da cinta de amarração intermediária e da laje de concreto no topo.

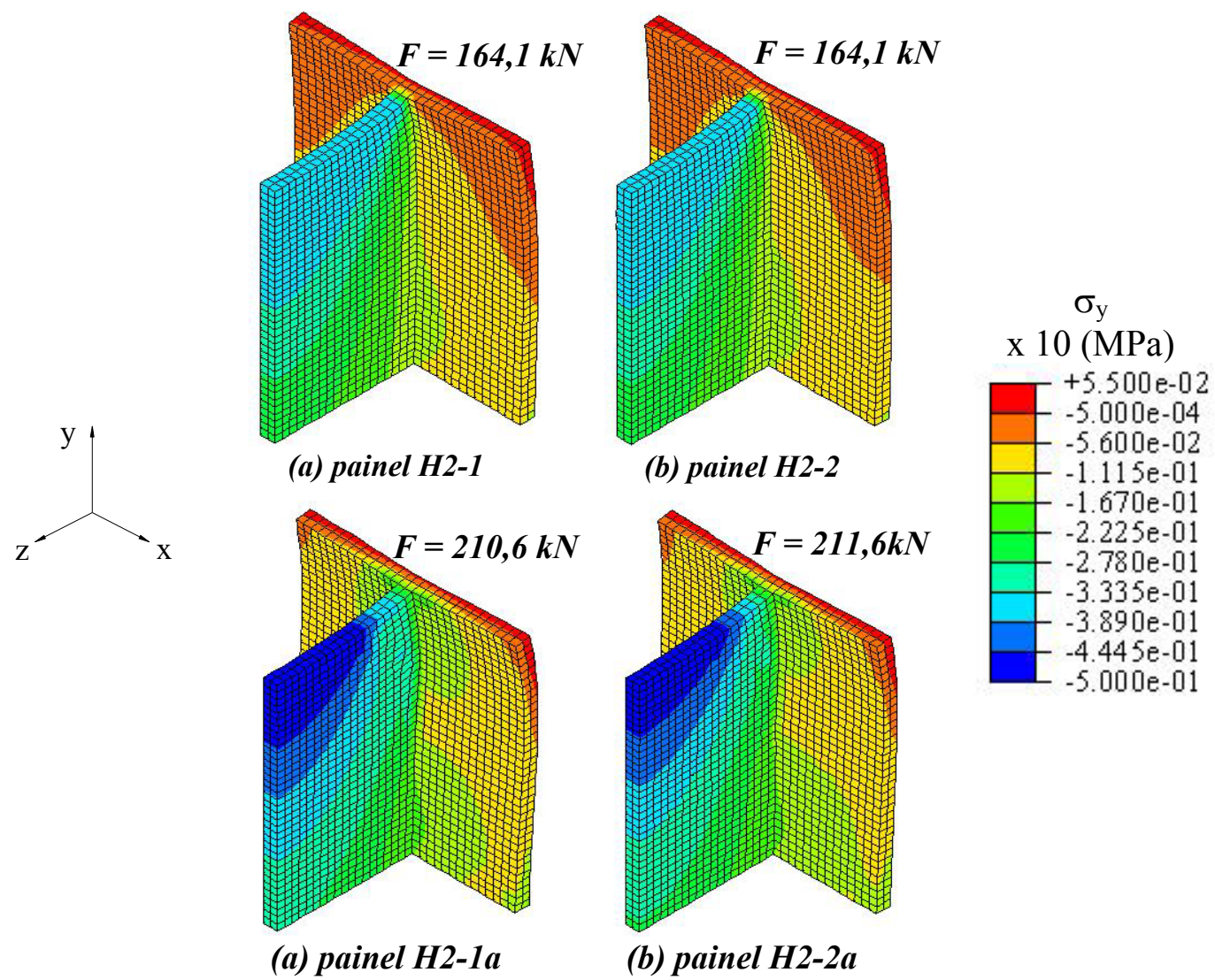

Figura 8.63 - Distribuição das tensões normais verticais nos painéis tipo H2

As distribuições das tensões cisalhantes no plano "zy" na ruptura dos painéis tipo H2 estão ilustradas na Figura 8.64. Analogamente aos painéis tipo H1, os painéis tipo H2 com a laje no topo apresentam tensões cisalhantes superiores às dos painéis sem laje, pois as forças máximas são maiores. Em todas as situações, as maiores tensões cisalhantes ocorrem na região da cinta de amarração de topo. Nota-se que, em todos os 
painéis, os níveis das tensões de cisalhamento na alvenaria são próximos. Entretanto, nos painéis com laje no topo as regiões mais solicitadas estendem-se por uma maior área. Em todos os casos, o cisalhamento se concentra próximo à interseção das paredes, que é a região que apresenta maior fissuração nos ensaios realizados. Mais uma vez, os modelos numéricos representam qualitativamente o comportamento do cisalhamento dos painéis de alvenaria.

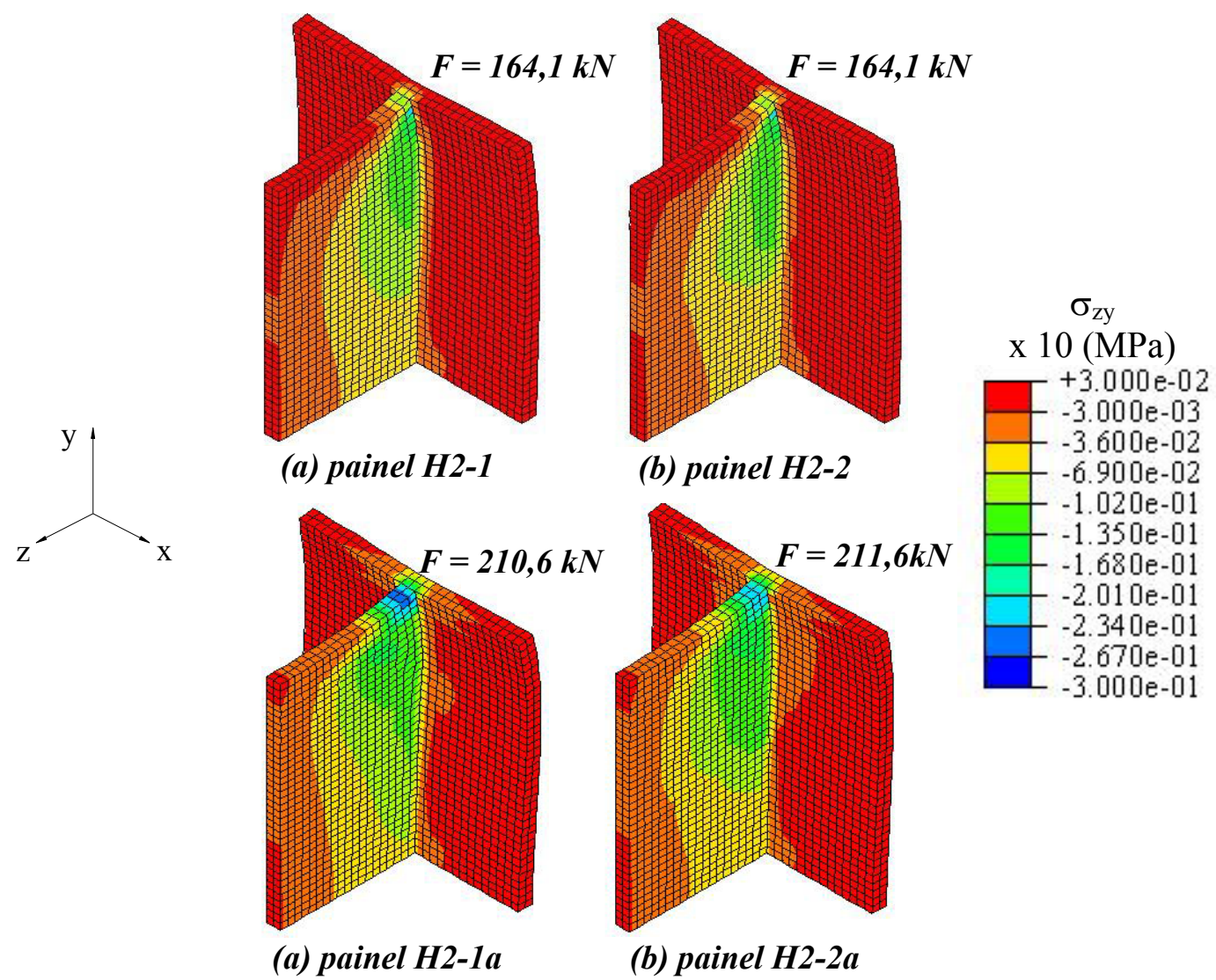

Figura 8.64 - Distribuição das tensões cisalhantes no plano “zy” nos painéis tipo H2

$\mathrm{Na}$ Figura 8.65 comparam-se algumas deformações obtidas nas análises numéricas, lineares e não-lineares, com os valores experimentais dos painéis tipo H2. Nota-se que nos painéis com laje no topo (Figuras 8.65-b e -d) o comportamento é relativamente bem representado pelos modelos numéricos até o instante em que se iniciam as perturbações nas leituras experimentais das deformações. Já nos painéis sem laje no topo (Figuras 8.65-a e -c) os modelos numéricos não são capazes de representar as variações nas deformações verticais que ocorrem desde os estágios iniciais de carregamento. Acredita-se, novamente, que essa má representação das perturbações verificadas nos ensaios esteja associada à falta de representatividade do comportamento da interseção das paredes pelos modelos numéricos. 


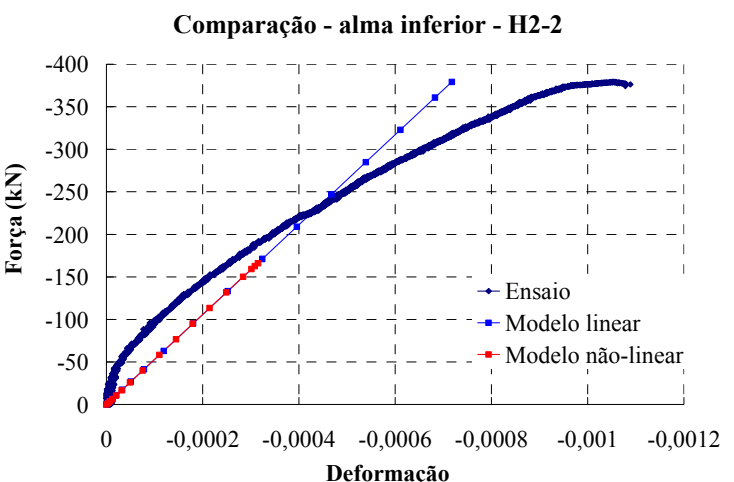

(a)

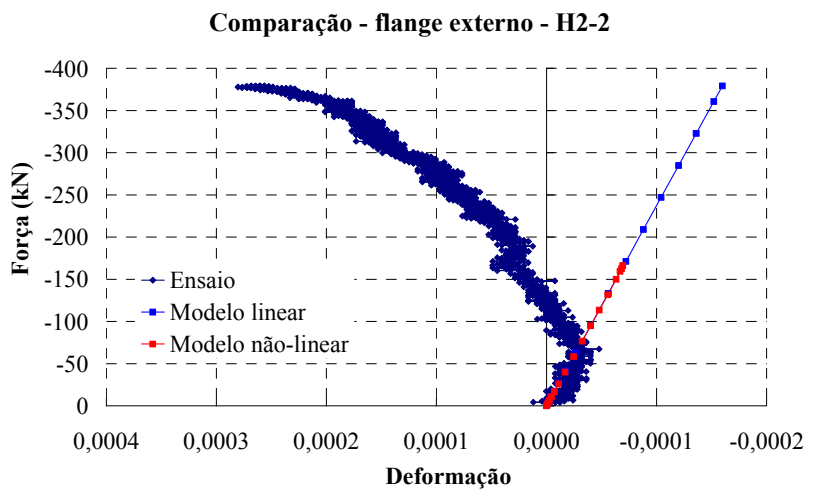

(c)

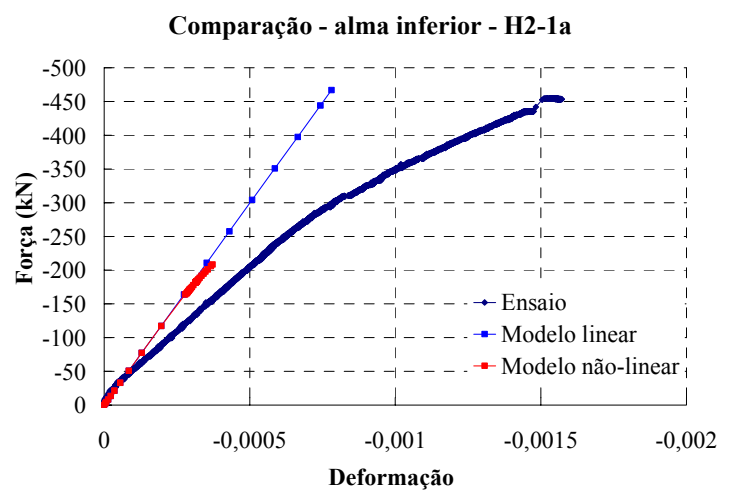

(b)

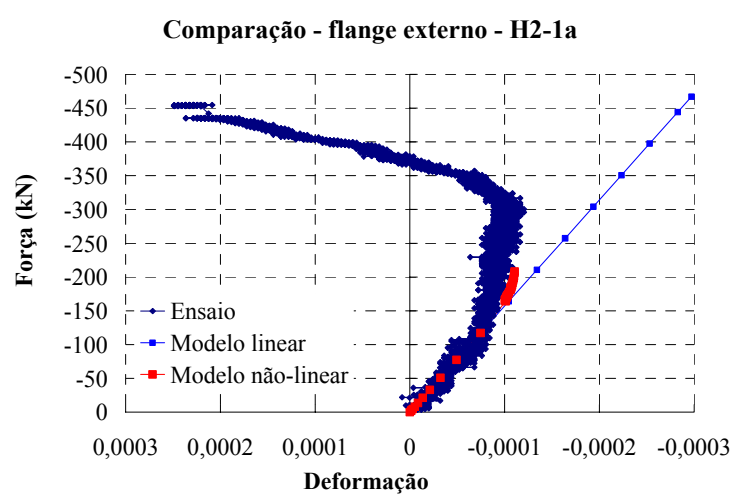

(d)

Figura 8.65 - Comparação entre os resultados numéricos e experimentais dos painéis tipo H2

O modelo numérico do painel tipo $\mathrm{H} 2$ com dois pavimentos está apresentado na Figura 8.66, sendo que neste caso os materiais utilizados são a alvenaria (em verde), as cintas de amarração (em amarelo) e as placas de aço (em vermelho). Toma-se o cuidado de aplicar o carregamento no modelo numérico de acordo com o ensaio realizado, isto é, as forças são aplicadas com a mesma intensidade e simultaneamente em dois níveis. Ressalta-se que, similarmente ao ensaio, a placa de aço sobre a parede central não é interligada com a placa de aço sobre os flanges.

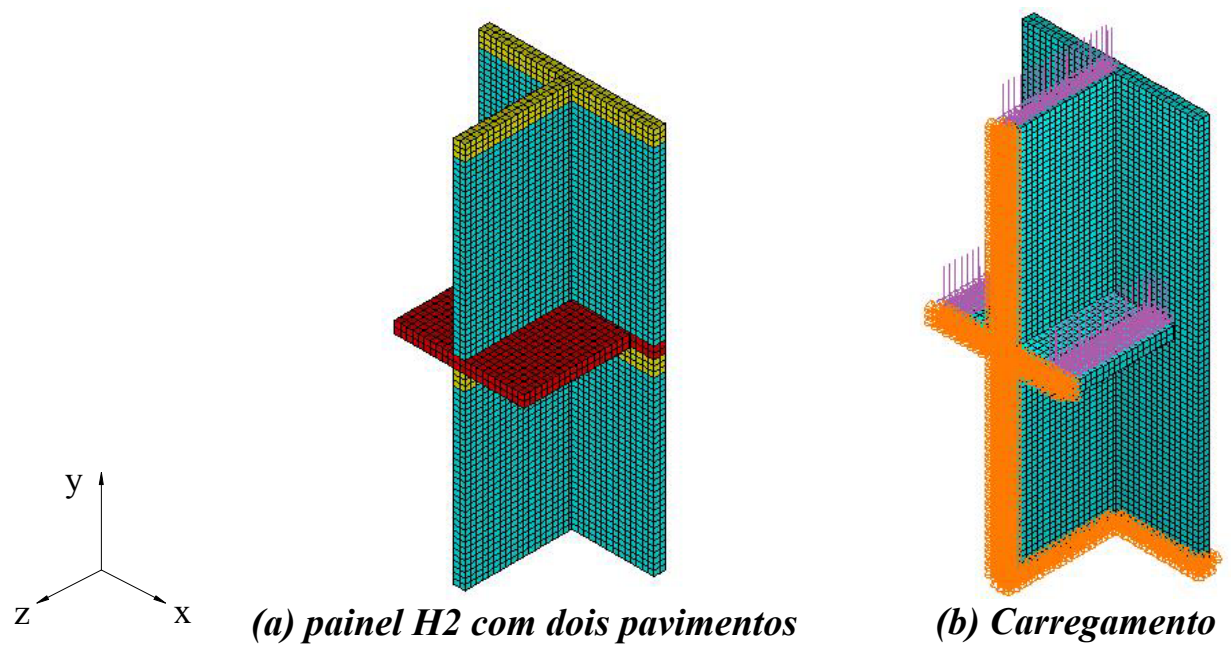

Figura 8.66 - Modelagem numérica do painel $\mathrm{H} 2$ com dois pavimentos 
Na Tabela 8.22 realiza-se a comparação entre a força de ruptura numérica e a experimental do painel tipo $\mathrm{H} 2$ com dois pavimentos. Observa-se, mais uma vez, que o modelo numérico não é capaz de representar o valor da força de ruptura do ensaio, sendo que neste caso a razão entre o valor numérico e o experimental é de cerca de $57 \%$. Contudo, percebe-se que a força de ruptura do painel tipo H2 com dois pavimentos é praticamente o dobro do valor obtido para os painéis tipo $\mathrm{H} 2$ com um pavimento e sem laje no topo $\left(\mathrm{F}_{\text {num }}=164 \mathrm{kN}\right)$. Desse modo, o modelo numérico permite representar o ganho de resistência verificado experimentalmente quando o carregamento é aplicado em mais de um pavimento.

Tabela 8.22 - Comparação entre a força de ruptura numérica e experimental do painel tipo $\mathrm{H} 2$ com dois pavimentos

\begin{tabular}{|c|c|c|c|}
\hline Painel & $\begin{array}{c}\text { Força de ruptura } \\
\text { numérica }\left(\mathbf{F}_{\text {num }}\right)\end{array}$ & $\begin{array}{c}\text { Força de ruptura } \\
\text { experimental }\left(\mathbf{F}_{\text {exp }}\right)\end{array}$ & $\mathbf{F}_{\text {num }} / \mathbf{F}_{\text {exp }}$ \\
\hline Painel 2 pavimentos & $325,0 \mathrm{kN}$ & $570,8 \mathrm{kN}$ & $56,9 \%$ \\
\hline
\end{tabular}

A distribuição das tensões normais verticais no instante da ruptura do painel $\mathrm{H} 2$ com dois pavimentos está ilustrada na Figura 8.67. Neste caso, para melhor visualização, são suprimidas as placas de aço no topo do $1^{\circ}$ pavimento. Nota-se na figura que os níveis e as formas de distribuição das tensões são diferentes para cada pavimento. No $2^{\circ}$ pavimento, devido à menor força aplicada, os níveis de tensão de compressão na parede central são inferiores aos observados no $1^{\circ}$ pavimento, em que a força total está atuando. Lembra-se que a ruptura experimental se dá justamente por compressão na parede central do $1^{\circ}$ pavimento. Observa-se, como verificado no ensaio, que enquanto os flanges do $2^{\circ}$ pavimento estão submetidos à flexão, os flanges do $1^{\circ}$ pavimento estão todos comprimidos. Essa diferença deve-se à transferência de parte do carregamento aplicado no topo do $2^{\circ}$ pavimento para os flanges, comprimindo, assim, os flanges do $1^{\circ}$ pavimento. Percebe-se, também, que o comportamento do $2^{\circ}$ pavimento aproxima-se dos painéis tipo H2 sem laje no topo (Figura 8.63- a e -b). Com estes resultados pode-se concluir que o modelo numérico representa qualitativamente o comportamento das tensões normais verticais, verificado no ensaio do painel com dois pavimentos.

Na Figura 8.68 apresenta-se a distribuição das tensões cisalhantes no plano "zy" no instante da ruptura do painel $\mathrm{H} 2$ com dois pavimentos. Verifica-se que, ao contrário das tensões normais verticais, as máximas tensões de cisalhamento ocorrem no $2^{\circ}$ pavimento. O que está condizente com o observado no ensaio, onde as fissuras de 
cisalhamento se iniciaram no $2^{\circ}$ pavimento. Todavia, percebe-se que no $1^{\mathrm{o}}$ pavimento, apesar de apresentar valores inferiores ao $2^{\circ}$ pavimento, também aparecem tensões cisalhantes com valores significativos. Tal fato explica o posterior surgimento de fissuras de cisalhamento no $1^{\mathrm{o}}$ pavimento. Portanto, comprova-se a capacidade do modelo numérico em representar qualitativamente as tensões cisalhantes do ensaio do painel $\mathrm{H} 2$ com dois pavimentos.

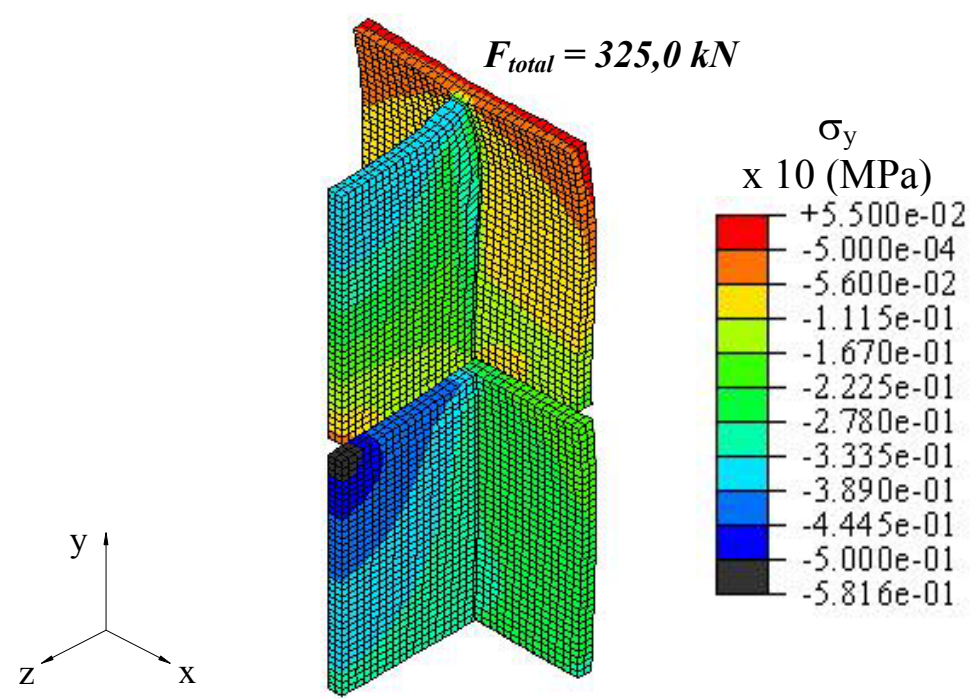

Figura 8.67 - Distribuição das tensões normais verticais no painel H2 com dois pavimentos

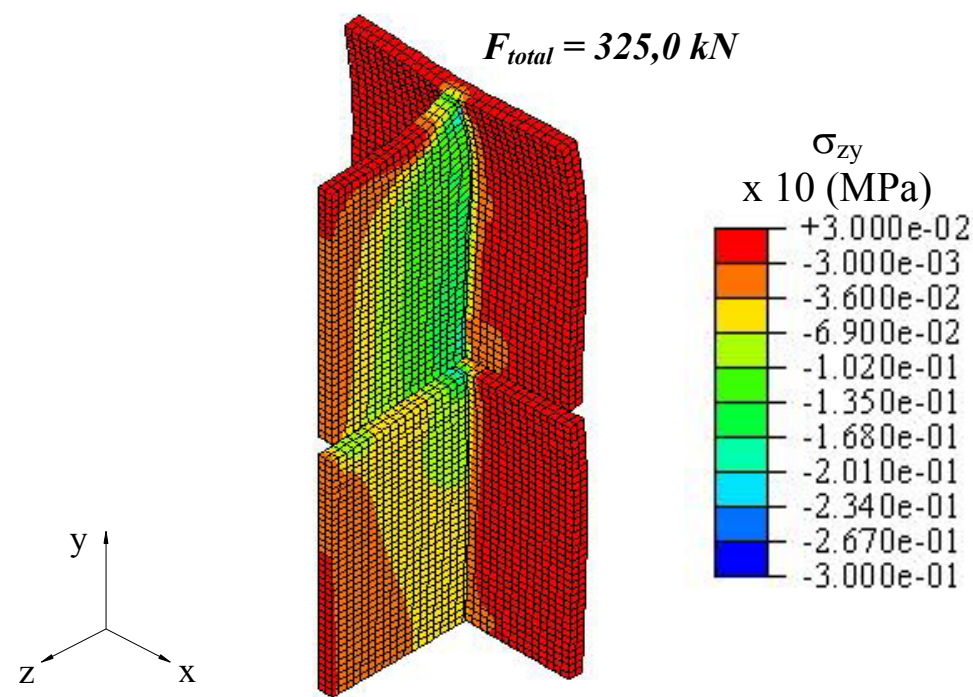

Figura 8.68 - Distribuição das tensões cisalhantes no plano “zy” no painel H2 com dois pavimentos

As comparações de algumas deformações obtidas na análise numérica, lineares e não-lineares, com os valores experimentais do painel H2 com dois pavimentos estão apresentadas na Figura 8.69. Observa-se que os modelos numéricos são capazes de representar o comportamento linear do painel de alvenaria. Contudo, como nos casos anteriores, a análise numérica realizada não é apta para representar as perturbações nas 
leituras experimentais das deformações (Figura 8.69- b e -d). Acredita-se que os modelos numéricos só fornecerão melhores resultados quando o comportamento da interseção das paredes for corretamente representado.

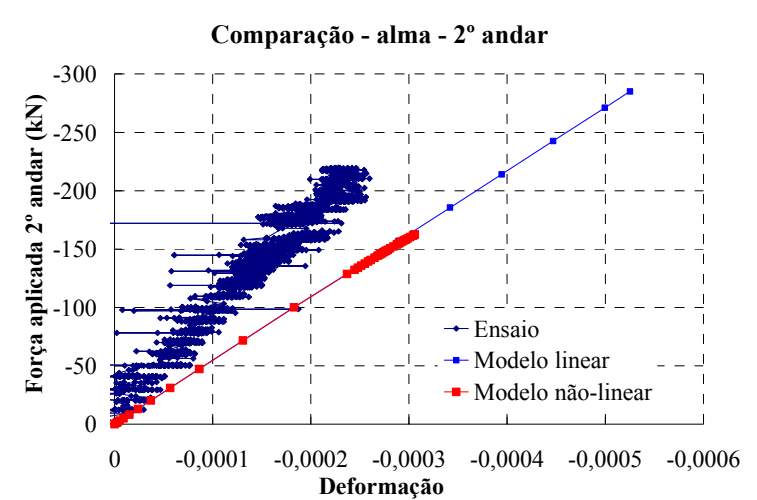

(a)

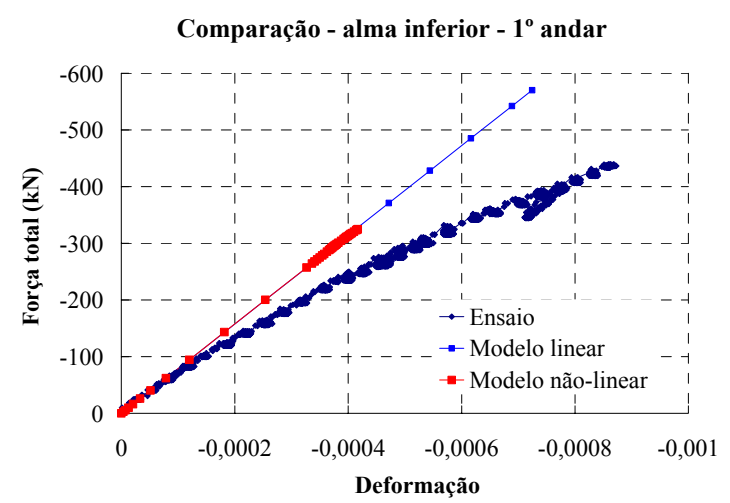

(c)

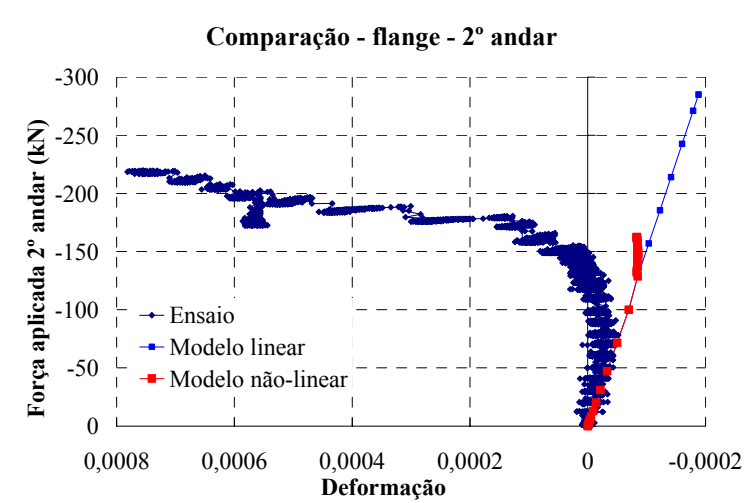

(b)

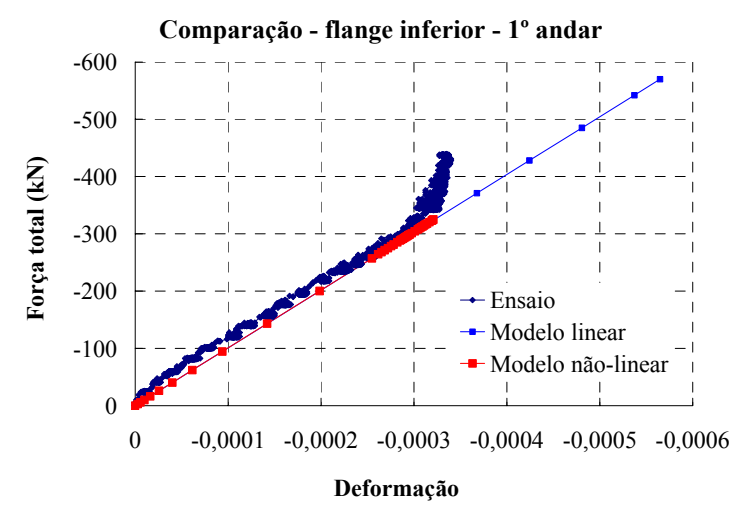

(d)

Figura 8.69 - Comparação entre os resultados numéricos e experimentais do painel com dois pavimentos

\section{6- Comentários}

A utilização dos gabaritos em alumínio para a construção dos corpos-de-prova e dos painéis foi determinante para a agilidade e a qualidade dos trabalhos de execução. Sem o seu emprego não se alcançaria o nível de precisão necessário para a construção do painel $\mathrm{H} 2$ com dois pavimentos.

A realização do ensaio do painel tipo H1-1 em escala reduzida (1:3) permitiu a comparação com os ensaios em escala natural (1:1) de Capuzzo Neto (2000), demonstrando, novamente, a habilidade dos modelos reduzidos em representarem o comportamento da alvenaria em escala natural.

Os ensaios dos painéis tipo $\mathrm{H} 1$ e $\mathrm{H} 2$ com laje no topo demonstraram o efeito benéfico introduzido pela laje. As forças de ruptura desses painéis foram cerca de $30 \%$ superiores aos painéis sem laje no topo. Outra influência percebida foi a diminuição da 
flexão dos flanges. Já em relação à presença da cinta intermediária investigada nos painéis tipo H2, não se percebeu uma influência significativa na resistência.

Apesar das análises numéricas dos ensaios não representarem o valor da força de ruptura obtidos nos ensaios, verificou-se que em termos qualitativos os modelos numéricos foram representativos do comportamento dos painéis de alvenaria. Concluise que somente com a representação correta do comportamento da interseção das paredes pelos modelos numéricos será possível obter melhores resultados. 


\section{Capítulo}

\section{Y CONCLUSÕES}

O objetivo principal deste trabalho foi investigar a interação de paredes em alvenaria estrutural sob ações verticais, por meio de análises experimentais e numéricas, para se obter uma maior compreensão do fenômeno, visando sua aplicação em projetos estruturais. Ressalta-se que o estudo enfoca apenas o caso de amarração direta de paredes em alvenaria estrutural não-armada.

Para se alcançar tal objetivo realizou-se, nos capítulos iniciais, uma abrangente revisão bibliográfica englobando os estudos da interação de paredes de alvenaria estrutural não-armada, dos modelos físicos reduzidos e da modelagem numérica da alvenaria estrutural.

Do capítulo 2, interação de paredes de alvenaria estrutural não armada, chegouse às seguintes questões:

- não há um estudo conclusivo sobre o assunto;

- a interação de paredes de alvenaria estrutural é usualmente considerada por diferentes métodos de distribuição das ações verticais, apesar de nem sempre ficar explícito;

- quase a totalidade desses métodos de distribuição não contempla a capacidade de transmissão de forças das interfaces de paredes;

- é necessário avaliar a atuação das restrições horizontais provenientes das lajes;

- há indicações de que o fenômeno da distribuição das tensões normais verticais é influenciado pelas características geométricas dos grupos de paredes que compõem o edifício, baseado no Princípio de Saint Venant; 
- diferentes estudos experimentais comprovam a transferência de forças entre paredes, apresentando um quadro de fissuração típica de cisalhamento na interface das paredes;

- os painéis de alvenaria, nos ensaios, tendem a uma ruptura localizada por compressão, devido à concentração de tensões na região de aplicação do carregamento;

- para os ensaios analisados em escala real, a amarração direta apresenta uma maior capacidade de transmissão de forças do que a amarração indireta, porém essa última tem a vantagem de levar a uma ruptura dúctil;

- estudos numéricos indicam que o ensaio de painéis com um pavimento é uma situação extrema, muito distante da situação real de um edifício;

- análises numéricas apontam uma grande redução nas tensões máximas para situações em que o carregamento do painel é dividido em diferentes níveis;

- os modelos numéricos estudados não são capazes de representar os ensaios após a separação das paredes devido à fissuração de cisalhamento.

Com base nesses estudos, percebeu-se a necessidade do desenvolvimento de um ensaio para a determinação da resistência ao cisalhamento vertical da interface. Também se verificou a necessidade de maiores estudos, tanto numéricos como experimentais, da influência das dimensões dos painéis no processo de interação de paredes, incluindo a presença da laje de concreto e do número de pavimentos. Ficou patente a necessidade de aprimoramento do modelo numérico para o estudo do comportamento da interação de paredes.

Para viabilizar a parte experimental da pesquisa, optou-se pela utilização de ensaios em escala reduzida. Dessa forma, realizou-se uma revisão bibliográfica sobre modelos físicos reduzidos no capítulo 3. Por meio desse estudo foram levantados os seguintes pontos:

- o modelo físico reduzido ideal para análise estrutural é o que apresenta completa semelhança com o protótipo, sendo, porém, de difícil execução;

- o modelo distorcido, que permite o relaxamento nas leis de semelhança através de fatores de escalas específicos, é uma opção viável, mas que deve ser usada com cautela; 
- ensaios de pesquisadores consagrados comprovam a viabilidade de se utilizarem ensaios de alvenaria em escala reduzida, apesar das dificuldades devidas à alvenaria ser um material composto;

- deve-se definir cuidadosamente desde os materiais até os processos de fabricação e execução para que os requisitos de semelhança para a alvenaria sejam atendidos;

- no Brasil existe um crescente interesse no uso de modelos reduzidos, visto a possibilidade da realização de ensaios de estruturas mais complexas, bem como a redução de custos;

- a maioria dos estudos realizados são na escala (1:3), pois escalas menores acarretam dificuldades na execução das juntas de argamassa;

- para a caracterização das propriedades físicas dos materiais são realizados quase que exclusivamente ensaios de compressão na direção normal às juntas de assentamento.

A partir desses pontos levantados, iniciou-se o desenvolvimento e a produção dos blocos cerâmicos em escala reduzida (1:3), procurando-se manter a máxima semelhança possível em relação aos materiais e aos processos de execução. No entanto, não foi possível utilizar a mesma seção geométrica por motivos operacionais. Assim, o modelo utilizado na pesquisa foi o distorcido, que deve ter seus fatores de escalas definidos cuidadosamente a partir de ensaios de caracterização na escala real (1:1) e reduzida $(1: 3)$.

No capítulo 4 realizou-se uma revisão bibliográfica sobre a modelagem numérica da alvenaria para auxiliar nos estudos numéricos do desenvolvimento do corpo-de-prova de cisalhamento e da interação das paredes. Nesse estudo verificou-se que:

- há diferentes opções de modelagem numérica, de acordo com o objetivo desejado, desde os mais simples (macro-modelagem) até os mais complexos (micro-modelagem detalhada);

- em cada tipo de modelagem é necessário conhecer um conjunto de propriedades mecânicas da alvenaria estrutural, determinadas por meio de ensaios de laboratório;

- a escolha de uma análise bidimensional ou tridimensional depende dos objetivos pretendidos; 
- a análise numérica pode ser linear, adequada para se obter distribuição de tensões, deformações e deslocamentos para situações em serviço. Adicionalmente, permite realizar comparações de diferentes arranjos de ensaios para a escolha do mais adequado;

- já o comportamento não-linear, que pode ser dividido em diferentes tipos de não-linearidades (geométrica, do material e de contato), tem o objetivo de representar o comportamento da estrutura até a sua ruptura.

- o programa ABAQUS apresenta um modelo de não-linearidade do material, já consagrado para representar o comportamento da alvenaria, e outro para representar a não-linearidade de contato, pouco empregado no estudo da alvenaria.

Percebeu-se que o sucesso nas análises numéricas depende do conhecimento das propriedades da alvenaria. Dessa forma, reforçou-se a necessidade da realização de ensaios de caracterização da unidade, da argamassa, da junta bloco-argamassa e da alvenaria como um material composto. Essa caracterização dos materiais, tanto na escala real quanto na reduzida, foi realizada no capítulo 5.

Nos ensaios de caracterização, determinaram-se as principais propriedades mecânicas, tanto dos materiais isolados (unidade, argamassa e interface) quanto do conjunto (alvenaria). Verificou-se que os valores de absorção, massa específica e razão entre as resistências de tração indireta e de compressão das unidades foram próximos para as duas escalas, indicando que as características do material cerâmico eram as mesmas. Observou-se que os modelos reduzidos representaram bem o comportamento dos ensaios para carregamento na direção normal à junta de assentamento em escala real, obtendo-se os fatores de escalas para a correlação dos resultados. Já na direção paralela à junta de assentamento, a representatividade da escala reduzida não foi boa, principalmente devido às diferenças nas seções transversais dos blocos nas duas escalas. Entretanto, o comportamento nessa direção não é um fator importante para os ensaios realizados neste trabalho, visto que todos os carregamentos foram aplicados na direção normal à junta de assentamento e as tensões normais devidas à flexão foram de baixa intensidade.

No capítulo 6 iniciaram-se os estudos numéricos do trabalho. Com base na revisão bibliográfica, optou-se pela análise tridimensional em todos os casos, o que permitiu simular a distribuição de tensões, inclusive nos flanges. Para o 
desenvolvimento do corpo-de-prova de cisalhamento e para o estudo da influência das características geométricas dos painéis na interação de paredes optou-se pela micromodelagem simplificada com o comportamento linear, pois o objetivo primordial era a comparação dos comportamentos de diferentes arranjos.

$\mathrm{Na}$ investigação dos comportamentos de diferentes configurações geométricas e formas de restrições para o corpo-de-prova de cisalhamento, chegou-se às seguintes conclusões:

- a ausência do bloco especial de amarração não gera uma excentricidade apreciável;

- a distribuição mais uniforme das tensões de cisalhamento ao longo da altura ocorre para a situação em que os deslocamentos da base da parede central estão livres;

- o corpo-de-prova com cinco fiadas possui uma melhor situação de simetria para a amarração realizada com blocos e meios-blocos, além de permitir o estudo da influência da cinta de amarração;

- há indicações teóricas que modelo com o flange restrito seja o mais apropriado para a representação do corpo-de-prova em que a ruptura ocorra por cisalhamento

Também se analisaram numericamente painéis de alvenaria com diferentes dimensões, simétricos (painéis tipo " $H$ ”) ou anti-simétricos (painéis tipo “Z”), com um ou dois pavimentos, com carregamentos em um ou dois níveis para estudar a influência das características geométricas dos painéis na interação de paredes. Dessa investigação verificou-se que:

- o Princípio de Saint Venant é adequado para se determinar a altura mínima necessária para a uniformização das tensões normais verticais;

- a presença de restrições horizontais (efeito da laje) atenua a excentricidade nos painéis tipo " $Z$ " e auxilia na transmissão das tensões cisalhantes;

- a estimativa da tensão máxima cisalhante proposta por Corrêa e Page (2001) se mostra válida para as todas as análises numéricas realizadas;

- quando o carregamento é aplicado em dois níveis diferentes, ocorre uma significativa redução das tensões máximas;

- é necessário avaliar experimentalmente o comportamento até a ruptura dos painéis; 
Ainda no Capítulo 6, com o intuito de obter resultados numéricos representativos dos valores experimentais, estudaram-se diferentes formas de modelagem numérica para os ensaios de caracterização anteriormente realizados. Para alcançar tal objetivo foi necessário considerar o comportamento não-linear do material, adotando-se a micro-modelagem simplificada para os ensaios de pequenas dimensões e a macro-modelagem nos ensaios de maiores dimensões. Ressalta-se que em todos os casos não-lineares foram utilizados os modelos de comportamento do material e do contato do programa ABAQUS. Desse estudo chegou-se às seguintes conclusões:

- as análises numéricas dos ensaios com carregamento na direção normal à junta de assentamento apresentam bons resultados, tanto em termos de rigidez quanto de resistência, enquanto que as análises na direção paralela são representativas apenas em termos de rigidez;

- a seção geométrica do bloco é fator determinante para os ensaios na direção paralela, pois a influência das variações das espessuras dos septos transversais, da existência de tensões residuais provenientes do processo de queima, entre outras razões, são mais destacadas nos ensaios nessa direção. Como tais fatores são difíceis de serem considerados nos modelos numéricos, os resultados alcançados são limitados;

- a micro-modelagem com os blocos vazados e a macro-modelagem são as que geraram resultados mais próximos dos valores experimentais;

- as micro-modelagens empregando modelos sólidos representam razoavelmente o módulo de deformação da alvenaria, conseqüentemente representam razoavelmente o comportamento linear da alvenaria;

- as análises numéricas dos ensaios de caracterização da alvenaria permitem calibrar as propriedades não-lineares do material, necessárias como dados de entrada do pacote computacional utilizado. Uma vez definidas tais propriedades, empregam-se sempre os mesmos valores nas análises numéricas dos ensaios mais complexos.

Os ensaios dos corpos-de-prova de cisalhamento da alvenaria no plano vertical, definidos na análise numérica inicial, foram realizados no capítulo 7. A maioria dos ensaios foi realizada na escala reduzida (1:3), ensaiando-se apenas um corpo-de-prova na escala real para comparação. Estudou-se, também, a influência da cinta de 
amarração presente no topo ou na fiada intermediária. Dessa investigação experimental foi possível concluir que:

- é nítida a ruptura por cisalhamento do corpo-de-prova;

- a boa correlação entre os ensaios em diferentes escalas indica que os modelos reduzidos são aptos a representarem o comportamento da alvenaria submetida ao cisalhamento;

- para a alvenaria na escala (1:3) a resistência ao cisalhamento é superior a 2,35 $\mathrm{MPa}$, enquanto que para a escala real $(1: 1)$ a resistência é de $1,21 \mathrm{MPa}$;

- apesar da cinta de amarração apresentar individualmente uma maior resistência ao cisalhamento, sua influência na resistência final do corpo-de-prova é inferior a $20 \%$;

Nesse mesmo capítulo foram realizadas análises numéricas dos ensaios dos corpos-de-prova, considerando-se as não-linearidades do material e de contato, com o emprego das técnicas de micro e macro-modelagem. Verificou-se que apenas a macromodelagem levou a níveis de carregamento próximos aos obtidos nos ensaios, mas não foi capaz de representar as perturbações observadas experimentalmente. Nos modelos em que se empregou a micro-modelagem, houve a perda da convergência numérica para baixos níveis de carregamento. A tentativa de se utilizarem elementos de contato na modelagem do corpo-de-prova não atingiu o resultado esperado. $\mathrm{O}$ comportamento qualitativo do corpo-de-prova foi bem representado. Todavia os modelos numéricos estudados não conseguiram representar corretamente o comportamento da interseção das paredes.

No capítulo 8 realizaram-se ensaios em painéis de alvenaria estrutural em escala reduzida (1:3), com o objetivo de comprovação experimental dos comportamentos verificados nos modelos numéricos estudados no capítulo 6. Em relação à distribuição das ações verticais, investigaram-se a influência da seção geométrica do painel, da presença de cintas de amarração e de lajes e do número de pavimentos em que é aplicado o carregamento. Dessa investigação inferiu-se que:

- o Princípio de Saint Venant fornece, comprovadamente, subsídios para a consideração da uniformização do carregamento aplicado em painéis de alvenaria; 
- a comparação dos ensaios dos painéis tipo H1 com os realizados por Capuzzo Neto (2000) demonstra novamente que os modelos reduzidos são representativos do comportamento da alvenaria em escala real;

- a influência das cintas de amarração na fiada intermediária é praticamente nula em termos de resistência, entretanto modifica o comportamento dos flanges e prolonga o trecho do comportamento linear;

- a presença das lajes de concreto no topo indica um acréscimo na resistência dos painéis de alvenaria, que foi cerca de $30 \%$ para os painéis ensaiados. Esse acréscimo é devido às lajes que impedem que a força transferida para os flanges se dissipe no instante da ruptura da interface das paredes;

- outros efeitos das lajes de concreto são a redução da flexão nos flanges dos painéis de alvenaria e o prolongamento do trecho de comportamento linear;

- o desenvolvimento do ensaio do painel de alvenaria de dois pavimentos com a aplicação do carregamento em dois níveis diferentes é considerado um sucesso;

- o segundo pavimento do painel é submetido a uma maior concentração de tensões de cisalhamento na interseção das paredes e a uma maior flexão nos flanges. Já no primeiro pavimento as tensões de cisalhamento na interseção e nos flanges são inferiores às anteriores, porque a transferência de forças para os flanges no pavimento superior adiciona compressão no nível inferior;

- percebe-se que, mesmo após a intensa fissuração da interface do pavimento superior, o painel continua a resistir ao carregamento aplicado;

- a ruptura do painel de dois pavimentos ocorre pelo esgotamento da capacidade resistente à compressão da parede central do pavimento inferior;

- observa-se pelos gráficos da força aplicada versus deformação que o andar inferior do ensaio do painel com dois pavimentos está numa condição mais favorável que os painéis com um único pavimento;

- apesar dos indicativos das análises numéricas e do resultado do ensaio de dois pavimentos, não se pode afirmar que a maior força de ruptura seja originada pelo fato do carregamento ser aplicado em níveis diferentes ou se pela maior resistência à compressão da alvenaria.

Além dos ensaios dos painéis de alvenaria, realizaram-se, também, análises numéricas no capítulo 8 , com a consideração exclusiva da macro-modelagem. Com base nos resultados obtidos, conclui-se que os modelos numéricos representam 
qualitativamente o comportamento de todos os painéis ensaiados, indicando as regiões de concentração de tensão de cisalhamento e de compressão, as regiões submetidas às maiores flexões, etc. Contudo, para a obtenção de resultados mais precisos, verificou-se a necessidade do desenvolvimento de modelos numéricos que considerem o comportamento das interfaces das paredes de forma mais aprimorada.

Após todo o estudo realizado nesta pesquisa recomenda-se, para o desenvolvimento de projetos de edifícios de alvenaria estrutural, a utilização de processos de distribuição das ações verticais que considerem a interação de paredes. A utilização do princípio de Saint Venant é indicada para a definição da região a partir da qual pode-se considerar a uniformização das tensões. No entanto, é necessário verificar o nível de cisalhamento atuante nas interfaces, com o intuito de evitar concentrações de tensão que possam levar à ruptura da ligação das paredes. Ressalta-se que essas indicações são válidas apenas para o caso de amarração direta, sendo necessários estudos complementares para aplicações em situações com amarração indireta.

Para futuros trabalhos sugere-se realizar um estudo numérico sobre o comportamento da interface das paredes, objetivando uma melhor representação dos ensaios dos painéis de alvenaria no aspecto quantitativo. Em conjunto com esse estudo, propõe-se investigar uma correlação entre o comportamento do corpo-de-prova de cisalhamento e do painel de alvenaria. Desse modo, ao saber a resistência ao cisalhamento obtida no ensaio do corpo-de-prova define-se a máxima tensão que pode atuar com segurança na interface dos painéis. Também é interessante realizar um levantamento dos níveis de cisalhamento que ocorrem em edifícios de múltiplos andares de alvenaria, incluindo a parcela devida às ações horizontais (vento, empuxo desequilibrado, etc.). Com esses níveis de cisalhamento pode-se impor uma resistência mínima ao cisalhamento da alvenaria que permita considerar a transferência das forças entre as paredes. Sugere-se, também a realização de ensaios de corpos-de-prova produzidos com blocos não-cerâmicos para a determinação das suas resistências ao cisalhamento. 


\section{REFERÊNCIAS BIBLIOGRÁFICAS}

ABBOUD, B. E. ; HAMID, A.A. ; HARRIS, H.G. (1990). Small-scale modeling of concrete block masonry structures. In: ACI STRUCTURAL JOURNAL, Detroid, v.87, n.2, p.145-155, mar/apr, 1990.

ABRAMS, D.P. (1988). Dynamic and static testing of reinforced concrete masonry structures. In: THE MASONRY SOCIETY JOURNAL. January-June.

ALI, S.S. ; SINHA, B.P. ; USMANI, A. (2000). Solid masonry walls stiffened by returns. In:INTERNATIONAL SEMINAR ON STRUCTURAL MASONRY FOR DEVELOPING COUNTRIES , 6 , Bangalore, India, 11-13 October 2000. Proceedings /ed. B.V.V. Reddy, B.P. Sinha. p. $119-127$.New Delhi : Allied Publishers.

AMERICAN CONCRETE INSTITUTE - Committee 444- Models of Concrete Structures. (1987) - Models of Concrete Structures - State of the Art. Detroid. American Concrete Institute.

Detroid, Michigan.

. (1995). ACI 530-92 - Building code requirements for masonry structures.

AMERICAN SOCIETY FOR TESTING AND MATERIALS (1997). C 67 - Standard test method for sampling and testing brick and structural clay tile. Detroid, Michigan.

. (1996). C 1006 - Standard test method for splitting tensile strength of masonry units. Detroid, Michigan.

. (1984) C 1019-Sampling and testing grout. Detroid, Michigan.

. (1994) C 1072- Standard test methods for measurement of masonry flexural bond strength. Detroid, Michigan.

. (1997) C 1314-Constructing and testing masonry prisms used to determine compliance with specified compressive strength of masonry. Detroid, Michigan.

. (1995). E 72 - Standard test methods of conducting strength tests of panels for building construction. Detroid, Michigan.

. (1993). E 518 - Standard test methods for flexural bond strength of masonry. Detroid, Michigan.

ANDOLFATO, R.P. (2002). Desenvolvimento das técnicas de produção de blocos de concreto para alvenaria estrutural na escala(1:4). Ilha Solteira, 2002. 110p. Dissertação (Mestrado) - Faculdade de Engenharia de Ilha Solteira da Universidade Estadual Paulista "Júlio de Mesquita Filho".

ANDRADE, J.R.L. (s.d). Curso de alvenaria estrutura . Disciplina SET-156. (Notas de aula). EESC - USP, São Carlos. 
ASSOCIAÇÃO BRASILEIRA DA CONSTRUÇÃO INDUSTRIALIZADA (1990). Manual técnico de alvenaria. São Paulo, ABCI / Projeto.

ASSOCIAÇÃO BRASILEIRA DE NORMAS TÉCNICAS (1983). NBR 6.461 - Bloco cerâmico para alvenaria - Verificação da resistência à compressão . Rio de Janeiro.

. (1992). NBR 7.171 - Bloco cerâmico para alvenaria. Rio de Janeiro.

. (1983). NBR 7.211 - Agregado para concreto. Rio de Janeiro.

granulométrica. Rio de Janeiro.

. (1983). NBR 8.043 - Bloco cerâmico portante para alvenaria - Determinação da área líquida. Rio de Janeiro.

. (1983). NBR 8.215 - Prismas de blocos vazados de concreto simples para alvenaria estrutural - Preparo e ensaio à compressão . Rio de Janeiro.

. (1984). NBR 8.522 - Concreto - Determinação do módulo de deformação estática e diagrama - tensão-deformação . Rio de Janeiro.

. (1985). NBR 8.798 - Execução e controle de obras em alvenaria estrutural de blocos vazados de concreto . Rio de Janeiro.

. (1985). NBR 8.947 - Telha cerâmica - Determinação da massa e da absorção de água. Rio de Janeiro.

. (1985). NBR 8.949 - Paredes de alvenaria estrutural - Ensaio à compressão simples. Rio de Janeiro.

. (1989). NBR 10.837 - Cálculo de alvenaria estrutural de blocos vazados de concreto. Rio de Janeiro.

. (1999). NBR 14.321 - Paredes de alvenaria estrutural - Determinação da resistência ao cisalhamento. Rio de Janeiro.

. (1999). NBR 14.322 - Paredes de alvenaria estrutural - Verificação da resistência à flexão simples ou à flexo-compressão. Rio de Janeiro.

AUSTRALIAN STANDARD (1998). AS 3700 - Masonry structures. 2 ed. Homebush, Australia.

BENEDETTI, D.; CARYDIS, P.; PEZZOLI, P. (1998). Shaking table tests on simple masonry buildings. In: EARTHQUAKE ENGINEERING AND STRUCTURAL DYNAMICS. v. 27, p.67-90

BENJAMIN, J.R.; WILLIANS, H.A. (1958). The behavior of one-story brick shear walls. In: JOURNAL OF THE STRUCTURAL DIVISION, PROCEEDINGS OF ASCE. v. 84, ST4, july. 
BRICK INDUSTRY ASSOCIATION - BIA (1986). Techincal notes on brick construction 9: Manufacturing, classification and selection of brick manufacturing part I. Virginia.

BRITISH STANDARDS INSTITUTION (1992). BS 5628 - Code of practice for structural use of masonry. Part 1. Unreinforced masonry. Londres, Inglaterra.

CAMACHO, J.S. (1995). Contribuição ao estudo de modelos físicos reduzidos de alvenaria estrutural cerâmica. São Paulo. 157p. Tese de Doutorado - Escola Politécnica, Universidade de São Paulo.

CAMACHO, J.S.; ANDOLFATO, R.P. (2000). Development of the production tecniques of the small scale concrete blocks. In: INTERNATIONAL BRICK/BLOCK MASONRY CONFERENCE, 12, Madrid,Spain, 25-28 June 2000. Proceedings. v.1, p.385-395.

CAMACHO, J.S.; RAMALHO M.A.; ANDOLFATO, R.P. (2001). An experimental study of the interaction among walls submitted to vertical loads. In: 6th AUSTRALIAN MASONRY CONFERENCE .12-13 July 2001. Adelaide University.

CAPUZZO NETO, V. (2000). Estudo teórico e experimental da interação de paredes de alvenaria estrutural submetidas a ações verticais. São Carlos, 2000. 111p. Dissertação (Mestrado) - Escola de Engenharia de São Carlos, Universidade de São Paulo.

CHEN, H.L.; SHAH, S.P. (1988). Test of model masonry single pier under dynamic shaking and quasistatic cyclic loading. In.: MASONRY : MATERIALS, DESIGN, CONSTRUCTION, AND MAINTENANCE, ASTM STP 992. H.A. Harris, Ed. , American Society for Testing and Materials, Philadelphia, p.145-165.

CHOWDHURY, A.H.; WHITE, R.N. (1977). Materials and modeling techiniques for reinforced concrete frames. In: JOURNAL OF THE AMERICAN CONCRETE INSTITUTE. November/1977.

CORRÊA, M.R.S.; PAGE, A.W. (2001)- The Interaction of Load-Bearing Masonry Walls Subjected to Vertical Loads. Research Report No. 218.12.2001. The University of Newcastle. Newcastle - Australia.

CORREAA, M.R.S.; RAMALHO, M.A.(1998a). Wall cracking under building roofs. In: AUSTRALASIAN MASONRY CONFERENCE, 5, Gladstone, Australia, 1- 3 july 1998. Proceedings. Rockhampton North, CQU Publishing Unit. P. 325-334.

.(1998b). Alvenaria estrutural. São Carlos, EESC-USP. (Notas de aula da disciplina: "SET-606 - Alvenaria estrutural").

..(1998c). Procedure for the analysis of masonry buildings under vertical loads. In: AUSTRALASIAN MASONRY CONFERENCE, 5, Gladstone, Australia, 1 - 3 july 1998. Proceedings. Rockhampton North, CQU Publishing Unit. P.57-66. 
CURTIN, W.G.; SHAW, G.; BECK, J.K.; PARKINSON, G.I. (1984) Structural masonry detailing. Londres, Granada Publishing.

DHANASEKAR, M.; PAGE, A.W.; KLEEMAN, P.W. (1985). The failure of brick masonry under biaxial stresses. In: PROCEEDINGS INSTITUTE CIVIL ENGINEERS, Part 2, V. 79, june, p.295-313.

DRYSDALE, R.G.; HAMID, A.A.; BAKER, L.R. (1994). Masonry structures: behavior and design. Enhllewood Cliffs, New Jersey, Prentice Hall.

EGERMAN, R.;COOK,D,A.; ANZANI, A. (1991). An investigation into the behaviour of scale model brick walls. In: INTERNATIONAL BRICK/BLOCK MASONRY CONFERENCE, 9, Proceedings, Berlin. P.628-635.

EUROCODE 6 (1997). Design of masonry structures. Part 1-1 : General rules for buildings. Rules for reinforced and unreinforced masonry. Madrid, Espanha.

GARCIA, P.D. (2000). Contribuições ao estudo da resistência à compressão de paredes de alvenaria de blocos cerâmicos. Dissertação (Mestrado) - Escola de Engenharia de São Carlos, Universidade de São Paulo.

GUINEA, G.V.; HUSSEIN, G.; ELICES, M.; PLANAS, J. (2000). Micromechanical modeling of brick-masonry fracture. In: CEMENT AND CONCRETE RESEARCH. v.30, p.731-737.

HAMID, A,A,; CHANDRAKEERTHY, S.R.S. (1992). Compressive strength of partially grouted concrete masonry using small scale wall elements. In: : THE MASONRY SOCIETY JOURNAL. August.

HAMID, A.A.; ABBOUD,B.E. (1986). Direct modeling of concrete block masonry under shear and in-plane tension. In: JOURNAL OF TESTING AND EVALUATION. v.14, 2, p.112-121, march.

HARRIS, H.G ;SABNIS, G.M (1999). Structural modeling and experimental techniques. Second edition. Boca Raton, Florida. CRC Press.

HENDRY, A. W.; MURTHY, C. K. (1965). Comparative tests on 1/3 and 1/6 scale model brickwork piers and walls. In: BRITISH CERAMIC SOCIETY PROCEEDINGS, Stoke-on-Trent, n.4, p.45-66, jul.1965.

HENDRY, A.W. (1981).Structural Brickwork. Londres, The Macmillan Press Ltd.

HENDRY, A.W.; SINHA, B.P.; DAVIES, S.R. (1981). An introduction to load bearing brickwork desing. Chichester, England, Ellis Horwood Ltd.

HOGG, V.; CHOO, B.S. (2000). A study of scale effects in masonry arch bridges : is testing of large-scale structures still necessary? In: THE STRUCTURAL ENGINEER. v. 78,5 , march. 
HOLANDA JR, O. G. (2002). Influência de recalques em edifícios de alvenaria estrutural. São Carlos. 224 p. Tese (Doutorado) - Escola de Engenharia de São Carlos, Universidade de São Paulo.

HOSSDORF, H. (1972). Modelos reducidos - método de cálculo. Madrid. Instituto Eduardo Torroja de la Construccion y del Cemento.

HUGHES, T.G.; KITCHING, N.(2000). Small scale testing of masonry. In: INTERNATIONAL BRICK/BLOCK MASONRY CONFERENCE, 12, Madrid, Spain, 25-28 June 2000. Proceedings. v.2, p.893-902.

JUKES, P.; RIDDINGTON, J.R. (1997). A review of masonry joint shear strength test methods. In: MASONRY INTERNATIONAL, V.11, 2, p.37-42.

KHALIL, M.R.A; SHRIVE, N.G.; AMENY, P. (1987). Three-dimensional stress distribution in concrete masonry prisms and walls. In: MAGAZINE OF CONCRETE RESEARCH, V.39, 139, p.73-82.

LISSEL, S.L.; SHRIVE, N.G.; PAGE, A.W. (2000). Shear in plain, bed joint reinforced, and posttensioned masonry. In : CANADIAN JOURNAL OF CIVIL ENGINEERING, v. 27,5 , p.1021-1030.

LITLE, W.A.; PAPARONI, M. (1966). Size effect in small-scale models of reinforced concrete beams. In: JOURNAL OF THE AMERICAN CONCRETE INSTITUTE.. v.63, 11 , november.

LOURENÇO, P.J.B.B. (1996). Computacional strategies for masonry structures. Delft, The Netherlands, Delft University Press.

MACHADO JR., E.F. ;TAKEYA, T ; VAREDA, L.V. (1999). Ensaios de compressão simples em paredes de alvenaria de blocos cerâmicos. Relatório técnico : Cerâmica Selecta. São Carlos.

NASCIMENTO NETO, J. A. (2003). Estudo de painéis com abertura constituidos por alvenaria estrutural de blocos. São Carlos. 319 p. Tese (Doutorado). Escola de Engenharia de São Carlos, Universidade de São Paulo.

PAGE, A.W. (1978). Finite element model for masonry. In: JOURNAL OF THE STRUCTURAL DIVISION, PROCEEDINGS OF ASCE. v. 104, ST8, August.

PAGE, A.W.; KLEEMAN, P.W. (1991). The influence of capping material and platen restraint on the failure of hollow masonry units and prism. In: INTERNATIONAL BRICK/BLOCK MASONRY CONFERENCE, 9, Proceedings, Berlin. P.662-670.

PARSEKIAN, G.A; FRANCO, L.S. (2002). Alvenaria: Método para distribuição de esforços verticais entre paredes de edifícios de alvenaria estrutural. In: TÉCHNE REVISTA DE TECNOLOGIA E NEGÓCIOS DA CONSTRUÇÃO, V.61, p.48-53. 
PELETEIRO, S.C. (2002). Contribuições à modelagem numérica de alvenaria estrutural. São Carlos. 143p. Tese (Doutorado) - Escola de Engenharia de São Carlos, Universidade de São Paulo.

PREECE, B.W.; DAVIES, J.D. (1964). Models for structural concrete. London. CR Books Limited.

RIDDINGTON, J.R.; FONG, K.H., JUKES, P. (1997). Numerical study of failure initiation in different joint shear tests. In: MASONRY INTERNATIONAL, V.11, 2, p.44-50.

ROCHA, M. (1952). Publicação 21: Dimensionamento experimental das estruturas. Lisboa. Ministério das Obras Públicas. Laboratório de Engenharia Civil.

ROLL, F. (1968). Materials for structural models. In: JOURNAL OF THE STRUCTURAL DIVISION, PROCEEDINGS OF ASCE. v. 94, ST6, june.

ROYLES, R. HENDRY, A.W.(1991). Models tests on masonry arches. In: PROC. INSTN. CIV. ENGRS. Part 2, 91, June, p. 299-321.

SABNIS, G.M.; HARRIS, H.G.; WHITE, R.N.; MIRZA, M.S. (1983). Structural modeling and experimental techniques. Englewood Cliffs. Prentice-Hall.

SABNIS, G.M.; ROLL, F. (1971). Significance of scaled compression cylinders in shear studies of model reinforced concrete slabs. JOURNAL OF THE AMERICAN CONCRETE INSTITUTE. March/1971.

SANTOS, F.A. (2001). Efeito do não-preenchimento de juntas verticais no desempenho de edifícios em alvenaria estrutural. Florianópolis.154 p. Tese (Doutorado). Universidade Federal de Santa Catarina.

SAYED-AHMED, E.Y.; SHRIVE, N.G. (1995). Numerical analysis of facel-shel bedded hollow masonry walls subject to concentrated loads. In: CANADIAN JOURNAL OF CIVIL ENGINEERING, 22, p-802-818.

. (1996a). Nonlinear finite-element model of hollow masonry. In: JOURNAL OF STRUCTURAL ENGINEERING, ASCE, V 122, 6, p-683-690.

(1996b). Design of facel-shel bedded hollow masonry walls subject to concentrated loads. In: CANADIAN JOURNAL OF CIVIL ENGINEERING, 23, p-98106.

SIGNOR, R.; ROMAN, H.R. (2002). Ensaio de transferência de cargas verticais entre grupos de paredes ortogonais. In: INTERNATIONAL SEMINAR ON STRUCTURAL MASONRY FOR DEVELOPING CONTRIES, 7., Belo Horizonte, Brazil, 18-20 Sep. 2002. Proceedings. Belo Horizonte, CEFET-MG / University of Edinburgh, p.209-218.

SILVA, W.J. (2003). Estudo experimental de ligações entre paredes de alvenaria estrutural de blocos cerâmicos sujeitas a ações verticais. Ilha Solteira, 2003. 144p. Dissertação (Mestrado) - Faculdade de Engenharia de Ilha Solteira da Universidade Estadual Paulista "Júlio de Mesquita Filho". 
SINHA, B.P. (1982). Compressive strength of axially loaded diaphragm walls and walls restrained on their vertical edges. In : PROCEEDINGS OF THE BRITISH CERAMIC SOCIETY (30). p.118-128.

SINHA, B.P.; HENDRY.A.W. (1979). Compressive strength of axially loaded brick walls stiffened along their vertical edges. In: INTERNATIONAL BRICK MASONRY CONFERENCE, 5., Washington, USA, 05-10 Oct. 1979. Proceedings. Washington, Brick Institute of America, p.254-261.

TOMAZEVIC, M.; VELECHOVSKY, T. (1992). Some aspects of testing small-scale masonry building models on simple earthquake simulators. In: EARTHQUAKE ENGINEERING AND STRUCTURAL DYNAMICS. v. 21, p.945-963.

VEKEMANS, H.J.; ARCE, O.A. (1993). Masonry walls with flanges. In : NORTH AMERICAN MASONRY CONFERENCE, 6, Philadelphia, Pennsylvania, USA. Proceedings. p.99-110.

VEKEMANS, H.J. (1994). Numerical analysis of masonry t-walls. In : INTERNATIONAL BRICK/BLOCK MASONRY CONFERENCE, 10, Calgary, Canada. Proceedings. p.41-50.

YI,J.; SHRIVE, N.G. (2000) - 3D finite element models of face-shel bedded hollow masonry prismas subjected to eccentric loading In: INTERNATIONAL BRICK/BLOCK MASONRY CONFERENCE, 12, Madrid,Spain, 25-28 June 2000. Proceedings. v.2, p.1493-1508.

. (2001) - 3D finite element models of plain and bond-deamed hollow masonry walls subjected to concentric and eccentric loads In: CANADIAN MASONRY SYMPOSIUM, 9, Proceedings. 


\section{BIBLIOGRAFIA COMPLEMENTAR}

ACCETTI, K. M. (1998). Contribuições ao projeto estrutural de edificios em alvenaria. São Carlos. 247 p. Dissertação (Mestrado) - Escola de Engenharia de São Carlos, Universidade de São Paulo.

ALDRIDGE, W.W.; BREEN, J.E. (1967). Size effect in small-scale models of reinforced concrete beams. (Discussion). In: JOURNAL OF THE AMERICAN CONCRETE INSTITUTE.. v.64, 6,part. 2,june.

ALVARENGA, R..C. S. S. (2002). Análise teórico-experimental de estruturas compostas de pórticos de aço preenchidos com alvenaria de concreto celular autoclavado. São Carlos. 280p. Tese (Doutorado) - Escola de Engenharia de São Carlos, Universidade de São Paulo.

ALY, V.L.C. (1991). Determinação da capacidade resistente do elemento parede de alvenaria armada de blocos de concreto, submetidos a esforços de compressão. São Paulo. 103 p. Dissertação (Mestrado). Escola Politécnica, Universidade de São Paulo.

AMRHEIN, J. E. (1978). Reinforced masonry engineering handbook. Masonry Institute of America.

ANDRADE, A.A. (1998). Comportamento estrutural das paredes de alvenaria. São Paulo. 97 p. Dissertação (Mestrado). Escola Politécnica, Universidade de São Paulo.

ASSOCIAÇÃO BRASILEIRA DE NORMAS TÉCNICAS (1984). NBR 5738 Moldagem e cura de corpos de prova de concreto, cilíndricos ou prismáticos. Rio de Janeiro.

de Janeiro.

. (1994). NBR 6.136 - Blocos vazados de concreto simples para alvenaria. Rio . (1983). NBR 8.042- Bloco cerâmico para alvenaria - Formas e dimensões. Rio de Janeiro.

. (1987). NBR 9.775 - Agregados - Determinação da umidade superficial em agregados miúdos por meio do frasco de Chapman. Rio de Janeiro.

. (1987). NBR 9.776 - Agregados - determinação da massa específica de agregados miúdos por meio do frasco Chapman. Rio de Janeiro.

ATAÍDE, C. A. V. (2005). Estudo comparativo entre o método das tensões admissíveis $e$ o dos estados limites para alvenaria estrutural. São Carlos. 144 p. Dissertação (Mestrado) - Escola de Engenharia de São Carlos, Universidade de São Paulo.

BARBOSA, C. S. (2004). Resistência e deformabilidade de blocos vazados de concreto e suas correlações com as propriedades mecânicas do material constituinte. São Carlos. 153 p. Dissertação (Mestrado) - Escola de Engenharia de São Carlos, Universidade de São Paulo. 
BARBOSA, P. C. (2000). Estudo da interação de paredes de alvenaria estrutural com vigas de concreto armado. São Carlos. 110 p. Dissertação (Mestrado) - Escola de Engenharia de São Carlos, Universidade de São Paulo.

BASTOS, P. S. S. (1993). Contribuições ao projeto de edifícios de alvenaria estrutural pelo método das tensões admissíveis. São Carlos. 242 p. Dissertação (Mestrado) Escola de Engenharia de São Carlos, Universidade de São Paulo.

BAUER, L.A.F. (1985). Materiais de construção. Rio de Janeiro. Ed. Livros Técnicos e Científicos. 2a ed.

CAMACHO, J.S. (1986). Alvenaria estrutural não armada - parâmetros básicos a serem considerados no projeto dos elementos resistentes. Porto Alegre.183p. Dissertação (Mestrado) - Universidade Federal do Rio Grande do Sul.

CAMACHO, J.S.; BERTOLINO JR., R.; ANDOLFATO, R.P. (2000). An experimental investigation of correlations between prototypes and small-scale modeling of ceramic block masonry. In: INTERNATIONAL BRICK/BLOCK MASONRY CONFERENCE, 12, Madrid,Spain, 25-28 June 2000. Proceedings. v.1, p.373-383.

CAPUZZO NETO,V. ; CORRÊA, M. R. S. ; RAMALHO, M. A. (2000). A interação de paredes de alvenaria estrutural submetida a ações verticais. In: JORNADAS SUDAMERICANAS DE INGENIERIA ESTRUCTURAL, XXIX, Punta del Leste, Uruguay, 13-17 noviembre 2000. Proceedings. (CD-ROM).

. (2000). A theoretical and experimental study of intersecting bonded walls under vertical loads. In: INTERNATIONAL BRICK/BLOCK MASONRY CONFERENCE, 12, Madrid,Spain, 25-28 June 2000. Proceedings. v.2, p.1493-1508.

. (2001). Influence of the number of floors in vertical load distribution in masonry walls. In: AUSTRALIAN MASONRY CONFERENCE ,6,12-13 July 2001. Adelaide University.

CORRÊA, M. R. S. ; RAMALHO, M. A. (1994). Efeitos de aberturas em painéis de alvenaria estrutural. In: INTERNATIONAL SEMINAR ON STRUCTURAL MASONRY FOR DEVELOPING CONTRIES, 5., Florianópolis, Brazil, 21-24 Aug. 1994. Proceedings. Florianópolis, Univ. Fed. Santa Catarina / University of Edinburgh/ ANTAC, 1994. p. 359-367.

. (1994). Procedimento para análise de edifícios de alvenaria estrutural submetidos a ações verticais. In: INTERNATIONAL SEMINAR ON STRUCTURAL MASONRY FOR DEVELOPING CONTRIES, 5., Florianópolis, Brazil, 21- 24 Aug. 1994. Proceedings. Florianópolis, Univ. Fed. Santa Catarina / University of Edinburgh/ ANTAC, p. 305-314.

CORREAA,M.R.S.;RAMALHO,M.A.;BASSO,ADMIR.(1997). Fissuras em paredes de alvenaria estrutural sob lajes de cobertura de edifícios. In: IV CONGRESSO IBEROAMERICANO DE PATOLOGIA DAS CONSTRUÇÕES, 1., Porto Alegre, Brasil, 21-24 Out. 1997. Anais. Universidade Federal do Rio Grande do Sul, 1997. p. 367-374. 
DICKEY, W. L. ; SCHNEIDER, R. R. (1994). Reinforced mansory design. Englewood Cliffs, Prentice Hall.

FONSECA, F. B. (2002). Desempenho estrutural de paredes de alvenaria de blocos de concreto de agregados reciclados de rejeitos de construção e demolição. São Carlos. 141 p. Dissertação (Mestrado) - Escola de Engenharia de São Carlos, Universidade de São Paulo.

FRANCO, L.S. (1987). Desempenho estrutural do elemento parede de alvenaria empregado na alvenaria estrutural não armada, quando submetido a esforços de compressão. São Paulo. 136p. Dissertação (Mestrado)- Escola Politécnica, Universidade de São Paulo.

GAllegOS, H. (1989). Albañileria estructural. 2 ed. Lima, Fondo Editorial da Pontificia Universidad Católica del Peru.

. (1993). Albañileria estructural : Diseño y calculo de muros . 2 ed. Lima, Fondo Editorial da Pontificia Universidad Católica del Peru.

GOMES, N.S. (1983). A resistência das paredes de alvenaria. São Paulo. 190p. Dissertação (Mestrado)- Escola Politécnica, Universidade de São Paulo.

JOAQUIM, M. M. (1999). Flexão e flexo-compressão em elementos de alvenaria estrutural. São Carlos. 134 p. Dissertação (Mestrado) - Escola de Engenharia de São Carlos, Universidade de São Paulo.

JUSTE, A. E. (2001). Estudo da resistência e da deformabilidade da alvenaria de blocos de concreto submetida a esforços de compressão. São Carlos. 126 p. Dissertação (Mestrado) - Escola de Engenharia de São Carlos, Universidade de São Paulo.

MAMEDE, F. C. (2001). Utilização de pré-moldados em edificios de alvenaria estrutural. São Carlos. 169 p. Dissertação (Mestrado) - Escola de Engenharia de São Carlos, Universidade de São Paulo.

MARTINS, A.R., FUSCO, P.B. (1991). Propriedades mecânicas do microconcreto para aplicação em modelos reduzidos. In: XXV JORNADAS SUL-AMERICANAS DE ENGENHARIA ESTRUTURAL. v. IV. p.213-222. Porto Alegre. Universidade Federal do Rio Grande do Sul.

MEDEIROS, J.S. (1993). Alvenaria estrutural não armada de blocos de concreto: produção de componentes e parâmetros de projeto. São Paulo. 2 v. Dissertação (Mestrado)- Escola Politécnica, Universidade de São Paulo.

MULLER, M.S.K. (1989). Estudo das correlações entre resistências à compressão de paredes e prismas de alvenaria estrutural cerâmica não armada submetidos a esforços de compressão axial. São Paulo. 269 p. Dissertação (Mestrado)- Escola Politécnica, Universidade de São Paulo. 
NASCIMENTO NETO, J. A. (1999). Investigação das solicitações de cisalhamentos em edificios de alvenaria estrutural submetidos a ações horizontais. São Carlos. 127 p. Dissertação (Mestrado). Escola de Engenharia de São Carlos, Universidade de São Paulo.

OLIVEIRA, F. L. (2001). Reabilitação de paredes de alvenaria pela aplicação de revestimentos resistentes de argamassa armada. São Carlos. 195p. Tese (Doutorado) Escola de Engenharia de São Carlos, Universidade de São Paulo.

OLIVEIRA JR, V. (1992). Recomendações para o projeto de edifícios em alvenaria estrutural. São Carlos. 266p. Dissertação (Mestrado) - Escola de Engenharia de São Carlos, Universidade de São Paulo.

OLIVEIRA JR., V.; PINHEIRO L. M. (1994). Análise de paredes de alvenaria estrutural calculadas no estado limite último. In: INTERNATIONAL SEMINAR ON STRUCTURAL MASONRY FOR DEVELOPING CONTRIES, 5., Florianópolis, Brazil, 21-24 Aug. 1994. Proceedings. Florianópolis, Univ. Fed. Santa Catarina / University of Edinburgh/ ANTAC, p.295-304.

. (1994). Método prático para distribuição das ações verticais em paredes de alvenaria. In: INTERNATIONAL SEMINAR ON STRUCTURAL MASONRY FOR DEVELOPING CONTRIES, 5., Florianópolis, Brazil, 21-24 Aug. 1994. Proceedings. Florianópolis, Univ. Fed. Santa Catarina / University of Edinburgh/ ANTAC, p.315322.

PALACIOS SOLORZANO, M.G. (1994). Caracteristicas e desempenho de juntas de argamassa na alvenaria estrutural de blocos de concreto. São Paulo. 203 p. Dissertação (Mestrado). Escola Politécnica, Universidade de São Paulo.

PETRUCCI, E.G.R (1995). Materiais de construção. São Paulo. Ed.Globo. 10a ed.

PHIPPS, M.E.; BELL, A.J.; YANG, L. (1994). Slender brickwork columns. In : INTERNATIONAL BRICK/BLOCK MASONRY CONFERENCE, 10, Calgary, Canada. Proceedings. p.589-596.

PRUDÊNCIO JR., L.R. (1986). Resistência à compressão da alvenaria e correlação entre resistência de unidades, prismas e paredes. Porto Alegre. Dissertação (Mestrado). Universidade do Rio Grande do Sul.

RAZENTE, J. A. (2004). Aplicação de recursos computacionais em projetos de edifícios em alvenaria. São Carlos. 133p. Dissertação (Mestrado) - Escola de Engenharia de São Carlos, Universidade de São Paulo.

RENÉ TOBAR,R., MARCO CAPRIROLI, Z. (1991). Dosificacion y preparacion de microhormigones para utilizar en modelos. In: XXV JORNADAS SULAMERICANAS DE ENGENHARIA ESTRUTURAL. v. IV. p.223-234. Porto Alegre. Universidade Federal do Rio Grande do Sul. 
SABBATINI, F.H. (1984). Processo construtivo de edifícios de alvenaria sílicocalcaria. São Paulo. 298 p. Dissertação (Mestrado). Escola Politécnica, Universidade de São Paulo.

SAHLIN, S. (1971). Structural masonry. Englewood Cliffs. Prentice-Hall.

SILVA, I. M. (1996). Análise de edifícios de alvenaria estrutural sujeitos às ações do vento. São Carlos. 80 p. Dissertação (Mestrado) - Escola de Engenharia de São Carlos, Universidade de São Paulo.

SILVA, T. F.T. (2005). Estudo da interação entre edifícios de alvenaria estrutural e pavimentos em concreto armado. 106 p. Dissertação (Mestrado) - Escola de Engenharia de São Carlos, Universidade de São Paulo

TAKEYA, T. (1988). Introdução à análise experimental de estruturas. Notas de aula . SET 5816 - Análise experimental de estruturas. São Carlos, Escola de Engenharia de São Carlos, Universidade de São Paulo.

TOMAZELA, C. A. (1995). Ação conjunta parede-viga na alvenaria estrutural. São Carlos. 249 p. Dissertação (Mestrado) - Escola de Engenharia de São Carlos, Universidade de São Paulo.

VILATÓ, R.R. (1998). Estudo da metodologia do projeto para edificios em alvenaria estrutural não armada. São Paulo. 175 p. Dissertação (Mestrado). Escola Politécnica, Universidade de São Paulo. 